\title{
Os Fundamentos
}

\section{Experimentais e}

Historicos da Eletricidade Volume 2

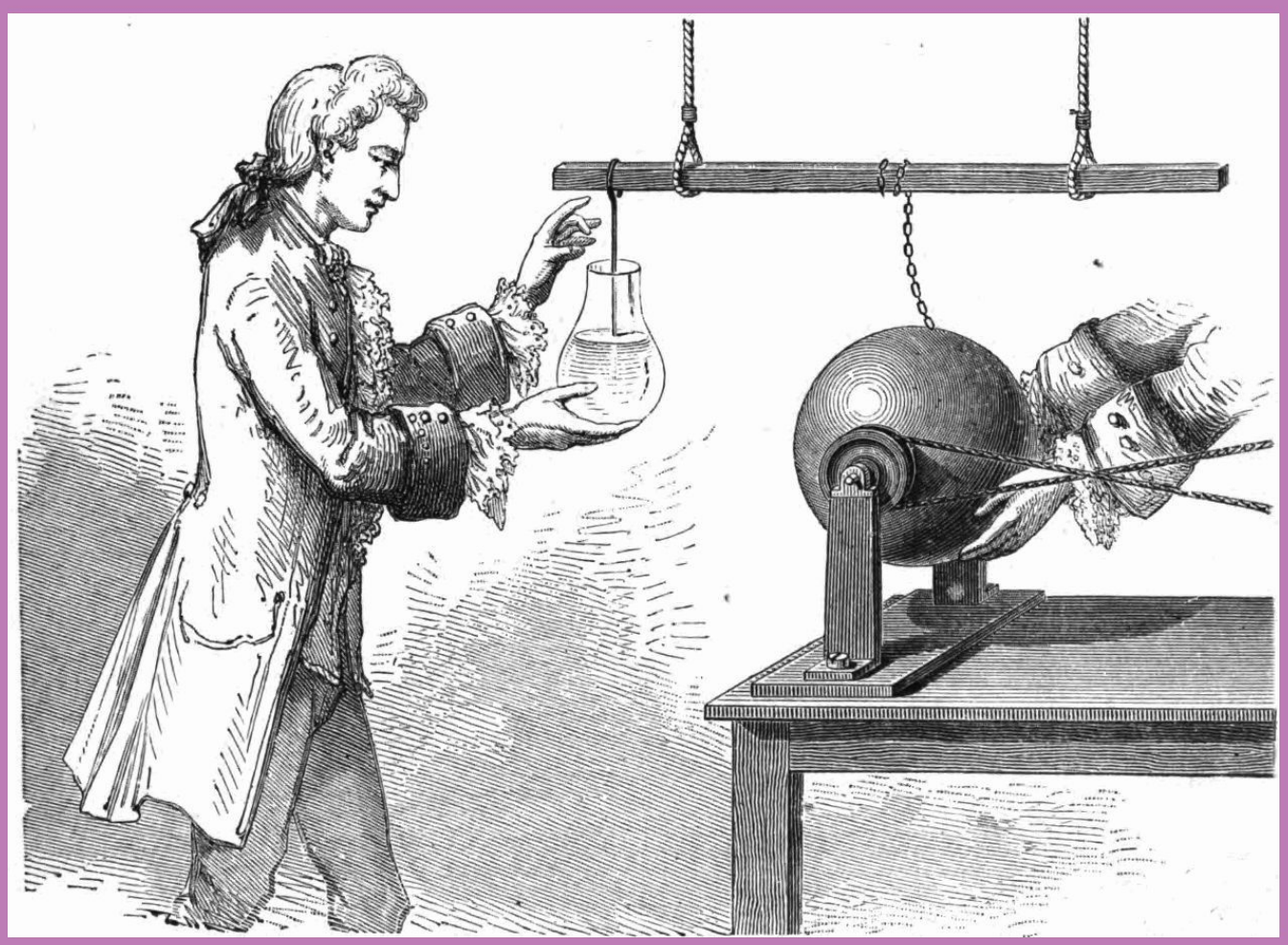

\section{André K.T. Assis}




\section{Os Fundamentos}

Experimentais e Históricos da Eletricidade Volume 2

André Koch Torres Assis

$0 \int_{\text {Montreal }}^{\text {Apeiron }}$ 
Published by C. Roy Keys Inc.

4405, rue St-Dominique

Montreal, Quebec H2W 2B2 Canada

http://redshift.vif.com

(C) André Koch Torres Assis 2018

First Published 2018

Library and Archives Canada Cataloguing in Publication

Assis, André Koch Torres, 1962-

[Experimental and historical foundations of electricity. Portuguese]

Os fundamentos experimentais e históricos da eletricidade / Andre Koch

Torres Assis.

Issued in print and electronic formats.

Translation of: The experimental and historical foundations of electricity. Includes bibliographical references.

ISBN 978-1-987980-09-7 (v. 2 : softcover).--ISBN 978-1-987980-12-7 (v. 2 : PDF)

1. Electricity--Experiments. 2. Electricity--History. I. Title. II. Title: Experimental and historical foundations of electricity. Portuguese.

QC533.A88167 2010

$537 ' .078$

C2010-900626-7

C2018-901457-1

Capa da frente: Uma das primeiras representações da experiência da garrafa de Leiden (1745). Fonte: A. P. Deschanel, Elementary Treatise on Natural Philosophy. D. Appleton and Co., New York, 1876. Parte 3, pág. 570, Figura 382. Traduzido por J. D. Everett. 


\title{
OS FUNDAMENTOS EXPERIMENTAIS E HISTÓRICOS DA ELETRICIDADE
}

\section{Volume 2}

\author{
ANDRÉ KOCH TORRES ASSIS \\ Instituto de Física \\ Universidade Estadual de Campinas-UNICAMP \\ 13083-859 Campinas, SP, Brasil \\ E-mail: assis@ifi.unicamp.br \\ Homepage: www.ifi.unicamp.br/ assis \\ (c) André Koch Torres Assis
}




\section{Sumário}

Apresentação e Agradecimentos $\quad 9$

1 Introdução 13

1.1 O Efeito Âmbar . . . . . . . . . . . . . . . . . 13

1.2 A Série Triboelétrica . . . . . . . . . . . . . . . 15

1.2.1 A Posição da Água na Série Triboelétrica . . . . . . . . . 15

1.3 Fatos Simples e Primitivos sobre a Eletricidade . . . . . . . . . . 17

1.3.1 Não Explicamos Estes Fatos, Eles Foram Apenas Descri-

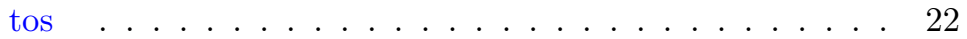

1.3.2 Nomenclatura da Física . . . . . . . . . . . . 22

2 Instrumentos Elétricos $\quad 25$

2.1 Materiais para as Experiências . . . . . . . . . . . . 25

2.2 O Eletroscópio: Instrumento Mais Importante da Eletrostática 26

2.2.1 Principais Componentes do Eletroscópio . . . . . . . . . 28

2.2.2 Comparação entre o Eletroscópio de Folhas de Ouro e o Eletroscópio Feito com Materiais de Baixo Custo . . . . 28

2.2.3 O Eletroscópio e a Descoberta dos Raios Cósmicos . . . . 29

2.3 O Versório . . . . . . . . . . . . . . . . . . 30

2.3.1 O Versório Metálico Apoiado sobre um Alfinete . . . . . 31

2.3.2 O Versório Metálico Apoiado sobre um Plástico Pontudo 31

2.3.3 O Versório de Plástico . . . . . . . . . . . . . . . 31

2.3.4 Versório de Du Fay . . . . . . . . . . . . . . . . . . 32

2.3.5 Principais Componentes Destes Versórios . . . . . . . . 32

2.4 O Pêndulo Elétrico . . . . . . . . . . . . . . . . . . 33

2.4.1 O Pêndulo Elétrico Clássico . . . . . . . . . . . 33

2.4.2 O Pêndulo de Seta . . . . . . . . . . . . . . . . 34

2.4.3 O Pêndulo de Plástico . . . . . . . . . . . . . 35

2.4.4 Principais Componentes Destes Pêndulos . . . . . . . . . 35

2.5 A Linha Pendular de Gray . . . . . . . . . . . . . . . . 35

2.6 Coletores de Carga . . . . . . . . . . . . . . . . . 36

2.7 Circuito de Teste . . . . . . . . . . . . . . . . . 38 
3.1 Classificando os Corpos como Condutores ou Isolantes pelo Eletroscópio

3.1.1 Definição de Condutor e Isolante quando é Aplicada uma Alta Diferença de Potencial entre as Extremidades do Corpo .......................

3.1.2 Corpos que se Comportam como Condutores ou Isolantes nas Experiências Usuais de Eletrostática . . . . . . . . .

3.2 Classificando os Corpos como Condutores ou Isolantes pelo Circuito de Teste . . . . . . . . . . . . . . 50

3.2.1 Definição de Condutor e Isolante quando é Aplicada uma Baixa Diferença de Potencial entre as Extremidades do Corpo . . . . . . . . . . . . . . . . . . . 52

3.2.2 Corpos que se Comportam como Condutores ou Isolantes nas Experiências Usuais com Corrente Constante . . . .

3.3 Fatores que Influenciam no Comportamento Condutor ou Isolante de um Corpo . . . . . . . . . . . . . . . . . . 54

3.3.1 Natureza ou Composição Química do Corpo . . . . . . . 54

3.3.2 Diferença de Potencial entre as Extremidades do Corpo . 55

3.3.3 O Tempo Necessário para Descarregar um Corpo Eletri-

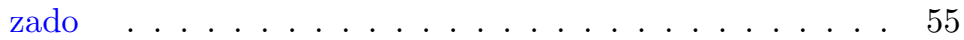

3.3.4 O Comprimento do Corpo . . . . . . . . . . 56

3.3.5 A Área de Seção Reta do Corpo . . . . . . . . . . . . . . 60

3.3 .6 Umidade . . . . . . . . . . . . . . . . . . . 66

3.3.7 Orientação do Corpo em Relação à Voltagem Aplicada sobre Ele . . . . . . . . . . . . . . . . 68

3.3 .8 Temperatura . . . . . . . . . . . . . . . . . 71

3.3 .9 Iluminação . . . . . . . . . . . . . . . . . . . . . 72

3.3.10 Outros Fatores . . . . . . . . . . . . . . . . 72

3.4 Leis Relacionadas aos Circuitos com Corrente Constante . . . . 73

4 Condutores e Isolantes em Algumas Experiências Simples $\quad \mathbf{7 5}$

4.1 Condutores e Isolantes no Efeito Âmbar . . . . . . . . . . . . . 75

4.1.1 Explicação do Efeito Âmbar nos Livros Didáticos . . . . 75

4.1.2 Nossa Explicação do Efeito Âmbar . . . . . . . . . . . 77

4.1.3 A Importância de se Apresentar uma Explicação Detalhada do Efeito Âmbar . . . . . . . . . . . . . . . 79

4.2 Condutores e Isolantes na Experiência do Desvio do Filete de Água ....................... 80

4.2.1 Explicação do Desvio do Filete de Água nos Livros Didáticos 81

4.2.2 Nossa Explicação do Desvio do Filete de Água . . . . . . .

4.2.3 A Importância de se Apresentar uma Explicação Detalhada do Desvio do Filete de Água . . . . . . . . . . . . 84

4.3 Diferenças entre os Vidros da Época de Gray e os Vidros Atuais 84 4.3.1 Comportamento Isolante ou Condutor . . . . . . . . . . 85 
4.3.2 Densidade Superficial das Cargas Adquiridas pelo Atrito 87

4.3.3 O Tipo de Eletrização Adquirida pelo Vidro Atritado . . 88

4.3.4 O Vidro nos Livros Didáticos Atuais e a Importância de Corrigir o que Afirmam . . . . . . . . . . . . . 89

4.4 O Mecanismo ACR . . . . . . . . . . . . . . . . . 91

4.4.1 Explicação do Mecanismo $A C R$. . . . . . . . . . 94

4.4.2 Situações em que Não Ocorre o Mecanismo $A C R \quad$. . . . 95

4.5 A Importância da Descoberta dos Condutores e Isolantes por Stephen Gray ～. . . . . . . . . . . . . . . . . . . . 98

5 Eletrização de Fitas Adesivas 101

5.1 Comportamento Isolante ou Condutor da Fita . . . . . . . . . 101

5.2 Eletrização da Fita . . . . . . . . . . . . . . . . . . . . 105

5.3 Neutralização da Fita . . . . . . . . . . . . . . . . . . . . . 108

5.4 Fitas Eletrizadas com Cargas Opostas . . . . . . . . . . . 110

5.5 Dipolos Elétricos . . . . . . . . . . . . . . . . . . . . . 113

5.6 Aspectos Gerais sobre as Fitas Adesivas . . . . . . . . . . . 117

6 O Eletróforo 119

6.1 O Instrumento . . . . . . . . . . . . . . . . . . . . . 119

6.2 Operação do Eletróforo . . . . . . . . . . . . . . . . . 120

6.3 Um Relato Pessoal . . . . . . . . . . . . . . . . . . . . . . . 125

7 Distribuição de Cargas em um Condutor $\quad 129$

7.1 Distribuição de Cargas em Condutores . . . . . . . . . . . 129

7.1.1 Experiências com Eletroscópios _. . . . . . . . . . 129

7.1.2 Coletando as Cargas nas Paredes Interna e Externa de um Condutor Eletrizado . . . . . . . . . . . . . . . . . . 133

7.1.3 Gray, Franklin e a Distribuição de Cargas em Condutores Eletrizados . . . . . . . . . . . . . . 136

7.1.4 Condutores Eletrizados Tocando as Paredes Interna e Externa de Outro Condutor . . . . . . . . . . . . . . . . 139

7.1.5 Distribuição de Cargas em Condutores Abertos e Fecha$\operatorname{dos} \ldots \ldots \ldots \ldots \ldots \ldots$

7.2 Cargas Induzidas nas Paredes Interna e Externa de um Condutor

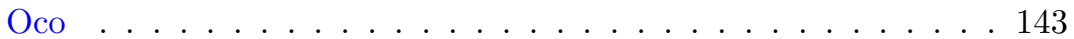

7.3 Ação de um Condutor Oco Eletrizado sobre Corpos Internos e Externos . . . . . . . . . . . . . . . . 146

7.4 Experiência do Balde de Gelo de Faraday . . . . . . . . . . . 147

8 Blindagem Elétrica $\quad 151$

8.1 Efeito da Colocação de Condutores ou Isolantes entre um Corpo Eletrizado e um Corpo Leve . . . . . . . . . . . . . . . . . 151

8.1.1 Algumas Pesquisas Antigas sobre Blindagem . . . . . . . 154

8.2 Experiências com Condutores Ocos . . . . . . . . . . . 156

8.3 Presença ou Ausência de Blindagem Efetiva . . . . . . . . 160 
8.4 Gaiola de Faraday . . . . . . . . . . . . . . . . . . . . 165

9 O Poder das Pontas $\quad 167$

9.1 Ilustrando o Poder das Pontas com Eletroscópios . . . . . . . . . 167

9.2 Coletando e Comparando as Cargas Superficiais . . . . . . . . 169

9.3 Gray e o Poder das Pontas . . . . . . . . . . . . . . . . . . 172

9.4 Intensificando o Efeito Âmbar . . . . . . . . . . . . . 176

10 Equilíbrio Elétrico e o Instrumento para Indicar Diferença de $\begin{array}{ll}\text { Potencial } & 179\end{array}$

10.1 Equilíbrio Elétrico de um Condutor _ . . . . . . . . . . . 179

10.2 O Potencial Elétrico de um Condutor . . . . . . . . . . . . 181

10.3 Eletroscópio com Envoltório Condutor . . . . . . . . . . . . . 182

10.4 Experiências Utilizando o Eletroscópio com Envoltório Condutor 188

10.4.1 Mostrando que Todas as Partes de um Condutor em Equilíbrio

Estão no Mesmo Potencial . . . . . . . . . . . . . 188

10.4.2 Fatores que Alteram o Potencial de um Condutor em Relação a Outro Condutor . . . . . . . . . . . . . . 192

10.5 Kelvin e o Eletrômetro para Medida de Diferença de Potencial . 195

11 Descargas Elétricas no Ar 199

11.1 Faíscas ou Raios . . . . . . . . . . . . . . . . . . . . . . . 199

11.2 Comentários sobre Estas Experiências ． . . . . . . . . . . 204

11.3 Para-Raios . . . . . . . . . . . . . . . . 206

11.4 Para-Raios Isolado do Solo . . . . . . . . . . . . . . . 207

11.5 Descargas Elétricas no Mecanismo ACR . . . . . . . . . 208

11.6 Lâmpada de Neon . . . . . . . . . . . . . . . . . . . . . . 209

11.7 Gray, Franklin, o Poder das Pontas e a Natureza Elétrica dos

Raios e Relâmpagos . . . . . . . . . . . . . . . . . . . 211

11.8 Aplicações do Poder das Pontas . . . . . . . . . . . . . . . . 219

12 A Garrafa de Leiden e os Capacitores 221

12.1 Construindo um Capacitor . . . . . . . . . . . . . . . . . 221

12.1.1 Não se Deve Utilizar uma Garrafa de Vidro para Isolar o

Condutor Interno do Condutor Externo . . . . . . . . . . 223

12.2 Experiências com o Capacitor . . . . . . . . . . . . . . . 224

12.3 Funcionamento do Capacitor . . . . . . . . . . . . . 230

12.4 Gray, Du Fay e a Eletrização da Água . . . . . . . . . . . . . . 231

12.5 Os Primeiros Capacitores ou Condensadores . . . . . . . . 238

13 Preservação Temporal da Eletrização dos Corpos $\mathbf{2 4 5}$

13.1 Perda de Eletrização no Ar . . . . . . . . . . . . . . . . . 245

13.2 Preservando a Eletrização de Isolantes . . . . . . . . . . . . 246

13.2.1 Algumas Considerações sobre Estas Experiências . . . . . 248

13.3 Preservando a Eletrização de Condutores . . . . . . . . . . . . 249

13.4 Eletretos . . . . . . . . . . . . . . . . . . 251 
13.4 .1 Definições . . . . . . . . . . . . . . . . . 251

13.5 Fabricação de Eletretos . . . . . . . . . . . . . . . . . 253

13.5.1 Materiais Utilizados . . . . . . . . . . . . . . . 253

13.5.2 Preparação das Peças . . . . . . . . . . . . . . . 254

13.6 Eletróforos com Bases de Eletreto . . . . . . . . . . . . 257

13.7 Stephen Gray, os Eletretos e a Preservação Temporal da Eletrização dos Corpos . . . . . . . . . . . . . . . . 258

13.8 Desenvolvimento e Aplicações dos Eletretos . . . . . . . . . . . . 264

14 As Misteriosas Forças Não Eletrostáticas $\quad \mathbf{2 6 7}$

14.1 Força Eletrostática ou Força de Coulomb . . . . . . . . . . . 267

14.2 Forças Não Eletrostáticas em Situações de Equilíbrio Estável . 269

14.3 Forças Não Eletrostáticas no Efeito Âmbar . . . . . . . . . . . . 274

14.3.1 Outros Mistérios no Efeito Âmbar . . . . . . . . . . . 277

14.4 Forças Não Eletrostáticas em uma Pilha . . . . . . . . . . . 278

14.5 Forças Não Eletrostáticas em um Circuito com Corrente Constante . . . . . . . . . . . . . . . . . 279

14.6 Forças Não Eletrostáticas em Outras Situações . . . . . . . . . 280

14.7 Origem das Forças Não Eletrostáticas . . . . . . . . . . . . . . 281

14.7.1 Teoria de Faraday e Maxwell Baseada em Campos Eletromagnéticos . . . . . . . . . . . . . . 283

14.7.2 Eletrodinâmica de Weber Baseada na Interação entre as Partículas Eletrizadas . . . . . . . . . . . . . . . 284 


\section{Apresentação e Agradecimentos}

Reproduzimos aqui com algumas modificações a Apresentação incluída no Volume 1 desta obra. ${ }^{1}$

No início da década de 1990 conheci o trabalho de Norberto Cardoso Ferreira, do Instituto de Física da Universidade Estadual de São Paulo, USP. Ele conseguia mostrar os aspectos mais importantes da eletricidade utilizando experiências feitas com materiais muito simples e facilmente acessíveis. Tive a oportunidade de visitá-lo pessoalmente na USP em 1993. Durante esta visita ele me presenteou com um pequeno conjunto de materiais experimentais feitos de cartolina, canudo de plástico de refresco, papel de "seda," colchete, etc. Mostrou-me como realizar as experiências principais, assim como seu livro Plus et Moins: Les Charges Électriques. ${ }^{2}$ Fiquei fascinado com o que aprendi, percebendo como se podem ver experimentalmente coisas bem profundas de física trabalhando com materiais facilmente acessíveis. Guardei este material como um tesouro durante 10 anos, embora não o tenha utilizado nem desenvolvido durante este período. Fico extremamente grato ao Norberto Ferreira pelo que aprendi com ele. Recentemente vim a conhecer outras obras suas, como sempre ricas e criativas. ${ }^{3}$ Aprendi também pela discussão com seus estudantes, como Rui Manoel de Bastos Vieira e Emerson Izidoro dos Santos.

Em 2005 conheci Alberto Gaspar e seu livro Experiências de Ciências para $o$ Ensino Fundamental, ${ }^{4}$ com o qual muito aprendi. O mesmo pode ser dito de outras obras suas que conheci depois. ${ }^{5}$

Entre 2004 e 2007 ministrei aulas em cursos de aperfeiçoamento para professores da rede pública do ensino fundamental e médio dentro do projeto Teia do Saber da Secretaria de Educação do Governo do Estado de São Paulo. Foi um privilégio muito grande ter sido convidado a atuar neste programa. $\mathrm{O}$ apoio que recebi por parte da Secretaria de Educação e do Grupo Gestor de Projetos Educacionais da UNICAMP, assim como o contato com os alunos que participaram

\footnotetext{
${ }^{1}$ [Ass10b], [Ass10a], [Ass11], [Ass15b] e [Ass17].

2 [FM91].

3 [Fer78], [Fera], [Ferb], [Ferc], [Ferd], [Fer06], [Fer01c], [Fer01d], [Fer01b] e [Fer01a].

${ }^{4}[$ Gas03].

${ }^{5}$ [Gas91] e [Gas96].
} 
de minhas aulas, foram extremamente enriquecedores para mim. Também foram muito proveitosas as trocas de experiências com os professores da UNICAMP que participaram deste projeto. Como parte do meu envolvimento neste projeto resolvi ensinar aos professores de ensino fundamental e médio aquilo que havia aprendido com o Norberto Ferreira. Com isto retomei aquelas atividades e tive uma motivação adicional para escrever este livro, no sentido de compartilhar com o maior número possível de pessoas todas estas coisas.

A inspiração para a maior parte das experiências descritas neste livro foi tirada das obras originais, assim como dos trabalhos de Norberto Ferreira e de Alberto Gaspar. Desde então descobri diversas outras obras impressas e na internet que têm sido fundamentais para o meu aprendizado, como o site Feira de Ciências, de Luiz Ferraz Netto. ${ }^{6}$

John L. Heilbron sugeriu mudanças importantes em relação à primeira versão do Volume 1 deste livro. Sua grande obra, Electricity in the 17th and 18th Centuries: A Study in Early Modern Physics, ${ }^{7}$ forneceu a maior parte das informações históricas citadas aqui. Muitas sugestões relevantes para melhorar versões anteriores dos Volumes 1 e 2 desta obra também foram dadas por Arthur Baraov, Sérgio Luiz Bragatto Boss, Juliano Camillo, Daniel Gardelli, Robert W. Gray, John B. Eichler, Steve Hutcheon, C. Roy Keys, Breno Arsioli Moura, Anabel Cardoso Raicik, Fabio Miguel de Matos Ravanelli, João Ricardo Neves da Silva e Bertrand Wolff.

Agradeço a Arthur Baraov por ter feito uma tradução para o russo deste livro, ${ }^{8}$ assim como a Pietro Cerreta, Andrea Cerreta, Raffaele Cerreta, Rita Serafini e Riccardo Urigu pela tradução e publicação desta obra em italiano. ${ }^{9}$ Pietro Cerreta, Derk Frerichs e Stephan Pfeiler fizeram vários vídeos mostrando experiências baseadas nesta obra. ${ }^{10}$ Agradeço ainda a Fernando Lang da Silveira e Jenaro Guisasola por suas resenhas sobre este livro. ${ }^{11}$

As Figuras do Volume 1 foram feitas por Daniel Robson Pinto, através de uma Bolsa Trabalho concedida pelo Serviço de Apoio ao Estudante da UNICAMP, ao qual agradecemos. O Daniel auxiliou também na obtenção de imagens e referências.

Agradeço ainda a diversas outras pessoas por sugestões, discussões, correções e referências relacionadas com os dois volumes deste livro: Dayane de Souza Bancoff, Christine Blondel, Paolo Brenni, Thiago Augusto de Lima Burgo, João José Caluzi, Hugo Bonette de Carvalho, Danylo do Amaral Cavalcanti, João Paulo Martins de Castro Chaib, Asit Choudhuri, Roberto Clemente (in Memoriam), Silvio Dahmen, Charbel El-Hani, Henrique Ennes, Moacir Pereira de Souza Filho, Junichiro Fukai, Cláudio H. Furukawa, Hans Gaab, Fernando Galembeck, Robert Harry van Gent, Harald Goldbeck-Löwe, Jürgen Gottschalk, Jenaro Guisasola, Hermann Härtel, Peter Heering, Elizabeth Ihrig, Antonio Iovane, John

\footnotetext{
${ }^{6}$ [Net].

7 [Hei99].

8 [Ass15b].

${ }^{9}[$ Ass 17].

10 [Cer14a], [Cer14b], [Cer17] e [Fre].

11 [Sil10c] e [Gui12].
} 
Jenkins, Basilio José Augusto José, Kostas Kampourakis, Siegfried Kett, Martin Kostal, Ellen Kuhfeld, Wolfgang Lange, Fabio Menezes de Souza Lima, Lin Liu, José Joaquín Lunazzi, Ceno Pietro Magnaghi, Francisco das Chagas Marques, Thiago Marques, Michael Matthews, Alexandre Medeiros, Eduardo Meirelles, Manoel Guilherme da Silva Mello, Mahmoud Melehy (in Memoriam), Paulo Henrique Dias Menezes, Dennis Nawrath, Marcos Cesar Danhoni Neves, Horst Nowacki, Ronaldo Furtado de Oliveira, Martin Panusch, Sônia Peduzzi, Luiz O. Q. Peduzzi, José Rafael Boesso Perez, Gerald H. Pollack, Eugênio Maria de França Ramos, Karin Reich, Edson Eduardo Reinehr, Ricardo Rodrigues, Waldyr Alves Rodrigues Jr. (in Memoriam), Torsten Rüting, Dirceu Tadeu do Espírito Santo, Emely Giron dos Santos, Wayne M. Saslow, Daniel dos Anjos Silva, Carlos Augusto Silva, Valter Aparecido da Silva Junior, Leandro Herculano da Silva, Fernando Lang da Silveira, Moacir Pereira de Souza Filho, Julian David Medina Tamayo, Milton G. Tarazona, Christian Ucke, Alvaro Vannucci, Geraldo Magela Severino Vasconcelos, Haroldo Fraga Campos Velho, Greg Volk, Karl-Heinrich Wiederkehr (in Memoriam), Bernd Wolfram e Gudrun Wolfschmidt.

Ao Instituto de Física, ao Instituto de Matemática, ao Grupo Gestor de Projetos Educacionais e ao Fundo de Apoio ao Ensino, à Pesquisa e à Extensão da UNICAMP, que forneceram as condições necessárias para a realização deste trabalho. Agradeço também ao Instituto de História das Ciências Naturais da Universidade de Hamburgo, Alemanha, e à Fundação Alexander von Humboldt, da Alemanha, por uma Bolsa Pesquisa no ano de 2009 durante a qual coletei uma grande quantidade de material bibliográfico relacionado com este livro.

Roy Keys, o Editor de Apeiron, tem me apoiado por muitos anos. Sem o seu encorajamento alguns de meus livros talvez não tivessem sido publicados. Ele fez um trabalho editorial excelente para esta obra.

André Koch Torres Assis Instituto de Física Universidade Estadual de Campinas - UNICAMP

13083-859 Campinas, SP, Brasil

E-mail: assis@ifi.unicamp.br

Homepage: www.ifi.unicamp.br/ assis 


\section{Capítulo 1}

\section{Introdução}

\subsection{O Efeito Âmbar}

Experiência 1.1 - Eletrizando um corpo por atrito

A experiência mais simples, comum e antiga da eletricidade, que deu origem a todo o estudo desta área, é o chamado efeito âmbar. ${ }^{1}$ Ela era feita originalmente com âmbar (elétron em grego), que é uma resina fóssil proveniente de uma espécia extinta de pinheiro. Uma experiência análoga será reproduzida aqui com um material plástico. Este comportamento também é denominado de efeito triboelétrico ou de triboeletricidade (o prefixo "tribo" também tem origem grega, significando atrito, fricção ou a ação de esfregar). Este efeito refere-se à eletrização de corpos obtida através do atrito.

Colocam-se alguns pedacinhos de papel sobre a mesa. Aproxima-se deles uma régua de acrílico ou canudo plástico que não tenha sido atritada, sem tocálos, observando-se que nada acontece, Figura 1.1.

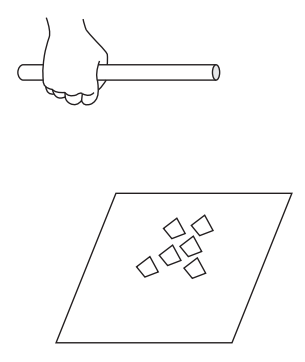

(a)

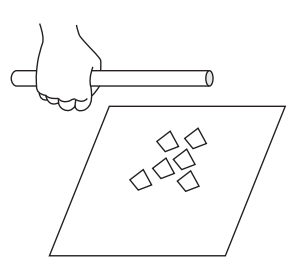

(b)

Figura 1.1: (a) Canudo plástico longe de papeizinhos. (b) Ao aproximar o canudo dos papeizinhos, nada acontece a eles.

\footnotetext{
${ }^{1}$ Experiência 2.1 de [Ass10b], [Ass10a], [Ass11], [Ass15b] e [Ass17].
} 
Agora atritamos a régua ou o canudo no cabelo ou em um guardanapo de papel (ou em um papel toalha, papel higiênico ou em uma folha de papel), esfregando-o rapidamente para frente e para trás. Vamos representar pelas letras $F$ a região do canudo que foi friccionada, Figura 1.2.

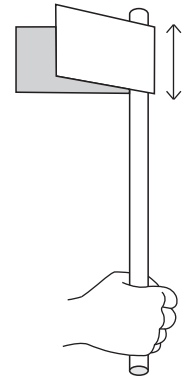

(a)

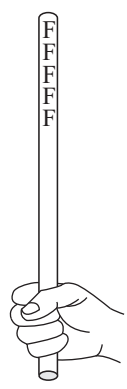

(b)

Figura 1.2: (a) Canudo plástico sendo atritado em um guardanapo. (b) A região friccionada do canudo é representada pelas letras $F$.

Em seguida aproximamos o canudo atritado dos papeizinhos, novamente sem tocá-los, apenas chegando bem perto. Observa-se que a partir de uma certa distância eles pulam para o canudo atritado e alguns papeizinhos ficam grudados nele, Figura 1.3. Podemos afastar o canudo da mesa que eles continuam grudados nele.

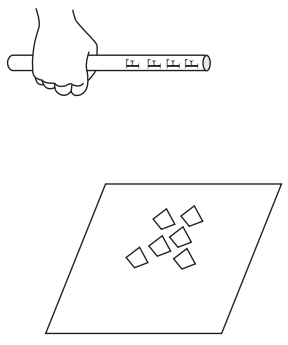

(a)

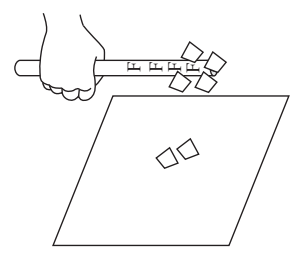

(b)

Figura 1.3: (a) Um canudo atritado longe de papeizinhos. (b) $\mathrm{O}$ canudo atritado atrai os papeizinhos ao se aproximar deles.

Nem todos os papeizinhos ficam grudados no canudo atritado. Alguns deles batem no canudo e caem. Outros ficam grudados por algum tempo e depois são lançados de volta à mesa. Este tema será discutido na Seção 4.4.

O comportamento dos papeizinhos quando estão próximos destes canudos permitem que se façam as seguintes definições. 


\section{Definição 1.1}

Dizemos que o canudo plástico que não atrai papeizinhos ao se aproximar deles está neutro, eletricamente neutro, que possui carga nula, ou que não está eletrizado. Quando o canudo após ser atritado passa a atrair papeizinhos ao se aproximar deles, dizemos que adquiriu uma carga elétrica ou que está eletrizado, eletrificado, carregado eletricamente ou simplesmente carregado. $\mathrm{O}$ processo é chamado de carga obtida por atrito, eletrização por atrito, eletrificação por atrito ou de efeito triboelétrico. A atração entre estes corpos é chamada algumas vezes de atração elétrica ou de atração eletrostática.

\subsection{A Série Triboelétrica}

Como discutido no Volume 1 deste trabalho, ${ }^{2}$ existem dois tipos de corpos eletrizados, usualmente chamados de corpos positivos e negativos. Quando atritamos dois corpos neutros diferentes, um deles fica positivamente eletrizado e o outro negativamente eletrizado. Se um destes corpos for um condutor, ele só vai permanecer carregado se estiver isolado do solo. Após realizar muitas experiências chegamos na Tabela 1.1.

A maneira de se ler esta Tabela é a seguinte. Se atritamos um corpo $I$ contra um corpo $I I$, vai ficar positivamente carregado aquele que estiver mais acima na Tabela, isto é, mais próximo do símbolo + . Por exemplo, ao atritarmos a seda contra o canudo de plástico, a seda fica com carga positiva e o canudo com carga negativa.

\section{Definição 1.2}

Uma sequência como a da Tabela 1.1 é chamada de série triboelétrica. O prefixo "tribo" vem do grego, significando atrito ou a ação de esfregar. Logo a série triboelétrica indica os tipos de eletrização obtidos na fricção.

Um canudo plástico e uma régua de acrílico ficam atritados negativamente quando atritados no cabelo ou em uma folha de papel. Vamos então representar daqui por diante um canudo plástico ou uma régua de acrílico atritados contra estes materiais como tendo cargas negativas ou como estando negativamente eletrizados.

\subsubsection{A Posição da Água na Série Triboelétrica}

É também possível analisar a eletrização de líquidos quando eles fluem ao longo de uma superfície sólida. ${ }^{3}$ Desde 1675 se sabia que ao agitar um barômetro com

\footnotetext{
${ }^{2}$ Capítulo 5 de [Ass10b], [Ass10a], [Ass11], [Ass15b] e [Ass17].

${ }^{3}$ [Gre94].
} 


\begin{tabular}{|c|}
\hline+ \\
\hline cabelo \\
\hline vidro liso \\
\hline pele humana \\
\hline poliamida sintética \\
\hline algodão \\
\hline seda \\
\hline papel ou papelão \\
\hline couro \\
\hline porcelana \\
\hline papel de alumínio \\
\hline madeira \\
\hline cortiça \\
\hline pano de acrílico \\
\hline isopor \\
\hline saco plástico \\
\hline canudo plástico \\
\hline acrílico rígido \\
\hline tubo de PVC \\
\hline borracha dura \\
\hline- \\
\hline
\end{tabular}

Tabela 1.1: Série triboelétrica.

mercúrio aparecia uma luz na região evacuada no topo do tubo. Muito tempo depois mostrou-se que este fenômeno era originado na eletrização produzida no atrito vindo do movimento entre o mercúrio e o vidro. Em 1840 um motorista de um trem a vapor tomou um choque na Inglaterra ao colocar uma mão próxima de um jato de vapor a alta pressão saindo da caldeira enquanto tocava acidentalmente com a outra mão na caldeira. William Armstrong (1810-1900) investigou este fenômeno isolando eletricamente a caldeira do solo e direcionando o jato de vapor para um outro condutor metálico também isolado do solo. Este condutor ficou positivo e a caldeira negativa. Em 1843 construiu um gerador hidro-elétrico explorando este fenômeno. Michael Faraday (1791-1867) interessou-se por este assunto. Após uma série de pesquisas mostrou em 1843 que o efeito era devido ao atrito do vapor e das gotículas de água expelidas pela caldeira contra as paredes do bico ou bocal por onde saía o vapor. Mostrou que um jato de ar seco não produzia o efeito, enquanto que havia separação de cargas caso fosse utilizado ar úmido. Além disso, conseguiu alterar o sinal da carga adquirida pelas gotículas ao variar o material de que era feito o bocal. Concluiu ainda que a eletrização não era devida à evaporação ou mudança de estado da água (de líquido para vapor), surgindo apenas no atrito do vapor com as paredes sólidas por onde ele fluía, assim como ocorre no efeito âmbar. Além disso, para obter o efeito e coletar uma boa quantidade de eletricidade no vapor 
ou na caldeira (carga de um tipo adquirida pelo vapor e carga de sinal oposto adquirida pela caldeira), tinha de usar água pura ou destilada, já que quando a água continha substâncias condutoras, qualquer eletricidade que tivesse surgido pelo atrito era facilmente descarregada ou dissipada para o ambiente. Quanto mais isolante fosse o líquido utilizado nas experiências, maior era a quantidade de eletricidade que podia ser coletada. Ao comparar a posição da água na série triboelétrica com várias outras substâncias, Faraday concluiu que a água estava perto do topo da série, ficando positiva ao fluir por paredes sólidas da grande maioria dos materiais, sendo que estes materiais ficavam em geral negativos. Uma de suas conclusões, com nossas palavras entre colchetes: ${ }^{4}$

2107. Tendo apresentado dessa forma o resultado do atrito do vapor e da água contra tantos corpos, posso apontar aqui a circunstância notável da água ficar positiva em relação a todos eles. É muito provável que encontraremos seu lugar [na série triboelétrica] acima de todas as outras substâncias, até mesmo do pelo de gato e do oxalato de lima (2131).

Estas pesquisas têm continuado até os dias atuais. Burgo, Galembeck e Pollack, por exemplo, fizeram a água fluir por tubos de diferentes materiais, concluindo que ela sempre ficava positivamente eletrizada, embora fique negativa ao fluir no ar. ${ }^{5}$

Este processo de eletrificação no qual gotículas de um fluido fluem através de paredes sólidas foi utilizado por Robert Andrews Millikan (1868-1953) em suas famosas experiências nas quais determinou o valor da carga do elétron usando gotículas eletrizadas de óleo. Estas gotículas ficavam carregadas ao serem pulverizadas dentro da câmara experimental. Em seu livro de 1917, O Elétron, mencionou o seguinte: ${ }^{6}$

Encontrou-se que estas gotículas [...] tinham sido em geral fortemente carregadas pelo processo de fricção ao soprar o spray [de óleo através de um pequeno orifício ....].

Em muitas séries triboelétricas encontradas na literatura e na internet, o ar aparece no topo da lista do lado + , acima até mesmo da água e de outros materiais.

\subsection{Fatos Simples e Primitivos sobre a Eletrici- dade}

No Volume 1 deste livro apresentamos de forma estruturada as bases experimentais e conceituais da eletricidade. Em geral começamos cada tópico com algumas experiências e a partir delas fomos construindo os conceitos principais.

\footnotetext{
4 [Far43b, artigo 2107].

5 [BGP16] e [GB17, Seção 6.5].

${ }^{6}$ [Gre94] e [Mil17, pág. 66].
} 
Resumimos o conjunto da obra na Seção 8.2 do Volume $1,{ }^{7}$ na qual apresentamos os principais aspectos que denominamos de fatos simples e primitivos sobre a eletricidade. Ou seja, apresentamos apenas as características principais a partir das quais podemos explicar uma série de fenômenos relacionados ao tema. Estamos aqui apenas descrevendo os fatos observados, eles não serão explicados. Por este motivo eles são considerados como primitivos. Isto é, pode-se utilizar estes princípios simples para explicar outros fenômenos e também experiências mais complicadas, mas os próprios princípios fundamentais não são explicados. Nunca é possível explicar tudo, sempre é necessário partir de algumas coisas que são consideradas como verdadeiras, para então explicar com estas coisas primitivas outras observações da natureza. Há sempre a necessidade de se assumir alguns princípios ou postulados para depois deduzir teoremas e outros resultados a partir das coisas que são consideradas como mais básicas. Vamos então aos princípios primitivos:

1. Os corpos na natureza podem se encontrar em três estados diferentes que são chamados de: (a) eletricamente neutro, não eletrizado, descarregado ou sem carga elétrica, (b) eletrizado ou carregado positivamente, além de (c) eletrizado ou carregado negativamente. Quando falamos de uma "carga elétrica", seja ela positiva ou negativa, deve-se entender que estamos falando de um corpo eletrizado ou de uma partícula eletrizada. Também se diz que estes corpos nestes três estados diferentes possuem, respectivamente, (a) carga resultante nula, carga total nula, ou carga líquida nula; (b) carga resultante positiva, carga total positiva, ou carga líquida positiva; e (c) carga resultante negativa, carga total negativa, ou carga líquida negativa.

2. Estes estados são caracterizados pelos comportamentos observados dos corpos. Dois corpos neutros não se atraem nem se repelem, com exceção da situação em que estão polarizados, sendo esta configuração de polarização descrita em outro item. Há uma atração entre um corpo positivo e um corpo inicialmente neutro, assim como há uma atração entre um corpo negativo e um corpo inicialmente neutro.

3. Corpos com cargas opostas se atraem. Corpos com cargas de mesmo sinal normalmente se repelem, mas em algumas situações eles podem se atrair. ${ }^{8}$

4. Estas forças de atração e de repulsão aumentam de intensidade com a diminuição da distância entre os corpos. Elas também aumentam de intensidade com o aumento da eletrização dos corpos, ou com a quantidade de carga nos corpos. Elas são mútuas, atuando com igual intensidade nos dois corpos que estão interagindo. Elas atuam ao longo da linha reta que une os dois corpos, mas agem em sentidos opostos sobre cada corpo. Elas são chamadas de forças eletrostáticas ou coulombianas.

\footnotetext{
${ }^{7}$ Seção 8.2 de [Ass10b], [Ass10a], [Ass11], [Ass15b] e [Ass17].

${ }^{8}$ Como mostrado nas experiências da Seção 7.10 de [Ass10b], [Ass10a], [Ass11], [Ass15b] e [Ass17].
} 
5. Os corpos podem ser divididos em dois grupos, chamados de condutores e isolantes. A diferença principal é que os condutores possuem partículas eletrizadas móveis que podem se deslocar por todo o volume do condutor. Isto é, os condutores permitem a passagem ou o fluxo de partículas elétricas através de seus corpos e através de suas superfícies. Os isolantes, ao contrário, não possuem partículas eletrizadas móveis que podem se deslocar por todo o volume do isolante. As partículas eletrizadas que possuem podem deslocar-se apenas no interior de suas moléculas. Os isolantes não permitem a passagem ou o fluxo de partículas eletrizadas através deles.

6. Tanto os condutores quanto os isolantes podem estar eletricamente neutros, positivos ou negativos.

7. Uma maneira classificar os corpos entre condutores e isolantes utilizando um eletroscópio eletrizado será vista na Seção 3.1. A cartolina de um eletroscópio eletrizado é ligada à Terra através de vários corpos diferentes. Os corpos que descarregam o eletroscópio são chamados de condutores e os que não descarregam o eletroscópio são chamados de isolantes.

8. Quando um condutor eletrizado entra em contato com a Terra, ele se descarrega, sendo este processo chamado de descarga ou aterramento. Já um isolante eletrizado não é descarregado ao entrar em contato com a Terra.

9. A maior parte dos corpos sólidos e líquidos se comporta como condutores para as experiências usuais de eletrostática, poucos são os isolantes. Entre estes se destacam o ar seco, o âmbar, a seda, os óleos e a maior parte dos plásticos e resinas.

10. Também podemos classificar os corpos como condutores e isolantes utilizando um circuito de teste que será descrito na Seção 3.2. Montamos um circuito contendo um pedaço de fio $A$, uma pilha, um pedaço de fio intermediário, uma lâmpda e um outor pedaço de fio $B$. Ligamos os fios $A$ e $B$ através de um corpo que está sendo testado. Quando a lâmpada acende, o corpo é chamado de condutor. Quando a lâmpada não acende, o corpo é chamado de isolante.

11. Um corpo que se comporta como um isolante quando suas extremidades estão sob a ação de uma pequena diferença de potencial elétrico (até tipicamente algumas dezenas de volts) pode passar a se comportar como um condutor quando esta diferença de potencial ultrapassa um certo limite. Nas experiências usuais de eletrostática lidamos com altas diferenças de potencial, tipicamente entre 1.000 e 10.000 volts, quando então a grande maioria dos corpos líquidos e sólidos se comporta como condutor.

12. Existem vários fatores, além da composição química do corpo e da diferença de potencial a que está submetido, que fazem com que ele se comporte como condutor ou isolante. Vamos supor que uma extremidade do 
corpo esteja em contato com a cartolina de um eletroscópio eletrizado e a outra extremidade do corpo esteja em contato com o solo. Alguns dos fatores que influenciam na condutividade do corpo são as seguintes: (a) $\mathrm{O}$ tempo necessário para descarregar o eletroscópio (quanto maior o tempo de contato, maior é a descarga). (b) O comprimento do corpo entre a Terra e o eletroscópio (quanto maior este comprimento, mais lentamente ocorre a descarga). (c) A área de seção reta do corpo ligando o eletroscópio à Terra (quanto maior é esta área, mais rapidamente ocorre a descarga). No Capítulo 3 deste livro fazemos um estudo detalhado destes fatores.

13. Os corpos neutros podem ser carregados de diversas maneiras. A mais comum é o atrito entre dois corpos neutros (pode ser o atrito entre dois isolantes, entre dois condutores, ou entre um condutor e um isolante). Após o atrito, um dos corpos fica positivo e o outro negativo. Qual deles vai ficar positivo ou negativo vai depender de sua colocação na chamada série triboelétrica que é obtida empiricamente. Além disso, para que seja coletada a carga de um condutor que está sendo atritado, ele tem de estar totalmente isolado do solo durante o atrito. Ele pode ser preso a um cabo isolante, por exemplo.

14. Os isolantes ficam eletrizados apenas no local onde foram atritados. Já a carga adquirida pelos condutores no atrito vai se espalhar por toda sua superfície externa se estiverem cercados por isolantes. Por outro lado, caso o condutor atritado esteja em contato com a Terra (seja diretamente ou através de um outro corpo condutor), então a carga que adquiriu por atrito será imediatamente neutralizada pelo solo.

15. Um condutor neutro também adquire uma carga de um isolante carregado ao entrar em contato com ele, sem atrito. Um exemplo deste processo é a carga adquirida pelo papelzinho dependurado por um fio de seda em um pêndulo elétrico ao ser atraído por um plástico eletrizado, entrar em contato com este plástico, sendo depois repelido por ele. Este mecanismo é chamado de $A C R$, a saber, atração, comunicação da eletricidade e repulsão. A Seção 4.4 apresenta uma análise deste mecanismo. Esta carga adquirida pelo condutor tem mesmo sinal que a carga do isolante eletrizado. Neste processo o isolante perde uma quantidade de carga igual à adquirida pelo condutor. Por outro lado, é desprezível a carga adquirida por um isolante neutro ao entrar em contato com um outro isolante carregado pelo simples contato entre ambos, quando não há atrito entre eles, ou seja, quando um destes plásticos não é raspado contra o outro.

16. Os condutores isolados eletricamente da Terra se polarizam eletricamente na presença de um corpo carregado próximo a eles. A parte do condutor mais próxima do corpo eletrizado fica com uma carga de sinal oposto à do corpo. A parte mais afastada do condutor fica com uma carga de mesmo sinal que a do corpo carregado. Se estas duas partes forem separadas uma da outra por um isolante enquanto o corpo carregado estiver próximo ao 
condutor, as duas partes do condutor ficarão eletrizadas com cargas de sinais opostos.

17. Se o condutor for aterrado enquanto o corpo carregado estiver próximo a ele, a parte do condutor mais próxima do corpo eletrizado fica com uma carga de sinal oposto à do corpo. Já as cargas do condutor que estão na parte mais afastada do corpo eletrizado serão neutralizadas pela Terra. Se removermos o aterramento enquanto o corpo carregado ainda estiver próximo ao condutor, o condutor ficará eletrizado com uma carga de sinal oposto à do corpo próximo.

18. As moléculas de um isolante se polarizam na presença de um corpo carregado próximo ao isolante. A parte de qualquer molécula mais próxima do corpo fica com uma carga de sinal oposto à do corpo, enquanto que a parte mais afastada da molécula fica com uma carga de mesmo sinal que a carga do corpo. Estas cargas ficam restritas às moléculas e não se deslocam ao longo do isolante. Estas cargas polarizadas também não fluem para um condutor que entre em contato com o isolante.

19. A quantidade de cargas positivas e negativas em um condutor polarizado próximo de um corpo eletrizado aumenta ao diminuir a distância entre eles. O mesmo ocorre com a polarização efetiva de um isolante próximo de um corpo carregado.

20. A quantidade de cargas polarizadas em condutores e isolantes também aumenta quando cresce a eletrização do corpo próximo.

21. Alguma força de origem não eletrostática mantém em repouso as cargas sobre a superfície de condutores e de isolantes carregados ou polarizados.

22. É também uma força de origem não eletrostática a responsável pela separação de cargas durante o atrito entre dois corpos, fazendo com que um destes corpos fique eletrizado positivamente enquanto o outro fica eletrizado negativamente. No Capítulo 14 mostramos diversas situações onde são necessárias estas forças de origem não eletrostática.

Ao descrever os fatos simples deve-se ter em conta que estamos falando em linhas gerais, referindo-nos implicitamente às experiências descritas no Volume 1 deste livro. Tudo depende das ordens de grandeza envolvidas, sempre existem exceções em todas as descrições experimentais. Por exemplo, quando dizemos que dois corpos neutros não interagem, estamos desconsiderando a atração gravitacional entre eles, que não é observável usualmente com os nossos sentidos no caso de corpos pequenos e leves, mas apenas quando possuem dimensões astronômicas. Quando dizemos que um corpo carregado atrai um corpo inicialmente neutro, estamos supondo corpos leves ou apoiados em suportes, tal que possuam pouco atrito para se deslocarem lateralmente, podendo aproximar-se mutuamente. Além disso, para que seja observado este efeito de atração, a distância entre eles não pode ser muito grande e a carga do corpo atritado não 
pode ser muito pequena, senão estes efeitos não serão perceptíveis. O mesmo vale para os outros princípios.

\subsubsection{Não Explicamos Estes Fatos, Eles Foram Apenas Descritos}

Estamos aqui apenas listando os fatos simples e primitivos sobre eletricidade. Não estamos explicando-os nem vamos tentar justificar diversas coisas tais como:

- A existência de dois tipos de eletricidade (positiva e negativa) em vez de existirem $1,3,4, \ldots$, ou até mesmo infinitos tipos diferentes de eletricidade.

- O motivo de cargas de sinais opostos se atraírem, nem o de cargas iguais se repelirem.

- O motivo da força eletrostática depender da distância.

- Os mecanismos responsáveis pela eletrização por atrito.

- O ordenamento da série triboelétrica.

- A origem da força não eletrostática responsável pela separação de cargas opostas no efeito âmbar.

- O motivo de alguns corpos se comportarem como condutores e outros como isolantes.

- O motivo da condutividade de um corpo depender de vários fatores tais como: a diferença de potencial atuando entre suas extremidades, o comprimento e a seção reta do corpo, sua temperatura, etc.

- A origem da força não eletrostática que mantém as cargas paradas em condutores e isolantes carregados ou polarizados.

- Etc.

\subsubsection{Nomenclatura da Física}

Antes de prosseguir é importante citar aqui uma distinção relevante apresentada por Gaspar com a qual concordamos plenamente: ${ }^{9}$

"Carga $q "$ ou "ponto material de carga $q " ?$

Não é comum falar que "uma força é aplicada à massa $m$ ", mas é muito comum falar que "a carga $q$ sofre a ação de uma força", o que está fisicamente incorreto. Massa, como carga elétrica, é uma propriedade da matéria, não é matéria, não é coisa. Corpo, partícula, ponto material ou coisas equivalentes têm massa e podem ter carga elétrica. Mas não existe

\footnotetext{
${ }^{9}$ [Gas00, pág. 22] e [Gas13, pág. 25].
} 
carga sem corpo, como não existe massa sem corpo. Por isso, a rigor, é incorreto falar em "massa $m$ " ou em "carga $q$ " sem mencionar o corpo portador da massa ou da carga elétrica. É claro que o corpo portador da massa ou da carga pode ser subentendido, mas a omissão dos termos não contribui para a compreensão do conceito e deve ser evitada.

Neste livro tratamos com um enfoque macroscópico. Não entraremos em detalhes do modelo atômico. Vamos então falar de corpos carregados ou de partículas eletrizadas. 


\section{Capítulo 2}

\section{Instrumentos Elétricos}

Apresentamos aqui alguns dos principais instrumentos elétricos utilizados neste livro.

\subsection{Materiais para as Experiências}

Listamos aqui alguns dos principais materiais que serão necessários para a realização das experiências. Pode ser útil reunir estas coisas antes de começar as montagens.

- Canudos plásticos, régua de acrílico e tubo de PVC.

- Guardanapos de papel e sacos plásticos.

- Cartolina ou papel cartão.

- Papel ofício e papel de alumínio.

- Papel de "seda" ou papel de bala de coco.

- Carretel de linha de seda, poliamida ou poliéster.

- Carretel de linha de algodão e barbante.

- Colchetes, alfinetes, agulhas e pregos.

- Rolhas.

- Óleo vegetal de cozinha.

- Espetos de madeira e arame.

- Bases para os pêndulos elétricos e eletroscópios feitas com copinhos plásticos de café, colchetes e gesso.

- Fios de cobre encapados, pilhas e lâmpadas de lanterna. 
- Lâmpada de neon e LED (diodo emissor de luz). Estes dois itens não são essenciais e podem ser obtidos mais tarde.

- Fitas adesivas (durex, esparadrapo e fita isolante).

- Latinhas de refrigerante.

- Garrafas plásticas de 200 ou 300 ml.

- Copos de vidro, de metal e de plástico.

- Forma de pizza, formas de empadinha, concha de alumínio ou de ferro (concha de feijão).

- Para a fabricação de eletretos vamos usar principalmente parafina (obtida de velas ou em barra). Também vamos descrever eletretos feitos de cera de carnaúba, embora não seja essencial obter este material.

- Alguns outros materiais especificados em certas experiências.

\subsection{O Eletroscópio: Instrumento Mais Impor- tante da Eletrostática}

No Volume 1 deste livro construímos diversos equipamentos elétricos, a saber, perpendículos, versórios metálicos, versórios de Du Fay, pêndulos elétricos, linhas pendulares, eletroscópios e coletores de carga. Dentre estes aparelhos, o mais relevante é sem dúvida alguma o eletroscópio, já que é ele que permite a distinção prática entre condutores e isolantes. Antes de começar qualquer experiência elétrica ou a construção de qualquer instrumento é fundamental testar os materiais para saber como se comportam no sentido de conduzir ou não a eletricidade. Muitas experiências não funcionam devido ao fato de que as pessoas não prestam atenção neste aspecto crucial. Elas podem achar, por exemplo, que uma borracha vai ser um isolante pelo simples fato de ser uma borracha. Mas na prática muitas borrachas se comportam como condutoras nas experiências de eletrostática. Caso o corpo ou instrumento que está sendo estudado ou utilizado esteja ligado ao solo por uma destas borrachas, elas vão deixar escapar por aterramento qualquer carga elétrica presente no corpo ou no instrumento. Com isto os efeitos desejados não vão existir, frustrando a pessoa que não tiver consciência deste fato, sendo que ela vai ficar sem entender o que deu errado na experiência ou no aparelho elétrico que estava construindo.

O suporte que vamos usar na maioria das experiências com o eletroscópio e com o pêndulo elétrico é feito com um copinho plástico de café no qual fazemos um pequeno furo no fundo, passamos um colchete metálico (de tamanho número 5 ou 7, por exemplo), preenchemos com gesso mole e esperamos secar com a boca virada para cima. Depois de seco viramos o copo com a boca para baixo e com as duas pernas do colchete para cima, Figura 2.1. 


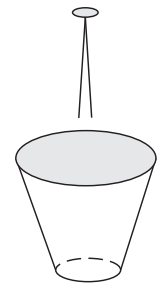

(a)

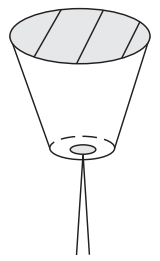

(b)

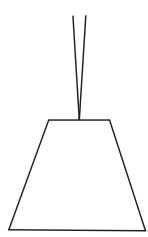

(c)

Figura 2.1: (a) Copinho plástico de café e colchete (b) Copinho preenchido com gesso amolecido. (c) Suporte para o eletroscópio e para o pêndulo elétrico feito de copinho de café, colchete e gesso.

Também podem ser utilizados outros suportes tais como um pedaço de massa de modelar com um prego, palito, clipe ou colchete atravessando-o, sendo que o prego, palito, clipe ou colchete vão ficar dentro de um canudo, apoiando o canudo na vertical. ${ }^{1}$ Também pode ser utilizada uma base de madeira, um prato ou copo de plástico ou de isopor com um furo no meio onde o canudo será encaixado. $^{2}$

Lembramos aqui o eletroscópio simples que usamos em todas as experiências do Volume 1, Figura 2.2: ${ }^{3}$

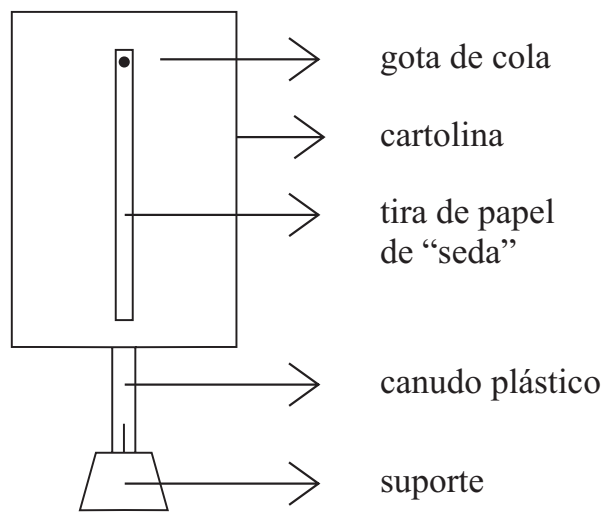

Figura 2.2: Eletroscópio visto de frente.

A cartolina ou papel cartão pode ter, por exemplo, $7 \mathrm{~cm}$ por $10 \mathrm{~cm}$, ficando o lado maior na vertical. A tira de papel de "seda" deve ter uns $9 \mathrm{~cm}$ de

\footnotetext{
${ }^{1}$ [FM91, pág. 10], [Ferb, Material para experiências em eletrostática, págs. 1-2], Seção 4.4 de [Ass10b], [Ass10a], [Ass11], [Ass15b] e [Ass17].

2 [Gas03, págs. 225-6].

${ }^{3}$ Seções 6.1 e 6.5 de [Ass10b], [Ass10a], [Ass11], [Ass15b] e [Ass17].
} 
comprimento, sendo bem fina, com 1 a $3 \mathrm{~mm}$ de largura. A tira pode ser feita de papel de "seda" utilizado para construir pipas ou papagaios, ou então para cobrir balas de coco. Estamos colocando a palavra "seda" entre aspas pois, na verdade, estes papéis não são feitos de seda. Só recebem este nome por terem uma espessura muito pequena, sendo quase transparentes.

Na Figura 2.3 apresentamos o eletroscópio de frente, de costas e de perfil.

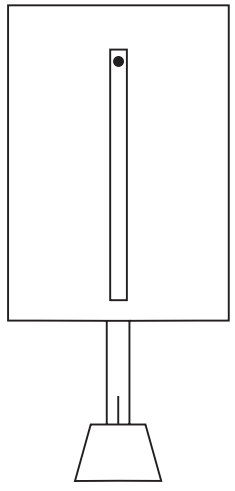

(a)

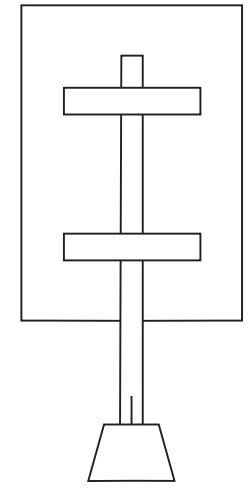

(b)

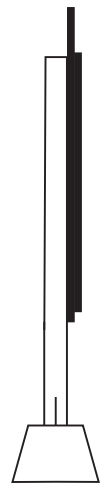

(c)

Figura 2.3: (a) Eletroscópio visto de frente. (b) De costas. (c) De perfil.

\subsubsection{Principais Componentes do Eletroscópio}

Tanto a cartolina quanto o papel de "seda" comportam-se como condutores nas experiências de eletrostática. Já o canudo plástico que sustenta a cartolina comporta-se como isolante, sendo o elemento mais importante do eletroscópio. É ele que impede a fuga de cargas para a Terra quando o eletroscópio está eletrizado. Também o ar seco funciona como um isolante. Na Figura 2.4 apresentamos as principais componentes de um eletroscópio.

Se em vez do canudo de plástico tivéssemos um palito de madeira de churrasco ou então um arame, o eletroscópio eletrizado se descarregaria para a Terra através do palito ou do arame. Isto é, não seria possível manter o eletroscópio carregado depois de ter sua cartolina raspada com uma régua previamente eletrizada. Um espeto de madeira ou um arame comportam-se como condutores na eletrostática.

\subsubsection{Comparação entre o Eletroscópio de Folhas de Ouro e o Eletroscópio Feito com Materiais de Baixo Custo}

Os livros didáticos apresentam usualmente o eletroscópio quando discutem condutores e isolantes, ou quando mencionam a eletrização por indução ou polarização. Normalmente eles citam apenas o eletroscópio de folhas de ouro, 


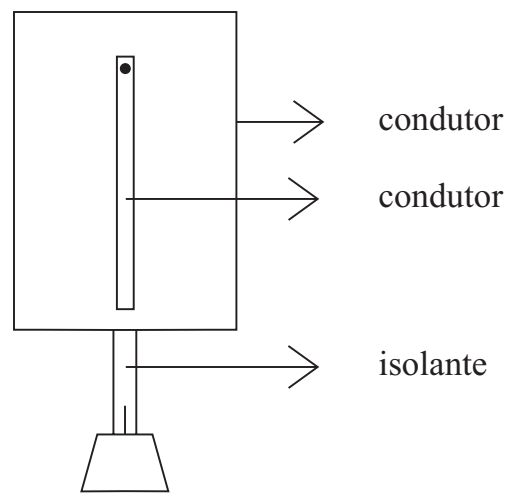

Figura 2.4: Composição de um eletroscópio.

mostrando figuras ou fotos do instrumento. Este eletroscópio possui duas folhas móveis que se abrem quando estão eletrizadas. Estes livros usualmente não explicam como fazer um eletroscópio com material simples e facilmente acessível.

Contudo, o eletroscópio apresentado nesta Seção funciona perfeitamente bem. Ele é muito sensível. Sua tirinha de papel de "seda" levanta facilmente com uma pequena eletrização do instrumento. Ela é muito leve e está presa à cartolina apenas pela gota de cola na parte superior, com o restante da tirinha podendo se afastar da cartolina sem que haja qualquer impedimento, basta que o eletroscópio fique um pouco eletrizado. O canudo plástico é um excelente isolante, garantindo a preservação de qualquer carga adquirida pelo instrumento, especialmente em dias secos e frios.

A grande vantagem deste instrumento simples em relação ao eletroscópio com folhas de ouro é que ele pode ser facilmente construído pelo professor ou até mesmo por cada aluno. O custo é essencialmente nulo. O instrumento é muito sensível e com ele podem ser feitas inúmeras experiências. Este fato confere uma grande autonomia aos alunos, fazendo com que se apoderem deste conhecimento.

Um aluno normalmente não vai pensar em construir um eletroscópio de folhas de ouro já que deve ser muito caro simplesmente por conter ouro. Só o nome já sugere algo científico e difícil de ser feito, já que não é um material qualquer. Muitos podem até mesmo pensar que há vácuo no interior do recipiente de vidro que envolve o eletroscópio. Este fato faz com que os alunos fiquem apáticos diante da explicação fornecida pelos livros didáticos, não estimulando sua criatividade, não sugerindo que eles próprios podem construir este instrumento ou tentar as experiências com suas próprias mãos.

\subsubsection{O Eletroscópio e a Descoberta dos Raios Cósmicos}

Para ilustrar a importância do eletroscópio vamos falar da descoberta dos raios cósmicos. Há muito tempo se sabia que um eletroscópio eletrizado é descarre- 
gado lentamente no ar. Uma das causas da condutividade do ar é a presença de íons na atmosfera, ou seja, de partículas eletrizadas. Desde 1896 Henri Becquerel (1852-1908) havia verificado que sais de urânio emitiam raios ionizantes que aumentavam a condutividade do ar. Os raios $\gamma$ (radiação eletromagnética de alta frequência), em particular, possuem esta característica ionizante. Eles penetram até uma certa distância no ar quando então interagem com átomos neutros, ionizando-os. Para saber a origem da ionização do ar, no início do século XX começaram a ser feitas pesquisas sobre a condutividade atmosférica em diferentes altitudes. A maioria dos pesquisadores da época acreditava que a origem da radiação ionizante estava no interior da Terra devido à presença de substâncias radioativas. Um trabalho fundamental neste campo foi feito pelo físico austríaco-estadunidense Victor Franz Hess (1883-1964). Suas pesquisas sobre os raios cósmicos foram feitas principalmente entre 1911 e 1913. Fez voos de balão neste período levando consigo eletroscópios desenvolvidos por Theodor Wulf (1868-1946) no qual a eletrização é indicada pela separação entre dois fios condutores. Eletrizava estes eletroscópios até uma separação específica entre os dois fios condutores e media o tempo que levava para serem descarregados em função da altitude. Chegou a voar até $5,3 \mathrm{~km}$ acima do nível do mar. Hess encontrou que o nível de radiação diminuía até uma altitude de aproximadamente $1 \mathrm{~km}$, aumentando consideravelmente desde então, podendo chegar a duas vezes o nível da radiação a nível do mar quando estava a $5 \mathrm{~km}$ de altura. Concluiu então que a radiação vinha do espaço, não tendo origem terrestre. Voou também durante um eclipse solar e à noite, encontrando que o nível da radiação era muito próximo do valor durante o dia, concluindo que a fonte não era o Sol. Sua conclusão final foi que a radiação penetrando a atmosfera vinha do espaço, sendo esta radiação chamada então de ultra-radiação. O nome atual de "radiação cósmica" foi introduzido por Robert A. Millikan em 1925. Millikan foi outro pesquisador dos raios cósmicos e do efeito fotoelétrico, tendo recebido o prêmio Nobel em 1923 pela medida da carga do elétron, como discutido na Subseção 1.2.1. Hess recebeu o prêmio Nobel de física em 1936 pela descoberta da radiação cósmica, compartilhando-o com Carl David Anderson (1905-1991), físico estadunidense, que descobriu o pósitron em 1932.

O eletroscópio foi essencial na criação de uma nova área de pesquisa em física, a saber, a radiação cósmica.

\subsection{O Versório}

Os instrumentos elétricos mais antigos são o perpendículo de Girolamo Fracastoro (1478-1553) e o versório de William Gilbert (1544-1603). ${ }^{4}$ Vamos aqui apresentar os principais tipos de versório.

\footnotetext{
${ }^{4}$ Capítulo 3 de [Ass10b], [Ass10a], [Ass11], [Ass15b] e [Ass17].
} 


\subsubsection{O Versório Metálico Apoiado sobre um Alfinete}

Um versório simples pode ser feito com um colchete tendo uma pequena deformação em seu centro, sem ser furado. O versório é então apoiado por esta deformação sobre a ponta de um alfinete fincado em uma rolha, com liberdade para girar ao redor do alfinete, figura 2.5 .

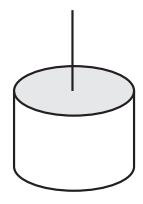

(a)

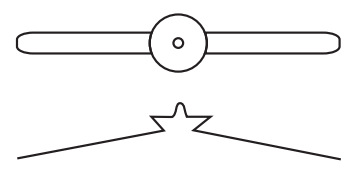

(b)

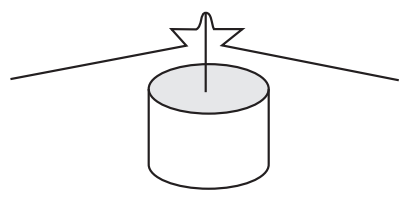

(c)

Figura 2.5: Versório metálico. (a) Alfinete preso na base. (b) Colchete visto de cima e de perfil. (c) O versório montado.

\subsubsection{O Versório Metálico Apoiado sobre um Plástico Pon- tudo}

Em vez de apoiar o versório metálico sobre um alfinete de metal, podemos fazer com que fique apoiado sobre um canudo plástico pontudo, tendo ainda liberdade para girar ao redor do canudo. A diferença principal em relação ao versório apoiado sobre um alfinete é que o plástico é um material que se comporta como um bom isolante. Logo o colchete vai estar isolado eletricamente da Terra, podendo acumular uma carga resultante não nula se for eletrizado. Caso um corpo eletrizado fique próximo deste versório, o versório vai se polarizar eletricamente.

Para montar este versório basta cortar um canudo plástico com uns $5 \mathrm{~cm}$ de comprimento. Em seguida faz-se uma ponta em um dos lados do pedaço de canudo com uma tesoura. O canudo é então apoiado no suporte de gesso da Figura 2.1 com a ponta para cima, como mostrado na Figura 2.6 (a). O versório metálico de colchete da Figura 2.5 fica agora apoiado sobre o canudo plástico, Figura 2.6 (c).

\subsubsection{O Versório de Plástico}

O versório de plástico aparece na Figura 2.7. Em (a) temos sua base, neste caso um prego preso a uma tábua, com a ponta para baixo. Uma maneira prática de fazer um versório de plástico é fixando o alfinete na parte móvel horizontal do versório, feita de plástico, Figura 2.7 (b). Vamos chamar de "chapéu" à parte horizontal do versório de plástico na qual é fixada o alfinete. O alfinete deve furar o chapéu, atravessando-o em seu ponto médio, com a ponta do alfinete apontando para baixo. O alfinete fica preso ao versório e gira junto com ele em relação ao laboratório. Este sistema é então apoiado sobre uma pequena 


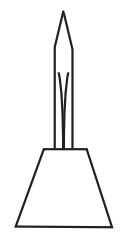

(a)

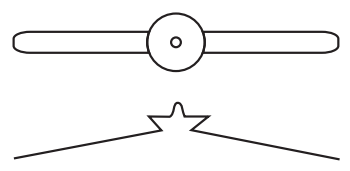

(b)

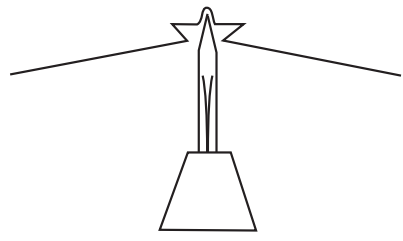

(c)

Figura 2.6: Versório metálico apoiado sobre um canudo plástico pontudo. (a) Suporte da Figura 2.1 com um canudo de plástico pontudo ao redor das duas pernas do colchete. (b) Colchete metálico visto de cima e de perfil. (c) O versório metálico apoiado sobre o plástico pontudo.

superfície horizontal plana, como a cabeça de um prego fixado em uma tábua ou fincado em uma rolha. O chapéu tem suas abas voltadas para baixo. Na Figura 2.7 (c) temos o versório montado, com a ponta do alfinete apoiada sobre a cabeça horizontal do prego.

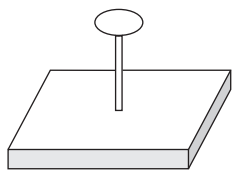

(a)

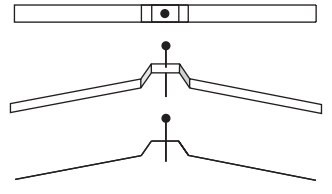

(b)

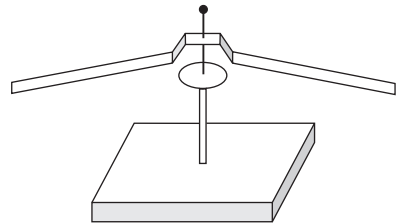

(c)

Figura 2.7: Versório de plástico, com o alfinete fixado na parte móvel horizontal do versório. (a) Base fixa do versório. (b) Chapéu do versório (tira de plástico) com o alfinete preso nele. (c) Versório montado.

Observação importante: Para que o versório não tombe, é crucial que o centro de gravidade da parte móvel do sistema (composta pelo chapéu e pelo alfinete preso nele) esteja abaixo da ponta do alfinete.

\subsubsection{Versório de Du Fay}

O versório de Du Fay é feito de plástico com um pedaço de papel de alumínio em uma das pontas, Figura 2.8.

\subsubsection{Principais Componentes Destes Versórios}

As componentes fundamentais destes quatro tipos de versório estão apresentadas na Figura 2.9.

No caso do versório metálico usual, Figura 2.9 (a), temos um condutor horizontal (como o colchete metálico) apoiado sobre um outro condutor, em geral 


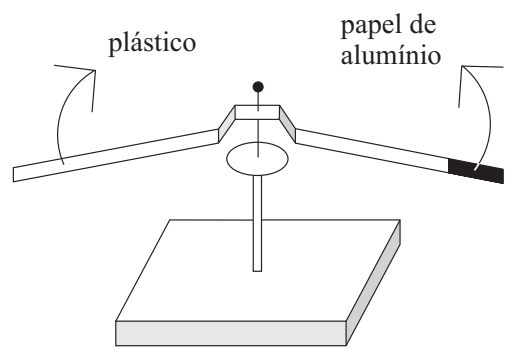

Figura 2.8: Versório de Du Fay.

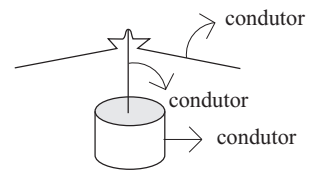

(a)

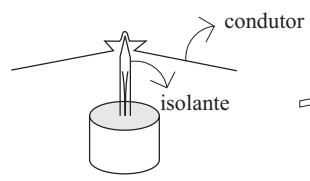

(b)

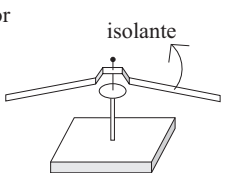

(c)

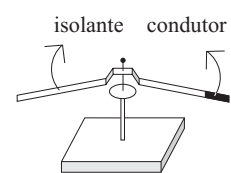

(d)

Figura 2.9: Composição dos diferentes tipos de versório. (a) Versório metálico sobre alfinete metálico. (b) Versório metálico sobre plástico pontudo. (c) Versório de plástico. (d) Versório de Du Fay.

um alfinete metálico vertical fincado na madeira ou na rolha. Ou seja, todos os elementos deste versório são condutores. O versório metálico apoiado sobre um plástico pontudo, Figura 2.9 (b), é feito de um material condutor apoiado sobre um isolante. O versório de plástico, Figura 2.9 (c), é feito com um chapéu horizontal isolante. Em geral seu eixo é um condutor, como o alfinete preso em seu centro, mas o material de que é feito este eixo não é tão relevante. Já o versório de Du Fay, Figura 2.9 (d), é feito com um material isolante na horizontal (o plástico), possuindo um condutor em uma única ponta (o papel de alumínio). Em geral não é importante o material de que é feito o eixo vertical ao redor do qual ele gira.

\subsection{O Pêndulo Elétrico}

Apresentamos aqui alguns tipos básicos de pêndulos elétricos. ${ }^{5}$

\subsubsection{O Pêndulo Elétrico Clássico}

O pêndulo elétrico clássico é apresentado na Figura 2.10.

Temos um pequeno disco de papel ou de papel de alumínio amarrado na ponta de uma linha de seda, poliamida (tal como náilon) ou poliéster. A ponta

\footnotetext{
${ }^{5}$ [FM91, pág. 47], [Ferb, Eletrização por contato: Pêndulo, pág. 8; Eletrização por indução: Pêndulo, pág. 14; e Campo elétrico: Vetor, pág. 22], [Gas03, págs. 228-229] e Seções 4.4, 4.10 e 7.6 de [Ass10b], [Ass10a], [Ass11], [Ass15b] e [Ass17].
} 


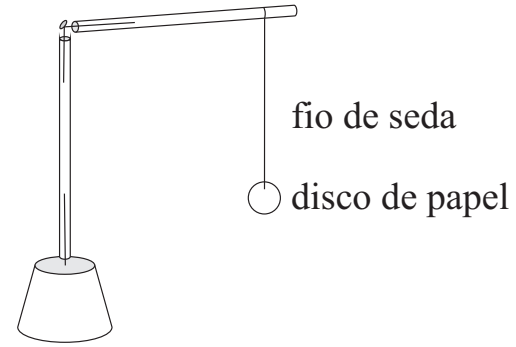

Figura 2.10: Pêndulo elétrico com suporte.

superior da linha é amarrada em um canudo plástico, que é ligado a outro canudo plástico por um colchete. Todo o pêndulo é apoiado em um outro colchete preso em um copinho de café com gesso como aquele da Figura 2.1.

\subsubsection{O Pêndulo de Seta}

Uma variação deste pêndulo apropriada para indicar o poder das $\operatorname{pontas}^{6}$ e o mapeamento da força elétrica é o pêndulo elétrico no formato de seta. Neste caso substituímos o disco de papel por uma seta de papel ou de papel de alumínio. A seta é suspensa em um fio de seda ou de poliéster. O fio também pode ser de poliamida, tal como náilon, desde que a seta tenha liberdade para girar ao redor do fio vertical. Para que ela tenha esta liberdade, se o fio for de náilon, o ideal é que o fio seja bem fino e maleável. A seta pode ser amarrada diretamente no fio, Figura 2.11 (a), ou então colada ao redor de um canudo plástico, Figura 2.11 (b). Na posição de equilíbrio ela deve apontar na direção horizontal.

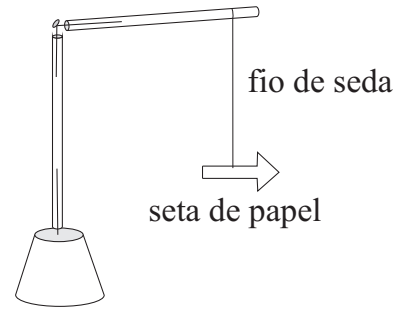

(a)

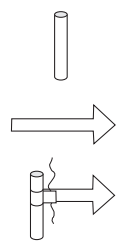

(b)

Figura 2.11: Pêndulo elétrico no formato de seta.

\footnotetext{
${ }^{6}$ Assunto a ser discutido no Capítulo 9.
} 


\subsubsection{O Pêndulo de Plástico}

Por último deve ser feito um pêndulo elétrico de plástico no qual substituímos o disco de papel por um disco de plástico, Figura 2.12. O plástico deve ser fino e leve, como as sacolas descartáveis de supermercado. Além disso, antes de construir este pêndulo deve-se confirmar que este plástico está neutro e que se comporta como um isolante para as experiências de eletrostática.

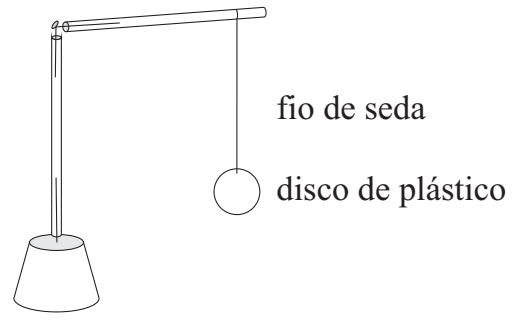

Figura 2.12: Pêndulo elétrico de plástico.

\subsubsection{Principais Componentes Destes Pêndulos}

As componentes fundamentais destes três tipos de pêndulo estão indicadas na Figura 2.13.

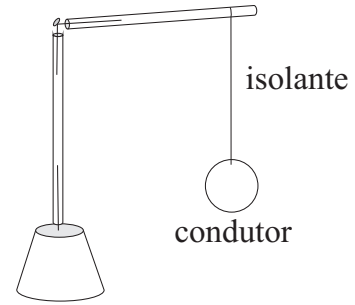

(a)

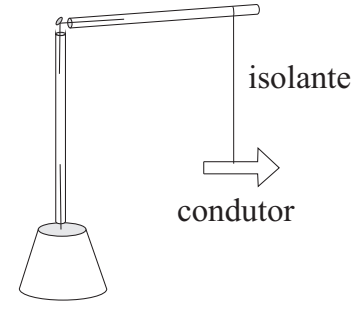

(b)

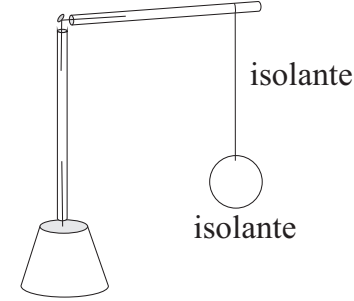

(c)

Figura 2.13: (a) Pêndulo elétrico clássico. (b) Pêndulo elétrico no formato de seta. (c) Pêndulo elétrico de plástico.

\subsection{A Linha Pendular de Gray}

Apresentamos agora a "linha pendular," um instrumento construído intencionalmente por Stephen Gray (1666-1736) em 1729 e chamado por ele de a pendulous thread. ${ }^{7}$

\footnotetext{
${ }^{7}$ [Grab], [Grad], [Grag] e Seção 4.9 de [Ass10b], [Ass10a], [Ass11], [Ass15b] e [Ass17].
} 
Ele é simplesmente uma linha fina de linho ou de algodão presa a uma vareta de madeira, Figura 2.14 (a). Ao contrário do pêndulo elétrico que utilizava um fio de seda ou de náilon, agora é importante que o fio seja de algodão ou de linho. A vareta de madeira é segurada com a mão e mantida na horizontal.

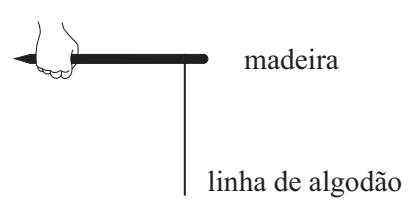

(a)

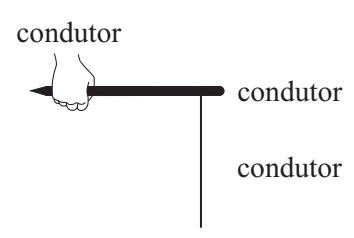

(b)

Figura 2.14: (a) Linha pendular de Gray. (b) Principais componentes deste instrumento.

As principais componentes de uma linha pendular estão representadas na Figura 2.14. Ou seja, temos uma linha condutora presa a uma vareta condutora e aterrada pela mão.

Gray utilizava sua linha pendular para testar se os corpos estavam ou não carregados eletricamente. Com esta finalidade ele colocava a linha pendular próxima a um corpo. Caso a linha pendular fosse atraída pelo corpo, inclinandose no sentido do corpo, isto indicava que o corpo estava eletrizado. Caso a linha permanecesse vertical, isto indicava que o corpo estava neutro.

\subsection{Coletores de Carga}

Os coletores de carga são instrumentos utilizados para coletar partículas eletrizadas de um corpo eletrizado. ${ }^{8}$ Depois de coletadas, pode-se analisar se estas partículas são positivas ou negativas, se o corpo está muito ou pouco eletrizado (ou seja, determinar sua densidade superficial de carga), etc. Ele também serve para transportar partículas eletrizadas entre dois condutores separados espacialmente.

A estrutura básica de um coletor de carga é a de um condutor (C) preso a um suporte ou cabo isolante (I). Seguramos e manipulamos o coletor apenas pelo isolante, sem tocar no condutor. O condutor entra em contato com o corpo eletrizado que queremos analisar. Durante este contato ocorre uma transferência de partículas eletrizadas tal que o coletor fica eletrizado com cargas de mesmo sinal que o corpo eletrizado. Na Figura 2.15 apresentamos alguns destes coletores.

Na Figura 2.15 (a) podemos ter, por exemplo, um pêndulo elétrico. O isolante pode ser uma linha de seda, náilon ou poliamida. O condutor pode ser um disco de papel ou de papel de alumínio. Ele também pode ser uma bolinha de

\footnotetext{
${ }^{8}$ Seção 7.2 de [Ass10b], [Ass10a], [Ass11], [Ass15b] e [Ass17].
} 

(a) $\bigodot_{\mathrm{C}}^{\mathrm{I}}$
(b)
$\bigoplus^{C}$
(c)

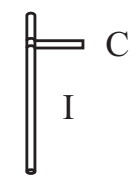

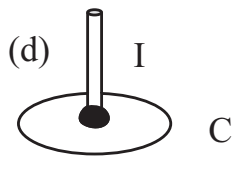

(e)

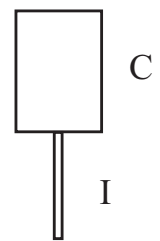

Figura 2.15: Coletores de carga compostos por um condutor $C$ preso a um suporte ou cabo isolante $I$.

cortiça ou da medula envelhecida de plantas como o sabugueiro, como se utilizava antigamente. Na Figura 2.15 (b) podemos ter um canudo plástico preso a uma bola de papel de alumínio, ou um tubo de PVC preso a uma esfera metálica. Na Figura 2.15 (c) podemos ter uma tirinha de papel de alumínio presa a um canudo plástico. Na Figura 2.15 (d) podemos ter um disco de cartolina ou de papel cartão preso a um canudo plástico por massa de modelar. Também pode ser uma tampa metálica de alguma lata de alimentos ou uma forma de alumínio de pizza fixada no centro a um tubo de PVC com cola araldite. Na Figura 2.15 (e) podemos ter um eletroscópio sem a tirinha de papel de "seda", isto é, um retângulo de cartolina ou de papel cartão preso a um canudo plástico.

O modelo da Figura 2.15 (d) é chamado de plano de prova de Coulomb, em homenagem ao seu inventor, Charles Augustin de Coulomb, Figura 2.16.

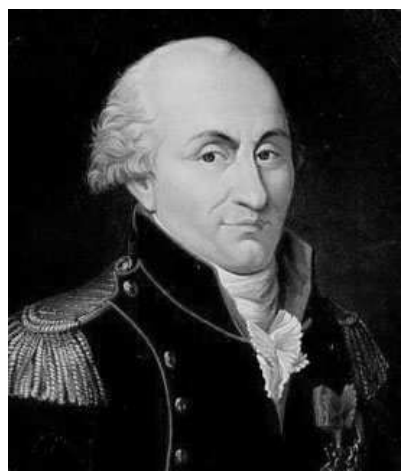

Figura 2.16: Charles-Augustin de Coulomb (1736-1806).

O plano de prova nada mais é do que um disco condutor preso no centro de 
um dos lados por um suporte isolante. Coulomb o utilizou para determinar a distribuição de carga ao longo das superfícies de dois ou mais condutores eletrizados que estavam em contato (esferas metálicas se tocando, por exemplo). A quantidade de carga armazenada pelo plano de prova é proporcional à densidade superficial de carga no local do condutor que ele toca. O modelo que vamos utilizar aqui é um disco de cartolina com $3 \mathrm{~cm}$ de diâmetro. Pode-se colar papel de alumínio sobre uma das faces, mas isto não é essencial. Corta-se um pedaço de um canudo de plástico tendo $5 \mathrm{~cm}$ de comprimento. O canudo vai ficar ortogonal ao disco, como se fosse seu eixo de simetria. Uma das extremidades do canudo é presa no centro do disco com cola ou com um pedaço de massa de modelar, Figura 2.17. Quando se manipula o plano de prova, deve-se tocar apenas no canudo, mas não na massa de modelar nem no disco de cartolina.

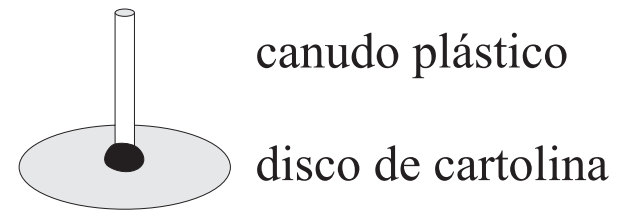

Figura 2.17: Plano de prova de Coulomb.

\subsection{Circuito de Teste}

Para construir um circuito de teste utilizamos uma pilha $\mathrm{D}$ de $1,5 \mathrm{~V}$, uma lâmpada de lanterna que acenda com $1,5 \mathrm{~V}$ enroscada em um bocal ou soquete apropriado, assim como 3 fios metálicos desencapados nas pontas, Figura 2.18.

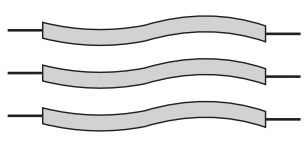

(a)

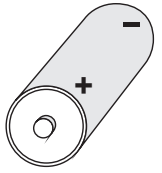

(b)

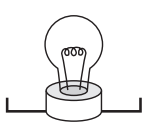

(c)

Figura 2.18: (a) Três fios desencapados nas pontas. (b) Uma pilha. (c) Uma lâmpada.

Para testar o comportamento isolante ou condutor dos corpos quando submetidos a baixas diferenças de potencial montamos o circuito de teste indicado na Figura 2.19.

A extremidade de um destes fios é ligada ao terminal negativo da pilha com uma fita adesiva ou prendendo-a com a mão, sendo sua outra extremidade indicada pela letra $A$ na Figura 2.19. O segundo fio é ligado entre o terminal positivo da pilha (prendendo sua extremidade ao terminal positivo da pilha com uma fita adesiva ou com a mão) e a um dos contatos do bocal da lâmpada. Uma 


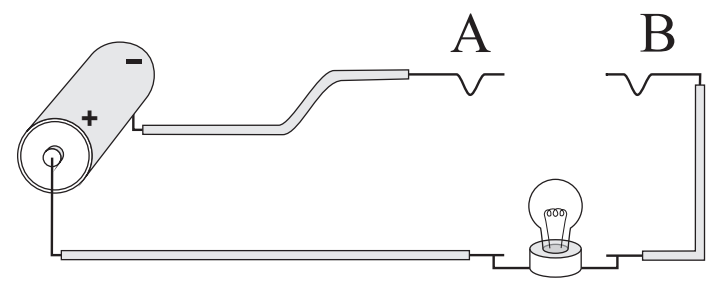

Figura 2.19: Montagem para testar se uma certa substância é condutora ou isolante.

extremidade do terceiro fio é ligada no outro contato do bocal da lâmpada, sendo sua outra extremidade representada pela letra $B$ na figura.

Podemos agora colocar várias substâncias entre $A$ e $B$ para testar seu comportamento condutor ou isolante. Se a lâmpada acender, o material será classificado como condutor. Se a lâmpada não acender, o material será classificado como isolante. Estas experiências serão apresentadas na Seção 3.2. 


\section{Capítulo 3}

\section{Condutores e Isolantes}

Um dos aspectos mais importantes de toda a ciência da eletricidade é a distinção entre condutores e isolantes. Antes de começar qualquer experiência é fundamental testar os corpos para saber se eles vão se comportar como condutores ou como isolantes. E o instrumento crucial para fazer este teste na eletrostática é o eletroscópio.

\subsection{Classificando os Corpos como Condutores ou Isolantes pelo Eletroscópio}

Experiência 3.1 - Carregando um eletroscópio pelo contato com um corpo eletrizado

Eletrizamos uma régua de acrílico ou um canudo plástico ao atritá-los rapidamente contra o cabelo ou contra um guardanapo de papel. Em seguida eletrizamos ou carregamos um eletroscópio ao raspar a parte de cima da cartolina com este canudo eletrizado, Figura 3.1. Vimos que neste caso o eletroscópio fica eletrizado com carga de mesmo sinal que a do canudo eletrizado. ${ }^{1}$

\section{Definição 3.1}

Dizemos que o eletroscópio adquiriu uma carga elétrica devido ao contato com um outro corpo previamente carregado, ou que ficou carregado por contato, eletrizado por contato ou eletrificado por contato. O processo é chamado de carga por contato, transferência de cargas por contato, eletrização por contato ou eletrificação por contato.

Experiência 3.2 - Descarregando um eletroscópio ao tocá-lo com a mão

\footnotetext{
${ }^{1}$ Experiência 6.5 de [Ass10b], [Ass10a], [Ass11], [Ass15b] e [Ass17].
} 


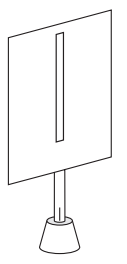

(a)

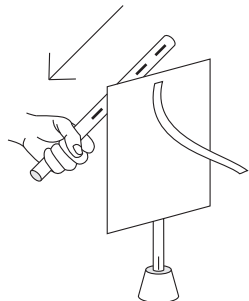

(b)

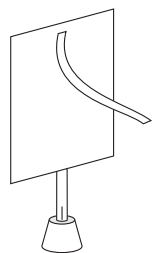

(c)

Figura 3.1: (a) Eletroscópio com a tirinha inicialmente abaixada. (b) Raspa-se a parte superior da cartolina com um plástico atritado. (c) Ao afastar o plástico observa-se que a tirinha fica levantada.

Ao tocar na cartolina com o dedo observa-se que a tirinha do eletroscópio abaixa imediatamente, permanecendo abaixada depois que o dedo é afastado, Figura 3.2.

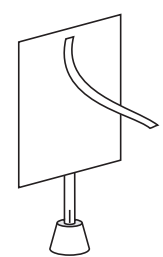

(a)

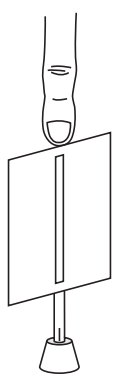

(b)

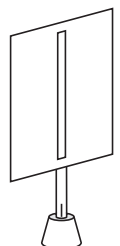

(c)

Figura 3.2: Descarregando um eletroscópio pelo contato com o dedo. (a) Eletroscópio inicialmente carregado. (b) Toca-se na cartolina com o dedo e a tirinha abaixa. (c) Afasta-se o dedo e a tirinha permanece abaixada.

O eletroscópio foi descarregado por este processo, que recebe um nome especial: 


\section{Definição 3.2}

Diz-se que o eletroscópio carregado perdeu sua carga elétrica pelo contato com o dedo, ou que foi descarregado pelo contato, ficando descarregado eletricamente ou, simplesmente, descarregado. O processo é chamado de descarga por contato ou descarga por aterramento. O processo também é chamado de aterrar, aterramento elétrico ou simplesmente aterramento. A origem para estes nomes é que o corpo carregado está sendo descarregado pelo corpo humano, que está em contato com a Terra.

Em vez de ficar desenhando o dedo, muitas vezes utiliza-se um símbolo especial para representar o aterramento, como indicado na Figura 3.3 (b).

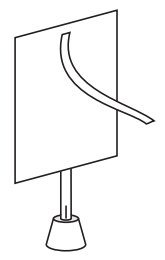

(a)

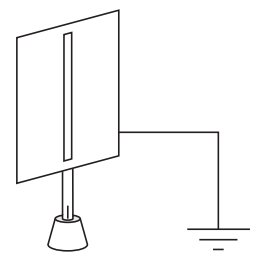

(b)

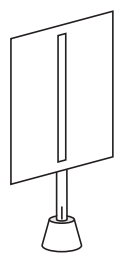

(c)

Figura 3.3: Símbolo para representar o aterramento, substituindo o dedo da Figura 3.2 .

Experiência 3.3 - Tocando um eletroscópio carregado com um canudo plástico neutro

A experiência mais importante que pode ser feita com um eletroscópio eletrizado é tocar na parte superior da cartolina com um corpo preso à mão. Na Figura 3.4 mostramos que nada acontece ao tocá-lo com um canudo plástico neutro. Ou seja, o eletroscópio continua eletrizado.

O eletroscópio não é descarregado ao tocá-lo com um plástico preso à mão.

Experiência 3.4 - Tocando um eletroscópio carregado com um arame

Na Figura 3.5 mostramos o que acontece ao tocar a cartolina de um eletroscópio eletrizado com um espeto de madeira ou com um arame preso à mão. Mais uma vez observamos que o eletroscópio é descarregado, desta vez pela madeira ou pelo arame, assim como havia acontecido ao tocar na cartolina diretamente com o dedo, como na figura 3.2.

Nesta experiência deve-se utilizar um palito de madeira bruta, tal como um palitinho de churrasco. Não se deve empregar uma madeira pintada nem envernizada, já que a tinta ou o verniz podem ser isolantes, afetando desta maneira o resultado da experiência. 


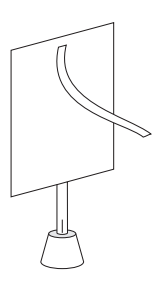

(a)

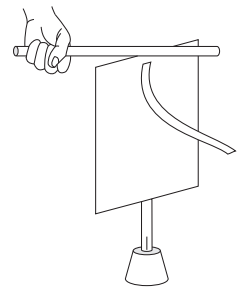

(b)

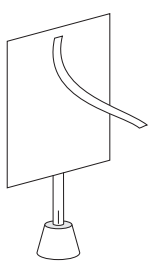

(c)

Figura 3.4: (a) Eletroscópio inicialmente carregado. (b) Toca-se em sua cartolina com a ponta de um canudo plástico neutro preso à mão. Nada ocorre com a tirinha. (c) Afasta-se o canudo e a tirinha continua levantada.

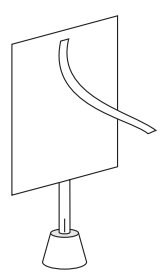

(a)

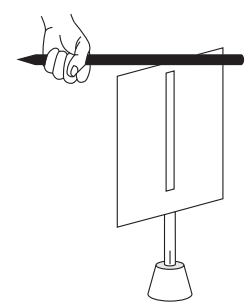

(b)

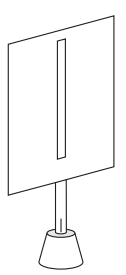

(c)

Figura 3.5: (a) Eletroscópio inicialmente carregado. (b) Toca-se em sua cartolina com a ponta de um palito de madeira ou com um arame preso à mão. A tirinha abaixa imediatamente. (c) Afasta-se o palito e a tirinha continua abaixada.

O eletroscópio é descarregado imediatamente ao tocá-lo com um arame preso à mão. O mesmo ocorre com a maioria dos espetos de madeira presos à mão. Porém, dependendo do tipo de madeira, pode ser percebido que a descarga é rápida mas não instantânea, levando alguns segundos para descarregar o eletroscópio.

Observamos aqui mais uma vez o descarregamento do eletroscópio eletrizado, assim como havia acontecido na Experiência 3.2, Figura 3.2. Desta vez a descarga ocorreu através do palito de madeira ou do arame.

\subsubsection{Definição de Condutor e Isolante quando é Aplicada uma Alta Diferença de Potencial entre as Extremi- dades do Corpo}

O eletroscópio permite observar a existência de dois conjuntos de corpos na natureza, a saber, os condutores e os isolantes. No caso das experiências usuais de eletrostática podemos fazer as seguintes definições fundamentais: 


\section{Definição 3.3}

Os condutores de eletricidade, condutores elétricos ou simplesmente condutores são os corpos que, sendo segurados pela mão, descarregam um eletroscópio eletrizado ao tocarem na parte superior da cartolina, como ocorreu na Experiência 3.4. Já os isolantes são os corpos que, sendo segurados pela mão, não descarregam um eletroscópio eletrizado ao tocarem na parte superior da cartolina, como ocorreu na Experiência 3.3. Estes corpos também são chamados de não condutores ou de dielétricos.

\subsubsection{Corpos que se Comportam como Condutores ou Iso- lantes nas Experiências Usuais de Eletrostática}

Ao realizar atividades como as Experiências 3.3 e 3.4 com diversos materiais obtemos os seguintes resultados: ${ }^{2}$

\section{- Condutores para experiências comuns de eletrostática:}

Ar úmido, corpo humano, todos os metais, papel, cartolina, papel de alumínio, papel de "seda," papelão, madeira, algodão, giz, boa parte dos vidros à temperatura ambiente, porcelana, parede, lousa, cortiça, farinha de trigo, fubá, fio de acrílico, sal, açúcar, serragem, couro, terra, tijolo, alguns tipos de borracha, sabonete, gelo, etc.

\section{- Principais isolantes para experiências comuns de eletrostática:}

Ar seco, seda, resinas naturais como o âmbar e resinas sintéticas como os plásticos em geral.

Experimentalmente verifica-se que existe um número muito maior de substâncias condutoras do que de substâncias isolantes. A partir destas duas listas conclui-se que a maior parte dos materiais comporta-se como um condutor, bem poucos materiais comportam-se como isolantes. Entre os condutores alguns são muito bons, descarregando o eletroscópio quase que instantaneamente, como é o caso do corpo humano, dos metais, do algodão ou do papel. Embora a madeira seja condutora, ela não conduz tão bem quanto os metais ou o corpo humano. Isto é indicado pelo maior tempo necessário para descarregar o eletroscópio quando o tocamos com a madeira, comparado com o tempo muito curto quando o tocamos com nosso corpo ou com algum metal.

Entre as substâncias isolantes temos essencialmente o ar seco, a seda (linha ou pano), as resinas naturais (âmbar, copal, laca ou goma-laca), assim como as resinas sintéticas (plásticos em geral, PVC, náilon ou poliamida, poliéster, acrílico, isopor, etc.)

Os plásticos foram uma grande invenção do século XX. A primeira resina sintética, a baquelite, foi criada por Leo Hendrik Baekeland (1863-1944), sendo apresentada à Sociedade Americana de Química em 1909. Ele é usualmente

\footnotetext{
${ }^{2}$ Capítulo 6 de [Ass10b], [Ass10a], [Ass11], [Ass15b] e [Ass17].
} 
considerado o pai da indústria química. Estas resinas receberam o nome genérico de "plástico" pois podiam ser fundidas e moldadas na forma desejada. Além destas substâncias, podemos citar como isolantes alguns vidros aquecidos, a lã, um fio de cabelo, uma barra de chocolate, café em pó, parafina e outros tipos de borracha (diferentes das borrachas condutoras).

Estas duas listas não devem ser aceitas de forma irrestrita. Cada pessoa deve construir seu eletroscópio e testar ela própria diferentes materiais. O motivo para este cuidado é que existem muitos fatores que podem afetar o comportamento condutor ou isolante de qualquer substância. Entre estes fatores citamos a composição química do corpo, impurezas superficiais, processo de fabricação, idade do material etc.

Damos aqui apenas um exemplo. Um tubo de PVC em geral comporta-se como um bom isolante, não descarregando um eletroscópio eletrizado. Uma vez construímos um gerador eletrostático gotejante de Kelvin utilizando tubos de PVC como isolantes. ${ }^{3}$ Tivemos de fazer mais de uma montagem até que funcionasse. Descobrimos que em uma das montagens que não funcionou o problema era um tubo de PVC que estávamos usando achando que era isolante. Depois verificamos que este tubo em particular comportava-se como condutor. Não chegamos a investigar o motivo deste comportamento anômalo deste tubo de PVC particular. Ao ser trocado por um outro tubo que foi previamente testado como sendo um bom isolante, tivemos sucesso na montagem e na produção da faísca com este gerador.

\section{Experiência 3.5 - Tocando um eletroscópio carregado com água}

Podemos verificar por um procedimento similar quais líquidos são condutores ou isolantes. Antes de começar a experiência, pega-se um copo ou um pote vazio que depois será preenchido com o líquido a ser testado. É melhor que o recipiente seja condutor. Para verificar isto, carrega-se um eletroscópio, segurase o copo ou pote com a mão e toca-se o copo na parte superior da cartolina do eletroscópio. Caso a tirinha abaixe, isto vai significar que o copo ou pote é de fato condutor. Exemplos de condutores são copos de metal ou de madeira. Alguns tipos de copos de vidro também se comportam condutores na temperatura ambiente. Pode-se então prosseguir a experiência.

Inicialmente o copo é cheio até a borda com o líquido que se quer testar. Vamos ilustrar o que ocorre no caso de um líquido condutor como a água de torneira. Isto está ilustrado na Figura 3.6.

Neste caso temos na Figura 3.6 (a) um eletroscópio carregado, seguro apenas por seu canudo, sem tocarmos em sua cartolina ou na tirinha de papel de "seda". Afunda-se uma quina do eletroscópio eletrizado em um copo cheio de água até a borda. Deve-se evitar de tocar com a cartolina no copo. No caso da água, observa-se que a tirinha abaixa imediatamente após o toque, Figura 3.6 (b). Ao retirarmos o eletroscópio da água, observa-se que a tirinha permanece abaixada, Figura 3.6 (c).

O eletroscópio eletrizado foi descarregado ao entrar em contato com a água.

\footnotetext{
${ }^{3}$ [Cam06], [CA08] e Seção 7.12 de [Ass10b], [Ass10a], [Ass11], [Ass15b] e [Ass17].
} 


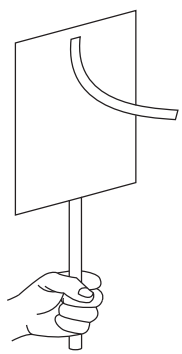

(a)

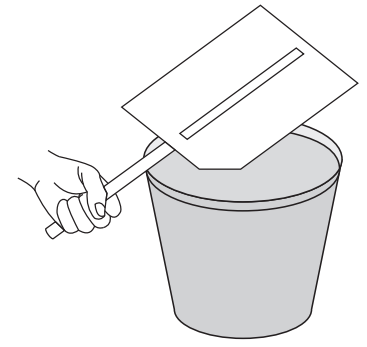

(b)

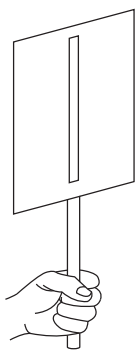

(c)

Figura 3.6: (a) Eletroscópio inicialmente carregado. (b) Afunda-se uma quina da cartolina em um copo cheio de água, observando-se que a tirinha abaixa. (c) Ao retirar o eletroscópio da água, a tirinha continua abaixada.

Experiência 3.6 - Tocando um eletroscópio carregado com óleo vegetal

Na Figura 3.7 ilustramos o que ocorre no caso de um líquido isolante como o óleo vegetal de cozinha. Na Figura 3.7 (a) temos um eletroscópio carregado, seguro apenas por seu canudo, sem tocarmos em sua cartolina ou na tirinha de papel de "seda". Afunda-se uma quina do eletroscópio eletrizado no recipiente cheio de óleo até a borda. Deve-se evitar de tocar com a cartolina no recipiente. Neste caso observa-se que a tirinha permanece afastada da cartolina, Figura 3.7 (b). Ao retirarmos o eletroscópio do óleo observa-se que a tirinha permanece levantada, Figura 3.7 (c).

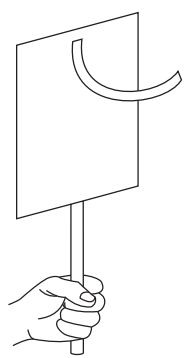

(a)

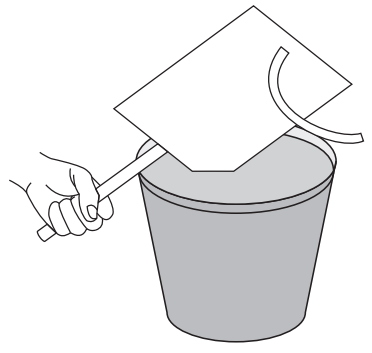

(b)

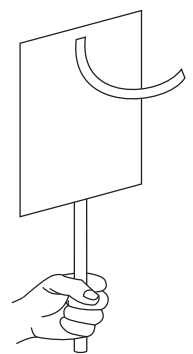

(c)

Figura 3.7: (a) Eletroscópio inicialmente carregado. (b) Afunda-se uma quina da cartolina em um copo cheio de óleo vegetal até a borda, observando-se que a tirinha permanece levantada. (c) Ao retirar o eletroscópio do óleo, a tirinha permanece levantada.

O eletroscópio eletrizado não foi descarregado ao entrar em contato com o óleo de cozinha. 
Ao realizar atividades como a Experiência 3.5 e 3.6 obtemos os seguintes resultados: ${ }^{4}$

- Líquidos condutores para experiências comuns de eletrostática: Água de torneira, água oxigenada, água de-ionizada, água destilada, água sanitária, soro fisiológico, álcool, xampu, querosene, leite, refrigerante, cachaça ou vodca, detergente, molho de soja shoyu, vinagre, sabonete líquido, mel, cola, amaciante de roupa, esmalte sintético (para pintar madeira ou metal), tinta acrílica de parede, óleo sintético automotivo, etc.

\section{- Líquidos isolantes para experiências comuns de eletrostática:}

Parafina derretida e a maior parte dos óleos.

Ou seja, quase todos os líquidos encontrados no dia a dia comportam-se como condutores. Entre os isolantes temos essencialmente os óleos em geral (óleos vegetais de soja ou de canola, azeite de oliva, óleo de máquina, óleo mineral, óleo de peroba tipo lustra-móveis, etc.). A exceção é o óleo sintético automotivo que se comporta como condutor nas experiências de eletrostática.

O mesmo procedimento usado para testar quais líquidos são condutores ou isolantes, pode ser usado para testar a condutividade das farinhas. Ou seja, um recipiente condutor é cheio com a farinha a ser testada. Afunda-se uma quina do eletroscópio carregado na farinha e é observado se sua tirinha abaixa ou não. Os cuidados principais são o de evitar que a quina do eletroscópio toque no recipiente condutor e no nosso corpo.

Experiência 3.7 - Corpo eletrizado atraindo um filete de água

Agora vamos ver o efeito do âmbar atritado ao chegar perto de líquidos. Nestas experiências utilizamos uma régua de acrílico atritada ou um canudo plástico atritado no lugar do âmbar atritado. Novamente o ideal é aproximar um canudo (estando ou não atritado) do líquido, mas sem que exista o toque entre ambos.

Abre-se uma torneira e deixa-se escorrer de forma contínua um fino filete de água, Figura 3.8 (a). Aproxima-se um canudo de plástico neutro do filete e nada acontece, Figura 3.8 (b).

Agora atrita-se o canudo e repete-se a experiência. Neste caso observa-se que o filete de água curva-se visivelmente no sentido do canudo, Figura 3.8 (c)! Isto é mais facilmente observado quando aproximamos o canudo atritado da parte superior do filete, onde a água tem uma velocidade menor. Algumas vezes a atração é tão grande que o filete de água encosta no canudo. A experiência também funciona com a água caindo em gotas, sendo o efeito mais facilmente observado com o canudo próximo das gotas mais lentas.

Algo análogo acontece ao aproximarmos um plástico atritado de um filete de leite, detergente, álcool, querosene, xampu, soro fisiológico ou de todos os

\footnotetext{
${ }^{4}$ Capítulo 6 de [Ass10b], [Ass10a], [Ass11], [Ass15b] e [Ass17].
} 


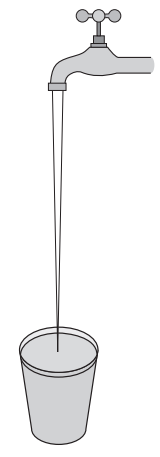

(a)

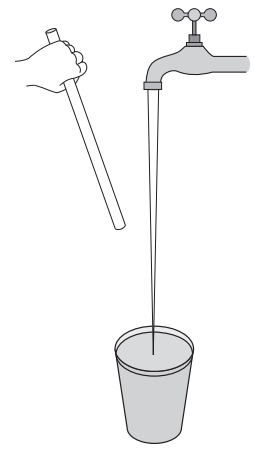

(b)

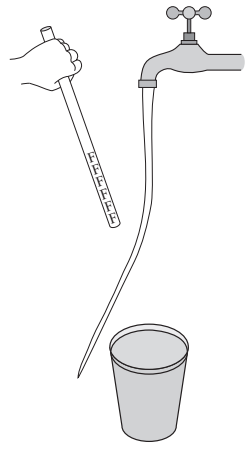

(c)

Figura 3.8: (a) Filete de água. (b) O filete não é atraído por um canudo plástico neutro em suas proximidades. (c) Um canudo atritado atraindo o filete de água.

líquidos classificados como condutores na Seção 3.1. Ou seja, todos estes filetes são claramente atraídos pelo plástico atritado. Eles não são atraídos por um plástico neutro.

Experiência 3.8 - Corpo eletrizado atraindo um filete de óleo vegetal

Repetimos a Experiência 3.7 tentando agora atrair um líquido isolante como o óleo de cozinha. Deixa-se cair um filete de óleo de uma lata ou de um copo com óleo, Figura 3.9 (a). Ao aproximarmos um canudo de plástico neutro, nada acontece, Figura 3.9 (b). Atrita-se o canudo e ele é novamente aproximado do filete de óleo, observando-se uma pequena atração, Figura 3.9 (c).

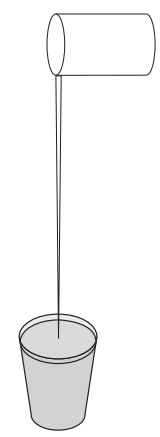

(a)

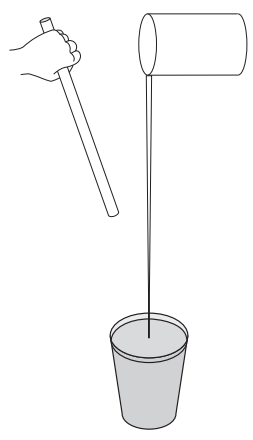

(b)

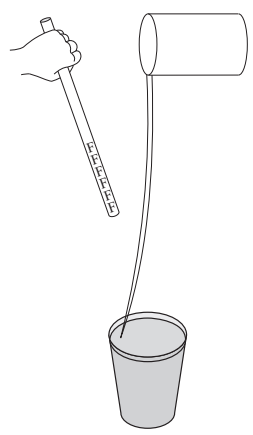

(c)

Figura 3.9: (a) Filete de óleo. (b) O filete não é atraído por um canudo plástico neutro em suas proximidades. (c) Um canudo atritado atraindo fracamente o filete de óleo. 
Observa-se que embora o filete de óleo seja atraído por um canudo eletrizado, a curvatura é bem menor do que no caso dos líquidos condutores da Experiência 3.7. Isto é, a curvatura da água na Figura 3.8 (c) é maior do que a curvatura do óleo na Figura 3.9 (c) supondo que o canudo esteja à mesma distância da vertical passando pelo local de onde a água e o óleo começam a cair.

As Experiências 3.7 e 3.8 mostram que a atração exercida por um corpo eletrizado sobre um condutor é bem maior do que sobre um isolante. ${ }^{5}$ Suponha que temos duas substâncias, uma condutora e uma isolante, do mesmo tamanho, peso e formato. Vamos supor ainda que elas sejam colocadas à mesma distância de um corpo eletrizado. As experiências mostram que a substância condutora sofrerá uma força de atração maior do que a isolante, sendo estas forças exercidas pelo mesmo corpo eletrizado. Podemos extrair uma regra prática destas experiências, a saber, que se um corpo eletrizado atrai visivelmente substâncias leves, então estas substâncias leves vão comportar-se como condutoras para as experiências usuais de eletrostática (ou seja, vão descarregar um eletroscópio eletrizado ao tocar na cartolina enquanto são segurados pela mão).

O inverso também se aplica. Isto é, as substâncias que descarregam um eletroscópio vão ser aquelas que serão atraídas com grande força por um corpo eletrizado. Já as substâncias isolantes que não descarregam um eletroscópio eletrizado vão ser pouco atraídas por um corpo eletrizado.

\subsection{Classificando os Corpos como Condutores ou Isolantes pelo Circuito de Teste}

No Volume 1 deste livro vimos que a diferença de potencial atuando nas extremidades de um corpo é um fator importante para saber se o corpo vai se comportar como condutor ou isolante. ${ }^{6}$ Um corpo que se comporta como um isolante quando suas extremidades estão sob a ação de uma pequena diferença de potencial elétrico (até tipicamente algumas dezenas de volts) pode passar a se comportar como um condutor quando esta diferença de potencial ultrapassa um certo limite. Nas experiências usuais de eletrostática lidamos com altas diferenças de potencial, variando tipicamente entre $1.000 \mathrm{~V}$ e $10.000 \mathrm{~V}$, quando então a grande maioria dos corpos líquidos e sólidos se comporta como condutor. Já para baixas diferenças de potencial de até algumas dezenas de volts a grande maioria dos corpos sólidos e líquidos comporta-se como isolante. Os metais são uma exceção pois comportam-se como excelentes condutores tanto para altas diferenças de potencial quanto para baixas diferenças de potencial. As resinas naturais e sintéticas como o âmbar e os plásticos em geral também são exceções, já que se comportam como bons isolantes para estas baixas e altas diferenças de potencial.

\footnotetext{
${ }^{5}$ Seção 7.7 de [Ass10b], [Ass10a], [Ass11], [Ass15b] e [Ass17].

${ }^{6}$ Seção 6.6 de [Ass10b], [Ass10a], [Ass11], [Ass15b] e [Ass17].
} 
Fazemos agora algumas experiências utilizando o circuito de teste da Figura 2.19. Vamos lidar com baixas diferenças de potencial e faremos uma nova definição de condutor e isolante apropriada para este caso.

Experiência 3.9 - Fechando o circuito de teste com um fio metálico

Ao ligarmos as extremidades de um fio metálico entre os pontos $A$ e $B$ da Figura 2.19, tal como um fio de cobre desencapado nas duas pontas, observamos que a lâmpada acende, como indicado na Figura 3.10.

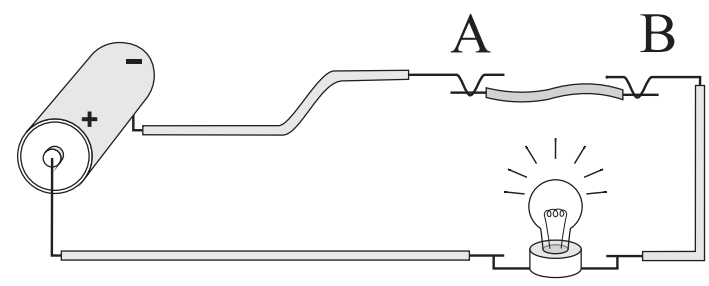

Figura 3.10: Ao ligar um fio de cobre desencapado nas duas pontas entre $A$ e $B$, observa-se que a lâmpada acende.

É importante que esta experiência seja feita em primeiro lugar e que a lâmpada acenda para assim termos certeza de que todas as ligações elétricas estão bem feitas. Este fato também indicará que está fluindo uma corrente elétrica pelo circuito.

Além disso, a lâmpada não deve ficar acesa muito tempo para evitar de descarregar a pilha. O ideal é desligar as conexões assim que percebermos que ela acendeu. Podemos então prosseguir para testar outras substâncias.

Experiência 3.10 - Fechando o circuito de teste com um canudo plástico ou palito de madeira

Ao ligarmos um canudo plástico entre $A$ e $B$, ou então ao ligarmos um palito de madeira entre $A$ e $B$, observamos que a lâmpada fica apagada, Figura 3.11.

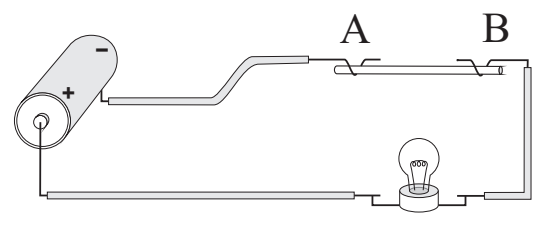

(a)

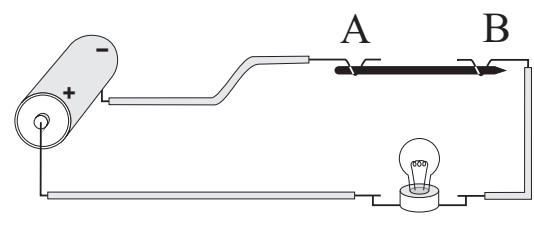

(b)

Figura 3.11: (a) Ao ligar um canudo plástico nas duas pontas entre $A$ e $B$, observase que a lâmpada não acende. (b) A lâmpada permanece desligada ao ligar $A$ e $B$ através de um palito de madeira. 
Ao colocar água de torneira ou da chuva em um copo plástico e ligar as extremidades $A$ e $B$ na água, percebemos que a lâmpada continua apagada, Figura 3.12 .

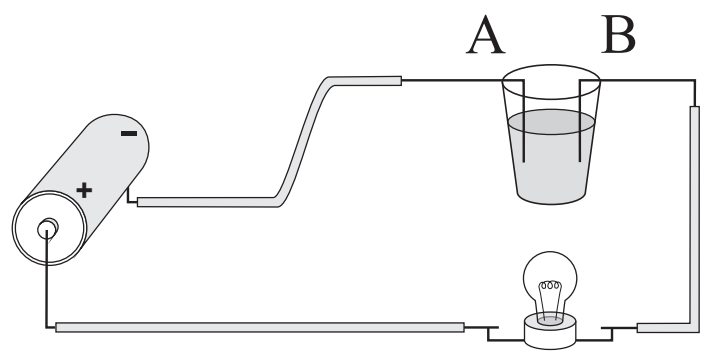

Figura 3.12: Ao ligar através da água as duas pontas desencapadas $A$ e $B$ apoiadas em um copo plástico, observa-se que a lâmpada não acende.

\subsubsection{Definição de Condutor e Isolante quando é Aplicada uma Baixa Diferença de Potencial entre as Extremi- dades do Corpo}

Seguindo os procedimentos das Experiências 3.9 até 3.11 com várias substâncias podemos fazer uma nova classificação de materiais condutores e isolantes apropriada para baixas diferenças de potencial.

\section{Definição 3.4}

Se a lâmpada da Figura 2.19 acende quando uma certa substância conecta os pontos $A$ e $B$, como indicaco na Figura 3.10, esta substância é chamada de condutor. Se a lâmpada não acende, como indicado na Figura 3.11, esta substância é chamada de isolante.

Das experiências citadas conclui-se que o fio de cobre é condutor quando está sob a ação de uma diferença de potencial de 1,5 volt. Se a lâmpada ficar ligada por um tempo suficientemente longo, vai descarregar a bateria. Já um canudo plástico, um palito de madeira, a água de torneira ou da chuva são isolantes para uma diferença de potencial de 1,5 V. Como observado por Gaspar, também o grafite, a água salgada e um limão comportam-se como isolantes para diferenças de potencial de $1,5 \mathrm{~V}$, ao contrário do que se encontra afirmado em diversos livros didáticos. ${ }^{7}$

\footnotetext{
${ }^{7}$ [Gas03, págs. 252-256].
} 


\subsubsection{Corpos que se Comportam como Condutores ou Iso- lantes nas Experiências Usuais com Corrente Cons- tante}

Testes realizados com várias substâncias ao seguir as Experiências 3.9 até 3.11 levam ao seguinte resultado:

- Corpos que se comportam como condutores quando estão sob a ação de uma diferença de potencial de 1,5 V:

Todos os metais.

- Corpos que se comportam como isolantes quando estão sob a ação de uma diferença de potencial de 1,5 V:

Ar seco, ar úmido, âmbar, plástico, seda, madeira, vidro aquecido, vidro à temperatura ambiente, náilon ou poliamida sintética, algodão, PVC, poliéster, lã, cabelo humano, tubo de acrílico, pano de acrílico, isopor, barra de chocolate, café em pó, papel, cartolina, papel de "seda," giz, porcelana, água de torneira ou de chuva, água salgada, água com limão, xampu, querosene, leite, refrigerante, detergente, óleo vegetal, parede, lousa, cortiça, couro, farinha de trigo, fubá, fio de acrílico, sal, açúcar, serragem, solo ou barro, tijolo, borracha, etc.

Podem ser feitas diversas variações destas experiências. Por exemplo, caso não sejam encontrados bocais destas lâmpadas de lanterna, os fios podem ser soldados diretamente nos terminais da lâmpada. Ou seja, a parte desencapada da extremidade de um fio é soldada na rosca da lâmpada e a parte desencapada de uma extremidade do outro fio é soldada na base da lâmpada. É possível ainda prender com a mão ou com uma fita adesiva um fio na rosca da lâmpada e outro fio na base da lâmpada. As extremidades desencapadas dos fios podem ser presas aos terminais das pilhas com fitas adesivas ou com fitas isolantes. Existem também alguns suportes de pilha que já vêm com um fio ligado ao terminal positivo da pilha e outro fio ligado ao terminal negativo da pilha. Estes suportes facilitam os contatos entre os terminais das pilhas e as lâmpadas ou outros componentes do circuito elétrico. Também podem ser utilizadas 2 pilhas de 1,5 V ligadas em série, juntamente com lâmpadas que acendam com uma diferença de potencial de $3 \mathrm{~V}$ entre seus terminais.

É importante observar que existem várias substâncias que se comportam como condutoras de acordo com a Definição 3.3, mas comportam-se como isolantes de acordo com a Definição 3.4. Exemplos: água de torneira, um espeto de madeira, papel, alguns tipos de vidro na temperatura ambiente, etc. Estas substâncias descarregam um eletroscópio eletrizado quando há uma diferença de potencial variando tipicamente entre $1.000 \mathrm{~V}$ e $10.000 \mathrm{~V}$ entre o eletroscópio e o solo. Portanto elas comportam-se como condutoras para estas altas voltagens. Contudo, elas não permitem a passagem de uma corrente elétrica com intensidade capaz de acender a lâmpada (isto é, não permitem um fluxo razoável de partículas eletrizadas através delas) quando suas extremidades estão sob a ação 
de uma pequena voltagem que pode chegar a algumas dezenas de volts. Portanto estas mesmas substâncias comportam-se como isolantes para estas baixas voltagens.

Como mencionado no Volume 1 deste livro, devido a este fato seria mais apropriado mudar nossa terminologia. Dizemos normalmente que um certo corpo $A$ é um condutor, enquanto que um outro corpo $B$ é um isolante. Contudo, pelo que acabou de ser visto, seria mais apropriado dizer que sob certas circunstância o corpo A comporta-se como um condutor, enquanto que sob outras circunstâncias ele comporta-se como um isolante. A mesma terminologia valeria para o corpo $B$. Contudo, esta forma de expressão tornaria as sentenças muito longas e complicadas. Por este motivo manteremos a terminologia usual dizendo que os corpos são condutores ou isolantes. De qualquer forma deve ficar claro para todo mundo que estes conceitos de condutor e isolante são relativos. O comportamento dos corpos depende não apenas de suas propriedades intrínsecas, mas também das condições externas a que estão sujeitos.

\subsection{Fatores que Influenciam no Comportamento Condutor ou Isolante de um Corpo}

\subsubsection{Natureza ou Composição Química do Corpo}

As experiências da Seção 3.1 mostram que existem dois tipos de corpos, a saber, os condutores e os isolantes. Nas experiências de eletrostática, que envolvem diferenças de potencial variando tipicamente entre $1.000 \mathrm{~V}$ e $10.000 \mathrm{~V}$, os corpos podem ser classificados utilizando um eletroscópio. Eletrizamos um canudo plástico ou régua de acrílico por atrito contra o cabelo, guardanapo ou algum pano. Raspamos então a régua de acrílico eletrizada na cartolina de um eletroscópio por algumas vezes até que sua tirinha permaneça levantada depois que afastamos a régua. Em seguida seguramos um corpo neutro pela mão e tocamos com uma outra região deste corpo na cartolina do eletroscópio eletrizado. Caso o eletroscópio permaneça eletrizado, dizemos que o corpo é isolante, como ocorre com um canudo plástico neutro. Caso o eletroscópio seja descarregado após o toque, dizemos que o corpo é condutor, como ocorre com um arame.

Destas experiências conclui-se que a principal característica para a classificação dos corpos é a sua natureza ou composição química. A grande maioria dos corpos comporta-se na eletrostática como condutor, como é o caso dos metais, da água, do papel, da madeira sem estar envernizada, alguns tipos de vidro à temperatura ambiente e até mesmo de vários tipos de borrachas. Apenas algumas poucas substâncias comportam-se como isolantes. Entre estas temos o ar seco, a seda, o óleo, o âmbar e outras resinas naturais, assim como os plásticos em geral e outras resinas sintéticas.

As experiências da Seção 3.2 mostram que também quando aplicamos uma baixa diferença de potencial entre as extremidades de um corpo podemos classificá-los como condutores ou isolantes. Esta nova classificação é feita com um circuito de teste, Figura 2.19. Utilizamos uma pilha nova e ligamos as extre- 
midades de um corpo entre $A$ e $B$. Caso a lâmpada acenda, dizemos que o corpo é um condutor. Caso a lâmpada fique apagada, dizemos que o corpo é um isolante.

Destas experiências conclui-se que também para as experiências usuais nas quais pode fluir uma corrente constante, a principal característica para a classificação dos corpos é a sua natureza ou composição química. Neste caso de baixas diferenças de potencial (até algumas centenas de Volts) todos os metais comportam-se como condutores. A grande maioria das outras substâncias comporta-se como isolante. Exemplos: água, papel, madeira, vidro, borracha, ar seco ou úmido, seda, óleo, âmbar e resinas naturais, plástico e resinas sintéticas, etc.

\subsubsection{Diferença de Potencial entre as Extremidades do Corpo}

As Seções 3.1 e 3.2 mostram que além das propriedades intrínsecas ou internas ao corpo, uma outra característica fundamental para classificar uma substância como condutora ou isolante é a diferença de potencial externa aplicada nas extremidades do corpo. Os metais comportam-se como condutores tanto para baixas quanto para altas diferenças de potencial. Outras substâncias comportam-se como isolantes tanto para baixas quanto para altas diferenças de potencial: o ar seco, a seda, o óleo, o âmbar e outras resinas naturais, assim como os plásticos em geral e outras resinas sintéticas.

Por outro lado, existem várias substâncias que comportam-se como condutoras nas experiências de eletrostática (que lidam com altas diferenças de potencial) e como isolantes nas experiências usuais com fluxo de corrente elétrica (que lidam com baixas diferenças de potencial). Entre estas substâncias podemos citar: o ar úmido, a água, o papel, a madeira sem estar envernizada, alguns tipos de vidro à temperatura ambiente e até mesmo vários tipos de borrachas. As Subseções 3.1.2 e 3.2.2 apresentam as classificações separadas para cada caso.

\subsubsection{O Tempo Necessário para Descarregar um Corpo Eletrizado}

Experiência 3.12 - Um eletroscópio parado sobre a mesa vai descarregando com a passagem do tempo

Carregamos um eletroscópio como na Experiência 3.1, Figura 3.1, ao raspar sua cartolina com uma régua plástica eletrizada por atrito. Deixamos então este eletroscópio eletrizado sobre a mesa em um dia seco. Observa-se que a tirinha permanece levantada por vários segundos ou até mesmo por alguns minutos. Porém, se esperarmos por um tempo suficientemente longo, como por exemplo uma hora, veremos que o eletroscópio se descarrega totalmente.

Isto significa que a Definição 3.3 de condutor ou de isolante, como apresentada na Subseção 3.1.1, depende do intervalo de tempo para que ocorra a descarga. Para um intervalo de tempo de alguns segundos vem que o ar seco é 
um bom isolante. Já para um intervalo de tempo de uma hora vem que o ar seco pode ser classificado como um condutor por permitir a descarga do eletroscópio.

Podemos tornar mais clara esta distinção sendo um pouco mais precisos em nossas definições. Vamos nos referir aqui aos procedimentos experimentais descritos na Seção 3.1.

\section{Definição 3.5}

Para os objetivos deste livro, podemos definir os bons condutores como sendo as substâncias que, ao entrarem em contato com um eletroscópio eletrizado, o descarregam em um intervalo de tempo menor do que 5 segundos. Os maus condutores, ou maus isolantes, são as substâncias que o descarregam durante um intervalo de tempo que vai de uns 5 segundos até uns 20 ou 30 segundos. Estes corpos também são chamados de condutores imperfeitos ou de isolantes imperfeitos. Já os bons isolantes são as substâncias que necessitam de um intervalo de tempo maior do que 20 ou 30 segundos para descarregar um eletroscópio eletrizado. Neste livro vamos em geral nos referir aos bons condutores simplesmente como condutores, enquanto que os bons isolantes serão chamados normalmente de isolantes.

\subsubsection{O Comprimento do Corpo}

As experiências desta Subseção e aquelas da Subseção 3.3.5 devem ser feitas apenas em dias secos nos quais um eletroscópio eletrizado como na Experiência 3.1, Figura 3.1, permanece carregado estando isolado do solo por um tempo igual ou superior a 30 segundos. Em dias chuvosos ou úmidos o eletroscópio descarrega rapidamente para o ar ao redor logo depois de ter sido eletrizado ao raspar sua cartolina com um canudo ou régua plástica atritada. Nestes dias chuvosos os resultados das experiências desta Subseção e da Subseção 3.3.5 não serão tão claros. Por este motivo deve-se evitar de realizar estas atividades nestes dias úmidos.

Nesta Subseção consideramos a influência do comprimento de uma substância que entra em contato com um eletroscópio eletrizado no que diz respeito às suas propriedades condutoras ou isolantes.

Experiência 3.13 - Descarregando um eletroscópio ao tocá-lo com tiras de papel

Recortam-se várias tiras de papel sulfite com larguras de $2 \mathrm{~cm}$ e comprimentos indo de $10 \mathrm{~cm}$ até $1 \mathrm{~m}$. Para alcançar este comprimento maior podem ser coladas as extremidades de várias fitas ou então elas podem ser unidas por clipes. Carregamos um eletroscópio e o deixamos sobre a mesa em um dia seco. Segura-se uma extremidade da tira de $10 \mathrm{~cm}$ entre os dedos e encosta-se a outra extremidade na cartolina do eletroscópio carregado. ${ }^{8}$ Observa-se que o

\footnotetext{
${ }^{8}$ Seção 6.7 de [Ass10b], [Ass10a], [Ass11], [Ass15b] e [Ass17].
} 
eletroscópio descarrega rapidamente, de 1 a 3 segundos, Figura 3.13 (b) e (c). Portanto, pela Definição 3.5 da Subseção 3.3.3, vem que esta tira de papel pode ser considerada como boa condutora.

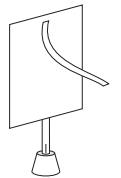

(a)

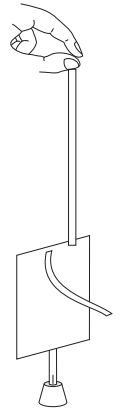

(b)

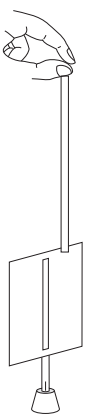

(c)

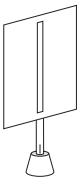

(d)

Figura 3.13: (a) Eletroscópio carregado. (b) e (c): Uma tira de papel presa na mão descarrega rapidamente um eletroscópio ao tocar nele. (d) Ao afastar a tira, observa-se que o eletroscópio permanece descarregado.

Carregamos novamente o eletroscópio e repete-se a experiência com uma tira de $30 \mathrm{~cm}$. Segura-se uma extremidade da tira entre os dedos e encosta-se a outra extremidade na cartolina do eletroscópio carregado. Agora já se percebe claramente o intervalo de tempo de 4 a 6 segundos que são necessários até que ele descarregue. Dependendo do tipo de papel, vem que esta tira de $30 \mathrm{~cm}$ por $2 \mathrm{~cm}$ pode ser considerada como mau condutora.

Esta experiência mostra também visivelmente que, com a passagem do tempo, aumenta a quantidade de carga que o eletroscópio eletrizado vai perdendo, ver a Subseção 3.3.3. Neste caso a perda principal é pela tira de papel, juntamente com o aterramento pela mão, não ocorrendo através do ar.

Carrega-se novamente o eletroscópio e repete-se a experiência com a tira de $1 \mathrm{~m}$ por $2 \mathrm{~cm}$. Observa-se que o eletroscópio permanece carregado por uns 10 segundos. Se o dia estiver bem seco e dependendo do tipo de papel, este tempo pode aumentar indo a 20 ou 30 segundos, por exemplo.

Esta experiência mostra que o comprimento de um corpo influencia em seu comportamento como condutor ou isolante. Quanto maior for o comprimento do corpo entre a mão que o segura e o eletroscópio eletrizado, vem que maior será o tempo necessário para descarregar o eletroscópio.

Experiência 3.14 - Descarregando um eletroscópio ao tocá-lo com linhas de algodão

A Experiência 3.13 pode ser repetida com vários materiais. Além do papel, outras substâncias interessantes que mostram a influência do comprimento podem ser uma cartolina ou papel cartão, barbante, linha de costura de algodão, etc. Apresentamos na Tabela 3.1 alguns exemplos de medidas de tempo com estes materiais seguindo o procedimento da Experiência 3.13. 


\begin{tabular}{|c|c|c|c|}
\hline Substância \comprimento & $10 \mathrm{~cm}$ & $30 \mathrm{~cm}$ & $1 \mathrm{~m}$ \\
\hline tira de papel & $1-3 \mathrm{~s}$ & $4-6 \mathrm{~s}$ & $10-30 \mathrm{~s}$ \\
\hline linha de algodão & $2 \mathrm{~s}$ & $3 \mathrm{~s}$ & $6 \mathrm{~s}$ \\
\hline
\end{tabular}

Tabela 3.1: Intervalos de tempo aproximados para descarregar o eletroscópio.

Os valores numéricos desta e de outras Tabelas deste livro devem ser consideradas apenas de modo qualitativo. Podemos obter valores bem diferentes dos que são apresentados aqui dependendo do grau de eletrização do eletroscópio, do seu tamanho, das condições atmosféricas do dia em que a experiência está sendo realizada, da qualidade ou da composição química do material que utilizamos, etc. Estes números servem apenas para indicar um comportamento qualitativo dos fatores que influenciam nas propriedades condutoras ou isolantes do corpo.

Experiência 3.15 - Tocando um eletroscópio carregado com outras substâncias

Por outro lado, se tocarmos o eletroscópio carregado com um canudo plástico tendo $10 \mathrm{~cm}, 30 \mathrm{~cm}$ ou $1 \mathrm{~m}$ de comprimento (ligando vários canudos pelas pontas), observa-se que o eletroscópio não descarrega por mais de 20 ou 30 segundos em um dia seco. Logo todos estes comprimentos do canudo podem ser considerados bons isolantes. Neste caso não dá para perceber a influência do comprimento, já que mesmo para canudos com $10 \mathrm{~cm}$ de comprimento não se percebe a descarga.

Ao tocar no eletroscópio com tiras de papel de alumínio tendo $2 \mathrm{~cm}$ de largura e vários comprimentos, de $10 \mathrm{~cm}$ até $1 \mathrm{~m}$, observa-se que o eletroscópio descarrega praticamente instantaneamente com todos estes comprimentos ao ser tocado. Logo o papel de alumínio pode ser considerado um bom condutor em todos estes casos. Novamente não dá para perceber a influência do comprimento nestes casos, já que mesmo para tiras com $1 \mathrm{~m}$ de comprimento a descarga do eletroscópio é muito rápida para ser medida com um relógio comum.

\section{Experiência 3.16 - Carregando dois eletroscópios ligados por tiras de papel}

Uma variação destas experiências utiliza dois eletroscópios ligados por tiras ou linhas feitas de materiais diferentes tais como: papel sulfite, papel cartão, papel de alumínio, canudo plástico, barbante ou linha de algodão. ${ }^{9}$ Estes materiais podem ser presos às cartolinas dos eletroscópios por clipes, Figura 3.14.

Vamos supor que os ligamos por uma tira de papel com $2 \mathrm{~cm}$ de largura e $10 \mathrm{~cm}$ de comprimento. Os dois eletroscópios estão inicialmente descarregados. Eletrizamos uma régua de acrílico por atrito contra o cabelo ou guardanapo. Raspamos esta régua eletrizada por algumas vezes em um dos eletroscópios até que fique eletrizado. Percebemos então quanto tempo leva para o outro eletroscópio carregar. Esta medida não é muito confiável, já que o segundo eletroscópio vai carregando não apenas ao final do processo, mas também enquanto

\footnotetext{
${ }^{9}$ [FM91, págs. 43-45], [Ferc, pág. 70] e [FR08, pág. 18].
} 


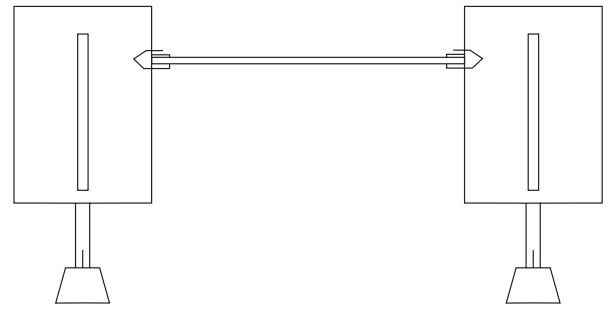

Figura 3.14: Dois eletroscópios ligados por uma tira de papel.

raspamos o primeiro eletroscópio com a régua já das primeiras vezes. Algumas vezes é necessário dar uns petelecos no canudinho do segundo eletroscópio para que a tirinha de papel de "seda" se solte da cartolina e comece a subir.

Experiência 3.17 - Descarregando dois eletroscópios ligados por tiras de papel

Para ter uma medida de tempo mais confiável, é melhor aguardar que os dois eletroscópios da Experiência 3.17, conectados pela tira de papel, estejam igualmente eletrizados. Então tocamos com o dedo na cartolina do primeiro eletroscópio, observando que se descarrega praticamente instantaneamente. Mantemos o dedo na cartolina e observamos o que acontece na tirinha do segundo eletroscópio. O segundo eletroscópio acaba também ficando descarregado. Marcamos o tempo entre o toque do dedo no primeiro eletroscópio e o instante em que o segundo eletroscópio se descarrega totalmente. Neste caso obtemos de 2 a $3 \mathrm{~s}$.

Repetimos a experiência com tiras de $2 \mathrm{~cm}$ de largura, sendo num caso com $30 \mathrm{~cm}$ de comprimento e noutro com $1 \mathrm{~m}$ de comprimento. Podemos fazer o mesmo com uma linha de costura de algodão ligando os dois eletroscópios, tendo $10 \mathrm{~cm}, 30 \mathrm{~cm}$ ou $1 \mathrm{~m}$ de comprimento. Os resultados estão indicados na Tabela 3.2 .

\begin{tabular}{|c|c|c|c|}
\hline Substância \comprimento & $10 \mathrm{~cm}$ & $30 \mathrm{~cm}$ & $1 \mathrm{~m}$ \\
\hline tira de papel & $2-3 \mathrm{~s}$ & $5 \mathrm{~s}$ & $20-25 \mathrm{~s}$ \\
\hline linha de algodão & $2 \mathrm{~s}$ & $4 \mathrm{~s}$ & $15-20 \mathrm{~s}$ \\
\hline
\end{tabular}

Tabela 3.2: Intervalos de tempo aproximados para descarregar um dos eletroscópios carregados quando o outro eletroscópio é aterrado ao ser tocado com o dedo.

Podemos também ligar os dois eletroscópios por canudos plásticos com 10 $\mathrm{cm}, 30 \mathrm{~cm}$ ou $1 \mathrm{~m}$ de comprimento. Inicialmente eletrizamos igualmente os dois eletroscópios ao raspar suas cartolinas com canudos plásticos atritados. Suas tirinhas devem ficar igualmente levantadas em relação às respectivas cartolinas no início da experiência. Percebemos então que ao descarregarmos um dos eletroscópios ao tocar com o dedo em sua cartolina, o outro eletroscópio permanece 
eletrizado, não sendo descarregado mesmo depois de transcorridos mais de 20 ou 30 segundos em um dia seco.

Em uma outra experiência ligamos os dois eletroscópios por tiras de papel de alumínio com $2 \mathrm{~cm}$ de largura e tendo $10 \mathrm{~cm}, 30 \mathrm{~cm}$ ou $1 \mathrm{~m}$ de comprimento. Inicialmente eletrizamos os dois eletroscópios de tal maneira que suas tirinhas fiquem igualmente levantadas em relação às respectivas cartolinas. Percebemos então que ao descarregarmos um dos eletroscópios ao tocar com o dedo em sua cartolina, o outro eletroscópio também é descarregado imediatamente.

Nestes dois últimos casos não percebemos a influência do comprimento nestas medidas simples, já que os intervalos de tempo ou são curtos demais para serem indicados por um relógio comum, ou são longos demais.

De qualquer forma, nos casos em que o tempo para descarregar um eletroscópio leva de 1 segundo até uns 2 minutos, percebe-se que quanto maior é o comprimento do corpo com uma extremidade presa à mão, maior será o tempo para descarregar um eletroscópio eletrizado ao tocar com a outra extremidade do corpo na cartolina do eletroscópio. Da mesma forma, quando temos dois eletroscópios eletrizados ligados por um destes corpos, quanto maior for seu comprimento, maior será o tempo necessário para descarregar o segundo eletroscópio ao aterrar o primeiro eletroscópio tocando com o dedo em sua cartolina.

\subsubsection{A Área de Seção Reta do Corpo}

Experiência 3.18 - Descarregando um eletroscópio ao tocá-lo com fios de cabelo

Carrega-se um eletroscópio e o deixamos sobre a mesa em um dia seco. Segura-se uma extremidade de um único fio de cabelo na mão e encosta-se a outra extremidade do fio de cabelo na cartolina do eletroscópio carregado como na Figura 3.13. Observa-se que o eletroscópio permanece carregado por vários segundos, indicando que podemos classificá-lo como um bom isolante.

Carrega-se um eletroscópio e repete-se a experiência aumentando o número de fios de cabelo que seguramos pela mão e cujas extremidades livres encostamos simultaneamente na cartolina do eletroscópio. Observa-se que quanto maior for este número, mais rapidamente o eletroscópio será descarregado. Por exemplo, quando temos algumas dezenas de fios de cabelo observa-se que ele descarrega em poucos segundos. Isto indica que podemos classificar este conjunto de fios de cabelo como um bom condutor.

Experiência 3.19 - Descarregando um eletroscópio ao tocá-lo com tiras de papel

Repetimos a Experiência 3.13 mantendo agora um comprimento fixo e variando a largura das tiras de papel presas pela mão por uma extremidade e cuja outra extremidade vai entrar em contato com a cartolina do eletroscópio carregado. Na Tabela 3.3 mostramos o resultado para tiras de papel com 1 metro de comprimento e duas larguras diferentes: $0,5 \mathrm{~cm}$ e $2 \mathrm{~cm}$. 


\begin{tabular}{|c|c|c|}
\hline Largura da tira de papel & $0,5 \mathrm{~cm}$ & $2 \mathrm{~cm}$ \\
\hline Tempos & $50 \mathrm{~s}$ & $10 \mathrm{~s}$ \\
\hline
\end{tabular}

Tabela 3.3: Intervalos de tempo aproximados para descarregar o eletroscópio.

Experiência 3.20 - Descarregando um eletroscópio ao tocá-lo com fios de algodão

Repetimos a Experiência 3.13 mantendo agora um comprimento fixo e variando a espessura da linha de algodão presa pela mão por uma extremidade e cuja outra extremidade vai entrar em contato com a cartolina do eletroscópio carregado. Na Tabela 3.4 mostramos o resultado para uma linha fina de algodão como a linha de costura e um barbante de algodão bem mais grosso, ambos com $1 \mathrm{~m}$ de comprimento.

\begin{tabular}{|c|c|c|}
\hline Algodão & linha fina & barbante \\
\hline Tempos & $6 \mathrm{~s}$ & $6-7 \mathrm{~s}$ \\
\hline
\end{tabular}

Tabela 3.4: Intervalos de tempo aproximados para descarregar o eletroscópio.

Experiência 3.21 - Descarregando dois eletroscópios ligados por uma tira de papel

Repetimos a Experiência 3.16 ligando os dois eletroscópios por tiras de papel tendo o mesmo comprimento e larguras ou seções retas diferentes. Na Tabela 3.5 comparamos os tempos necessários para descarregar o eletroscópio 2 ao tocar com o dedo a cartolina do eletroscópio 1 supondo materiais de ligação com 1 metro de comprimento.

\begin{tabular}{|c|c|c|}
\hline Largura da tira de papel & $0,5 \mathrm{~cm}$ & $2 \mathrm{~cm}$ \\
\hline Tempos & $60 \mathrm{~s}$ & $20-25 \mathrm{~s}$ \\
\hline
\end{tabular}

Tabela 3.5: Intervalos de tempo aproximados para descarregar um dos eletroscópios carregados quando o outro é aterrado ao ser tocado com o dedo.

Experiência 3.22 - Descarregando dois eletroscópios ligados por um fio de algodão

Repetimos a Experiência 3.16 ligando os dois eletroscópios por linhas de algodão tendo o mesmo comprimento e larguras ou seções retas diferentes. $\mathrm{Na}$ Tabela 3.6 comparamos os tempos necessários para descarregar o eletroscópio 2 ao tocar com o dedo a cartolina do eletroscópio 1 supondo materiais de ligação com 1 metro de comprimento. 


\begin{tabular}{|c|c|c|}
\hline Algodão & linha fina & barbante \\
\hline Tempos & $15-20 \mathrm{~s}$ & $6-7 \mathrm{~s}$ \\
\hline
\end{tabular}

Tabela 3.6: Intervalos de tempo aproximados para descarregar um dos eletroscópios carregados quando o outro é aterrado ao ser tocado com o dedo.

Experiência 3.23 - Descarregando um eletroscópio ao tocá-lo com várias tiras de papel

Em vez de variar a largura das tiras de papel, outra possibilidade é aumentar o número de tiras de mesma espessura. Podemos, por exemplo, fazer a experiência com tiras de $1 \mathrm{~m}$ de comprimento. No caso do papel utilizamos tiras com $0,5 \mathrm{~cm}$ de largura. Numa experiência eletrizamos um eletroscópio, seguramos a extremidade de uma tira como na Figura 3.13 e encostamos a outra extremidade na cartolina do eletroscópio, medindo o tempo que ele leva para descarregar.

Em outra experiência, juntamos 3 tiras iguais com 1 clipe em cada extremidade do conjunto. Seguramos um dos clipes com a mão e encostamos o outro clipe no eletroscópio eletrizado, medindo o tempo para descarga. Na Tabela 3.7 apresentamos a comparação destes casos.

\begin{tabular}{|c|c|c|}
\hline Número de tiras de papel & 1 & 3 \\
\hline Tempo para descarregar & $50 \mathrm{~s}$ & $3 \mathrm{~s}$ \\
\hline
\end{tabular}

Tabela 3.7: Intervalos de tempo aproximados para descarregar o eletroscópio.

Experiência 3.24 - Descarregando um eletroscópio ao tocá-lo com vários fios de algodão

Em vez de variar a área de seção reta das linhas de algodão, outra possibilidade é aumentar o número de linhas com a mesma espessura. Podemos, por exemplo, fazer a experiência com linhas de $1 \mathrm{~m}$ de comprimento. Podemos fazer a mesma experiência com uma única linha de algodão de $1 \mathrm{~m}$ de comprimento, ou com 3 linhas iguais, cada uma com $1 \mathrm{~m}$ de comprimento, presas em conjunto por 1 clipe em cada extremidade. Na Tabela 3.8 apresentamos a comparação destes casos.

\begin{tabular}{|c|c|c|}
\hline Número de linhas de algodão & 1 & 3 \\
\hline Tempo para descarregar & $6 \mathrm{~s}$ & $2-3 \mathrm{~s}$ \\
\hline
\end{tabular}

Tabela 3.8: Intervalos de tempo aproximados para descarregar o eletroscópio. 
Experiência 3.25 - Descarregando dois eletroscópios ligados por várias tiras de papel

Em outra experiência ligamos dois eletroscópios como na Experiência 3.16 com uma única tira de papel e medimos o intervalo de tempo.

$\mathrm{Na}$ experiência seguinte, ligamos os dois eletroscópios com 3 tiras tendo as mesmas larguras que no caso anterior. Vamos supor aqui que todas as tiras possuem $1 \mathrm{~m}$ de comprimento, sendo todas as tiras de papel com $0,5 \mathrm{~cm}$ de largura. Na Tabela 3.9 apresentamos a comparação destes casos.

\begin{tabular}{|c|c|c|}
\hline Número de tiras de papel & 1 & 3 \\
\hline Intervalos de tempo & $60 \mathrm{~s}$ & $15 \mathrm{~s}$ \\
\hline
\end{tabular}

Tabela 3.9: Intervalos de tempo aproximados para descarregar um dos eletroscópios carregados quando o outro é aterrado ao ser tocado com o dedo.

Experiência 3.26 - Descarregando dois eletroscópios ligados por várias linhas de algodão

Em outra experiência ligamos dois eletroscópios como na Experiência 3.16 com uma única linha de algodão e medimos o intervalo de tempo.

$\mathrm{Na}$ experiência seguinte ligamos os dois eletroscópios com 3 linhas tendo as mesmas seções retas que no caso anterior. Vamos supor aqui que todas as linhas possuem $1 \mathrm{~m}$ de comprimento, sendo todas as linhas de algodão obtidas do mesmo carretel e tendo a mesma área de seção reta. Na Tabela 3.10 apresentamos a comparação destes casos.

\begin{tabular}{|c|c|c|}
\hline Número de linhas de algodão & 1 & 3 \\
\hline Intervalos de tempo & $15-20 \mathrm{~s}$ & $16-18 \mathrm{~s}$ \\
\hline
\end{tabular}

Tabela 3.10: Intervalos de tempo aproximados para descarregar um dos eletroscópios carregados quando o outro é aterrado ao ser tocado com o dedo.

Experiências como estas mostram que a área de seção reta de um corpo influencia em seu comportamento como condutor ou isolante. Quando maior for a área de seção reta entre a mão que o segura e o eletroscópio eletrizado, vem que menor será o tempo necessário para descarregar o eletroscópio. Da mesma forma, quanto maior for a área de seção reta do corpo ligando dois eletroscópios eletrizados, vem que menor será o tempo necessário para descarregar o segundo eletroscópio ao aterrar o primeiro eletroscópio tocando sua cartolina com o dedo.

Apresentamos agora algumas definições importantes. 


\section{Definição 3.6}

A passagem ou fluxo de partículas eletrizadas é chamada de corrente elétrica. Ela é proporcional à quantidade de carga que flui pela seção reta do condutor e inversamente proporcional ao intervalo de tempo em que ocorre este fluxo. Ou seja, é proporcional à quantidade de carga que atravessa o condutor pela unidade de tempo.

Um exemplo de corrente elétrica é o fluxo de cargas através da tira de papel ou da linha de algodão nas experiências já descritas.

Este fluxo depende do material, já que o papel de alumínio conduz melhor que o papel comum, que conduz muito melhor que o plástico. Suponha que queremos descarregar um eletroscópio inicialmente eletrizado ao segurar uma tira de alguma substância por uma extremidade e ao tocar com a outra extremidade na cartolina do eletroscópio. Vamos supor sempre tiras de mesmo comprimento, largura e espessura. A quantidade de carga que vai passar por ela vai ser sempre a mesma, a saber, a carga inicial do eletroscópio. O tempo de descarga com uma tira de papel de alumínio é menor do que o tempo com uma tira de papel comum, que é muito maior do que o tempo com uma tira de plástico que quase não descarrega o eletroscópio.

Para um mesmo material e supondo as mesmas condições iniciais, este fluxo depende do comprimento. Por exemplo, quanto mais longo for o corpo ligando dois eletroscópios eletrizados, mais lentamente descarregamos um deles ao aterrar o outro eletroscópio.

Esta corrente elétrica depende também da seção reta do condutor, supondo as mesmas condições iniciais. Por exemplo, quanto mais fino for o corpo, mais lentamente vai ocorrer a descarga do eletroscópio.

\section{Definição 3.7}

Dizemos ainda que o corpo ligando os dois eletroscópios nestas experiências possui uma resistência elétrica. Em cada instante de tempo esta resistência é proporcional à diferença de potencial entre os dois eletroscópios e inversamente proporcional à corrente elétrica que passa pelo corpo.

Vamos supor as mesmas condições iniciais, por exemplo, os dois eletroscópios inicialmente eletrizados ligados por um corpo como a tira de papel ou linha de algodão. Aterramos um dos eletroscópios ao tocá-lo com o dedo e medimos o intervalo de tempo para descarregar o segundo eletroscópio. Quanto maior for este tempo, dizemos que maior é a resistência do corpo de ligação. Ou seja, para a mesma diferença de potencial entre as extremidades de um corpo de ligação, sua resistência é inversamente proporcional à corrente elétrica que flui por ele. Pelas experiências anteriores concluímos então que a resistência do corpo de 
ligação aumenta com o comprimento deste corpo, diminui com o tamanho da sua seção reta, dependendo ainda do material ou composição química de que é feito este corpo.

\section{Experiência 3.27 - Comparando os intervalos de tempo}

Uma questão curiosa é a de comparar os tempos de descarga de um eletroscópio nos casos das Figuras 3.13 e 3.14. No primeiro caso o eletroscópio está eletrizado, seguramos uma extremidade da tira ou da linha com a mão e tocamos a outra extremidade no eletroscópio, medindo o tempo para descarregá-lo. No segundo caso temos dois eletroscópios eletrizados ligados por uma tira ou linha, tocamos com a mão na cartolina de um eletroscópio e medimos o intervalo de tempo para descarregar o segundo eletroscópio. Em geral, utilizando o mesmo corpo nos dois casos (por exemplo, uma tira de mesma largura e mesmo comprimento), vem que o tempo para descarregar o eletroscópio no primeiro caso é menor do que o tempo para descarregar o eletroscópio no segundo caso. A explicação para esta diferença de tempos é que no segundo caso não apenas o segundo eletroscópio estava eletrizado, mas também o corpo de ligação (tira de papel ou linha de algodão). Logo, quando tocamos com o dedo num dos eletroscópios que está conectado ao outro por este corpo de ligação, vem que temos de descarregar não apenas o outro eletroscópio, mas também este corpo de ligação. Já no primeiro caso não era necessário descarregar a tira de papel ou a linha de algodão pois estes corpos de ligação já estavam descarregados ao serem segurados pela mão.

Pode-se comprovar que a tira de papel ou linha de algodão ficam eletrizados quando os dois eletroscópios da Figura 3.14 estão carregados. Para isto basta colocar um versório metálico perto da tira ou linha, no mesmo plano horizontal, em qualquer ponto ao longo do comprimento da tira ou linha. Inicialmente o versório deve apontar em uma direção arbitrária quando os dois eletroscópios estão descarregados. Ao eletrizar os dois eletroscópios raspando a borda da cartolina de um deles com uma régua de acrílico atritada, observa-se então que o versório passa a apontar para a tira ou linha, indicando que esta tira ou linha ficou eletrizada.

\section{Experiência 3.28 - Descarregando alternadamente dois eletroscópios}

Uma outra experiência interessante pode ser feita com os dois eletroscópios da Figura 3.14 supondo que ambos estejam igualmente eletrizados no início do procedimento. Vamos supor que temos uma tira de papel com $1 \mathrm{~m}$ de comprimento e $0,5 \mathrm{~cm}$ de largura ligando os dois eletroscópios eletrizados. Neste caso, ao tocarmos com o dedo na cartolina do eletroscópio 1, sua tirinha abaixa imediatamente, enquanto que a tirinha do eletroscópio 2 leva uns 60 segundos para baixar enquanto mantemos o dedo na cartolina do eletroscópio 1 .

Repetimos esta experiência. Agora, tocamos com o dedo na cartolina 1 e sua tirinha abaixa imediatamente, sendo que a tirinha do eletroscópio 2 ainda permanece levantada. Tiramos o dedo depois de uns 5 segundos. A tirinha do 
eletroscópio 1, que estava abaixada ao tirarmos o dedo, vai levantando lentamente. Já a tirinha do eletroscópio 2, que tinha abaixado apenas um pouco despois destes 5 segundos, abaixa um pouco mais ao tirarmos o dedo. Isto é, ela vai abaixando enquanto a tirinha 1 vai levantando. Depois elas permanecem igualmente levantadas. Podemos ir repetindo este processo, mas alternando em qual eletroscópio tocamos rapidamente com o dedo. Perceberemos então que o conjunto vai sendo descarregado pouco a pouco.

\section{Experiência 3.29 - Carregando alternadamente dois eletroscópios}

É também curioso começar com os 2 eletroscópios descarregados, raspar apenas uma vez ou poucas vezes uma régua de acrílico eletrizada na cartolina do eletroscópio 1, vendo que sua tirinha sobe quase que instantaneamente (aumentando um pouco o quanto subiu em cada raspada). Já a tirinha do eletroscópio 2 levanta-se pouco a pouco com a passagem do tempo. Esta subida da tirinha do eletroscópio 2 ocorre lentamente mesmo quando a tirinha do eletroscópio 1 já está de pé, caso a tira de papel que liga os dois eletroscópios tenha um longo comprimento e uma pequena espessura.

Depois que o equilíbrio foi atingido, raspe a régua atritada na cartolina do eletroscópio 2. Sua tirinha sobe ainda mais quase que instantaneamente. Já a tirinha do eletroscópio 1 levanta pouco a pouco.

\subsubsection{Umidade}

\section{Umidade do Corpo de Ligação}

Experiência 3.30 - Variando a umidade do corpo que aterra o eletroscópio

Podemos repetir as experiências da Seção 3.1 e da Subseção 3.3.4 variando apenas a umidade da substância que vai ser conectada ao eletroscópio carregado como no caso da Figura 3.13. Por exemplo, em todos os casos vamos tocar no eletroscópio com tiras de $30 \mathrm{~cm}$ de comprimento e $0,5 \mathrm{~cm}$ de largura, todas recortadas da mesma folha de papel. Segura-se a tira por sua extremidade superior e então mede-se o tempo necessário para descarregar o eletroscópio a partir do toque nele pela extremidade inferior da tira de papel. Nesta experiência variamos apenas o grau de umidade das tiras. No primeiro caso utiliza-se uma tira seca.

No segundo caso, utiliza-se uma tira molhada nos dois lados ao longo de todo o seu comprimento através de um borrifador de água. Observa-se que quanto mais seca está a tira, maior é o tempo necessário para descarregar o eletroscópio. Logo, mais isolante é o comportamento da tira.

Obviamente este comportamento se deve à água absorvida pela tira, já que a água é um bom condutor. Ao comparar as condutividades da água de torneira e do papel com a mesma seção reta e o mesmo comprimento, obtém-se que a água é um condutor bem melhor do que o papel. Logo, ao absorver água, o papel úmido torna-se um melhor condutor do que um papel seco.

Além disso, a água é absorvida pelo papel em toda sua seção reta, não apenas em sua superfície. 


\section{Umidade do Ar}

Em dias secos e frios é fácil realizar experiências de eletrostática, a maioria delas funciona bem, dando efeitos visíveis e perceptíveis. Em dias quentes e úmidos, ou então quando há chuva, a situação é bem diferente. Ou os efeitos não ocorrem, ou ocorrem com baixa visibilidade e pequena intensidade.

\section{Experiência 3.31 - Eletroscópio sobre uma mesa em um dia seco}

É fácil carregar um eletroscópio em um dia seco. Basta raspar em sua cartolina um canudo plástico atritado no cabelo, como mostrado na Experiência 3.1, Figura 3.1. O eletroscópio permanece eletrizado por vários segundos ou por alguns minutos após a raspagem, Figura 3.1 (c). Isto significa que o ar seco comporta-se como um bom isolante elétrico, de acordo com a Definição 3.5 dada na Subseção 3.3.3.

Experiência 3.32 - Eletroscópio sobre uma mesa em um dia úmido

Repete-se a Experiência 3.31 em um dia úmido e chuvoso. Enquanto o canudo atritado no cabelo está sendo raspado na cartolina, observa-se que a tirinha do eletroscópio fica levantada, como na Figura 3.15 (b).

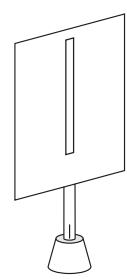

(a)

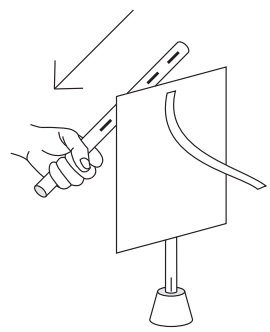

(b)

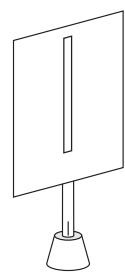

(c)

Figura 3.15: (a) Eletroscópio descarregado. (b) Sua tirinha fica levantada enquanto a cartolina está sendo raspada com um canudo eletrizado. (c) Quando o canudo é afastado, a tirinha abaixa rapidamente em um dia úmido e chuvoso.

Porém, logo que o canudo atritado é afastado do eletroscópio, observa-se que a tirinha não permanece levantada por muito tempo. Ela vai abaixando rapidamente, voltando logo à orientação vertical encostada na cartolina, Figura 3.15 (c). Quanto maior for a umidade do dia, mais rapidamente a tirinha abaixa. Dependendo do valor desta umidade, o ar pode se comportar como um mau condutor ou como um bom condutor. A presença do vapor de água no ar úmido é um dos fatores que faz com que o ar se comporte como um condutor, já que a própria água se comporta como condutora nas experiências usuais da eletrostática. ${ }^{10}$ Uma superfície eletrizada pode atrair moléculas ou gotículas de

\footnotetext{
${ }^{10}$ Seção 7.11 de [Ass10b], [Ass10a], [Ass11], [Ass15b] e [Ass17].
} 
água que entram em contato com ela, ficam eletrizadas, sendo então repelidas pela superfície. Ver o mecanismo $A C R$ descrito na Seção 4.4. Este processo pode descarregar a superfície.

Em dias úmidos temos então um comportamento anômalo do eletroscópio quando comparamos com o que ocorre em dias secos e frios, a saber, a dificuldade de eletrizá-lo e a facilidade com que o eletroscópio descarrega. ${ }^{11}$ Existem dois fatores principais que influenciam nestes comportamentos do eletroscópio, fator I e fator II. O eletroscópio está em contato essencialmente com o ar ao seu redor e com o canudo plástico que o liga à Terra. Ele pode então descarregar para o ar ao seu redor (fator I), ou para a Terra através do seu suporte isolante (fator II). Na Seção 3.1 vimos que a água comporta-se como um bom condutor para as experiências de eletrostática. Fator I: A umidade do ar aumenta sua condutividade, fazendo com que o ar conduza mais facilmente comparado aos dias secos. Há então uma maior facilidade de trocas de cargas entre o eletroscópio e o ar ao seu redor, descarregando qualquer eletrização que tenha sido fornecida ao eletroscópio pelo canudo eletrizado. Fator II: O vapor de água pode também condensar na superfície de qualquer suporte do eletroscópio que o liga à Terra, como é o caso dos canudos plásticos dos eletroscópios usuais utilizados neste livro. Esta umidade acumulada na superfície dos canudos ou de outros suportes do eletroscópio fazem com que estes suportes passem a se comportar como condutores, facilitando a troca de partículas eletrizadas com o solo e descarregando o eletroscópio. Este efeito é especialmente importante em materiais hidrófilos que têm afinidade pela água, fazendo com que ela fique presa à superfície destes corpos.

\subsubsection{Orientação do Corpo em Relação à Voltagem Apli- cada sobre Ele}

Existem materiais anisotrópicos cuja resistência elétrica varia dependendo da direção ou orientação do material. O grafite, por exemplo, tem uma estrutura de camadas ou folhas sobrepostas. A resistência elétrica é baixa no plano destas camadas e alta na direção normal a estas camadas.

Existem alguns materiais polares que se comportam como condutores em um sentido e como isolantes no sentido inverso. O exemplo mais comum e com enorme aplicação prática é o diodo semicondutor. Ele é facilmente encontrado em lojas de materiais elétricos ou eletrônicos, sendo de baixo custo (preço de alguns centavos por diodo). Estes materiais possuem grande aplicação na indústria eletrônica, sendo usados como retificadores de corrente elétrica, como chaves ou interruptores, além de muitas outras funções. Na Figura 3.16 (a) apresentamos a aparência real deste dispositivo, enquanto que em (b) apresentamos sua representação esquemática como aparece nos circuitos elétricos. Suas duas polaridades são chamadas de ânodo (ou anodo) e cátodo (ou catodo).

\section{Experiência 3.33 - Polaridade do diodo}

\footnotetext{
${ }^{11}$ Seções 7.11 e 7.13 de [Ass10b], [Ass10a], [Ass11], [Ass15b] e [Ass17].
} 


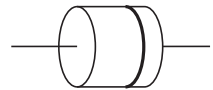

(a)

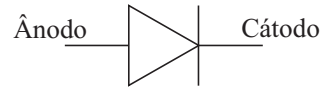

(b)

Figura 3.16: (a) Representação de um diodo real. (b) Representação esquemática.

Pode-se observar o comportamento de um diodo com um circuito simples composto por uma lâmpada de lanterna que acende com 1,5 ou $3 \mathrm{~V}$, com uma ou mais pilhas comuns de 1,5 V, juntamente com alguns pedaços de fio. A pilha pode ser usada sozinha ou então com duas ou mais pilhas ligadas em série. Montamos o circuito como na Figura 3.17 (a). Observa-se que a lâmpada acende. Neste caso o ânodo do diodo está ligado ao terminal positivo da pilha, sendo esta configuração chamada de polarização direta. Como a lâmpada acende, o diodo está se comportando como um condutor nesta polarização. Antes de prosseguir com a experiência é importante observar que de fato a lâmpada está acendendo nesta polarização, garantindo com isto que todos os contatos e conexões dos fios estão funcionando bem.

Quando invertemos a polaridade do diodo como na Figura 3.17 (b), a lâmpada não acende. Neste caso o ânodo do diodo está ligado ao terminal negativo da pilha, sendo esta configuração chamada de polarização inversa ou indireta. Como a lâmpada não acende, o diodo está se comportando como um isolante nesta polarização.

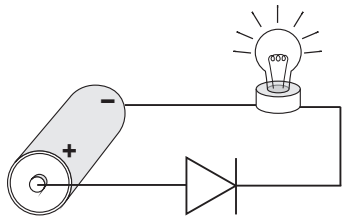

(a)

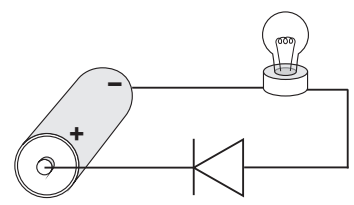

(b)

Figura 3.17: (a) Polarização direta, com o diodo comportando-se como um condutor. (b) Polarização inversa, com o diodo comportando-se como um isolante.

Este é um comportamento fascinante. A simples orientação do diodo em relação à pilha faz com que ele mude completamente suas propriedades condutoras. Por este motivo dizemos que ele é polar. Não é fácil entender o que ocorre dentro dele, ou como é sua constituição interna. De qualquer forma, depois que se compreende seu comportamento em experiências como esta, fica fácil utilizá-lo em diversas aplicações.

\section{Experiência 3.34 - Aplicando uma alta voltagem a um diodo}

Na Experiência 3.33 vimos que dependendo da orientação de um diodo em um circuito simples (composto por fios, lâmpada e pilha), ele se comporta como condutor ou isolante. Este fato depende da diferença de potencial que se aplica 
entre suas extremidades. No caso da experiência 3.33 tínhamos uma ou mais pilhas em série gerando uma diferença de potencial de alguns volts. Já nas experiências de eletrostática lidamos com voltagens muito maiores, variando tipicamente entre $1.000 \mathrm{~V}$ e $10.000 \mathrm{~V}$. Nesta experiência vamos analisar o comportamento de um diodo na eletrostática.

Inicialmente eletrizamos um eletroscópio, Figura 3.18 (a). Seguramos um diodo pelo cátodo e encostamos o ânodo do diodo na cartolina do eletroscópio eletrizado. Observa-se que a tirinha abaixa imediatamente, Figura 3.18 (b). Ao afastarmos o diodo observa-se que a tirinha continua abaixada, indicando que o eletroscópio foi descarregado.

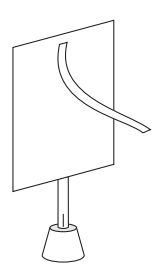

(a)

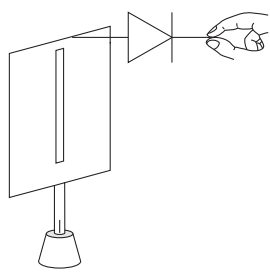

(b)

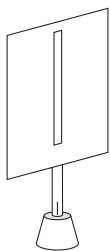

(c)

Figura 3.18: (a) Eletroscópio eletrizado. (b) Segurando o diodo pelo cátodo, encosta-se o ânodo do diodo no eletroscópio e a tirinha abaixa. (c) A tirinha permanece abaixada após afastarmos o diodo.

O mesmo efeito ocorre quando seguramos um diodo pelo ânodo e encostamos o cátodo do diodo na cartolina do eletroscópio eletrizado, Figura 3.19.

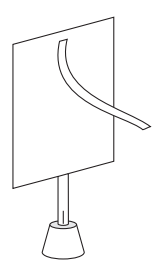

(a)

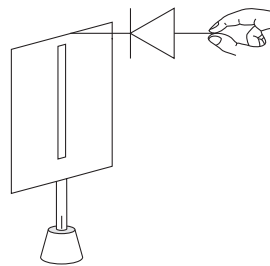

(b)

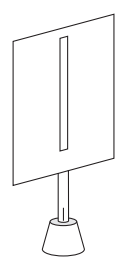

(c)

Figura 3.19: (a) Eletroscópio eletrizado. (b) Segurando o diodo pelo ânodo, encosta-se o cátodo do diodo no eletroscópio e a tirinha abaixa. (c) A tirinha permanece abaixada após afastarmos o diodo.

Ou seja, tanto na polarização direta quanto na polarização inversa o diodo comporta-se como um condutor para as experiências de eletrostática. Este é mais um exemplo de que o comportamento condutor ou isolante de um corpo depende da diferença de potencial que aplicamos entre as extremidades do corpo, como mostrado na Subseção 3.3.2.

Não enfatizamos aqui se o eletroscópio estava eletrizado positivamente ou 
negativamente, já que este aspecto não é relevante para o resultado da experiência. Ou seja, o comportamento das Figuras 3.18 e 3.19 ocorre tanto para um eletroscópio positivamente eletrizado quanto para um eletroscópio negativamente eletrizado. Nestes dois casos o diodo comporta-se como condutor nas experiências de alta voltagem da eletrostática, tanto na polarização direta quanto na polarização inversa.

\section{Experiência 3.35 - Polaridade de um LED}

Existem alguns tipos especiais de diodos que emitem luz, chamados de LEDs (light emitting diodes). Os formatos são variados, sendo que na Figura 3.20 (a) apresentamos a aparência de um LED real, enquanto que em (b) apresentamos sua representação esquemática como aparece nos circuitos eletrônicos. Eles também são baratos e facilmente encontrados em lojas de eletrônica (preço de alguns centavos por LED). Alguns acendem com 1,5 ou $3 \mathrm{~V}$.

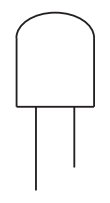

(a)

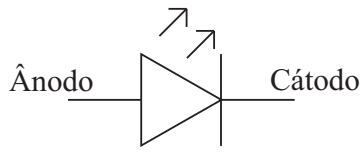

(b)

Figura 3.20: (a) Representação de um LED real. (b) Símbolo de um LED como aparece nos circuitos eletrônicos.

Os LEDs podem ser utilizados no lugar das lâmpadas de lanterna das Seções 2.7, 3.2 e da Subseção 3.3.2. O único cuidado a ser tomado com os LEDs é que eles são polares. Ou seja, quando está diretamente polarizado ele acende, como indicado na Figura 3.21. Na polarização direta o terminal positivo da pilha deve ser ligado ao ânodo do LED, enquanto que o terminal negativo é ligado ao cátodo do LED.

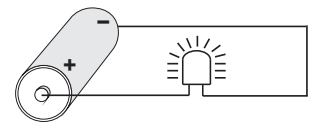

(a)

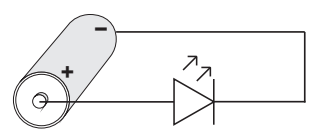

(b)

Figura 3.21: (a) LED aceso na polarização direta. (b) Representação esquemática do LED na polarização direta.

Já na polarização inversa ou indireta ele não acende, como indicado na Figura 3.22 .

\subsubsection{Temperatura}

A resistência elétrica de muitos materiais como os metais comuns varia consideravelmente com sua temperatura. Em geral a resistência de um metal cresce com 


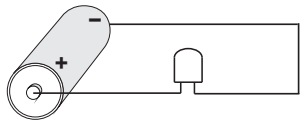

(a)

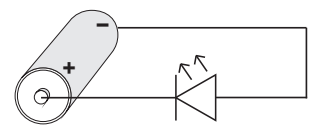

(b)

Figura 3.22: (a) LED apagado na polarização inversa. (b) Representação esquemática do LED na polarização inversa.

sua temperatura, embora nem sempre de forma linear. Ou seja, quanto mais quente ele estiver, mais isolante será seu comportamento. Algumas substâncias tornam-se supercondutoras (resistência nula) a temperaturas muito baixas.

A resistência elétrica dos isolantes também varia com a temperatura, embora o comportamento não seja tão simples como no caso dos metais. Em alguns isolantes a resistência diminui com o aumento da temperatura. Este comportamento também não é linear.

Existem também alguns materiais semicondutores chamados de termistores cujas resistências variam com a temperatura (dependendo do material, sua resistência pode aumentar ou então diminuir quando há um aumento de temperatura).

\subsubsection{Iluminação}

Existem alguns materiais (em geral semicondutores) cuja resistência varia de acordo com a intensidade de luz que incide sobre eles. Nestes casos em geral a resistência diminui com o aumento da intensidade luminosa. Estes materiais são utilizados em sensores de luz, controle de iluminação, detectores de incêndio, fotocélulas, etc. Algumas vezes são chamados de fotorresistores, fotorresistências, fotocondutores, ou resistores dependentes da luz. São também conhecidos pelo símbolo LDR (light-dependent resistor).

\subsubsection{Outros Fatores}

Existem diversos outros fatores que podem afetar o comportamento condutor ou isolante de um corpo. Podemos citar aqui a pressão, as impurezas em sua composição, o processo de fabricação, etc. A condutividade do ar, por exemplo, varia bastante com a pressão. Esta variação não é linear. Não entraremos em maiores detalhes neste livro. O mais importante é ter sempre em mente que nenhum corpo é condutor ou isolante. Ele apenas vai se comportar como condutor ou isolante dependo não apenas de fatores intrínsecos ao corpo, mas também das condições externas a que está sujeito. Ao alterar estes fatores internos e externos podemos mudar o comportamento condutor ou isolante de qualquer material. 


\subsection{Leis Relacionadas aos Circuitos com Cor- rente Constante}

Luigi Galvani (1737-1798) foi um pesquisador italiano, professor de anatomia na Universidade de Bologna, que fez descobertas importantes na década de 1780 ligadas à eletricidade animal, uma expressão cunhada por ele. Em particular, obteve contrações musculares em rãs ao tocar seus nervos com hastes bimetálicas, publicando um trabalho famoso sobre o tema. Alessandro Volta (1745-1827) interessou-se por este assunto a partir das experiências de Galvani. Inicialmente aceitou suas ideias mas depois opôs-se fortemente a elas, tendo havido uma grande rivalidade entre ambos. Foi durante esta controvérsia que construiu sua famosa pilha entre 1795 e 1799. Em 1800 publicou suas descobertas em um artigo muito importante já traduzido para a língua portuguesa. ${ }^{12}$ A partir de então passou-se a ter uma fonte controlada de corrente constante alimentada por uma fonte de baixa voltagem.

Ao trabalhar com uma pilha voltaica, H. C. Oersted (1777-1851) observou em 1820 a deflexão de uma agulha imantada quando havia a presença de um longo fio com corrente em suas proximidades. Seu trabalho de apenas quatro páginas contendo sua descoberta causou um forte impacto na física, sendo traduzido em diversos idiomas. ${ }^{13}$ Seguindo estas pesquisas Thomas Johann Seebeck (17701831) descobriu o efeito termoelétrico em 1821. Em particular, se um anel composto de dois metais diferentes tiver as duas juntas mantidas a temperaturas diferentes, vai fluir uma corrente ao longo do anel.

Humphry Davy (1778-1829) foi um importante químico inglês que também trabalhou com eletricidade. Em 1821 descobriu que o poder condutor de um fio metálico ligado aos terminais de uma pilha voltaica é inversamente proporcional ao seu comprimento, diretamente proporcional à área de sua seção reta, mas independente do formato desta seção reta. Concluiu então que a corrente constante flui ao longo de toda a seção reta do condutor e não apenas sobre sua superfície. Entre 1823 e 1826 Antoine-César Becquerel (1788-1878) confirmou estes resultados por pesquisas independentes.

Georg Simon Ohm (1789-1854) foi um físico alemão influenciado pelas descobertas de Volta, Oersted e Seebeck que fez pesquisas importantes ligadas aos circuitos elétricos entre 1825 e 1827. Inicialmente trabalhou com uma pilha voltaica, mas as pilhas iniciais enfraqueciam rapidamente, o que diminuía a diferença de potencial entre seus terminais. Passou então a utilizar um par termoelétrico como fonte de voltagem. A vantagem em relação à pilha é que ao manter as duas junções deste par em temperaturas constantes, conseguia em suas experiências uma fonte de voltagem constante ao longo do tempo. Também investigou a condutividade de metais diferentes, assim como a influência do comprimento, da seção reta e da diferença de "força eletroscópica" (expressão introduzida por ele) entre as extremidades do metal. Identificava esta força eletroscópica com a densidade volumétrica de carga. Foi apenas em 1849 que

\footnotetext{
12 [Vol00a], [Vol00b], [Vol64], [Mag06] e [MA08].

13 [Oer20b], [Oer20a], [Oer65], [Fra81] e [Ørs86].
} 
G. Kirchhoff (1824-1887) identificou corretamente a força eletroscópica de Ohm com o conceito de potencial eletrostático. Estas pesquisas levaram ao que se chama nos livros didáticos de lei de Ohm. ${ }^{14}$ De acordo com esta lei, a diferença de potencial atuando nas extremidades de um fio metálico é diretamente proporcional à corrente elétrica que vai fluir pelo metal. A constante de proporcionalidade é chamada de resistência do metal. Ela depende do tipo de metal, sendo ainda diretamente proporcional ao seu comprimento e inversamente proporcional à sua área de seção reta.

\footnotetext{
14 [Ohm25], [Ohm26], [Ohm66], [OF38], [Whe43], [Kir49], [Kir50], [Ros90, págs. 210-214 e 494-499], [Ram], [Sch63], [Whi73a, págs. 88-93 e 224-226], [JM86, págs. 51-62], [Ach96, Capítulos 6, 9, 10, 11 e 12], [Kip09], [Hae12] e [BW12a].
} 


\section{Capítulo 4}

\section{Condutores e Isolantes em Algumas Experiências Simples}

\subsection{Condutores e Isolantes no Efeito Âmbar}

A experiência mais antiga da eletricidade é o chamado efeito âmbar, Seção 1.1. Quase todas as pessoas já fizeram uma experiência deste tipo atritando um canudo plástico ou uma régua de acrílico no cabelo e atraindo pedacinhos de papel sobre a mesa. Em nosso livro anterior apresentamos uma descrição do que ocorre no efeito âmbar após discutir uma grande série de experiências relacionadas ao tema. ${ }^{1}$ Queremos aqui chamar a atenção para o fato de que esta descrição é diferente da explicação que se encontra na maioria dos livros didáticos.

Vamos supor então que inicialmente temos papeizinhos em repouso sobre uma mesa. Aproximamos deles então uma régua plástica eletrizada por atrito, de cima para baixo. Quando ela se aproxima suficientemente dos papeizinhos, alguns deles são visivelmente atraídos pela régua, pulando em sua direção. Este é o fenômeno observado. Vamos ver agora sua explicação, começando com o que é dito na maioria dos textos.

\subsubsection{Explicação do Efeito Âmbar nos Livros Didáticos}

A maioria dos livros didáticos sobre eletricidade menciona o efeito âmbar. Estes livros afirmam explicitamente que uma régua plástica atritada polariza as moléculas do papelzinho. Algumas vezes esta afirmação não é explícita, mas pode ser deduzida das figuras que aparecem nestes livros. Eles afirmam que a parte de cada molécula do papel que está mais próxima do plástico eletrizado

\footnotetext{
${ }^{1}$ Seção 8.3 de [Ass10b], [Ass10a], [Ass11], [Ass15b] e [Ass17].
} 
fica carregada com carga de sinal oposto à carga do plástico. Já a parte mais afastada de cada molécula do papel que está mais afastada do plástico eletrizado fica carregada com uma carga de mesmo sinal que a carga do plástico. A força elétrica diminui com o aumento da distância entre os corpos interagentes. Logo, a parte da molécula do papel mais próxima do plástico é atraída por ele com uma força de intensidade maior do que a intensidade da força repulsiva entre o plástico eletrizado e a parte mais afastada da molécula do papel. Haveria então uma força resultante $F$ de atração entre o plástico eletrizado e todas as moléculas polarizadas do papelzinho. Se esta força for maior do que o peso $P$ do papelzinho, o papelzinho iria em direção ao plástico eletrizado. Ou seja, os livros didáticos explicam que o papelzinho é atraído pelo plástico eletrizado pela diferença de força que existe entre o plástico eletrizado e as partes de cada molécula do papel polarizado. Uma representação desta explicação aparece na Figura 4.1.

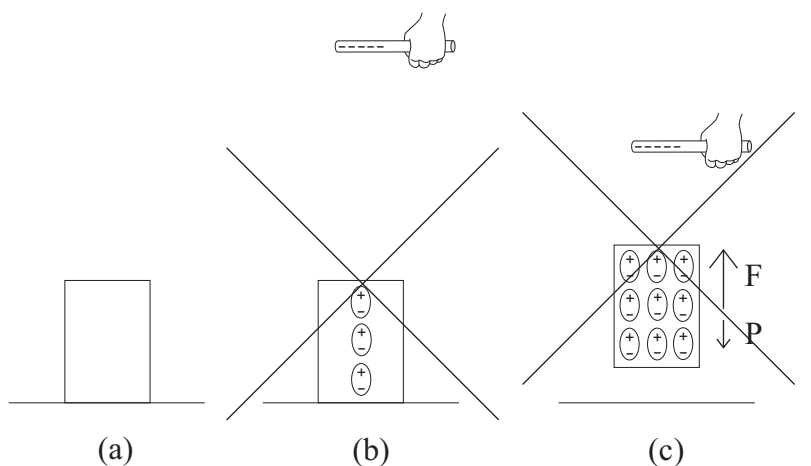

(a)

(b)

(c)

Figura 4.1: Explicação errada do efeito âmbar. (a) Um papelzinho sobre a mesa. (b) Moléculas polarizadas do papelzinho devido à presença de um canudo eletrizado próximo a ele. (c) Quando o canudo fica mais próximo do papel, aumenta a polarização das moléculas. Quando a força $F$ de atração exercida pelo plástico eletrizado sobre as moléculas polarizadas for maior do que o peso $P$ do papelzinho, este será atraído em direção ao plástico eletrizado.

Acreditamos que esta não seja a explicação correta para o efeito âmbar usual e por este motivo colocamos um grande símbolo $\times$ na Figura 4.1. Embora o que os livros didáticos estejam descrevendo possa de fato ocorrer, não nos parece que este seja o aspecto principal do fenômeno. Nesta descrição apresentada pelos livros didáticos assume-se implicitamente que os papeizinhos se comportam como isolantes. Mas os papéis e a grande maioria das outras substâncias leves usualmente atraídas por um âmbar ou plástico atritado comportam-se como materiais condutores.

Além disso, os livros não se preocupam em discutir se o suporte no qual os papeizinhos estão apoiados inicialmente é um condutor ou isolante. 


\subsubsection{Nossa Explicação do Efeito Âmbar}

Apresentamos agora nossa descrição para o efeito âmbar. O pedacinho de papel é representado pela letra $C$, indicando que é um condutor. Vamos assumir que ele está sobre uma superfície isolante $I$, Figura 4.2 (a).

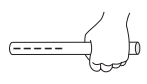

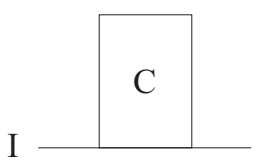

(a)

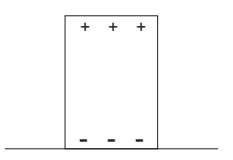

(b)
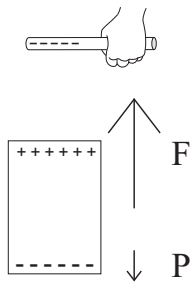

(c)

Figura 4.2: (a) Papelzinho condutor $C$ sobre uma superfície isolante $I$. (b) Polarização macroscópica do condutor apoiado sobre um isolante devido à presença de um corpo eletrizado em suas proximidades. (c) Se o plástico se aproximar ainda mais, aumenta a quantidade de cargas polarizadas do papel. Quando a força $F$ de atração exercida pelo plástico eletrizado sobre o condutor polarizado macroscopicamente for maior do que o peso $P$ do papelzinho, este será atraído em direção ao plástico eletrizado.

O efeito principal que ocorre com substâncias condutoras que estão próximas de um plástico eletrizado é uma polarização macroscópica de cargas, uma separação real de cargas ao longo de todo o volume do papelzinho. Ou seja, não é apenas uma separação de cargas dentro de cada molécula do papel. O que ocorre é um deslocamento ao longo do volume macroscópico do papelzinho das partículas eletrizadas que existem em seu interior. Na Figura 4.2 (b) apresentamos qualitativamente esta polarização macroscópica de um papelzinho supondo que ele está sobre uma superfície isolante $I$. Não apresentamos nesta figura as moléculas polarizadas do suporte isolante. Ao aproximar ainda mais o plástico eletrizado do papel, aumentam as quantidades de cargas positivas e negativas no papel polarizado. Quando a força $F$ de atração exercida pelo plástico eletrizado sobre o condutor polarizado macroscopicamente for maior do que o peso $P$ do papelzinho, este será atraído em direção ao plástico eletrizado, Figura 4.2 (c).

Vamos supor que aproximamos uma régua plástica eletrizada à mesma distância de um condutor e de um isolante, tendo o condutor o mesmo tamanho e formato que o isolante. A polarização macroscópica deste condutor será maior do que a polarização efetiva do isolante. Na Figura 4.1 (c) a polarização efetiva do papel, considerado erradamente como um isolante, está representada por três cargas positivas na parte superior e por três cargas negativas na parte 
inferior, sendo que as cargas positivas e negativas em seu interior essencialmente se cancelam. Já na Figura 4.2 (c) a polarização efetiva do papel considerado como um condutor está representada por seis cargas positivas na parte superior e por seis cargas negativas na parte inferior. Como esta polarização é maior do que a polarização efetiva de um isolante, a força resultante $F$ exercida pela régua plástica eletrizada sobre o papel polarizado está representada por um vetor maior na Figura 4.2 (c) do que na Figura 4.1 (c).

Porém, o caso mais comum é quando o papelzinho está apoiado sobre uma superfície condutora $C$, como é o caso do solo comum, de uma mesa de madeira não envernizada, ou então de uma superfície de metal, Figura 4.3 (a).

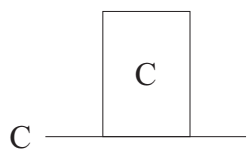

(a)

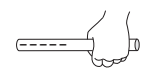

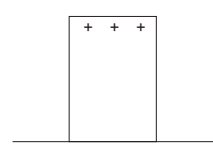

(b)
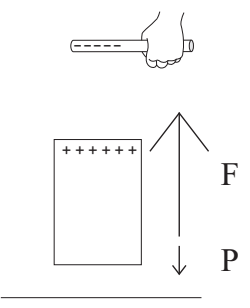

(c)

Figura 4.3: (a) Papelzinho condutor $C$ sobre uma superfície condutora $C$. (b) Por estar aterrado, o papelzinho adquire uma carga de sinal oposto à do plástico eletrizado quando há uma aproximação entre eles. (c) Se o plástico se aproximar ainda mais, aumenta a quantidade de carga sobre o papel. Quando a força $F$ de atração exercida pelo plástico eletrizado sobre o papelzinho eletrizado for maior do que o peso $P$ do papelzinho, este será atraído em direção ao plástico eletrizado.

Neste caso o papelzinho está aterrado. Logo, com a aproximação da régua plástica eletrizada, ele vai adquirir uma carga resultante não nula, de sinal oposto à carga da régua. Esta situação está representada na Figura 4.3 (b). Não apresentamos nesta imagem as cargas sobre a superfície condutora. Ao aproximar ainda mais o plástico eletrizado do papel, aumenta a quantidade de cargas positivas no papel. Quando a força $F$ de atração exercida pelo plástico eletrizado sobre o condutor carregado macroscopicamente for maior do que o peso $P$ do papelzinho, este será atraído em direção ao plástico eletrizado, Figura 4.3 (c).

Neste caso a força resultante $F$ exercida pela régua plástica eletrizada sobre o papel eletrizado com carga oposta à da régua é ainda maior do que a força resultante do caso da Figura 4.2 (c). Por este motivo ampliamos ainda mais a seta representando esta força $F$.

Nas Figuras 4.1 (c), 4.2 (c) e 4.3 (c) estamos assumindo que o canudo plástico está igualmente eletrizado em todos os casos. Além disso, o canudo está sempre desenhado à mesma distância $d$ de um pedacinho de papel específico que está 
deslocando-se em direção ao canudo. O tamanho das setas representa a intensidade da força $F$ exercida pelo canudo eletrizado sobre o papelzinho. A força $F$ da Figura 4.2 (c) é maior do que a força da Figura 4.1 (c) pelo fato de que a polarização de um condutor é maior do que a polarização efetiva de um isolante. A força $F$ da Figura 4.3 (c) é maior do que a força da Figura 4.2 (c) pelo fato de que o papelzinho da Figura 4.3 (c) tem uma carga resultante diferente de zero, enquanto que o papel da 4.2 (c) está apenas polarizado, não tendo uma carga resultante.

É um preconceito errôneo muito difundido considerar o papel, a madeira, o vidro e a borracha como materiais isolantes. Na prática algumas destas substâncias (alguns tipos de vidro, de madeira e de borracha, a maior parte dos papeis) comportam-se como condutoras nas experiências usuais de eletrostática, como é o caso do efeito âmbar. Por isto fomos cuidadosos em nossa descrição deste efeito em nosso livro anterior no qual apresentamos uma discussão detalhada deste efeito com várias figuras. ${ }^{2}$

A primeira experiência do Volume 1 apresentou o efeito âmbar. A última experiência apresentou um fenômeno análogo no qual foi possível testar a carga resultante adquirida pelo papelzinho. Além disso, no meio do livro discutimos vários instrumentos utilizando o papel (ou substâncias análogas tais como a cartolina e o papel de "seda") como um condutor, em especial o pêndulo elétrico e o eletroscópio. ${ }^{3}$ Toda esta organização do livro foi feita de propósito, pensada cuidadosamente. Embora a experiência do efeito âmbar seja simples de fazer, a descrição correta dos vários aspectos envolvidos neste fenômeno é complexa.

\subsubsection{A Importância de se Apresentar uma Explicação De- talhada do Efeito Âmbar}

A Subseção 4.1.1 apresentou a explicação do efeito âmbar como aparece em diversos livros didáticos. Na Subseção 4.1.2 apresentamos nossa descrição dos principais fenômenos que ocorrem neste mesmo efeito. Ela é bem diferente do que se encontra nos livros didáticos. Consideramos importante corrigir os livros didáticos com uma explicação mais precisa sobre os principais fenômenos que ocorrem no efeito âmbar por diversos motivos:

- Esta é uma das experiência mais simples da eletricidade, sendo aquela que dá origem a toda está área de pesquisa. Não é bom que os livros modernos apresentem uma explicação errada de um fenômeno tão antigo.

- Quase todas as pessoas realizaram esta experiência como uma brincadeira durante o ensino médio atritando um canudo plástico ou uma régua de acrílico no cabelo e atraindo papeizinhos colocados sobre uma mesa. Para os jovens que abandonam os estudos após o ensino médio ou para aqueles que fazem um curso superior na área de ciências humanas ou biológicas,

\footnotetext{
${ }^{2}$ Seção 8.3 de [Ass10b], [Ass10a], [Ass11], [Ass15b] e [Ass17].

${ }^{3}$ Seções 2.1, 2.2, 4.4, 6.1, 6.5 e 7.15 de [Ass10b], [Ass10a], [Ass11], [Ass15b] e [Ass17].
} 
esta pode ser uma das poucas experiências de eletricidade que vão fazer durante suas vidas. Logo seria importante que aprendessem uma explicação correta deste fenômeno.

- A explicação da Subseção 4.1.1 pode ser considerada mais simples do que a descrição da Subseção 4.1.2. Apesar disto, é melhor apresentar uma descrição um pouco mais cuidadosa e complexa, mas que seja essencialmente correta, do que apresentar uma explicação simples e errônea. A explicação mais simples nem sempre é a melhor. Aprendemos muito mais ao pensar com calma sobre este fenômeno aparentemente simples e ao perceber vários aspectos que são importantes para descrevê-lo corretamente.

- Mesmo os fenômenos aparentemente simples e corriqueiros muitas vezes escondem surpresas e sutilezas relevantes, como é o caso do efeito âmbar.

- A descrição correta deste fenômeno requer a compreensão dos condutores e isolantes, assim como de suas principais propriedades. Quando se compreendem estes aspectos passamos a ter uma visão mais correta do que está ocorrendo, fazendo com que passemos a prestar atenção nestes aspectos ao analisar fenômenos mais complicados.

- Com a explicação correta aprendemos que as substâncias leves (tais como pedacinhos de papel, penas ou uma linha de algodão) atraídas pelo plástico atritado comportam-se normalmente como substâncias condutoras nas experiências de eletrostática.

- Com a explicação correta também aprendemos que a maior parte das superfícies nas quais as substâncias leves estão apoiadas antes de serem atraídas (tais como uma mesa de madeira ou de metal) também comportase como uma superfície condutora e aterrada na eletrostática.

Estes dois últimos itens são bem importantes. Ao aprender sobre eles abrimos nossa cabeça para diversos aspectos relevantes relacionados aos fenômenos elétricos.

\subsection{Condutores e Isolantes na Experiência do Desvio do Filete de Água}

Uma experiência que muitas pessoas já fizeram e que aparece descrita em diversos livros didáticos de eletricidade é a do desvio de um filete de água ao aproximarmos uma régua plástica eletrizada, Experiência 3.7. Queremos aqui chamar a atenção para o fato de que a descrição que apresentamos sobre o que acontece neste fenômeno em nossa obra anterior é diferente da explicação que aparece na maioria dos livros didáticos. ${ }^{4}$ Vamos supor aqui que a régua tenha ficado negativamente eletrizada pelo atrito. Quando aproximamos esta régua plástica

\footnotetext{
${ }^{4}$ Seções 2.5 e 7.11 de [Ass10b], [Ass10a], [Ass11], [Ass15b] e [Ass17].
} 
eletrizada de um filete de água, a água curva-se em direção à régua, Figura 3.8. Esta atração representa o fenômeno observado na experiência. Apresentamos agora brevemente a explicação usual que aparece na maioria dos livros didáticos que discutem este fenômeno.

\subsubsection{Explicação do Desvio do Filete de Água nos Livros Didáticos}

Nos livros didáticos menciona-se em geral que as moléculas da água são polares, isto é, apresentando permanentemente um lado positivo e um lado negativo. Consideram então que ao aproximarmos uma régua plástica eletrizada de um filete de água, estas moléculas polares se orientam em relação à régua, com a parte positiva de cada molécula ficando mais próxima da régua negativa do que a parte negativa de cada molécula. A força elétrica diminui com o aumento da distância entre os corpos interagentes. Logo, a parte positiva da molécula seria atraída pela régua negativa com uma força de maior intensidade do que a intensidade da força repulsiva sofrida pela parte mais afastada da molécula. Esta seria a explicação para a atração do filete de água pela régua plástica eletrizada de acordo com os livros didáticos. Uma representação qualitativa desta explicação encontra-se na Figura 4.4.

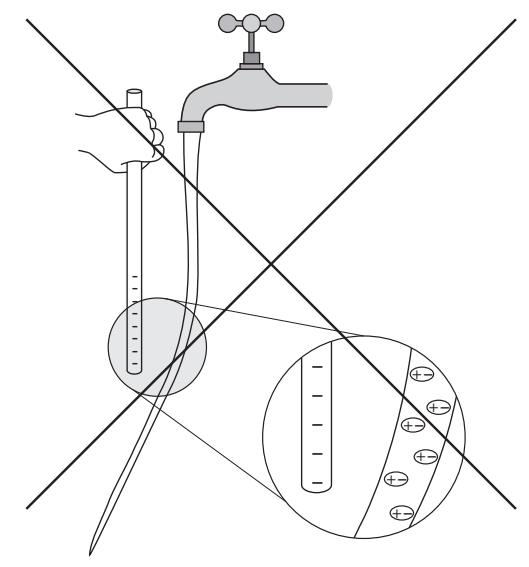

Figura 4.4: Explicação errada do desvio de um filete de água devido à orientação das moléculas polares da água com a aproximação de um corpo eletrizado.

Acreditamos que esta não seja a explicação correta para este fenômeno e por este motivo colocamos um grande símbolo $\times$ na Figura 4.4. Nos livros didáticos assume-se implicitamente que a água seja um isolante. Se este fosse o caso, ela não teria cargas livres que poderiam deslocar-se pelo volume macroscópico da água. A régua eletrizada pode orientar as moléculas polares da água. Não duvidamos que as moléculas da água sejam polares e que possam, de fato, ser orientadas pela régua eletrizada. Contudo, não acreditamos que este seja o principal mecanismo responsável pela curvatura do filete de água. 


\subsubsection{Nossa Explicação do Desvio do Filete de Água}

Apresentamos agora nossa descrição deste fenômeno. A principal diferença entre nossa descrição e a que aparece na maioria dos livros didáticos é que consideramos a água como condutora para as experiências de eletrostática, já que descarrega um eletroscópio eletrizado, como mostrado na Experiência 3.5, Figura 3.6. A água é composta principalmente de moléculas polares de $\mathrm{H}_{2} \mathrm{O}$. Mas ela também contém sais, várias impurezas, $\mathrm{H}_{3} \mathrm{O}^{+}, \mathrm{OH}^{-}$, juntamente com outros íons, além de diversas outras substâncias. Este conjunto de substâncias confere um comportamento condutor à água.

Inicialmente vamos considerar uma torneira pingando, Figura 4.5 (a).

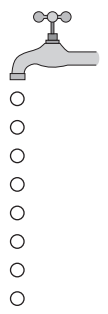

(a)

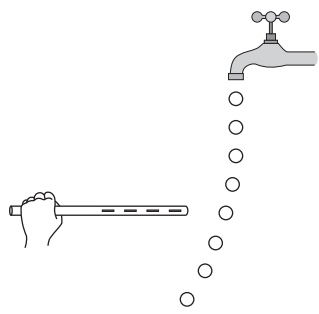

(b)

Figura 4.5: (a) Torneira pingando. (b) Régua negativamente eletrizada atraindo as gotas.

Uma régua negativamente eletrizada curva a trajetória das gotas quando se aproxima delas, Figura 4.5 (b). Vamos supor que a régua está longe da torneira e que só influencia significativamente as gotas que chegam perto dela. Assumindo que a água comporta-se como um condutor, ao aproximarmos a régua eletrizada negativamente das gotas, ocorre uma separação macroscópica real das cargas em cada gota. A parte da gota mais próxima da régua fica positivamente eletrizada, enquanto que a parte mais afastada fica negativamente eletrizada, ver a Figura 4.6 na qual exageramos o tamanho da gota.
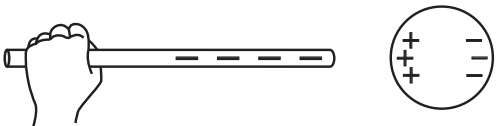

Figura 4.6: Gota polarizada pela régua eletrizada.

Como a intensidade da força elétrica aumenta com a diminuição da distância, a parte positiva da gota é atraída pela régua por uma força maior do que a repulsão sofrida pela parte negativa da gota. Vai haver então uma força resultante sobre a gota fazendo-a deslocar-se em direção à régua.

Vamos considerar agora o caso de um filete contínuo de água. Novamente assumimos que a água comporta-se como um condutor. Ao aproximarmos uma 
régua plástica negativamente eletrizada do filete, ocorre uma separação macroscópica real das cargas na água. A parte do filete mais próxima da régua fica positiva e a parte mais afastada do filete fica negativa. Supondo o filete contínuo, a parte mais afastada do filete acaba sendo neutralizada pelas cargas que podem fluir entre a água e a Terra. Afinal de contas o filete está aterrado eletricamente (por estar em contato com o restante da água, com o encanamento, com a caixa d'água, etc.). Devido a este aterramento, o filete de água acaba tendo uma carga resultante de sinal oposto à da régua, com estas cargas concentradas no lado do filete que está próximo da régua. ${ }^{5}$ Vai haver então uma atração entre as partículas negativas da régua e as partículas positivas na água, fazendo com que o filete curve-se em direção à régua. Na figura 4.7 apresentamos qualitativamente a distribuição de cargas no filete de água.

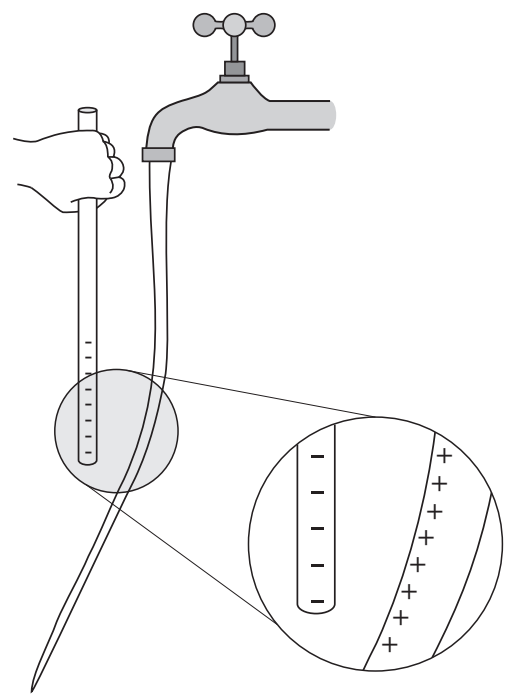

Figura 4.7: Eletrização do filete de água aterrado devido à aproximação de um corpo eletrizado. A água comporta-se como um bom condutor nestas experiências de eletrostática.

Novamente é um preconceito errôneo muito difundido supor que a água de torneira seja um isolante tal que suas moléculas polares possam apenas ser orientadas por uma força elétrica externa. Na realidade a água é um excelente condutor para as experiências de eletrostática, podendo ser polarizada macroscopicamente ou mesmo acumular facilmente uma carga resultante se estiver aterrada na presença de um corpo eletrizado colocado próximo à água. Os efeitos causados por estas cargas polarizadas ou por estas cargas resultantes acumuladas na água vão em geral ser muito mais relevantes do que qualquer eventual orientação que possa estar ocorrendo de suas moléculas polares. ${ }^{6} \mathrm{Um}$

\footnotetext{
${ }^{5}$ Seções 2.5 e 7.11 de [Ass10b], [Ass10a], [Ass11], [Ass15b] e [Ass17].

${ }^{6}$ Para uma discussão deste tema ver [WB11], [Jec12], [BW12d], assim como Seções 2.5 e
} 
destes efeitos pode ser a curvatura do filete de água. A curvatura do filete para um líquido condutor como a água é muito maior do que a curvatura para um líquido isolante como o óleo, assumindo que estes dois líquidos estão à mesma distância do mesmo canudo eletrizado, Figuras 3.8 e 3.9.

Feynman, Leighton e Sands são alguns dos raros autores modernos que consideram a água de torneira como um condutor. ${ }^{7}$

\subsubsection{A Importância de se Apresentar uma Explicação De- talhada do Desvio do Filete de Água}

A Subseção 4.2.1 apresentou a explicação do desvio de um filete de água como aparece em diversos livros didáticos. Na Subseção 4.2.2 apresentamos nossa descrição dos principais fenômenos que ocorrem neste efeito. Ela é bem diferente do que se encontra nos livros didáticos. Consideramos importante corrigir os livros didáticos com uma explicação mais precisa sobre os principais fenômenos que ocorrem no desvio de um filete de água por diversos motivos. Além daqueles citados na Subseção 4.1.3 podemos mencionar:

- Esta é uma das experiência mais simples da eletricidade. Não é bom que os livros modernos apresentem uma explicação errada de um fenômeno tão simples.

- Muitas pessoas já viram esta experiência descrita em livros didáticos, em vídeos na internet ou já a realizaram em casa ou na escola como uma diversão. É importante que elas recebam uma explicação correta dos principais aspectos físicos que estão ocorrendo neste fenômeno que muitos já vivenciaram em primeira mão.

- Com a explicação correta aprendemos que a água comporta-se como um condutor nas experiências de eletrostática. Este é um dado importante que abre a nossa cabeça para diversos aspectos relevantes da eletricidade relacionados com a água e com a umidade dos corpos e do ambiente.

\subsection{Diferenças entre os Vidros da Época de Gray e os Vidros Atuais}

Os fenômenos elétricos foram descobertos pelos antigos gregos quando observaram que um pedaço de âmbar atritado tinha a capacidade de atrair corpos leves (tais como penugens, cascas de sementes, etc.) ao se aproximar deles. Nos séculos XVII e XVIII era comum utilizar-se um tubo de vidro em vez do âmbar para realizar experiências deste tipo. Podemos citar, por exemplo, as experiências de Francis Hauksbee (c. 1666-1713), Stephen Gray (1666-1736),

7.11 de [Ass10b], [Ass10a], [Ass11], [Ass15b] e [Ass17].

7 [FLS64, pág. 9-8]. 
Charles Du Fay (1698-1739), Jean Antoine Nollet (1700-1770) e Benjamin Franklin (1706-1790), por exemplo. Existem três diferenças muito importantes no que diz respeito às experiências de eletrostática entre os vidros utilizados naquela época para os vidros encontrados comumente hoje em dia. Estas diferenças discutidas aqui referem-se ao comportamento elétrico destes vidros. Quando nos referimos aos vidros comuns encontrados atualmente, estes podem ser tanto aqueles de nossas residências (e.g. copo, garrafa, recipiente ou pote para guardar alimentos, janela, espelho, etc.), quanto aqueles adquiridos facilmente no comércio (e.g. béquer, tubo de ensaio, lente, lâmina de microscópio, etc.).

Estas diferenças podem ser devidas tanto às composições destes vidros, quanto aos processos de fabricação destes materiais. Gray, em particular, realizou a maior parte de suas experiências eletrizando um tubo de vidro de flintglass, isto é, um vidro à base de chumbo também chamado de vidro flint. ${ }^{8}$ Estes tipos de vidro foram desenvolvidos por George Ravenscroft (1632-1683) ao redor de 1662, sendo os precursores dos vidros ou cristais de chumbo ingleses, muitas vezes chamados simplesmente de cristais (embora sejam materiais amorfos que não possuem uma estrutura cristalina).

É importante enfatizar estas diferenças tanto pelo aspecto histórico relacionado às experiências originais de Gray e dos outros pesquisadores de sua época, quanto pelos aspectos pedagógicos e didáticos quando se tenta reproduzir algumas destas experiências com vidros atuais, já que elas podem não funcionar da mesma maneira como foram descritas pelos pesquisadores antigos. Estas diferenças são discutidas nas próximas três Subseções, começando com a diferença mais relevante. ${ }^{9}$

\subsubsection{Comportamento Isolante ou Condutor}

O tubo de flint-glass utilizado por Gray era eletrizado por atrito contra suas mãos nuas, como afirma em seu artigo de 1707-1708. ${ }^{10}$ Depois de atritado, o tubo permanecia eletrizado durante suas experiências enquanto era segurado por Gray com uma de suas mãos. Outros pesquisadores deste período tais como Hauksbee, Du Fay e Nollet também atritavam materiais feitos de vidro. Os tubos, cilindros e esferas utilizados para as experiências de eletricidade pelos pesquisadores do período podiam tanto ser feitos dos vidros comuns daquela época, quanto podiam ser feitos de flint-glass. Estes vidros também permaneciam eletrizados enquanto eram manipulados pelos pesquisadores. Na maioria das figuras e pinturas da época os pesquisadores aparecem segurando e manipulando estes tubos eletrizados com suas mãos nuas.

Isto indica que os tubos de vidro daquela época se comportavam como excelentes isolantes elétricos, já que não eram descarregados pelo contato com a mão do pesquisador, que estava aterrada. Por outro lado, muitos tipos mo-

\footnotetext{
8 [Chi54], [Hau], [RR57, págs. 570 e 584-585], [Hom81, pág. 13] e [Hei99, págs. 235-236].

9 [Bos11, Seção 2.5] e [BAC12, Seção 4.5, págs. 93-100]. Ver também Capítulo 1, Seções 5.1 e 6.3, juntamente com o Apêndice B, Seção B.1 de [Ass10b], [Ass10a], [Ass11], [Ass15b] e [Ass17].

${ }^{10}$ [Chi54, págs. 34 e 37].
} 
dernos de vidro comum comportam-se com bons condutores nas experiências de eletrostática. Esta é a principal diferença entre os vidros antigos e os vidros modernos.

Este comportamento condutors dos vidros modernos é facilmente verificado percebendo que eles descarregam um eletroscópio eletrizado ao tocarem na parte superior da cartolina enquanto estão sendo segurados pela pessoa que faz a atividade, ver a Experiência 3.4 da Seção 3.1. Ou seja, se temos um eletroscópio eletrizado e tocamos sua cartolina com um copo de vidro segurado pela mão, observa-se que para vários tipos de vidro o eletroscópio é descarregado rapidamente. Sua tirinha de papel de "seda" é abaixada em poucos segundos neste contato, permanecendo abaixada após o afastamento do copo. Embora este comportamento condutor ocorra com boa parte dos vidros modernos, alguns tipos de vidros atuais comportam-se como isolantes.

Isto significa que não conseguimos eletrizar os vidros atuais que se comportam como condutores utilizando o procedimento de Gray. Por exemplo, seguramos um copo de vidro com uma mão e o atritamos contra o cabelo, contra um papel ou contra um pano de seda ou de algodão. Quando aproximamos este vidro atritado de papeizinhos colocados sobre uma mesa, não se observa nenhuma atração exercida pelo copo. Mesmo quando ocorre alguma atração, ela tem pouca intensidade, não sendo facilmente perceptível. A explicação desta falta de atração é que, qualquer que seja a quantidade de carga que o copo tenha adquirido pelo atrito, esta carga é logo neutralizada através da mão do pesquisador, que está em contato com o solo (aterramento).

Segundo Bossa e colaboradores, ${ }^{11}$ "a condutividade elétrica dos vidros é uma propriedade muito sensível às variações de composição." Desta forma, é possível existirem vidros condutores e isolantes, sendo que esta propriedade define se o material ficará ou não carregado eletricamente no processo mais comum de eletrização por atrito, i.e., segurar o objeto com uma das mãos e atritá-lo com algum material na outra mão. Materiais isolantes podem ser eletrizados facilmente desta maneira. Já os condutores precisam estar isolados eletricamente da mão que os segura para que possam ser eletrizados desta forma. Isto significa que antes de tentar reproduzir qualquer experiência de Gray utilizando os vidros atuais, é necessário testar inicialmente se estes vidros se comportam como isolantes ou condutores. Caso eles se comportem como condutores, não será possível reproduzir a experiência da mesma forma em que foi realizada por Gray, a não ser que este vidro seja previamente isolado eletricamente do contato com a Terra e com o corpo do pesquisador.

Um procedimento que auxilia bastante na alteração do comportamento elétrico do vidro é o aquecimento. Um vidro que se comporta como condutor elétrico pode passar a se comportar como isolante ao ser aquecido no fogo ou em um micro-ondas. O suor da mão de quem realiza o experimento ou a umidade acumulada na superfície de um vidro aumentam suas propriedades condutoras, fazendo com que as cargas elétricas fluam mais livremente sobre ele. O vidro é um material higroscópico, que absorve a umidade do ar, adquirindo assim uma

\footnotetext{
${ }^{11}[\mathrm{Bos}]$.
} 
condutividade superficial. ${ }^{12}$ Esta condutividade superficial depende bastante da composição do vidro e do estado de sua superfície. Ao ser aquecido, parte do suor e da umidade sobre a superfície do vidro é evaporado ou eliminado, fazendo com que o vidro passe a se comportar como um isolante elétrico.

Outro fator que auxilia neste comportamento isolante do vidro é trabalhar com tubos longos que são atritados em uma extremidade, enquanto são segurados pela mão na outra extremidade. A importância do comprimento do corpo no que diz respeito às suas propriedades elétricas foi discutido na Subseção 3.3.4. Quanto mais longo for o tubo, maior será o tempo em que as cargas adquiridas pelo atrito ficarão sobre sua superfície. Gray, em particular, trabalhava frequentemente com um tubo que tinha 1 metro de comprimento.

\subsubsection{Densidade Superficial das Cargas Adquiridas pelo Atrito}

Mesmo quando um vidro atual se comporta como isolante elétrico (seja por sua composição intrínseca, ou pelo fato de ter sido previamente aquecido), ainda assim existe uma diferença grande entre os vidros modernos e aqueles da época de Gray. Os pesquisadores da época de Gray conseguiam produzir efeitos muito grandes e perceptíveis com seus tubos de vidro eletrizados. Conseguiam, por exemplo, atrair corpos leves que estavam a dezenas de centímetros dos tubos eletrizados. Também conseguiam transmitir a virtude elétrica a mais de 100 metros do tubo, desde que houvesse um condutor entre o tubo eletrizado e o ponto onde era observada a atração de corpos leves. Nestas experiências a extremidade do condutor que estava mais afastada do tubo era capaz de atrair corpos leves, desde que a primeira extremidade do condutor estivesse em contato ou próxima do tubo eletrizado. Além disso, Gray gerava faíscas e descargas elétricas com certa facilidade ao aproximar seu tubo de vidro eletrizado de outros corpos condutores. É difícil reproduzir alguns destes efeitos descritos por Gray utilizando os materiais comuns de hoje em dia. Para realizar estas experiências temos de eletrizar um isolante por atrito. Este isolante pode ser, por exemplo, um vidro previamente aquecido, um canudo plástico, uma régua de acrílico ou um tubo de PVC. Mesmo quando conseguimos reproduzir alguns dos fenômenos descritos por Gray, a ordem de grandeza observada atualmente é em geral menor do que aquela descrita por ele. Por exemplo, a distância crítica a partir da qual observamos a atração de corpos leves quando aproximamos deles um isolante eletrizado é em geral menor do que aquela descrita por Gray. Podemos também transmitir a eletricidade para a extremidade livre de condutores que estejam ligados ao nosso isolante eletrizado. Também neste caso o comprimento máximo deste condutor para o qual conseguimos observar a atração de corpos leves por sua extremidade livre é menor do que aquele das experiências de Gray. Dificilmente conseguimos faíscas e descargas elétricas visíveis ao eletrizar um isolante por atrito e aproximá-lo de um condutor. Já para Gray a observação deste fenômeno não parecia ser tão difícil.

\footnotetext{
${ }^{12}$ [WB09].
} 
A explicação desta diferença de comportamento está nas densidades superficiais de carga obtidas pelo atrito. O tubo de Gray era não apenas um excelente isolante, mas tinha a capacidade de adquirir uma grande densidade de carga ao ser atritado. Esta densidade de carga que ele obtinha ao atritar seu tubo era bem maior do que aquela que obtemos hoje em dia, mesmo quando utilizamos bons isolantes elétricos (como é o caso dos canudos de plástico, das réguas de acrílico ou um tubo de PVC). Devido a esta pequena densidade superficial de carga obtida hoje em dia, fica difícil reproduzir algumas das experiências de Gray, pelo menos com a intensidade descrita por ele.

\subsubsection{O Tipo de Eletrização Adquirida pelo Vidro Atri- tado}

A terceira diferença refere-se ao tipo de eletrização adquirida pelo vidro quando é atritado com a pele humana. ${ }^{13}$

A proposta da existência dos dois tipos de eletricidade é devida a Du Fay. Foi ele também quem propôs a regra segundo a qual dois corpos eletrizados com eletricidade do mesmo tipo se repelem, enquanto que dois corpos eletrizados com eletricidades de tipos diferentes se atraem. Estas descobertas foram publicadas em $1733 .{ }^{14}$ Ele denominou de eletricidade vítrea ao primeiro tipo de eletricidade, chamando de eletricidade resinosa ao segundo tipo de eletricidade. Ele obteve que o vidro e a lã adquiriam eletricidade do primeiro tipo ao serem atritados com a pele e com a seda. Por outro lado, obteve que as resinas e a seda adquiriam eletricidade do segundo tipo ao serem atritadas com a pele e com um outro pedaço de seda.

Vinte anos depois de Du Fay publicar estas descobertas, começaram a surgir algumas anomalias. Em particular, foi observado que um mesmo tipo de vidro áspero podia obter eletricidade do primeiro ou do segundo tipo, dependendo do material com o qual era atritado. O mesmo ocorria com outras substâncias. Isto levou à criação das chamadas séries triboelétricas, sendo as primeiras publicadas em 1757 e 1759. Os termos "vítrea" e "resinosa" deixaram de ter sentido após estas descobertas. Passou-se a chamar a eletricidade do primeiro tipo de eletricidade positiva, enquanto que a eletricidade do segundo tipo passou a ser chamada de eletricidade negativa. Se atritamos dois corpos entre si, $C_{1}$ e $C_{2}$, aquele que estiver mais próximo do sinal + da série triboelétrica vai adquirir eletricidade positiva, enquanto que o outro corpo vai adquirir eletricidade negativa, já que se encontra mais próximo do sinal - da série triboelétrica. Convencionou-se então chamar de eletricidade positiva à eletricidade que era chamada de vítrea na época de Du Fay. Também ficou convencionado que a eletricidade chamada de resinosa na época de Du Fay passasse a ser chamada de eletricidade negativa.

A terceira diferença que ocorre entre os vidros da época de Gray e os atuais está relacionado à carga adquirida por eles ao serem atritados contra a pela humana. Os vidros atuais estão muito próximos da pele nas séries triboelétricas. ${ }^{15}$

\footnotetext{
${ }^{13}$ Seções 5.2 a 5.4 de [Ass10b], [Ass10a], [Ass11], [Ass15b] e [Ass17].

14 [DF33b], [DF] e [BC07].

${ }^{15}$ Seção 5.4 de [Ass10b], [Ass10a], [Ass11], [Ass15b] e [Ass17].
} 
Isto significa que alguns vidros atuais vão estar mais próximos da carga + do que a pele humana nestas séries triboelétricas. Vamos chamá-los de vidros do tipo $A$. Já outros vidros atuais vão estar mais próximos da carga - do que a pele humana nestas séries triboelétricas. Vamos chamá-los de vidros do tipo $B$, Tabela 4.1.

\begin{tabular}{|c|}
\hline+ \\
\hline vidro do tipo $A$ \\
\hline pele humana \\
\hline vidro do tipo $B$ \\
\hline- \\
\hline
\end{tabular}

Tabela 4.1: Série triboelétrica para os vidros atuais.

Ou seja, quando atritamos um vidro do tipo $A$ contra a pele, este vidro adquire carga + . Por outro lado, ao atritar um vidro do tipo $B$ contra a pele, este vidro adquire carga - . Para saber se um certo vidro é do tipo $A$ ou $B$, temos de atritá-lo contra a pele humana e testar a carga adquirida pelo vidro ao compará-la com uma outra carga positiva ou negativa já conhecida. Somente experiências deste tipo vão permitir classificá-lo como um vidro do tipo $A$ ou do tipo $B$.

Isto significa que os vidros atuais podem adquirir carga + ou - ao serem atritados contra a pele, dependendo se são do tipo $A$ ou $B$, respectivamente. Por outro lado, os vidros utilizados por Gray e por outros pesquisadores de sua época, quase sempre adquiriam carga + ao serem atritados contra a pele.

\subsubsection{O Vidro nos Livros Didáticos Atuais e a Importância de Corrigir o que Afirmam}

Muitos livros didáticos modernos começam o estudo da eletricidade falando do efeito âmbar, mas utilizando um tubo de vidro no lugar do âmbar. Estes livros também mencionam vidros eletrizados ao discutirem os dois tipos de eletricidade, positiva e negativa. Nestes dois casos assume-se explicitamente ou implicitamente que o vidro é um material isolante para as experiências de eletrostática.

A experiência do efeito âmbar é ilustrada com um bastão de vidro sendo utilizado no lugar do âmbar. Discutem então a atração de papeizinhos colocados sobre a mesa, o efeito do vidro sobre um pêndulo elétrico ou sobre um eletroscópio etc. As figuras são sempre do bastão eletrizado sendo segurado pela mão enquanto são feitas as experiências. Acreditamos que na maior parte das vezes os autores destes livros estão apenas copiando de outros livros, sem terem feito eles próprios as experiências. Em primeiro lugar não é fácil encontrar hoje em dia um bastão ou tubo de vidro. Mas mesmo que se tente a experiência atritando um copo de vidro ou um tubo de ensaio feito de vidro, os efeitos em geral não acontecem ou só acontecem com uma pequena intensidade que não é 
facilmente percebida. O motivo para esta falta de efeitos, como já mencionamos, é que a maior parte dos vidros atuais comporta-se como um bom condutor elétrico. Logo, mesmo que ele tivesse adquirido alguma eletrização ao ser atritado contra o cabelo, papel ou pano, esta eletrização seria logo perdida pelo aterramento do vidro devido ao contato com a mão da pessoa que o segura.

Outra experiência descrita em muitos livros didáticos refere-se aos dois tipos de carga, positiva e negativa. Algumas vezes ela é ilustrada com um tubo de vidro positivo ao ser atritado com a seda, enquanto que um tubo de borracha fica negativo ao ser atritado com um pano de acrílico. A força de repulsão entre dois tubos de vidro atritados com seda é mostrada com um deles dependurado por um fio enquanto que o outro é segurado na mão, Figura 4.8 (a), ou então com dois tubos dependurados por fios, Figura 4.8 (b).

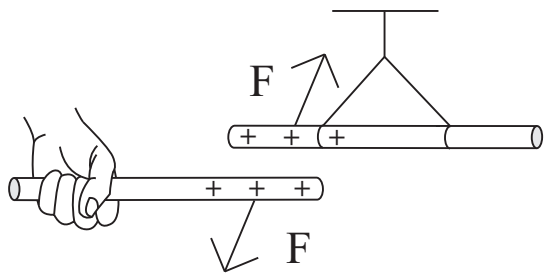

(a)

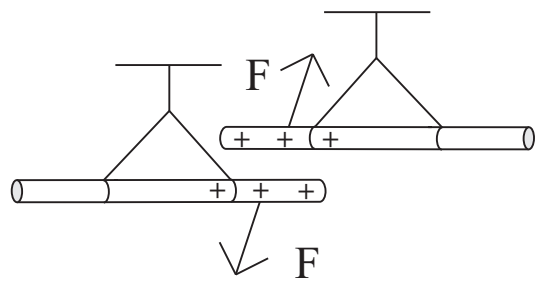

(b)

Figura 4.8: (a) Forças de repulsão entre um tubo de vidro na mão e outro dependurado por um fio. (b) Forças de repulsão entre dois tubos de vidro dependurados por fios.

Ao substituir um dos bastões de vidro dependurado por um tubo ou bastão de borracha negativo, ilustram as forças de atração entre cargas opostas.

Mais uma vez os livros didáticos assumem explicitamente ou implicitamente que o vidro comporta-se como um isolante, já que permanece eletrizado quando está na mão da pessoa ou quando está dependurado por um fio, sendo que os autores destes livros não especificam se o fio é condutor ou isolante.

Um dos problemas mais sérios com estas representações dos livros didáticos é que se qualquer aluno tentar reproduzir a experiência do efeito âmbar, ou então a repulsão entre dois vidros eletrizados, usando um tubo (ou copo de vidro) atritado e mantido na sua mão, é que provavelmente não vai observar nenhum efeito. O motivo, como já mencionamos, é que a maioria dos vidros encontrados facilmente hoje em dia comporta-se como condutor para experiências de eletrostática. Logo não vai permanecer eletrizado quando é seguro pela mão de alguém. Também não vai permanecer eletrizado ao ser dependurado por um fio se este fio for um condutor, como acontece com fios de algodão, linho, cobre etc. Isto pode levar a uma frustração por parte do aluno ou até mesmo levá-lo a concluir que o problema é com ele por não ter habilidade para fazer experiências de física. Pode abandonar seu interesse nesta área de estudos.

É claro que alguns dos autores destes livros didáticos podem de fato ter feito 
as experiências utilizando vidros que se comportam como isolantes. Mesmo que este tenha sido o caso, deveriam chamar a atenção que a maioria dos tipos de vidro encontrados usualmente nas residências comporta-se como materiais condutores nas experiências de eletrostática. É fundamental testar o comportamento condutor ou isolante de qualquer vidro antes de tentar qualquer destas experiências.

\subsection{O Mecanismo $A C R$}

Vimos no Volume 1 desta obra que um fenômeno importante da eletricidade é o chamado mecanismo $A C R$ descoberto por Du Fay em $1733 .{ }^{16}$ Esta regularidade ocorre quando um pequeno condutor isolado eletricamente da Terra é atraído por um corpo eletrizado, se aproxima ou toca nele, passando então a ser repelido por este corpo. Heilbron denominou de regularidade $A C R$ a esta regra simples de atração, comunicação da eletricidade, e repulsão (isto é, Atrai, Comunica e Repele). ${ }^{17}$ Estas letras às vezes também são interpretadas como vindo das iniciais das palavras atração, contato e repulsão.

As Experiências 4.1, 4.2 e 4.3 mostram situações simples nais quais pode-se visualizar este fenômeno.

\section{Experiência 4.1 - Levitando um pedacinho de algodão}

Inicialmente pegamos uma penugem ou um pedaço bem pequeno de algodão, tipo alguns fiapos. O importante é que seja escolhida uma quantidade bem pequena que demore um longo tempo para cair no ar, da ordem de uns 10 segundos para descer de uma distância de 2 metros quando o algodão é solto do repouso. Se ele cair mais lentamente é ainda melhor. Por outro lado, se ele cair muito rápido, não se consegue realizar a experiência que vamos descrever agora. Logo a quantidade apropriada de algodão deve ser escolhida de antemão.

Em seguida atrita-se bem um canudo de plástico ou uma régua de acrílico no cabelo. Depois que o canudo foi bem atritado, ele é mantido na horizontal preso por uma das pontas entre o dedão e o indicador. Então solta-se com a outra mão o pequeno pedaço de algodão um pouco acima do canudo. O algodão é atraído pelo canudo e fica grudado nele, Figura 4.9 (a) e (b).

Se observarmos atentamente, o algodão começa a se esticar, como se quisesse pular para fora do canudo. Algumas vezes ele de fato se solta. Quando isto não acontece, podem ser dados alguns petelecos no canudo para soltar o algodão, ou então soprar de leve o algodão. Depois que o algodão se soltou do canudo e começou a cair, pode-se aproximar o canudo atritado por baixo do algodão que ele vai começar a ser repelido pelo canudo. Algumas vezes isto não acontece da primeira vez, sendo necessário que o algodão seja atraído mais uma ou duas vezes pelo canudo, sendo solto a cada vez com um sopro ou peteleco, antes de passar a ser repelido por ele. Quanto mais eletrizado estiver o canudo, mais rapidamente o algodão passará a ser repelido por ele, Figura 4.9 (c).

\footnotetext{
${ }^{16}$ Seções 4.2 e 4.8 de [Ass10b], [Ass10a], [Ass11], [Ass15b] e [Ass17].

17 [Hei99, págs. 5 e 255-258].
} 


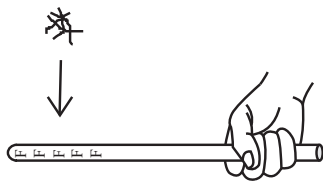

(a)

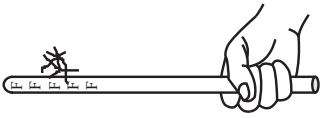

(b)

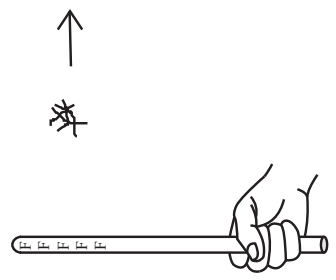

(c)

Figura 4.9: (a) Uma penugem ou fiapo de algodão é inicialmente atraída por um canudo atritado. (b) A penugem toca na parte atritada do canudo. (c) Depois do contato, a penugem passa a ser repelida pelo canudo atritado. Ela pode ser mantida flutuando sobre ele, apesar da atração gravitacional da Terra!

Ao movermos o canudo lentamente embaixo do algodão flutuante, podemos levá-lo para onde quisermos dentro da sala. Caso o algodão se aproxime do nosso corpo, da parede ou de algum outro corpo, ele acaba sendo atraído por este corpo e gruda nele. Se não deixarmos o algodão se aproximar do nosso corpo nem de outros objetos, podemos facilmente mantê-lo flutuando a $10 \mathrm{ou}$ a $20 \mathrm{~cm}$ do canudo, dependendo da eletrização do canudo. Para que ocorra esta levitação, o canudo não pode ficar imóvel. Caso o canudo eletrizado fique imóvel, o algodão acaba se afastando dele e caindo ao solo. Para que se mantenha o algodão no ar, é necessário ir mexendo aos poucos com o canudo atritado embaixo do algodão, acompanhando seu movimento, ao mesmo tempo em que o direcionamos para onde quisermos.

\section{Experiência 4.2 - Levitando uma semente de dente de leão}

Na Figura 4.10 apresentamos a mesma experiência feita com uma semente da planta dente-de-leão, que termina em cerdas bem finas, dando ao conjunto um aspecto de paraquedas. A vantagem do dente-de-leão em relação ao algodão é que a semente já cai com uma velocidade bem lenta, apropriada para esta experiência. É fácil fazê-la flutuar acima de um canudo plástico atritado no cabelo ou acima de uma régua de acrílico atritada com um guardanapo de papel.

Quando se utiliza a semente do dente-de-leão muitas vezes o procedimento é mais simples do que com um pedacinho de algodão. Isto é, ao ser solta no ar ela é atraída pelo canudo atritado abaixo dela, vai em sua direção, toca no canudo e imediatamente passa a ser repelida por ele.

As Experiências 4.1 e 4.2 são bem simples de serem realizadas, sendo extremamente curiosas e chamam muito a atenção. Experiências como estas foram realizadas por O. v. Guericke (1602-1686), Stephen Gray e Du Fay. Elas tiveram uma grande relevância histórica. Um vídeo muito interessante mostrando uma reprodução moderna da levitação de uma fina folha de ouro foi feito por 


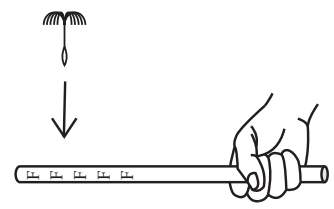

(a)

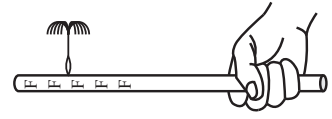

(b)

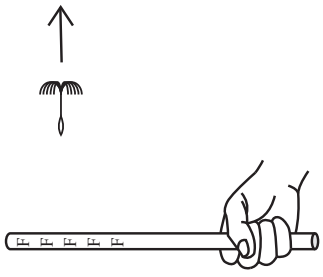

(c)

Figura 4.10: A Experiência 4.9 pode ser feita facilmente com uma semente de dente-de-leão sendo mantida no ar por um canudo atritado no cabelo.

Blondel e Wolff, 18 "La danse des feuilles d'or."

Experiência 4.3 - Repulsão entre um corpo eletrizado e o disco de papel de um pêndulo elétrico

Vamos utilizar agora um pêndulo elétrico clássico constituído por um pequeno círculo de papel ou de papel de alumínio tendo 1 ou $2 \mathrm{~cm}$ de diâmetro amarrado na ponta de uma linha de seda, náilon ou poliamida, Figura 2.10. Eletrizamos um canudo plástico ou régua de acrílico por atrito no cabelo, guardanapo ou pano. Aproximamos lentamente o canudo do disco do pêndulo. Observa-se que o disco é atraído, toca no canudo e passa a ser repelido, Figura 4.11.

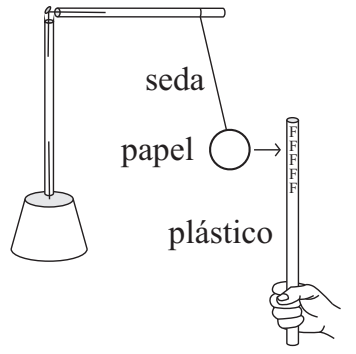

(a)

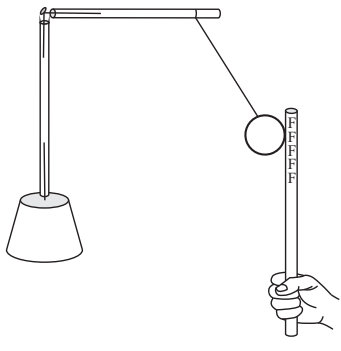

(b)

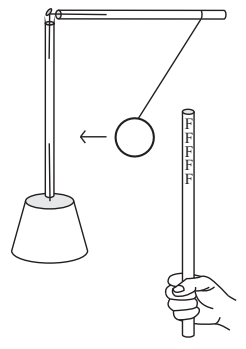

(c)

Figura 4.11: (a) O disco de papel do pêndulo elétrico é atraído por um plástico atritado, (b) toca no plástico e (c) passa a ser repelido por ele.

Algumas vezes o disco de papel do pêndulo não passa a ser repelido pelo canudo atritado imediatamente após o toque, mas fica grudado nele durante algum tempo. Nestes casos é possível observar a repulsão dando uns pequenos toques, petelecos ou batidas no canudo para que o papelzinho se desgrude dele, passando então a ser repelido pelo plástico. Em vez de se bater no canudo, podese também levantá-lo e abaixá-lo seguidamente, até que o papel se desgrude dele,

\footnotetext{
${ }^{18}$ [BW12b] e [BW12c].
} 
passando então a ser repelido pelo plástico. Em alguns casos é necessário que o canudo atritado atraia 2 ou 3 vezes o disco do pêndulo, sempre deixando que se toquem em cada atração, até que finalmente o disco do pêndulo passe a ser repelido pelo canudo.

Para recomeçar o processo deve-se tocar com o dedo no disco de papel. Não é necessário apertá-lo, basta tocar com o lado do dedo no disco. Ele então perde sua eletrização pelo aterramento, voltando a ficar neutro. Pode-se então aproximar novamente o canudo plástico eletrizado do pêndulo que o disco vai ser mais uma vez atraído, vai tocar no canudo, passando então a ser repelido por ele.

\subsubsection{Explicação do Mecanismo $A C R$}

A explicação para este comportamento é simples. Vamos ilustrar a explicação do mecanismo $A C R$ utilizando a Experiência 4.3. Vamos supor que o canudo ou régua plástica tenham sido eletrizados negativamente e que o disco de papel do pêndulo esteja inicialmente neutro eletricamente. $\mathrm{O}$ disco de papel do pêndulo comporta-se como um condutor. Ele é suportado por um fio de seda isolante. Ao aproximar o canudo do disco de papel, o disco se polariza, ficando positivamente eletrizado perto do canudo e negativamente eletrizado longe dele, Figura 4.12 (a).

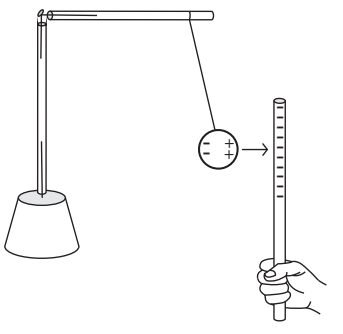

(a)

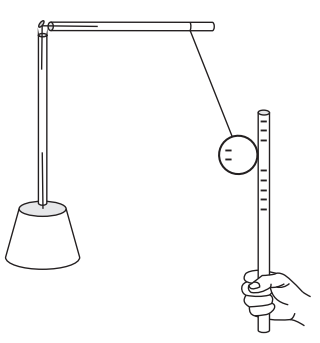

(b)

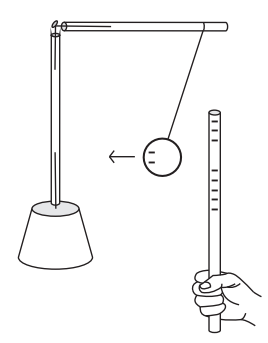

(c)

Figura 4.12: (a) O disco do pêndulo fica polarizado pela proximidade com o canudo eletrizado, havendo uma atração resultante entre eles. (b) No contato ocorre uma troca de partículas eletrizadas entre eles deixando o disco eletrizado com cargas de mesmo sinal que o canudo. (c) O disco eletrizado passa a ser repelido pelo canudo eletrizado.

A distância entre as parte positiva do disco polarizado e o canudo negativamente eletrizado é menor do que a distância entre a parte negativa do disco polarizado e o canudo. A força elétrica é atrativa entre corpos eletrizados com cargas de sinais opostos e repulsiva entre corpos eletrizados com cargas de mesmo sinal. Além disso, a intensidade destas forças aumenta com a diminuição da distância entre os corpos eletrizados. Logo a atração sofrida pela parte positivamente eletrizada do disco próxima ao canudo é maior do que a repulsão sofrida pela parte negativamente eletrizada do disco que está mais afastada do canudo, gerando 
uma força resultante atrativa sobre o disco. Quando o disco toca no canudo, há uma troca de partículas eletrizadas entre eles, neutralizando a parte polarizada do disco próxima ao canudo, assim como os pontos do canudo que entraram em contato com o disco, Figura 4.12 (b). Exageramos nesta figura a região que ficou neutralizada no canudo. O plástico é isolante, logo as partículas negativas das outras regiões do canudo não se deslocam. O disco fica então eletrizado como o canudo, a saber, negativamente. Há então uma repulsão entre eles, Figura 4.12 (c).

\subsubsection{Situações em que Não Ocorre o Mecanismo $A C R$}

Experiência 4.4 - Atração entre um corpo eletrizado e um disco de papel preso a uma linha de algodão

Repetimos a Experiência 4.3 utilizando agora um disco de papel aterrado. Para isto basta amarrar uma linha de algodão em um palito de madeira ou arame. O disco de papel é então amarrado na outra ponta da linha de algodão. Segura-se o palito de madeira com a mão e o disco pende verticalmente abaixo dele. Este pêndulo com um disco de papel aterrado pela linha de algodão é um instrumento análogo à linha pendular de Gray descrita na Seção 2.5.

Aproxima-se agora lentamente um canudo plástico eletrizado do disco. Observase que o disco é atraído pelo canudo, toca nele e permanece grudado, Figura 4.13 .

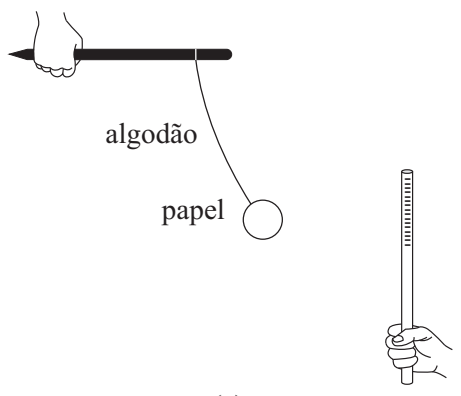

(a)

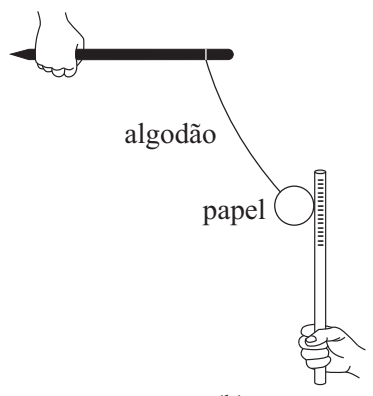

(b)

Figura 4.13: (a) O disco do pêndulo aterrado é atraído por um canudo eletrizado. (b) O disco toca no canudo e permanece grudado nele.

Mesmo quando este processo é repetido várias vezes, havendo muitos toques entre o disco de papel e o canudo eletrizado, o disco permanece sempre grudado no canudo, não ocorrendo o mecanismo $A C R$ de atração, contato e repulsão.

Experiência 4.5 - Atração entre um corpo eletrizado e um disco de plástico

Repetimos a Experiência 4.3 utilizando agora o disco isolante de um pêndulo elétrico de plástico da Figura 2.12. 
Atritamos um canudo no cabelo e o aproximamos do pêndulo de plástico neutro. Observa-se que o disco de plástico é atraído pelo canudo, Figura 4.14 (a).

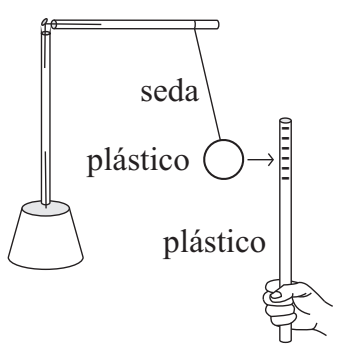

(a)

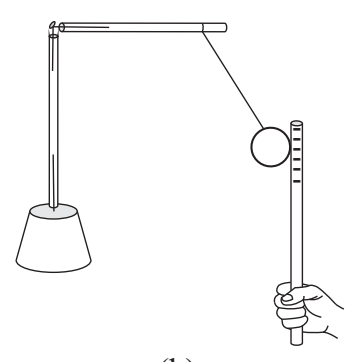

(b)

Figura 4.14: (a) O disco isolante de um pêndulo elétrico de plástico é atraído por um canudo atritado. (b) $\mathrm{O}$ disco toca no canudo atritado e fica grudado nele.

A atração exercida pelo canudo atritado sobre o disco de plástico é menor do que a atração que o mesmo canudo exerce sobre o disco de papel de um pêndulo elétrico clássico. Esta força é indicada pelo ângulo de inclinação do fio em relação à vertical quando o canudo atritado está à mesma distância dos dois pêndulos. Ou seja, supondo discos de mesmo peso e tamanho, a inclinação do pêndulo elétrico com um disco de papel é maior do que a inclinação do pêndulo elétrico com um disco de plástico.

Se deixarmos que o canudo eletrizado e o disco de plástico se toquem, observamos que vão permanecer grudados, Figura 4.14 (b).

Para que o mecanismo $A C R$ funcione é fundamental que o condutor (disco de papel) esteja isolado eletricamente da Terra (pelo ar e pelo fio de seda), como foi o caso da Experiência 4.3. Vemos no caso da Experiência 4.4 que se o disco condutor estiver aterrado, não vai haver a repulsão depois do toque com o canudo eletrizado.

Podemos explicar este comportamento. Para isto temos de lembrar que os único isolantes nesta experiência são o ar e o canudo plástico eletrizado. Todos os outros corpos comportam-se como condutores: disco de papel, linha de algodão, palito de madeira e mão da pessoa ligada à Terra. Vamos supor que o canudo esteja eletrizado negativamente. Ao aproximá-lo do disco do pêndulo, este tende a ficar polarizado. Porém, como é um condutor aterrado, as partículas negativamente eletrizadas são neutralizadas pelo aterramento. $\mathrm{O}$ disco fica então eletrizado positivamente na região próxima ao canudo, figura 4.15 (a).

Ao tocar no canudo, ocorre uma troca de partículas eletrizadas entre eles que tende a neutralizar o disco e os pontos eletrizados do canudo que entraram em contato com o disco. Como o canudo é isolante, suas outras partículas 


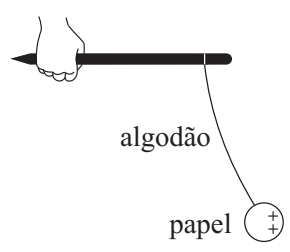

(a)

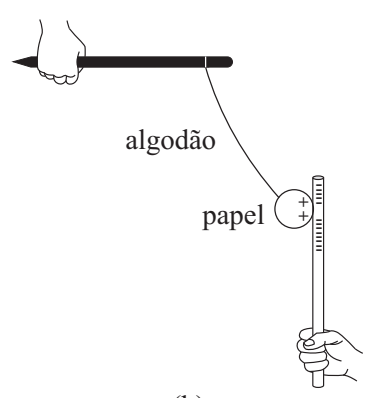

(b)

Figura 4.15: (a) O disco do pêndulo aterrado eletrizado positivamente na região próxima ao canudo negativo. (b) $\mathrm{O}$ disco aterrado continua eletrizado positivamente na região próxima ao canudo, sendo atraído pelas regiões negativamente eletrizadas do canudo isolante.

eletrizadas não têm liberdade de movimento, permanecendo em seus lugares. Estas partículas negativas continuam exercendo uma força sobre as partículas eletrizadas livres do disco condutor. Estas forças tendem novamente a polarizar o disco, deixando-o positivo na região em contato com o canudo e negativo na região em contato com a linha de algodão. Devido ao aterramento, a região do disco em contato com a linha condutora se neutraliza. Sobra então apenas a região positiva do disco que está próxima ao canudo negativo, como indicado na Figura 4.15 (b). Nesta figura exageramos a região neutralizada do canudo que está em contato com o disco.

Deve ser enfatizado que o mecanismo $A C R$ também não funciona com um pequeno isolante que está sendo atraído por um corpo eletrizado. Este fato foi observado na Experiência 4.5. Ou seja, neste caso não ocorreu o fenômeno $A C R$ que havíamos visto na Experiência 4.3. Para que ocorra a sequência de atração, contato e repulsão, é necessário que o corpo atraído seja um condutor. Caso ele seja um isolante, ele vai ser atraído pelo corpo carregado que se aproxima dele. E pode até chegar a tocar nele, mas não vai adquirir uma carga significativa de mesmo sinal que este corpo. Por este motivo, não vai ser em seguida repelido por ele. Se o isolante chegar a adquirir alguma carga pelo simples toque com um corpo eletrizado, sem que seja raspado no corpo, esta carga será de pequena intensidade, dificilmente sendo perceptível. O mecanismo $A C R$ só vai ocorrer com um isolante depois de vários toques, ou quando raspamos o canudo atritado no plástico.

Esta é uma diferença importante entre condutores e isolantes. Para carregarmos um isolante como o plástico, temos de atritá-lo, como vimos na Experiência 1.1. Já um condutor pode ser carregado não apenas pelo atrito, mas também pelo método $A C R$. Neste último caso, basta o contato com um corpo previamente carregado para que uma parte desta carga seja transferida para o condutor. 


\subsection{A Importância da Descoberta dos Conduto- res e Isolantes por Stephen Gray}

A menção mais antiga que temos do efeito âmbar vem com Platão (aproximadamente 428-348 a.C.). ${ }^{19}$ Por dois mil anos pouco se avançou no estudo da eletricidade. Sabia-se apenas que o âmbar e algumas poucas substâncias adquiriam a capacidade de atrair a maioria dos corpos leves após serem atritadas. Em 1729 Stephen Gray percebeu que podia classificar os corpos em dois grupos distintos, chamados hoje em dia de condutores e isolantes. Também caracterizou algumas das principais propriedades dos condutores e isolantes. Publicou seus resultados em $1731 \mathrm{em}$ um dos artigos mais importantes da história da eletricidade. ${ }^{20}$ No Volume 1 desta obra apresentamos uma descrição detalhada deste trabalho de Gray. ${ }^{21}$

Com esta descoberta fundamental passou-se a ter um controle sobre a eletricidade, descobriu-se o aterramento, abriu-se a possibilidade para o armazenamento da eletricidade ao manter os condutores eletrizados isolados da Terra, conseguiu-se eletrizar metais, o corpo humano, a água, etc. Foi possível transmitir a eletricidade (ou a capacidade de atrair corpos leves) para lugares distantes de onde estava ocorrendo o atrito, utilizando fios condutores para o escoamento das cargas elétricas. Todas estas descobertas, juntamente com várias outras relacionadas aos fenômenos elétricos, são devidas a Gray. Entre outras coisas ele descobriu como preservar a eletricidade ao longo do tempo, isto é, como fazer para aumentar o tempo durante o qual um corpo permanece eletrizado. Criou os primeiros eletretos, isto é, corpos que mantêm durante um longo tempo uma carga resultante, ou que preservam temporalmente uma polarização elétrica (criando um dipolo elétrico permanente, também chamado de um ímã da eletricidade). ${ }^{22}$ Os eletretos vão ser discutidos na Seção 13.4. Ele também foi um dos primeiros cientistas a fazer experiências relacionadas com a conservação da carga elétrica. ${ }^{23}$

Du Fay, seguindo os passos de Gray, reconheceu a repulsão como um fenômeno elétrico, além de descobrir o mecanismo $A C R .^{24}$ Ao perceber uma anomalia neste mecanismo, ou seja, uma situação na qual sua regra não funcionava, convenceu-se em 1733 da existência de dois tipos de eletricidade que denominou de vítrea e resinosa. ${ }^{25}$ Até então só se conhecia essencialmente um tipo de eletricidade e a propriedade básica de corpos eletrizados atraírem corpos leves. Hoje em dia estes dois tipos de eletricidade são chamadas de eletricidade positiva e

\footnotetext{
19 [Pla52, Seções 79 a 80, págs. 470-471], [Pla09, Seções 79 a 80, págs. 163-165] e Seção 2.2 de [Ass10b], [Ass10a], [Ass11], [Ass15b] e [Ass17].

${ }^{20}$ [Graf] com tradução para a língua portuguesa em [Bos11, Capítulo 6] e [BAC12, Capítulo 7].

${ }^{21}$ Apêndice B de [Ass10b], [Ass10a], [Ass11], [Ass15b] e [Ass17]. Ver também [RP13a], [RP13b], [RP13c], [Rai15], [RP15b], [RP15a] e [RP16].

22 [Net94], [Sil10b], [Sil10a], [Bos11, Capítulo 8, págs. 226-248] e [BAC12, Capítulo 19, págs. 373-392].

${ }^{23}$ Seção 6.10 de [Ass10b], [Ass10a], [Ass11], [Ass15b] e [Ass17].

${ }^{24}$ Seção 4.8 de [Ass10b], [Ass10a], [Ass11], [Ass15b] e [Ass17].

${ }^{25}$ [DF33b], [DF] e [BC07].
} 
negativa, respectivamente. Outras expressões análogas utilizadas hoje em dia são as de carga elétrica positiva e negativa, ou corpos carregados positivamente e negativamente.

O desenvolvimento da eletricidade tem sido vertiginoso desde a descoberta de Gray. O que faltava essencialmente era conhecer os dois tipos básicos de materiais na natureza, a saber, condutores e isolantes, juntamente com suas propriedades mais importantes. Hoje em dia este fato parece uma coisa trivial. Mas sem dúvida alguma um dos fatores fundamentais que impediu o avanço no estudo da eletricidade nos dois mil anos anteriores a Gray foi o desconhecimento das propriedades distintas destes dois tipos fundamentais de materiais que existem na natureza. Em um livro de 2012 publicamos uma tradução comentada de todas as suas obras relacionadas com eletricidade, juntamente com uma reprodução de suas principais experiências utilizando materiais de baixo custo facilmente acessíveis a todos. ${ }^{26}$

${ }^{26}$ [BAC12]. 


\section{Capítulo 5}

\section{Eletrização de Fitas Adesivas}

Neste Capítulo vamos fazer algumas experiências relacionadas com um tema curioso, a saber, a eletrização que ocorre em fitas adesivas. ${ }^{1}$

\subsection{Comportamento Isolante ou Condutor da Fita}

Experiência 5.1 - Isolante ao longo de seu comprimento

Começamos com um rolo de fita adesiva comum tendo 1 ou $2 \mathrm{~cm}$ de largura, tipo durex ou fita mágica. Inicialmente vamos analisar se ela é condutora ou isolante. Vamos representar o lado com cola pela letra $C$ e o lado liso pela letra $L$. Carregamos um eletroscópio e o deixamos sobre a mesa, Figura 5.1 (a).

Em seguida desenrolamos uns 10 ou $20 \mathrm{~cm}$ de uma fita adesiva e a seguramos entre as duas extremidades. Tocamos então com o lado liso na borda ou na quina da cartolina, Figura 5.1 (b). Observa-se que a tirinha do eletroscópio continua levantada. O mesmo ocorre ao tocar na cartolina com a parte com cola, Figura 5.1 (c).

Esta experiência mostra que os dois lados da fita adesiva se comportam como isolantes ao longo de seus comprimentos para as experiências de eletrostática.

Experiência 5.2 - A fita é condutora através de seu lado

Começamos novamente com um eletroscópio carregado, Figura 5.2 (a).

Segurando a fita adesiva pelas suas duas extremidades, tocamos na quina da cartolina com o centro do lado liso de uma fita adesiva e a tirinha continua levantada, Figura 5.2 (b). Enquanto um lado da fita adesiva está encostado com a parte lisa na quina da cartolina, uma outra pessoa toca com um dedo no outro lado da fita, no centro da parte com cola, tomando cuidado para que

\footnotetext{
1[Jef59], [Bea96], [CS02, Capítulo 14], [Mor04b], [Mor04a] e [Vas05].
} 


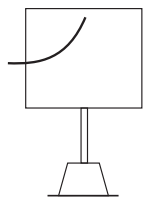

(a)

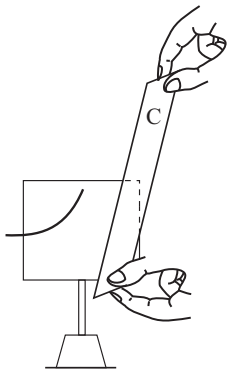

(b)

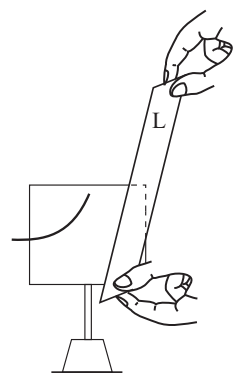

(c)

Figura 5.1: (a) Eletroscópio eletrizado. (b) Tocamos na quina da cartolina do eletroscópio com a parte lisa, $L$, de uma fita adesiva, estando a parte com cola, $C$, para o lado de fora. A tirinha continua levantada. (c) O mesmo ocorre ao tocar na cartolina com a parte com cola.

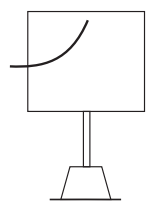

(a)

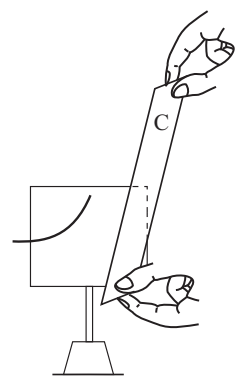

(b)

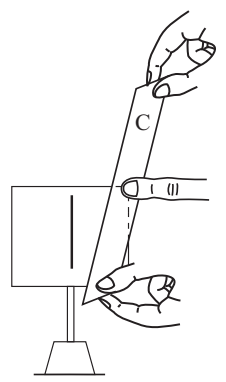

(c)

Figura 5.2: (a) Eletroscópio eletrizado. (b) O centro do lado liso de uma fita adesiva toca na quina da cartolina, estando a parte com cola, $C$, para o lado de fora. A tirinha continua levantada. (c) A tirinha abaixa quando um dedo de outra pessoa toca no centro do lado com cola da fita.

o dedo não toque diretamente na cartolina. A fita deve ficar entre a quina da cartolina e o dedo. Neste caso a tirinha abaixa em poucos segundos, Figura 5.2 (c).

O mesmo ocorre se tocarmos a cartolina de um eletroscópio carregado com a parte com cola de uma fita e em seguida tocarmos com o dedo do outro lado da fita.

Ou seja, conseguimos descarregar o eletroscópio tendo uma fita adesiva entre a cartolina e o aterramento (nosso dedo). Esta experiência mostra que a fita adesiva comporta-se como um material condutor através de seu lado, embora ela se comporte como um isolante através de seu comprimento.

Experiência 5.3 - Várias fitas sobrepostas 
Repetimos a Experiência 5.2 sobrepondo várias fitas adesivas. Para fazer isto colamos uns 10 ou $20 \mathrm{~cm}$ de fita sobre a superfície lisa de uma mesa. Sobre esta fita vamos colando outras fitas de mesmo comprimento. Quando alcançar o número de fitas que se quiser testar, retira-se o conjunto e o seguramos pelas duas extremidades. Sempre encostamos o conjunto na quina da cartolina, depois encostamos o dedo do outro lado do conjunto e medimos o tempo para descarregar o eletroscópio. Um exemplo destas medidas aparece na Tabela 5.1.

\begin{tabular}{|c|c|}
\hline Número de fitas sobrepostas & Tempo para descarregar \\
\hline 1 & $1-5 \mathrm{~s}$ \\
\hline 5 & $5 \mathrm{~s}$ \\
\hline 10 & $10 \mathrm{~s}$ \\
\hline 15 & $15-20 \mathrm{~s}$ \\
\hline 20 & $25-60 \mathrm{~s}$ \\
\hline
\end{tabular}

Tabela 5.1: Intervalos de tempo aproximados para descarregar o eletroscópio.

O conjunto com umas 20 fitas sobrepostas pode então ser considerado como um bom isolante de acordo com a Definição 3.5. Esta situação está representada na Figura 5.3.

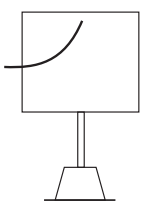

(a)

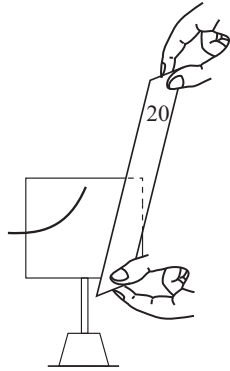

(b)

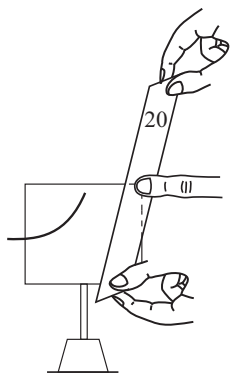

(c)

Figura 5.3: (a) Eletroscópio eletrizado. (b) Tocamos na quina da cartolina do eletroscópio com uma sobreposição de 20 fitas adesivas. A tirinha continua levantada. (c) A tirinha descarrega lentamente ao tocarmos com o dedo no lado oposto das fitas sobrepostas.

Esta Experiência ilustra mais uma vez o assunto discutido na Subseção 3.3.4. Isto é, o comportamento isolante ou condutor de um corpo não depende apenas de sua natureza, mas também de seu comprimento ou de sua espessura. No caso atual, quanto maior for a espessura da fita, mais isolante ela será.

Experiência 5.4 - Outros tipos de fita

Podemos repetir as Experiências 5.1 e 5.2 com outros tipos de fita adesiva. 
O esparadrapo, por exemplo, comporta-se como um condutor ao longo de seu comprimento e através de seu lado. A fita adesiva tipo durex é feita de um material plástico isolante. Já o esparadrapo é feito de tecido ou de papel, que são materiais condutores.

Já uma fita isolante (em geral vendida na cor preta) comporta-se como o durex, ou seja, isolante ao longo de seu comprimento e condutora através de seu lado. Ela em geral é feita de plástico, PVC ou vinil.

Ao aumentar o número de fitas isolantes sobrepostas também aumentamos seu comportamento isolante. Um conjunto de 15 a 20 fitas sobrepostas já pode ser considerado como um bom isolante através de seu lado, já que o eletroscópio necessita de 20 segundos ou mais para descarregar, como ilustrado na Figura 5.3 .

Experiência 5.5 - Comportamento isolante ao longo de seu comprimento para baixas diferenças de potencial

O comportamento da fita isolante na Experiência 5.4 pode surpreender devido ao próprio nome da fita, a saber, "isolante". A surpresa é que através do lado de uma única fita ela comporta-se como um material condutor, apesar de ter o nome usual de "fita isolante". Fazemos agora duas novas experiências para esclarecer esta nomenclatura.

Inicialmente repetimos a Experiência 3.9. Quando os pontos condutores $A$ e $B$ entram em contato direto, ou quando são ligados por um fio metálico, a lâmpada acende, Figura 5.4 (a).

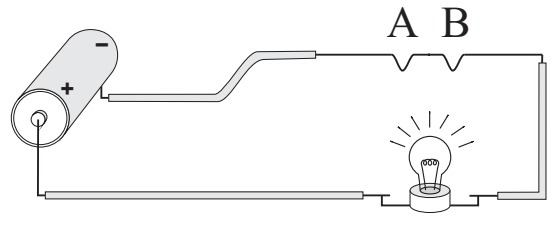

(a)

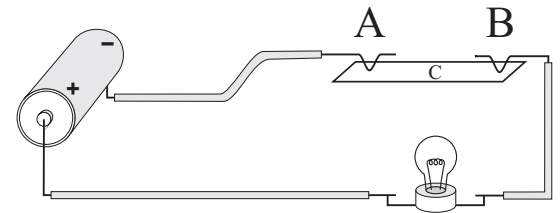

(b)

Figura 5.4: (a) A lâmpada acende quando os condutores $A$ e $B$ entram em contato. (b) A lâmpada fica apagada quando $A$ e $B$, separados por 2 ou $5 \mathrm{~cm}$, tocam o mesmo lado de uma fita adesiva.

Colocamos agora um pedaço de fita de 2 a $5 \mathrm{~cm}$ de comprimento entre estes pontos, com $A$ e $B$ tocando o lado com cola destas fitas. Observa-se que não apenas a fita isolante, mas também o esparadrapo e uma fita adesiva tipo durex comportam-se como isolantes, como ilustrado na Figura 5.4 (b). E isto ocorre tanto no lado com cola quanto no lado liso destas fitas.

Todos estes tipos de fita adesiva comportam-se como isolantes ao longo de seus comprimentos para baixas voltagens.

Experiência 5.6 - Comportamento isolante através de seu lado para baixas diferenças de potencial 
Em seguida testamos como estas fitas se comportam através de seus lados. Inicialmente ligamos $A$ e $B$ para verificar que a lâmpada acende e que todas as conexões estão bem feitas, Figura 5.5 (a).

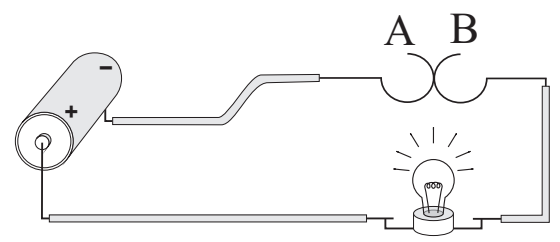

(a)

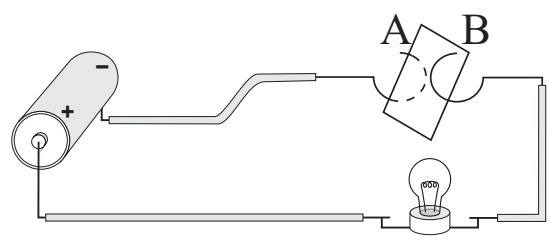

(b)

Figura 5.5: (a) A lâmpada acende quando os condutores $A$ e $B$ estão em contato. (b) A lâmpada não acende quando $A$ toca um lado da fita e $B$ toca do outro lado da fita.

Colocamos agora um pedaço de fita em um plano vertical, encostamos $A$ no centro de um lado desta fita e encostamos $B$ no centro do outro lado desta fita. Observa-se que a lâmpada não acende tanto no caso de uma fita adesiva comum, quanto no caso do durex e de uma fita isolante, Figura 5.5 (b).

A Experiência 5.4 mostra que a fita isolante comporta-se como um material condutor através de seu lado nos fenômenos de eletrostática nos quais ocorrem diferenças de potencial variando tipicamente entre $1.000 \mathrm{~V}$ e $10.000 \mathrm{~V}$. Já a Experiência 5.6 mostra que a fita isolante comporta-se como uma material isolante através de seu lado para baixas voltagens, da ordem de alguns volts. Ela também é um bom isolante para diferenças de potencial indo até uns $300 \mathrm{~V}$. É devido a esta propriedade que ela recebe a nomenclatura de fita isolante. Este é mais um exemplo do assunto que foi discutido na Subseção 3.3.2, a saber, o comportamento condutor ou isolante de um corpo depende não apenas de propriedades intrínsecas ao corpo, mas também da diferença de potencial externo aplicada a este corpo.

\subsection{Eletrização da Fita}

Para padronizar as experiências e para ter resultados que possam ser reproduzidos por outras pessoas é importante que a fita adesiva a ser testada seja sempre retirada de outra fita adesiva que estava abaixo dela. Ilustramos aqui este procedimento.

Desenrolamos de 10 a $20 \mathrm{~cm}$ de uma fita adesiva e a colamos sobre uma superfície lisa de uma mesa. Ela será chamada de base e indicada pela letra $B$. Em seguida ela deve ser alisada passando o dedo sobre sua superfície. Sobre a base colamos uma outra fita de mesmo comprimento, chamada de superior e indicada pela letra $S$, Figura 5.6.

É útil dobrar uma ponta para facilitar sua manipulação. Ela também deve ser alisada passando o dedo sobre sua superfície. 


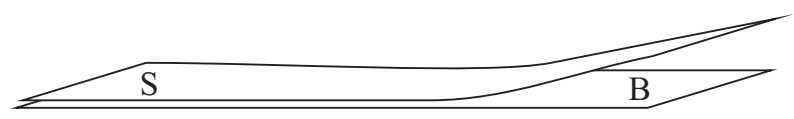

Figura 5.6: Fita superior $S$ sobre a base $B$.

\section{Experiência 5.7 - Fita adesiva atraindo corpos leves}

Coloca-se um eletroscópio descarregado sobre a mesa, Figura 5.7 (a).

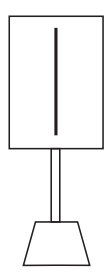

(a)

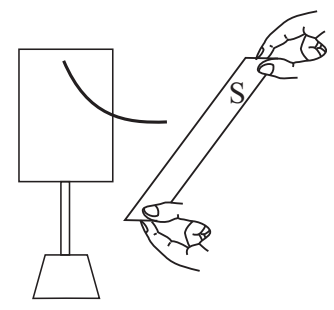

(b)

Figura 5.7: (a) Eletroscópio descarregado. (b) Fita $S$ atraindo a tirinha do eletroscópio.

Preparam-se as fitas $S$ e $B$ como na Figura 5.6. Segura-se a fita superior pela ponta dobrada e ela é retirada rapidamente da base. A fita $S$ é segurada pelas extremidades e aproximada da parte inferior da tirinha do eletroscópio, sem tocá-la. Observa-se que a tirinha é atraída pela fita, Figura 5.7 (b).

Esta fita também orienta um versório metálico ao aproximar-se dele. Este fato pode ser observado mantendo a fita vertical e aproximando-a de qualquer das pernas do versório, que é então atraída pela fita. Isto é, o versório passa a apontar para a fita. Se movermos a fita ao redor do versório, ele acompanha seu movimento.

Esta experiência mostra que a fita adesiva ficou eletrizada ao ser separada rapidamente da fita de base. O que se observa aqui é análogo ao efeito âmbar, Seção 1.1. Além disso, esta experiência também ilustra que a fita comporta-se como um isolante ao longo de seu comprimento. Afinal de contas, está sendo segurada por nossos dedos em suas extremidades, não ficando descarregada com este aterramento.

Experiência 5.8 - Fita adesiva sendo atraída por condutores inicialmente neutros

Retira-se uma nova fita $S$ rapidamente de uma fita $B$ ao puxá-la pela extremidade dobrada. Em seguida cola-se a outra extremidade em um lápis, palito ou qualquer suporte tal que a fita fique dependurada na vertical, Figura 5.8 (a) e (b).

Aproxima-se então um dedo da fita. O dedo deve estar na horizontal, apontando para a região inferior da fita, ortogonalmente ao plano da fita. Observa-se 


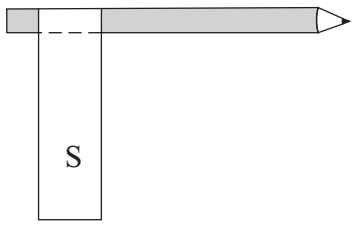

(a)

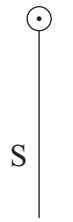

(b)

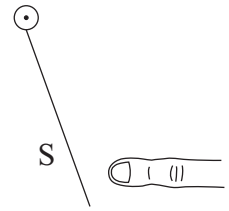

(c)

Figura 5.8: (a) Fita superior $S$ dependurada na vertical e vista de perfil. (b) Vista de costas. (c) Ela é atraída por um dedo que se aproxima dela.

que a fita inclina-se em direção ao dedo, Figura 5.8 (c). Deve-se evitar o toque entre a fita e o dedo. Esta atração ocorre não apenas quando o dedo é aproximado da parte com cola, mas também quando é aproximado da parte lisa da fita.

Esta experiência ilustra que a fita adesiva ficou eletrizada ao ser separada rapidamente da fita de base. Estamos observando aqui o oposto do efeito âmbar, a saber, o princípio de ação e reação. ${ }^{2}$ No efeito âmbar temos um corpo eletrizado atraindo um corpo leve que inicialmente estava neutro. Este corpo leve em geral é um condutor. No fenômeno oposto temos um condutor inicialmente neutro (como o dedo nesta experiência) atraindo um corpo eletrizado quando ambos estão próximos. Quando ocorre a atração, o dedo não mais estará neutro, tendo adquirido uma carga de sinal oposto à carga da fita adesiva eletrizada.

As Experiências 5.7 e 5.8 devem ser testadas com marcas diferentes de fitas adesivas, usando sempre a mesma marca para cada par $B S$. A marca da fita $S$ que ficar mais eletrizada deve ser utilizada nas próximas experiências.

Estas experiências mostram que a fita $S$ ficou eletrizada ao ser retirada rapidamente da fita de base. Estas experiências funcionam bem em dias secos.

Enquanto está sendo retirada da fita de base, a fita $S$ deve se eletrizar apenas na parte com cola. Afinal de contas, antes de ser retirada ela havia sido alisada passando lentamente um dedo sobre ela. Como o dedo é um condutor, toda a parte lisa foi aterrada. Porém, como visto na Seção 5.1, a fita é condutora através de seu lado. Vamos considerar agora que a fita $S$ acabou de ser separada da fita de base, estando eletrizada. Como ela comporta-se como um material condutor através de seu lado, é possível que haja uma migração de partículas eletrizadas entre o lado com cola e o lado liso da fita eletrizada. Quando se atinge o equilíbrio após alguns segundos, pode ser que os dois lados da fita fiquem eletrizados com cargas de mesmo sinal, mesmo que inicialmente apenas o lado com cola tenha sido carregado. De qualquer forma, não vamos testar aqui se a fita ficou eletrizada em apenas um lado ou se ficou carregada nos dois lados.

Experiência 5.9 - Determinando o sinal das cargas na fita

\footnotetext{
${ }^{2}$ Seção 3.5 de [Ass10b], [Ass10a], [Ass11], [Ass15b] e [Ass17].
} 
Eletrizamos dois eletroscópios com cargas opostas. Isto pode ser obtido, por exemplo, por indução. ${ }^{3}$ Eles são colocados separadamente em uma mesa com suas tirinhas levantadas. Deve-se prestar atenção qual deles está eletrizado positivamente e qual está eletrizado negativamente.

Retira-se rapidamente uma fita $S$ de uma fita $B$. Ela é segurada na horizontal pelas pontas e aproximada lentamente de cada uma das tirinhas, sem tocá-las. Observa-se que ela atrai a tirinha de um dos eletroscópios e repele a tirinha do outro eletroscópio. Conhecendo o sinal da carga dos eletroscópios eletrizados, pode-se determinar o sinal da carga da fita adesiva. Com a maioria das fitas que utilizamos, encontramos que elas ficaram negativamente eletrizadas, já que repeliam a tirinha do eletroscópio negativo e atraíam a tirinha do eletroscópio positivo.

Dependendo do tipo de fita adesiva, pode ocorrer o contrário. Ou seja, a fita $S$ pode ficar positivamente eletrizada.

\subsection{Neutralização da Fita}

Discutimos nesta Seção como neutralizar uma fita que estava inicialmente eletrizada.

\section{Experiência 5.10 - Com a passagem do tempo a fita descarrega}

Vamos supor que temos uma fita $S$ que foi eletrizada como descrito na Seção 5.2. Dependure-a na vertical em algum suporte apropriado, Figura 5.8 (a) e (b).

A maneira mais simples de descarregar a fita é deixá-la dependurada por alguns minutos ao ar livre. Depois deste tempo, quando um dedo é aproximado da fita, ela não mais se inclina em direção ao dedo. Da mesma forma, se ela for aproximada da tirinha de um eletroscópio descarregado, observa-se que a tirinha não é atraída por ela. Um versório metálico também não é mais orientado por ela.

\section{Experiência 5.11 - Descarregando a fita através de seu lado liso}

Apresentamos agora um outro procedimento para descarregar a fita $S$. Inicialmente colamos a extremidade superior de uma fita eletrizada em algum suporte apropriado tal como um lápis ou a quina de uma mesa. Seguramos sua extremidade inferior e deslizamos algumas vezes para a frente e para trás, lentamente, a ponta de um dedo ao longo de seu lado liso, Figura 5.9.

Em seguida podemos testar sua eletrização como nas Experiências 5.7 e 5.8. Em geral observa-se que um dedo não mais a atrai. Da mesma forma, ela não atrai a tirinha de um eletroscópio descarregado e também não orienta um versório metálico.

Experiência 5.12 - Dificuldade de descarregar a fita através de seu lado com cola

\footnotetext{
${ }^{3}$ Seção 7.5 de [Ass10b], [Ass10a], [Ass11], [Ass15b] e [Ass17].
} 


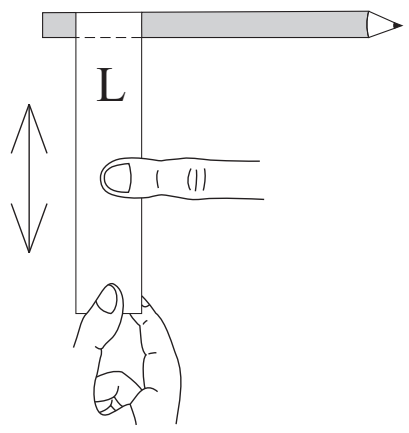

Figura 5.9: Passando o dedo pelo lado liso da fita.

Começamos com uma nova fita $S$ eletrizada e dependurada na vertical. Repetimos agora o procedimento da Experiência 5.11, só que agora passando algumas vezes o dedo pelo lado com cola da fita. Em seguida testamos sua eletrização como nas Experiências 5.7 e 5.8. Neste caso observa-se que a fita continua eletrizada.

Esta experiência surpreende um pouco. Afinal de contas, a fita $S$ deve ter ficado inicialmente eletrizada apenas em seu lado com cola ao ser retirada rapidamente da fita de base. Logo, poderia se esperar que ao passar um dedo por este lado com cola ela fosse neutralizada. A presente Experiência indica que isto não ocorre. Um dos motivos para ela permanecer eletrizada neste caso está relacionado com a própria cola. Ou seja, não conseguimos deslizar o dedo pelo lado com cola. Logo, não conseguimos aterrar todos os pontos da fita. Talvez ela se neutralize apenas nos pontos que foram tocados pelo dedo, permanecendo eletrizada em vários outros pontos. Além disso, quando o dedo é separado da cola, a fita pode ficar novamente eletrizada nestes pontos, pelo mesmo processo que ocorre na eletrização de uma fita ao separá-la de outra fita.

Já a Experiência 5.11 indicou que ela pode ser descarregada passando o dedo pelo lado liso. O primeiro motivo para isto é que a fita é condutora através de seu lado, como mostrado na Experiência 5.2. Logo, ao passar o dedo pelo lado liso, conseguimos descarregar as partículas eletrizadas que estejam dos dois lados da fita. Além disso, como o dedo consegue deslizar por toda a área do lado liso, conseguimos aterrar todos os pontos da fita. Este aterramento geral já não ocorria ao passar o dedo pelo lado com cola já que a própria cola impedia o movimento do dedo.

\section{Experiência 5.13 - Descarregando metade de uma fita}

Prepara-se uma fita $S$ eletrizada com uns $20 \mathrm{~cm}$ de comprimento. Depois que ela está na vertical, deve-se passar o dedo pela parte lisa da fita, como ilustrado na Figura 5.9. Nesta experiência o deslizamento do dedo deve ocorrer apenas pela metade inferior da fita, ou seja, nos $10 \mathrm{~cm}$ da parte de baixo. Depois afasta-se a mão. Em seguida aproxima-se um dedo ortogonalmente ao lado fita, a uns $5 \mathrm{~cm}$ da extremidade inferior (ou seja, a meia altura da parte alisada). 
Observa-se que a fita não é atraída pelo dedo. Pode-se também segurar a fita na horizontal. Esta parte central da região alisada da fita é então aproximada da parte inferior da tirinha de um eletroscópio descarregado. Observa-se que a tirinha não é atraída pela parte alisada da fita.

Em seguida a parte central da região que não foi alisada da fita (com a fita ainda na horizontal) deve ser aproximada da parte inferior da tirinha de um eletroscópio descarregado. Neste caso observa-se que a tirinha é atraída pela parte não alisada da fita. Pode-se também prender a fita na vertical com a parte alisada ficando sobre a parte não alisada. Aproxima-se então um dedo ortogonalmente ao lado da fita, a uns $5 \mathrm{~cm}$ da extremidade inferior (ou seja, a meia altura da parte não alisada da fita). Neste caso observa-se que a fita é atraída pelo dedo.

Esta experiência ilustra vários fatos. O primeiro é que ao deslizar um dedo sobre a parte lisa de uma fita eletrizada, conseguimos neutralizar esta região. Por outro lado, a parte da fita eletrizada que não teve o dedo deslizando sobre ela continua eletrizada. Vemos então mais uma vez que uma fita adesiva comportase como um isolante ao longo de seu comprimento. Ou seja, podemos manter apenas metade da fita eletrizada ao longo de seu comprimento, sem que estas partículas eletrizadas migrem longitudinalmente para a outra extremidade da fita.

\subsection{Fitas Eletrizadas com Cargas Opostas}

Preparamos agora um novo conjunto, desta vez com 3 fitas sobrepostas. A fita de base $B$ deve ter de 10 a $20 \mathrm{~cm}$ de comprimento, sendo colada em uma superfície lisa. Ela é alisada passando o dedo sobre ela. Sobre a base colamos uma segunda fita do mesmo comprimento que deve ter uma de suas extremidades dobrada para facilitar a manipulação. Ela também deve ser alisada passando o dedo sobre sua superfície. Como ela vai ficar abaixo da próxima fita, vamos chamá-la de inferior e designá-la pela letra $I$. Em seguida colamos uma terceira fita do mesmo comprimento sobre a segunda. Ela será chamada de superior e designada pela letra $S$. Uma de suas extremidades deve ser dobrada para facilitar a manipulação, com a pontas dobrada de $S$ em cima da ponta dobrada de $I$. A fita $S$ também deve ser alisada passando o dedo sobre sua superfície. As letras $B, I$ e $S$ devem ser escritas nas fitas para não gerar confusão. O conjunto está representado na Figura 5.10.

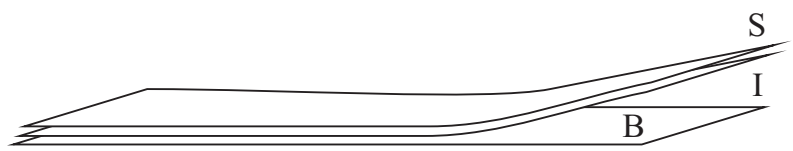

Figura 5.10: Fita superior $S$ sobre a fita inferior $I$, que por sua vez está sobre a fita de base $B$.

Experiência 5.14 - Neutralidade de um par de fitas sobrepostas 
Em seguida devemos retirar conjuntamente as fitas $I$ e $S$ da fita de base, lentamente. Depois que o par $I S$ foi retirado, ele deve ser passado algumas vezes entre nossos dedos.

Deve-se verificar que este par não atrai a tirinha de um eletroscópio descarregado, como indicado na Figura 5.11.

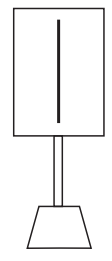

(a)

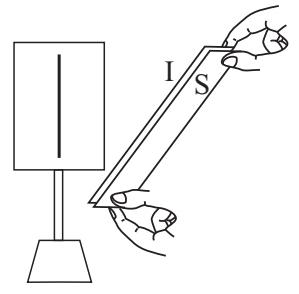

(b)

Figura 5.11: (a) Eletroscópio descarregado. (b) Par IS neutro não atrai a tirinha do eletroscópio.

O par IS deve ficar então dependurado na vertical por uma das extremidades, Figura 5.12 (a) e (b). Ao aproximar nosso dedo do conjunto, o par de fitas em geral não é atraído pelo dedo, permanecendo na vertical, Figura 5.12 (c).

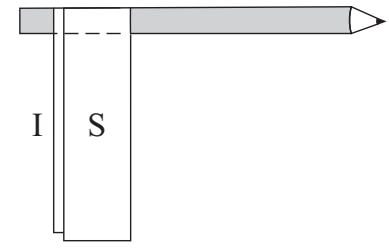

(a)

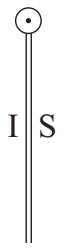

(b)

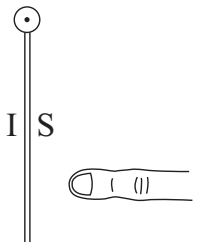

(c)

Figura 5.12: (a) Par IS dependurado na vertical e visto de lado. (b) Visto de costas. (c) Este par não é atraído por um dedo que se aproxima.

Caso o dedo esteja atraindo o par de fitas, elas devem ser neutralizadas antes de prosseguir com a experiência.

Para descarregar o par, podemos deixá-lo dependurado na vertical por alguns minutos. Também podemos passá-lo novamente entre nossos dedos. Ou então basta colar sua extremidade superior em algum suporte, segurá-lo pela extremidade inferior e passar um dedo ao longo do lado liso da fita $S$, como mostrado na Figura 5.9. Em seguida o par é deixado novamente na vertical. Ao aproximar um dedo da horizontal o par não deve mais ser atraído por ele, como indicado na Figura 5.12 (c).

Quando tudo isto ocorre, o par está neutro e podemos prosseguir com as experiências. É importante neutralizar o par $I S$ antes de prosseguir com as experiências. Desta forma evitamos que o par $I S$ tenha uma carga resultante, o que poderia atrapalhar na análise das próximas atividades. 


\section{Experiência 5.15 - Atração e repulsão entre fitas eletrizadas}

Vamos supor que a Experiência 5.14 tenha sido feita com sucesso e que o par $I S$ esteja neutro. A extremidade superior do par pode estar dependurada em um lápis ou em outro suporte apropriado. Seguramos então as pontas dobradas das duas fitas que estão na extremidade inferior e as separamos rapidamente. Em seguida dependuramos cada uma delas em um lápis diferente e estes 2 conjuntos devem ficar separados. Neste momento devemos verificar que cada uma destas fitas está eletrizada utilizando algum dos procedimentos das Experiências 5.7 ou 5.8 .

Fazemos o mesmo procedimento com um outro par $I S$ neutro até termos mais uma fita $S$ e mais uma fita $I$, ambas eletrizadas.

Aproximamos então os dois lápis com fitas $S$ e observa-se que as fitas se repelem, Figura 5.13 (a). O mesmo ocorre com duas fitas $I$, Figura 5.13 (b). Já uma fita $S$ e uma fita $I$ se atraem, Figura 5.13 (c).

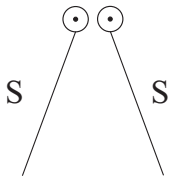

(a)

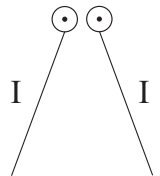

(b)

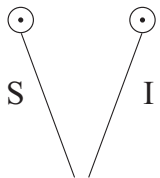

(c)

Figura 5.13: (a) Repulsão entre duas fitas $S$. (b) Repulsão entre duas fitas $I$. (c) Atração entre uma fita $S$ e uma fita $I$.

Ou seja, as fitas $S$ e $I$ ficam eletrizadas com cargas opostas, uma positiva e outra negativa.

O ângulo de inclinação entre as fitas aumenta com a diminuição da distância entre os lápis que as suportam. Este fato ilustra mais uma vez que a força elétrica, seja ela atrativa ou repulsiva, aumenta de intensidade quando diminuímos a distância entre os corpos.

Experiência 5.16 - Determinando o sinal das cargas em cada fita

Dependuramos uma fita $S$ eletrizada e uma fita $I$ eletrizada na vertical, separadas entre si. Aproximamos então um canudo eletrizado com carga de sinal conhecido da parte inferior de cada uma destas fitas. Vamos supor um canudo negativamente eletrizado ao ser raspado no cabelo ou em uma folha de papel. No caso da maioria das fitas com que trabalhamos, observou-se que a fita $S$ era repelida pelo canudo enquanto que a fita $I$ era atraída por ele.

Um canudo fica positivamente eletrizado ao ser rapidamente puxado entre duas borrachas duras como as usadas em mangueira de chuveiro ou entre dois tubos de PVC. ${ }^{4}$ Ao aproximar este canudo das duas fitas adesivas eletrizadas, observa-se que a superior é atraída pelo canudo positivo enquanto que a inferior é repelida por ele.

\footnotetext{
${ }^{4}$ Seção 5.3 de [Ass10b], [Ass10a], [Ass11], [Ass15b] e [Ass17].
} 
Ou seja, a fita superior em geral fica negativamente eletrizada, enquanto que a fita inferior fica positivamente eletrizada, Figura 5.14.

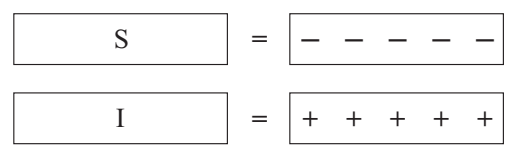

Figura 5.14: Fita superior negativamente eletrizada e fita inferior positivamente eletrizada.

\subsection{Dipolos Elétricos}

Um dipolo elétrico é constituído por duas partículas eletrizadas com cargas opostas e de mesma intensidade separadas por uma certa distância. Também é chamado de dipolo elétrico um corpo com carga total nula mas no qual as cargas positivas e negativas estão separadas ao longo do corpo. Consideramos nesta Seção algumas maneiras de construir estes dipolos e alguns efeitos que podem ser observados com eles. A interação entre dois dipolos elétricos tem características análogas à interação entre dois ímãs.

Experiência 5.17 - Dipolo elétrico feito com fitas adesivas

Nesta experiência construímos um dipolo elétrico utilizando fitas adesivas eletrizadas com cargas opostas de mesma intensidade, Seção 5.4. Começamos com um versório de plástico, Subseção 2.3.3. Vamos supor que cada perna do versório tenha uns $5 \mathrm{~cm}$ de comprimento. Vamos supor ainda que suas duas pernas estejam inicialmente neutras. Para isto basta verificar que ele não é orientado por um dedo que se aproxima de qualquer das pernas. Prepara-se o conjunto de 3 fitas $B, I$ e $S$ da Figura 5.10, com cada fita tendo uns 4 ou $5 \mathrm{~cm}$ de comprimento. Eletrizam-se então duas fitas $S$ e $I$ com cargas opostas, como na Experiência 5.15. Em seguida cola-se a fita $S$ em uma perna do versório e a fita $I$ na outra perna, Figura 5.15 (a).

Ao aproximar um canudo negativo de qualquer das pernas observa-se que o versório gira. Em particular, a perna $S$ é repelida pelo canudo enquanto que a perna $I$ é atraída por ele. No equilíbrio o versório fica orientado como indicado na Figura 5.15 (c).

Este dipolo elétrico possui cargas opostas de mesma magnitude em pernas diferentes do versório. Ele é análogo a uma bússola comum e pode ser chamado de bússola elétrica. ${ }^{5}$ A interação entre dois destes versórios de plástico polarizados comporta-se como a interação entre uma bússola e um ímã que se aproxima dela.

Contudo, enquanto que uma bússola é orientada pela Terra e por um ímã próximo, este dipolo elétrico é orientado não apenas por outro dipolo elétrico,

\footnotetext{
${ }^{5}$ [Net94] e [CS02, pág. 466].
} 
(a)

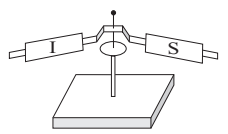

(b)

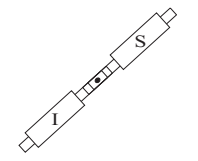

(c)
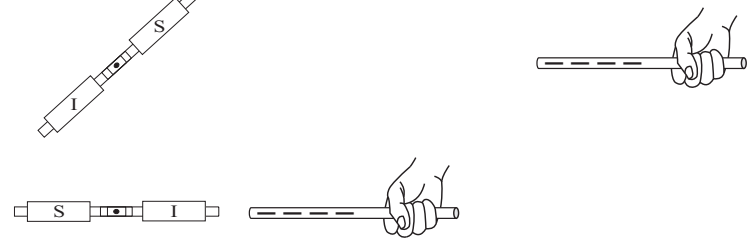

Figura 5.15: (a) Versório de plástico no qual foi colada uma fita $S$ em uma perna e uma fita $I$ na outra. (b) Versório visto de cima em uma orientação arbitrária quando um canudo eletrizado está longe dele. (c) Orientação do versório quando o canudo se aproxima.

mas também por um canudo eletrizado com apenas um tipo de carga (positiva ou negativa). Não existe um análogo magnético de um canudo eletrizado. Isto é, não se conhece nenhum material que tenha apenas um polo magnético (apenas um polo Norte ou apenas um polo Sul). Quando quebramos ao meio um ímã em forma de barra, cada metade vai ter um polo Norte e um polo Sul, Figura 5.16 .

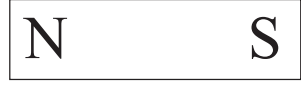

(a)

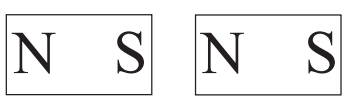

(b)

Figura 5.16: (a) Ímã em forma de barra. (b) Ao quebrar o ímã formamos dois novos ímãs. Cada ímã pequeno possui um polo Norte e um polo Sul.

A experiência não funciona bem se as fitas adesivas eletrizadas forem fixadas em um versório metálico. Há dois motivos para isto. (a) O primeiro motivo é que este versório é condutor. Vimos que a fita adesiva também comporta-se como um material condutor através de seu lado. Logo, pode haver uma neutralização das cargas das duas fitas através do versório metálico.

(b) O segundo motivo atrapalha a experiência mesmo quando não ocorre esta neutralização e quando as duas fitas continuam com suas cargas. Como o versório é condutor, ao aproximar o canudo eletrizado de qualquer uma de suas pontas, esta ponta vai ficar eletrizada com carga de sinal oposto à carga do canudo. Logo esta ponta vai ser atraída pelo canudo, tendendo a girar o versório. Esta força é grande e pode ser maior que a eventual atração ou repulsão que vai ocorrer entre a eletrização das fitas e as cargas do canudo. Quando isto ocorrer, os dois lados do versório serão atraídos pelo canudo, embora com forças de intensidades totais diferentes. Por exemplo, vamos supor que o canudo esteja negativamente eletrizado. Quando o canudo chega perto do lado positivo do 
versório, este lado será atraído tanto pelas cargas positivas induzidas na ponta da perna, quanto pelas cargas positivas que estão no durex preso a este lado. Já quando o canudo chega perto do outro lado do versório, este lado será atraído pelas cargas positivas induzidas na ponta da perna e será repelido pelas cargas negativas que estão no durex preso a este segundo lado. Logo, a força total ou resultante sobre um lado terá magnitude diferente da força total ou resultante sobre o outro lado.

\section{Experiência 5.18 - Outras maneira de fazer dipolos elétricos}

Na Experiência 5.17 mostramos como fazer um dipolo elétrico com fitas adesivas. Nesta atividade mostramos como fazê-los de outras formas.

A partir da série triboelétrica, Tabela 1.1, temos que um canudo plástico fica negativamente eletrizado ao ser atritado no cabelo, no papel ou na pele. Por outro lado, ao ser puxado entre duas mangueiras duras de borracha (como aquelas usadas nos chuveiros elétricos) ou entre dois canos de PVC, ele fica positivamente eletrizado. Pegamos então um canudo e o dobramos no formato da letra $V$ invertida. Dependuramos o canudo em uma linha de seda passando por seu centro. Atritamos metade do canudo em um guardanapo de papel e a outra metade passando-a rapidamente entre dois tubos de PVC. O primeiro lado vai ficar negativo e o segundo lado positivo. Embora o canudo fique eletricamente polarizado com este procedimento, nem sempre as duas pernas vão ficar eletrizadas com a mesma intensidade. Pode acontecer, por exemplo, que a perna negativa tenha mais cargas (ou fique mais eletrizada) do que a perna positiva, Figura 5.17 (a). Neste caso o canudo tem uma carga resultante não nula. Caso as duas pernas fiquem igualmente eletrizadas com cargas opostas como na Figura 5.17 (b), teremos um dipolo elétrico.

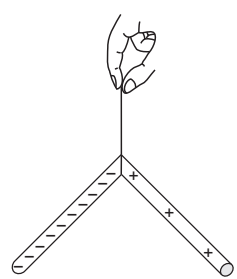

(a)

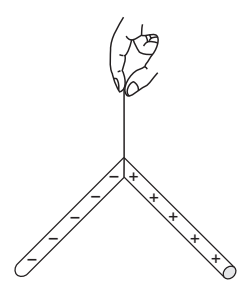

(b)

Figura 5.17: (a) Perna negativa mais eletrizada do que a perna positiva. (b) Pernas igualmente eletrizadas com cargas opostas.

Podemos aproximar um canudo negativamente eletrizado deste dipolo elétrico que ele vai girar apontando para este canudo, com a perna mais próxima sendo a positiva.

Um outro dipolo elétrico pode ser feito com uma barra ou paralelepípedo de isopor tendo, por exemplo, dimensões de $2 \times 2 \times 7 \mathrm{~cm}$ ou $0,5 \times 0,5 \times 5 \mathrm{~cm}^{6}$ O tamanho não é tão importante. Pela série triboelétrica, Tabela 1.1, vem que

\footnotetext{
${ }^{6}$ [Ferb, Corpo com duas cargas diferentes, pág. 11; e Pêndulo de isopor, pág. 30].
} 
o isopor fica negativamente eletrizado ao ser atritado no cabelo, no papel ou na pele. Por outro lado, ele fica positivo ao ser atritado em um saco plástico, na fórmica ou no acrílico rígido. Esfregamos então uma das extremidades da barra de isopor no papel e outra extremidade no acrílico rígido. Ele é então dependurado como um pêndulo elétrico, substituindo o disquinho de papel da Figura 2.10. Na Figura 5.18 apresentamos este dipolo elétrico na qual supomos cargas iguais e opostas nas duas extremidades.

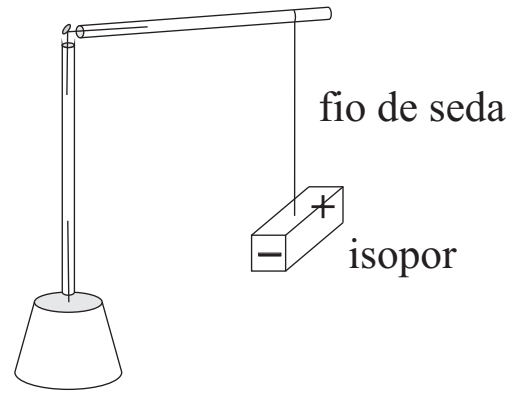

Figura 5.18: Barra de isopor igualmente eletrizada com cargas opostas nas duas extremidades.

Ao aproximar um canudo negativamente eletrizado da extremidade negativa da barra, esta será repelida. A extremidade positiva do isopor é atraída por este canudo. Se colocarmos dois destes pêndulos lado a lado, eles vão girar tal que as faces mais próximas estarão opostamente eletrizadas. Além disto, estas duas barras vão se atrair nesta orientação.

Uma outra maneira de fazer um dipolo elétrico utiliza um versório de plástico. São escolhidos dois materiais apropriados para atritá-lo que estejam em lados opostos da série triboelétrica (um material localizado entre este plástico e a carga positiva, enquanto que o outro material fica entre este plástico e a carga negativa). Atrita-se uma perna com o primeiro destes materiais e a outra perna com o outro material. A primeira perna ficará negativa e a outra perna ficará positiva. Caso as duas pernas estejam eletrizadas com cargas de mesma intensidade, teremos um dipolo elétrico, Figura 5.19.

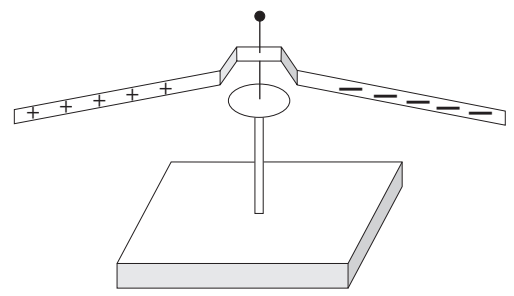

Figura 5.19: Versório de plástico com cargas iguais e opostas nas duas pernas. 
A perna negativa é repelida por um canudo negativamente eletrizado e atraída por um canudo positivamente eletrizado. Já a perna positiva é repelida pelo canudo positivo e atraída pelo canudo negativo.

\subsection{Aspectos Gerais sobre as Fitas Adesivas}

Substâncias adesivas são conhecidas há milhares de anos. As fitas adesivas foram inventadas em 1845 pelo médico Horace Day. Ele criou adesivos cirúrgicos ao aplicar uma cola feita com base de borracha em fitas de tecidos. No início do século XX foram introduzidas fitas adesivas comerciais. As fitas isolantes foram criadas no início da década de 1930 usando um adesivo feito com base de borracha isolante em uma fita de tecido. Em meados da década de 1940 foram introduzidas as fitas isolantes com o substrato (a fita) feito de material plástico tipo vinil.

A maioria das fitas adesivas utiliza um adesivo sensível à pressão. Ou seja, o grau de ligação depende da pressão aplicada. A fita em geral é feita de celofane ou de algum filme plástico. Em um lado da fita (que vai ficar na parte interna ao ser enrolada) aplica-se o adesivo. No outro lado aplica-se uma camada antiaderente que vai impedir com que o adesivo grude na própria fita quando ela é enrolada. 


\section{Capítulo 6}

\section{O Eletróforo}

\subsection{O Instrumento}

Apresentamos agora um instrumento que foi muito importante na história da eletricidade, o eletróforo. Ele é composto de duas partes: (a) uma base isolante eletrizada, juntamente com (b) um coletor de cargas. Este coletor de cargas é composto por um condutor preso a um cabo ou suporte isolante, Seção 2.6. A base isolante também é chamada de placa ou torta dielétrica. Ela pode ser eletrizada por atrito ou por qualquer outro meio. Na Figura 6.1 temos uma base isolante positivamente eletrizada juntamente com o coletor de cargas do eletróforo.

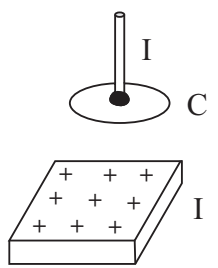

(a)
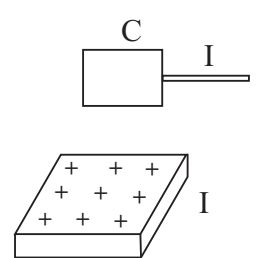

(b)
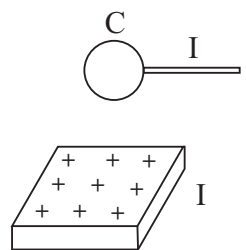

(c)

Figura 6.1: Exemplos de eletróforo com uma base isolante $I$ positivamente eletrizada, juntamente com seu coletor de cargas, a saber, um condutor $C$ preso a um cabo isolante $I$.

Normalmente tanto a base isolante quanto o condutor do coletor de cargas são planos, já que vão ser encostados um contra o outro. Mas não é essencial que sejam planos nem que tenham a mesma forma. A base isolante é do mesmo tamanho ou um pouco maior do que o condutor. A base pode ser uma folha plástica, uma placa de isopor, uma tampa plástica de $\mathrm{CD}$, uma placa ou forro de PVC, uma lâmina de acrílico, etc. Ela pode ficar eletrizada, por exemplo, atritando-a rapidamente com guardanapo de papel, lã ou com qualquer outro 
material apropriado.

É comum denominar de eletróforo apenas à parte (b) do conjunto, a saber, ao condutor com o cabo isolante. Esta parte (b) funciona como um coletor de cargas elétricas.

Na Figura 6.1 (a) podemos ter como coletor de cargas, por exemplo, uma tampa metálica de uma lata de alimento ou uma forma de alumínio de pizza presa a um cabo de PVC com cola araldite. Ou então pode ser o plano de prova de Coulomb, a saber, um disco condutor de cartolina ou papel cartão preso a um canudo plástico através de massa de modelar. ${ }^{1}$ Pode também ser um pratinho de alumínio (como os de festa) no qual foi preso com fita adesiva um garfo plástico horizontal ou um copo de isopor. Na Figura 6.1 (b) podemos ter, por exemplo, um eletroscópio típico como o que está sendo utilizado neste livro, sem a tirinha de papel de "seda", a saber, uma cartolina retangular presa a um canudo plástico. Na Figura 6.1 (c) podemos ter uma bola de papel de alumínio presa a um canudo plástico ou então uma esfera metálica presa a um tubo de PVC.

Um eletróforo com o qual conseguimos uma boa eletrização utiliza uma forma de pizza de alumínio, com $30 \mathrm{~cm}$ de diâmetro, presa no centro por um cabo isolante. A base isolante deste eletróforo pode ser uma placa ou forro de PVC de formato quadrado com $40 \mathrm{~cm}$ de lado que é eletrizada ao ser atritada rapidamente por um guardanapo de papel ou papel toalha. Uma montagem como esta foi feita por Cláudio Furukawa da Universidade de São Paulo. ${ }^{2}$

O eletróforo foi inventado pelo sueco Johan Carl Wilcke (1732-1796), publicando seus resultados em $1762 .{ }^{3}$ Wilcke havia publicado a primeira série triboelétrica da história em 1757. O eletróforo foi melhorado e popularizado por Alessandro Volta ao redor de 1775. O nome "eletróforo" é devido a Volta, sendo derivado das palavras gregas para "âmbar" e "portador", elétron e foro, significando um portador de eletricidade. ${ }^{4}$ Este instrumento é muitas vezes chamado de "eletróforo de Volta" embora tenha sido inventado por Wilcke.

Um dos maiores eletróforos já construídos foi feito em 1777 pelo cientista alemão Georg Christoph Lichtenberg (1742-1799). O coletor de cargas continha um disco metálico com $2 \mathrm{~m}$ de diâmetro, sendo movimentado por um sistema de polias. Chegava a produzir faíscas com uns $40 \mathrm{~cm}$ de comprimento. Ele o utilizava para produzir as famosas figuras de Lichtenberg. ${ }^{5}$

\subsection{Operação do Eletróforo}

Experiência 6.1 - Eletrizando o coletor de cargas de um eletróforo

Nesta primeira experiência vamos descrever a operação do eletróforo, Figura 6.2. Em (a) exemplificamos o eletróforo com uma base isolante de isopor que

\footnotetext{
${ }^{1}$ Seção 2.6.

$2[\mathrm{MF}]$.

3 [Hei99, págs. 418-419].

4 [Hei99, págs. 416-417].

${ }^{5}$ [Lic56], [Har67, pág. 89], [BJ92], [Beu92], [Ach96, Capítulo 5].
} 
ficou negativamente eletrizada em sua superfície superior ao ser atritada contra um guardanapo de papel. O coletor de cargas pode ser um disco de cartolina com o cabo sendo um pedaço de canudo plástico, ou então um disco metálico com cabo de PVC. Em (b) colocamos o disco sobre a base. Em (c) tocamos com o dedo em qualquer parte do lado de cima do disco metálico. Em (d) afastamos o dedo. Sem tocar mais no disco, levantamos o coletor de cargas segurando-o apenas pelo cabo isolante, Figura 6.2 (e).

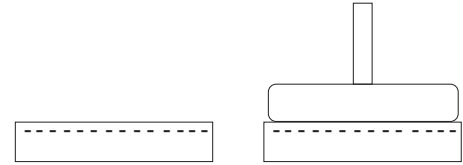

(a) (b)

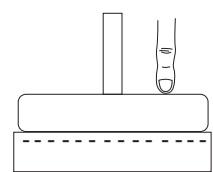

(c)

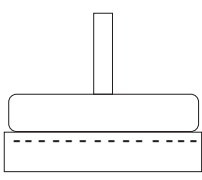

(d)

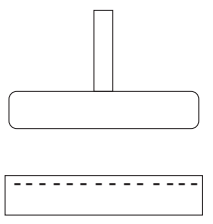

(e)

Figura 6.2: Operação do eletróforo.

Podemos testar se o eletróforo ficou ou não eletrizado aproximando-o de dois pêndulos elétricos, um carregado positivamente e outro negativamente. Ao fazer isto observamos que o eletróforo repele o pêndulo positivo e atrai o negativo. Concluímos então que o eletróforo ficou eletrizado positivamente nesta operação.

A explicação desta experiência é simples, baseada na polarização ou indução elétrica, Figura 6.3.

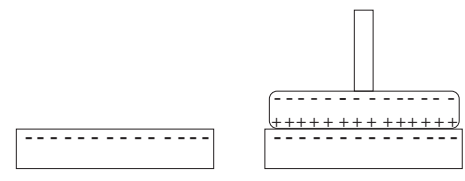

(a) (b)

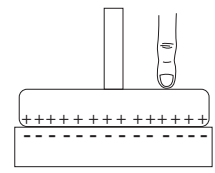

(c)

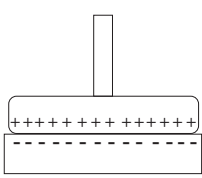

(d)

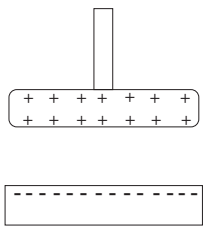

(e)

Figura 6.3: Eletrização do coletor de cargas do eletróforo com carga de sinal oposto à carga da base. 
Ou seja, ao encostar o disco condutor na base isolante eletrizada, o disco se polariza. Ao tocar o disco com o dedo, aterramos o disco, neutralizando a eletrização da parte superior do disco. A eletrização da parte inferior do disco permanece a mesma nos casos (b), (c) e (d) da Figura 6.3 devido à presença da base isolante eletrizada. Ao tirar o dedo, nada muda no disco. Ao afastar o eletróforo segurando-o pelo cabo isolante, ocorre uma redistribuição de cargas de tal forma que no final as cargas positivas resultantes ficam redistribuídas nas partes superior e inferior do disco. No final do processo o coletor de cargas do eletróforo fica eletrizado com carga de sinal oposto à carga da base, Figura 6.3 (e).

Na Figura 6.4 apresentamos o caso em que o coletor de cargas que é encostado na base eletrizada é uma esfera metálica presa a um cabo isolante, estando a base isolante positivamente eletrizada.

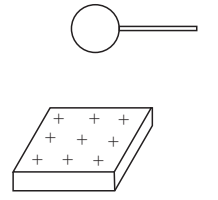

(a)

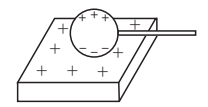

(b)

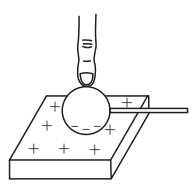

(c)

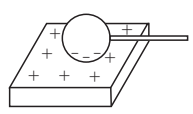

(d)

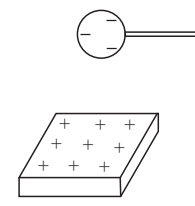

(e)

Figura 6.4: Condutor esférico tocando uma base isolante positivamente eletrizada.

Na Experiência 6.1 vimos que na operação do eletróforo seu coletor de cargas fica eletrizado com carga de sinal oposto à carga da base. A eletricidade armazenada no coletor de cargas do eletróforo pode ser facilmente transportada para qualquer lugar segurando-o apenas pelo cabo isolante. Ela pode então ser transferida a outro condutor que esteja isolado da Terra quando qualquer região do disco do eletróforo toca este outro condutor. Vai ocorrer então uma divisão da carga entre eles. Caso este outro condutor seja bem maior do que o eletróforo, praticamente toda a carga do eletróforo vai ser transferida para este outro condutor.

Além de ser muito fácil de manipular, a grande vantagem do eletróforo é que todo o processo de sua eletrização pode ser repetido um grande número de vezes sem que a base se descarregue apreciavelmente. Se em cada ciclo de operações transferirmos toda a carga do eletróforo para um outro grande condutor, podemos ao final de vários ciclos transferir uma quantidade de carga muito maior do que a magnitude da quantidade de carga que está localizada na base. Este fato se deve a que em cada ciclo o eletróforo toca na base apenas em alguns pontos, sendo que apenas nestes pontos a base pode se neutralizar. As outras regiões da 
base não se neutralizam por ela ser isolante, não permitindo o deslocamento de suas partículas eletrizadas. Além disso, as cargas que o eletróforo adquire em cada ciclo não são fornecidas pela base eletrizada, mas sim pela Terra através do aterramento com o dedo. A base apenas polariza o eletróforo, sendo que ele passa a ficar com uma carga resultante apenas quando ocorre o aterramento. Como a área da Terra é gigantesca comparada com a área do eletróforo, ela possui uma quantidade praticamente inesgotável de cargas livres que podem ser fornecidas ao eletróforo em vários ciclos de operação.

Além da quantidade bem pequena de partículas eletrizadas que são trocadas entre o eletróforo e a base nos pontos de contato, a base também vai se descarregando pouco a pouco devido à pequena condutividade do ar. Ela também perde uma quantidade bem pequena de cargas para a Terra por estar em contato com o solo. Embora a base seja um isolante, não existem isolantes perfeitos e um pouco de condutividade todos os plásticos possuem. Mas em geral todas estas perdas de eletrização são bem pequenas e não são facilmente perceptíveis em dias secos. Podemos fazer experiências durante vários minutos, repetindo vários ciclos de operação do eletróforo, sem que se perceba qualquer diminuição na eletrização da base. Além disso, mesmo que a eletrização da base diminua um pouco com a passagem do tempo ou com a repetição das operações do eletróforo, basta atritar novamente a base que podemos repetir o procedimento de carregar o eletróforo por muitas vezes.

O fato de podermos carregar o eletróforo várias vezes, sem descarregar apreciavelmente a base eletrizada, fez com que Volta desse o nome de elettroforo perpetuo a este instrumento, isto é, um portador de eletricidade cuja carga na base nunca se esgota. De acordo com Volta, a base deste fornecedor inesgotável de eletricidade tem a seguinte propriedade: ${ }^{6}$

Ao ser eletrizada apenas uma vez, de maneira rápida e moderadamente, nunca perde sua eletricidade e, embora seja tocada repetidamente, preserva obstinadamente a intensidade de seus sinais.

\section{Experiência 6.2 - Carregando um eletroscópio que toca uma base eletrizada}

Fazemos agora uma nova experiência com o eletróforo na qual a base retangular isolante eletrizada está em um plano vertical, fixa em relação ao solo, Figura 6.5 (a).

Como coletor de cargas do eletróforo vamos usar uma cartolina retangular de $10 \mathrm{~cm} \times 7 \mathrm{~cm}$ presa a um canudo plástico. Colamos agora uma tirinha de papel de "seda" no lado de fora deste coletor de cargas, ou seja, no lado em que o canudo está preso na cartolina. Quando encostamos a cartolina na base eletrizada, segurando-a pelo canudo, observa-se que a tirinha fica levantada, Figura 6.5 (b). Enquanto a cartolina está encostada na base, aterramos a cartolina. Este aterramento pode ser obtido, por exemplo, encostando um dedo em alguma parte da cartolina. Observa-se que sua tirinha abaixa, encostando na cartolina, Figura 6.5 (c). A tirinha continua abaixada quando retiramos o aterramento,

\footnotetext{
${ }^{6}$ [Hei99, pág. 416].
} 


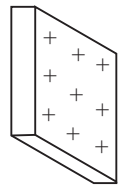

(a)
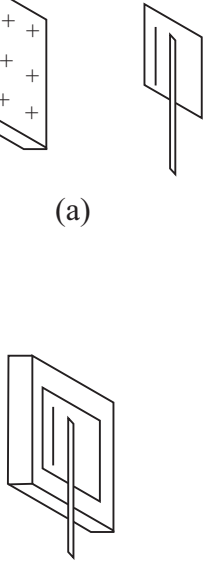

(d)

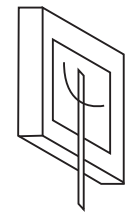

(b)

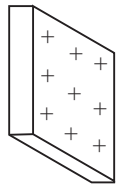

(e)

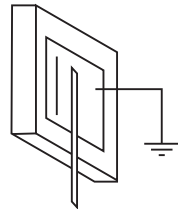

(c)
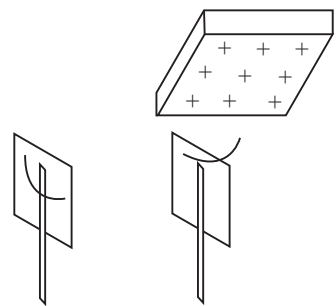

(f)

Figura 6.5: (a) Base eletrizada e eletróforo com tirinha de papel de "seda." (b) Tirinha levanta quando eletróforo toca na base. (c) Tirinha abaixa no aterramento. (d) Tirinha permanece abaixada ao tirar o aterramento. (e) Tirinha levanta ao afastar o eletróforo da base. (f) Tirinha atraída pela base eletrizada.

Figura 6.5 (d). Ao afastar então o eletróforo da base eletrizada, a tirinha volta a subir, afastando-se da cartolina, Figura 6.5 (e). Colocamos agora a base isolante na horizontal, por cima da cartolina, com seu lado eletrizado na parte inferior. Se aproximarmos agora a base isolante da cartolina retangular, veremos a tirinha sendo atraída pela base, indicando que o eletróforo ficou eletrizado com carga oposta à da base, Figura 6.5 (f).

Este comportamento pode ser explicado com a distribuição de cargas da Figura 6.3, invertendo os sinais de todas as cargas.

\section{Experiência 6.3 - A cobra elétrica}

Uma experiência interessante que pode ser feita com um eletróforo é a da cobra elétrica. ${ }^{7}$ Vamos usar um eletróforo de disco como aquele da Figura 6.1 (a). Colocamos alguns pedacinhos ou tirinhas de papel sulfite (ou papel celofane, ou papel de alumínio, ou papel de "seda") no disco do eletróforo, no lado do disco ligado ao cabo isolante. Eletrizamos o eletróforo como na Experiência 6.1. Depois que afastamos o eletróforo da base eletrizada, aproximamos o dedo dos papeizinhos que ainda ficaram no disco. Observa-se que eles são atraídos pelo dedo, tocam nele e depois voltam a cair no eletróforo. Algumas vezes eles pulam para fora do eletróforo simplesmente ao afastá-lo da base, mesmo antes da aproximação do dedo.

Embora o papel celofane pareça um material plástico, ele deriva da celulose (assim como o papel), não sendo feito do petróleo. Já o plástico comum é

\footnotetext{
${ }^{7}$ [FR08, pág. 86].
} 
normalmente feito a partir do petróleo. O papel celofane é um mau condutor, pior do que o papel sulfite ou o papel de "seda", mas ainda assim descarrega um eletroscópio eletrizado quando seguramos uma das extremidades de uma tira de papel celofane com a mão e tocamos sua outra extremidade na cartolina do eletroscópio. Uma das características que faz com que o papel celofane seja um condutor melhor do que o plástico é o fato do celofane absorver a umidade do ar.

Esta experiência não funciona bem se utilizarmos pequenos materiais isolantes (como pedacinhos ou tirinhas de plástico) em vez de condutores.

Esta experiência é de certa forma o oposto do que ocorre no efeito âmbar. No caso do efeito âmbar aproximamos uma régua plástica eletrizada de papeizinhos sobre a mesa e os observamos serem atraídos pela régua. Embora eles estejam inicialmente neutros, são polarizados pela aproximação da régua, ficando com carga resultante oposta à da régua caso estejam sobre uma superfície condutora. Ao serem atraídos pela régua, possuem uma carga de sinal oposta à dela antes de tocá-la. ${ }^{8}$

Já na presente experiência o eletróforo e os papeizinhos ficam eletrizados com cargas de mesmo sinal ao afastar o eletróforo da base. Devido à repulsão que cada papelzinho eletrizado sofre do disco eletrizado do eletróforo sobre o qual está apoiado, muitas vezes eles já pulam para fora do disco ao afastá-lo da base. Mesmo que isto não ocorra, com a aproximação de um dedo depois que o eletróforo foi afastado da base, eles acabam sendo atraídos pelo dedo. O dedo está aterrado e é um condutor. Embora esteja inicialmente neutro, acaba ficando eletrizado em sua extremidade com carga oposta à do eletróforo ao se aproximar dele, devido à indução produzida no dedo pelas cargas do eletróforo. Os papeizinhos eletrizados passam então a ser atraídos pela aproximação do dedo cuja extremidade está eletrizada com carga oposta à dos papeizinhos, além de serem repelidos pela carga do eletróforo que tem mesmo sinal que a carga dos papeizinhos. Muitas vezes a força resultante atuando sobre os papeizinhos, apontando para cima, é forte o suficiente para superar seus pesos e eles deslocamse em direção ao dedo. Ao tocarem nele adquirem uma carga resultante de mesmo sinal que o dedo pelo mecanismo $A C R$, passando então a ser repelidos pelo dedo e a ser atraídos pelo eletróforo, sendo puxados novamente para baixo.

Esta experiência ilustra então o princípio de ação e reação. Isto é, não apenas uma régua plástica eletrizada atrai papeizinhos inicialmente neutros, mas também papeizinhos eletrizados são atraídos por um dedo inicialmente neutro.

\subsection{Um Relato Pessoal}

Gostaria de citar aqui um relato pessoal que pode ser útil a outras pessoas. Durante meus estudos de graduação em física na UNICAMP (1980-1983) li sobre o eletróforo e resolvi construir este instrumento. Como coletor de cargas

\footnotetext{
${ }^{8}$ Como discutido na Subseção 4.1.2. Ver também a Seção 8.3 de [Ass10b], [Ass10a], [Ass11], [Ass15b] e [Ass17].
} 
peguei uma tampa metálica circular de uma lata de um produto alimentício. Serrei um pedaço de uns $20 \mathrm{~cm}$ de comprimento de um cabo de vassoura de madeira para servir como cabo isolante. Prendi o cabo à tampa metálica com um prego. Como base isolante a ser eletrizada por atrito tentei um saco plástico e também um disco de vinil (material plástico do tipo de PVC). Atritava estas bases com guardanapos de papel, pedaços de pano e com outros materiais.

Tentei fazer as experiências simples descritas nos livros didáticos (como algumas descritas neste trabalho) mas não consegui os efeitos desejados, já que nada acontecia com meu instrumento. Achei inicialmente que talvez fosse a eletrização insuficiente da base. Variei um pouco os materiais da base, mas nada mudou. Variei os materiais com os quais atritava a base, sendo que continuei não tendo sucesso com as experiências. Finalmente mudei a maneira de atritá-la. Mesmo assim não tive sucesso com a experiência, já que não conseguia reproduzir os fenômenos elétricos descritos nos livros. Desisti então de fazer esta experiência e outras de eletricidade. Acabei concluindo que a falha era minha e que não tinha jeito para física experimental. Esta experiência frustrada foi um dos motivos pelos quais passei a me dedicar a partir daquela época apenas à física teórica.

Foi apenas no início da década de 1990, quando descobri os trabalhos de Norberto Ferreira, ${ }^{9}$ que encontrei a explicação correta para o meu fracasso. Não foi a falta de habilidade manual. Meu erro foi ter usado um cabo de madeira achando que, simplesmente por ser madeira, seria um material isolante. Afinal de contas esta era a mensagem implícita na maioria dos livros didáticos, a saber, que materiais como madeira, vidro, borracha, água e várias outras substâncias semelhantes eram isolantes, já que estes livros apresentam suas constantes dielétricas. Já os metais e o corpo humano seriam condutores. Na época nem imaginei que a madeira pudesse se comportar como um condutor, logo não cheguei a trocar os materiais que usava como cabo no coletor de cargas (por exemplo, não pensei na possibilidade de trocar o cabo de madeira por um tubo de PVC). Hoje sei que a maior parte dos tipos de madeira crua comporta-se como um material condutor nas experiências de eletrostática. Provavelmente o cabo de madeira que utilizei era condutor, não permitindo o acúmulo de cargas quando o cabo era seguro por minha mão.

Com os trabalhos de Norberto Ferreira descobri que a maior parte destes materiais (incluindo a maioria das madeiras, vidros e borrachas, assim como a água de torneira) comporta-se como um condutor para as experiências de eletrostática. Esta descoberta foi a coisa mais importante que aprendi com Norberto Ferreira. Ou seja, em vez de dizer que algum corpo é condutor ou isolante, o mais correto é dizer que ele se comporta como condutor ou isolante, dependendo das condições a que está sujeito. Em particular, se for aplicada uma alta diferença de potencial entre as extremidades de um corpo, um material que normalmente é considerado um isolante pode passar a se comportar como um condutor. Esta situação é muito comum nas experiências de eletrostática, que muitas vezes lidam com altas diferenças de potencial variando tipicamente entre

\footnotetext{
${ }^{9}$ [Fer78], [FM91], [Fera], [Ferb], [Ferc], [Ferd], [Fer06], [Fer01c], [Fer01d], [Fer01b] e [Fer01a].
} 
$1.000 \mathrm{~V}$ e $10.000 \mathrm{~V}$.

Ao substituir o cabo de madeira por um tubo de PVC ou de outro material isolante, as experiências simples com o eletróforo descritas nos livros passam a funcionar sem maiores problemas.

Este fracasso ou frustração ilustra a importância de sempre testar com antecedência os materiais que vão ser usados em qualquer experiência de eletrostática para saber se eles se comportam como condutores ou isolantes nas condições práticas em que serão utilizados. Para isto é fundamental o teste do eletroscópio indicado na Seção 3.1. Norberto Ferreira também me ensinou como construir eletroscópios e vários outros instrumentos utilizando materiais de baixo custo. Estes instrumentos funcionam perfeitamente bem. Esta foi a segunda grande lição que aprendi com ele. 


\section{Capítulo 7}

\section{Distribuição de Cargas em um Condutor}

Nas experiências descritas neste livro faremos diversas experiências com um condutor oco. Ele será uma casca cilíndrica de papel, de cartolina ou de metal (como uma latinha de refrigerante ou de alimento). Algumas vezes esta casca cilíndrica será chamada simplesmente de cilindro. Ele será aberto na tampa de cima e/ou na tampa de baixo para que possamos observar o que se passa dentro dele. É também possível utilizar uma tela metálica na forma de uma casca cilíndrica. Se quisermos isolá-la da Terra, basta prender na casca cilíndrica canudos plásticos por meio de fitas adesivas, com os canudos apoiados em copinhos de café com gesso e colchetes. Ou então o cilindro pode ficar apoiado sobre uma lâmina de isopor. Quanto mais espessa for a lâmina, melhor será o isolamento. Uma lâmina comum com 2 ou $5 \mathrm{~cm}$ de espessura já funciona como um bom isolante para as experiências usuais de eletrostática.

\subsection{Distribuição de Cargas em Condutores}

\subsubsection{Experiências com Eletroscópios}

Experiência 7.1 - Eletrizando uma casca cilíndrica

Inicialmente preparamos a casca cilíndrica da Figura 7.1 (a). Ela funcionará como um eletroscópio. As tirinhas de papel de "seda" internas e externas indicarão as densidades de carga nas paredes de dentro e de fora da casca.

Recortamos um retângulo de papel sulfite ou de cartolina com um tamanho aproximado de $10 \mathrm{~cm} \times 20 \mathrm{~cm}$ (ou $10 \mathrm{~cm} \times 30 \mathrm{~cm})$. Prendemos com fitas adesivas no meio do retângulo um canudo plástico paralelo ao plano do papel, de tal forma que uma parte do canudo fique para fora do papel. Fechamos o retângulo fazendo uma casca cilíndrica e então colamos ou grampeamos suas extremidades. Esta casca cilíndrica será às vezes chamada simplesmente de 


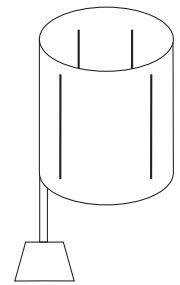

(a)

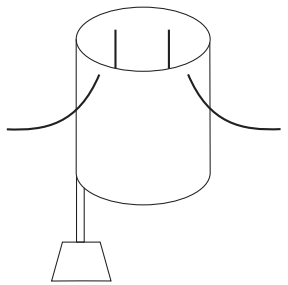

(b)

Figura 7.1: (a) Casca cilíndrica de papel isolada e neutra. (b) Casca cilíndrica eletrizada. Apenas as tirinhas de fora se levantam. Quanto mais eletrizado estiver o cilindro, mais levantadas elas ficam.

cilindro. Colamos as extremidades superiores de tirinhas de papel de "seda" tanto do lado de dentro quanto do lado de fora do cilindro. Estas tirinhas devem ter de 5 a $9 \mathrm{~cm}$ de comprimento e uma espessura de 1 a $3 \mathrm{~mm}$. Em seguida apoiamos o canudo em um copinho de café com gesso e colchete, Figura 7.1 (a).

Eletrizamos uma régua de plástico ou acrílico por atrito contra um guardanapo de papel ou um pedaço de lã. Raspamos a régua plástica eletrizada algumas vezes na borda superior do cilindro até que ele fique bem eletrizado. $\mathrm{O}$ cilindro também pode ser carregado utilizando um eletróforo como aquele feito de cartolina presa a um canudo plástico, Figura 6.1 (b). Para isto tocamos com um eletróforo eletrizado na parte superior do cilindro. Repetimos este processo algumas vezes, sempre eletrizando o eletróforo antes de tocá-lo no cilindro a cada vez. Observa-se que quando o cilindro está eletrizado, apenas as tirinhas de fora ficam levantadas, enquanto que as tirinhas de dentro permanecem abaixadas, como mostrado na Figura 7.1 (b).

Além do mais, a cada vez que raspamos a régua plástica eletrizada no cilindro ou que o tocamos com um eletróforo eletrizado, mais as tirinhas de fora vão levantando, indicando que ele está ficando cada vez mais carregado. Depois de um certo número de vezes de repetição deste processo, atinge-se uma saturação tal que as tirinhas não levantam mais além de um certo ponto.

\section{Experiência 7.2 - Eletrizando um retângulo de papel}

Recortamos uma folha de papel sulfite ou cartolina flexível, de forma retangular, com lados de $7 \mathrm{~cm} \times 20 \mathrm{~cm}($ ou $10 \mathrm{~cm} \times 30 \mathrm{~cm})$. Prendemos dois ou três canudos plásticos na folha com fitas adesivas, com os canudos no plano da folha, sobrando uma parte dos canudos para fora do papel. A folha e os canudos ficam então em um plano vertical, com os canudos apoiados em copinhos de café com gesso e colchete. Colamos a extremidade superior de duas tirinhas de papel de "seda" com $6 \mathrm{~cm}$ de comprimento e largura de 1 a $3 \mathrm{~mm}$, uma tirinha de cada lado do retângulo, no meio dele, como indicado na Figura 7.2. É como se fosse um eletroscópio mais largo, com tirinhas dos 2 lados. Ele está isolada da Terra pelos canudos plásticos. 


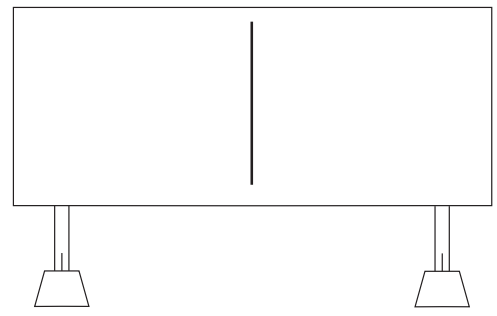

(a)

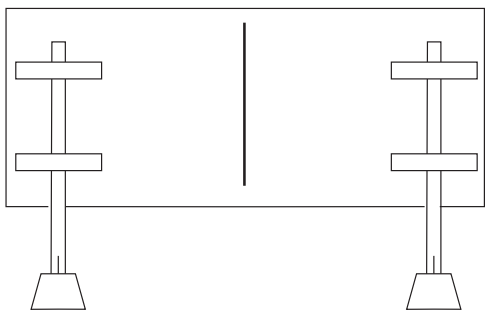

(b)

Figura 7.2: Retângulo de papel de frente (a) e de costas (b).

Eletrizamos este retângulo raspando nele algumas vezes uma régua de acrílico atritada no guardanapo. Observa-se que as tirinhas dos dois lados do retângulo se levantam, Figura 7.3. O retângulo também pode ser eletrizado encostando em sua borda superior o coletor de cargas de um eletróforo eletrizado. Este processo deve ser repetido algumas vezes, sempre eletrizando o eletróforo antes de tocá-lo no retângulo.

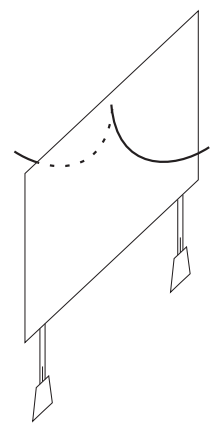

Figura 7.3: Retângulo eletrizado.

Quanto mais eletrizado estiver o retângulo, mais levantadas ficarão suas tirinhas de papel de "seda".

Experiência 7.3 - Curvando um retângulo eletrizado

Chame de $A$ um lado do retângulo e $B$ o outro lado. Segura-se o retângulo eletrizado da Experiência 7.2 pelos canudos plásticos ou pelas bases feitas de copinho de café com gesso, sem tocar na cartolina. Ele é então curvado tal que forme uma faixa circular. ${ }^{1}$ Observa-se que ao ir fechando o círculo, a tirinha do lado de dentro $B$ da faixa retangular vai abaixando, enquanto que a tirinha do lado de fora $A$ vai ficando mais levantada, Figura 7.4 (a). Quando fechamos o círculo, a tirinha do lado de dentro fica abaixada. Além disso, a tirinha do lado

\footnotetext{
${ }^{1}$ [FM91, págs. 74-75], [Ferb, Gaiola de Faraday, pág. 45] e [FR08, págs. 89-90].
} 
de fora fica mais levantada na Figura 7.4 (a) do que qualquer uma das tirinhas da Figura 7.3.

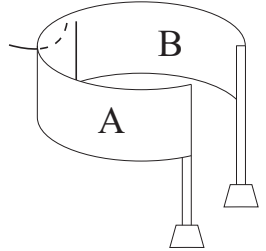

(a)

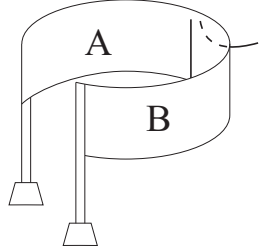

(b)

Figura 7.4: Faixa circular eletrizada. (a) e (b): Apenas as tirinhas de fora se levantam, enquanto que as tirinhas de dentro ficam abaixadas.

Agora vamos abrindo a faixa circular, voltamos ao retângulo e fazemos uma nova faixa circular curvada para o outro lado. A tirinha do lado $B$ que estava abaixada do lado de dentro na Figura 7.4 (a) fica agora do lado de fora do novo círculo, observando-se que fica levantada, Figura 7.4 (b). Já a tirinha do lado $A$ que estava levantada do lado de fora da Figura 7.4 (a) fica agora do lado de dentro do novo círculo, observando-se que fica abaixada, Figura 7.4 (b).

\section{Experiência 7.4 - Separando as duas partes de um condutor eletrizado}

Uma experiência análoga utiliza duas partes independentes que podem ser movidas separadamente. ${ }^{2}$ A primeira parte é um eletroscópio simples composto por uma cartolina retangular presa a dois canudos plásticos. Estes canudos ficam apoiados nos colchetes fixados a dois copinhos de café com gesso. São colocadas duas tirinhas de papel de "seda" neste eletroscópio, uma de cada lado, como na Figura 7.2. A segunda parte é uma faixa cilíndrica feita de papel ou cartolina com a mesma altura da cartolina da primeira parte. Esta faixa cilíndrica fica presa a um ou mais canudos plásticos apoiados nos colchetes fixados a um ou mais copinhos de café com gesso. Inicialmente encostamos as duas bordas da casca cilíndrica na cartolina retangular. Tanto a tirinha de papel de "seda" do lado de dentro quanto a tirinha do lado de fora ficam abaixadas.

Eletrizamos então o sistema raspando uma régua plástica eletrizada na cartolina. Observa-se que apenas a tirinha externa do retângulo se levanta, Figura 7.5 (a).

Afastamos as duas partes segurando-as apenas pelos canudos, evitando de tocar nas cartolinas. Observa-se então que a tirinha de fora abaixa um pouco mas permanece levantada, enquanto que a tirinha que estava do lado de dentro no caso da Figura 7.5 (a) agora também se levanta, como indicado na Figura 7.5 (b).

\footnotetext{
${ }^{2}$ [Fer78, Seção 4.10.9, págs. 89-90].
} 


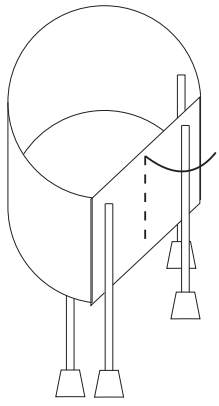

(a)

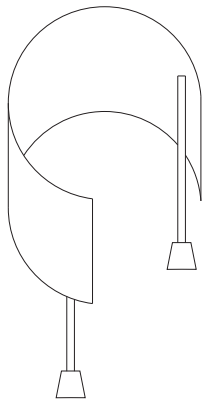

(b)

Figura 7.5: (a) Sistema eletrizado com as duas cartolinas em contato. Apenas a tira externa se levanta. (b) Quando afastamos a faixa cilíndrica, a tira de fora abaixa um pouco, enquanto que a tira de dentro também passa a ficar levantada.

\subsubsection{Coletando as Cargas nas Paredes Interna e Externa de um Condutor Eletrizado}

Nas experiências anteriores comparamos apenas o comportamento das tirinhas de papel de "seda." Agora vamos tentar coletar diretamente uma parte das cargas distribuídas nas paredes interna e externa de uma casca cilíndrica eletrizada.

Experiência 7.5 - Tentando coletar cargas da parede interna de uma casca cilíndrica eletrizada

Utilizamos a casca cilíndrica da Experiência 7.1 sem tirinhas do lado de dentro e com apenas uma tirinha do lado de fora. O cilindro isolado da Terra pelo canudo plástico é inicialmente eletrizado negativamente raspando uma régua plástica eletrizada na borda superior da cartolina cilíndrica, até que sua tirinha fique bem levantada, Figura 7.6 (a).

Vamos utilizar ainda um coletor de cargas na forma de uma bola de papel de alumínio presa na ponta de um canudo plástico, Figura 2.15 (b). Este coletor deve estar inicialmente descarregado, Figura 7.6 (a).

Segurando o coletor pelo canudo, tocamos com a bola de papel de alumínio na parede interna do cilindro eletrizado, Figura 7.6 (b). Em seguida removemos o coletor do cilindro. Podemos testar sua carga aproximando-o de um pêndulo elétrico descarregado ou de um versório metálico. Como o pêndulo elétrico e o versório não são afetados pelo coletor, concluímos que a bola de papel de alumínio continua neutra. Ou seja, o coletor não adquiriu nenhuma carga ao tocar na parede interna do cilindro eletrizado, Figura 7.6 (c).

Experiência 7.6 - Coletando cargas da parede externa de uma casca cilíndrica eletrizada 


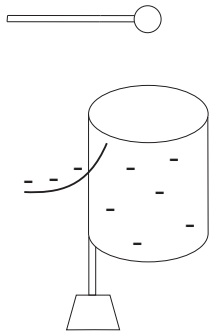

(a)

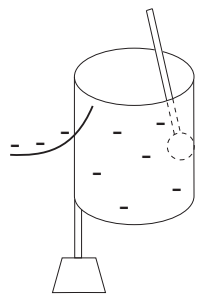

(b)

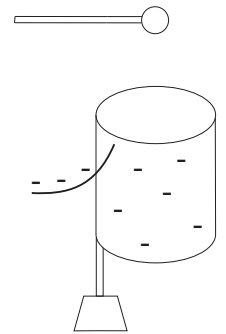

(c)

Figura 7.6: (a) Bola de papel de alumínio descarregada e casca cilíndrica negativamente eletrizada. (b) Bola de papel tocando a parede interna da casca cilíndrica. (c) Ao retirar a bola de papel observa-se que continua descarregada.

Repetimos a Experiência 7.5 começando com a casca cilíndrica negativa e com o coletor descarregado, Figura 7.7 (a)

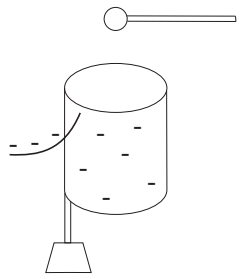

(a)

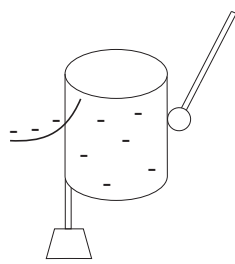

(b)

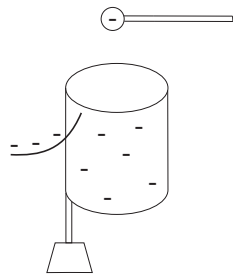

(c)

Figura 7.7: (a) Bola de papel descarregada e casca cilíndrica negativamente eletrizada. (b) Bola de papel tocando a parede externa da casca cilíndrica. (c) Ao retirar a bola de papel, observa-se que ela também fica negativamente eletrizada.

Só que agora tocamos com o coletor de cargas descarregado na parede externa do cilindro eletrizado, Figura 7.7 (b). Ao retirar o coletor de cargas e testar sua eletrização, conclui-se que ele adquiriu uma certa quantidade de carga, já que atrai um pêndulo elétrico neutro ou um versório metálico. Podemos então descobrir o sinal de sua carga ao aproximar o coletor eletrizado de dois pêndulos eletrizados que estão separados entre si e eletrizados com cargas opostas. Observa-se que o coletor atrai o pêndulo positivo e repele o pêndulo negativo. Conclui-se então que o coletor adquiriu carga de mesmo sinal que a carga da casca cilíndrica. Além disso, a casca cilíndrica continua eletrizada, já que sua tirinha ainda fica levantada, Figura 7.7 (c).

Experiência 7.7 - Utilizando um pequeno eletroscópio para tentar coletar cargas da parede interna de uma casca cilíndrica eletrizada

A Experiência 7.5 pode ser feita com outro coletor de cargas, uma cartolina de $5 \mathrm{~cm} \times 5 \mathrm{~cm}$ presa a um canudo plástico. Pode-se colocar uma tirinha de 
papel de "seda" nesta cartolina para indicar quando está eletrizada. Vai ser usada como um eletroscópio usual, mas com a tirinha colada na extremidade oposta do que ocorre no eletroscópio. Neste caso, ao contrário do que ocorre com um eletroscópio comum, a parte superior da tirinha vai ficar colada na cartolina como indicado na Figura 7.8 (a). Este coletor pode ser eletrizado como um eletróforo, ou então raspando uma régua plástica eletrizada na borda da cartolina quadrada. Neste caso a tirinha do coletor vai ficar levantada, Figura 7.8 (b).

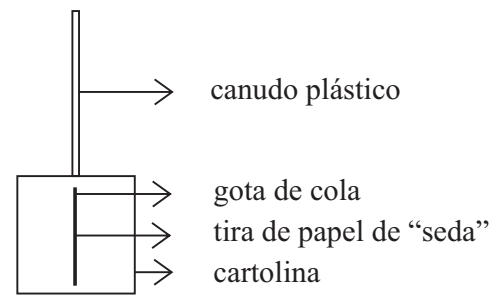

(a)

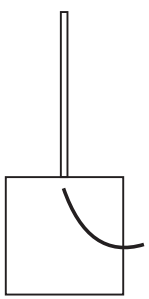

(b)

Figura 7.8: (a) Coletor de cargas não eletrizado. (b) Coletor eletrizado.

O coletor de cargas deve estar inicialmente descarregado, com sua tirinha abaixada. Eletrizamos uma casca cilíndrica negativamente. Esta eletrização é indicada pela tirinha externa da casca cilíndrica, que fica levantada quando a casca está bem eletrizada, Figura 7.9 (a).

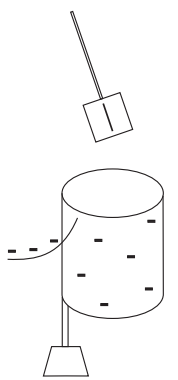

(a)

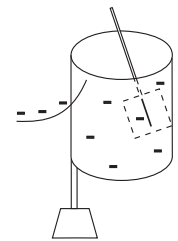

(b)

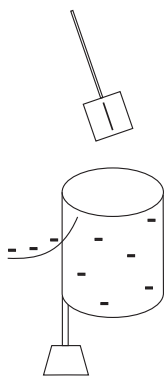

(c)

Figura 7.9: (a) Coletor de cargas descarregado e casca cilíndrica negativamente eletrizada. (b) Tocando com a quina da cartolina do coletor na parede interna da casca cilíndrica. (c) Ao retirar o coletor de cargas observa-se que continua descarregado.

Segurando-se o coletor pelo canudo plástico, toca-se com a quina de sua cartolina na parede interna da casca cilíndrica eletrizada, Figura 7.9 (b). Sua tirinha continua abaixada, permanecendo assim mesmo depois que o coletor é retirado de dentro da casca cilíndrica, Figura 7.9 (c). Ou seja, não conseguimos coletar carga alguma ao tocar na parede interna da casca cilíndrica eletrizada. 
Experiência 7.8 - Utilizando um pequeno eletroscópio para coletar cargas da parede externa de uma casca cilíndrica eletrizada

Repetimos a Experiência 7.7 começando novamente com o coletor descarregado e com a casca cilíndrica negativamente eletrizada, Figura 7.9 (a).

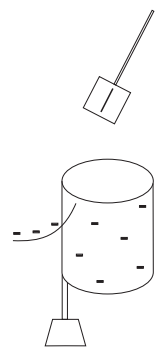

(a)

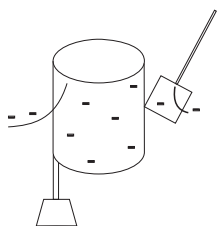

(b)

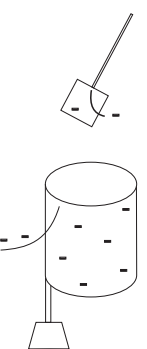

(c)

Figura 7.10: (a) Coletor de cargas descarregado e casca cilíndrica negativamente eletrizada. (b) Tocando com a quina da cartolina do coletor na parede externa da casca cilíndrica. (c) Ao retirar o coletor de cargas observa-se que está negativamente eletrizado.

Toca-se agora com a quina da cartolina na parede externa do cilindro eletrizado. Observa-se que sua tirinha levanta um pouco, enquanto que a tirinha do cilindro abaixa um pouco, Figura 7.10 (b). Ao retirar o coletor de cargas sua tirinha continua levantada, assim como a casca cilíndrica. Pode-se testar a carga que o coletor adquiriu aproximando-o de uma régua plástica eletrizada negativamente e de outra régua eletrizada positivamente. No primeiro caso a tirinha do coletor é repelida, sendo atraída pela segunda régua. Conclui-se então que este coletor adquiriu carga negativa, do mesmo sinal que as cargas da casca cilíndrica eletrizada.

\subsubsection{Gray, Franklin e a Distribuição de Cargas em Con- dutores Eletrizados}

Estas experiências mostram que em um condutor oco eletrizado, as cargas ficam distribuídas sobre a parede externa do condutor. Stephen Gray foi o primeiro a chegar nesta conclusão fazendo um outro tipo de experiência publicada em $1731 .^{3}$ Ele prendeu dois cubos de madeira de mesmo tamanho por um fio condutor (ou seja, a linha de comunicação de Gray), sendo um cubo oco e outro maciço, com os dois cubos ficando à mesma distância do solo. Abaixo dos cubos colocou pequenas lâminas de latão. Suspendeu o fio condutor através de dois fios isolantes (ou seja, as linhas muito finas de Gray). Então aproximou do centro do fio condutor um tubo de vidro eletrizado. Observou que os dois cubos atraíam a mesma quantidade de lâminas, Figura 7.11.

\footnotetext{
${ }^{3}$ Ver a Seção B.8 de [Ass10b], [Ass10a], [Ass11], [Ass15b] e [Ass17].
} 


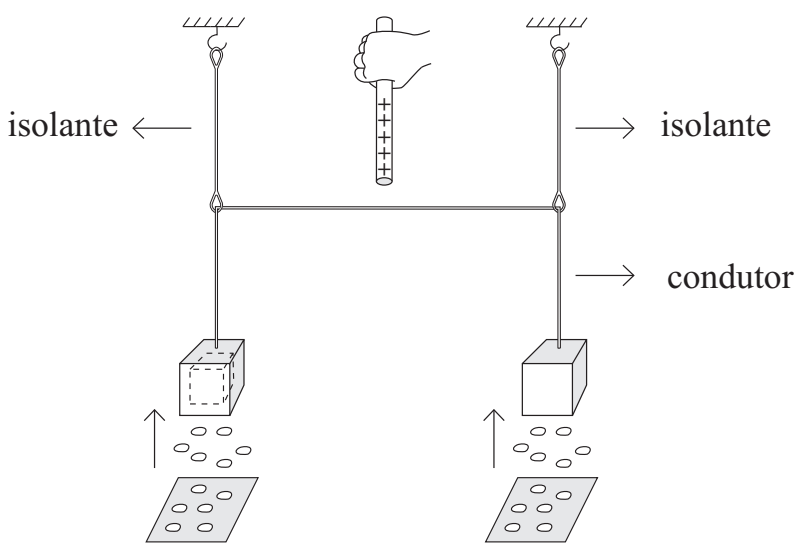

Figura 7.11: Dois cubos de madeira, um oco e outro maciço, atraem com a mesma força pequenas lâminas de latão.

Apresentamos as palavras de Gray descrevendo sua experiência (com nossas palavras em colchetes e com nossa ênfase em itálico na sua conclusão): ${ }^{4}$

Algum tempo depois, [na casa do] Sr. Wheler, fizemos os experimentos a seguir, a fim de testar se a atração elétrica é proporcional à quantidade de matéria nos corpos.

Foram feitos dois cubos de carvalho, de [faces com] aproximadamente 6 polegadas quadradas $\left[15,2 \mathrm{~cm}^{2}\right]$, um maciço e o outro oco. Esses [cubos] foram suspensos por duas linhas muito finas, quase da mesma maneira que no experimento mencionado acima. A distância entre os cubos era, por estimativa, de aproximadamente 14 ou 15 pés [4,2 ou $4,5 \mathrm{~m}$ ]. A linha de comunicação foi amarrada a cada linha muito fina, e as lâminas de latão [foram] colocadas embaixo dos cubos. O tubo [de vidro] foi atritado e mantido acima da parte central da linha [isto é, acima da parte central do barbante horizontal que interligava as linhas finas verticais presas ao teto], e tão próximo quanto se possa imaginar, a iguais distâncias dos cubos, os quais atraíram e repeliram as lâminas de latão ao mesmo tempo e à mesma altura, de forma que pareceu não haver mais atração no cubo maciço do que no oco. Apesar disso, estou inclinado a pensar que os eflúvios elétricos passam através de todas as partes interiores do cubo maciço, apesar de nenhuma parte, exceto a superfície, atrair; pois a partir de vários experimentos parece que se algum outro corpo tocar aquele que atrai, sua atração cessa até que o corpo seja removido, e [aquele que atraía] seja novamente excitado pelo tubo.

Benjamin Franklin foi o primeiro a realizar uma atividade análoga às Experiências 7.5 e 7.7 em 1755, mas não soube explicar o resultado obtido. Citamos aqui o trecho relevante, nossas palavras entre colchetes: ${ }^{5}$

\footnotetext{
${ }^{4}$ [Graf, p. 35], [Bos11, pp. 160-161] e [BAC12, pp. 154-155].

5 [Fra69, Carta 24, págs. 326-327] e [Hei99, pág. 464].
} 
Eletrizei uma caneca de prata, sobre um suporte elétrico [ou seja, mantida sobre um isolante], e então abaixei dentro dela uma bola de cortiça, com um diâmetro aproximado de uma polegada $[2,54 \mathrm{~cm}]$, dependurada por um fio de seda, até que a cortiça tocasse o fundo da caneca. A cortiça não foi atraída pelo lado de dentro da caneca como teria sido [atraída] pelo lado de fora e, embora tenha tocado o fundo, contudo, quando removida, encontrou-se que não estava eletrizada por este toque, assim como teria ficado ao tocar o lado de fora. O fato é singular. Você quer a explicação; eu não a conheço.

Em 1775 Joseph Priestley (1733-1804) utilizou esta experiência de Franklin para concluir que a atração elétrica, assim como a gravitacional, varia com o inverso do quadrado da distância entre os corpos: ${ }^{6}$

Não podemos concluir a partir desta experiência que a atração da eletricidade está sujeita às mesmas leis que aquela da gravidade, sendo portanto de acordo com o quadrado das distâncias; pois é facilmente demonstrado que se a Terra tivesse a forma de uma casca [esférica], um corpo dentro dela não seria mais atraído por um lado do que por outro.

Priestley está aqui se referindo a dois teoremas fundamentais devidos a Isaac Newton (1642-1727), Figura 7.12.

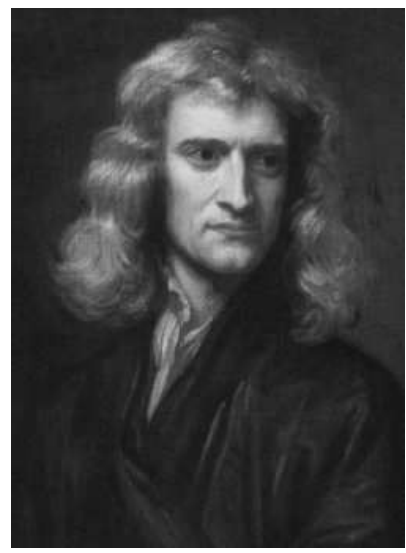

Figura 7.12: Isaac Newton (1642-1727). Esta é a pintura mais famosa de Newton, feita por Godfrey Kneller (1646-1723) em 1689. Newton aparece com seu cabelo natural, no auge de sua carreira científica, dois anos após a publicação do Principia.

Estes teoremas estão incluídos na Seção XII do Livro I de sua obra Princípios Matemáticos de Filosofia Natural: ${ }^{7}$

Seção XII: As forças atrativas de corpos esféricos

\footnotetext{
6 [Pri75, págs. 372-374], [Pri66, págs. 372-374], [Whi73a, págs. 53-54] e [Hei99, pág. 464].

7 [New34, p. 193], [New90, pág. 221], [Ass13, págs. 9-10] e [Ass14, págs. 10-11].
} 
Proposição 70. Teorema 30: Se para cada ponto de uma superfície esférica tenderem forças centripetas iguais, que diminuem com o quadrado das distâncias a partir desses pontos, afirmo que um corpúsculo localizado dentro daquela superfície não será atraído de maneira alguma por aquelas forças.

$[\ldots]$

Proposição 71. Teorema 31: Supondo-se o mesmo que acima, afirmo que um corpúsculo localizado fora da superfície esférica é atraído em direção ao centro da esfera com uma força inversamente proporcional ao quadrado de sua distância até este centro.

Este teorema é válido para uma casca esférica. Ele não é válido para uma caneca com densidade superficial de massa constante. Franklin, por outro lado, mostrou que uma caneca eletrizada não exerce força sobre uma cortiça condutora neutra colocada em qualquer lugar de seu interior. A diferença em relação ao caso gravitacional é que as cargas são livres para se rearranjarem sobre a superfície da caneca. Quando a caneca eletrizada está em equilíbrio, a densidade de cargas sobre ela varia de um ponto a outro de sua superfície. Além disso, no equilíbrio ela não polariza condutores colocados em qualquer ponto de seu interior (exceto perto da tampa superior aberta). Como os condutores neutros colocados em seu interior não são polarizados pela caneca, estes condutores neutros não são atraídos pelas paredes da caneca eletrizada, mesmo que se aproximem de um dos lados da caneca.

\subsubsection{Condutores Eletrizados Tocando as Paredes Interna e Externa de Outro Condutor}

Nas Experiências 7.5 até 7.8 começamos com uma casca cilíndrica eletrizada e um coletor descarregado. Agora invertemos o procedimento e começamos com um coletor de cargas eletrizado que vai tocar em uma casca cilíndrica inicialmente descarregada.

Experiência 7.9 - Eletrizando uma casca cilíndrica ao tocar sua parede interna com um coletor de cargas eletrizado

Utilizamos a casca cilíndrica da Experiência 7.1 sem tirinhas do lado de dentro e com apenas uma tirinha do lado de fora. O cilindro isolado da Terra pelo canudo plástico ou por estar apoiado sobre uma lâmina de isopor deve estar inicialmente descarregado, com a tirinha abaixada. Vamos utilizar ainda um coletor de cargas na forma de uma bola de papel de alumínio presa na ponta de um canudo plástico, Figura 2.15 (b). Ele é utilizado na forma de um eletróforo, sendo eletrizado como indicado na Figura 6.4. Ou seja, eletrizamos por atrito uma base retangular de isopor ou um forro de PVC. Seguramos o coletor de cargas pelo canudo, encostamos a parte inferior da bola de papel de alumínio na base eletrizada, tocamos com o dedo na parte superior da bola, tiramos o dedo e finalmente levantamos o canudo desencostando a bola da base. 
Pode-se verificar que o coletor ficou eletrizado aproximando-o de um pêndulo elétrico descarregado e percebendo que o disquinho do pêndulo desloca-se em direção à bola de papel de alumínio. Eles não devem se tocar.

Segurando o coletor eletrizado pelo canudo, encosta-se então a bola de papel alumínio eletrizada na parte interna da casca cilíndrica. Este processo é repetido algumas vezes, sempre eletrizando a bola no eletróforo antes de cada toque. Percebe-se que a tirinha do lado de fora do cilindro vai levantando a cada toque. Ao analisar a carga do cilindro, observa-se que é do mesmo sinal que a carga que havia na bola. Este fato pode ser visualizado eletrizando novamente a bola no eletróforo e aproximando-a da tirinha levantada, observando que se repelem.

Eletriza-se novamente a bola no eletróforo, toca-se com ela na parede interna do cilindro e então retira-se a bola. Ao aproximar então o coletor de cargas de um pêndulo elétrico descarregado, observa-se que não há atração entre eles, indicando que a bola foi totalmente descarregada ao tocar no interior no cilindro. Mesmo quando o cilindro já está eletrizado, a bola eletrizada é sempre totalmente descarregada ao tocar no interior do cilindro, Figura 7.13.

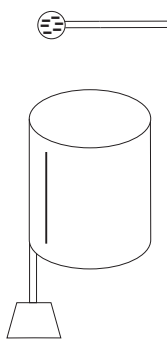

(a)

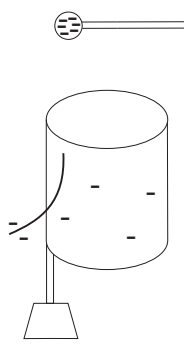

(d)

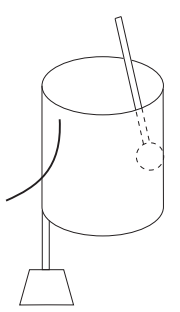

(b)

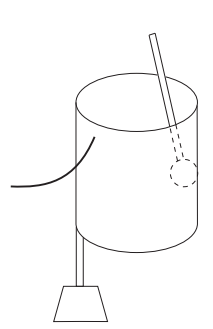

(e)

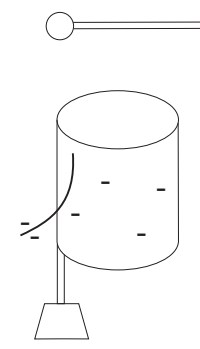

(c)

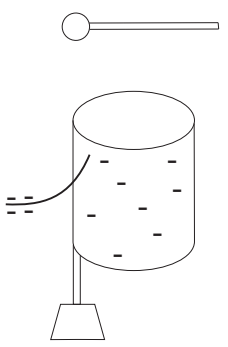

(f)

Figura 7.13: (a) Cilindro descarregado e coletor eletrizado. (b) Toca-se com o coletor na parede interna do cilindro, com este procedimento podendo ser repetido algumas vezes. (c) até (f): O coletor fica totalmente descarregado após cada toque e o cilindro fica cada vez mais eletrizado.

Experiência 7.10 - Aproximando uma bola condutora neutra ou eletrizada da tirinha externa de uma casca cilíndrica 
Algumas outras coisas também podem ser observadas na Experiência 7.9. Vamos supor que descarregamos a casca cilíndrica, eletrizamos o coletor de cargas no eletróforo e aproximamos a bola carregada da tirinha externa da casca cilíndrica, sem deixar que se toquem. Observa-se que a tirinha é atraída em direção à bola. Esta atração é devida à polarização da casca cilíndrica produzida pela proximidade da bola eletrizada.

Em seguida repete-se a Experiência 7.9 eletrizando a casca cilíndrica. Para eletrizar a casca cilíndrica fazemos com que a bola eletrizada toque em sua parede interna, repetindo este procedimento algumas vezes até que a tirinha fique bem levantada.

Se agora eletrizarmos novamente a bola do coletor de cargas do eletróforo e a aproximarmos da tirinha levantada, veremos que a tirinha se afasta da bola, indicando como já foi dito que a bola e a tirinha estão eletrizados com cargas de mesmo sinal.

Vamos supor agora que, estando a casca cilíndrica eletrizada, tocamos com a bola carregada na parede interna da casca cilíndrica. Este toque descarrega totalmente a bola condutora, como foi visto na Experiência 7.9. Ao retirar a bola descarregada e aproximá-la da tirinha levantada, observa-se que a tirinha é atraída pela bola. Neste caso a atração é devida novamente à polarização da bola (isolada pelo canudo plástico), sendo esta polarização causada pela eletrização do cilindro e de sua tirinha.

\section{Experiência 7.11 - Casca cilíndrica com tirinhas internas e externas}

A Experiência 7.9 também pode ser feita tendo tirinhas do lado de dentro e de fora do cilindro. Começamos com a casca cilíndrica descarregada, com suas tirinhas abaixadas. Neste caso, quando a bola de papel de alumínio eletrizada penetra no cilindro, a tirinha de dentro é atraída pela bola. Se deixarmos que se toquem e depois as separarmos, veremos que a tirinha interna cai, ficando na vertical, não sendo mais atraída pela bola que acabou de tocar. Retirando-se o coletor de cargas, observa-se que ficou descarregado.

Após algumas repetições deste processo, observa-se que as tirinhas internas do cilindro permanecem abaixadas, enquanto que as de fora vão ficando cada vez mais levantadas. Além disso, mesmo quando o cilindro já está eletrizado, toda vez que o coletor eletrizado penetra no cilindro, as tirinhas internas são atraídas, tocam nele, caem após serem separadas e, ao retirar o coletor, observa-se que ficou totalmente descarregado.

Experiência 7.12 - Eletrizando uma casca cilíndrica ao tocar sua parede externa com um coletor de cargas eletrizado

Uma variação da Experiência 7.9 é fazer com que a bola eletrizada toque apenas na parede externa da casca cilíndrica. Depois de cada toque a bola é novamente eletrizada no eletróforo. Observa-se que a tirinha externa da casca vai levantando a cada toque. Caso a casca tenha uma tirinha interna, esta tirinha não se levanta, ficando sempre abaixada mesmo depois de vários toques. Tanto no início da experiência quanto depois que a casca já está eletrizada, 
como indicado por sua tirinha externa levantada, eletriza-se novamente a bola no eletróforo e toca-se mais uma vez a bola na parede externa da casca. Ao analisar a carga da bola depois deste toque, observa-se que ela ainda está um pouco eletrizada. Este fato pode ser observado aproximando a bola de um outro eletroscópio descarregado e observando que a bola atrai a tirinha deste eletroscópio. Ou então aproximando a bola da tirinha externa levantada da própria casca cilíndrica que acabou de tocar, observando que a tirinha é repelida pela bola. Concluímos então que em cada toque na parede externa a bola perde um pouco de sua carga mas não fica totalmente descarregada, enquanto que o cilindro recebe um pouco de carga como indicado pelo levantamento de sua tirinha, Figura 7.14.

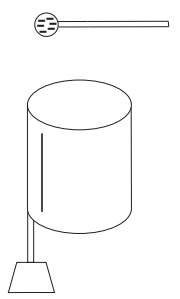

(a)

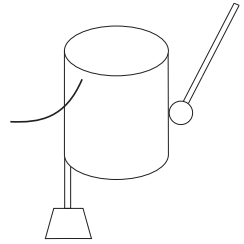

(b)

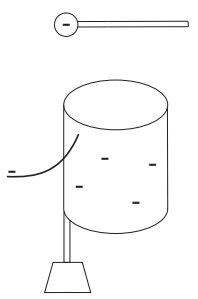

(c)

Figura 7.14: (a) Cilindro descarregado e coletor eletrizado. (b) Toca-se com o coletor na parede externa do cilindro. (c) $\mathrm{O}$ coletor ainda fica um pouco eletrizado e o cilindro um pouco carregado.

\section{Experiência 7.13 - Repetindo estas experiências com um pequeno eletroscópio}

As Experiências 7.9 e 7.12 podem ser repetidas utilizando o coletor de cargas da Experiência 7.7, Figura 7.8. Inicialmente este coletor de cargas deve ser eletrizado de tal forma que sua tirinha fique levantada.

Segurando o coletor eletrizado pelo canudo e tocando-o com a cartolina quadrada na parte interna do cilindro inicialmente descarregado, observa-se que o coletor é imediatamente descarregado, já que sua tirinha fica abaixada. Ao mesmo tempo, a tirinha externa do cilindro começa a se levantar. Repetindose este processo algumas vezes é possível eletrizar bastante o cilindro, como indicado por sua tirinha externa cada vez mais levantada. E toda vez que o coletor eletrizado toca na parede interna do cilindro, o coletor perde sua carga. Para que ele perdesse toda sua carga a casca cilíndrica teria de ser totalmente fechada, com tampas em cima e embaixo. Como pelo menos uma das tampas tem de estar aberta para que o coletor passe por ela, às vezes acontece de o coletor ainda ficar um pouco eletrizado após tocar em sua parede interna. Mas dá para perceber que ele continua perdendo praticamente toda sua carga após cada toque.

Por outro lado, caso o coletor eletrizado toque na parede externa do cilindro isolado inicialmente neutro, a tirinha do coletor abaixa mas não totalmente, 
enquanto que a tirinha externa do cilindro levanta um pouco. Se repetirmos este processo algumas vezes, sempre carregando o coletor antes de cada toque, veremos que a tirinha do cilindro vai ficando cada vez mais levantada. Mas a tirinha do coletor não abaixa totalmente em cada toque, sempre fica um pouco levantada, indicando que o coletor não perdeu totalmente sua carga após os contatos. A partir de uma certa quantidade de carga no cilindro, observa-se que quando o coletor eletrizado toca na parede externa do cilindro, não há mais troca de cargas entre eles. Ou seja, a tirinha do cilindro permanece com seu ângulo de abertura constante antes e depois do toque, o mesmo ocorrendo com o ângulo de abertura da tirinha do coletor de cargas.

\subsubsection{Distribuição de Cargas em Condutores Abertos e Fechados}

Estas experiências mostram que em um condutor curvo, as cargas ficam do lado de fora, como indicado pela inclinação das tirinhas da Figura 7.4. Além disso, como as tirinhas da Figura 7.4 estão mais levantadas do que as duas tirinhas da Figura 7.3, observa-se que as cargas que estavam de um lado do retângulo foram para o outro lado ao curvá-lo em uma faixa circular.

$\mathrm{Na}$ Figura 7.15 (a) apresentamos a distribuição qualitativa de cargas quando vemos de cima o retângulo de cartolina da Figura 7.3.

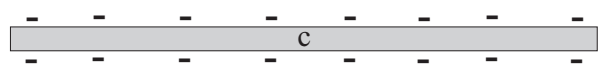

(a)

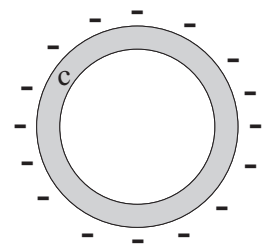

(b)

Figura 7.15: (a) Representação qualitativa das cargas na cartolina retangular da Figura 7.3 vista de cima. (b) Idem no caso da cartolina cilíndrica da Figura 7.4 vista de cima.

A letra "c" representa o condutor (ou seja, a cartolina). Ela foi representada com uma espessura exagerada apenas para indicar que as cargas ficam sobre sua superfície externa. Quando ela é curvada na forma de uma casca cilíndrica, como na Figura 7.4, as cargas de um dos lados fluem para o outro lado, de tal forma que no final deste processo não tenham cargas no lado de dentro e todas fiquem do lado de fora do cilindro, Figura 7.15 (b).

\subsection{Cargas Induzidas nas Paredes Interna e Ex- terna de um Condutor Oco}

Experiência 7.14 - Régua eletrizado dentro de uma casca cilíndrica 
Utiliza-se uma casca cilíndrica condutora com tirinhas de papel de "seda" no lado externo. O cilindro será isolado da Terra ao ser apoiado por canudos plásticos ou sobre uma lâmina de isopor, estando inicialmente neutro com suas tirinhas abaixadas, Figura 7.16 (a).

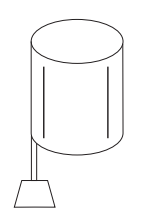

(a)

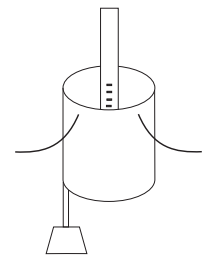

(b)

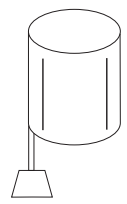

(c)

Figura 7.16: (a) Casca cilíndrica isolada e descarregada. (b) Ao penetrar com uma régua plástica eletrizada, as tirinhas se levantam. (c) Ao retirar a régua, as tirinhas se abaixam.

Eletriza-se uma régua plástica negativamente por atrito contra um guardanapo de papel. Quando se penetra com a parte eletrizada da régua no cilindro, sem tocá-lo, suas tirinhas levantam, Figura 7.16 (b). Ao retirar a régua as tirinhas abaixam, Figura 7.16 (c).

Repetimos agora esta experiência. Porém, enquanto a régua plástica negativa está dentro do cilindro, aproximamos da tirinha levantada, por fora do cilindro, uma segunda régua negativamente eletrizada, sem deixar que se toquem. Observamos uma repulsão entre elas, como indicado pelo fato desta tirinha se afastar um pouco da régua plástica eletrizada, Figura 7.17 (a). Se aproximarmos da tirinha levantada uma régua ou canudo positivamente eletrizado (por exemplo, puxando o canudo plástico rapidamente entre dois tubos de PVC pressionados um contra o outro), veremos que agora ocorre uma atração, Figura 7.17 (b).

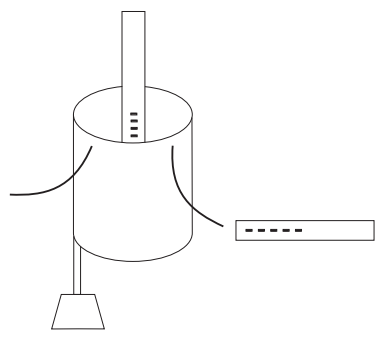

(a)

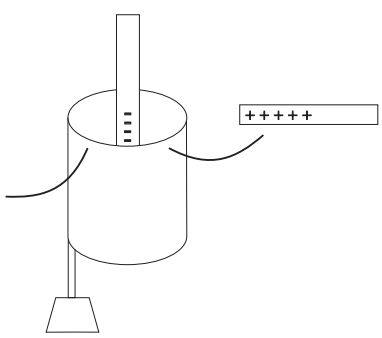

(b)

Figura 7.17: (a) Tirinha repelida por uma régua negativa. (b) Tirinha atraída por uma régua positiva.

Temos aqui uma experiência de polarização elétrica. O cilindro está isolado da Terra. Quando a régua negativa penetra nele, a parede interior do cilindro 
fica positivamente eletrizada, enquanto que a parede externa fica negativamente eletrizada.

Experiência 7.15 - Aterrando a casca cilíndrica enquanto a régua eletrizada está dentro dela

Repete-se a Experiência 7.14. Inicialmente temos uma casca cilíndrica descarregada, Figura 7.18 (a).

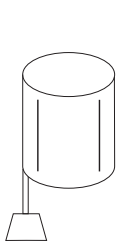

(a)

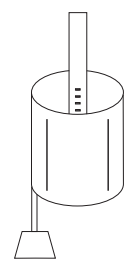

(d)

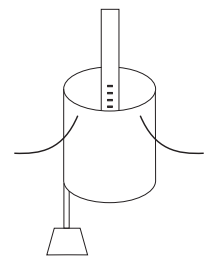

(b)

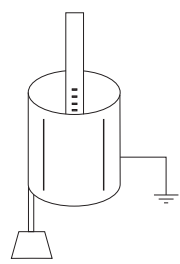

(c)

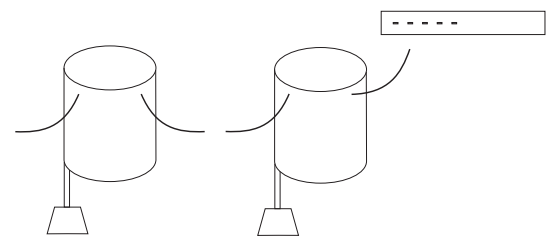

(e)

Figura 7.18: Eletrização da casca cilíndrica por indução.

Ao colocar uma régua negativamente eletrizada dentro da casca, as tirinhas levantam, Figura 7.18 (b). Mas agora, depois que a régua negativamente eletrizada está dentro do cilindro, aterra-se o cilindro. Observa-se que as tirinhas abaixam, Figura 7.18 (c). Retira-se o aterramento com a régua ainda dentro do cilindro e observa-se que as tirinhas continuam abaixadas, Figura 7.18 (d). Ao retirar a régua, as tirinhas voltam a levantar e permanecem assim, Figura 7.18 (e). Se aproximarmos agora a régua negativamente eletrizada do cilindro, observa-se que ela atrairá as tirinhas, Figura 7.18 (f).

Esta experiência ilustra a eletrização por indução. No final da experiência o cilindro ficou eletrizado com carga de sinal oposto à da régua plástica eletrizada. Quando a régua negativamente eletrizada penetra no cilindro, ocorre uma polarização de suas cargas, com a parede interna do cilindro ficando positivamente eletrizada, enquanto que sua parede externa ficou negativamente eletrizada, Figura 7.19 (a).

No aterramento ocorre uma neutralização das cargas na parede externa do cilindro, enquanto que a parede interior do cilindro permanece positivamente eletrizada devido à ação atrativa das cargas negativas da régua, Figura 7.19 (b). Ao retirar o aterramento, tudo continua do mesmo jeito, Figura 7.19 (c). Ao afastar a régua, ocorre um rearranjo de cargas no cilindro, de tal forma que agora ele fica positivamente eletrizado apenas em sua parede externa, Figura 7.19 (d). 


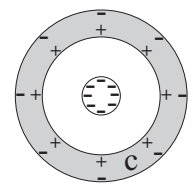

(a)

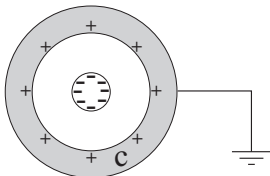

(b)

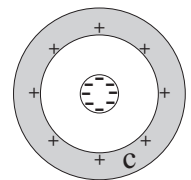

(c)

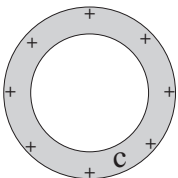

(d)

Figura 7.19: (a) Condutor $c$ oco, isolado da Terra, polarizado devido à presença de um corpo eletrizado com uma carga negativa em seu interior. (b) Condutor aterrado com a neutralização das cargas em sua parede externa. (c) Podemos retirar o aterramento sem afetar a distribuição de cargas. (d) Com a retirada da carga interna, as cargas se redistribuem de tal forma que apenas a parede externa do condutor fique eletrizada.

\subsection{Ação de um Condutor Oco Eletrizado sobre Corpos Internos e Externos}

Experiência 7.16 - Ação de uma casca cilíndrica eletrizada sobre um pêndulo elétrico interno

Começamos com uma casca cilíndrica condutora descarregada e isolada eletricamente da Terra ao estar presa em canudos plásticos ou apoiada sobre uma lâmina de isopor. A casca pode ser feita de papel, cartolina ou pode ser uma latinha de refrigerante. Cola-se a extremidade superior de uma tirinha de papel de "seda" no lado de fora da casca. Vamos utilizar ainda um pêndulo elétrico constituído por um disquinho de papel dependurado em um fio de seda. Este pêndulo deve estar inicialmente neutro. Colocamos o disquinho de papel dependurado por um fio de seda de um pêndulo elétrico no interior da casca, próximo de sua parede mas sem tocá-la, a meia altura entre as tampas de cima e debaixo da casca, Figura 7.20 (a).

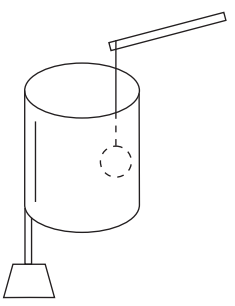

(a)

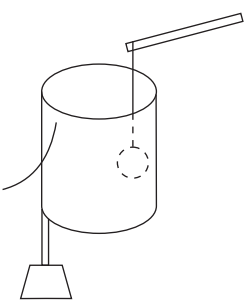

(b)

Figura 7.20: (a) Casca cilíndrica condutora isolada da Terra com um pêndulo elétrico em seu interior. (b) $O$ disquinho de papel não é afetado quando a casca é eletrizada.

Mantemos o pêndulo elétrico no interior da casca cilíndrica, com o disco de papel perto de sua parede interna mas sem tocá-la. Eletriza-se a casca 
raspando nela uma régua plástica carregada por atrito ou tocando sua borda superior com um eletróforo eletrizado. Esta eletrização é indicada pela tirinha levantada. Observa-se que o pêndulo interno não é afetado por esta eletrização, não sendo atraído nem repelido pela casca, Figura 7.20 (b).

Experiência 7.17 - Ação de uma casca cilíndrica eletrizada sobre um pêndulo elétrico externo

Repete-se a Experiência 7.16 começando com o pêndulo elétrico do lado de fora da casca cilíndrica, estando o disquinho de papel próximo dela, Figura 7.21 (a).

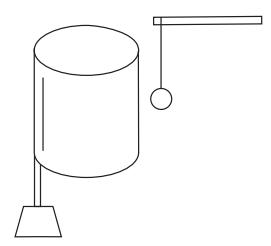

(a)

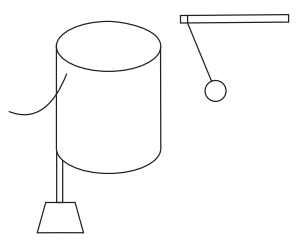

(b)

Figura 7.21: (a) Casca cilíndrica condutora isolada da Terra com um pêndulo elétrico fora dela. (b) $\mathrm{O}$ disquinho de papel é afetado quando a casca é eletrizada.

Ao eletrizar a casca, observa-se que o disquinho é atraído pela casca e toca nela. Algumas vezes ele já se solta imediatamente e passa a ser repelido por ela pelo mecanismo $A C R$. Outras vezes é necessário eletrizar bem a casca para que se observe esta repulsão, ou então é preciso dar alguns petelecos no pêndulo para que ele se solte. Em geral, depois que a casca cilíndrica ficou bem eletrizada, consegue-se perceber que o pêndulo passa a ser repelido pela casca eletrizada, como indicado na Figura 7.21 (b).

\subsection{Experiência do Balde de Gelo de Faraday}

Michael Faraday realizou em 1843 uma atividade análoga à Experiência 7.9. Para isto utilizou um balde de gelo metálico isolado da Terra, com uma altura de $27 \mathrm{~cm}$ e um diâmetro de $18 \mathrm{~cm}^{8}$ Como coletor de cargas usou uma esfera de bronze isolada por uma linha de seda tendo de 90 a $120 \mathrm{~cm}$ de comprimento. Na Figura 7.22 o balde metálico é representado pela letra $A$, a esfera de bronze pela letra $B$, enquanto que o isolamento do balde e da esfera é representado pelas letras $I$. A parede externa do balde era ligada por um fio condutor até um eletroscópio $E$ de folhas de ouro bem sensível.

O balde era inicialmente descarregado, ficando as lâminas do eletroscópio abaixadas. Ao penetrar com a esfera positivamente carregada no balde, sem tocá-lo, as lâminas do eletroscópio levantavam, indicando que o exterior do balde tinha ficado eletrizado. Ao analisar a carga do eletroscópio, Faraday

\footnotetext{
8 [Far43a].
} 


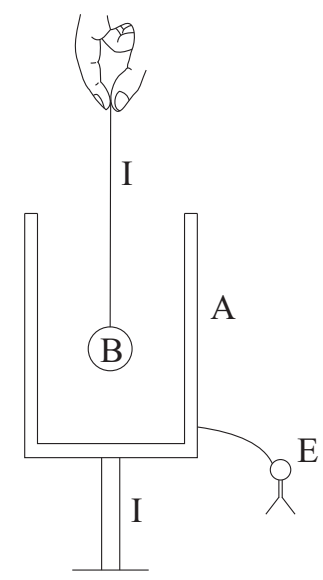

Figura 7.22: Experiência de Faraday com o balde de gelo.

encontrou que ele também estava positivamente eletrizado. Ao retirar a esfera do balde, as lâminas do eletroscópio abaixavam. Quando a esfera eletrizada penetrava lentamente no balde, encontrou que as lâminas iam levantando até que a esfera estivesse ao redor de 7,6 $\mathrm{cm}$ abaixo da superfície superior do balde, permanecendo então com um ângulo constante de abertura mesmo que a esfera descesse ainda mais. Este fato indicava que toda a ação indutiva de $B$ era exercida nas paredes internas do balde. Ao tocar com a esfera metálica no fundo do balde, o ângulo de abertura do eletroscópio não era afetado, permanecendo constante. Além disso, toda a carga da esfera era transferida para o balde já que, ao retirar a esfera do balde, observou que estava totalmente descarregada. Logo, a carga induzida pela esfera $B$ no exterior do balde tinha exatamente o mesmo valor e sinal que a carga da esfera. Já a carga induzida na parede interna do balde tinha o mesmo valor numérico que a carga da esfera, mas era de sinal contrário. Ao tocar na parede interna havia uma neutralização entre as cargas da parede interna e a carga da esfera, não sendo alterada a distribuição de cargas na parede externa. Ao substituir a esfera de bronze por um pedaço isolante de goma-laca eletrizado, observou que os mesmos efeitos ocorriam, com uma exceção. Ao tocar a goma-laca no fundo do balde, observou que sua carga não era comunicada ao balde.

Além disso, observou que a esfera metálica eletrizada podia se aproximar de qualquer dos lados do balde sem afetar a abertura do eletroscópio. Este fato mostrou que a distribuição de cargas na parede externa do balde não era afetada pela posição do corpo carregado $B$ no interior do recipiente. Esta conclusão está ilustrada na Figura 7.23.

Na Figura 7.23 (a) temos um corpo $B$ positivamente eletrizado no centro do balde $A$ isolado. As cargas induzidas no balde estão simetricamente distribuídas tanto na parede interna quanto na externa. Ao aproximar o corpo $B$ de uma das paredes do balde, como no caso (b), ocorre uma redistribuição apenas das 


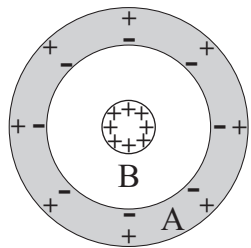

(a)

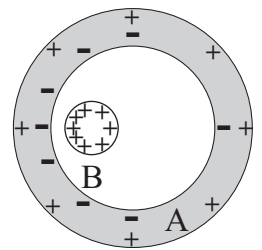

(b)

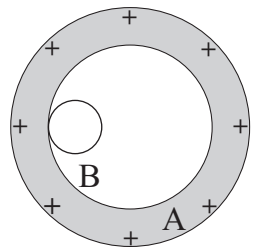

(c)

Figura 7.23: (a) Balde $A$ isolado da Terra, polarizado devido à carga $B$ no centro. As cargas nas paredes interna e externa do condutor têm a mesma intensidade que a carga do interior. (b) Redistribuição das cargas na parede interna do balde e no condutor $B$ quando a carga interna aproxima-se de uma das paredes. (c) Quando a esfera condutora $B$ toca no balde, ocorre uma neutralização entre as cargas da esfera e as cargas de mesma magnitude distribuídas sobre a parede interna do balde.

cargas da parede interna do balde, sem que sejam afetadas as posições das cargas induzidas na parede externa. Nesta Figura também representamos a redistribuição de cargas que ocorre no condutor $B$. Na Figura 7.23 (c) mostramos a neutralização que ocorre das cargas do condutor $B$ com as cargas de mesma magnitude distribuídas sobre a parede interna do balde quando há o toque entre eles. A distribuição de cargas na parede externa do balde não é afetada.

James Clerk Maxwell (1831-1879), Joseph John Thomson (1856-1940) e James H. Jeans (1877-1946) se basearam nesta experiência de Faraday para quantificar o conceito de carga elétrica. ${ }^{9} \mathrm{O}$ ângulo de abertura das palhetas do eletroscópio seria um indicador da quantidade de carga no corpo que estava dentro do balde. Suponha que um corpo $A$ produz uma abertura $\theta_{A}$ no eletroscópio quando está sozinho dentro do balde. Suponha que um corpo $B$ produz uma abertura $\theta_{B}$ no eletroscópio quando está sozinho dentro dele. Caso $\theta_{A}=\theta_{B}$, diremos que a carga elétrica de $A$ tem a mesma intensidade que a carga elétrica de $B$. Dois corpos teriam cargas iguais e opostas se, ao serem introduzidos simultaneamente no balde, eles não produzirem qualquer abertura nas palhetas do eletroscópio. Ao seguir com este procedimento poderíamos também definir as cargas positivas e negativas, assim como valores múltiplos de qualquer carga. Por exemplo, suponha que um corpo $C$ produz uma abertura $\theta_{C}$ quando está sozinho dentro do balde. Caso $\theta_{C}$ seja igual à abertura do eletroscópio quando apenas $A$ e $B$ estão juntos dentro do balde, sendo que $A$ e $B$ possuem cargas de mesma intensidade e mesmo sinal, diremos que a carga de $C$ é o dobro da carga de $A$. E assim por diante.

\footnotetext{
${ }^{9}$ [Max54a, artigos 27-36, págs. 32-41], [Tho21, págs. 5-6] e [Jea27, págs. 7-10].
} 


\section{Capítulo 8}

\section{Blindagem Elétrica}

\subsection{Efeito da Colocação de Condutores ou Iso- lantes entre um Corpo Eletrizado e um Corpo Leve}

Experiência 8.1 - Tentando atrair papeizinhos com uma régua eletrizada quando há um coador metálico entre eles

Repetimos a experiência do chamado efeito âmbar. Eletrizamos uma régua plástica ou de acrílico ao friccioná-la contra um guardanapo de papel ou lã. Vamos supor que conseguimos atrair papeizinhos colocados sobre a mesa quando aproximamos deles a régua de acrílico eletrizada a uma distância de uns $5 \mathrm{~cm}$.

Colocamos agora um coador metálico sobre os papeizinhos e novamente aproximamos deles a régua de acrílico eletrizada. Neste caso, mesmo que ela se aproxime a distâncias menores do que $5 \mathrm{~cm}$, não consegue atrair os papeizinhos.

Experiência 8.2 - Tentando atrair papeizinhos com uma régua eletrizada quando há um coador plástico entre eles

Agora em vez de cobrir os papeizinhos com um coador metálico, os cobrirmos com um coador de plástico. Antes de começar a experiência temos de verificar se a tela deste coador é realmente isolante, ou seja, se não descarrega um eletroscópio eletrizado. Daqui por diante vamos supor que seja isolante. Ao repetir a experiência do efeito âmbar, cobrindo os papeizinhos com este coador isolante, vemos que os papeizinhos continuam sendo atraídos pela régua de acrílico eletrizada quando ela se aproxima deles a distâncias de $5 \mathrm{~cm}$. Algumas vezes pode ser percebida uma pequena diminuição na atração, sendo que a régua tem de chegar mais perto deles, comparado ao caso sem coador, para que se perceba a atração. 


\section{Definição 8.1}

Estas experiências mostram que ao colocar um condutor aterrado entre um corpo eletrizado e pedacinhos de papel, os pedacinhos deixam de se deslocar em direção ao corpo eletrizado que está próximo deles. Este fenômeno é chamado de blindagem eletrostática ou blindagem elétrica.

Se substituirmos o condutor aterrado por um isolante, não vai ocorrer esta blindagem. Neste caso ainda vai ocorrer atração dos papeizinhos pelo corpo eletrizado quando houver uma aproximação entre eles, mesmo com a presença do isolante entre o corpo eletrizado e os papeizinhos.

Experiência 8.3 - Tentando atrair o disco de um pêndulo elétrico com uma régua eletrizada quando há uma folha de papel entre eles

Desta vez utilizamos um pêndulo elétrico constituído por um disquinho de papel ou de papel de alumínio suspenso por um fio de seda. Vamos supor que o pêndulo esteja neutro, descarregado. Ao aproximar uma régua de acrílico eletrizada, percebemos que o disco de papel se desloca em direção à régua quando a distância entre eles é de uns $10 \mathrm{~cm}$, Figura 8.1 (a).

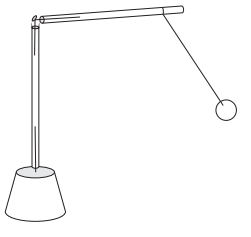

(a)

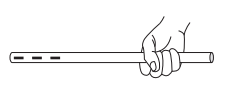

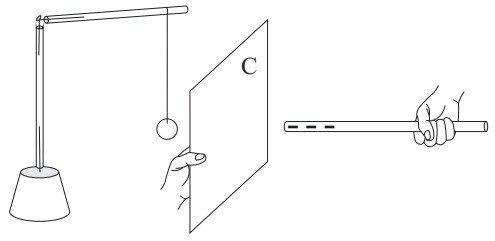

(b)

Figura 8.1: (a) O disco do pêndulo sendo atraído por uma régua de acrílico eletrizada. (b) Ao colocar uma folha condutora $C$ entre o pêndulo e a régua, o disco não sofre força resultante.

Vamos supor que não deixamos que se toquem. Ou então, caso se toquem, vamos supor que descarregamos o pêndulo tocando de leve no disquinho com o dedo. Desta vez colocamos uma folha de papel sulfite tipo A4 entre o disquinho e a régua de acrílico que vai ser aproximada. A folha deve estar em um plano vertical, apoiada por algum suporte condutor (como a mão da Figura 8.1 (b)). A folha de papel não deve tocar no disquinho, ficando a uma pequena distância dele, da ordem de uns $5 \mathrm{~cm}$, com o disquinho perto do centro da folha. Ao aproximar a régua eletrizada do disquinho do pêndulo, observa-se que ele não se desloca em direção à régua mesmo que ela se aproxime dele a uma distância de $10 \mathrm{~cm}$ ou ainda menos, Figura 8.1 (b). Algumas vezes percebemos que a folha de papel é atraída pela régua de acrílico eletrizada, mas não o disquinho do pêndulo que está do outro lado da folha.

A mesma falta de atração vai ocorrer se substituirmos a folha de papel por uma tela metálica de mesmo tamanho. Ou seja, para que o disco do pêndulo 
deixe de ser atraído, basta colocar um condutor aterrado entre ele e a régua de acrílico eletrizada. Este condutor não precisa ser contínuo, pode ter furos como a tela, desde que os furos não sejam muito grandes.

Experiência 8.4 - Tentando atrair o disco de um pêndulo elétrico com uma régua eletrizada quando há uma folha plástica entre eles

Agora colocamos uma folha plástica transparente e neutra no lugar da folha de papel. Se a folha plástica e o pêndulo elétrico estiverem neutros, não vai haver atração entre esta folha plástica e o disquinho do pêndulo mesmo quando estão bem próximos. Desta vez, ao aproximar a régua de acrílico eletrizada do outro lado da folha plástica, percebemos que o disquinho do pêndulo é atraído em direção à régua quando estão próximos, mesmo com a interposição da folha plástica, Figura 8.2.

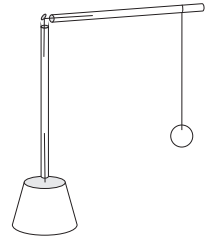

(a)

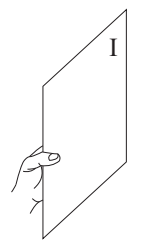

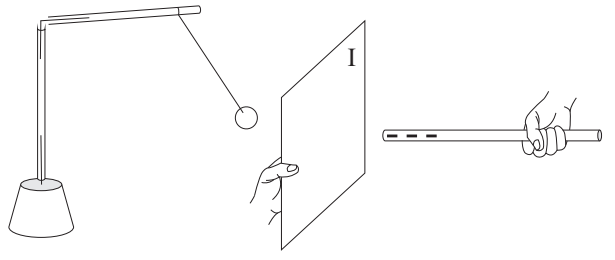

(b)

Figura 8.2: (a) Uma folhas isolante $I$ perto de um pêndulo descarregado. (b) $O$ disco do pêndulo é atraído por uma régua de acrílico eletrizada que se aproxima do outro lado da folha de plástico.

Experiência 8.5 - Tentando atrair o disco de um pêndulo elétrico com uma régua eletrizada quando o pêndulo está dentro de um copo plástico ou de vidro

Um outra experiência simples e interessante que pode ser feita utiliza dois copos transparentes e do mesmo tamanho, um de plástico e outro de vidro. Vamos supor copos com diâmetro de 6 a $8 \mathrm{~cm}$ e altura de 7 a $10 \mathrm{~cm}$. O plástico tem que se comportar como um bom isolante e o vidro como um bom condutor. Antes de começar a experiência devem ser testadas as propriedades isolantes e condutoras do plástico e do vidro com o procedimento da Seção 3.1. Eletrizamos um eletroscópio, seguramos o copo de plástico com a mão e o tocamos na cartolina. Se o eletroscópio permanecer eletrizado por mais de uns 20 segundos após o toque, podemos utilizar este plástico na experiência. Fazemos o mesmo procedimento com o copo de vidro. Se o eletroscópio descarregar em menos de 3 segundos após o copo tocar na cartolina, podemos utilizar este vidro na experiência.

A experiência deve começar com o copo de plástico. Prendemos um disquinho de papel na extremidade de uma linha de seda com uns $5 \mathrm{~cm}$ de comprimento. Prendemos a extremidade livre da linha no interior do copo plástico. Podemos utilizar cola ou um pedaço de durex para fixar a linha no fundo do 
copo. O ideal é que a linha fique fora do centro, a $1 \mathrm{ou} 2 \mathrm{~cm}$ do lado do copo. O copo é então colocado de cabeça para baixo sobre uma mesa com o pêndulo ficando na vertical. $\mathrm{O}$ disco de papel não deve encostar na mesa nem no lado do copo. Quando uma régua de acrílico eletrizada por atrito está longe do copo, o pêndulo fica parado na vertical, Figura 8.3 (a). Quando a régua é aproximada do copo, na altura do disco, este desloca-se em direção à régua, chegando a tocar na parede interior do copo, Figura 8.3 (b). Ao afastar a régua, o pêndulo volta à vertical, Figura 8.3 (c).

(a)
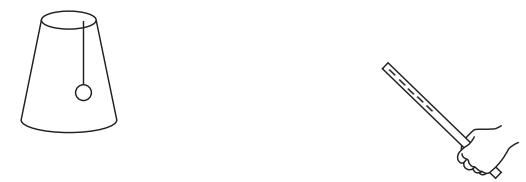

(b)
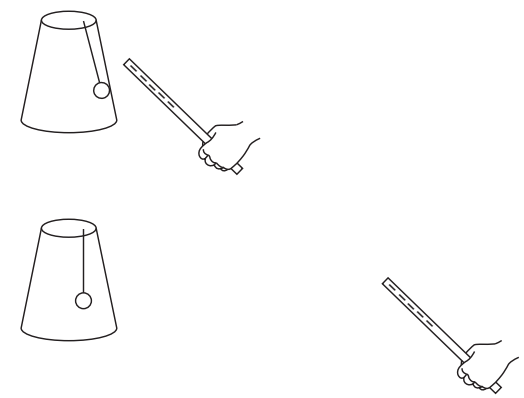

(c)

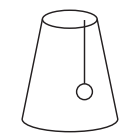

Figura 8.3: Copo de plástico de cabeça para baixo com um pêndulo elétrico em seu interior. (a) Régua eletrizada longe do pêndulo. (b) Quando a régua se aproxima do copo, o disco é atraído e toca no lado. (c) Ao afastar a régua, o pêndulo volta à vertical.

Se esta parte da experiência tiver funcionado, pode-se prosseguir. Faz-se o mesmo procedimento com um copo de vidro. Neste caso o pêndulo permanece na vertical, estando a régua eletrizada longe ou perto do copo, Figura 8.4.

O pêndulo também permanece parado se substituirmos o copo de vidro por uma tela metálica que siga o formato e tamanho do copo. Neste caso o movimento da mão ao aproximar a régua da tela deve ser lento para evitar que correntes de ar movimentem o disco de papel. Algumas vezes observa-se um pequeno movimento do pêndulo ao aproximar a régua eletrizada, mas ele não chega a tocar no lado da tela como ocorreu na Figura 8.3 (b).

\subsubsection{Algumas Pesquisas Antigas sobre Blindagem}

Girolamo Cardano (1501-1576) catalogou em seu livro de 1550 algumas diferenças entre os fenômenos elétricos e magnéticos. Entre outras coisas observou que o ímã atua sobre o ferro através de corpos colocados entre eles, enquanto que a atração do âmbar sobre corpos leves é impedida por estes corpos. ${ }^{1}$ William

\footnotetext{
${ }^{1}$ [Hei99, pág. 174].
} 
(a)
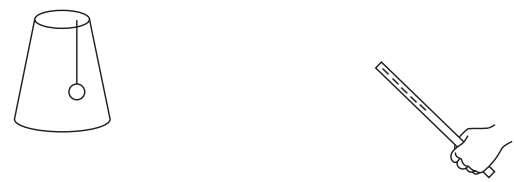

(b)

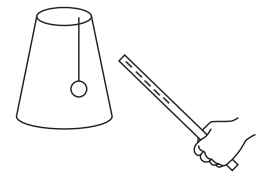

(c)
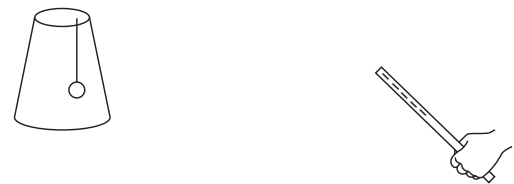

Figura 8.4: Copo de vidro de cabeça para baixo com um pêndulo elétrico em seu interior. (a) Régua eletrizada longe do pêndulo. (b) Quando a régua se aproxima do copo, o disco continua na vertical. (c) Ao afastar a régua, o pêndulo continua parado.

Gilbert também mencionou algo análogo em seu livro de 1600, nossas palavras entre colchetes: ${ }^{2}$

Em todos os corpos de todas as partes estão presentes duas causas ou princípios pelas quais os corpos são produzidos, a saber, matéria (materia) e forma (forma). Os movimentos elétricos surgem da matéria, mas [os movimentos] magnéticos [surgem] da forma primordial; e estes dois [movimentos] diferem amplamente entre si e tornam-se diferentes - um deles enobrecido por muitas virtudes, e dominante; o outro humilde, de menor potência, e confinado a certas prisões, por assim dizer; por isso sua força tem de ser despertada pelo atrito até que a substância alcance um calor moderado, e emita um eflúvio, e sua superfície chegue a brilhar. O ar úmido soprado sobre ele pela boca ou uma corrente de ar úmido da atmosfera abafa suas forças; e se uma folha de papel ou um pano de linho for interposto [entre o âmbar atritado e os corpos leves] não há movimento [dos corpos leves em direção ao âmbar]. Mas o ímã natural, sem ter sido atritado nem aquecido, quer esteja seco ou encharcado com líquido, quer esteja no ar ou na água, atrai corpos magnéticos [como o ferro], e isto [ocorre], embora os corpos mais sólidos ou tábuas, ou lajes grossas de pedra ou placas de metal, estejam interpostos [entre o ímã e os corpos magnéticos].

Honoré Fabri (1607-1688) e os cientistas da Accademia del Cimento (Academia da Experiência) ampliaram estas experiências entre 1657 e 1667. Pesquisaram o efeito da blindagem para descobrir qual é a resistência suficiente que impede a atração do âmbar atritado. Começaram colocando, entre o âmbar e

\footnotetext{
${ }^{2}$ [Gil78, pág. 30], [Gil00, págs. 52-53] e [Hei99, pág. 174].
} 
as substâncias leves, folhas de papel perfuradas com agulhas e tesoura, depois fizeram furos maiores com um grande prego. Observaram o seguinte, citando as palavras de Heilbron: ${ }^{3}$

Os furos aumentaram; [porém] as atrações não aumentaram.

Fabri e os outros cientistas também pesquisaram a blindagem de líquidos. Citaram que o âmbar atritado perde sua eletricidade quando umedecido com água, mas a mantém quando recoberto por óleo. ${ }^{4}$

Em 1731 Stephen Gray mencionou que seu amigo Granville Wheler (17011770) havia utilizado um tubo de vidro eletrizado e conseguiu atrair com ele uma linha (provavelmente de algodão ou de linho, ou seja, feita de um material condutor) que estava dentro de cinco recipientes sobrepostos de vidro. ${ }^{5}$ Deve-se lembrar que a maioria dos vidros da época de Gray comportava-se como bons isolantes.

Gianfrancesco Cigna (1734-1790) mencionou em sua tese de doutorado de 1757 que as atrações ocorrem mesmo para corpos carregados que estavam imersos em óleo. Este fato também foi discutido por Alessandro Volta. ${ }^{6}$

Todos estes fatos foram importantes para debilitar a suposição de que o âmbar atraía por meio de algum eflúvio material que emitia ou por alguma atmosfera que existisse ao seu redor. ${ }^{7}$

Estas várias experiências só foram totalmente entendidas depois que se descobriram os corpos condutores e isolantes, os dois tipos de eletricidade e os efeitos da polarização elétrica em condutores e isolantes. A água, por exemplo, comporta-se como condutora. Já o óleo comporta-se como isolante.

\subsection{Experiências com Condutores Ocos}

Agora vamos fazer algumas experiências com condutores ocos tais como aqueles descritos na Seção 7.2.

Experiência 8.6 - Tentando atrair a tira externa de uma casca cilíndrica com uma régua eletrizada

Utiliza-se um cilindro isolado da Terra e inicialmente neutro, com uma ou mais tirinhas de papel de "seda" com suas extremidades superiores coladas na parede externa do cilindro, Figura 8.5 (a).

Eletriza-se uma régua plástica negativamente por atrito contra um guardanapo de papel. Aproxima-se a régua do cilindro, sem tocar nele ou na tirinha. Observa-se que a tirinha externa é atraída pela régua, Figura 8.5 (b). Mesmo ao aterrar o cilindro (tocando-o com o dedo, por exemplo), a tirinha continua sendo atraída pela régua, Figura 8.5 (c).

\footnotetext{
${ }^{3}$ [Hei99, pág. 201].

4 [Hei99, págs. 195-196 e 200-201].

5 [Grae, pág. 399], [Bos11, págs. 253-255], [BAC12, págs. 194-199] e [Hei99, pág. 249].

6 [Hei99, págs. 406, 413 e 415].

7 [Hei99, Capítulos V e XVII].
} 


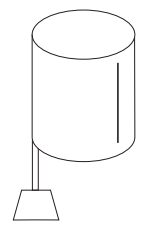

(a)

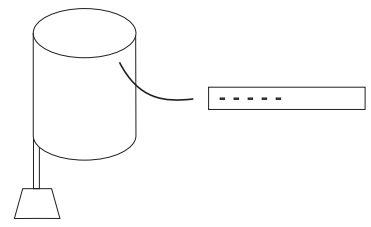

(b)

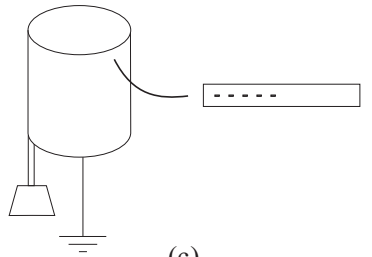

(c)

Figura 8.5: (a) Casca cilíndrica descarregada. (b) Ao aproximar uma régua plástica eletrizada, a tirinha externa é atraída. (c) A tirinha continua sendo atraída quando a casca é aterrada.

A tirinha também é atraída quando o cilindro está inicialmente aterrado, ocorrendo então a aproximação da régua plástica eletrizada.

Experiência 8.7 - Tentando atrair a tira interna de uma casca cilíndrica com uma régua eletrizada

Repete-se a Experiência 8.6, mas agora com a extremidade superior de uma ou mais tirinhas de papel de "seda" coladas na parede interna da casca cilíndrica condutora isolada, Figura 8.6 (a).

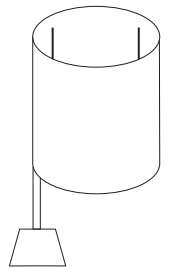

(a)

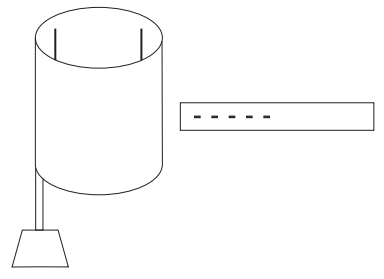

(b)

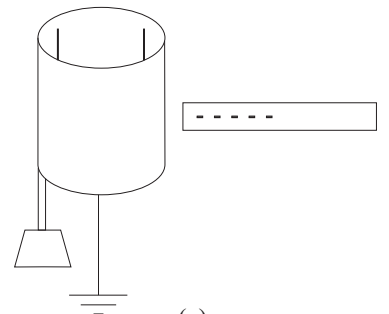

(c)

Figura 8.6: (a) Casca cilíndrica descarregada. (b) Ao aproximar uma régua plástica eletrizada, as tirinhas internas não são atraídas. (c) As tirinhas internas continuam não sendo atraídas quando a casca é aterrada.

Quando aproximamos a régua plástica eletrizada do cilindro, as tirinhas continuam abaixadas, Figura 8.6 (b). Elas continuam abaixadas ao aterrarmos a casca cilíndrica, Figura 8.6 (c).

As tirinhas também permanecem abaixadas quando o cilindro está inicialmente aterrado, ocorrendo então a aproximação da régua plástica eletrizada.

Experiência 8.8 - Tentando atrair um pêndulo elétrico dentro de uma casca cilíndrica

Utiliza-se uma casca cilíndrica condutora isolada da Terra, inicialmente neutra. Coloca-se o disquinho condutor dependurado por um fio de seda de um pêndulo elétrico no interior da casca, na altura média entre as extremidades 
superior e inferior da casca, perto de sua parede mas sem tocá-la. Eletriza-se uma régua plástica negativamente ao atritá-la contra um guardanapo de papel. Aproxima-se pelo lado de fora a régua do disquinho. Observa-se que o disquinho não é atraído em direção à régua, Figura 8.7 (a). Algumas vezes a borda superior da casca atrai um pouco o fio de seda, mas dá para perceber que a atração é sobre o fio e não sobre o disquinho no interior.

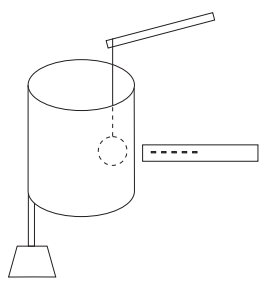

(a)

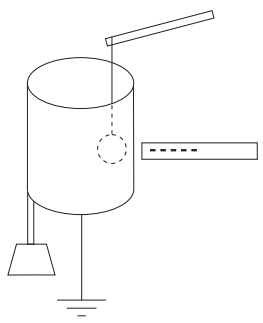

(b)

Figura 8.7: (a) O pêndulo elétrico dentro da casca condutora não é atraído em direção à régua plástica eletrizada quando ela se aproxima do pêndulo pelo lado de fora. (b) Ele continua não sendo atraído quando a casca está aterrada.

Mesmo que a casca cilíndrica esteja inicialmente aterrada, o disquinho continua sem se mover com a aproximação da régua plástica eletrizada, Figura 8.7 (b).

Experiência 8.9 - Tentando atrair um pêndulo elétrico fora de uma casca cilíndrica

Repete-se a Experiência 8.8, mas agora com o pêndulo elétrico fora da casca cilíndrica. A casca está inicialmente neutra, isolada da Terra pelo canudo plástico. O pêndulo fica colocado bem perto da casca cilíndrica, sem tocála, com o disquinho na altura média entre as extremidades superior e inferior da casca. A régua plástica negativamente eletrizada é aproximada lentamente pelo outro lado do cilindro, externamente a ele, na altura do disquinho. Observa-se que quando ela chega bem próximo da casca, sem tocá-la, que o disco é atraído pela casca, toca nela e passa a ser repelido pelo mecanismo $A C R$, Figura 8.8.

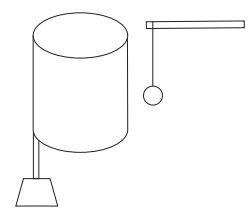

(a)

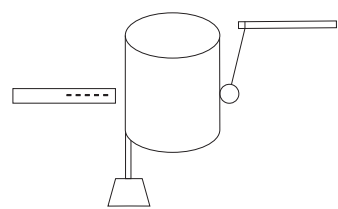

(b)

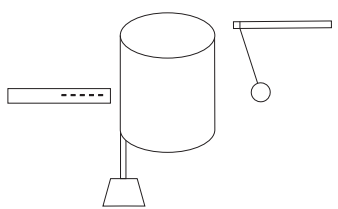

(c)

Figura 8.8: O pêndulo elétrico fora da casca condutora é atraído em direção a ela, toca na casca e passa a ser repelido quando ocorre a aproximação de uma régua plástica eletrizada do outro lado do cilindro. 
Ao analisar-se o sinal da carga do disco, encontra-se que ela tem o mesmo sinal que a carga da régua. Algumas vezes o disco não desgruda imediatamente da casca após o toque, sendo necessário algum peteleco ou sopro para que ele se solte, ou então é preciso afastar um pouco a régua e depois aproximá-la novamente.

Por outro lado, caso a casca esteja inicialmente aterrada, não ocorre o mecanismo $A C R$. Neste caso podemos aproximar uma régua plástica eletrizada da casca cilíndrica que o pêndulo próximo ao outro lado da casca permanece verticalmente em repouso, Figura 8.9.

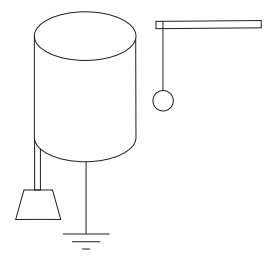

(a)

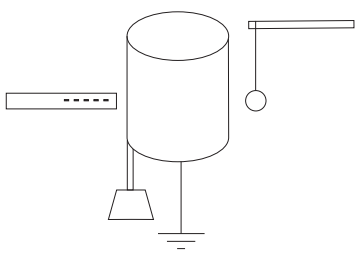

(b)

Figura 8.9: Não ocorre o mecanismo $A C R$ quando uma régua plástica eletrizada é aproximada de uma casca cilíndrica inicialmente aterrada.

Experiência 8.10 - Régua eletrizada dentro da casca cilíndrica e pêndulo elétrico fora dela

Utiliza-se novamente uma casca cilíndrica condutora isolada da Terra, inicialmente neutra. Coloca-se a parte eletrizada de uma régua plástica negativamente eletrizada no interior da casca, perto de uma de suas paredes, mas sem tocá-la. Coloca-se o disquinho de um pêndulo elétrico do lado de fora da casca, na mesma altura da parte eletrizada da régua, longe da casca, Figura 8.10 (a).

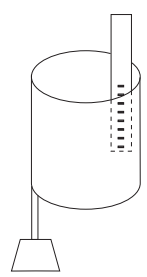

(a)
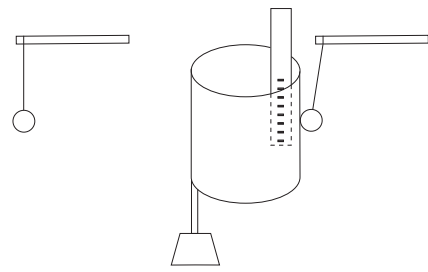

(b)

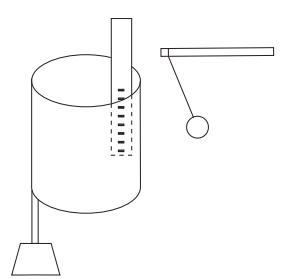

(c)

Figura 8.10: (a) Pêndulo elétrico distante de uma casca cilíndrica isolada que tem uma régua negativamente eletrizada dentro dela. (b) e (c): Ao aproximar o pêndulo elétrico da casca condutora isolada, o disco é atraído em direção à casca, toca nela e passa então a ser repelido para fora da casca.

Aproxima-se lentamente o pêndulo da régua, estando a casca cilíndrica entre eles. Quando estão bem próximos, observa-se que o disquinho é atraído em direção à régua, toca na casca e passa a ser repelido por ela pelo mecanismo 
$A C R$, Figura 8.10 (b) e (c). Ao analisar a carga adquirida pelo disquinho, encontra-se que ele ficou eletrizado com cargas de mesmo sinal que as cargas da régua interna.

Repete-se esta experiência, só que agora com a casca cilíndrica inicialmente aterrada. Neste caso, a régua plástica pode ser aproximada da casca e do disquinho do pêndulo que este não se movimenta em direção à régua nem acontece o mecanismo $A C R$, Figura 8.11.

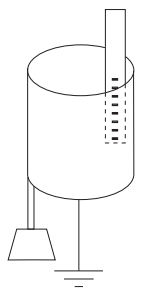

(a)

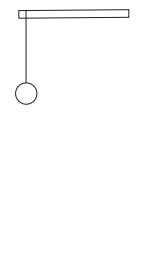

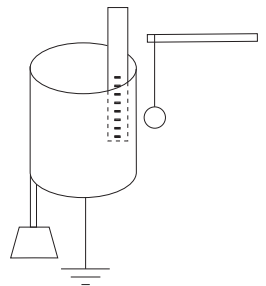

(b)

Figura 8.11: (a) Pêndulo elétrico distante de uma casca cilíndrica aterrada que tem uma régua negativamente eletrizada dentro dela. (b) Agora o pêndulo pode se aproximar da casca condutora que não é atraído em sua direção.

\subsection{Presença ou Ausência de Blindagem Efetiva}

Queremos chamar a atenção aqui para a presença ou ausência de blindagem.

Na Experiência 7.15 temos uma casca cilíndrica condutora isolada do solo. Na Figura 7.18 (b) vemos que quando uma régua eletrizada é colocada dentro da casca, ela afeta as tirinhas localizadas no exterior do cilindro. Porém, ao aterrar o cilindro condutor, as tirinhas abaixam, apesar da presença da régua no interior do cilindro, Figura 7.18 (c). Vemos então que um condutor fechado, aterrado, blinda externamente os efeitos da régua plástica eletrizada localizada no interior do cilindro.

O mesmo comportamento pode ser observado na Experiência 8.10 comparando as Figuras 8.10 e 8.11. Temos um condutor fechado com uma carga dentro dele. Quando o condutor fechado não está aterrado, ele afeta o disquinho de um pêndulo elétrico que se aproxima dele, fazendo com que ocorra o mecanismo $A C R$. Por outro lado, quando o condutor está aterrado, podemos aproximar dele um pêndulo elétrico que não vai ocorrer o mecanismo $A C R$.

Já na Experiência 8.6, Figuras 8.5 e 8.6, temos uma casca cilíndrica condutora com uma carga externa (a régua plástica eletrizada). Ao aproximar da casca cilíndrica a régua plástica eletrizada, observa-se que as tirinhas externas são afetadas, estando o cilindro isolado da Terra ou aterrado. Já as tirinhas internas não são afetadas, esteja o cilindro isolado da Terra ou aterrado.

Este comportamento também pode ser observado com o pêndulo elétrico da Experiência 8.8. Temos uma casca cilíndrica condutora com a régua plástica eletrizada fora dela, enquanto que o pêndulo elétrico está dentro do cilindro, 
com seu disquinho perto de uma parede, mas sem tocar, na altura média entre as bordas da casca cilíndrica. Podemos aproximar do disquinho a régua plástica eletrizada que não haverá força resultante sobre ele, já que permanece imóvel, Figura 8.7. Esta ausência de força resultante ocorre tanto para o cilindro isolado da Terra, quanto para o cilindro aterrado.

Já na Experiência 8.9 temos que a régua externa a uma casca cilíndrica condutora isolada da Terra afeta um pêndulo elétrico também externo à casca. Neste caso, quando a régua plástica eletrizada é aproximada do cilindro, observase o mecanismo $A C R$ no pêndulo, Figura 8.8. Este fenômeno $A C R$ deixa de ocorrer quando a casca cilíndrica está aterrada, Figura 8.9.

Concluímos então que não há efeitos resultantes sobre cargas externas a um condutor fechado e aterrado, quando existem cargas internas ao condutor. Temos uma blindagem elétrica neste caso. Também não há efeitos resultantes sobre cargas internas a um condutor fechado quando existem cargas externas ao condutor, esteja o condutor isolado da Terra ou aterrado.

Por outro lado, existem efeitos resultantes sobre cargas externas a um condutor fechado e isolado da Terra, quando existem cargas internas ao condutor.

Estes comportamentos podem ser explicados pelas distribuições de cargas em condutores. Inicialmente vamos considerar a blindagem que ocorre no exterior de um condutor fechado e aterrado que possui uma carga em seu interior. Como condutor vamos supor que temos uma casca esférica inicialmente neutra e isolada da Terra. Vamos considerar o caso em que uma carga resultante $-Q$, negativa, é colocada no interior da casca. A presença desta carga polariza a casca, com cargas positivas em sua parede interna e cargas negativas em sua parede externa, Figura 8.12 (a). Quando o condutor é aterrado, são neutralizadas as cargas sobre sua parede externa, Figura 8.12 (b).

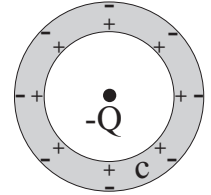

(a)

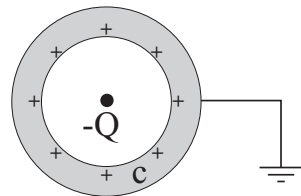

(b)

Figura 8.12: (a) Condutor $c$ isolado da Terra, polarizado devido à presença de um corpo eletrizado com uma carga negativa $-Q$ em seu interior. (b) Condutor aterrado com a neutralização das cargas em sua parede externa.

Vamos supor que temos um corpo eletrizado com uma carga $q$ positiva colocada externamente ao condutor aterrado da Figura 8.12 (b). Vamos supor ainda $q<<Q$ e vamos desprezar a polarização de cargas produzida no condutor devida à presença desta carga $q$ externa. Existem duas forças atuando sobre o corpo externo, a saber, a força atrativa $F_{A}$ exercida pelo corpo interno eletrizado negativamente com a carga $-Q$, juntamente com a força repulsiva $F_{R}$ exercida pelo conjunto de cargas espalhadas sobre a parede interna do condutor. Estas duas forças possuem mesma intensidade e sentidos opostos, cancelando-se 
mutuamente, Figura 8.13.
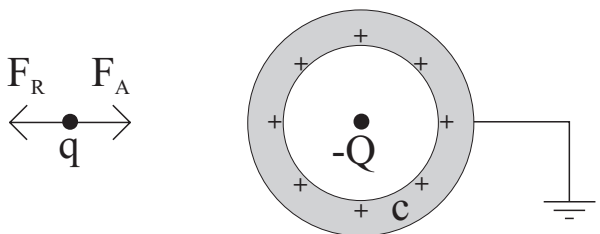

Figura 8.13: Forças atrativa e repulsiva, $F_{A}$ e $F_{R}$, atuando sobre um corpo eletrizado com carga $q$.

Deve ser enfatizado aqui que é nula a força resultante atuando sobre a carga $q$ externa ao condutor aterrado. Apesar disto, a presença do condutor aterrado não elimina a força atrativa $F_{A}$ exercida pela carga $-Q$ interna ao condutor, sendo que esta força atrativa atua sobre a carga $q$ externa. O que ocorre é que além desta força atrativa $F_{A}$ exercida por $-Q$, vai haver uma força repulsiva $F_{R}$ exercida sobre $q$ pelas cargas positivas espalhadas na parede interna da casca esférica. Estas duas forças têm mesma intensidade, mas sentidos opostos, de tal forma que se cancelam.

Na Figura 8.14 (a) mostramos a força atrativa $F_{A}$ exercida por $-Q$ em $q$ quando estão separadas por uma distância $d$, não havendo nada entre elas. Quando temos um condutor aterrado ao redor de $-Q$, como na Figura 8.14 (b), a força atrativa exercida por $-Q$ em $q$ continua exatamente a mesma, supondo que continuem à mesma distância $d$. Porém, a força resultante sobre $q$ é nula neste caso, devido à força repulsiva $F_{R}$ exercida pelas cargas positivas distribuídas na parede interna do condutor. Esta força $F_{R}$ não está representada nesta figura. A força de reação exercida por $q$ em $-Q$ é dada por $-F_{A}$, onde $F_{A}$ está representada na Figura 8.14 (a) e (b). Esta força de reação também não está representada nesta figura.

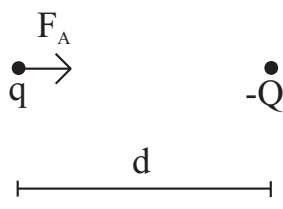

(a)

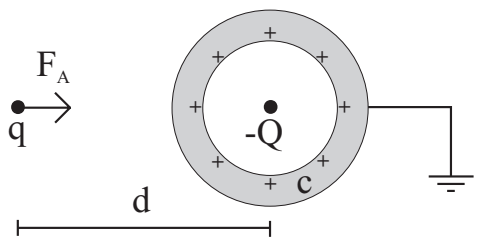

(b)

Figura 8.14: A força atrativa $F_{A}$ exercida por $-Q$ em $q$ quando estão separadas por uma distância $d$ é exatamente a mesma quando não há nada entre elas, (a), ou quando um condutor aterrado está ao redor de $-Q$, (b).

Vamos agora considerar o caso da blindagem que ocorre no interior de um condutor fechado, estando este condutor isolado da Terra ou aterrado, quando um corpo carregado está fora dele. Novamente vamos supor como condutor uma 
casca esférica inicialmente neutra e isolada da Terra. Vamos considerar o caso em que uma carga $-Q$, negativa, é colocada fora da casca. A presença desta carga polariza a casca isolada em sua parede externa, Figura 8.15 (a). Quando a casca é aterrada, são neutralizadas as cargas na parede externa próximas ao aterramento, além de haver um rearranjo das cargas na parede externa da casca comparado com o arranjo sem aterramento, Figura 8.15 (b).

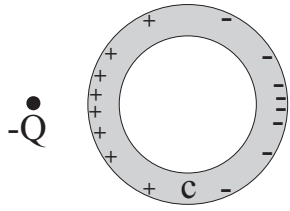

(a)

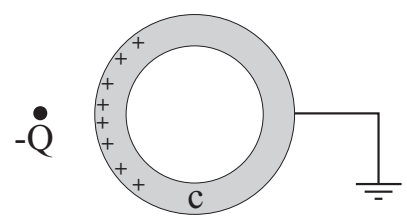

(b)

Figura 8.15: (a) Condutor $c$ isolado da Terra, polarizado na parede externa devido à presença de um corpo eletrizado com uma carga $-Q$ fora dele. (b) Condutor aterrado, ocorrendo a neutralização das cargas na parede externa próximas ao aterramento, além de haver um rearranjo de cargas.

Vamos supor que temos um corpo eletrizado com uma carga $q$ positiva colocada internamente ao condutor da Figura 8.15 (a). Vamos supor ainda que $q<<Q$ e vamos desprezar a polarização de cargas produzida no condutor devida à presença desta carga $q$ interna. Existem três forças atuando sobre o corpo eletrizado com carga $q$, a saber, a força atrativa $F_{A}$ apontando para a esquerda exercida pelo corpo externo eletrizado negativamente com a carga $-Q$, a força repulsiva $F_{1}$ apontando para a direita exercida pelas cargas positivas distribuídas pela parede externa do condutor, juntamente com a força atrativa $F_{2}$ apontando para a direita exercida pelas cargas negativas distribuídas pela parede externa do condutor. Estas três forças se equilibram entre si, gerando uma força resultante nula, $\left|\vec{F}_{A}\right|=\left|\vec{F}_{1}+\vec{F}_{2}\right|$, Figura 8.16 (a).

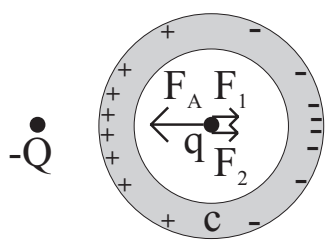

(a)

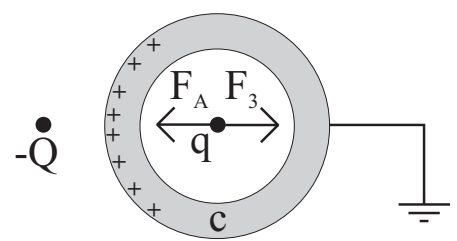

(b)

Figura 8.16: (a) Forças sobre a carga $q$ interna ao condutor isolado da Figura 8.15 (a), $\left|\vec{F}_{A}\right|=\left|\vec{F}_{1}+\vec{F}_{2}\right|$. (b) Forças sobre a carga $q$ interna ao condutor aterrado da Figura $8.15(\mathrm{~b}),\left|\vec{F}_{A}\right|=\left|\vec{F}_{3}\right|$.

Já no caso do condutor aterrado da Figura 8.15 (b), temos duas forças iguais e opostas atuando sobre a carga $q$ interna, a saber, a força atrativa $F_{A}$ 
apontando para a esquerda exercida pela carga $-Q$ externa, juntamente com a força repulsiva $F_{3}$ apontando para a direita exercida pelas cargas positivas distribuídas pela parede externa do condutor, Figura 8.16 (b). Estas duas forças têm mesma intensidade, mas sentidos opostos, tal que se equilibram, $\left|\vec{F}_{A}\right|=\left|\vec{F}_{3}\right|$.

É importante enfatizar aqui que embora a força resultante sobre a carga interna $q$ seja nula nos dois casos da Figura 8.16, a força exercida em $q$ pela carga externa $-Q$ continua existindo e atuando em $q$ sempre com a mesma intensidade, independente de como estão distribuídas as cargas na parede externa do condutor. Ou seja, a presença do condutor não elimina esta força exercida pela carga externa. O que ocorre é que a presença da carga externa ocasiona uma redistribuição de cargas no condutor, de tal forma que a força exercida pelas cargas distribuídas na parede externa do condutor tem mesma intensidade que a força exercida pela carga externa, só que aponta no sentido oposto, de tal forma que haja um equilíbrio destas forças.

Na Figura 8.17 (a) mostramos a força atrativa $F_{A}$ exercida por $-Q$ em $q$ quando estão separadas por uma distância $d$ não havendo nada entre elas. $\mathrm{Na}$ mesma figura mostramos que a força atrativa exercida por $-Q$ em $q$ continua exatamente a mesma ao colocarmos um condutor ao redor de $q$, estando este condutor isolado como em (b) ou aterrado como em (c). Não estamos mostrando nesta figura as forças exercidas em $q$ pelas cargas distribuídas na parede externa do condutor. A força de reação exercida por $q$ em $-Q$ é dada por $-F_{A}$ nos casos (a), (b) e (c) da Figura 8.17. Também não estamos representando esta força de reação nesta figura.

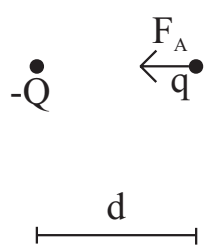

(a)

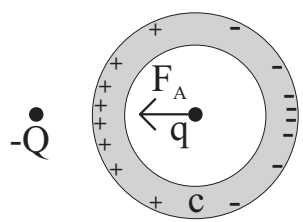

d

(b)

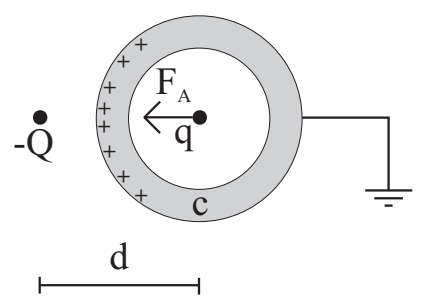

(c)

Figura 8.17: A força atrativa $F_{A}$ exercida por $-Q$ em $q$ quando estão separadas por uma distância $d$ é exatamente a mesma quando não há nada entre elas, (a), quando um condutor isolado da Terra está ao redor de $q$, (b), e também quando um condutor aterrado está ao redor de $q$.

Analisando as Figuras 8.13 e 8.14 conclui-se que a presença de um condutor aterrado ao redor de uma carga interna $-Q$ causa uma blindagem efetiva desta carga. Ou seja, é nula a força resultante exercida sobre uma carga externa ao condutor aterrado, sendo esta força devida tanto à carga interna ao condutor oco, quanto às cargas distribuídas sobre a superfície interna do condutor. Mas não ocorre uma blindagem real da força exercida pela carga interna, já que esta força continua atuando com a mesma intensidade sobre a carga externa, 
independente da ausência ou presença do condutor aterrado.

O mesmo pode ser dito comparando as Figuras 8.16 e 8.17. Neste caso o condutor aterrado também oferece uma blindagem efetiva em relação à carga externa $-Q$. Ou seja, é nula a força resultante exercida sobre uma carga interna ao condutor oco aterrado, sendo esta força devida tanto à carga externa ao condutor, quanto às cargas distribuídas sobre a superfície externa do condutor. Porém, não ocorre uma blindagem real da força exercida pela carga externa, já que esta força continua atuando com a mesma intensidade sobre uma carga interna, independente da ausência ou presença do condutor aterrado. ${ }^{8}$

\subsection{Gaiola de Faraday}

Michael Faraday realizou algumas experiências muito interessantes utilizando um sistema que desde então ficou popularmente conhecido como a gaiola de Faraday. Este sistema é um condutor oco e fechado. Citação do texto de Faraday de 1838, nossas palavras entre colchetes: ${ }^{9}$

Construí uma gaiola cúbica com doze pés [3,6 m de largura]. Foi feita uma estrutura cúbica leve de madeira e foi trançado um fio de cobre em todas as direções ao redor dela, de forma que os lados tinham uma grande rede, sendo então tudo coberto com papel conectado com os fios, tendo faixas de estanho em todas as direções, de tal forma que o conjunto tinha uma boa comunicação metálica, sendo um bom condutor em toda parte. Esta gaiola foi isolada [eletricamente da Terra] no auditório da Royal Institution; [...]

1174. Coloquei um sensível eletrômetro de folhas de ouro dentro do cubo, e então eletrizei fortemente o sistema por algum tempo através de uma comunicação externa; porém nem durante o carregamento nem após a descarga o eletrômetro ou o ar interno indicaram quaisquer sinais de eletricidade. Carreguei e descarreguei todo o sistema de várias formas, mas em nenhum caso obtive a menor indicação de uma carga absoluta [adquirida pelo eletrômetro ou pelo ar interno]; ou de uma [carga obtida] por indução na qual a eletricidade de um tipo [positiva ou negativa] tivesse a menor superioridade quantitativa sobre a outra [eletricidade, a saber, negativa ou positiva]. Entrei no cubo e fiquei dentro dele, e usando velas acesas, eletrômetros, e todos os outros testes de estados elétricos, não encontrei a menor influência sobre eles, ou uma indicação de qualquer coisa em particular fornecida a eles, embora durante todo o tempo o exterior do cubo estivesse fortemente eletrizado, e grandes faíscas e raios estivessem sendo lançados de toda parte de sua superfície externa. Cheguei à conclusão de que tanto não condutores quanto condutores nunca tiveram uma carga absoluta e independente de [apenas] um tipo de eletricidade comunicadas a eles, e de que ao que tudo indica é impossível um tal estado da matéria.

\footnotetext{
8 [Roc89].

9 [Far38, parágrafos 1173-1174, págs. 442-443].
} 
As experiências da Seção 8.1 estão relacionadas com os fenômenos observados por Faraday. Em particular, não há efeitos resultantes no interior de um condutor fechado devido à presença de cargas externas ao condutor ou espalhadas por sua superfície. 


\section{Capítulo 9}

\section{O Poder das Pontas}

Existem vários efeitos elétricos que são bem mais intensos nas pontas de condutores do que em suas partes menos pontudas. Vários destes efeitos recebem a denominação genérica de poder das pontas ou efeito das pontas. Listamos aqui alguns destes fenômenos associados aos condutores, sempre comparados com os fenômenos análogos que ocorrem nas partes menos pontudas:

1. As partículas eletrizadas acumulam-se com maior densidade superficial nas pontas de condutores carregados ou polarizados.

2. Pequenos corpos localizados sobre condutores pontudos são atraídos com mais força por um outro corpo eletrizado do que quando estão sobre condutores planos.

3. As regiões pontudas de condutores são atraídas ou repelidas com maior intensidade por outros corpos eletrizados.

Vamos ilustrar estas propriedades com algumas experiências simples.

\subsection{Ilustrando o Poder das Pontas com Eletros- cópios}

Pode-se visualizar o poder das pontas com algumas experiências simples utilizando eletroscópios feitos de cartolina ou de papel cartão na forma de uma raquete de tênis, de uma tábua de bater carne, ou de um chapéu de palhaço. ${ }^{1}$ Apresentamos apenas uma sugestão de tamanho. O importante é o formato assimétrico do eletroscópio. Ele é preso em um canudo plástico que fica apoiado na vertical (por exemplo, com sua extremidade inferior ao redor de um colchete preso a um copinho de café preenchido com gesso). Em cada um destes eletroscópios são coladas as extremidades superiores de duas tirinhas de papel de

\footnotetext{
1[FM91, págs. 60-61], [Ferb, Poder das pontas, pág. 39] e [Gas03, págs. 239-243].
} 
"seda", uma na parte mais fina ou pontuda da cartolina, enquanto a outra fica na parte mais larga, Figura 9.1. É importante que estas duas tirinhas tenham tamanhos iguais, de mesma espessura e de mesmo comprimento.

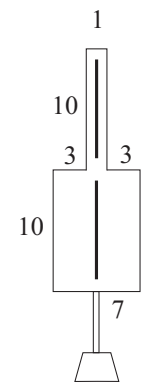

(a)

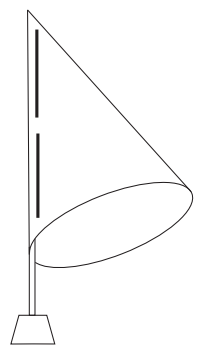

(b)

Figura 9.1: (a) Eletroscópio na forma de uma tábua de carne com dimensões aproximadas em centímetros. (b) Eletroscópio de chapéu de palhaço.

\section{Experiência 9.1 - Carregando um eletroscópio assimétrico}

Eletriza-se uma régua de acrílico por atrito contra o cabelo, um pano ou um guardanapo. Raspa-se a régua de acrílico eletrizada no papel cartão destes eletroscópios algumas vezes até que eles se eletrizem, como indicado pelo afastamento das tirinhas. Afasta-se a régua. Observa-se que a tirinha presa na parte mais larga afasta-se menos da cartolina do que a tirinha na parte mais estreita. Isto é, o ângulo de afastamento da tirinha presa na parte mais larga, em relação à vertical, é menor do que o ângulo de afastamento da tirinha presa na parte mais estreita, Figura 9.2.

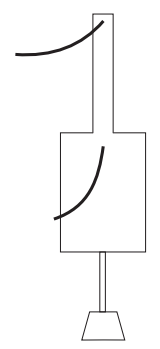

(a)

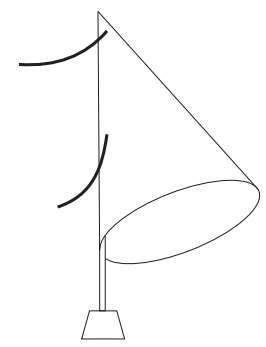

(b)

Figura 9.2: Eletroscópios eletrizados. Observa-se que as tirinhas nas partes mais estreitas ficam mais levantadas.

Vimos no Volume 1 desta obra que o ângulo de inclinação da tirinha de um eletroscópio eletrizado é um indicador qualitativo da quantidade de carga de um eletroscópio, ou da densidade superficial de carga no eletroscópio. ${ }^{2}$ Concluímos

\footnotetext{
${ }^{2}$ Experiência 6.9 de [Ass10b], [Ass10a], [Ass11], [Ass15b] e [Ass17].
} 
então que a densidade superficial de carga na parte estreita ou pontuda de um eletroscópio eletrizado é maior do que na parte mais larga. Esta concentração diferente de cargas ao longo dos eletroscópios está indicada na Figura 9.3.

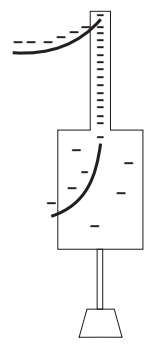

(a)

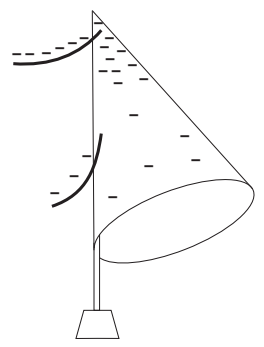

(b)

Figura 9.3: Concentração de cargas nas pontas de um eletroscópio eletrizado.

Experiência 9.2 - Carregando uma longa fita retangular de papel

Recortamos agora uma tira de cartolina com $10 \mathrm{~cm}$ de largura e um comprimento que pode ir de $1 \mathrm{~m}$ até $2 \mathrm{~m}$. Em vez da cartolina podem também ser utilizadas várias tiras de papel sulfite com $10 \mathrm{~cm}$ de largura grampeadas lado a lado até que alcancem um comprimento de 1 ou $2 \mathrm{~m}$. Elas são presas em um plano vertical em alguns canudos plásticos apoiados sobre colchetes presos em copinhos de café com gesso. São coladas as extremidades superiores de algumas tirinhas de papel de "seda" ao longo do comprimento da tira, como na Figura 9.4 .

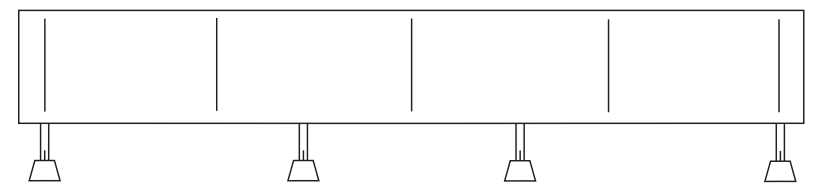

Figura 9.4: Tira de cartolina com $10 \mathrm{~cm}$ de largura e $1 \mathrm{~m}$ de comprimento.

Eletriza-se esta tira raspando várias vezes uma régua plástica eletrizada na borda da cartolina até que as tirinhas fiquem bem levantadas. Observa-se que as tirinhas das extremidades levantam mais que as tirinhas do meio, Figura 9.5 (a). Isto indica que a concentração de cargas é maior nas pontas do retângulo, Figura 9.5 (b).

\subsection{Coletando e Comparando as Cargas Super- ficiais}

Experiência 9.3 - Coletando as cargas superficiais de um eletroscópio assimétrico 


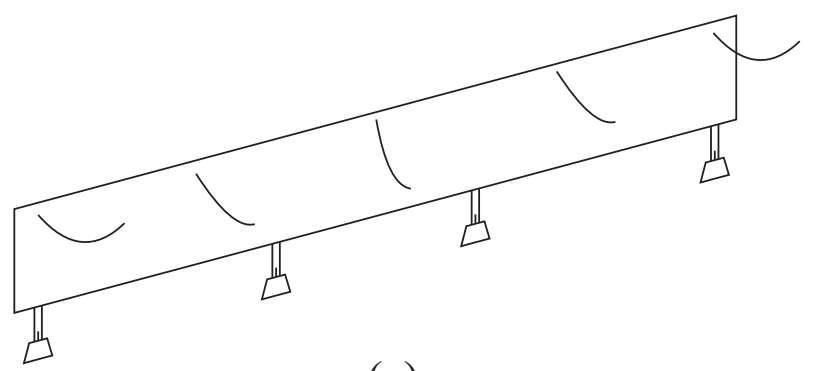

(a)

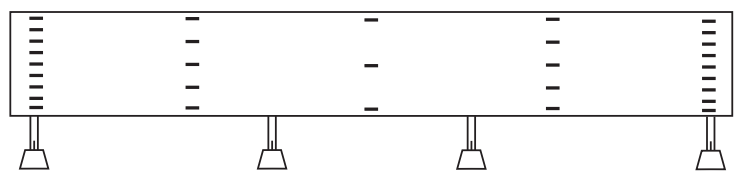

(b)

Figura 9.5: (a) As tirinhas das extremidades levantam mais que as do meio. (b) Distribuição qualitativa de cargas no retângulo.

Uma maneira mais direta de se comparar as densidades superficiais de carga em condutores de formato assimétrico utiliza o plano de prova de Coulomb, como aquele representado na Figura 2.17 da Seção 2.6. Neste caso o disco de cartolina pode ter $1 \mathrm{~cm}$ de diâmetro, preso a um canudo plástico de $4 \mathrm{~cm}$ de comprimento utilizando cola ou massa de modelar. A intensidade da carga coletada por ele será estimada percebendo a que distância ele afeta as tirinhas de outros dois eletroscópios, um deles eletrizado positivamente e outro eletrizado negativamente. Estes eletroscópios ficam afastados um do outro, além de estarem afastados do condutor assimétrico. Depois que coletamos carga em diferentes pontos deste condutor assimétrico, aproximamos lentamente o plano de prova das tirinhas destes eletroscópios, observando para que distâncias as tirinhas começam a ser atraídas ou repelidas pelo plano de prova.

Como condutores assimétricos podemos utilizar o eletroscópio em formato de tábua de carne da Figura 9.1 (a), sem as tirinhas de papel de "seda", Figura 9.6 (a).

Este condutor assimétrico também pode ser uma tira de papel com $10 \mathrm{~cm}$ de largura e $60 \mathrm{~cm}$ de comprimento presa por três ou quatro canudos plásticos fixados em copinhos de café com gesso e colchete. As duas extremidades desta tira devem ser coladas ou presas com clipes de tal forma que ela fique no formato de uma gota, Figura 9.6 (b).

Eletrizamos o condutor com formato de tábua de carne raspando sua cartolina com uma régua plástica eletrizada por atrito contra um guardanapo. Em seguida coletamos um pouco de carga de sua ponta (ou seja, de seu cabo) utilizando o plano de prova, Figura 9.7 (a). Testamos então a que distância este 


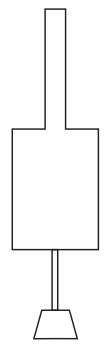

(a)

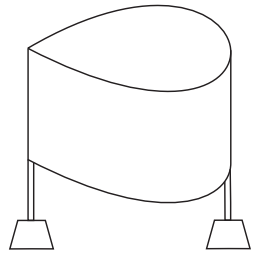

(b)

Figura 9.6: Condutores assimétricos isolados da Terra por canudos plásticos.

coletor eletrizado afeta as tirinhas de outros dois eletroscópios eletrizados, um positivo e outro negativo.

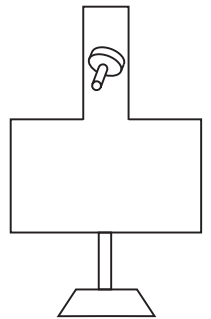

(a)

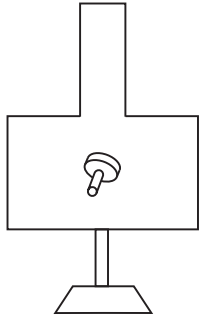

(b)

Figura 9.7: (a) Coletando cargas do cabo do eletroscópio assimétrico. (b) Coletando cargas da tábua do eletroscópio.

Repetimos o procedimento coletando agora cargas da parte central mais larga do condutor (ou seja, da tábua), Figura 9.7 (b).

Comparamos as distâncias críticas para afetar as tirinhas dos eletroscópios tanto no primeiro caso (cargas coletadas do cabo do eletroscópio) quanto do segundo caso (cargas coletadas da tábua do eletroscópio). Verifica-se que no segundo caso temos de chegar com o coletor eletrizado mais perto das tirinhas dos eletroscópios carregados para que elas sejam afetadas por ele, do que quando havíamos coletado carga do cabo do eletroscópio. Concluímos que a densidade superficial de carga é maior na ponta do condutor do que em sua parte mais larga (ou seja, é maior no cabo do que na tábua), como indicado na Figura 9.3 (a).

O mesmo ocorre com o condutor em tira na forma de gota. Isto é, a carga coletada na parte pontuda da gota é maior do que aquela coletada na parte mais encurvada e plana da gota. Uma representação qualitativa da distribuição de cargas neste caso aparece na Figura 9.8.

Experiência 9.4 - Coletando as cargas superficiais de uma longa tira de papel 


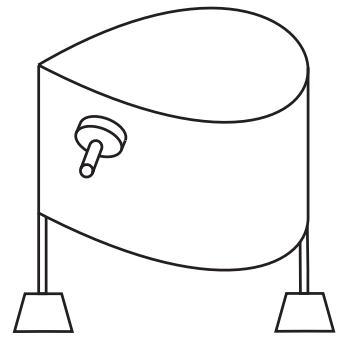

(a)

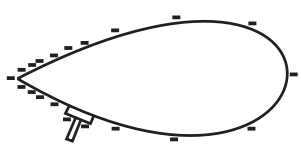

(b)

Figura 9.8: (a) Plano de prova sobre um condutor assimétrico. (b) Distribuição qualitativa de cargas sobre o condutor.

Também pode ser feita uma coleta direta de cargas em diferentes posições da tira de cartolina com $10 \mathrm{~cm}$ de largura e 1 ou $2 \mathrm{~m}$ de comprimento da Experiência 9.2. Para que as tirinhas de papel de "seda" não atrapalhem o coletor de cargas, elas podem ser eliminadas da metade direita da cartolina, a metade na qual os coletores vão encostar na cartolina, permanecendo apenas na metade esquerda para indicar que a tira está bem eletrizada. Assim que a carga é coletada em um ponto qualquer da tira, testa-se o coletor carregado para ver a que distância ele afeta um outro eletroscópio eletrizado positivamente ou negativamente. Observa-se que os coletores carregados que estiveram em contato com as extremidades da tira eletrizada adquirem uma maior quantidade de carga do que os coletores carregados que estiveram em contato com as regiões centrais da tira eletrizada, Figura 9.5 (b).

Os resultados destas experiências algumas vezes não são muito claros já que as diferenças das densidades superficiais de carga muitas vezes não são tão grandes, além do fato de que não é fácil determinar com clareza a distância entre o plano de prova carregado e as tirinhas dos eletroscópios eletrizados para que se perceba uma interação entre eles. O ideal é fazer pequenos movimentos de ida e volta com o plano de prova assim que se chegar a uma distância de aproximação da tirinha de um eletroscópio tal que ela comece a se deslocar. Deve-se então aproximar e afastar o plano de prova da tirinha ao redor desta distância, percebendo então os movimentos de ida e volta da tirinha.

\subsection{Gray e o Poder das Pontas}

Vimos no Volume 1 desta obra que Stephen Gray apresentou em 1731 talvez a primeira descrição do chamado poder das pontas. ${ }^{3}$ Em particular, colocou lâminas de latão em três lugares, a saber, sobre o solo, sobre um cilindro de

\footnotetext{
${ }^{3}$ Seção B.9 de [Ass10b], [Ass10a], [Ass11], [Ass15b] e [Ass17].
} 
madeira com $30 \mathrm{~cm}$ de diâmetro e $30 \mathrm{~cm}$ de altura, assim como sobre um cone achatado na ponta com $30 \mathrm{~cm}$ de altura, diâmetro superior de 7,6 cm e diâmetro inferior de $11,4 \mathrm{~cm}$. Percebeu então que as lâminas eram atraídas por um bastão de vidro eletrizado mais fortemente quando estavam sobre o cone do que quando estavam sobre o cilindro ou sobre o solo. A distância crítica entre o bastão e as lâminas para que houvesse atração era ao redor de três vezes maior quando estavam sobre o cone do que quando estavam sobre o solo, Figura 9.9.

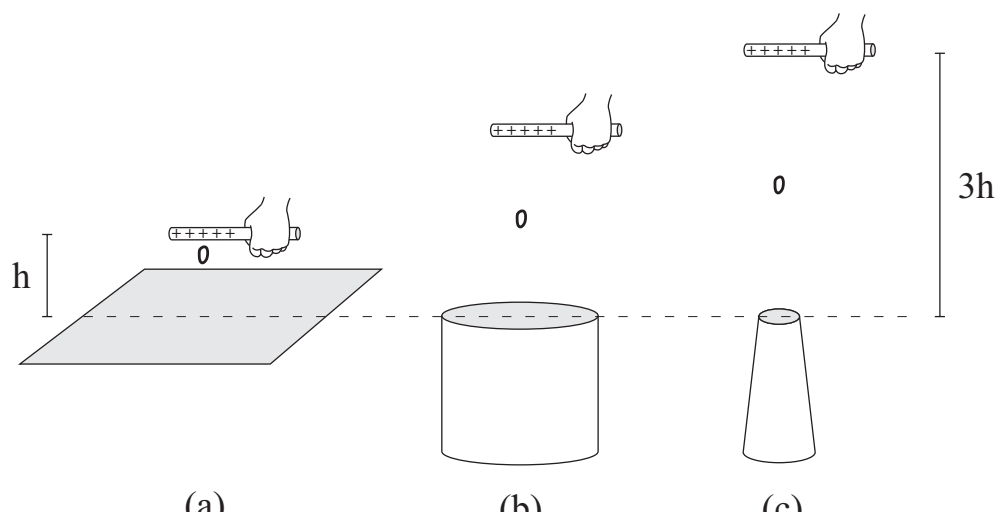

(a)

(b)

(c)

Figura 9.9: (a) Uma lâmina de latão é atraída até uma altura $h$ por um bastão eletrizado quando está apoiada sobre o solo. (b) Ao ser apoiada sobre um cilindro condutor com $30 \mathrm{~cm}$ de diâmetro, é atraída até uma altura maior. (c) Se estiver apoiada sobre um cone pontudo condutor com $30 \mathrm{~cm}$ de altura, diâmetro superior de $7,6 \mathrm{~cm}$ e diâmetro inferior de $11,4 \mathrm{~cm}$, chega a subir três vezes mais do que se estiver sobre o solo.

\section{Experiência 9.5 - Reproduzindo a experiência de Gray}

A experiência de Gray pode ser facilmente reproduzida. Vamos comparar as alturas mínimas que uma régua plástica eletrizada consegue atrair pedacinhos de papel quando estão colocados no centro de uma folha A4 de papel sulfite, no centro de um cilindro de papel com $4 \mathrm{~cm}$ de diâmetro e $10 \mathrm{~cm}$ de altura, assim como no topo de um cone de papel com diâmetro inferior de uns $6 \mathrm{~cm}$ e uma altura de $10 \mathrm{~cm}$. Para que os papeizinhos possam ser colocados sobre a ponta do cone, recorta-se um pedaço do cone perto da ponta e coloca-se na ponta um pequeno disco de papel na horizontal tendo aproximadamente $0,5 \mathrm{~cm}$ de diâmetro. A folha de papel deve ser apoiada sobre 3 ou 4 colunas também feitas de papel (por exemplo, por 3 ou 4 cilindros de papel), tal que ao iniciar a experiência esta folha e a parte superior do cilindro e do cone estejam no mesmo plano horizontal. Eles ficam afastados sobre uma mesa. Atrita-se uma régua de acrílico e ela é colocada na horizontal. Aproxima-se lentamente a régua eletrizada dos papeizinhos sobre a folha de papel, abaixando em direção a eles. Observa-se que eles começam a ser atraídos quando ela está a uma distância de 
uns $2 \mathrm{~cm}$. No caso do cilindro, os papeizinhos começam a ser atraídos quando a régua plástica eletrizada está a uma distância de uns $4 \mathrm{~cm}$. No caso dos papeizinhos sobre a ponta do cone, a distância crítica para começar a atração é de uns $6 \mathrm{~cm}$.

Os valores destas distâncias são apenas aproximados já que dependem não apenas do grau de eletrização da régua plástica, mas também do tamanho e formato dos papeizinhos. Mas a experiência deixa claro que para superfícies de mesma natureza (neste caso tudo feito de papel), a atração ocorre a uma distância maior quando os corpos leves estão sobre superfícies pontudas do que sobre superfícies planas.

Experiência 9.6 - Régua eletrizada colocada abaixo de uma folha, de um cilindro e de um cone de papel

Apoiamos três folhas plásticas do tamanho de um papel A4 sobre 3 ou 4 cilindros de papel com uns $10 \mathrm{~cm}$ de altura. Colocamos os três corpos de papel da Experiência 9.5 (a saber, a folha, o cilindro e o cone) apoiados nestas folhas plásticas de tal forma que suas bases fiquem na mesma altura, Figura 9.10.

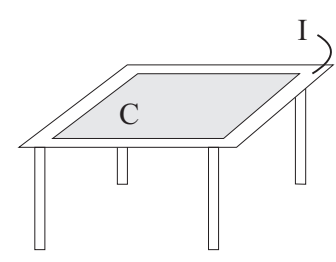

(a)

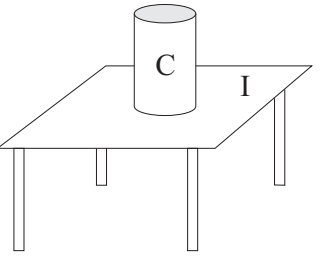

(b)

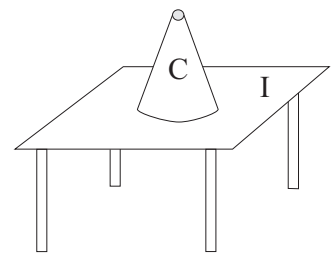

(c)

Figura 9.10: (a) Uma folha condutora de papel $C$ apoiada sobre uma folha isolante plástica $I$. (b) Um cilindro condutor $C$ sobre um plástico isolante $I$. (c) Um cone condutor $C$ sobre um plástico isolante $I$.

Então colocamos papeizinhos no centro da folha de papel, no centro da tampa superior do cilindro e no topo do cone. Eletrizamos a régua de acrílico e a aproximamos da folha de papel, do cilindro e do cone, só que agora passando-a por baixo das folhas plásticas. A régua deve se aproximar estando sempre na horizontal. Caso a régua esteja bem eletrizada, observa-se que os papeizinhos na folha e no cilindro não se mexem, enquanto que aqueles na ponta do cone são lançados para fora, Figura 9.11.

Estas experiências podem ser explicadas supondo que as cargas acumulamse com maior densidade superficial nas pontas de condutores eletrizados ou polarizados. Vamos supor que a régua de acrílico tenha ficado negativamente eletrizada ao ser atritada contra o cabelo. O papel comporta-se como condutor nas experiências de eletrostática. Vamos analisar os papeizinhos sendo lançados para fora do cone no caso da Experiência 9.6. O cone está apoiado por uma folha plástica isolante. Logo, quando a régua plástica eletrizada fica embaixo do 


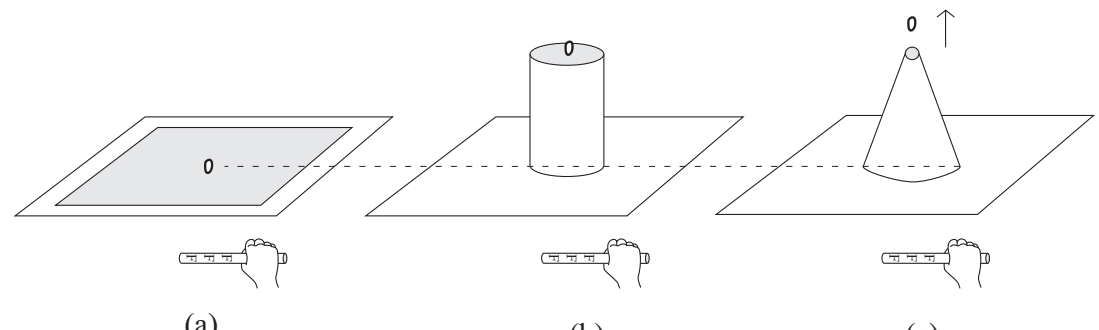

(a)

(b)

(c)

Figura 9.11: Uma régua plástica eletrizada é colocada abaixo de uma folha (a), de um cilindro (b) e de um cone (c) feitos de papel. Os papeizinhos não se mexem em (a) e (b). No caso (c) observa-se que os papeizinhos na ponta são lançados para fora do cone.

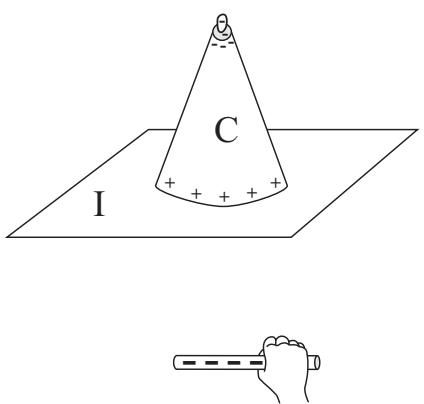

(a)

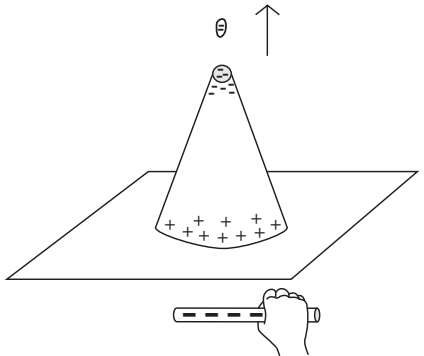

(b)

Figura 9.12: (a) Cone polarizado pela régua plástica eletrizada. O cone condutor $C$ está apoiado por um plástico isolante $I$. Há uma densidade superficial de cargas maior na ponta do que na base. (b) Ao aproximar mais a régua, o papelzinho é lançado para fora do cone.

cone, este começa a se polarizar, ficando positivo na parte debaixo e negativo na parte de cima, Figura 9.12 (a).

A densidade de cargas é maior na ponta do que na base. O papelzinho no topo do cone também fica eletrizado negativamente, sendo repelido pelas outras partes negativas da ponta do cone. No caso (a) desta Figura a força repulsiva ainda é menor do que o peso do papelzinho e ele não é lançado para fora do cone. Quando a régua aproxima-se ainda mais da base do cone, aumentam as densidades de carga tanto embaixo quanto em cima do cone, assim como também sobre o papelzinho. Chega uma hora em que a repulsão que o papelzinho eletrizado sofre das partes bem negativas da ponta do cone supera o peso do papelzinho e ele é então lançado para fora do cone, Figura 9.12 (b). Embora o papelzinho negativo seja repelido pela régua negativa, a força principal para lançá-lo para fora do cone vem da repulsão que sofre das outras partículas negativas na ponta 
do cone que estão bem mais perto dele do que a régua.

No caso do cilindro da Figura 9.11 (b), mesmo que a régua aproxime-se de sua base a mesma distância que ela se aproximou da base do cone, o papelzinho não chega a ser lançado para cima. O motivo para isto é que a densidade superficial de cargas no topo do cilindro não é tão intensa quanto no topo do cone da Figura 9.11 (c). Por isto a repulsão sofrida pelo papelzinho negativo do topo negativo não chega a ser tão intensa a ponto de superar seu peso.

No caso da Experiência 9.5 a situação é diferente. Agora o cone de papel está aterrado pelo seu contato com o solo. Embora inicialmente ele tenda a ser polarizado pela régua plástica eletrizada negativamente, o aterramento faz com que ele tenha uma carga resultante com sinal oposto à eletrização da régua, Figura 9.13 (a).

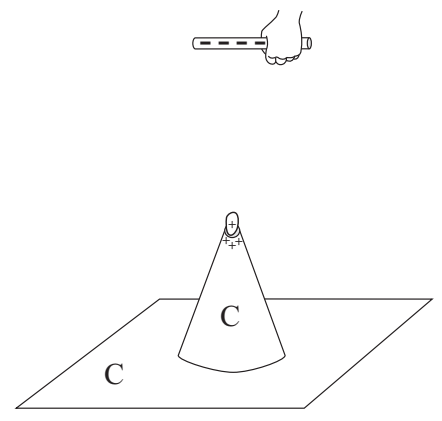

(a)

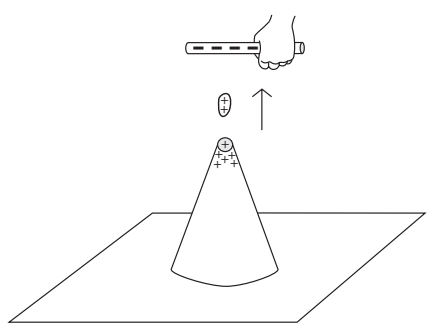

(b)

Figura 9.13: (a) Cone condutor $C$ sobre uma superfície condutora $C$, aterrando o cone. A ponta do cone e o papelzinho ficam positivamente eletrizados pela presença da régua negativa. (b) Quando a régua se aproxima ainda mais do cone, o papelzinho positivo é atraído com mais intensidade pela régua negativa e repelido com mais intensidade pela ponta ainda mais positiva positiva do cone, indo em direção à régua.

Esta eletrização concentra-se na ponta do cone e nos papeizinhos sobre ele. O papelzinho positivo sofre então uma força dupla, sendo atraído pela régua negativa e repelido pelas outras partes positivas da ponta do cone. Estas duas forças apontam para cima, contrariamente ao peso do papelzinho. Na medida em que a régua negativa se aproxima da ponta do cone, esta ponta vai ficando cada vez mais positiva, assim como o papelzinho sobre a ponta. Chega uma hora em que estas duas forças para cima superam o peso do papelzinho e ele vai em direção à régua, Figura 9.13 (b).

\subsection{Intensificando o Efeito Âmbar}

Os aspectos que foram vistos no Volume 1 desta obra e as últimas experiências permitem listar diversos aspectos que intensificam o efeito âmbar, a experiência 
mais antiga da eletricidade, análoga à Experiência 1.1. Intensificar o efeito significa torná-lo mais visível, mais evidente, de maior alcance ou com uma maior intensidade. Estes aspectos são os seguintes:

- Fazer a experiência em um dia seco ou com pouco umidade. Este aspecto facilita o acúmulo de cargas ao diminuir a perda de eletrização para o ambiente.

- Eletrizar bem o material que vai atrair as substâncias leves. Para isto é importante que esta substância seja um bom isolante, para evitar que se descarregue por estar em contato com a mão. Caso a substância que vai ser atritada seja um condutor, ela tem de ser segurada por um cabo isolante para evitar a perda por aterramento das cargas eventualmente adquiridas no atrito.

- Testar vários materiais isolantes diferentes. Podemos tentar atritar no cabelo, por exemplo, um canudo plástico, uma régua de acrílico, um tubo de PVC, uma lâmina de isopor, etc. Veja qual destes materiais, após atritado, vai atrair uma maior quantidade de papeizinhos.

- Variar as substâncias com a qual atritamos cada um destes corpos. Podemos tentar atritar um tubo de PVC, por exemplo, no cabelo, em um guardanapo de papel, em um saco plástico, em um tecido de algodão, etc. Veja qual destas substâncias vai produzir uma maior eletrização do corpo atritado.

- Além disso, quanto mais rápido o material for atritado contra o cabelo ou contra um guardanapo de papel, maior será a densidade superficial de carga adquirida pelo isolante. A velocidade do atrito é um fator muito importante para aumentar a quantidade de cargas adquirida pelo corpo que está sendo friccionado. ${ }^{4}$

- A substância leve a ser atraída deve, preferencialmente, ser um condutor (pedacinhos de papel ou de algodão, por exemplo). Afinal de contas, se temos uma régua plástica eletrizada atraindo um condutor e um isolante de mesmo peso, formato e tamanho, observa-se que a atração sobre o condutor é bem maior do que sobre o isolante. Em particular, observa-se a atração quando a distância crítica entre a régua e o condutor é maior do que a distância crítica na qual se observa a atração entre a régua e o isolante. Caso a régua plástica eletrizada esteja à mesma distância do condutor e do isolante, observa-se que o condutor é atraído mais intensamente pela régua do que o isolante, deslocando-se com um movimento mais rápido.

- Esta substância leve deve estar, preferencialmente, sobre uma superfície condutora. A substância leve é atraída com mais força quando está apoiada sobre uma superfície condutora do que sobre uma superfície isolante.

\footnotetext{
${ }^{4}$ [SGS31] e [Hei99, pág. 451, nota 6].
} 
- A superfície de apoio deve ser pontuda, com as substâncias leves colocadas sobre a ponta. 


\section{Capítulo 10}

\section{Equilíbrio Elétrico e o Instrumento para Indicar Diferença de Potencial}

\subsection{Equilíbrio Elétrico de um Condutor}

Os corpos da natureza podem ser divididos ou classificados em dois grupos básicos, chamados de condutores e isolantes. A diferença principal é que os condutores possuem partículas eletrizadas móveis que podem se deslocar por todo o volume do condutor e ao longo de suas superfícies. Os isolantes, ao contrário, não possuem partículas eletrizadas móveis que podem se deslocar por todo o volume do isolante. As partículas eletrizadas móveis que possuem podem deslocar-se apenas no interior de suas moléculas. Logo os isolantes não permitem a passagem ou o fluxo de partículas eletrizadas através de seus corpos nem através de suas superfícies. Lembramos que o comportamento condutor ou isolante de um certo corpo depende não apenas de sua natureza ou composição química, mas também da diferença de potencial que pode ser aplicada às extremidades deste corpo.

Seja um condutor $C$ em repouso em relação ao solo. Ele pode estar isolado eletricamente da Terra e de outros condutores. Alternativamente, ele pode estar ligado por substâncias condutoras à Terra ou a outros condutores. Ele pode ter uma carga resultante nula, positiva ou negativa. Ele pode estar sozinho ou sofrendo a ação de outros corpos eletrizados próximos dele (sendo, por exemplo, polarizado devido a uma carga próxima). Apresentamos a seguinte definição para o equilíbrio deste condutor, com esta definição sendo válida para todos estes casos: 


\section{Definição 10.1}

Considere um condutor eletrizado em repouso em relação ao solo. Ele pode estar sob a ação elétrica de outros corpos, ou totalmente isolado. Quando a distribuição de sua carga permanece inalterada no tempo, dizemos que sua eletricidade está em equilibrio ou equilibrada e que o condutor está em equilíbrio elétrico ou equilibrado eletricamente. Por outro lado, quando sua distribuição de carga varia no tempo, dizemos que sua eletricidade está desequilibrada e que o condutor está em desequilíbrio elétrico ou desequilibrado eletricamente.

William Thomson (1824-1907), também chamado de Kelvin ou Lorde Kelvin, apresentou uma definição similar em 1848: ${ }^{1}$

\section{Equilíbrio Elétrico.}

66. Quando um corpo mantido em repouso está eletrizado, e quando, estando sujeito à ação elétrica de outros corpos, ou totalmente isolado, a distribuição de sua carga fica permanentemente inalterada, diz-se que a eletricidade nele está em equilíbrio.

Na prática podemos utilizar tirinhas de papel de "seda" presas em diferentes locais do condutor como indicadoras da densidade superficial de carga em cada ponto. Quanto mais levantada estiver uma tirinha, maior é a densidade superficial de carga naquele ponto. Quando os ângulos de inclinação de todas as tirinhas em relação ao corpo permanecerem constantes no tempo, dizemos que o condutor está em equilíbrio elétrico. Quando o ângulo de inclinação de qualquer tirinha em relação ao corpo estiver variando no tempo, dizemos que o condutor não está em equilíbrio elétrico.

Exemplos deste desequilíbrio elétrico:

- Quando estamos carregando um condutor. Por exemplo, o intervalo de tempo durante o qual estamos raspando uma régua plástica eletrizada na cartolina de um eletroscópio inicialmente descarregado.

- Quando estamos descarregando um condutor. Considere, por exemplo, um condutor inicialmente eletrizado que é descarregado ao tocarmos em sua cartolina com um dedo. Ele está desequilibrado enquanto sua tirinha está abaixando durante o aterramento.

- Quando estamos aproximando ou afastando um corpo eletrizado de um condutor isolado da Terra. Neste caso fazemos com que o condutor fique polarizado, sendo que o grau desta polarização elétrica varia no tempo enquanto aproximamos ou afastamos o corpo eletrizado do condutor.

- Quando ligamos dois eletroscópios por um mau condutor (ou por um condutor imperfeito) como nas Experiências da Seção 3.3. Podemos ter os dois eletroscópios inicialmente descarregados e observar o tempo que um

\footnotetext{
${ }^{1}$ [Tho84d, pág. 46, §66].
} 
deles leva para ser eletrizado quando raspamos a cartolina do outro eletroscópio com uma régua plástica eletrizada.

- Podemos ter um eletroscópio inicialmente eletrizado isolado de outro eletroscópio inicialmente descarregado. Conectamos as cartolinas destes dois eletroscópios por um fio mau condutor. Eles estarão desequilibrados enquanto a tirinha do primeiro estiver abaixando um pouco e a tirinha do segundo estiver subindo. Podemos até medir o tempo necessário para alcançarem o equilíbrio (o equilíbrio vai acontecer quando as duas tirinhas tiverem inclinações fixas no tempo).

\subsection{O Potencial Elétrico de um Condutor}

No caso da física térmica ou da termologia, a grandeza que caracteriza o equilíbrio de um corpo é denominada de temperatura, enquanto que o instrumento que mede esta grandeza é chamado de termômetro. No caso da estática de líquidos e gases, ou de fluidos em geral, a grandeza que caracteriza o equilíbrio mecânico é denominada de pressão. O instrumento que mede a pressão atmosférica é chamado de barômetro, enquanto que manômetro é o nome que se dá a um instrumento que mede as pressões em geral.

$\mathrm{Na}$ eletrostática a grandeza que caracteriza o equilíbrio é denominada de potencial elétrico. Neste livro vamos denominar esta grandeza pela letra grega $\phi$. Temos então a seguinte definição adicional:

\section{Definição 10.2}

Todos os pontos no interior e na superfície de um condutor em equilíbrio elétrico estão no mesmo potencial elétrico, representado pela letra $\phi$. Além disso, este potencial elétrico é constante no tempo para um condutor em equilíbrio.

Apresentamos aqui algumas informações históricas sobre o potencial. ${ }^{2} \mathrm{O}$ conceito de potencial elétrico foi introduzido por Cavendish (1731-1810) em 1771, embora não empregasse o nome "potencial." A função potencial foi introduzida como um conceito matemático na gravitação em 1777 por Lagrange (1736-1813). Em 1782 Laplace (1749-1827) obteve a equação satisfeita por este potencial no espaço vazio, resultado publicado em 1785. Em 1811 Poisson (17811840) introduziu o potencial escalar no eletromagnetismo e ainda obteve um resultado mais geral que o de Laplace ao obter em 1813 a equação satisfeita pelo potencial não apenas no espaço vazio, mas também em regiões onde há matéria e cargas livres. O nome "potencial" foi introduzido por Green (1793-1841) em 1828.

\footnotetext{
2 [Tho84b, pág. 367], [Max54a, artigo 16, pág. 15], [Whi73a, págs. 54-55 e 61], [Roc89], [Ass92a, pág. 18], [Hei99, págs. 449 e 498-500] e [Ass15a, pág. 22].
} 
Neste livro vamos nos concentrar nos aspectos práticos de como indicar a igualdade ou diferença de potencial entre dois condutores, não entrando em detalhes dos aspectos matemáticos. Vamos analisar um instrumento específico que indica a igualdade ou a diferença de potencial entre dois condutores.

\subsection{Eletroscópio com Envoltório Condutor}

Nesta Seção apresentamos um instrumento que indica quando dois condutores estão no mesmo potencial elétrico ou quando estão em potenciais diferentes. ${ }^{3} \mathrm{Se}$ este instrumento for calibrado adequadamente, ele também permitirá a medida desta diferença de potencial.

Suponha que temos dois condutores $C_{1}$ e $C_{2}$ isolados eletricamente da Terra e entre si. Vamos supor que cada um deles esteja em equilíbrio elétrico, com potenciais $\phi_{1}$ e $\phi_{2}$, respectivamente. Qual instrumento pode indicar que $\phi_{1}=$ $\phi_{2}$ ou então que $\phi_{1} \neq \phi_{2}$ ? O eletroscópio utilizado no Volume 1 deste livro, representado na Seção 2.2, Figuras 2.2 e 2.3, indica a densidade superficial de carga e não o potencial. Quanto maior for a quantidade de carga por unidade de área na região da tirinha do eletroscópio, mais ela vai se levantar em relação à cartolina. Quando ela está abaixada isto indica que a densidade de carga é nula ou bem pequena no local em que se encontra.

No Capítulo 7 analisamos a distribuição de cargas nas paredes interna e externa de um condutor oco. Esta análise foi feita indiretamente utilizando tirinhas de papel de "seda." Quanto mais alta estivesse uma tirinha, maior era a densidade superficial de carga naquele local. Esta análise também foi feita diretamente recolhendo parte da eletrização das paredes interna e externa de um condutor utilizando um coletor de cargas ou um plano de prova.

No caso da Experiência 7.1, Figura 7.1, por exemplo, vimos que as cargas distribuem-se na parede externa de um cilindro oco eletrizado, não havendo cargas na parede interna. Este condutor eletrizado, feito de papel ou cartolina, está em equilíbrio. Embora as paredes interna e externa estejam em contato elétrico através da própria cartolina condutora, percebemos que é nula a densidade superficial de carga na parede interna, enquanto que na parede externa temos uma densidade superficial diferente de zero. Qual instrumento poderia indicar que as paredes interna e externa estão no mesmo potencial?

Este instrumento importante é constituído de duas partes condutoras, $A$ e $B$, isoladas eletricamente entre si, Figura 10.1.

Normalmente as partes $A$ e $B$ são feitas apenas de materiais condutores. $\mathrm{O}$ instrumento vai indicar a diferença de potencial entre as partes $A$ e $B$. A parte $A$ contém o indicador da diferença de potencial. A parte $B$ é um envoltório condutor que fica ao redor da parte $A$.

O indicador da diferença de potencial localizado na parte $A$ normalmente é o ângulo de abertura entre duas tiras ou palhetas móveis. Este indicador também pode ser o ângulo entre uma tira móvel e uma parte fixa. Neste último caso a parte $A$ pode ser, por exemplo, um eletroscópio usual, como aquele das Figuras

\footnotetext{
${ }^{3}$ [Tho84a], [Tho84c], [Per44] e [TP11].
} 


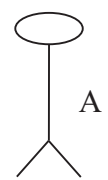

(a)

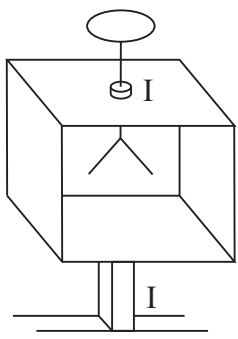

(c)

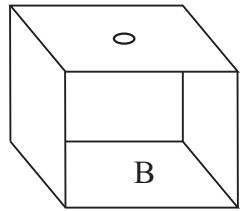

(b)

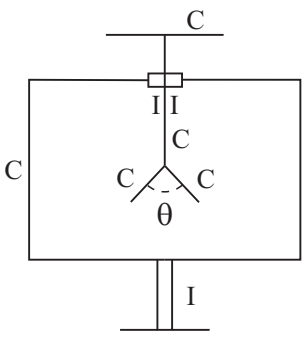

(d)

Figura 10.1: Eletroscópio com envoltório condutor. (a) Parte condutora A. (b) Parte condutora $B$. (c) Instrumento montado em perspectiva, mostrando ainda o isolante $I$ entre as partes $A$ e $B$, assim como o isolante entre a parte $B$ e a Terra. (d) Instrumento montado de perfil. As letras $C$ indicam as partes condutoras, as letras $I$ indicam as partes isolantes, enquanto que a letra $\theta$ indica o ângulo de abertura entre as palhetas móveis.

2.2 e 2.3, sendo a diferença de potencial indicada pelo ângulo de abertura entre a tirinha de papel de "seda" e a cartolina fixa.

Neste livro vamos denominar este instrumento de eletroscópio com envoltório condutor, Figura 10.1. A parte $A$ do instrumento está representada na letra (a) desta figura, sendo composta de um disco horizontal, uma haste ou eixo vertical, juntamente com duas palhetas móveis que podem se abrir. A parte $B$ está representada na letra (b) desta figura, sendo composta de uma caixa com um furo na parte superior. Estas duas partes são feitas inteiramente de condutores. $\mathrm{Na}$ letra (c) representamos o instrumento montado com um isolante $I$ que serve para fixar a parte $A$ na parte $B$ e principalmente para isolar eletricamente uma destas partes da outra. Também mostramos nesta letra (c) um outro isolante $I$ entre a parte condutora $B$ e o solo. Na letra (d) representamos o instrumento montado de perfil, no qual as letras $C$ indicam os condutores, as letras $I$ indicam os isolantes, enquanto que $\theta$ indica o ângulo de abertura indicado pelo eletroscópio.

Os princípios que justificam o funcionamento deste eletroscópio com envoltório condutor como sendo um instrumento apropriado para indicar a diferença de potencial entre suas duas partes $A$ e $B$, encontram-se nas experiências dos Capítulos 7 e 8.

Na Figura 10.2 apresentamos uma montagem do eletroscópio com envoltório 
condutor utilizando o eletroscópio simples das Figuras 2.2 e 2.3. O envoltório é uma faixa cilíndrica condutora feita de papel ou cartolina, apoiada em canudos plásticos isolantes. O isolante entre as partes $A$ e $B$ deste eletroscópio é simplesmente o ar. As duas partes estão isoladas da Terra pelos canudos isolantes.

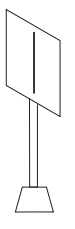

(a)

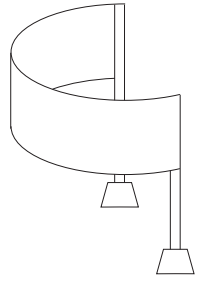

(b)

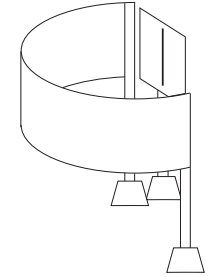

(c)

Figura 10.2: Eletroscópio com envoltório condutor. (a) Parte $A$ : Eletroscópio feito com uma tirinha de papel de "seda" colada a uma cartolina apoiada sobre um canudo plástico. (b) Parte $B$ : Arco cilíndrico feito de papel ou cartolina apoiado sobre canudos plásticos. (c) Eletroscópio montado.

Na Figura 10.3 apresentamos uma outra possível montagem do eletroscópio com envoltório condutor utilizando o eletroscópio simples das Figuras 2.2 e 2.3. O envoltório é uma caixa de sapato condutora da qual foram eliminadas duas faces e meia. $\mathrm{O}$ isolamento entre as partes $A$ e $B$ deste eletroscópio é simplesmente o ar. A parte $A$ está isolada da Terra pelo canudo plástico, enquanto que a parte $B$ está isolada da Terra pela lâmina de isopor.

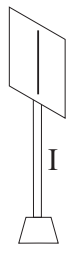

(a)

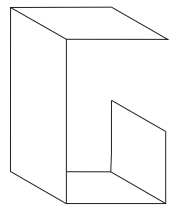

(b)

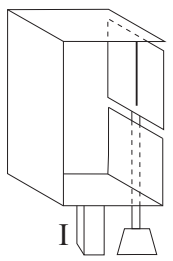

(c)

Figura 10.3: Outro possível eletroscópio com envoltório condutor. (a) Parte A: Eletroscópio feito com uma tirinha de papel de "seda" colada a uma cartolina apoiada sobre um canudo plástico isolante $I$. (b) Parte $B$ : Caixa de sapato da qual dois lados e meio foram cortados. (c) Eletroscópio montado apoiado sobre uma lâmina de isopor isolante $I$.

Uma outra representação deste instrumento encontra-se na Figura 10.4. A parte $A$ do instrumento está representada na letra (a) desta figura, a parte $B$ está representada na letra (b), enquanto que na letra (c) representamos o instrumento montado, na qual a letra $C$ indica os condutores, a letra $I$ indica os isolantes, enquanto que $\theta$ é o ângulo de abertura indicado pelo eletroscópio.

$\mathrm{Na}$ Figura 10.5 (a) e (b) temos um eletroscópio clássico com duas tiras 


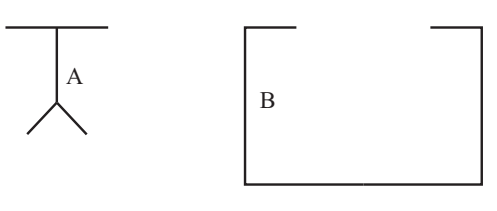

(a) (b)

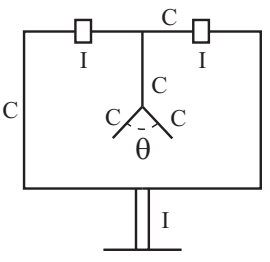

(c)

Figura 10.4: Eletroscópio com envoltório condutor visto de perfil. (a) Parte condutora $A$. (b) Parte condutora $B$. (c) Instrumento montado. As letras $C$ indicam as partes condutoras, as letras $I$ indicam as partes isolantes, enquanto que a letra $\theta$ indica o ângulo de abertura entre as palhetas móveis.

móveis, enquanto que em (c) e (d) temos um eletroscópio com apenas uma tira móvel.

O isolante que separa as partes $A$ e $B$ pode ser o ar, um pedaço de isopor, de plástico ou de PVC. Em alguns livros menciona-se uma cortiça ou rolha entre as partes $A$ e $B$. Esta não é uma boa escolha, já que a cortiça comporta-se como condutor para experiências de eletrostática, como mencionado na Seção 3.1. Se for usada alguma borracha ou qualquer outra substância entre $A$ e $B$, ela tem antes de ser testada para ver se realmente se comporta como isolante nas experiências de eletrostática. Afinal de contas, muitos tipos de borrachas e outras substâncias comportam-se na prática condutoras, pois descarregam um eletroscópio eletrizado ao serem o elo de ligação entre o eletroscópio e o solo.

As partes condutoras usualmente são metálicas, mas neste livro utilizaremos condutores feitos de papel, cartolina e tirinhas de papel de "seda".

Para que este instrumento tenha uma boa precisão, é necessário que a parte $B$ envolva totalmente a parte $A$, sem que haja condução elétrica entre as duas partes. Para que possamos ver o ângulo de abertura indicado por este eletroscópio, é necessário que haja alguma abertura na parte $B$. Idealmente esta abertura tem de ser pequena para que não afete a diferença de potencial indicada pelo instrumento. Neste livro vamos utilizar este instrumento apenas como um indicador qualitativo da diferença de potencial, logo podemos ter aberturas grandes.

Normalmente existem dois eletrodos condutores ligados às partes $A$ e $B$ de um eletroscópio com envoltório condutor. O chamado eletrodo principal, $E P$, liga a parte $A$ com um condutor $C_{1}$, enquanto que o chamado eletrodo secundário, $E S$, liga a parte $B$ com um outro condutor $C_{2}$, Figura 10.6.

Neste caso o ângulo de abertura $\theta$ da parte $A$ será então um indicador da diferença de potencial entre os condutores $C_{1}$ e $C_{2}$. Quando $\theta=0$ os condutores $C_{1}$ e $C_{2}$ estão no mesmo potencial. Quando $\theta \neq 0$ os condutores $C_{1}$ e $C_{2}$ estão em potenciais diferentes, sendo que quanto maior for $\theta$, maior será a diferença de potencial entre eles. Para que o eletroscópio com envoltório condutor não afete os condutores $C_{1}$ e $C_{2}$ ao ser ligado a eles, temos que em geral as partes $A$ e $B$ do eletroscópio têm de ter áreas pequenas comparadas com as áreas dos 


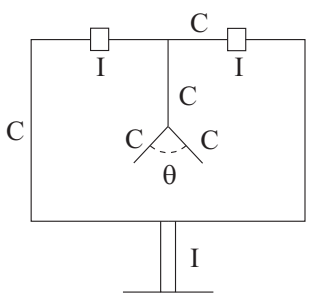

(a)

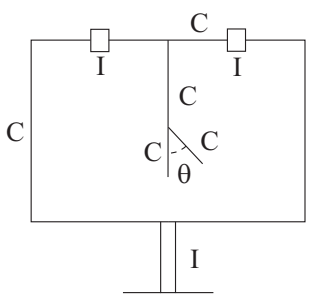

(c)

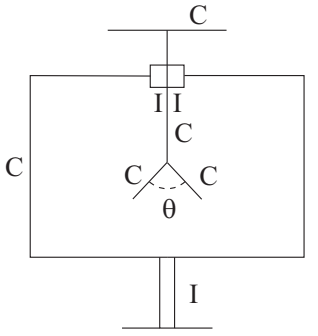

(b)

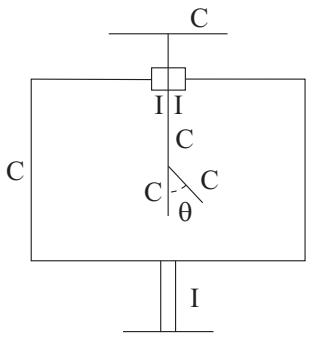

(d)

Figura 10.5: Eletroscópios com envoltório condutor contendo partes condutoras representadas pela letra $C$ e partes isolantes representadas pela letra $I$, sendo $\theta$ seu ângulo de abertura. (a) e (b): Eletroscópio com duas tiras móveis. (c) e (d): Eletroscópio com uma tira móvel que pode girar ao redor de uma parte fixa.

condutores $C_{1}$ e $C_{2}$.

Estes eletrodos podem também ser ligados a partes diferentes de um mesmo condutor para verificar se todos os seus pontos estão no mesmo potencial.

Usualmente o condutor $C_{2}$ é a própria Terra. Ou seja, o envoltório do eletroscópio está normalmente aterrado. Neste caso o ângulo de abertura vai indicar a diferença de potencial entre o condutor $C_{1}$ e a Terra (cujo potencial é usualmente definido como sendo nulo, por convenção). Diz-se então que o eletrodo secundário está aterrado, Figura 10.7 (a). Se a caixa condutora que envolve a parte $A$ do eletroscópio está apoiada sobre uma superfície metálica ou condutora ligada à Terra, não é necessário a presença do eletrodo secundário, Figura 10.7 (b).

Os eletrodos que conectam o eletroscópio ao condutor eletrizado que se quer testar são em geral fios metálicos. Eles têm de ser manipulados de forma a tocar no condutor. Para serem manipulados estes eletrodos têm de estar isolados eletricamente da Terra, evitando desta forma o descarregamento do condutor. Os fios encapados vendidos em lojas de material elétrico ou de construção já vêm com um isolamento que em geral é um material flexível feito de polietileno ou PVC. Embora este seja um bom isolante para voltagens de até uns 300 $\mathrm{V}$, não é um bom isolante para experiências de eletrostática que muitas vezes 


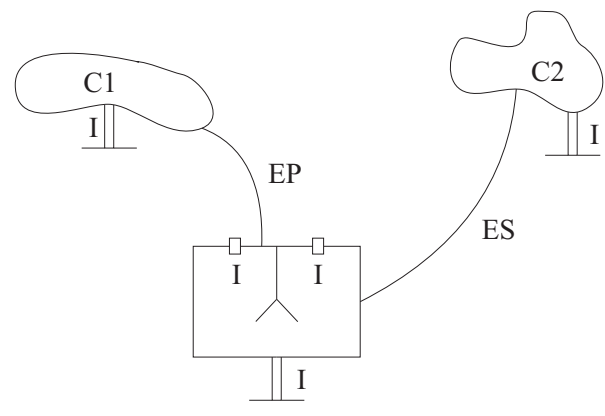

Figura 10.6: Eletroscópio com envoltório condutor tendo o eletrodo principal, $E P$, ligando a parte $A$ com o condutor $C_{1}$ enquanto que o eletrodo secundário, $E S$, liga a parte $B$ com o condutor $C_{2}$.

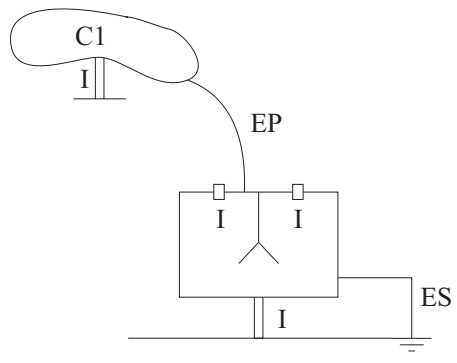

(a)

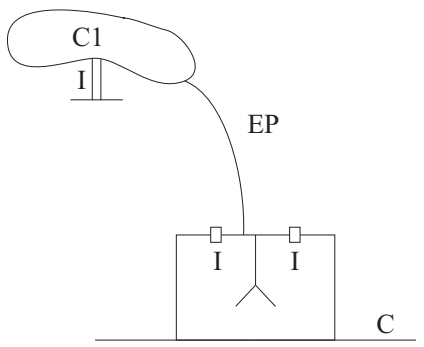

(b)

Figura 10.7: Eletroscópio com o envoltório aterrado. (a) Eletrodo secundário ligado à Terra. (b) Envoltório apoiado sobre uma superfície condutora $C$ ligada à Terra.

lidam com milhares de volts. Antes de usar estes fios como eletrodos destes eletroscópios, eles têm de ser testados para ver se o isolamento é adequado na eletrostática. Para isto segue-se o procedimento da Seção 3.1. Ou seja, eletrizamos um eletroscópio comum, seguramos uma extremidade da parte isolante deste fio com a mão e tocamos a outra extremidade isolante deste fio na cartolina do eletroscópio. Se ele permanecer eletrizado por mais de 30 segundos, podemos considerá-lo um bom isolante. Se ele descarregar em menos de 30 segundos, a parte em PVC deste fio será considerada condutora. Neste caso, para manipulá-lo, temos de adotar um procedimento mais cuidadoso. O ideal é prender uma parte deste fio em uma régua de acrílico ou em um tubo de PVC isolante. Pode-se, por exemplo, enrolar uma parte do fio na régua ou no tubo, Figura 10.8 (a). Nossa mão toca apenas a régua ou tubo isolante. Com isto podemos então ligar o eletrodo entre a parte $A$ do eletroscópio e o condutor eletrizado que está sendo testado, sem com isso descarregarmos este condutor.

Em vez de enrolar o fio no tubo, pode-se também utilizar um fio metálico no formato de mola, que pode ser esticado ou comprimido, prendendo-o a uma 


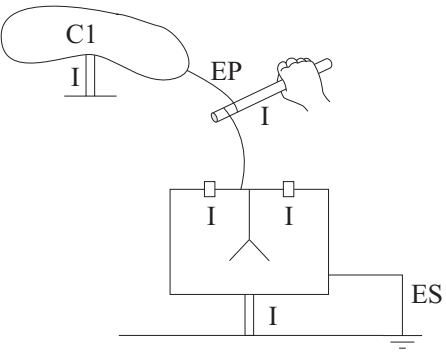

(a)

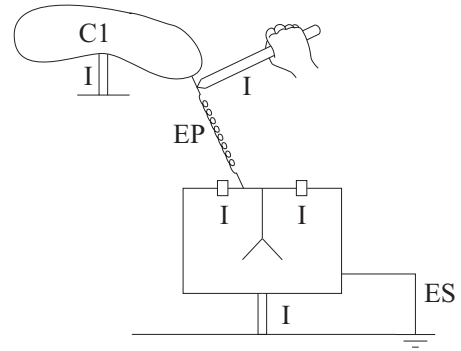

(b)

Figura 10.8: Eletroscópio com o envoltório aterrado, sendo o eletrodo principal preso a uma régua ou tubo isolante. (a) Fio enrolado no tubo. (b) Fio de mola preso no tubo.

régua ou tubo isolante, ${ }^{4}$ como indicado na Figura 10.8 (b).

Para que este eletroscópio se transforme em um eletrômetro, é preciso calibrá-lo de tal forma que cada ângulo de abertura de suas palhetas corresponda a uma diferença de potencial conhecida. Neste livro não vamos lidar com este problema e vamos apenas utilizar o eletroscópio com envoltório condutor para saber se dois pontos estão ou não no mesmo potencial, ou para saber se esta diferença de potencial aumenta ou diminui (como indicado pelo aumento ou diminuição do grau de abertura de suas palhetas) com certos procedimentos.

\subsection{Experiências Utilizando o Eletroscópio com Envoltório Condutor}

\subsubsection{Mostrando que Todas as Partes de um Condutor em Equilíbrio Estão no Mesmo Potencial}

Nesta Subseção descrevemos algumas experiências relacionadas com a igualdade de potencial entre todas as partes de um condutor eletrizado em equilíbrio. As experiências que fizemos utilizaram o eletroscópio simples cercado por uma faixa cilíndrica condutora como aquele da Figura 10.2, ou então o eletroscópio simples cercado por uma caixa de sapato condutora como aquele da Figura 10.3. A diferença de potencial é indicada qualitativamente pelo ângulo de abertura entre a tirinha de papel de "seda" e a cartolina onde está presa. Porém, os desenhos desta Seção serão feitos com o eletroscópio da Figura 10.6, que contém duas tirinhas condutoras móveis, para tornar mais claro o que queremos indicar.

Inicialmente vamos fazer algumas experiências mostrando que este instrumento indica que duas partes de um mesmo condutor eletrizado em equilíbrio estão de fato no mesmo potencial. Em seguida mostramos algumas condições

\footnotetext{
${ }^{4}$ [Per44, Fig. 1277, pág. 1421].
} 
que fazem com que o potencial da parte $A$ do eletroscópio seja diferente do potencial de sua parte $B$.

Experiência 10.1 - Tocando nas paredes interna e externa de uma casca cilíndrica eletrizada

Começamos com um condutor cilíndrico eletrizado como aquele da Figura 7.1. As cargas distribuem-se apenas sobre a superfície externa do cilindro, como indicado pelas tirinhas de papel de "seda" ou então por um plano de prova que for encostado na parede interna ou externa, sendo então determinada a carga adquirida pelo plano de prova. Nesta experiência supomos uma casca cilíndrica eletrizada apoiada por canudos isolantes, sem tirinhas presas na parede interna e com apenas uma tirinha na parede externa indicando que ele está eletrizado. Podemos mostrar que as paredes interna e externa estão no mesmo potencial utilizando o eletroscópio com envoltório condutor da Figura 10.6. Neste caso ligamos o eletrodo principal na parede interna do cilindro eletrizado e o eletrodo secundário na parede externa. Observa-se que as palhetas não se abrem, mostrando que as duas paredes estão em equilíbrio elétrico, no mesmo potencial, Figura 10.9.

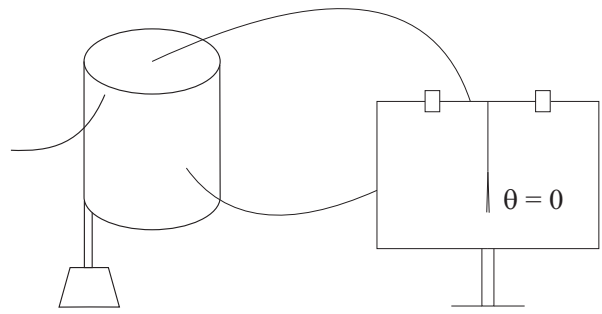

Figura 10.9: Eletroscópio com envoltório condutor com a parte $A$ ligada à parede interna de uma casca cilíndrica eletrizada e a parte $B$ ligada à parede externa, mostrando que as palhetas do eletroscópio ficam fechadas.

Este fato também pode ser mostrado utilizando o eletroscópio aterrado da Figura 10.7. Neste caso ligamos inicialmente o eletrodo principal com a parede interna do cilindro eletrizado e observamos o ângulo $\theta_{1}$ de abertura das tirinhas, Figura 10.10 (a). Em seguida ligamos o eletrodo principal na parede externa do cilindro eletrizado e observamos o ângulo $\theta_{2}$ de abertura das tirinhas, Figura 10.10 (b). Observa-se que $\theta_{1}=\theta_{2} \equiv \theta$, indicando que tanto a parede interna quanto a parede externa do cilindro eletrizado estão no mesmo potencial em relação à Terra. ${ }^{5}$ Logo, elas estão no mesmo potencial entre si, $\theta_{1}-\theta_{2}=0$, indicando que estão em equilíbrio elétrico.

Existe ainda uma terceira maneira de mostrar este mesmo fato invertendo qual eletrodo do eletroscópio com envoltório condutor está aterrado. Neste caso aterramos a parte $A$ do eletroscópio através do eletrodo principal. Já o eletrodo secundário será ligado tanto à parede interna quanto à parede externa da casca

\footnotetext{
${ }^{5} \mathrm{O}$ símbolo $\equiv$ está sendo usado para indicar uma definição.
} 


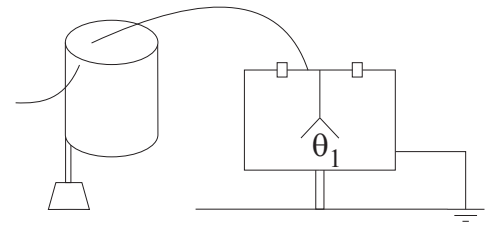

(a)

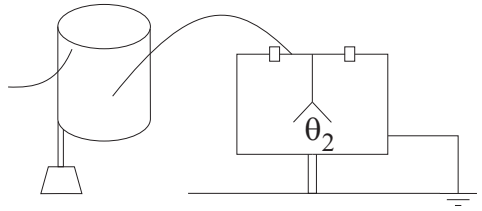

(b)

Figura 10.10: (a) Eletroscópio aterrado com sua parte $A$ ligada à parede interna de uma casca cilíndrica eletrizada. Ângulo de abertura $\theta_{1}$. (b) Idem com a parte $A$ ligada à parede externa. Ângulo de abertura $\theta_{2}$. Nos dois casos ocorre a mesma abertura entre as tirinhas, isto é, $\theta_{1}=\theta_{2}$.

cilíndrica eletrizada. Quando ele está ligado à parede interna, observa-se o ângulo $\theta_{1}$ de abertura da tirinha, Figura 10.11 (a). Quando ele está ligado à parede externa, observa-se o ângulo $\theta_{2}$, Figura 10.11 (b). Ao comparar estes dois ângulos, conclui-se que são iguais, $\theta_{1}=\theta_{2} \equiv \theta$. Ou seja, tanto num caso quanto no outro as tirinhas abrem de um mesmo ângulo $\theta$. Logo as paredes interna e externa desta casca cilíndrica eletrizada estão em equilíbrio no mesmo potencial elétrico.

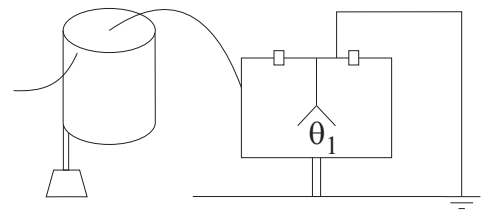

(a)

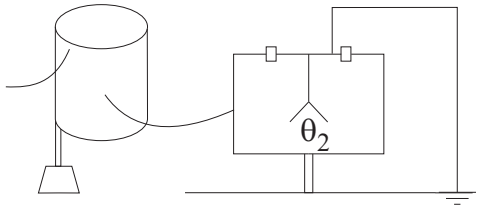

(b)

Figura 10.11: (a) Eletroscópio aterrado pela parte $A$, com a parte $B$ ligada à parede interna de uma casca cilíndrica eletrizada. Ângulo de abertura $\theta_{1}$. (b) Idem com a parte $B$ ligada à parede externa. Ângulo de abertura $\theta_{2}$. Nos dois casos ocorre a mesma abertura entre as tirinhas, isto é, $\theta_{1}=\theta_{2}$.

Este último caso é interessante por mostrar que as tirinhas abrem mesmo quando a parte $A$ ligada a elas está aterrada. A abertura das tirinhas ocorre devido ao fato de que embora a parte $A$ esteja no potencial nulo da Terra, a parte $B$ do eletroscópio está ligada à casca cilíndrica eletrizada que está em um potencial diferente do potencial da Terra.

\section{Experiência 10.2 - Tocando pontos diferentes de um condutor assimétrico}

Outra experiência deste tipo utiliza a tira condutora assimétrica em formato de gota da Figura 9.6 (b). Quando ela está eletrizada, vai haver uma densidade superficial de carga variável ao longo de sua superfície externa, maior na ponta e menor na parte mais arredondada, como mostrado por um plano de prova e como está indicado qualitativamente na Figura 9.8. Deixamos apenas uma 
tirinha no condutor para indicar que ele está eletrizado. Neste caso ligamos o eletrodo principal do eletroscópio aterrado em qualquer ponto da superfície externa da tira e observamos sempre o mesmo ângulo $\theta$ de abertura de suas tirinhas. A densidade superficial de carga $\sigma$ é diferente nos pontos 1,2 ou 3 , isto é, $\sigma_{1} \neq \sigma_{2} \neq \sigma_{3}$. Apesar disto, o ângulo de abertura das tirinhas do eletroscópio é a mesma quando o eletrodo principal toca em qualquer destes pontos. Ou seja, $\theta_{1}=\theta_{2}=\theta_{3} \equiv \theta$, Figura 10.12 .

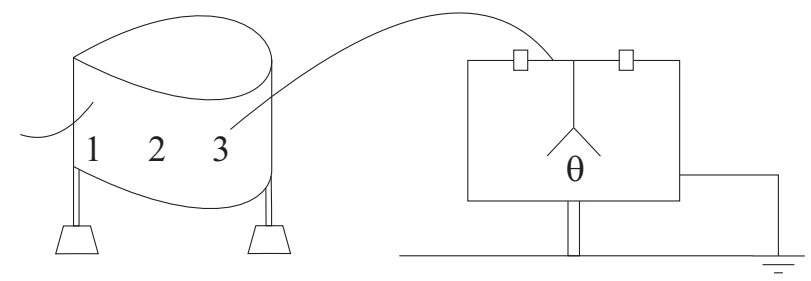

Figura 10.12: Eletroscópio aterrado indicando sempre a mesma abertura $\theta$ das tirinhas não importando se o eletrodo principal toca nos pontos 1,2 ou 3 da tira eletrizada em formato de gota.

Experiência 10.3 - Tocando pontos diferentes de uma longa tira eletrizada

Podemos fazer um teste análogo utilizando a tira eletrizada das Experiências 9.2 e 9.4, Figura 9.4. Eletrizamos bem a tira de tal forma que suas tirinhas fiquem bem levantadas. A densidade superficial de carga é maior nas extremidades da tira retangular do que em sua região central, Figura 9.5. Ligamos o eletrodo principal do eletroscópio aterrado em qualquer ponto da tira. Observamos que sempre vai haver o mesmo ângulo $\theta$ de abertura do eletroscópio, indicando que todos os pontos estão no mesmo potencial, embora as densidades de carga sejam maiores nas extremidades do que no meio da tira retangular, Figura 10.13.

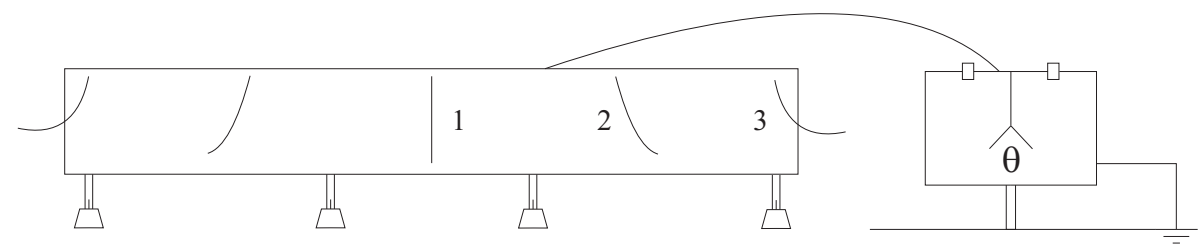

Figura 10.13: Eletroscópio aterrado indicando sempre a mesma abertura $\theta$ das palhetas, não importando se o eletrodo principal toca nos pontos 1,2 ou 3 da tira retangular eletrizada.

O procedimento também pode ser invertido. Agora aterramos a parte $A$ do eletroscópio e ligamos o eletrodo secundário entre sua parte $B$ e o ponto 1, 2 ou 3 da tira eletrizada. Observa-se que o ângulo de abertura é sempre o mesmo, não importando em qual ponto ele toque, Figura 10.14 (a). 


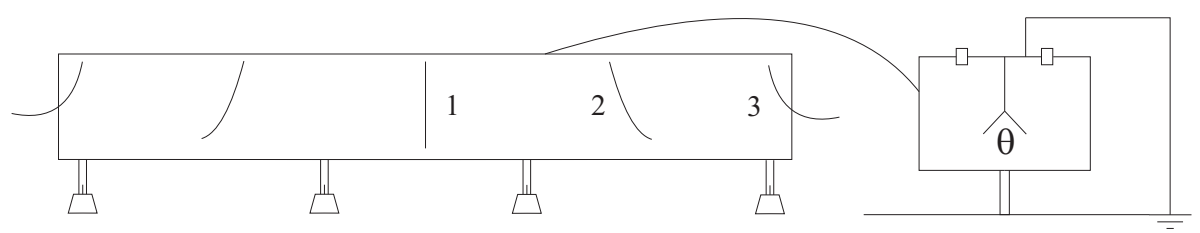

(a)

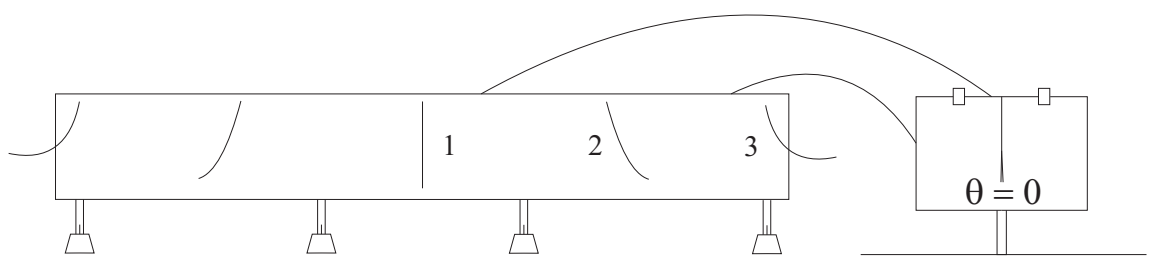

(b)

Figura 10.14: (a) Eletroscópio aterrado pela parte $A$, indicando sempre a mesma abertura $\theta$ das palhetas, não importando se o eletrodo secundário toca nos pontos 1, 2 ou 3 da tira retangular eletrizada. (b) Eletroscópio isolado da Terra, com sua parte $A$ ligada a um ponto da tira eletrizada e sua parte $B$ ligada em outro ponto qualquer, mostrando que suas palhetas ficam fechadas.

Isolamos agora este eletroscópio da Terra. Ligamos sua parte $A$ a um ponto da tira eletrizada e sua parte $B$ a um outro ponto qualquer da tira. Observa-se que as palhetas do eletroscópio permanecem fechadas, Figura 10.14 (b). Isto indica que todos os seus pontos estão no mesmo potencial, embora tenham densidades superficiais de carga diferentes.

\subsubsection{Fatores que Alteram o Potencial de um Condutor em Relação a Outro Condutor}

Nesta Subseção descrevemos algumas experiências relacionadas com a igualdade ou diferença de potencial entre dois condutores. Até agora vimos como que o eletroscópio com envoltório condutor indica que dois condutores (ou duas partes de um mesmo condutor) estão no mesmo potencial. Começamos agora a ver como alterar o potencial de um condutor em relação a outro condutor, ou como alterar o potencial da parte $A$ de um eletroscópio com envoltório condutor em relação ao potencial da parte $B$ deste eletroscópio.

Experiência 10.4 - Aproximando um corpo eletrizado de uma das partes do eletroscópio

Iniciamos com um eletroscópio aterrado pela parte $B$, com suas duas partes no potencial nulo da Terra, tal que suas tirinhas estejam fechadas, Figura 10.15 (a). Eletrizamos por atrito uma régua plástica. Ao aproximá-la da parte $A$ do eletroscópio, suas tirinhas se abrem de um ângulo $\theta_{1}$, indicando que o potencial 
desta parte ficou diferente em relação ao potencial nulo da Terra e da parte $B$, Figura 10.15 (b). Quanto mais próxima a régua estiver de $A$, maior será este ângulo.

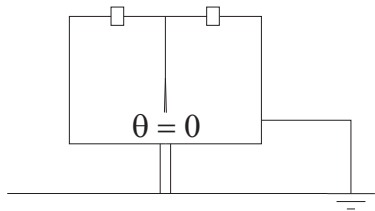

(a)

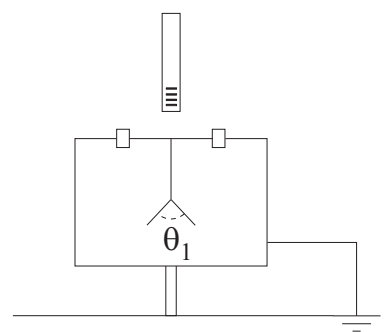

(b)

Figura 10.15: (a) Eletroscópio aterrado pela parte $B$, com suas duas partes no potencial nulo da Terra. (b) As tirinhas levantam quando uma régua plástica eletrizada se aproxima da parte $A$.

Ao afastar a régua eletrizada, as tirinhas se fecham novamente.

Aterramos então a parte $A$ do eletroscópio, ligada às tirinhas. Estando todo o eletroscópio no potencial da Terra, estas tirinhas ficam fechadas, Figura 10.16 (a). Aproximamos então da parte $B$ do eletroscópio a mesma régua plástica eletrizada. Observa-se que suas tirinhas se abrem de um ângulo $\theta_{2}$, indicando que o potencial desta parte ficou diferente do potencial nulo da Terra e da parte $A$, Figura 10.16 (b). Quanto mais próxima estiver a régua da parte $B$, maior será este ângulo.

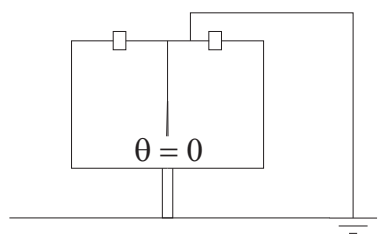

(a)

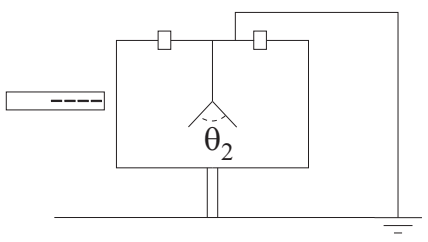

(b)

Figura 10.16: (a) Eletroscópio aterrado pela parte $A$, com suas duas partes no potencial nulo da Terra. (b) As tirinhas levantam quando uma régua plástica eletrizada se aproxima da parte $B$.

Experiência 10.5 - Aproximando um corpo eletrizado de uma das partes do eletroscópio, supondo que as partes $A$ e $B$ estejam ligadas por um fio condutor

Considere agora um eletroscópio com envoltório condutor isolado eletricamente da Terra. Suponha ainda que suas partes $A$ e $B$ estejam ligadas por um fio condutor. Podemos aproximar a régua plástica eletrizada da parte $A$ que as duas palhetas permanecerão fechadas, Figura 10.17 (a). Também podemos 
aproximar a régua plástica eletrizada da parte $B$ que as palhetas permanecerão fechadas, Figura 10.17 (b).

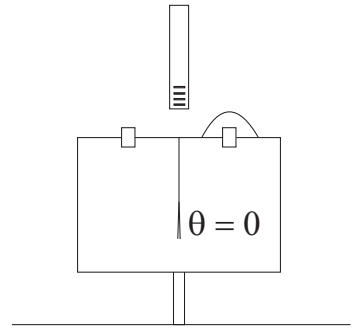

(a)

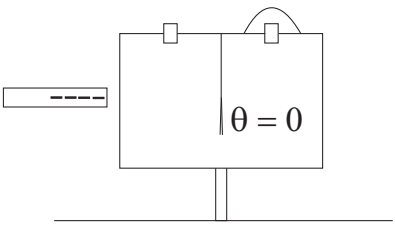

(b)

Figura 10.17: (a) Aproximação de uma régua plástica eletrizada da parte $A$ de um eletroscópio isolado da Terra, com as partes $A$ e $B$ ligadas por um condutor. (b) Idem com a régua aproximando-se da parte $B$.

A explicação para este comportamento é que a aproximação da régua plástica eletrizada aumenta do mesmo valor, em relação ao potencial nulo inicial, tanto o potencial da parte $A$ do eletroscópio quanto o potencial da parte $B$. Ou seja, com a régua eletrizada próxima do eletroscópio teremos $\phi_{A} \neq 0$ e $\phi_{B} \neq 0$, porém $\phi_{A}-\phi_{B}=0$, não interessando a posição ou proximidade da régua.

Experiência 10.6 - Eletrizando uma das partes do eletroscópio

Além da Experiência 10.4, uma outra maneira de causar uma diferença de potencial entre as partes $A$ e $B$ de um eletroscópio isolado eletricamente da Terra é a de eletrizar separadamente cada uma destas partes. Começamos com as duas partes descarregadas e no potencial nulo, com as palhetas fechadas. Eletrizamos a parte $A$. Isto pode ser feito raspando uma régua plástica eletrizada na cartolina do eletroscópio feito como na Figura 10.2 (a), ou então encostando nela um coletor de cargas de forma retangular carregado como um eletróforo. Observa-se que no caso de um eletroscópio com uma única tirinha, ela se levanta, Figura 10.18 (a). No caso de um eletroscópio com duas tirinhas móveis, elas se abrem, Figura 10.18 (b).

Descarregamos a cartolina do eletroscópio tal que tanto a parte $A$ quanto a parte $B$ tenham cargas e potenciais nulos. Agora eletrizamos apenas a parte $B$ (por exemplo, raspando a régua plástica eletrizada na faixa circular de cartolina da Figura 10.2 (b)). A eletrização da parte $B$ pode ser indicada pelo levantamento de uma tirinha externa, Figura 10.19 (a). Neste caso também se observa que a tirinha interna da parte $A$ se levanta no caso de um eletroscópio com uma única tira móvel, Figura 10.19 (a), ou suas palhetas se abrem no caso de um eletroscópio com duas tiras móveis, Figura 10.19 (b).

Ou seja, embora a parte $A$ não tenha sido eletrizada neste último caso, sua tirinha interna se levanta (ou as palhetas se abrem). O motivo para este comportamento é que, ao eletrizar apenas a parte $B$, passou a haver uma diferença de potencial entre as partes $A$ e $B$ deste eletroscópio com envoltório condutor. 


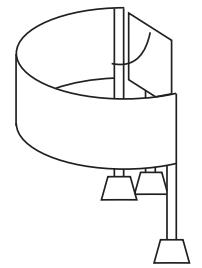

(a)

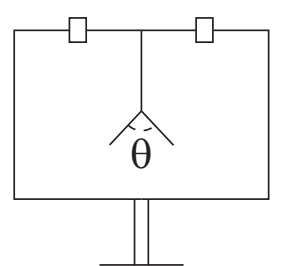

(b)

Figura 10.18: Eletrizamos apenas a parte $A$ de um eletroscópio com envoltório condutor que está isolado da Terra. (a) Sua tirinha levanta. (b) As palhetas se abrem em outro modelo de eletroscópio.

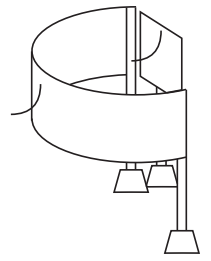

(a)

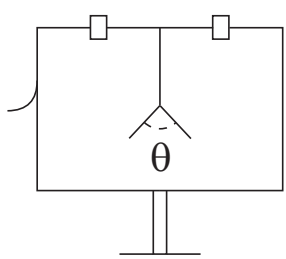

(b)

Figura 10.19: Eletrizamos apenas a parte $B$ de um eletroscópio com envoltório condutor que está isolado da Terra. (a) A tirinha externa da parte $B$ levanta, indicando que ela está eletrizada. Também a tirinha interna da parte $A$ levanta, indicando que há uma diferença de potencial entre as partes $A$ e $B$. (b) As palhetas da parte $A$ se abrem em outro modelo de eletroscópio.

Experiência 10.7 - Eletrizando uma das partes do eletroscópio, supondo que as partes $A$ e $B$ estejam ligadas por um fio condutor

Por outro lado, se as partes $A$ e $B$ estiverem ligadas por um condutor, podemos eletrizar o eletroscópio que a tirinha interna da parte $A$ não se levanta (ou suas palhetas permanecem fechadas), Figura 10.20 (a) e (b). Nesta Figura as tirinhas levantadas nas partes externas das letras (a) e (b) foram colocadas apenas para indicar que o eletroscópio isolado da Terra foi eletrizado como um todo.

\subsection{Kelvin e o Eletrômetro para Medida de Di- ferença de Potencial}

Kelvin foi muito claro ao especificar em 1860 que um eletroscópio ou eletrômetro com envoltório condutor é o instrumento adequado para indicar a igualdade ou a diferença de potencial entre dois condutores: ${ }^{6}$

\footnotetext{
${ }^{6}$ [Tho84a, Nota na pág. 192].
} 


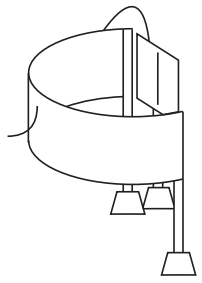

(a)

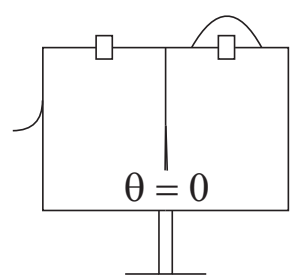

(b)

Figura 10.20: Ligamos por um condutor as partes $A$ e $B$ de um eletroscópio com envoltório condutor que está isolado da Terra. (a) Carregamos o eletroscópio e sua tirinha interna permanece abaixada. (b) Suas palhetas internas permanecem fechadas em outro modelo de eletroscópio.

Diz-se que dois corpos condutores estão no mesmo potencial elétrico quando, se forem colocados em comunicação condutora com os dois eletrodos de um eletrômetro, não for produzido qualquer efeito. Por outro lado, quando o eletrômetro mostrar um efeito, o valor deste efeito mede a diferença de potencial entre os dois corpos que estão sendo testados desta forma. [...]

O efeito a que Kelvin se refere aqui usualmente é o ângulo de abertura entre as palhetas da parte $A$ do eletrômetro com envoltório condutor. O eletrodo principal é ligado entre a parte $A$ e o primeiro corpo condutor, enquanto que o eletrodo secundário é ligado entre a parte $B$ do eletrômetro e o outro corpo condutor.

Uma outra citação de 1860 de Kelvin, nossas palavras entre colchetes e na nota de rodapé: ${ }^{7}$

336. Interpretação da medida feita pelo eletrômetro. Todo tipo de eletrômetro consiste de uma caixa ou recipiente contendo um condutor fixo e um condutor móvel, dos quais pelo menos um está isolado [eletricamente da Terra] e colocado em comunicação metálica, através daquilo que chamarei de eletrodo principal passando através de uma abertura na caixa ou recipiente, com o condutor cuja eletricidade é para ser testada. Em todo eletrômetro construído apropriadamente, a força elétrica sofrida pela parte móvel em uma dada posição não pode ser influenciada eletricamente a não ser mudando a diferença de potencial entre o eletrodo principal e o condutor ou sistema condutor não isolado no eletrômetro. Mesmo o melhor entre os eletrômetros comuns construídos até o momento não satisfaz esta condição, já que a superfície interna do vidro com o qual toda a caixa envoltória, ou parte dela, é feita usualmente, pode tornar-se eletrizada, e inevitavelmente fica assim quando qualquer eletrização muito alta é introduzida [no eletrômetro] intencional ou acidentalmente, mesmo que seja por um tempo muito curto; a consequência deste fato é que a parte móvel [do eletrômetro] não irá geralmente retornar à sua posição nula quando o eletrodo principal é perfeitamente aterrado. ${ }^{8}$ Há muito tempo

\footnotetext{
7 [Tho84c, págs. 258-259].

${ }^{8}$ No original: perfectly disinsulated.
} 
Faraday mostrou como prevenir este grande defeito ao revestir o interior do recipiente de vidro com uma fina rede de estanho; e parece estranho que mesmo nos dias atuais os eletrômetros para pesquisa científica como, por exemplo, para a investigação da eletricidade atmosférica, ainda sejam construídos com um defeito tão grande e óbvio que não tenha sido curado com um remédio tão simples e perfeito. Quando for desejado deixar o interior do eletrômetro com tanta luz quanto possível, e permitir que ele seja visto de qualquer posição externa com tão pouco impedimento quanto possível, pode ser feita uma caixa como uma gaiola de passarinho, com um fio metálico extremamente fino colocado sobre uma estrutura de metal, colocada na parte interna da redoma de vidro utilizada para proteger o instrumento das correntes de ar, etc., substituindo vantajosamente o revestimento de estanho do vidro. Portanto, parece que um eletrômetro construído apropriadamente é um instrumento para medir, por meio dos movimentos de um condutor móvel, a diferença de potencial de dois sistemas condutores isolados entre si, sendo que a caixa ou recipiente do instrumento faz parte de um deles. Deve ser observado de passagem, que algumas vezes é conveniente em algumas pesquisas especiais isolar [eletricamente da Terra] a caixa ou recipiente do instrumento, permitindo com que ela adquira um potencial diferindo do potencial da Terra, e que então, como sempre, o tema da medida é a diferença de potencial entre o eletrodo principal e a caixa ou recipiente, enquanto que no uso comum do instrumento [com a caixa aterrada] o potencial da caixa coincide com o potencial da Terra. Portanto podemos considerar o eletrômetro meramente como um instrumento para medir diferenças de potencial entre dois sistemas condutores mutuamente isolados; e o objetivo a ser alcançado ao aperfeiçoar qualquer tipo de eletrômetro (mais ou menos sensível, de acordo com os tipos de investigação para o qual será usado) é que, avaliações precisas em medida absoluta, das diferenças de potencial, possam ser obtidas imediatamente a partir de suas indicações.

A citação que Kelvin fez a Faraday refere-se a um trabalho de 1838. Neste trabalho sobre indução Faraday utilizou como eletrômetro a balança de torção de Coulomb, fazendo uma melhoria adicional, a saber, cobrindo a parte interior do recipiente de vidro (colocada ao redor dos corpos eletrizados internos que estavam se atraindo ou repelindo) com um material condutor aterrado. Com isto evitou as influências de corpos eletrizados externos à balança: ${ }^{9}$

Para que a ação indutiva dentro do eletrômetro pudesse ser uniforme em todas as posições da bola repelida e em todos os estados do instrumento, foram colocadas na superfície interna do cilindro de vidro duas bandas de estanho, com aproximadamente uma polegada cada uma, dando uma volta completa ao redor do cilindro, com uma distância de 0,4 polegadas entre elas e em tal altura que a superfície transparente intermediária ficasse no mesmo plano horizontal com a balança e a bola. Estas bandas foram conectadas entre si e com a Terra, e, sendo condutores perfeitos, sempre exerceram uma influência uniforme sobre as bolas eletrizadas internas, sendo que apenas a superfície de vidro não exercia [esta influência uniforme] devido à sua condição irregular em períodos diferentes.

\footnotetext{
${ }^{9}$ [Far38, artigo 1180, pág. 444].
} 


\section{Capítulo 11}

\section{Descargas Elétricas no Ar}

Existem alguns outros efeitos muito importantes que ocorrem nas pontas de condutores eletrizados ou polarizados, além daqueles descritos no Capítulo 9 relacionados ao poder das pontas. Eles estão associados a um assunto que tratamos brevemente no Vol. 1 deste livro, a saber, descargas elétricas e faíscas no ar. Vamos descrever alguns destes efeitos neste Capítulo.

1. O ar ioniza-se mais facilmente próximo das pontas de condutores eletrizados, podendo passar a comportar-se como um condutor.

2. Quando este comportamento ocorre, é possível eletrizar um condutor através de suas pontas, sem que haja contato com um outro corpo eletrizado próximo a ele. O condutor precisa estar isolado eletricamente do solo.

3. Também é possível descarregar um condutor através de suas pontas sem que ele seja aterrado. Neste caso basta aproximar um outro condutor aterrado de uma região pontuda do condutor que está eletrizado e isolado do solo.

\subsection{Faíscas ou Raios}

Existem algumas experiências extremamente simples e interessantes que podem ser feitas com um eletroscópio comum no qual prende-se um arame ou agulha. ${ }^{1}$ $\mathrm{O}$ arame ou agulha pode ser preso com uma fita adesiva na parte de trás do eletroscópio, saindo ao redor de 1 ou $2 \mathrm{~cm}$ para fora da cartolina, Figura 11.1.

\section{Experiência 11.1 - Eletrizando um eletroscópio sem contato}

Eletrizamos um canudo plástico ou régua de acrílico por atrito contra o cabelo ou em um guardanapo. Vamos supor que o canudo ficou negativamente eletrizado. Seguramos o canudo na horizontal a alguns centímetros da ponta da

\footnotetext{
${ }^{1}$ [FM91, pág. 62], [Ferb, Pára-raios: Igrejinha, pág. 40], [Gas03, págs. 239-243] e [LSB08].
} 


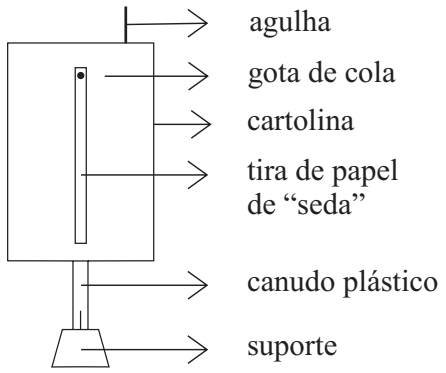

(a)

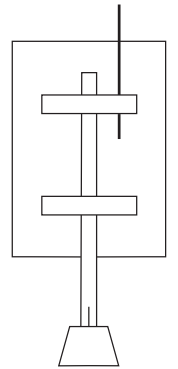

(b)

Figura 11.1: (a) Eletroscópio de frente, com agulha fixada na parte de trás. (b) Eletroscópio de costas.

agulha do eletroscópio. Neste caso nada acontece com a tirinha do eletroscópio. Quando aproximamos o canudo eletrizado lentamente da agulha, a tirinha do eletroscópio começa a se levantar quando ele está a uma distância de aproximadamente $1 \mathrm{~cm}$ da agulha. Ao remover o canudo a tirinha volta a abaixar.

Repetimos este procedimento com o eletroscópio inicialmente descarregado, Figura 11.2 (a).

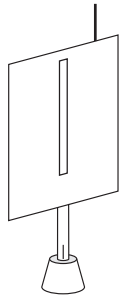

(a)

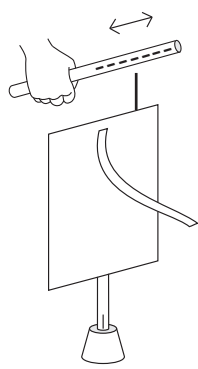

(b)

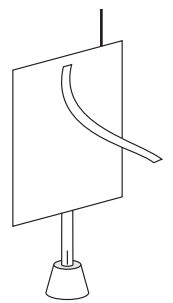

(c)

Figura 11.2: (a) Eletroscópio com agulha, descarregado. (b) Canudo eletrizado bem próximo da ponta da agulha, movendo-se horizontalmente para frente e para trás. Observa-se que a tirinha do eletroscópio levanta. (c) Ao afastar o canudo, observa-se que a tirinha permanece levantada.

Agora aproximamos ainda mais o canudo eletrizado da ponta da agulha, até que fique a uma pequena distância entre 1 e 3 milímetros da agulha, sem tocála. A tirinha do eletroscópio vai estar levantada. Nesta situação o canudo deve ser movido horizontalmente para frente e para trás, sempre passando acima da agulha, Figura 11.2 (b). O canudo deve ser girado durante este movimento de ida e volta. Depois afasta-se o canudo eletrizado e observa-se que a tirinha do eletroscópio permanece levantada, Figura 11.2 (c). 
O fato da tirinha do eletroscópio ter permanecido levantada após o afastamento do canudo eletrizado indica que o eletroscópio ficou eletrizado. Este fenômeno apresenta algo novo e surpreendente, a saber, a eletrização do eletroscópio sem que ele tenha sido tocado! No Volume 1 de nossa obra não discutimos este novo mecanismo de carregamento de um eletroscópio. Até agora só havíamos analisado a eletrização por três processos, a saber: (I) Por atrito, como no efeito âmbar, Seção 1.1. (II) Por contato de um condutor com um outro corpo já eletrizado, como no mecanismo $A C R$, Seção 4.4. (III) Eletrização por indução ou por polarização. ${ }^{2}$

Experiência 11.2 - Determinando o sinal da carga adquirida pelo eletroscópio

Depois que o eletroscópio com a agulha foi carregado ao passar o canudo eletrizado acima dele como na Experiência 11.1, aproxima-se lentamente da tirinha levantada o mesmo canudo atritado que carregou o eletroscópio. De preferência o canudo deve estar na horizontal, na mesma altura que a ponta inferior da tirinha. A aproximação deve ser lenta e o canudo não deve aproximarse demais da tirinha, evitando que se toquem. Deve-se observar atentamente em que sentido a tirinha tende a se mover, isto é, se no sentido do canudo ou se no sentido da cartolina. Ao fazer a experiência com cuidado, observa-se que a tirinha se desloca no sentido da cartolina, tendendo a afastar-se do canudo atritado.

Pode-se fazer um movimento alternado para frente e para trás com o canudo, aproximando-o e afastando-o da tirinha, que ela faz um movimento coordenado com o movimento do canudo, indo no sentido da cartolina e afastando-se dela. Para que se observe este movimento alternado, é necessário que o movimento do canudo seja de baixa amplitude. Isto é, com pequenos deslocamentos espaciais, sem se aproximar demais da tirinha, Figura 11.3.

Este comportamento da tirinha mostra que o eletroscópio com agulha foi carregado com carga de mesmo sinal que a carga do canudo eletrizado, já que há uma repulsão entre ambos. Podemos então representar as cargas no eletroscópio como tendo o mesmo sinal que as cargas do canudo atritado. Neste exemplo elas seriam negativas.

\section{Experiência 11.3 - Descarregando um eletroscópio sem tocá-lo}

Fazemos agora o inverso da Experiência 11.1. Desta vez começamos com o eletroscópio com agulha estando eletrizado, ou seja, com sua tirinha levantada, Figura 11.4 (a).

Seguramos então com a mão um espeto de madeira ou um arame na horizontal. O aproximamos da agulha do eletroscópio, até que esteja a uma pequena distância da ponta da agulha, entre 1 e 3 milímetros, sem tocá-la. Observa-se que a tirinha vai se abaixando até encostar na cartolina, Figura 11.4 (b) e (c). Afasta-se o espeto ou madeira e observa-se que a tirinha permanece abaixada, Figura $11.4(\mathrm{~d})$.

\footnotetext{
${ }^{2}$ Como discutido na Seção 7.5 de [Ass10b], [Ass10a], [Ass11], [Ass15b] e [Ass17].
} 
(a)
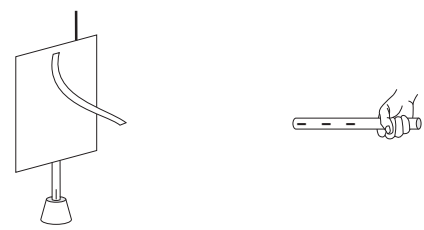

(b)

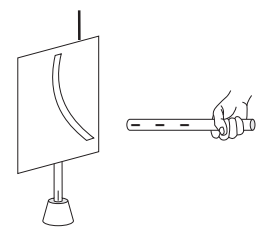

(c)
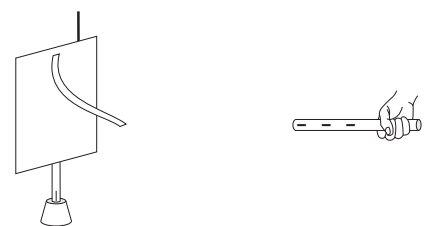

Figura 11.3: Repulsão entre o canudo eletrizado negativamente e o eletroscópio com agulha eletrizado sem contato com este canudo. (b) Quando se aproxima o canudo do eletroscópio, a tirinha abaixa. Quando se afasta o canudo, a tirinha levanta, (a) e (c).

Neste caso conseguimos descarregar um eletroscópio eletrizado sem tocá-lo, apenas aproximando um condutor (espeto de madeira ou arame) da ponta da agulha, estando o condutor aterrado pelo contato com a mão da pessoa que o segura.

Experiência 11.4 - Influência do número de agulhas no tempo necessário para descarregar um eletroscópio

Vamos agora comparar o tempo que um eletroscópio leva para descarregar no ar, com ou sem uma agulha presa nele. Pegamos dois eletroscópios de mesmo formato e tamanho. Um deles é o eletroscópio usual, sem agulha. O outro tem uma agulha vertical saindo da borda superior da cartolina.

Colocamos os dois eletroscópios afastados um do outro e os eletrizamos igualmente ao raspar suas cartolinas com um canudo ou régua plástica que foram atritados no cabelo, no guardanapo ou em um pano. A mesma eletrização inicial é obtida quando suas tirinhas ficam afastadas inicialmente do mesmo ângulo $\theta$ em relação à cartolina. Observa-se então o tempo que levam para serem descarregados no ar, ou seja, o tempo até que as tirinhas voltem a encostar nas respectivas cartolinas. É fácil perceber que o eletroscópio com agulha é descarregado mais rapidamente pelo ar do que o eletroscópio sem agulha.

Caso um eletroscópio tenha duas ou três agulhas (por exemplo, uma saindo para cima e as outras duas saindo horizontalmente, uma agulha de cada lado da 


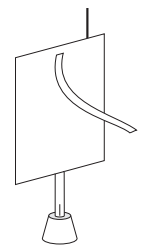

(a)

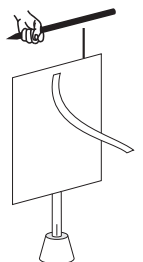

(b)

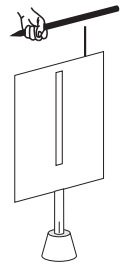

(c)

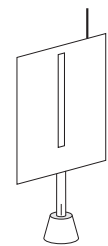

(d)

Figura 11.4: (a) Eletroscópio com agulha, eletrizado, como indicado pela tirinha levantada. (b) e (c) Ao colocar um espeto de madeira ou arame bem próximo da ponta da agulha, sem tocá-la, a tirinha vai abaixando. (d) Ao afastar o espeto ou arame, observa-se que a tirinha permanece abaixada.

cartolina do eletroscópio), ele é descarregado ainda mais rapidamente do que o eletroscópio com uma única agulha.

Experiência 11.5 - Transferência de cargas entre dois condutores separados entre si

Utilizamos agora duas latinhas de refrigerante vazias. Prendemos a extremidade superior de uma tirinha de papel de "seda" em cada uma delas. Prendemos um alfinete ou uma agulha horizontal em uma delas por um furo ou utilizando uma fita adesiva, com a ponta do alfinete apontando para fora. Apoiamos estas duas latinhas em lâminas de isopor isolantes. O alfinete que sai da lata $A$ deve ficar bem próximo ao centro da lata $B$, com a distância entre a ponta do alfinete e a lata sendo de 1 ou $2 \mathrm{~mm}$. Inicialmente as latinhas devem estar descarregadas com as tirinhas abaixadas, Figura 11.5 (a). Raspa-se algumas vezes uma régua plástica eletrizada na borda superior da lata $A$ até que ela fique carregada, Figura 11.5 (b). Depois de algum tempo observa-se que as duas latas ficam eletrizadas, Figura 11.5 (c). Ou seja, conseguimos eletrizar a lata $B$ sem contato com a lata $A$ carregada.

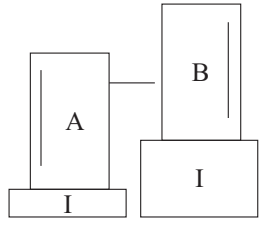

(a)

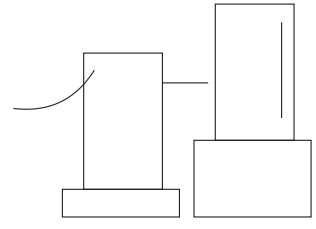

(b)

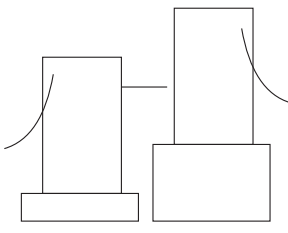

(c)

Figura 11.5: (a) Duas latinhas isoladas e descarregadas com um alfinete horizontal apontando de uma para outra. Elas estão apoiadas sobre lâminas isolantes representadas pela letra $I$. (b) Eletriza-se a latinha $A$. (c) Após algum tempo as duas latinhas ficam eletrizadas, como indicado por suas tirinhas levantadas. 
Pode-se também inverter o procedimento da Experiência 11.5. Inicialmente eletriza-se a lata $B$ que não tem a agulha, Figura 11.6 (b). Após algum tempo observa-se que as duas latas ficam eletrizadas, Figura 11.6 (c). Neste caso conseguimos eletrizar a lata $A$ com alfinete, sem que tenha havido contato com a lata $B$ carregada.

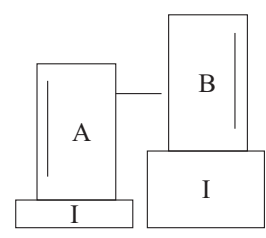

(a)

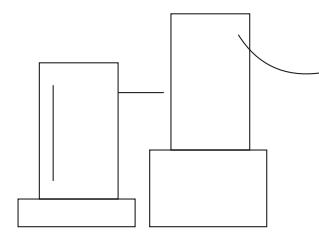

(b)

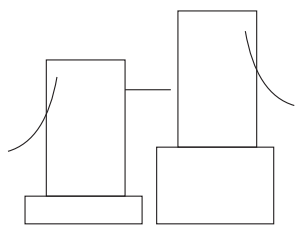

(c)

Figura 11.6: (a) Duas latinhas isoladas e descarregadas com um alfinete apontando de uma para outra. (b) Eletriza-se a latinha $B$. (c) Após algum tempo as duas latinhas ficam carregadas.

\subsection{Comentários sobre Estas Experiências}

As experiências da Seção 11.1 são extremamente interessantes.

$\mathrm{Na}$ Experiência 11.1 começamos com um eletroscópio descarregado tendo uma agulha saindo para fora dele. Aproximamos um canudo plástico eletrizado da ponta da agulha e o eletroscópio ficou carregado depois de algum tempo. Como não houve o contato entre o canudo eletrizado e a ponta da agulha, a eletrização teve de ocorrer pelo ar. O ar seco normalmente comporta-se como um bom isolante, já que um eletroscópio ao ser carregado permanece eletrizado por alguns minutos embora esteja em contato com o ar ao seu redor. Nesta Experiência 11.1, por outro lado, o ar comportou-se como um condutor, com várias de suas moléculas tendo sido ionizadas (ou seja, ficaram carregadas eletricamente). A ionização do ar deve ter ocorrido na região próxima à ponta condutora da agulha metálica. Foi então possível uma troca de partículas carregadas entre o canudo eletrizado, os íons do ar e o eletroscópio.

$\mathrm{Na}$ Experiência 11.3 obtivemos o efeito inverso. Utilizamos novamente um eletroscópio simples com uma agulha saindo para fora dele. Nesta experiência começamos com o eletroscópio eletrizado. Aproximamos então um condutor aterrado da ponta da agulha, sendo este condutor um palito de madeira ou fio metálico. Observamos que o eletroscópio foi descarregado. Nesta experiência ocorreu a descarga do eletroscópio sem que houvesse um aterramento usual. afinal de contas, o palito de madeira apenas aproximou-se da ponta da agulha, sem chegar a tocá-la. O ar passou a comportar-se como um condutor ao aproximarmos a madeira condutora da ponta condutora da agulha. Bastou que houvesse uma pequena distância entre a agulha condutora de um eletroscópio eletrizado 
e a madeira condutora, que estava aterrada por estar sendo segurada pela mão da pessoa, para que o ar passasse a se comportar como um condutor. Este comportamento condutor do ar foi ocasionado pela ionização de suas moléculas.

A Experiência 11.4 mostrou que a simples presença de pontas condutoras em um eletroscópio eletrizado facilita seu descarregamento através do ar ao seu redor. Mais uma vez temos que o ar ao redor das pontas de condutores eletrizados passa a se comportar como um condutor, facilitando o descarregamento do eletroscópio.

A mudança de comportamento do ar, de isolante para condutor, é um fenômeno complexo e que depende de vários fatores. Não vamos explicá-lo aqui, apenas descrever algumas de suas características principais. Esta mudança não é contínua e sim abrupta, sendo denominada de ruptura dielétrica ou de descarga em arco. Quando a diferença de potencial entre dois pontos do ar é menor do que um certo valor crítico, ele comporta-se como um bom isolante. Acima deste valor crítico, ele passa a comportar-se como um bom condutor. Este valor crítico da diferença de potencial para uma certa distância, ou da força por unidade de carga, recebe o nome de rigidez dielétrica do material. Este valor crítico para o ar depende, entre outras coisas, da pressão atmosférica. Na pressão normal de uma atmosfera, $P=1 \mathrm{~atm}=1 \times 10^{5} \mathrm{~N} / \mathrm{m}^{2}$, o valor da rigidez dielétrica do ar é da ordem de $3 \times 10^{6} \mathrm{~V} / \mathrm{m}=3.000$ volts $/ \mathrm{mm}^{3}$

Vamos considerar, por exemplo, o caso da Experiência 11.1. Suponha que o carregamento do eletroscópio ocorra quando a distância entre o canudo eletrizado e a ponta do alfinete seja de $2 \mathrm{~mm}$. Neste caso vai haver uma diferença de potencial de aproximadamente $6.000 \mathrm{~V}$ entre o canudo e o eletroscópio.

É através de experiências como estas, assim como pela observação da distância em que ocorre a faísca entre as duas pequenas esferas condutoras do gerador eletrostático gotejante de Kelvin, que se pode concluir que nas experiências usuais de eletrostática lidamos com altas diferenças de potencial, variando tipicamente entre $1.000 \mathrm{~V}$ e $10.000 \mathrm{~V}$, como mencionamos no Volume 1 de nossa obra. ${ }^{4}$ Embora estas diferenças de potencial sejam bem maiores do que aquelas fornecidas pelas pilhas ou baterias usuais (alguns volts), a quantidade de carga elétrica envolvida nas experiências de eletrostática é em geral bem pequena.

Deve-se enfatizar aqui que as descargas elétricas no ar não são devidas ao arrancamento de elétrons dos eletrodos, como algumas vezes se afirma erroneamente. Para que elétrons sejam emitidos de superfícies metálicas mantidas a baixas temperaturas, são necessárias forças por unidade de carga da ordem de $10^{8} \mathrm{~V} / \mathrm{m}$. Este valor é bem maior do que o valor de $3 \times 10^{6} \mathrm{~V} / \mathrm{m}$ necessário para ionizar o ar à pressão atmosférica, quando então ocorre a descarga elétrica. Ou seja, a força por unidade de carga necessária para ionizar o ar é bem menor do que a força por unidade de carga necessária para arrancar elétrons de eletrodos frios. ${ }^{5}$

\footnotetext{
3 [TM09, págs. 91 e 125].

4 [Tho], [Llo80], [Cam06], [CA08], ver ainda as Seções 6.6, 7.11 e 7.12 de [Ass10b], [Ass10a], [Ass11], [Ass15b] e [Ass17].

${ }^{5}$ [Sav, pág. 249], [Sil10c], [Sil11] e [Sil16].
} 


\subsection{Para-Raios}

As Experiências 11.1 e 11.3 mostram que é possível carregar ou descarregar um eletroscópio sem contato. A Experiência 11.4 mostra que o ar ao redor de uma ponta condutora eletrizada passa a se comportar como um condutor. Este comportamento condutor do ar perto de condutores pontudos eletrizados está na base do funcionamento dos para-raios. Podemos ilustrar seu funcionamento com experiências simples.

\section{Experiência 11.7 - Simulação de um para-raios}

Cortamos uma cartolina ou papel cartão na forma de uma casinha simples. Ela pode ficar presa ao solo ou a uma fresta em uma tábua de madeira. Prendese uma tirinha de papel de "seda" na casa para indicar se vai haver algum efeito elétrico sobre ela. Pega-se um fio metálico usual com uns 20 ou $30 \mathrm{~cm}$ de comprimento. Ele é colocado ao lado da casa, na vertical, isolado eletricamente da casa por algum pedaço de isopor ou de plástico rígido. A extremidade inferior do fio é presa ou fincada ao solo ou madeira na qual a casa está presa. Está pronto então nosso modelo de para-raios, Figura 11.7 (a), na qual $I$ representa um material isolante.

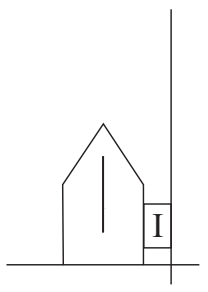

(a)

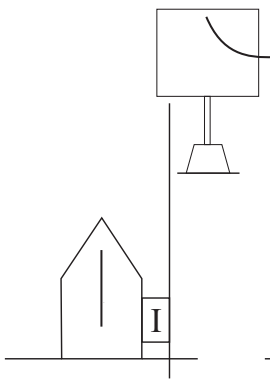

(b)

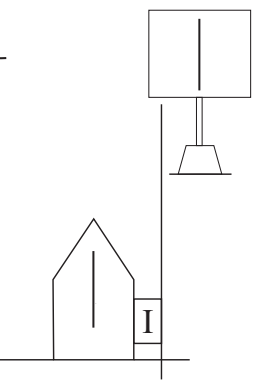

(c)

Figura 11.7: (a) O para-raios é um fio condutor isolado eletricamente da casa ou prédio que deve proteger. Sua extremidade inferior penetra no solo. (b) Colocase um eletroscópio eletrizado bem próximo da extremidade superior do fio. (c) $\mathrm{O}$ eletroscópio é descarregado para o solo, sem afetar a tirinha da casa.

Um eletroscópio usual feito de cartolina apoiada em um canudo plástico, com uma tirinha de papel de "seda" no meio da cartolina, vai servir como analogia para uma nuvem. Eletrizamos este eletroscópio ao raspá-lo com um canudo ou régua plástica atritados contra o cabelo, guardanapo ou pano. Este eletroscópio é apoiado por algum suporte acima do fio. Aproximamos a parte inferior da cartolina deste eletroscópio da ponta superior do fio metálico, Figura 11.7 (b). Quando a distância entre a ponta do fio e a borda inferior da cartolina for de 1 a $3 \mathrm{~mm}$, observamos que o eletroscópio descarrega sem que toque no fio, Figura 11.7 (c). Além disso, nenhum efeito ocorre na casa, como indicado por sua tirinha que permanece na vertical em todo o processo. 
Este é o papel dos para-raios usuais. Ele é um fio condutor com sua extremidade inferior presa ao solo, com sua extremidade superior saindo verticalmente da casa ou prédio que deve proteger, estando preso à casa por suportes isolantes. Quando uma nuvem eletrizada passa sobre o para-raios, a extremidade superior do para-raios fica eletrizada com carga de sinal oposto à carga da nuvem. Se houver uma alta voltagem da nuvem em relação ao solo, o ar ao redor da ponta superior do para-raios passa a se comportar como um condutor. Este canal condutor permite com que a nuvem seja descarregada para o solo através do fio do para-raios.

\subsection{Para-Raios Isolado do Solo}

O para-raios utilizado como proteção de casas e prédios é aterrado no solo.

Por outro lado, quando o condutor metálico está isolado eletricamente da Terra, temos o chamado fio de teste, para-raios isolado do solo ou para-raios de teste. Ele é usado para coletar uma parte da eletricidade acumulada em nuvens ou na atmosfera. Com isto podemos saber se esta eletricidade é positiva ou negativa, podemos conhecer sua intensidade a diferentes alturas, em climas variados, em diferentes horários ou épocas do ano, etc. É perigoso fazer experiências reais deste tipo ao ar livre para testar a eletricidade das nuvens. Neste livro vamos fazer algumas experiências didáticas utilizando pequenos arames metálicos isolados da Terra funcionando como nosso fio de teste. Já os eletroscópios eletrizados vão simular as nuvens carregadas.

\section{Experiência 11.8 - Removendo as cargas de um eletroscópio}

Finca-se um arame ou fio metálico em um bloco de isopor para que fique na vertical, tomando cuidado para que sua extremidade inferior não toque no solo. Ou seja, este arame vai estar isolado da Terra. A parte superior do arame vertical deve sair para fora do isopor, ficando livre no ar. Apoia-se um eletroscópio inicialmente descarregado em algum suporte isolante. A borda inferior da cartolina deste eletroscópio deve ficar afastada de 1 a $3 \mathrm{~mm}$ da ponta do fio. A meia altura do fio, coloca-se um versório metálico apoiado em algum suporte e apontando em uma direção arbitrária, Figura 11.8 (a).

Eletriza-se o eletroscópio ao raspar sua borda superior com um canudo eletrizado. A tirinha sobe imediatamente, Figura 11.8 (b). Observa-se depois de alguns segundos que a tirinha do eletroscópio abaixou um pouco e que o versório passou a apontar para o fio, Figura 11.8 (c).

Esta experiência não é de indução elétrica. Isto é, a orientação do versório não é ocasionada pela polarização do fio devida à presença do eletroscópio carregado que está em suas proximidades. Se o eletroscópio estiver negativamente eletrizado, a extremidade superior do fio ficará positivamente eletrizada por indução, enquanto que sua extremidade inferior ficará negativamente eletrizada. Esta indução é praticamente instantânea.

Já a orientação do versório leva alguns segundos para ocorrer. Ela é devida à eletrização gradual do fio, isto é, o fio passa a ficar com uma carga total diferente 


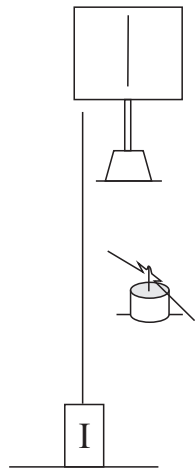

(a)

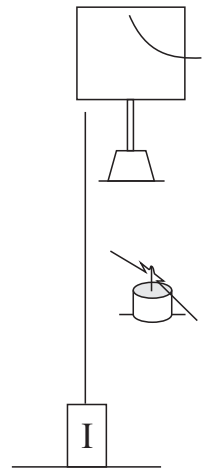

(b)

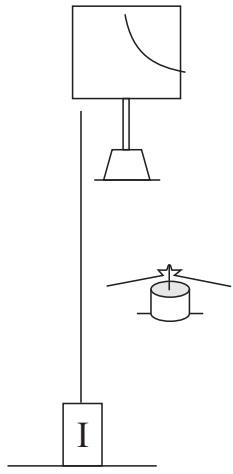

(c)

Figura 11.8: (a) Fio de teste vertical isolado da Terra com um versório próximo de seu ponto médio apontando em uma direção arbitrária. O eletroscópio está inicialmente descarregado. (b) Eletriza-se o eletroscópio. (c) Após alguns segundos, o eletroscópio perde um pouco de sua carga e o fio eletrizado passa a orientar o versório.

de zero. Esta eletrização lenta do fio ocorre através da ionização do ar próximo à ponta superior do fio. A eletrização do fio ocasiona uma redistribuição de cargas no versório, fazendo com que ele aponte para o fio.

Esta experiência também pode ser feita mais facilmente com o arame na horizontal apoiado sobre copos de isopor, Figura 11.9 (a). Inicialmente colocase um versório metálico na mesma altura do arame, próximo dele, apontando em uma direção arbitrária. Coloca-se um eletroscópio perto do arame. A extremidade do arame deve ficar bem próxima do centro da borda vertical do eletroscópio, a uma distância de 1 a $3 \mathrm{~mm}$. Eletriza-se o eletroscópio. Depois de passado algum tempo, observa-se a orientação do versório. Isto é, o versório passa a apontar para o arame, Figura 11.9 (b).

\subsection{Descargas Elétricas no Mecanismo $A C R$}

Na Seção 4.4 discutimos o mecanismo $A C R$, a saber, atração, comunicação da eletricidade, seguido da repulsão. A experiência 4.3 mostrou um exemplo deste mecanismo. Neste caso tínhamos um pequeno disco condutor inicialmente neutro e isolado eletricamente da Terra. Aproximamos do disco um isolante eletrizado, a saber, um plástico carregado eletricamente. O disco foi atraído pelo isolante eletrizado, tocou nele, passando então a ser repelido pelo plástico carregado ao adquirir uma carga resultante de mesmo sinal que o plástico. A atração inicial ocorreu devida à polarização elétrica do disco condutor. Esta polarização foi induzida pela carga do isolante que estava em suas proximidades. Em geral a comunicação da eletricidade no mecanismo $A C R$ ocorre durante o contato entre um pequeno condutor inicialmente neutro e um isolante eletrizado. 
(a)

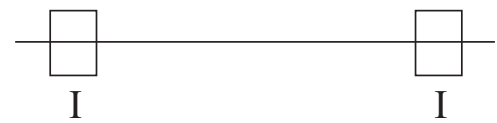

(b)

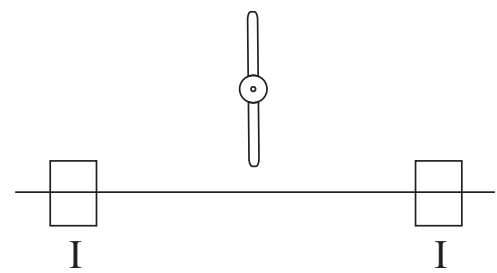

Figura 11.9: (a) Fio de teste horizontal isolado da Terra sobre dois copos de isopor representados pela letra $I$. Um versório é colocado próximo do centro do fio, apontando em uma direção arbitrária. (b) Quando o fio de teste fica eletrizado, ele orienta o versório. Isto é, o versório passa a apontar para o fio carregado.

Mas nem sempre é necessário o contato entre estes dois corpos para que ocorra o mecanismo $A C R$. Algumas vezes, a simples aproximação entre eles é suficiente para que o pequeno condutor passe a ser repelido pelo isolante. Nestes casos, o que ocorre é que o ar entre eles passa a se comportar como um condutor. Ocorre então uma descarga elétrica através do ar, com uma troca de partículas eletrizadas entre o condutor e os íons do ar. Ao final deste processo, o condutor fica com uma carga resultante de mesmo sinal que o isolante eletrizado, mesmo que não haja um contato direto entre eles.

O próprio Du Fay, que descobriu o mecanismo $A C R$, já estava ciente de que não é necessário o contato para que ocorra a repulsão. Algumas vezes, bastava uma aproximação entre o pequeno condutor e o isolante eletrizado, para que o condutor passasse em seguida a ser repelido pelo isolante. ${ }^{6}$

\subsection{Lâmpada de Neon}

É facilmente encontrado em lojas de material elétrico ou eletrônico, a chamada lâmpada de neon, néon ou neônio, Figura 11.10.

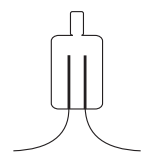

Figura 11.10: Lâmpada de neon.

\footnotetext{
${ }^{6}$ Seção 4.8 de [Ass10b], [Ass10a], [Ass11], [Ass15b] e [Ass17].
} 
Ela é utilizada nas chaves de teste para indicar qual é o fio fase e o fio neutro de uma tomada, por exemplo. Ela funciona bem em várias experiências de eletrostática. Ela pode indicar se um corpo está eletrizado ou descarregado. Além disso, ela também indica se o corpo carregado está eletrizado positivamente ou negativamente. Nesta Seção apresentamos algumas experiências com estas lâmpadas.

Experiência 11.9 - Raspando uma lâmpada de neon em uma régua negativamente eletrizada

Segura-se uma das pernas da lâmpada de neon com os dedos e encosta-se a outra perna em uma régua de acrílico neutra. Observa-se que a lâmpada não acende, Figura 11.11 (a).

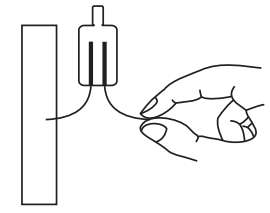

(a)

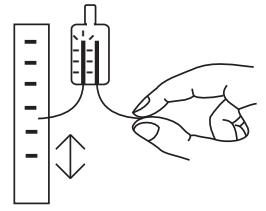

(b)

Figura 11.11: (a) Uma lâmpada de neon não acende ao tocar em uma régua neutra. (b) Ao raspar uma perna da lâmpada em uma régua plástica eletrizada negativamente, pisca o eletrodo ligado à régua.

Eletriza-se uma régua de acrílico negativamente ao raspá-la com um guardanapo de papel. Segura-se uma das pernas da lâmpada de neon com os dedos e encosta-se a outra perna na parte eletrizada da régua, deslizando ao longo dela. Se este procedimento for feito em um quarto escurecido, observa-se que a lâmpada pisca. Em particular, pisca o eletrodo do lado das cargas negativas da régua, Figura 11.11 (b).

Experiência 11.10 - Tocando uma lâmpada de neon em eletroscópios carregados positivamente e negativamente

Eletriza-se um eletroscópio positivamente e um outro negativamente. Isto pode ser feito raspando uma régua plástica eletrizada positivamente na cartolina de um eletroscópio e raspando uma régua plástica negativamente eletrizada na cartolina do outro eletroscópio. Também é possível eletrizar facilmente dois eletroscópios com cargas opostas utilizando a indução ou polarização elétrica. ${ }^{7}$ Segura-se uma lâmpada neon por uma das pernas e encosta-se a outra perna no eletroscópio positivo. Observa-se que o eletroscópio descarrega enquanto pisca o eletrodo ligado à mão, Figura 11.12 (a).

Ao repetir-se o procedimento com o eletroscópio negativo, observa-se que a lâmpada também pisca enquanto o eletroscópio descarrega, mas o eletrodo que acende é aquele que encosta no eletroscópio, Figura 11.12 (b).

\footnotetext{
${ }^{7}$ Seção 7.5 de [Ass10b], [Ass10a], [Ass11], [Ass15b] e [Ass17].
} 


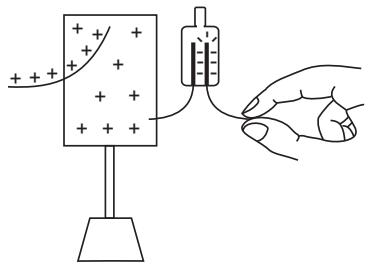

(a)

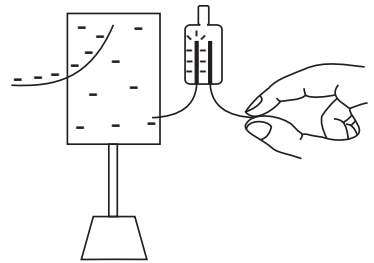

(b)

Figura 11.12: A lâmpada pisca ao tocar em eletroscópios eletrizados que se descarregam. (a) Pisca o eletrodo ligado à mão quando o eletroscópio está positivamente eletrizado. (b) Pisca o eletrodo ligado ao eletroscópio negativamente eletrizado.

Esta experiência pode ser repetida com eletróforos. ${ }^{8}$ Novamente vai piscar o eletrodo da lâmpada de neon que toca no eletróforo negativamente eletrizado. Caso a lâmpada de neon toque em um eletróforo positivamente eletrizado, vai piscar o eletrodo da lâmpada de neon que está ligado à mão da pessoa que segura a lâmpada.

A lâmpada de neon é então um instrumento útil não apenas para saber se um corpo está ou não eletrizado, mas também para indicar o sinal da carga elétrica no corpo.

\subsection{Gray, Franklin, o Poder das Pontas e a Na- tureza Elétrica dos Raios e Relâmpagos}

Alguns pesquisadores antigos perceberam diversas analogias entre as pequenas faíscas e descargas elétricas que produziam em suas experiências de eletrostática, com os raios e relâmpagos observados nas tempestades. Sugeriram então que eram o mesmo fenômeno, apenas em escalas ou ordens de grandeza bem diferentes. Entre estes cientistas citamos aqui Stephen Gray. Em uma carta enviada para o Secretário da Royal Society em 1734 e publicada em 1735, ele descreveu diversas experiências relacionadas com faíscas e luzes que conseguia produzir com seu tubo de vidro eletrizado e com a aproximação de condutores pontudos de corpos eletrizados. Citamos aqui o final deste artigo, nossas figuras e palavras nas notas de rodapé e entre colchetes: ${ }^{9}$

8. Peguei um prato de madeira (wooden dish) e coloquei-o sobre o suporte ${ }^{10}$ inicialmente vazio. Então, aplicando o tubo ${ }^{11}$ e o dedo ${ }^{12}$ próximo

\footnotetext{
${ }^{8}$ [Ferb, Lâmpada de néon, pág. 32; Lâmpada fluorescente, pág. 34; e Eletróforo de Volta, pág. 38].

${ }_{9}$ [Grac, pág. 24] com tradução comentada para a língua portuguesa em [Bos11, Capítulo 10] e [BAC12, Capítulo 11, págs. 221-238].

${ }^{10}$ Anteriormente no texto Gray afirmou que este suporte estava sobre um cilindro de vidro. Os vidros utilizados por Gray comportavam-se como isolantes.

${ }^{11}$ Isto é, um tubo de vidro eletrizado por atrito.

${ }^{12}$ No original consta o termo fin-. Provavelmente é um lapso de redação, devendo se referir
} 
ao prato, apareceu uma luz, mas não houve empurrão do dedo nem estalos. Depois, enchi o prato com água e ao colocar o tubo sobre a superfície da água, apareceu uma luz maior do que quando o dedo tinha sido aplicado ao prato vazio, mas não houve estalo. ${ }^{13}$ [Porém, ] ao colocar o tubo, depois de tê-lo atritado bem, à distância de duas ou três polegadas [5 ou $7,5 \mathrm{~cm}$ ] do dedo que estava colocado próximo à superfície da água, então o dedo foi empurrado e o estalo escutado, como quando o experimento foi feito com o prato de estanho. ${ }^{14}$

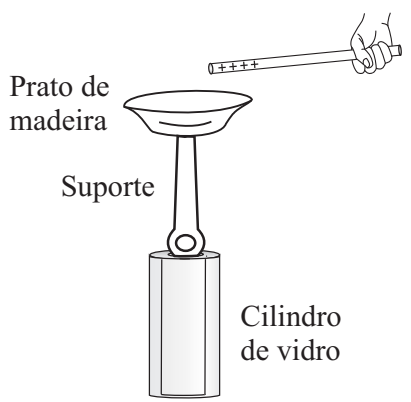

(a) Cilindro de vidro, suporte de madeira e o prato vazio.

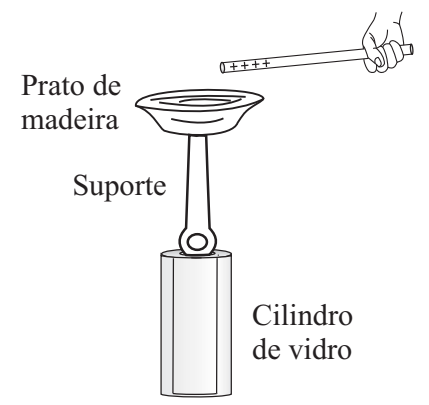

(b) Cilindro de vidro, suporte de madeira e o prato cheio de água.

\section{Figura 11.13: Cilindro de vidro, suporte de madeira e o prato.}

\section{Gray continuou seu relato com as seguintes palavras:}

Por estes experimentos vemos que podem ser produzidas pela comunicação da eletricidade uma chama real de fogo, juntamente com uma explosão e uma ebulição da água fria. ${ }^{15}$ Embora estes efeitos estejam presentes, mas em minimis [isto é, com uma intensidade muito pequena], é possível que no tempo certo possa ser encontrado um meio de coletar uma grande quantidade dela. ${ }^{16}$ Consequentemente, [será então possível] aumentar a força (force) desse fogo elétrico, ${ }^{17}$ o qual, por meio de vários outros experimentos (Si licet magnis componere parva $)^{18}$ parece ser da mesma natureza

a finger, dedo.

${ }^{13}$ A ilustração de uma possível conformação deste experimento pode ser vista na Figura 11.13 .

${ }^{14}$ A ilustração de uma possível conformação deste experimento pode ser vista na Figura 11.14 .

${ }^{15}$ A chama mencionada por Gray provavelmente refere-se à faísca ou luz emitida pelos objetos, a explosão refere-se aos estalidos, e a ebulição da água fria provavelmente refere-se às gotículas de água que se depositam no tubo eletrizado quando colocado próximo à superfície da água.

${ }^{16}$ Isto é, da chama de fogo ou faísca elétrica.

${ }^{17}$ Experiências realizadas posteriormente com a garrafa de Leiden confirmaram estas previsões de Gray, ver o Capítulo 12. Foi então possível não apenas armazenar a eletricidade, mas aumentar bastante os efeitos observados nas descargas elétricas.

${ }^{18}$ Esta é uma citação de um poema contido na obra Geórgicas do poeta romano Virgílio (70-19 a.C.). Tradução: Se for permitido comparar as coisas pequenas com as coisas grandes. 


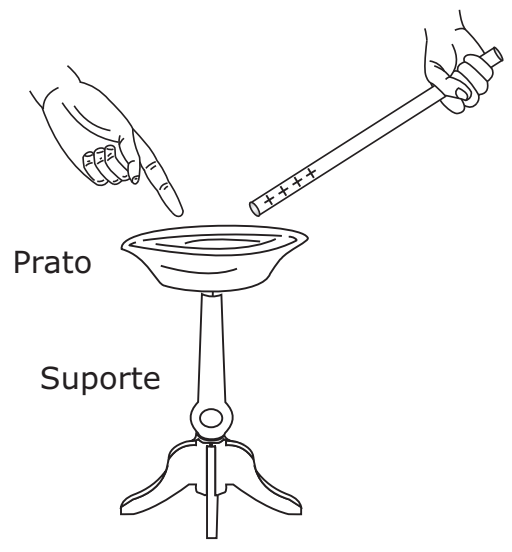

Figura 11.14: Um dedo está próximo da água do prato. Ao aproximar do dedo um tubo de vidro bem eletrizado, o dedo é empurrado e ouve-se um estalido.

do trovão e do raio. ${ }^{19}$

Gray descreveu diversas outras experiências relacionando o poder das pontas com as descargas elétricas através do ar, além de fazer algumas experiências mostrando a conservação da carga elétrica. ${ }^{20}$ Não entraremos em detalhes neste livro.

Benjamin Franklin (1706-1790) foi um autodidata que teve muitas atividades diferentes. Dedicou-se a pesquisas elétricas principalmente entre 1743 e 1753 após ouvir umas palestras públicas sobre este tema. ${ }^{21}$ Recebeu de presente um tubo de vidro que era facilmente eletrizado por atrito e que se comportava como um bom isolante elétrico. Adquiriu também um kit com alguns dos instrumentos elétricos típicos da época, dando então início às suas experiências. Descreveu para colegas europeus os resultados que obteve na Filadélfia através de cartas que tiveram grande circulação, sendo publicadas em conjunto pela primeira vez em Londres em 1751 na forma de um livro. Esta obra foi sendo ampliada em várias edições até 1774, sendo conhecida por seu título: Experiências e Observações sobre Eletricidade. ${ }^{22}$ Este livro teve um grande impacto na ciência de seu tempo, sendo traduzido para diversos idiomas. Vários termos utilizados hoje em dia na eletricidade são devidos a Franklin tais como "mais e menos" ou "positivo e negativo", "bateria elétrica", etc. Forneceu a explicação do funcionamento da garrafa de Leiden, difundiu o capacitor de placas paralelas, deu grande ênfase ao poder das pontas, além de ser um dos principais responsáveis

\footnotetext{
${ }^{19}$ Esta sugestão de Gray de que o raio e o trovão seriam fenômenos elétricos análogos às faíscas e estalidos que observou, mas com intensidade muito maior, foi depois confirmada pelas experiências da década de 1750, realizadas após os trabalhos de Benjamin Franklin.

${ }^{20}$ [Bos11] e [BAC12]; juntamente com a Seção 6.10 de [Ass10b], [Ass10a], [Ass11], [Ass15b] e [Ass17].

21 [Hei99, Capítulo 14], [SP06], [SP08] e [MB17].

22 [Fra69], [Fra41] e [Mor04b].
} 
pelo estabelecimento e utilização da lei de conservação das cargas elétricas. ${ }^{23}$ Os termos que utilizava para designar as partículas eletrizadas eram "fogo elétrico", "matéria elétrica" e "fluido elétrico". Ele trabalhava com a teoria de um único fluido elétrico, em vez de dois tipos distintos de eletricidade. Acreditava que havia uma quantidade ou densidade normal deste fluido nas substâncias. Quando um corpo estivesse eletrizado positivamente, seria devido ao fato de possuir mais fluido elétrico do que a quantidade normal. Da mesma forma, quando estivesse eletrizado negativamente, seria por possuir uma quantidade menor de fluido do que o normal. Hoje em dia adotamos a nomenclatura de Franklin, mas trabalhando com um paradigma diferente, a saber, aceitando a existência de dois tipos distintos de eletricidade ou de cargas elétricas.

Com sua concepção de conservação da carga elétrica, Franklin enfatizava que ela não era criada, gerada ou produzida no atrito entre duas substâncias, nem em qualquer outro processo de eletrização. A única coisa que ocorria durante o atrito era uma redistribuição ou transferência de carga. Isto é, um dos corpos recebia a mesma quantidade de fluido elétrico que o outro havia perdido.

Já em sua primeira correspondência de 1747, Franklin descreveu "o efeito maravilhoso dos corpos pontudos, tanto de extrair quanto de emitir o fogo elétrico." A primeira descrição é de como um condutor pontudo aterrado extrai o fluido elétrico de um outro condutor eletrizado que estava isolado da Terra, nossas palavras entre colchetes e nas notas de rodapé: ${ }^{24}$

Coloque uma bala de ferro ${ }^{25}$ tendo três ou quatro polegadas de diâmetro [7,6 a 10,2 cm] na boca de uma garrafa de vidro seca e limpa. ${ }^{26}$ Suspenda uma pequena bola de cortiça por uma fina linha de seda presa no teto, bem acima da boca da garrafa, tendo o tamanho aproximado de uma bola de gude; tendo o fio um comprimento tal que a bola de cortiça possa repousar sobre o lado da bala [de ferro]. Eletrize a bala [de ferro], então a bola [de cortiça] será repelida até a distância aproximada de quatro ou cinco polegadas [10,2 a $12,7 \mathrm{~cm}]$, de acordo com a quantidade de eletricidade [fornecida à bola de ferro].

Estando neste estado, se você apresentar à bala [de ferro] a ponta de um estilete comprido, fino e afiado, a uma distância de seis ou oito polegadas [15,2 a $20,3 \mathrm{~cm}]$, a repulsão é destruída imediatamente, e a cortiça voa para a bala. Para que um corpo rombudo produza o mesmo efeito, ele tem de ser trazido até a distância de uma polegada $[2,54 \mathrm{~cm}]$ e produzir uma faísca. Para provar que o fogo elétrico é extraído pela ponta, se você retirar a lâmina do estilete do cabo de madeira, e fixá-la em um pedaço de cera, e então apresentá-la à distância já mencionada, ou se você aproximála bastante, nenhum efeito deste tipo acontece; mas ao deslizar um dedo

\footnotetext{
${ }^{23}$ [Coh66], [Coh96] e [Hei99, Capítulo 14: Benjamin Franklin].

24 [Fra69, págs. 3-4], [Coh96, págs. 23-24], [Hei99, págs. 327-328] e [MB17].

${ }^{25}$ A expressão utilizado por Franklin foi "iron shot", que pode ser traduzida como uma bola, bala ou peso de ferro. Ao longo do texto ele vai falar também de uma "cork-ball", bola de cortiça. Para não confundir a palavra bola que poderia ser usada nas traduções destas duas expressões, vamos utilizar aqui a tradução de iron shot como sendo bala de ferro. Ela pode ser entendida como uma pequena bala de canhão.

${ }^{26}$ Esta garrafa de vidro comporta-se como um isolante.
} 
ao longo da cera até você tocar a lâmina, então a bola [de cortiça] voa para a bala [de ferro] imediatamente. ${ }^{27}$

Sua primeira descrição de como um condutor pontudo emite (ou arremessa) o fluido elétrico foi a seguinte: ${ }^{28}$

Coloque uma agulha longa e pontuda sobre a bala [de ferro descrita anteriormente], então você não consegue eletrizar a bala de tal forma que ela consiga repelir a bola de cortiça.

Neste caso temos novamente a bala de ferro isolada eletricamente da Terra por estar apoiada sobre a garrafa de vidro. Apesar disto, não conseguimos eletrizá-la, já que qualquer fluido elétrico adquirido por ela é perdido para o ar através da agulha pontuda.

Outra experiência similar que apresentou ilustrando a emissão do fluido elétrico: ${ }^{29}$

Fixe uma agulha à extremidade de um cano de arma, ou barra de ferro, de tal forma a apontar para fora dele como uma pequena baioneta; nestas circunstâncias o cano de arma, ou barra, não consegue ser eletrizado aplicando o tubo [eletrizado] na sua extremidade oposta de tal forma a produzir uma faísca, o fogo [isto é, fluido elétrico] saindo silenciosamente pela ponta.

Novamente a ponta metálica impede o acúmulo de cargas na extremidade da barra metálica em que se encontra.

A experiência descrita anteriormente na qual Franklin conseguiu extrair o fluido elétrico de um condutor isolado da Terra através de um outro condutor pontudo e aterrado, lhe inspirou uma maneira de testar a ideia de que raios e relâmpagos atmosféricos são fenômenos elétricos do mesmo tipo, apenas em escala bem maior. Em uma carta de 1750, publicada em 1751, propôs a experiência da guarita do sentinela para testar a eletrização das nuvens, nossas palavras entre colchetes: ${ }^{30}$

Para determinar a questão de saber se as nuvens que produzem raios são ou não eletrizadas, proporia uma experiência para ser testada onde possa ser feita convenientemente. No topo de alguma torre alta ou campanário, coloque um tipo de guarita de sentinela (como na Fig. 9 [ver a Figura 11.15]) grande o suficiente para conter um homem e um suporte elétrico [isto é, uma plataforma isolante]. Faça com que uma haste de ferro comece a partir do centro do suporte, sendo curvado para fora da porta, subindo então verticalmente por 20 ou 30 pés [6 ou $9 \mathrm{~m}$ ], terminando de forma

${ }^{27}$ A cera é um material isolante. Nesta última situação descrita por Franklin, a lâmina metálica não está mais aterrada inicialmente, já que a cera está funcionando como um cabo de suporte para a lâmina, isolando-a da mão do experimentador. Apenas quando o dedo toca a lâmina, esta lâmina passa a ficar aterrada, quando então ocorre a descarga da bola de ferro.

28 [Fra69, pág. 5] e [Coh96, pág. 24].

29 [Fra69, pág. 5] e [Coh96, pág. 24].

30 [Fra69, pág. 66], [Coh96, pág. 70], [Hei99, págs. 340-341] e [SP06]. 
bem afiada e pontuda. Se o suporte elétrico for mantido limpo e seco, um homem ficando em pé sobre ele quando tais nuvens estão passando a baixa altitude, poderia ser eletrizado e produzir faíscas, com a haste extraindo o fogo [elétrico] de uma nuvem. Se houver receio de qualquer perigo para o homem (embora ache que não haveria nenhum) deixe-o ficar em pé no chão de sua guarita, e então de vez em quando aproxime da haste o laço de um arame que tem uma extremidade presa à cobertura do telhado, com o homem segurando-o através de um cabo de cera [isto é, por um cabo isolante]; de tal forma que as faíscas, se a haste estiver eletrizada, irão da haste para o arame, e não vão afetá-lo.

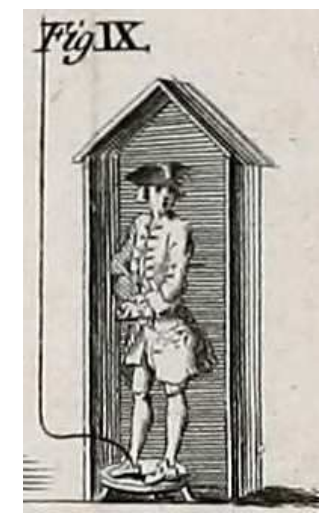

Figura 11.15: Experiência da guarita de sentinela sugerida por Franklin.

Franklin não chegou a fazer esta experiência. Ela foi realizada pela primeira vez em maio de 1752 na cidade de Marly, França, inspirado por esta previsão de Franklin. Foi feita pelo tradutor de seu livro para o francês, T. F. D'Alibard (1709-1778), sendo publicada logo em seguida: ${ }^{31}$

O Sr. D'Alibard escolheu, para este propósito [de verificar as conjecturas de Franklin sobre a analogia entre os raios e a eletricidade], um jardim situado em Marly, onde colocou sobre um corpo elétrico [isto é, sobre um isolante] uma barra pontuda de ferro, com 40 pés de altura [12 m]. No dia 10 de maio, às 2 horas e 20 minutos da tarde, tendo passado sobre o lugar onde estava a barra uma nuvem tempestuosa, aqueles que haviam sido designados para observá-la aproximaram-se [da barra], e atraíram dela faíscas de fogo, percebendo os mesmos tipos de comoções como aquelas que ocorrem nas experiências elétricas comuns.

O Sr. De Lor, ciente do sucesso desta experiência, decidiu repeti-la em sua residência em Estrapade em Paris. Levantou uma barra de ferro com 99 pés de altura [30 m], colocada sobre um bolo de resina [isolante], com dois pés quadrados [lado de $60 \mathrm{~cm}$ ] e espessura de 3 polegadas $[7,6 \mathrm{~cm}$ ]. No dia 18 de maio, entre 4 e 5 [horas] da tarde, tendo passado uma

\footnotetext{
${ }^{31}$ [Fra69, pág. 107], [Coh96, págs. 127-130] e [Hei99, págs. 349-351].
} 
nuvem tempestuosa sobre a barra, onde ele permaneceu por meia hora, obteve faíscas da barra. Estas faíscas eram como aquelas de uma arma, quando, nas experiências elétricas, o globo só é friccionado pela almofada [de um gerador elétrico que funciona por atrito], e elas produziram o mesmo barulho, o mesmo fogo, e o mesmo estalido. Foram obtidas as maiores faíscas na distância de 9 linhas $[1,9 \mathrm{~cm}]$, enquanto que a chuva, misturada com um pouco de granizo, caía da nuvem, sem que houvesse trovão ou raio; sendo esta nuvem, de acordo com as aparências, apenas a consequência de uma tempestade que ocorreu em algum outro lugar.

D'Alibard incluiu uma representação da experiência de Marly na segunda edição da tradução francesa do livro de Franklin, Figura 11.16. O aspecto principal a observar nesta montagem, é que a barra de ferro condutora está isolada eletricamente da Terra. Este isolamento é garantido pelas cordas de seda com a qual está amarrada e também pelas garrafas de vinho vazias que estão entre um banquinho e uma tábua de madeira na qual está apoiada a extremidade inferior da barra.

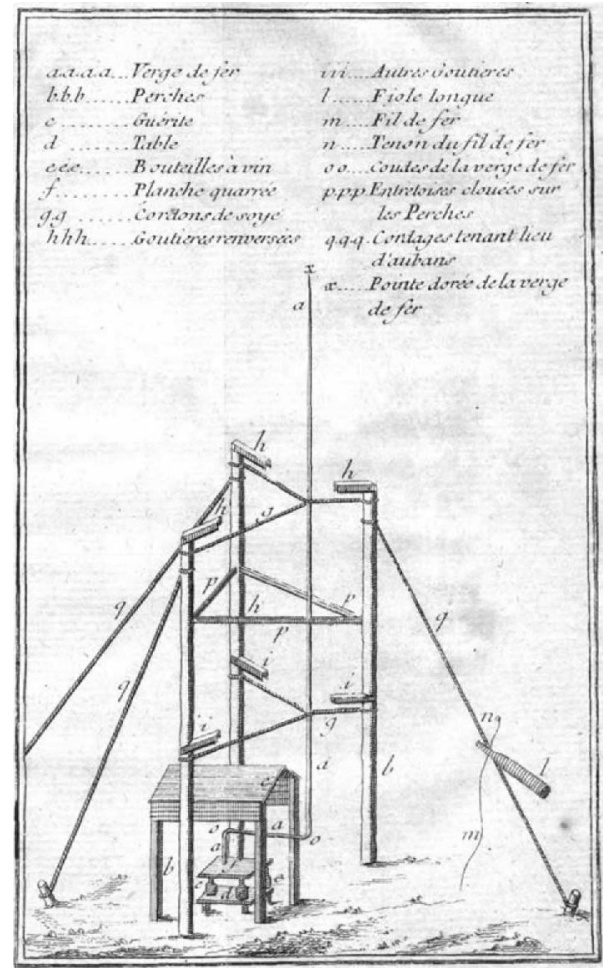

Figura 11.16: Barra de ferro isolada do solo.

Devido ao poder das pontas, quando houve uma alta diferença de potencial entre a nuvem eletrizada e a barra de ferro, o ar próximo à ponta superior da barra comportou-se como condutor. A barra condutora isolada adquiriu então 
um pouco da eletricidade da nuvem. Ao aproximar um condutor aterrado da barra eletrizada, foram produzidas faíscas com as mesmas propriedades que aquelas observadas nas experiências elétricas usuais. Estas foram as primeiras experiências que comprovaram a identidade dos raios e relâmpagos com a eletricidade. Alguns cientistas como Stephen Gray já haviam apresentado esta conjectura, mas Franklin foi o primeiro a propor uma experiência para testá-la. D'Alibard fez sua montagem influenciado diretamente pela previsão de Franklin. Outras experiências análogas foram feitas logo em seguida em diversos países utilizando barras condutoras isoladas eletricamente do solo.

As Experiências 11.1, 11.2 e 11.8 ilustram em baixa escala a experiência de Marly. Embora não tenhamos produzido faíscas nestas montagens, a eletrização de um eletroscópio e a orientação do versório pelo fio de teste vertical indicam alguns efeitos que ocorrem em um condutor isolado que tem uma ponta próxima de um outro corpo eletrizado.

Obviamente há um grande perigo ao fazer experiências como estas ao ar livre utilizando hastes condutoras isoladas da Terra. Em 1753 o cientista russo de origem alemã G. W. Richmann (1711-1753) morreu em São Petersburgo através de uma descarga de sua haste isolada enquanto realizava experiências deste tipo durante uma tempestade. ${ }^{32}$

Em 1752 Franklin sugeriu também uma experiência com uma pipa para testar a eletricidade das nuvens. Experiências deste tipo foram realizadas logo em seguida por diversos pesquisadores. ${ }^{33}$

Franklin tinha tanta confiança na identidade entre os relâmpagos e as descargas elétricas usuais, que mesmo antes que esta conjectura fosse de fato verificada na prática, já havia proposto em uma carta enviada em 1750 para Peter Collinson (1694-1768), publicada logo em seguida, a construção de para-raios para serem colocados como proteção de prédios. Como afirmado nas Seções $11.3 \mathrm{e}$ 11.4, existe uma grande diferença entre os para-raios de proteção e os para-raios de teste. Estes últimos são isolados eletricamente da Terra e têm como função coletar um pouco da eletricidade das nuvens ou da atmosfera. Já os para-raios de proteção são aterrados. A primeira proposta de Franklin de para-raios de proteção foi a seguinte: ${ }^{34}$

... não pode o conhecimento deste poder das pontas ser útil para a humanidade, ao preservar casas, igrejas, navios, etc. da queda de raios, nos guiando para fixar nas partes mais altas destes edifícios, hastes verticais de ferro pontudas como uma agulha, douradas para evitar a ferrugem, e a partir da base destas hastes [prender] um fio indo por fora do prédio penetrando no solo, ou descendo ao redor de uma das coberturas de um navio, até que alcance a água? Estas hastes pontudas não iriam provavelmente extrair o fogo elétrico silenciosamente de uma nuvem antes que ele fosse grande o suficiente para cair como um raio, protegendo-nos desta forma de um dano tão repentino e terrível?

32 [Coh96, págs. 5-6, 84-85, 113, 135, 157], [Hei99, págs. 352, 390, 391 e 460] e [Lom17].

33 [Coh96, págs. 5, 28, 67-70, 97, 125, 130], [Hei99, pág. 351] e [SP06].

34 [Fra69, págs. 65-66] e [Coh96, pág. 83]. 
A Experiência 11.7 ilustra em baixa escala o funcionamento de um pararaios. O eletroscópio eletrizado é descarregado através do fio aterrado próximo a ele, sem afetar a casa ao lado do fio que está separada dele através de um isolante.

Os primeiros para-raios foram instalados ainda em 1752 na Europa e na América do Norte, logo em seguida à experiência de Marly. ${ }^{35}$ Esta invenção deu grande fama a Franklin, motivou o estudo da eletricidade atmosférica tanto em períodos de chuva quanto de tempo bom, além de ser uma das primeiras aplicações práticas em grande escala do estudo da eletricidade.

\subsection{Aplicações do Poder das Pontas}

Apresentamos a seguir algumas aplicações do poder das pontas.

- Neste livro este efeito foi utilizado o tempo todo para eletrizar um eletroscópio ao raspar a borda da cartolina com um canudo ou régua plástica eletrizados. A eletrização é mais eficiente quando a cartolina é raspada em uma borda do que quando ela é raspada no centro de sua parte plana, já que na borda a cartolina é mais afiada. Ou seja, pode haver transferência de cargas para o eletroscópio não apenas pelo contato da cartolina com a régua plástica eletrizada, mas também pela simples aproximação entre a borda da cartolina e a régua plástica eletrizada. Neste último caso a eletrização do eletroscópio ocorre quando o ar entre a borda afiada e a régua plástica eletrizada fica ionizado, passando a se comportar como um condutor. ${ }^{36}$

- A utilização mais conhecida do poder das pontas é o para-raios.

- Uma outra aplicação importante ocorre no microscópio de efeito de campo construído em 1936 pelo físico Erwin Wilhelm Müller (1911-1977).

- Nos motores eletrostáticos e nos fenômenos associados ao chamado vento elétrico. $^{37}$

- Fotocopiadoras.

- Geradores do tipo van der Graaff.

- Microscópios de força atômica.

- Etc.

\footnotetext{
35 [Coh96, págs. 29, 67, 74, 82-83, 91 e 109].

36 [FM91, pág. 61].

37 [Jef71b], [Jef71a], [JW71] e [Jef73].
} 


\section{Capítulo 12}

\section{A Garrafa de Leiden e os Capacitores}

\subsection{Construindo um Capacitor}

Nesta Seção mostramos como construir um instrumento muito importante denominado hoje em dia de condensador ou capacitor. Uma de suas funções é a de armazenar cargas e energia elétrica. O primeiro deles, a chamada garrafa de Leiden, foi construído em 1745 e será discutido na Seção 12.5.

Um capacitor é essencialmente composto por dois condutores separados por um isolante. $\mathrm{O}$ isolante deve ser fino e os condutores devem ter faces quase que sobrepostas. Ele pode ter vários formatos (placas paralelas, garrafa, pote cilíndrico, ...). Antes de começar a construir este instrumento, é importante testar se o material que vai ser utilizado como isolante de fato comporta-se como esperado. Para isto deve-se utilizar o procedimento indicado na Figura 3.4. Se o material não descarregar um eletroscópio eletrizado enquanto o toca por uns 30 segundos, então será considerado um bom isolante, podendo ser utilizado para construir os capacitores. Daqui para a frente vamos utilizar como isolantes pratos e garrafas plásticas ou de isopor.

O capacitor mais simples é o de placas paralelas, inventado por pessoas ligadas a Benjamin Wilson (1721-1788) e difundido por Benjamin Franklin. ${ }^{1}$ Como isolante Franklin utilizava uma placa de vidro, mas aqui será feito com uma lâmina plástica rígida, com um pratinho plástico de festa ou então com uma lâmina retangular fina de isopor. De cada lado da lâmina isolante são colados dois papéis de alumínio de tamanho um pouco menor que o plástico e com o mesmo formato. Estas duas lâminas condutoras não podem se tocar, Figura 12.1.

Uma montagem muito comum, usualmente denominada de garrafa de Leiden, é a de uma garrafa plástica de água ou de refrigerante com 200 ou $300 \mathrm{ml}^{2}{ }^{2}$

\footnotetext{
${ }^{1}$ [Hei99, pág. 317, nota 31 e págs. 333-334, nota 29].

$2[\mathrm{MF}]$.
} 


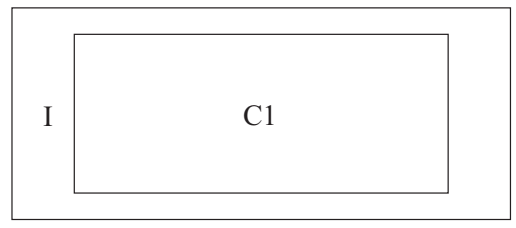

(a)

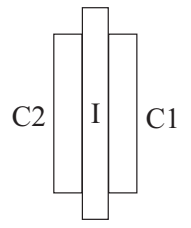

(b)

Figura 12.1: (a) Capacitor de placas paralelas retangular visto de cima: condutor $C 1$ acima do isolante $I$, sendo que abaixo do isolante tem o outro condutor $C 2$, que não aparece na figura da esquerda, tendo o mesmo formato e tamanho que o condutor $C 1$. (b) Sistema visto de lado.

Cola-se uma tira de papel de alumínio do lado de fora da garrafa, dando uma volta completa e cobrindo uns $3 / 4$ da altura lateral. Faz-se um furo no centro da tampa plástica e passa-se por este furo um arame rígido, prego ou parafuso comprido. O ideal é que o parafuso tenha uma cabeça arredondada que vai ficar no lado de fora, na parte de cima da tampa, para evitar perdas elétricas pelo poder das pontas quando o instrumento estiver eletrizado. A cabeça pode ter a forma de gancho ou então ser esférica, como uma bola metálica. O condutor interno pode ser simplesmente água de torneira. Outra alternativa é preencher a garrafa com papel de alumínio ou palha de aço (como aquelas utilizadas na cozinha). O arame, prego ou parafuso devem penetrar na água ou na palha de aço, Figura 12.2. Os condutores interno e externo às vezes são denominados de armadura interna e externa.

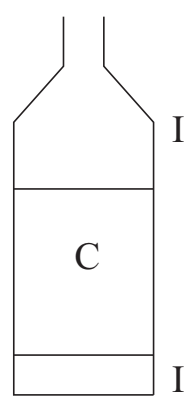

(a)

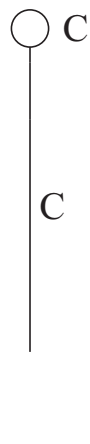

(b)

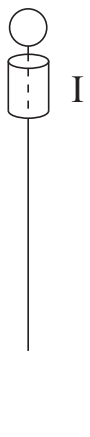

(c)

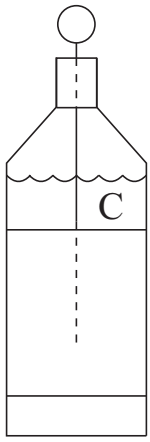

(d)

Figura 12.2: (a) Garrafa plástica isolante $I$ com uma faixa condutora $C$ do lado de fora. (b) Parafuso condutor $C$ com cabeça arredondada. (c) Tampa isolante $I$ com um furo no centro pelo qual passa o parafuso. (d) Capacitor montado preenchido com um condutor $C$ (água, papel de alumínio ou palha de aço).

Podem ser feitos capacitores de várias formas semelhantes. A seguir apresen- 
tamos alguns exemplos. ${ }^{3}$ (a) Usando potes plásticos de iogurte com uma tira de papel de alumínio por fora e preenchido na parte interna com papel de alumínio. (b) Utilizando pequenos potes plásticos cilíndricos (como os de vitamina $\mathrm{C}$, de medicamento ou de fio dental) com uma tira de papel de alumínio por fora e palha de aço por dentro. (c) Pode ser feito de canudo plástico com papel de alumínio por dentro e por fora, etc. A conexão do condutor interno com o exterior pode ser feita por um prego, arame, colchete ou clipe atravessando o centro da tampa plástica do recipiente.

O capacitor é um instrumento que armazena carga e energia elétrica. Podemos fazer as seguintes definições.

\section{Definição 12.1}

Diz-se que um capacitor está descarregado quando não existem cargas resultantes em nenhum dos condutores (ou seja, nos condutores dos dois lados da lâmina isolante no caso do capacitor de placas paralelas, ou nos condutores interno e externo de uma garrafa de Leiden). Diz-se que ele está carregado ou eletrizado quando tem uma carga elétrica $Q$ no condutor interno e uma carga $-Q$ no condutor externo.

Ou seja, a carga resultante de todo o sistema é nula quer o capacitor esteja carregado ou descarregado. A diferença é que, quando o capacitor está carregado, há uma energia elétrica acumulada que pode produzir muitos efeitos (choques, faíscas e descargas elétricas). Como a carga resultante é nula nos dois casos, seria mais apropriado dizer que no segundo caso o capacitor está polarizado eletricamente. Porém, como é uma terminologia de uso comum dizer que ele está carregado eletricamente neste segundo caso, vamos manter esta denominação. Mas deve-se ter em mente que não há carga resultante no capacitor como um todo, mesmo quando se diz que ele está carregado.

\subsubsection{Não se Deve Utilizar uma Garrafa de Vidro para Isolar o Condutor Interno do Condutor Externo}

Antes de prosseguir, é bom enfatizar mais uma vez que a maior parte das garrafas de vidro atuais comporta-se como um material condutor para as experiências de eletrostática, ver a Seção 4.3. Conhecemos pessoas que tentaram construir capacitores utilizando garrafas de vidro como materiais isolantes mas que não tiveram sucesso em reproduzir as experiências. A expressão "garrafa de Leiden" já sugere usualmente uma garrafa de vidro. Muitas pessoas acham que materiais como vidro, madeira, água, etc. são isolantes, já que os livros didáticos apresentam suas constantes dielétricas. Mas este não é o caso para as experiências de eletrostática, nas quais a maioria destas substâncias comporta-se como um condutor. Se utilizarmos uma garrafa condutora, não conseguiremos acumular

\footnotetext{
${ }^{3}$ [FM91, págs. 76-83], [Ferb, Garrafa de Leyden, pág. 31] e [Ferc, págs. 73-79].
} 
cargas opostas na parte interna e externa da garrafa, fazendo com que as experiências fracassem. Sobre este fato é bom lembrar de nosso relato pessoal na Seção 6.3.

Para utilizar uma garrafa de vidro funcionando como um isolante em um capacitor ou em uma garrafa de Leiden, ela tem de ter sido previamente testada com o método do eletroscópio descrito na Seção 3.1, Experiência 3.3, Figura 3.4. Somente se este teste indicar que este tipo de vidro comporta-se como isolante poderemos utilizar esta garrafa nas experiências.

\subsection{Experiências com o Capacitor}

\section{Experiência 12.1 - Carregando e descarregando um capacitor}

Inicialmente vamos utilizar um pequeno capacitor cilíndrico feito com um pote plástico de fio dental tendo uns $5 \mathrm{~cm}$ de altura e uns $3 \mathrm{~cm}$ de diâmetro, uma tira de alumínio do lado de fora, juntamente com palha de aço por dentro, Figura 12.3 (a). A palha de aço deve estar em contato com um prego passando pelo centro da tampa isolante, com a cabeça do prego do lado de fora, Figura $12.3(\mathrm{~b})$.

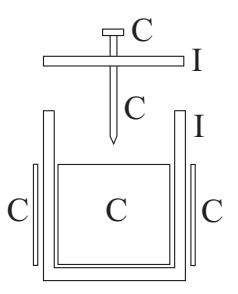

(a)

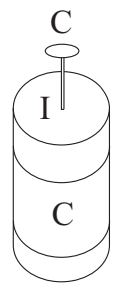

(b)

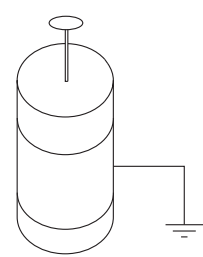

(c)

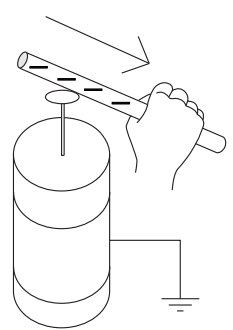

(d)

Figura 12.3: (a) Capacitor cilíndrico feito com condutores $C$ e isolantes $I$. (b) Sistema montado. (c) Capacitor aterrado. (d) Raspamos uma régua plástica eletrizada na cabeça do prego.

Inicialmente eletrizamos por atrito um canudo ou régua plástica. Aterramos o capacitor. Para isto, basta segurarmos o pote com uma mão tocando na tira de alumínio, Figura 12.3 (c). Com a outra mão esfregamos a régua plástica eletrizada pela cabeça do prego, Figura 12.3 (d). Este procedimento deve ser repetido várias vezes, sendo bom eletrizar algumas vezes a régua durante a atividade. Com a repetição deste procedimento, o capacitor fica bem eletrizado.

Daqui para a frente vamos assumir que o sistema está bem eletrizado. Seguramos o pote com a mão tocando na tira de papel de alumínio. A mão condutora tocando a tira está representada pela letra $C$ na Figura 12.4 (a). Então aproximamos um dedo da cabeça do prego. Sentimos um pequeno choque. Algumas vezes percebemos uma faísca e ouvimos uns estalidos no instante do choque, Figura 12.4 (b). 


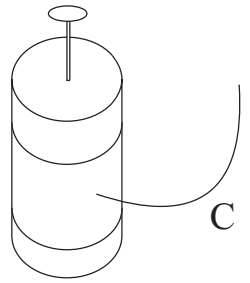

(a)

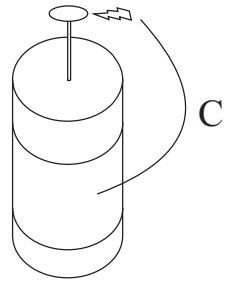

(b)

Figura 12.4: (a) Capacitor eletrizado com a mão condutora $C$ ligada à tira de papel de alumínio. (b) Ocorre uma faísca ao aproximar um dedo da cabeça do prego.

\section{Experiência 12.2 - Descarregando um capacitor sem tomar choque}

É possível fazer a Experiência 12.1 sem tomar choque. ${ }^{4} \mathrm{O}$ choque pode ser evitado isolando de nosso corpo o condutor ligado à faixa de papel de alumínio. Este condutor não será mais a nossa mão, mas um colchete com uma perna presa à tira de papel de alumínio. A cabeça do colchete vai estar inicialmente um pouco afastada da cabeça do prego que está enfiado na tampa do capacitor. A outra perna do colchete deve estar na horizontal, apontando para fora do capacitor, como indicado na Figura 12.5 (b).

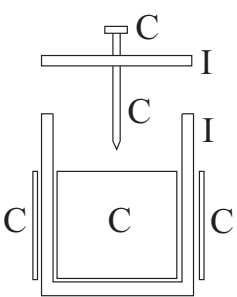

(a)

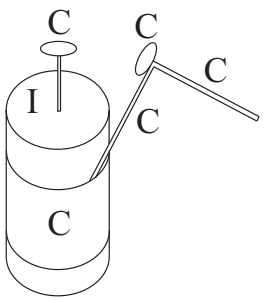

(b)

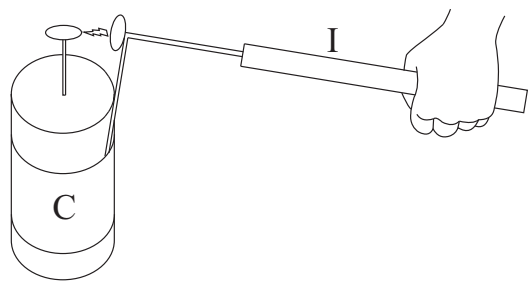

(c)

Figura 12.5: (a) Capacitor cilíndrico feito com condutores $C$ e isolantes $I$. (b) Sistema montado com um colchete condutor $C$ ligado à faixa de papel de alumínio. A cabeça do colchete está afastada da cabeça do prego. (c) Ocorre uma faísca quando a cabeça do colchete ligado à faixa de alumínio fica bem próxima da cabeça do prego.

Depois que o sistema está carregado, empurramos com uma régua de acrílico ou com um canudo plástico a cabeça do colchete em direção à cabeça do prego. Quando estiverem bem próximos, poderemos ouvir um estalido e perceber uma pequena faísca, Figura 12.5 (c).

Experiência 12.3 - Carregando um capacitor com um eletróforo

\footnotetext{
${ }^{4}$ [Ferc, pág. 73].
} 
A experiência 12.1 pode ser repetida mais facilmente carregando o capacitor com um eletróforo de Volta. Ou seja, enquanto seguramos o pote pela tira de papel de alumínio, tocamos a cabeça do prego por algumas vezes com o coletor eletrizado de um eletróforo de Volta. Depois que o sistema estiver eletrizado, basta tocar com a mesma mão na tira de papel de alumínio e na cabeça do prego para então sentir o choque.

\section{Experiência 12.4 - Carregando e descarregando uma garrafa de Leiden}

Mostramos agora como obter efeitos maiores, de grande intensidade, utilizando uma garrafa de Leiden composta de uma garrafa plástica de 200 ou 300 ml. Usamos também um eletróforo de Volta composto por uma forma de pizza com $30 \mathrm{~cm}$ de diâmetro com um cabo isolante em seu centro. Eletrizamos o coletor de cargas de um eletróforo de Volta, como representado pelo disco metálico eletrizado que está ao lado da garrafa de Leiden, Figura 12.6 (a). Este coletor de cargas deve ser segurado apenas pelo cabo isolante. Aterramos a tira de papel de alumínio externa do capacitor ao segurar nesta tira com a mão.

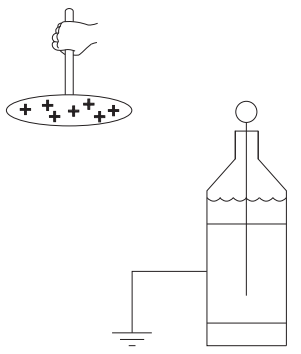

(a)

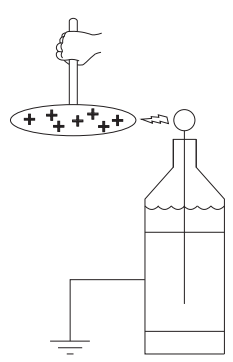

(b)

Figura 12.6: (a) Garrafa de Leiden aterrada e descarregada. Há um eletróforo de Volta carregado positivamente longe dela. (b) Ao aproximar o eletróforo do parafuso, ocorre uma faísca, carregando a garrafa.

Para eletrizar o capacitor, muitas vezes não é necessário encostar com o disco do coletor na cabeça arredondada do parafuso da garrafa, já que a simples aproximação entre eles já é suficiente para produzir uma faísca acompanhada de um estalido, principalmente se aproximarmos uma borda do disco da cabeça do parafuso, Figura 12.6 (b). Este procedimento deve ser repetido umas 5 ou 10 vezes para eletrizar bem o capacitor.

Vamos agora assumir que o capacitor já está bem carregado. Ele pode estar aterrado ou isolado da Terra. Tocamos com a mão em sua tira de papel de alumínio, Figura 12.7 (a). Pode-se então sentir um choque tocando simultaneamente com um dedo na tira de papel de alumínio e com outro dedo na cabeça do parafuso. Algumas vezes basta tocar na tira de papel de alumínio e aproximar um dedo da cabeça do parafuso, que já ocorre uma descarga elétrica no ar e sentimos o choque, Figura 12.7 (b).

Na Figura 12.8 (a) mostramos uma maneira de obter a faísca sem tomar choque. A garrafa de Leiden está eletrizada. Basta então pegar um fio metálico 


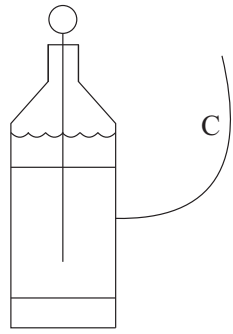

(a)

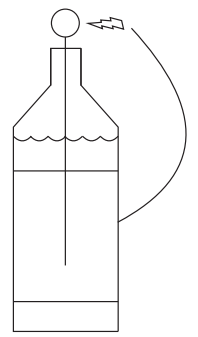

(b)

Figura 12.7: (a) Garrafa de Leiden eletrizada. Nossa mão pode tocar em sua tira de papel de alumínio. (b) Ao aproximar um dedo da cabeça do parafuso, ocorre uma faísca, descarregando a garrafa.

com uns $20 \mathrm{~cm}$ de comprimento, enrolando um lado na ponta de uma régua plástica, o outro lado na ponta de outra régua plástica, deixando as extremidades do fio saindo destas duas réguas.
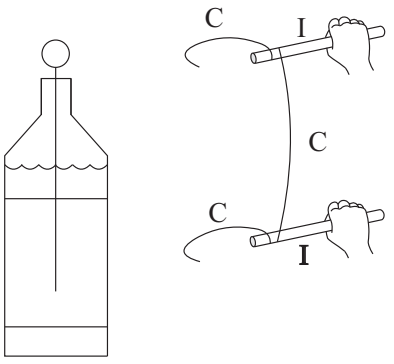

(a)

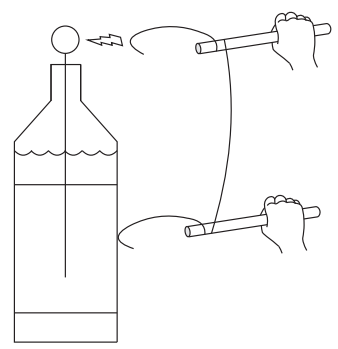

(b)

Figura 12.8: (a) Garrafa de Leiden eletrizada. Um único fio metálico $C$ enrolado nas extremidades de duas réguas plásticas $I$. (b) Descarregando a garrafa eletrizada ao ligar seus condutores interno e externo por meio de um fio metálico.

Segurando as réguas plásticas podemos então encostar um lado do fio na tira de papel de alumínio. Ao aproximar o outro lado do fio da cabeça do parafuso, observa-se uma faísca acompanhada de um estalido, Figura 12.8 (b).

Experiência 12.5 - Carregando um capacitor cilíndrico por sua faixa condutora lateral

Os capacitores das Experiências 12.1 e 12.3 também podem ser carregados raspando a régua plástica eletrizada na faixa de papel de alumínio presa no lado externo do pote. Para obter uma boa eletrização, o capacitor deve ser aterrado pelo condutor interno. Neste caso o ideal é que estejamos tocando com um dedo na cabeça do prego ou parafuso preso na tampa do capacitor, Figura 12.9 (a). 


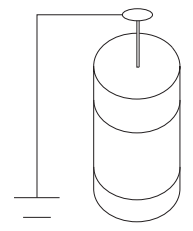

(a)

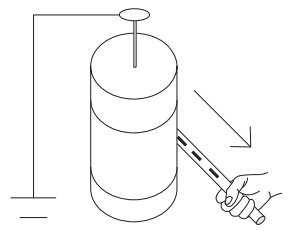

(b)

Figura 12.9: (a) Capacitor descarregado e aterrado por seu condutor interno. (b) Carregamento do capacitor ao raspar uma régua plástica eletrizada em seu condutor externo.

Estando o capacitor aterrado, raspamos então a régua plástica eletrizada em sua faixa condutora externa, Figura 12.9 (b).

Vamos supor que o capacitor esteja eletrizado. Encostamos um dedo na cabeça do prego, Figura 12.10 (a). Ao aproximarmos outro dedo da tira de papel de alumínio, sentimos o choque e às vezes percebemos a faísca, Figura 12.10 (b).

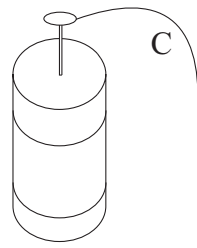

(a)

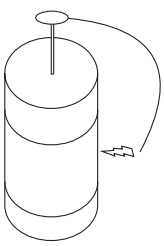

(b)

Figura 12.10: (a) Capacitor carregado com um condutor tocando no prego. (b) Ao aproximar o condutor da faixa condutora externa, produzimos uma faísca, sentimos um choque e descarregamos o capacitor.

Outra alternativa para eletrizar o capacitor pela faixa condutora externa utiliza um eletróforo de Volta. Neste caso, tocamos com um dedo na cabeça do prego ou parafuso enquanto tocamos ou aproximamos várias vezes o coletor de cargas de um eletróforo eletrizado na faixa de papel de alumínio. Depois que o sistema está eletrizado, basta tocar com a mesma mão na faixa de papel de alumínio e na cabeça do parafuso, que o choque também ocorre.

Experiência 12.6 - Aterrando qualquer dos dois condutores de um capacitor eletrizado sem descarregá-lo

Inicialmente carregamos os capacitores como nas Experiências 12.1 e 12.3, ou seja, com os capacitores aterrados durante o processo de carga. Em seguida tiramos a mão da faixa de papel de alumínio externa ao pote e deixamos o capacitor eletrizado sobre a mesa. As partes inferiores dos potes plásticos ou garrafas plásticas que estamos utilizando como capacitores são isolantes, Figuras 12.2 e 12.3 (b). Logo estes capacitores sobre a mesa estão isolados eletricamente 
da Terra. Caso haja algum pedaço do papel de alumínio indo para a parte debaixo do pote ou da garrafa plástica, então é importante apoiar o capacitor sobre um suporte isolante (como uma lâmina de isopor) antes de prosseguir esta experiência.

Encostamos então um dedo da cabeça do prego ou parafuso preso na tampa do capacitor, sem estar segurando o pote. Não sentimos choque.

Tiramos o dedo da cabeça do prego. Mantendo o capacitor carregado, tocamos agora com o dedo apenas na faixa lateral de papel de alumínio. Novamente não tomamos choque.

Porém, ao tocar simultaneamente com um dedo na cabeça do parafuso e com outro dedo na faixa de papel de alumínio, sentimos novamente o choque com a mesma intensidade de antes.

Esta é uma observação importante. Ou seja, se o capacitor eletrizado estiver isolado do solo, ele não é descarregado ao ser aterrado por nenhum de seus dois condutores. Isto é, podemos aterrar apenas a cabeça do parafuso de uma garrafa de Leiden eletrizada sem descarregá-la. Da mesma forma, se a garrafa eletrizada estiver isolada, podemos aterrar apenas sua faixa de papel de alumínio externo sem descarregar a garrafa.

Experiência 12.7 - Comparando as cargas adquiridas por um capacitor aterrado e por outro não aterrado

Vamos agora carregar o capacitor sem que ele esteja aterrado durante o processo de carga. Deixamos então a garrafa de Leiden inicialmente descarregada sobre a mesa. Vamos eletrizar a garrafa utilizando um eletróforo de Volta. Vamos supor que o coletor de cargas deste eletróforo seja um disco condutor preso por um cabo isolante. Depois que este coletor está eletrizado, aproximamos a borda do disco da cabeça do parafuso da garrafa. Observa-se uma faísca quando estão bem próximos.

Comparamos agora a faísca produzida nesta Experiência com aquela produzida nas Experiências 12.3 e 12.4 nas quais a garrafa estava aterrada. A primeira observação que pode ser feita é que esta faísca e seu estalido concomitante são menores do que a faísca e estalido que ocorrem ao seguir o mesmo procedimento com a garrafa aterrada.

O disco eletrizado do coletor de cargas é aproximado 5 vezes da cabeça do parafuso, para eletrizar bem o capacitor. Após este processo de carga, podemos descarregar o capacitor ao tocar simultaneamente na faixa de papel de alumínio e na cabeça do parafuso. Sentimos um pequeno choque durante esta descarga. Porém, este choque é menor do que aquele que sentimos ao descarregar um capacitor que foi eletrizado com as 5 aproximações entre o disco eletrizado do coletor de cargas e a cabeça do parafuso de um capacitor que estava aterrado pela faixa de papel de alumínio.

Repetimos o procedimento e carregamos o capacitor ao aproximar por 5 vezes o disco do eletróforo eletrizado da cabeça do parafuso, sem que o capacitor esteja aterrado. Se agora aterrarmos o parafuso do capacitor tocando nele com a mão, quase não sentimos choque e o capacitor fica totalmente descarregado. 
Repetimos o procedimento e carregamos o capacitor ao aproximar por 5 vezes o disco do eletróforo eletrizado da cabeça do parafuso, novamente sem que o capacitor esteja aterrado. Ao aproximar as costas da mão da faixa externa de papel de alumínio da garrafa, sentimos os pelos da mão sendo atraídos pela faixa. Ao tocar na faixa, sentimos algumas vezes um pequeno choque. Neste caso a garrafa não fica descarregada. Ao tocar em seguida simultaneamente na faixa e na cabeça do parafuso, às vezes se sente um pequeno choque.

\subsection{Funcionamento do Capacitor}

Pode-se entender estas experiências utilizando o fato do plástico entre os condutores ser um isolante. Este isolante evita a troca de partículas eletrizadas entre os condutores interno e externo de uma garrafa de Leiden. Vamos analisar o caso em que a garrafa vai sendo carregada enquanto está aterrada, ou seja, enquanto seguramos a faixa de papel de alumínio externa pela mão. Vamos supor que estamos raspando uma régua plástica positivamente eletrizada na cabeça do parafuso, ou então que aproximamos da cabeça do parafuso o coletor de cargas positivamente eletrizado de um eletróforo, obtendo faíscas entre o coletor e o parafuso. O condutor interno do capacitor fica então eletrizado com carga de mesmo sinal que aquela da régua ou do coletor de cargas. Neste exemplo o condutor interno fica positivamente eletrizado. Como a faixa de papel de alumínio está aterrada, ocorre uma troca de cargas com o solo, de tal forma que a tira de papel de alumínio fica negativamente eletrizada. As cargas positivas do condutor interno distribuem-se preferencialmente na superfície deste condutor que está próxima do condutor externo. As cargas negativas do condutor externo distribuem-se preferencialmente na superfície deste condutor que está próxima do condutor interno.

Na Figura 12.11 representamos capacitores carregados com diversos formatos. Indicamos por $C 1$ e $C 2$ seus dois condutores, enquanto que o isolante que os separa é representado pela letra $I$.

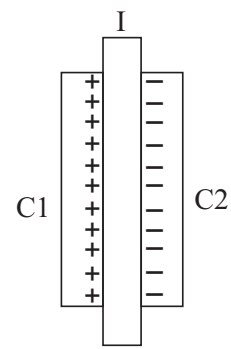

(a)

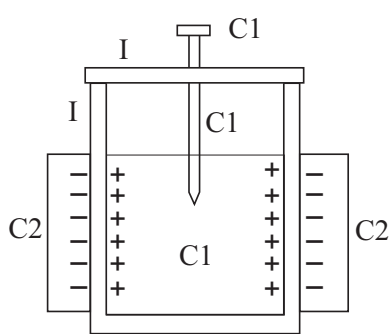

(b)

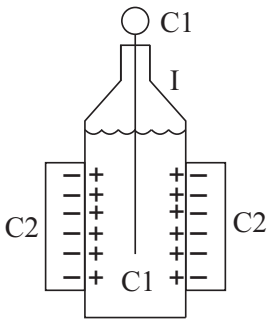

(c)

Figura 12.11: Capacitores carregados. (a) Placas paralelas. (b) Capacitor cilíndrico. (c) Garrafa de Leiden.

Na Figura 12.11 (a) temos um capacitor de cargas paralelas visto de perfil, 
na Figura 12.11 (b) temos um capacitor cilíndrico, enquanto que na Figura 12.11 (c) temos uma garrafa de Leiden. Exageramos a espessura da faixa de papel de alumínio externa para enfatizar que suas cargas se distribuem principalmente em sua face interna. As três distribuições de carga são apenas qualitativas.

Se aterrarmos apenas um dos condutores, mantendo a garrafa isolada do solo, ela não se descarrega devido à atração entre suas cargas opostas.

Por outro lado, se for feita a ligação entre $C 1$ e $C 2$ por um fio condutor, o capacitor será descarregado, havendo a neutralização entre suas cargas interna e externa através do fio.

\subsection{Gray, Du Fay e a Eletrização da Água}

Stephen Gray descobriu os condutores e isolantes em 1729, publicando seus resultados em 1731, sendo este trabalho um dos artigos mais importantes da história da eletricidade. ${ }^{5}$ No Volume 1 deste livro apresentamos uma descrição detalhada do trabalho de Gray. ${ }^{6}$ Entre as substâncias isolantes que descreveu encontravam-se uma linha de seda, crina de cavalo, resina endurecida, vidro aquecido, bolachas ou tabletes de cera de abelha, enxofre e goma-laca. Utilizava um tubo de vidro de flint-glass (vidro composto de chumbo) que eletrizava ao atritá-lo contra a mão. Segurava este vidro eletrizado com a mão e atraía corpos leves com ele. Este vidro era um bom isolante e adquiria uma grande densidade superficial de carga. Conseguiu transmitir a virtude atrativa deste vidro eletrizado a diversos condutores. Para obter este efeito, o condutor ficava isolado eletricamente da Terra, sendo apoiado por isolantes ou suspenso por fios de seda. Ao aproximar o tubo eletrizado de uma extremidade deste condutor, observava que a outra extremidade do condutor passava a atrair corpos leves. Entre outras coisas, conseguiu transmitir esta virtude atrativa para uma bolha de água. Citamos aqui um trecho de seu trabalho com nossas palavras entre colchetes: ${ }^{7}$

Em 23 de março [de 1730] dissolvi sabão na água do [rio] Tâmisa, então suspendi um cachimbo por uma linha fina [hair-line, provavelmente uma linha isolante feita de seda ou de crina de cavalo], de tal forma que ficasse quase na horizontal, com a boca da cabeça do cachimbo para baixo. Então, tendo mergulhado o cachimbo na solução de sabão, e assoprado uma bolha, a lâmina de latão estando sobre um suporte abaixo da bolha, sendo o tubo atritado, o latão foi atraído pela bolha, quando o tubo foi mantido próximo da linha fina. Repeti então a experiência com uma outra bolha, segurando o tubo próximo da ponta pequena do cachimbo, e a atração foi agora muito maior [do que antes], a lâmina de latão foi atraída até a altura de aproximadamente duas polegadas $[5 \mathrm{~cm}]$.

\footnotetext{
$7]$.

${ }^{5}$ [Graf] com tradução para a língua portuguesa em [Bos11, Capítulo 6] e [BAC12, Capítulo

${ }^{6}$ Apêndice B de [Ass10b], [Ass10a], [Ass11], [Ass15b] e [Ass17].

${ }^{7}$ [Graf, págs. 38-39], [Bos11, págs. 165-166] e [BAC12, págs. 162-163].
} 
Esta experiência, representada na Figura 12.12 (a), ilustra mais uma vez que a água se comporta como um condutor, neste caso uma água cheia de sabão. Na Figura 12.12 (b) apresentamos a distribuição qualitativa de cargas nesta experiência.

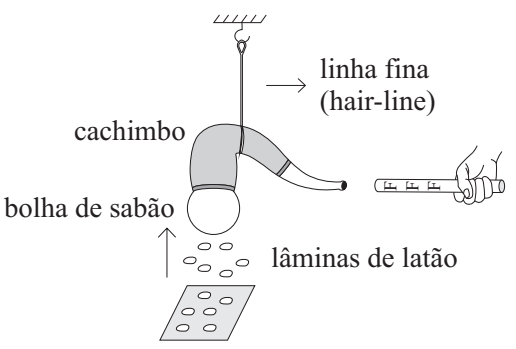

(a)

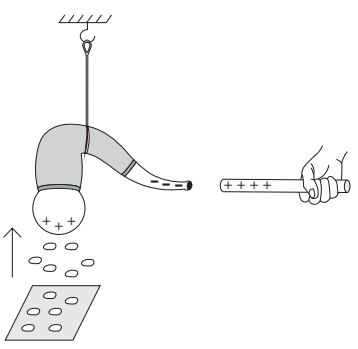

(b)

Figura 12.12: (a) Uma bolha de sabão atraindo lâminas leves de latão quando o tubo de vidro atritado está próximo da outra extremidade do cachimbo suspenso por uma linha fina isolante. (b) Representação qualitativa das cargas no tubo de vidro, no cachimbo e na bolha.

Gray conseguiu transmitir a capacidade de atrair corpos leves a diversos condutores tais como metais, madeira, etc. Já os materiais isolantes não conseguem atrair com tanta força. Os isolantes ficam bem menos polarizados na presença de um corpo eletrizado do que os condutores na presença deste mesmo corpo eletrizado. ${ }^{8}$

A interpretação atual desta experiência é a de que o cachimbo e a bolha comportaram-se como condutores, enquanto que a linha fina era um isolante (provavelmente um fio de seda ou uma crina de cavalo). Vamos supor que o bastão de vidro estivesse positivamente eletrizado. Ao aproximá-lo da ponta do cachimbo, este teria ficado polarizado eletricamente. A ponta fina do cachimbo teria ficado negativa e a bolha de sabão teria ficado positiva. A bolha eletrizada passou então a atrair pequenas lâminas de latão que estavam no chão abaixo dela.

Em 1731 Gray conseguiu eletrizar a água por um outro processo. Prendeu um prato de madeira sobre um suporte de vidro isolante. Colocou água no prato e passou algumas vezes um tubo eletrizado bem próximo à superfície da água, sem tocá-la. Ao retirar o tubo, percebeu com alguns testes que a água tinha ficado eletrizada. Citamos um trecho deste trabalho com nossas palavras entre colchetes e nas notas de rodapé: 9

I. Na apresentação anterior dos meus experimentos, descrevi uma maneira de comunicar uma atração para uma bolha de água com sabão. Mas agora encontrei que até mesmo um corpo de água recebe uma virtude atrativa e

\footnotetext{
${ }^{8}$ Ver as Seções 7.3, 7.6, 7.7, 7.9 e 8.3 de [Ass10b], [Ass10a], [Ass11], [Ass15b] e [Ass17].

9 [Grab, págs. 227-228], com tradução para a língua portuguesa em [Bos11, págs. 211-214] e [BAC12, Capítulo 8, págs. 172-174]; [DF33a, págs. 34-35] e [Hei99, pág. 253].
} 
também uma virtude repulsiva pela aplicação do tubo excitado próximo a ele, da mesma maneira que adquirem os corpos sólidos. ${ }^{10}$ Para executar este experimento girei um prato (dish) de madeira [para fazer] um buraco com rosca no fundo, de forma que [o buraco] não atravessasse a madeira. Este [prato] foi parafusado na extremidade superior de um dos suportes que tenho mencionado em outros experimentos, sendo retirada a outra extremidade superior. ${ }^{11} \mathrm{O}$ prato tinha aproximadamente quatro polegadas [10,2 cm] de diâmetro e uma polegada $[2,54 \mathrm{~cm}]$ de profundidade. Então, o suporte foi fixado sobre um pedaço de resina, ou sobre uma placa de vidro, ou sobre a borda de um copo, ou sobre um copo cilíndrico, tais como são utilizados para copos de água. O vidro deve ser inicialmente aquecido, então o prato é enchido com água. ${ }^{12} \mathrm{O}$ tubo atritado é movimentado embaixo do prato e em cima da água três ou quatro vezes, sem tocá-los. ${ }^{13}$ Depois de ter sido excitado, não só o prato, mas também a água tornase elétrica. ${ }^{14}$ E se um pequeno pedaço de linha, ${ }^{15}$ ou uma estreita tira de papel fino, ou um pedaço de folha de latão (sheet-brass), geralmente chamado de ouropel, ${ }^{16}$ for mantido sobre a água em uma posição horizontal, [a uma distância de] aproximadamente uma polegada $[2,54 \mathrm{~cm}] \mathrm{ou}$ algumas vezes mais, qualquer um dos corpos $\operatorname{citados}^{17}$ será atraído para a superfície da água, e será repelido, mas não tão frequentemente como por [corpos] sólidos. ${ }^{18}$ Se uma linha pendular for colocada a certa distância do lado de fora do prato, ela será atraída e repelida [pelo prato] muitas vezes seguidas com um movimento muito rápido, ${ }^{19}$ mas não a uma distância

\footnotetext{
${ }^{10}$ Grifo do autor. Ou seja, assim como um sólido pode receber uma virtude atrativa ou repulsiva pela aproximação de um tubo de vidro eletrizado, o mesmo pode ocorrer com um volume de água.

${ }^{11}$ Top no original em língua inglesa. Gray parece estar se referindo a algum outro objeto que estava preso à parte superior do suporte nas experiências anteriores.

${ }^{12} \mathrm{Ou}$ seja, o suporte do prato de madeira com água estava apoiado sobre um material isolante: um pedaço de resina ou um pedaço de vidro aquecido.

${ }^{13}$ Uma ilustração deste procedimento pode ser vista na Figura 12.13.

${ }^{14}$ Uma ilustração de como Gray pode ter concluído que o prato com água estava eletrizado encontra-se na Figura 12.14.

15 "Thread" no original. Provavelmente trata-se de um pequeno pedaço de uma linha de algodão ou de linho. Estes materiais comportam-se como condutores nas experiências usuais de eletrostática.

16 "Tinsel" no original. Ou seja, uma tira ou folha delgada de latão.

${ }^{17}$ Todos os corpos aqui citados (linha de algodão, tira de papel e lâmina de latão) comportam-se como condutores.

${ }^{18}$ Como Gray está falando de atração e repulsão, ele pode ter observado algum fenômeno similar ao mecanismo $A C R$. Se este foi o caso, então provavelmente estes materiais (pedaço de linha, tira de papel ou folha de latão) foram mantidos na horizontal ao terem uma de suas extremidades presas por algum cabo isolante, enquanto que a extremidade livre ficava na horizontal sobre a água.

${ }^{19}$ Gray não especificou de que material foi feita esta linha pendular. Contudo, neste exemplo em particular, afirma que a linha pendular "será atraída e repelida [pelo prato] muitas vezes seguidas com um movimento muito rápido." Para que ocorra este movimento repetido de atração e repulsão, o que nos parece mais provável é que esta linha pendular seja similar ao pêndulo elétrico que descreveu em 1720 [Graa, pág. 107]. Isto é, uma vareta de madeira tinha uma fina linha de seda presa em sua ponta. Na extremidade inferior da linha de seda era presa uma penugem. Gray segurava a vareta com a mão e a linha de seda ficava na vertical, com a penugem na extremidade inferior. Embora a vareta de madeira se comporte como um condutor, isto não é relevante neste caso. Os aspectos cruciais são que a linha de seda se
} 
tão grande como quando o prato está vazio.

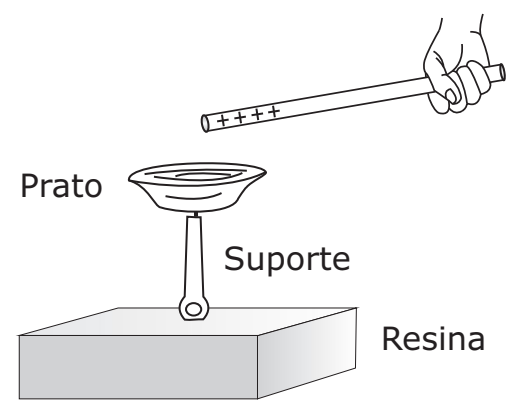

Figura 12.13: Prato com água fixado ao suporte que está sobre um pedaço de resina isolante. Movimenta-se o tubo eletrizado tanto por cima da água quanto por baixo do prato, sem que o tubo toque o prato ou a água.

Neste experimento, provavelmente o suporte é de madeira. Sendo assim, a menos da base de resina que é isolante, os outros corpos, i.e., a água, o prato e o suporte, são condutores elétricos. Com isso, é possível que o tubo tenha eletrizado não somente a água, mas todo o conjunto condutor em contato com a água. A eletrização provavelmente ocorreu devido a faíscas ou pequenas descargas elétricas entre o tubo de vidro eletrizado e a água. Caso tenha sido isto que tenha ocorrido nesta experiência, então o conjunto de prato e água devem ter ficado eletrizados com carga de mesmo sinal que a eletrização do tubo de vidro. Ou seja, neste caso não teria havido uma simples polarização elétrica do conjunto (como ocorreu na experiência do cachimbo e bolha de sabão), já que agora o sistema prato e água teria uma carga resultante diferente de zero. A Figura 12.15 ilustra uma possível maneira de como Gray pode ter concluído que a água ficou eletrizada.

O prato com água, supondo ambos condutores $(C)$, está apoiado sobre um material isolante $I$. Quando o sistema não está eletrizado como na Figura 12.15 (a), pode-se aproximar uma tira de papel condutora na horizontal que ela não é atraída pela água. Em seguida aproxima-se algumas vezes um tubo eletrizado do prato com água. Depois disto afasta-se o tubo. Ao aproximar novamente a

comporta como um isolante, enquanto que a penugem se comporta como um condutor.

Pode ser obtida uma sequência de atrações e repulsões com um pêndulo elétrico ao colocá-lo entre um corpo eletrizado e um condutor aterrado, ver a Experiência 4.15 de [Ass10b], [Ass10a], [Ass11], [Ass15b] e [Ass17]. No caso específico desta experiência de Gray, a penugem de seu pêndulo elétrico seria mantida pela linha de seda à qual estava presa na mesma altura do prato eletrizado. A penugem ficaria entre o prato eletrizado e um corpo aterrado, que vamos supor que seja um dedo de uma das mãos de Gray. Ao aproximar o pêndulo do prato eletrizado, a penugem é atraída pelo prato, toca nele, adquire uma carga de mesmo sinal que o prato, passa a ser repelida por ele, toca no dedo de Gray que está do outro lado da penugem, sendo então descarregada neste aterramento. Ela então volta a ser atraída pelo prato eletrizado e todo o procedimento se repete. Este movimento vibratório de atração e repulsão continuará até que o prato tenha sido descarregado, quando então deixará de atrair a penugem. Ver a Figura 12.14. 


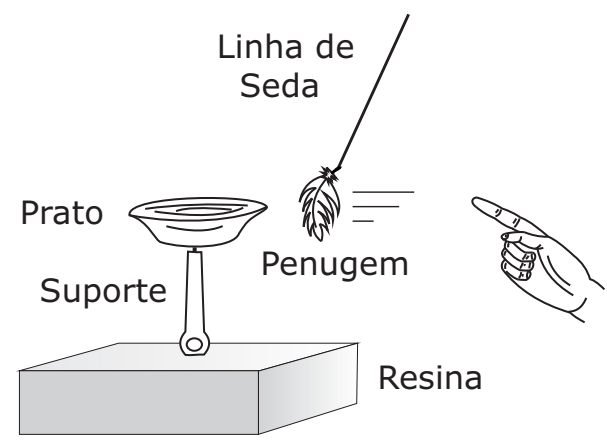

Figura 12.14: Depois que o prato com água estiver eletrizado, uma penugem condutora presa a uma linha de seda isolante é colocada nas proximidades do prato, ficando entre o prato e um dedo aterrado do outro lado. A penugem será então atraída pelo prato, ficará eletrizada ao tocar nele, sendo então repelida. Ela é descarregada ao tocar no dedo do outro lado, sendo então todo o procedimento repetido até que o prato tenha sido descarregado.

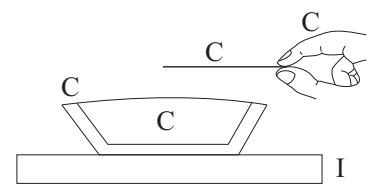

(a)

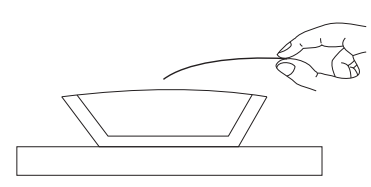

(b)

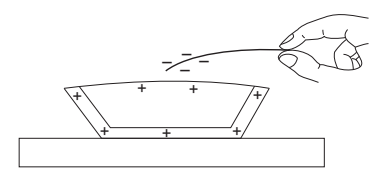

(c)

Figura 12.15: Prato com água apoiado sobre um suporte. Condutores representados pela letra $C$, enquanto o isolante está representado pela letra $I$. (a) Quando a água está neutra, não ocorre qualquer atração (b) Água eletrizada atraindo uma tira condutora. (c) Distribuição de cargas nesta experiência.

tira de papel na horizontal, observa-se que ela é agora atraída pela água, Figura 12.15 (b). Esta atração indica que a água ficou carregada durante a aproximação do tubo de vidro eletrizado. Na Figura 12.15 (c) ilustramos a água positivamente eletrizada induzindo cargas opostas na tira de papel aterrada e fazendo com que a tira seja atraída pela água.

Seguindo estas e outras descobertas de Gray, em 1733 Du Fay concluiu que quase todos os corpos inicialmente neutros podiam ser eletrizados se entrassem em contato (ou ao menos ficassem muito próximos) de um outro corpo que já estivesse eletrizado. ${ }^{20}$ Para que ocorresse esta eletrização, o corpo inicialmente neutro deveria ser um condutor, além de estar isolado da Terra. Um exemplo deste processo ocorre no chamado mecanismo $A C R$ descrito na Seção 4.4, Figura 4.11. Ou seja, atração, comunicação de eletricidade e repulsão. ${ }^{21}$ A carga adquirida pelo corpo inicialmente neutro é do mesmo tipo que a carga do iso-

\footnotetext{
20 [DF33a], [DF33c] e [Hei99, págs. 252-253].

${ }^{21}$ Seção 4.8 de [Ass10b], [Ass10a], [Ass11], [Ass15b] e [Ass17].
} 
lante eletrizado. Ficou conhecido como "regra de Du Fay" o princípio de que o corpo a ser eletrizado por este processo deveria estar isolado da Terra. Du Fay descreveu este mecanismo de eletrização da seguinte maneira, nossas palavras entre colchetes e na nota de rodapé: ${ }^{22}$

Vimos na primeira parte deste trabalho, ${ }^{23}$ que os líquidos podem ser eletrizados; sendo que a única maneira de ser bem sucedido em eletrizar [líquidos] pela aproximação do tubo [de vidro eletrizado] é a de colocálos em um pequeno recipiente de vidro, porcelana ou faiança [um tipo de cerâmica branca contendo menos caulim que a porcelana], e então colocar este recipiente sobre um suporte de vidro ou de cera de Espanha, pois tentaríamos em vão [esta experiência de eletrizar líquidos] caso colocássemos [o recipiente com o líquido] sobre [um suporte] feito de madeira ou metal; $[\ldots]$

O suporte de vidro e o suporte de cera de Espanha funcionavam aqui como isolantes. Du Fay afirmou que não conseguia eletrizar líquidos ao apoiá-los sobre suportes de madeira ou metal, isto é, sobre condutores aterrados. Desta forma Du Fay conseguiu eletrizar a água seguindo o procedimento que Gray já havia utilizado antes dele. Ou seja, aproximando um tubo eletrizado da superfície da água apoiada sobre um suporte isolante.

Du Fay também conseguiu eletrizar a água utilizando um novo procedimento, desta vez por contato com um outro condutor eletrizado. Inicialmente amarrou uma linha condutora em um tubo de vidro. Eletrizava o vidro ao atritá-lo com algum material apropriado. Após esta eletrização do vidro, a linha condutora presa a ele ficava polarizada. Ele então encostou a extremidade inferior desta linha na água, com a água colocada em um recipiente apoiado sobre um suporte isolante. Depois de afastar a linha, observou que a água tinha sido eletrizada. Apresentamos agora sua descrição desta experiência, com nossas palavras entre colchetes e na nota de rodapé: ${ }^{24}$

Em um outro volume das Transactions Philosophiques do ano passado, número $422,{ }^{25}$ o Sr. Gray mostrou que a água pode tornar-se elétrica. Vejamos de que maneira se faz esta experiência. Enche-se com água uma tigela de madeira, ou um pires de porcelana, e a colocamos sobre um destes pequenos pedestais, ou sobre um copo de vidro bem seco, e um pouco aquecido; pois quando tendo friccionado este tubo, o aproximamos do pires, passando-o acima e pelos lados duas ou três vezes, sem contudo tocá-lo, este procedimento já é suficiente para comunicar uma virtude elétrica bem perceptível à tigela, ou ao pires, e à água contida neles, o que pode ser verificado ao aproximar da superfície da água um fio de cabelo, ou um fio delicado em uma orientação horizontal, vê-se então que este fio se aproxima [da água] até que ele mergulhe nela. Consegui realizar esta experiência da maneira que acabei de descrever, e com igual facilidade,

22 [DF33c, pág. 84] e [Hei99, págs. 252-253].

${ }^{23}$ Ver [DF33a, págs. 33-34].

24 [DF33a, págs. 34-35] e [Hei99, pág. 253].

25 [Grab]. 
da maneira seguinte. Ajustei na extremidade de meu tubo [de vidro] uma rolha de cortiça na qual estava preso um pedaço de barbante, [então,] ao eletrizar o tubo por atrito, mergulhei a extremidade do barbante na tigela cheia de água, colocada sobre um vidro aquecido, este procedimento comunicou a virtude [elétrica] à superfície da água, da mesma forma que ocorreu pela operação precedente, sendo provável que ocorra o mesmo com todos os líquidos, mas deve ser observado que esta virtude [elétrica] tem uma intensidade menor na água do que nos corpos sólidos.

O procedimento de Du Fay para eletrizar a água está ilustrado na Figura 12.16. Seu bastão de vidro eletrizado comportava-se como um isolante, assim como o suporte sobre o qual ficava o recipiente com água. Tanto o barbante preso ao tubo de vidro quanto o prato e a água comportavam-se como condutores em sua experiência. Nesta figura os condutores estão representados pela letra $C$, enquanto que os isolantes estão representados pela letra $I$.

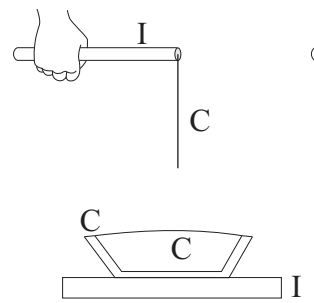

(a)

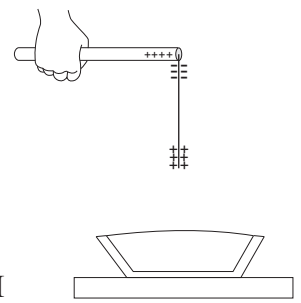

(b)

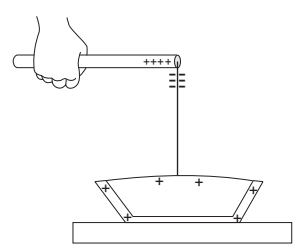

(c)

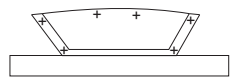

(d)

Figura 12.16: (a) Bastão de vidro isolante $I$ com barbante condutor $C$ na ponta. Prato com água condutora $C$ apoiado sobre um suporte isolante $I$. (b) Eletriza-se o bastão por atrito e o barbante fica polarizado. (c) Encosta-se o barbante na água e ocorre uma redistribuição das cargas na extremidade inferior do barbante, com a água ficando eletrizada. (d) Afasta-se o bastão com o barbante e a água fica eletrizada.

Caso a água estivesse em um recipiente condutor apoiado sobre um suporte condutor ligado ao solo (por exemplo, um suporte de madeira ou de metal), então não se conseguia eletrizar a água. Ela não era eletrizada nem pelo procedimento de Gray (passando bem próximo dela um tubo eletrizado e depois afastando o tubo), nem pelo procedimento de Du Fay (ligando um tubo eletrizado à água através de um fio condutor, depois afastando o tubo com o fio), como ilustrado na Figura 12.17.

Em princípio, ao eletrizar por atrito o tubo de vidro isolante, o barbante condutor preso a ele fica polarizado, Figura 12.17 (b). Ao encostar a extremidade inferior do barbante na água, todo o sistema fica aterrado. Neste exemplo a água, o prato e o suporte sob o prato comportam-se como condutores. Este aterramento faz com que sejam neutralizadas pelo solo as cargas que estavam na extremidade inferior do barbante, Figura 12.17 (c). Ao retirar o bastão com o barbante, a água não fica eletrizada neste caso, Figura 12.17 (d). 


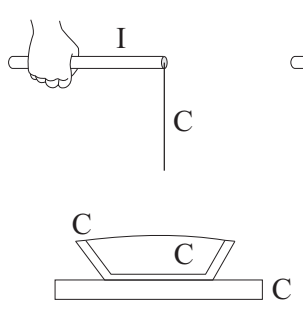

(a)

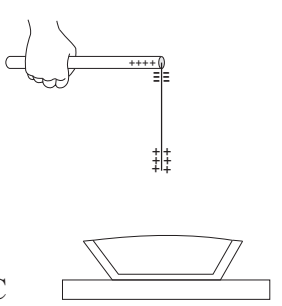

(b)

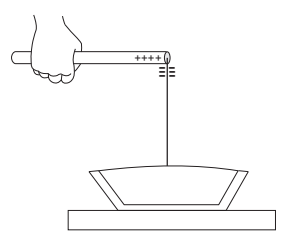

(c)

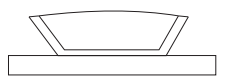

(d)

Figura 12.17: (a) Bastão de vidro isolante $I$ com barbante condutor $C$ na ponta. Prato condutor $C$ com água condutora $C$ apoiado sobre um suporte também condutor $C$ em contato com o solo. (b) Eletriza-se o bastão por atrito e o barbante fica polarizado. (c) Encosta-se o barbante na água e como o sistema está aterrado, ocorre uma neutralização das cargas na extremidade inferior do barbante. (d) Afasta-se o bastão com o barbante e a água não fica eletrizada.

\subsection{Os Primeiros Capacitores ou Condensado- res}

O condensador ou capacitor foi descoberto por acaso em 1745, na Alemanha e na Holanda. Ele ficou conhecido como garrafa de Leiden. ${ }^{26}$ No início ninguém entendia como ele funcionava, nem mesmo os cientistas que trabalhavam especificamente com eletricidade, já que violava a regra de Du Fay mencionada na Seção 12.4. A descoberta utilizava um gerador eletrostático que normalmente era um globo ou cilindro de vidro que girava ao redor de um eixo através de uma manivela. $\mathrm{O}$ vidro girando era atritado contra a mão de uma pessoa ou contra uma almofada, pano, couro ou outra substância apropriada. Em 1672 Guericke havia publicado algumas experiências como a de uma penugem flutuando acima de um globo de enxofre eletrizado por atrito. Francis Hauksbee construiu intencionalmente ao redor de 1708 os primeiros geradores elétricos. ${ }^{27}$ Ao redor de 1740 Georg Matthias Bose (1710-1761) introduziu uma melhoria nestes geradores, o chamado condutor primário. Ele nada mais era do que um condutor isolado eletricamente do solo. Podia ser uma espada, barra de ferro ou canhão. Uma extremidade do condutor primário ficava em contato ou muito próxima do vidro girando. Esta extremidade também podia estar em contato ou muito próxima de alguma almofada, pano, couro, pelo animal ou outro material que estivesse sendo atritado contra o vidro girante. Este condutor primário acumulava as cargas adquiridas pelo vidro atritado. Desta forma várias experiências de condução ou de descargas elétricas podiam ser feitas comodamente através de sua extremidade livre. ${ }^{28} \mathrm{O}$ condutor primário podia ser apoiado sobre suportes isolantes de vidro ou então suspenso por cordas de seda.

O primeiro condensador foi construído na Alemanha por Ewald Jürgen von

\footnotetext{
${ }^{26}$ [Whi73a, pág. 45], [Hei99, Capítulo XIII: The invention of the condenser] e [JG17].

${ }^{27}$ Seção 4.11 de [Ass10b], [Ass10a], [Ass11], [Ass15b] e [Ass17].

28 [Hei66] e [Hei99, págs. 264-265].
} 
Kleist (1700-1748) em 1745. Este pesquisador tinha um gerador eletrostático com um condutor primário ligado a ele. Conectou um fio metálico ligando o condutor primário até um recipiente com água. Este recipiente estava isolado eletricamente do solo. Ao fazer funcionar o gerador eletrostático, ele eletrizava o condutor primário e o recipiente com água. Conseguia produzir pequenas faíscas deste sistema eletrizado. Substituiu o recipiente com água por um carretel de madeira com um prego, conseguindo produzir faíscas do carretel ou do prego. Este sistema ainda estava isolado eletricamente do solo, embora ligado ao condutor primário eletrizado.

Vejamos agora sua descrição do condensador. Um prego foi introduzido em um vidrinho isolado do solo. Este sistema foi conectado ao gerador eletrostático através de um condutor. O gerador foi ligado e o sistema eletrizado. Só que desta vez ele por acaso fez algo diferente, já que segurou com a mão o sistema que já estava eletrizado. Ou seja, aterrou o sistema, em vez de deixá-lo isolado eletricamente do solo. Ao retirar o sistema do gerador, foram produzidos efeitos elétricos de maior potência e com maior duração do que os efeitos produzidos quando o vidrinho estava isolado do solo. Foi este procedimento casual que deu origem ao primeiro condensador: ${ }^{29}$

Se for introduzido um prego, um fio forte, etc. em um vidrinho de remédios com um pescoço estreito, e [o sistema for] eletrizado, efeitos especialmente poderosos serão produzidos. $\mathrm{O}$ vidrinho tem de estar bem seco e aquecido. Tudo funcionará ainda melhor se for adicionado [ao vidrinho] um pouco de mercúrio ou de álcool. A chama [ou clarão] aparece no vidrinho tão logo ele seja retirado da máquina [elétrica], e fui capaz de dar mais de sessenta passos pela sala utilizando a luz deste pequeno instrumento em chamas.

Na Figura 12.18 (a) apresentamos esquematicamente esta experiência.

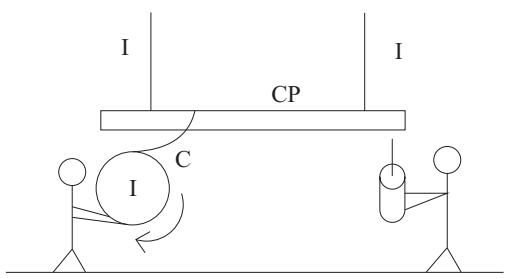

(a)

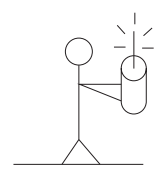

(b)

Figura 12.18: (a) Eletrização do vidrinho com prego. (b) Ao caminhar pela sala com o vidrinho na mão, o sistema brilha.

O gerador eletrostático é representado por um globo de vidro isolante girando ao redor do eixo. Ele é eletrizado ao ser atritado contra as mãos que o tocam. O condutor primário $C P$ está ligado ao globo por um fio condutor $C$, estando

\footnotetext{
${ }^{29}[$ Hei99, pág. 310].
} 
suspenso por cabos isolantes $I$. Ele é eletrizado por estar em contato com o globo girante que está sendo atritado. Uma pessoa segura um vidrinho com um prego preso ao vidro. Quando a ponta do prego toca ou fica bem próxima do condutor primário, o vidrinho fica eletrizado. Ao afastar o vidrinho do condutor primário e sair caminhando pela sala, o prego brilha por efeito corona (descargas elétricas no ar), Figura 12.18 (b). O vidrinho também pode ser eletrizado tocando com o prego diretamente no globo de vidro girante, ou com a ponta do prego ficando bem próxima do vidro girante, enquanto a pessoa segura o vidrinho.

Ele continuou sua descrição da seguinte forma: ${ }^{30}$

Quando eletrizo fortemente o prego, de tal forma que a luz no interior do vidrinho e as faíscas sejam visíveis, posso levá-lo para outra sala e acender vinho ou espírito de terebintina [através das faíscas produzidas pelo sistema].

Ele próprio ficou curioso com o funcionamento deste aparelho: ${ }^{31}$

O que realmente me surpreende em tudo isto é que o efeito poderoso só ocorre na mão. Não consigo acender nenhuma bebida alcoólica se ele [o instrumento] estiver sobre a mesa. Não importa quão fortemente eu eletrize o frasco, caso o coloque sobre a mesa e aproxime dele o meu dedo, não ocorre faísca, apenas um assobio ardente. Caso o segure novamente, sem eletrizá-lo mais uma vez, ele apresenta sua força original.

Pela regra de Du Fay mencionada na Seção 12.4, era de se esperar que o sistema descarregasse ao ser segurado pela mão. Mas não foi isto o que ocorreu. De fato aconteceu o oposto disto. Os efeitos elétricos aumentaram quando o vidrinho foi aterrado pela pessoa que o segurou enquanto caminhava pela sala. Ou seja, os efeitos ficaram maiores do que quando o vidrinho estava sobre a mesa.

Uma descoberta análoga foi feita de maneira independente na Holanda no mesmo ano de 1745. O professor de física experimental na cidade de Leiden, Pieter van Musschenbroek (1692-1761), inicialmente queria produzir faíscas a partir da água eletrizada. Para isto colocava um recipiente com água em um suporte isolante. Um fio ligava a água isolada ao condutor primário. Ao funcionar o gerador elétrico, ele eletrizava o condutor primário e a água conectada a ele. Ao aproximar então um dedo do condutor primário, faíscas eram produzidas. O advogado Andreas Cunaeus conhecia estas experiências por visitar o laboratório de Musschenbroek. Ao tentar repeti-las em casa, eletrizou a água enquanto segurava o recipiente, em vez de deixá-lo apoiado sobre um isolante. Ao tentar produzir a faísca aproximando a outra mão do fio ligando a água ao condutor primário, recebeu um grande choque. Ele contou o que ocorreu a Musschenbroek e a seu assitente Allamand. Os dois sentiram um grande choque ao repetir este procedimento. O relato mais famoso desta experiência foi apresentado por Musschenbroek em uma carta de janeiro de 1746 enviada para

\footnotetext{
30 [Hei99, págs. 310-311].

31 [Hei99, pág. 311].
} 
o cientista Réamur (1683-1757). Ela foi publicada nos Anais da Academia de Ciências de Paris: ${ }^{32}$

Como vejo que esta folha [contendo observações meteorológicas] não está totalmente cheia, gostaria de lhe informar sobre uma experiência nova mas terrível, que te aconselho a nunca tentar você mesmo, já que nem eu próprio, que a experimentei e sobrevivi pela graça de Deus, a tentaria de novo por todo o reino da França. Estava envolvido em revelar os poderes da eletricidade. Um tubo de ferro $A B$ foi suspenso por linhas de seda azuis; um globo [de vidro], girando rapidamente e friccionado, estava localizado próximo de $A$, e comunicava seu poder elétrico para $A B$. A partir de um ponto próximo da outra extremidade $B$ estava dependurado um fio de latão; na minha mão direita eu segurava o globo [de vidro] $D$, parcialmente cheio de água, na qual penetrava o fio [de latão]; com minha mão esquerda $E$ tentei produzir as faíscas com estalidos que saltam do tubo de ferro para o dedo; em consequência disso minha mão direita $F$ foi atingida com tal força que todo meu corpo tremeu da mesma forma que alguém atingido por um raio. Normalmente a descarga não quebra o vidro, não importando quão fino ele seja, nem arremessa a mão para fora [do frasco]; mas o braço e todo o corpo são afetados tão terrivelmente que não consigo descrevê-lo. Pensei que tinha morrido. Mas vão aqui algumas peculiaridades. Quando o globo $D$ é feito de vidro inglês não ocorre nenhum efeito, ou quase nenhum; tem de ser usado vidro alemão, o holandês também não funciona; [o frasco] $D$ não precisa ser um globo, um copo de vidro funciona; também não importa se ele é grande ou pequeno, espesso ou fino, comprido ou curto, ou de qualquer formato particular; mas tem de ser feito de vidro alemão ou da Boêmia. O globo $D$ que quase me matou era feito de um vidro branco muito fino, com diâmetro de cinco polegadas $[12,7 \mathrm{~cm}]$. Omito aqui a maioria dos outros fenômenos notáveis. É suficiente dizer que o homem tem de ficar de pé diretamente sobre o solo; que a mesma pessoa que segura o globo deve produzir a faísca; o efeito é pequeno se dois homens participarem, um segurando o globo e o outro extraindo as faíscas. Se o globo $D$ estiver sobre um metal apoiado sobre uma mesa de madeira, e alguém toca o metal com uma mão e provoca a faísca com a outra [mão], ele também será atingido com uma força imensa. Descobri tanta coisa sobre eletricidade que cheguei ao ponto no qual não entendo mais nada e não consigo explicar qualquer coisa. Bem, preenchi esta folha de papel muito bem.

A primeira representação desta experiência foi apresentada por Nollet em 1750, ver a Figura 12.19. ${ }^{33}$

É muito interessante ver que mesmo um grande cientista que trabalhava especificamente com eletricidade como Musschenbroek foi totalmente surpreendido por esta descoberta, não conseguindo explicar o funcionamento do instrumento.

Embora ele tenha dito que não tentaria de novo a experiência, pela sua própria descrição percebemos que após o susto inicial ele fez algumas variações da experiência alterando o tipo, espessura e formato dos vidros. Provavelmente o

\footnotetext{
32 [Hei99, págs. 313-314].

33 [Hei99, pág. 285].
} 


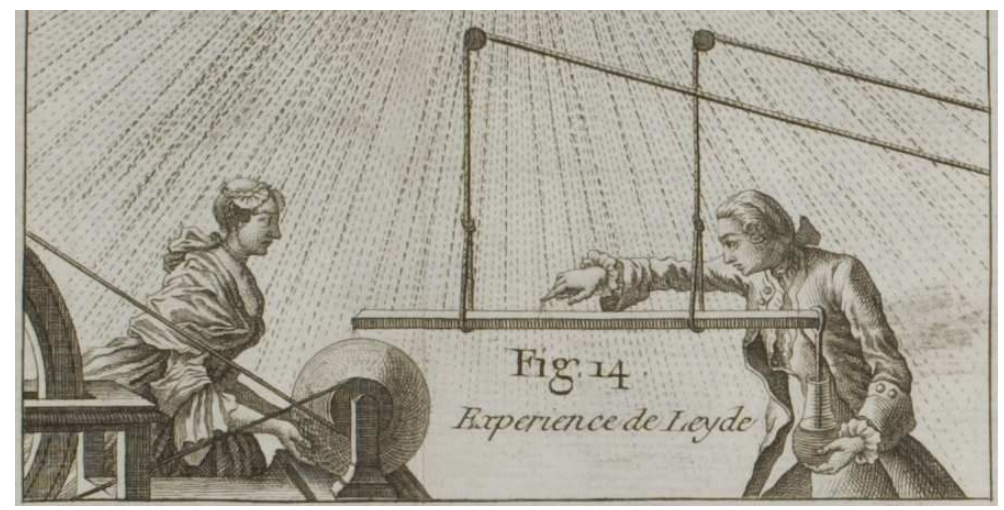

Figura 12.19: Primeira representação da experiência com a garrafa de Leiden. A barra horizontal representa o tubo de ferro $A B$ da descrição de Musschenbroek suspensa por linhas isolantes de seda, enquanto que a garrafa na mão do cientista representa seu globo de vidro $D$.

vidro alemão que utilizou quando tomou o choque se comportava como um bom isolante, permitindo o acúmulo de cargas opostas nos dois lados do vidro (isto é, no lado interno e no lado externo da garrafa). Já o vidro inglês e o holandês deviam se comportar como condutores para as experiências de eletrostática. Neste caso eles não permitiam o acúmulo de cargas opostas nos dois lados do vidro. Por este motivo não ocorria nenhum efeito nesta situação.

Uma outra representação da experiência de Cunaeus encontra-se na Figura $12.20 .^{34}$

Nas Figuras 12.19 e 12.20 temos um globo de vidro que é eletrizado por atrito contra as mãos de uma pessoa enquanto está girando ao redor de seu eixo. Uma barra metálica é suspensa por cordas isolantes. Na Figura 12.19 ela é eletrizada através de descargas elétricas no ar quando uma de suas extremidades fica muito próxima do vidro eletrizado. Já na Figura 12.20 ela é eletrizada por estar em contato com o vidro através de uma corrente metálica. Na extremidade da barra há um arame que entra em contato com a água que está em um recipiente de vidro. Este recipiente é isolante. Desta forma a água condutora também fica eletrizada por estar em contato com o arame ligado à barra eletrizada. A pessoa segura o recipiente com uma mão. Com a outra mão tenta produzir uma faísca ao se aproximar do arame ou da barra. É neste momento que toma um imenso choque.

A explicação para o funcionamento da garrafa de Leiden veio essencialmente com os trabalhos de Benjamin Franklin. ${ }^{35} \mathrm{O}$ ponto principal é que a garrafa de vidro funcionava como um isolante, enquanto que os condutores em contato com as superfícies interna e externa do vidro seriam a água no interior da garrafa e a mão do pesquisador segurando a garrafa. Ou seja, a pessoa segurando a garrafa

\footnotetext{
34 [Des76, Parte 3, pág. 570, figura 382].

35 [Hei99, págs. 330-334].
} 


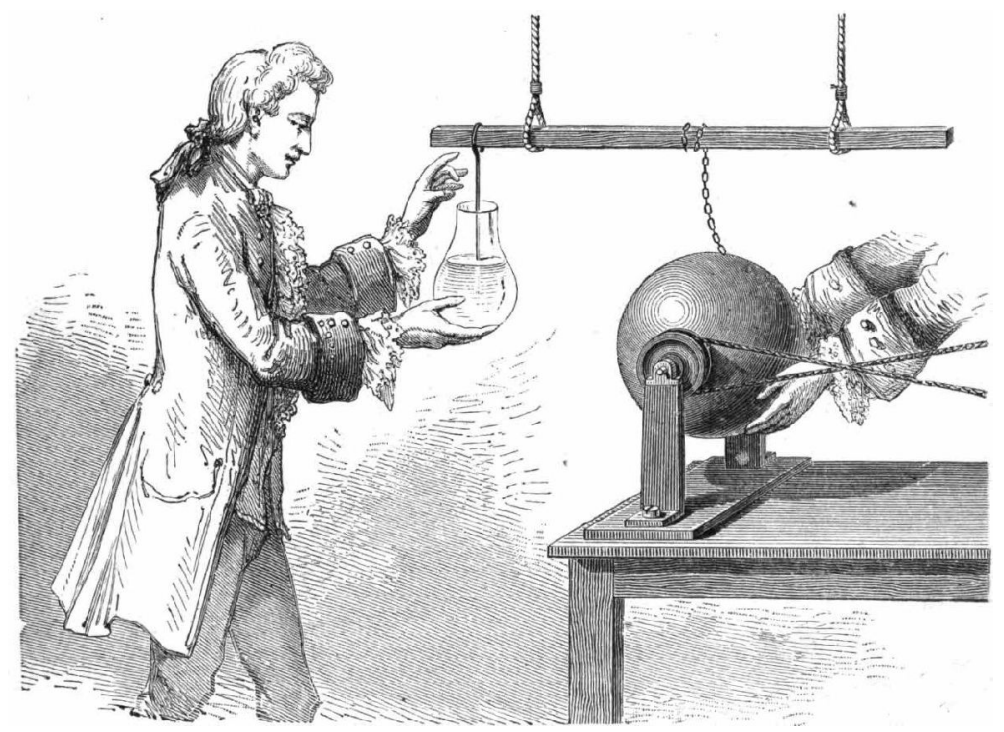

Figura 12.20: Outra representação da experiência com a garrafa de Leiden.

enquanto ela era eletrizada funcionava como um aterramento de sua superfície externa. Enquanto o sistema está sendo eletrizado, a água está em contato com o gerador eletrostático (ou com o condutor primário) através de um arame ou fio condutor. A água adquire então uma carga elétrica de mesmo sinal que a carga do globo de vidro atritado e da barra de ferro. Estas cargas resultantes ou livres da água concentram-se na interface da água em contato com a parede interna do vidro. Já a superfície externa do vidro está aterrada pelas mãos da pessoa que segura a garrafa. As mãos da pessoa ficam então eletrizadas com carga de sinal oposto ao sinal da carga na água. Estas cargas resultantes ou livres da mão da pessoa concentram-se na interface da mão em contato com a parede externa do vidro. Ao retirar a garrafa do gerador eletrostático, segurando a garrafa eletrizada pela mão, passamos a ter um condensador ou capacitor. Este capacitor está eletrizado com cargas de um tipo espalhadas pela água ao longo da superfície interna da garrafa e com cargas de sinais opostos e de mesma quantidade espalhadas pela mão da pessoa que segura a garrafa. Franklin disse o seguinte em uma carta de 1747 para seu amigo Collinson: ${ }^{36}$

No mesmo instante em que o fio e o topo da garrafa, etc., está eletrizado positivamente ou mais, o fundo da garrafa está eletrizado negativamente ou menos, em proporção exata; isto é, qualquer que seja a quantidade de fogo elétrico que penetra no topo, uma quantidade igual sai do fundo. ${ }^{37}$

\footnotetext{
36 [Fra69, pág. 13], [Fra04, Vol. 2], [Hei99, pág. 331] e [Mor04b, Versão 1.3, Seção III, pág. $4]$.

37 [Nota de rodapé adicionada por Franklin em uma edição posterior de seu livro:] O que foi dito aqui sobre o topo e o fundo da garrafa é verdadeiro para as superfícies interna e externa, e deveria ter sido expresso desta forma.
} 
Tem de haver um caminho durante a descarga da garrafa de Leiden através do qual o fogo elétrico (ou o fluido elétrico) possa ser transferido entre a superfície condutora externa ao vidro e a superfície condutora interna ao vidro. Esta trajetória não é através do vidro isolante. De acordo com Franklin, esta passagem do fogo elétrico ocorre através de algum condutor que toque o topo e o fundo. Ou seja, através de algum condutor que ligue a superfície condutora interna ao vidro com a superfície condutora externa à garrafa de vidro. Citamos aqui um trecho de sua carta, com nossas palavras entre colchetes: ${ }^{38}$

3. O equilíbrio não pode ser restabelecido na garrafa através de uma comunicação interna ou por um contato entre as partes; mas ele tem de ser obtido através de uma comunicação feita pelo lado externo da garrafa entre o topo e o fundo, por algum não-elétrico, [isto é, por algum corpo condutor,] tocando ou aproximando-se de ambos ao mesmo tempo; sendo que neste caso [o equilíbrio] é restaurado com uma violência e rapidez inexprimível; ou então, tocando cada um deles alternadamente, sendo que neste último caso o equilíbrio é restabelecido gradualmente.

Se a pessoa que está segurando a garrafa com uma mão tocar com a outra mão na água ou no condutor que está em contato com a água, vai tomar um grande choque ao permitir a passagem de uma corrente elétrica através de seu corpo, neutralizando assim as cargas opostas que estavam separadas pelo vidro isolante.

Pode-se ter uma ideia do choque sentido pelos pesquisadores antigos como Cunaeus ou Musschenbroek utilizando o eletróforo e garrafa de Leiden já descritos nas Seções 6.1 e 12.1. Para isto utilizamos uma forma de pizza de $30 \mathrm{~cm}$ de diâmetro presa no centro por um cabo isolante, Figura 2.15 (d). A base isolante deste eletróforo pode ser uma placa ou forro de PVC de formato quadrado com $40 \mathrm{~cm}$ de lado que é eletrizada ao ser atritada rapidamente por um guardanapo de papel ou papel toalha. A garrafa de Leiden é feita com uma garrafa plástica de água ou de refrigerante com 200 ou $300 \mathrm{ml}$, Figura 12.2. O procedimento de carga e descarga desta garrafa de Leiden está descrito na Experiência 12.4.

As experiências de Gray e Du Fay descritas na Seção 12.4, assim como a garrafa de Leiden discutida nesta Seção, mostram que a água tem a capacidade de armazenar ou acumular cargas elétricas. Este efeito foi utilizado no gerador eletrostático gotejante de Kelvin. ${ }^{39}$ Experiências utilizando este fato continuam a ser feitas até os dias atuais. ${ }^{40}$

\footnotetext{
38 [Fra69, págs. 13-14], [Fra04, Vol. 2] e [Mor04b, Versão 1.3, Seção III, pág. 5].

${ }^{39}$ Seção 7.12 de [Ass10b], [Ass10a], [Ass11], [Ass15b] e [Ass17].

40 [APZ06], [OP09], [San11], [Pol13, Cap. 5] e [GB17, Cap. 6].
} 


\section{Capítulo 13}

\section{Preservação Temporal da Eletrização dos Corpos}

Apresentamos neste Capítulo alguns procedimentos que aumentam o tempo de eletrização dos corpos, ou seja, o período em que permanecem eletrizados.

\subsection{Perda de Eletrização no Ar}

Experiência 13.1 - Isolante descarregando

Quando eletrizamos um isolante ou um condutor e o deixamos parado ao ar livre, ele acaba perdendo sua eletrização depois de alguns minutos. ${ }^{1}$ Suponha, por exemplo, que atritamos um canudo plástico no cabelo. Ele atrai papeizinhos sobre a mesa ao se aproximar deles, Figura 1.3. Porém, passados alguns minutos ou algumas horas, podemos aproximar novamente o canudo dos papeizinhos que eles não mais serão atraídos, Figura 13.1.

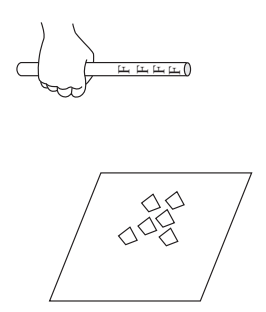

(a)

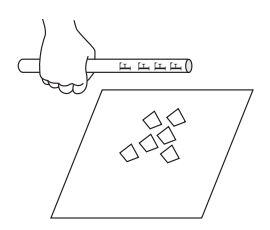

(b)

Figura 13.1: (a) Um canudo atritado longe dos papeizinhos. (b) Um canudo que foi atritado perde sua eletrização depois de alguns minutos, não atraindo papeizinhos ao se aproximar deles.

\footnotetext{
${ }^{1}$ Seções 7.13 e 7.14 de [Ass10b], [Ass10a], [Ass11], [Ass15b] e [Ass17].
} 
Só se o canudo for novamente atritado é que ele vai voltar a atrair os papeizinhos. O tempo que demora para o canudo perder sua eletrização vai depender de vários fatores: da condutividade do ar, do quão carregado o canudo tiver sido inicialmente eletrizado, se ele é um bom ou um mal isolante, etc. Em dias muito secos um canudo bem carregado pode manter-se eletrizado por algumas horas, já em dias úmidos ele vai perder sua eletrização depois de alguns minutos.

\section{Experiência 13.2 - Condutor descarregando}

Também um condutor perde sua eletrização simplesmente por ficar parado ao ar livre. Eletrizamos um eletroscópio ao raspar um canudo eletrizado em sua cartolina, Figura 13.2 (a). Deixamos ele parado ao ar livre. Ele vai descarregando aos poucos, como pode ser observado pelo abaixamento gradual de sua tirinha. Depois de alguns minutos ele fica totalmente descarregado, Figura 13.2 (b).

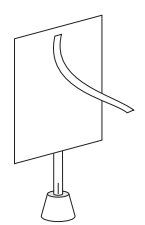

(a)

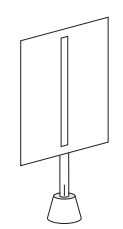

(b)

Figura 13.2: (a) Eletroscópio carregado. (b) Depois de alguns minutos ele fica descarregado.

Novamente observa-se que o tempo para o eletroscópio descarregar depende de vários fatores: das condições atmosféricas, de quão carregado ele tiver sido inicialmente eletrizado, da forma e tamanho do condutor, da condutividade do canudo que suporta a cartolina, etc. Quanto mais seco estiver o dia, mais tempo ele vai permanecer eletrizado.

Como fazer para aumentar o tempo de eletrização de isolantes e condutores?

\subsection{Preservando a Eletrização de Isolantes}

A maneira mais simples de aumentar o tempo no qual um isolante permanece eletrizado é de evitar o seu contato com o ar livre. ${ }^{2}$

Experiência 13.3 - Cobrindo isolantes eletrizados com condutores

Deixamos uns 10 ou 20 canudos plásticos bem eletrizados ao atritá-los rapidamente contra uma folha de papel ou guardanapo. Em seguida os colocamos lado a lado sobre flanelas de algodão ou guardanapos de papel e os cobrimos com estes materiais, Figura 13.3. Para evitar perturbações, o conjunto pode ser guardado dentro de uma caixa de sapatos.

\footnotetext{
${ }^{2}$ [Grad] com tradução comentada para a língua portuguesa em [Bos11, Capítulo 8] e [BAC12, Capítulo 9].
} 


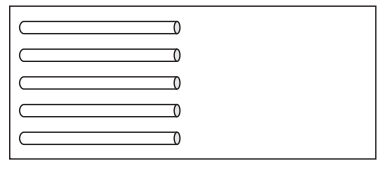

(a)

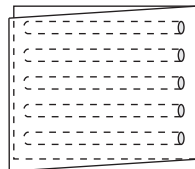

(b)

Figura 13.3: (a) Canudos eletrizados sobre uma flanela ou guardanapo de papel. (b) Canudos cobertos.

Em intervalos fixos (a cada dia ou a cada semana, por exemplo) podemos tirar um dos canudos e verificar se continua ou não eletrizado. Para fazer este teste é bom utilizar efeitos sensíveis tais como verificar se atrai a tirinha de um eletroscópio descarregado, se atrai o disquinho de papel de um pêndulo elétrico descarregado, ou se orienta um versório metálico. Caso os canudos tenham sido guardados bem eletrizados, o que se observa é que a eletrização continua por dias, semanas ou em alguns casos por uns poucos meses.

Novamente o tempo em que o canudo vai permanecer eletrizado depende de vários fatores: condições atmosféricas, o quão carregado ele estava inicialmente, se é um bom ou mau isolante, etc.

\section{Experiência 13.4 - Cobrindo isolantes eletrizados com outros isolantes}

Na Experiência 13.3 os canudos foram embrulhados em condutores tais como papel ou flanela de algodão. Agora repetimos o procedimento mas envolvendoos em isolantes tais como sacolas plásticas de supermercado ou sacos plásticos. Neste caso também se observa que a eletrização dos canudos continua por dias, semanas ou até mesmo alguns meses.

Experiência 13.5 - Cobrindo canudos eletrizados com papeis e com plásticos

Também podemos colocar no mesmo dia alguns canudos eletrizados embrulhados em condutores (como folhas de papel) e outros canudos embrulhados em isolantes (como sacos plásticos). Tentamos fazer com que todos os canudos estejam igualmente eletrizados no início. Então, de tempos em tempos, tiramos um canudo embrulhado no condutor e um canudo embrulhado no isolante. Verificamos se continuam eletrizados e comparamos a quantidade de carga elétrica em cada canudo. O grau de eletrização do canudo pode ser indicado pela intensidade do efeito que produz (quanto mais carregado ele está, maiores serão os efeitos que ele produzirá). Nestes casos às vezes se percebe que, no mesmo dia, aqueles envolvidos no plástico ficam com uma intensidade de eletrização um pouco maior do que aqueles embrulhados em condutores. Também se observa que os canudos embrulhados no isolante permanecem eletrizados por um intervalo de tempo maior do que aqueles embrulhados no condutor.

Na Tabela 13.1 comparamos os intervalos de tempo nos quais canudos carregados permanecem eletrizados quando deixados ao ar livre, quando estão embrulhados em papeis ou em sacos plásticos. 


\begin{tabular}{|c|c|}
\hline Condição & Duração \\
\hline Ao ar livre & Alguns minutos \\
\hline Embrulhado em condutor & Dias, semanas ou poucos meses \\
\hline Embrulhado em isolante & Dias, semanas ou poucos meses \\
\hline
\end{tabular}

Tabela 13.1: Intervalos de tempo aproximados para descarregar um canudo eletrizado.

Experiência 13.6 - Placa eletrizada descarregando no ar

Nesta experiência utilizamos algumas placas ou lâminas de PVC (tipo forro de PVC) ou de isopor. Elas podem ser quadradas (com uns 20 ou $30 \mathrm{~cm}$ de lado), circulares ou com qualquer forma. Elas vão ser bem atritadas passando rapidamente um pedaço de papel, guardanapo ou flanela sobre suas superfícies. Elas ficam então expostas ao ar livre sem serem atritadas novamente. A cada 10 minutos verificamos se continuam eletrizadas. Para fazer esta verificação podemos testar se as faces atritadas destas placas atraem a tirinha de um eletroscópio descarregado, se atraem o disco de papel de um pêndulo elétrico ou se orientam um versório metálico. Medimos então por quanto tempo permanecem eletrizadas.

Dependendo das condições atmosféricas, do material das placas e do grau de carga inicial, as placas podem ficar eletrizadas de 10 minutos a 1 hora, aproximadamente.

\section{Experiência 13.7 - Placas eletrizadas sobrepostas}

Repetimos a Experiência 13.6 eletrizando agora do mesmo jeito pares de placas do mesmo material e com o mesmo tamanho. Sobrepomos então as placas de cada par com as faces atritadas encostando uma na outra. Podemos prendê-los com elásticos para evitar que se separem. Os pares são então guardados em uma caixa. De tempos em tempos abrimos um destes pares e verificamos se a parte interna de cada placa continua eletrizada. Para fazer esta verificação, podemos testar se a face atritada atrai a tirinha de um eletroscópio descarregado, se atrai o disco de papel de um pêndulo elétrico ou se orienta um versório metálico. Caso continuem eletrizadas, podemos sobrepor as placas e guardá-las de novo. Vamos repetindo este procedimento até estarem totalmente descarregadas.

Dependendo das condições atmosféricas, do material das placas e do grau de carga inicial, as placas podem ficar eletrizadas por dias, semanas ou até mesmo alguns poucos meses, Tabela 13.2.

\subsubsection{Algumas Considerações sobre Estas Experiências}

As experiências desta Seção mostram que aumentamos bastante o tempo de eletrização de isolantes carregados ao protegê-los do ar ao seu redor. É claro que ao cobrir os canudos em flanelas ou plásticos, eles ainda estarão em contato 


\begin{tabular}{|c|c|}
\hline Uma placa ao ar livre & Alguns minutos a 1 hora \\
\hline Duas placas sobrepostas & Dias, semanas ou poucos meses \\
\hline
\end{tabular}

Tabela 13.2: Intervalos de tempo aproximados para descarregar uma placa isolante eletrizada.

com o ar. O mesmo ocorre ao sobrepor duas placas atritadas e guardá-las em uma caixa. Porém, as moléculas de ar que envolvem estes corpos serão aproximadamente as mesmas ao longo do tempo. Já quando um corpo eletrizado está exposto ao ar livre, sempre vai estar em contato com moléculas e íons diferentes ao longo do tempo. Mesmo em uma sala fechada há sempre movimento e circulação das partículas do ar. O mesmo não ocorre quando embrulhamos o corpo. Este parece ser um dos principais fatores que aumenta o tempo de eletrização dos isolantes.

Um canudo ao ar livre pode ser descarregado pelo mecanismo $A C R$. Ou seja, o vapor de água, assim como outras partículas, moléculas e íons presentes no ar, podem ser atraídos pelo canudo, tocar nele, adquirem um pouco de sua carga, sendo então repelidos pelo canudo. Ao cobrir o canudo eletrizado, diminui a possibilidade de ocorrer este processo de transferência de cargas com o ar externo.

Um outro aspecto que deve ser mencionado é que ao cobrir o canudo eletrizado com um condutor ou isolante, ocorre uma redistribuição de cargas nestes materiais que estão cobrindo o canudo. Isto faz com que diminua a força resultante que pode atuar nas partículas, moléculas e íons do ar externo. Ou seja, além da força exercida pelo canudo eletrizado, vão atuar também forças devido às cargas que foram redistribuídas no condutor ou isolante colocado ao redor do canudo. A força total atuando sobre qualquer partícula externa é então diminuída. Há então um tendência menor destas partículas externas interagirem com o canudo eletrizado.

\subsection{Preservando a Eletrização de Condutores}

\section{Experiência 13.8 - Garrafas de Leiden}

A Experiência 13.2 mostra que um condutor carregado perde sua eletrização em poucos minutos quando está ao ar livre. Mostramos agora um procedimento que amplia bastante a preservação desta eletrização.

Utilizamos aqui a garrafa de Leiden feita com uma garrafa plástica de água ou de refrigerante com 200 ou $300 \mathrm{ml}^{3}{ }^{3} \mathrm{O}$ ideal é ter 5 ou 10 garrafas do mesmo formato, tamanho e feitas dos mesmos materiais. Uma destas garrafas está representada na Figura 12.2. Ela será eletrizada com o eletróforo de Volta feito com forma de pizza com $30 \mathrm{~cm}$ de diâmetro presa a um cabo isolante, tendo um forro de PVC de $40 \mathrm{~cm}$ de lado como base que será eletrizada por atrito,

\footnotetext{
${ }^{3}$ Seção 12.1 e [MF].
} 
Figura 6.1 (a). Depois que a base está bem eletrizada, carregamos a forma de pizza com o procedimento descrito nas Figuras 6.2 a 6.4. A cada vez que a forma de pizza é eletrizada, ela deve ser descarregada quando a borda do disco é aproximada da esfera superior da garrafa de Leiden, Figura 12.6. Este procedimento deve ser repetido 20 vezes para carregar bem a garrafa de Leiden. O mesmo procedimento é feito no mesmo dia para todas as 5 ou 10 garrafas. Elas são então guardadas na prateleira de um armário, marcando-se o dia e hora em que foram eletrizadas.

Passado algum tempo (1 hora, ou 1 dia, ou 1 semana), deve ser verificado se uma das garrafas continua eletrizada. Para isto basta tocar com um dedo da mão na faixa condutora externa da garrafa e aproximar um outro dedo da mesma mão da esfera superior da garrafa. Suponha que ocorra um choque como na Figura 12.7. O choque significa que a garrafa ficou eletrizada entre o momento inicial de carregamento e este momento final de descarga. A garrafa que foi descarregada não deve mais ser utilizada na experiência. Passado mais algum tempo (mais 1 hora, ou mais 1 dia, ou mais 1 semana), verifica-se então se uma outra garrafa continua eletrizada. Este procedimento deve ser seguido com todas as garrafas.

Após realizar esta experiência, encontra-se que a garrafa pode continuar eletrizada por alguns dias (como 1 semana, por exemplo). O tempo exato vai depender, entre outras coisas, do quão isolante é o material da garrafa plástica, do tamanho da garrafa, assim como do grau de eletrização inicial que conseguirmos fornecer a ela.

Em vez de utilizar várias garrafas iguais, também podemos realizar esta experiência utilizando uma única garrafa. Seguimos o procedimento desta experiência para carregá-la. Depois de 1 hora, ou 1 dia, ou 1 semana, testamos se ela continua eletrizada. Após ser descarregada, ela deve ser eletrizada novamente com a mesma intensidade seguindo o procedimento desta experiência. Então, após 2 horas, ou 2 dias, ou 2 semanas, testamos se ela continua eletrizada. Após ser descarregada, ela deve ser mais uma vez eletrizada com a mesma intensidade seguindo o procedimento desta experiência. Então, após 3 horas, ou 3 dias, ou 3 semanas, testamos se ela continua eletrizada. Continuamos estes testes até o ponto em que observamos que ela deixou de ficar eletrizada após a passagem de um certo intervalo de tempo (que pode ser de 10 horas, 10 dias ou 10 semanas, por exemplo). Desta forma podemos descobrir por quanto tempo ela permanece eletrizada após ser guardada em um lugar seguro no qual nada acontece com ela.

Podemos então comparar a Experiência 13.2 com as experiências desta Seção. Estas últimas experiências mostram que as cargas sobre os condutores internos e externos de um capacitor como a garrafa de Leiden ficam armazenadas por um tempo bem maior do que as cargas distribuídas na cartolina condutora de um eletroscópio exposto ao ar livre. 


\subsection{Eletretos}

\subsubsection{Definições}

Chamamos de eletretos aos corpos que mantêm permanentemente uma eletrização ou polarização elétrica. Os eletretos são feitos de material isolante ou dielétrico. Na prática a eletrização de qualquer corpo decai com o tempo. Mas se este tempo de decaimento for longo comparado com o tempo de realização da experiência com este corpo ou da utilização deste material, podemos considerar o corpo eletrizado como um eletreto. Por exemplo, se a experiência ou utilização do material durar alguns segundos, um corpo que mantenha uma eletrização por alguns minutos pode ser considerado um eletreto. Neste sentido os canudos ou réguas plásticas eletrizadas por atrito podem ser considerados eletretos para a maior parte das experiências descritas neste livro. Existem diversos dispositivos que precisam utilizar corpos que permanecem eletrizados ao longo de semanas ou meses. Neste caso, um corpo que fique eletrizado por um ano pode ser considerado um bom eletreto. Podemos então tornar mais clara nossa definição:

\section{Definição 13.1 - Eletreto}

Chamamos de eletretos aos corpos que mantêm uma eletrização ou polarização elétrica quase permanente, com um tempo de decaimento muito maior do que os períodos em que estão sendo utilizados.

Em geral utiliza-se a palavra "eletreto" para corpos que mantêm uma eletrização ou polarização elétrica por alguns meses, anos ou décadas. Não é comum a utilização desta palavra para designar um canudo ou régua plástica eletrizados por atrito e que permanecem eletrizados por alguns minutos.

A palavra eletreto foi criada em 1885 por Oliver Heaviside (1850-1925): ${ }^{4}$

Uma palavra é evidentemente necessária para descrever um corpo que se apresenta naturalmente permanentemente eletrizado por causas internas. Observando que [a palavra] "magneto" é obtida de "magnetismo" reduzindo-a ao final, o mesmo pode ser feito a partir da palavra "eletricidade". Um "elétrico", que é a palavra resultante desta redução, poderia ser um nome muito bom para um corpo intrinsecamente eletrizado, exceto por duas razões. Primeiro, este termo foi originalmente empregado para descrever aquilo que agora denominamos de dielétrico ou isolante. Em segundo lugar, elétrico é hoje usado como um adjetivo [...]. Uma outra palavra que pode ser sugerida é eletreto, contra a qual não pesa nenhuma objeção exceto o fato de ela soar estranho. Esta é, entretanto, uma mera questão de hábito.

\footnotetext{
${ }^{4}$ [Hea87, Artigo 30: Electromagnetic induction and its propagation, Seção 12: Electrisation and Electrification. Natural Electrets, pág. 488], [JW80] e [Sil10b, pág. 30].
} 
Existem diversos tipos de eletretos e várias maneiras de serem produzidos. Eles são classificados de diversas maneiras e a nomenclatura varia de autor para autor. Apresentamos aqui uma classificação simples.

Os eletretos que possuem uma carga total não nula são chamados de eletretos monopolares ou eletretos de carga resultante. Na Figura 13.4 (a) apresentamos um eletreto com carga superficial, enquanto que na Figura 13.4 (b) temos um eletreto com carga espalhada ao longo de seu volume, no interior de seu corpo, chamado de eletreto com carga volumétrica.

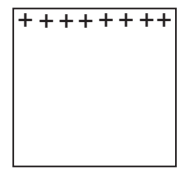

(a)

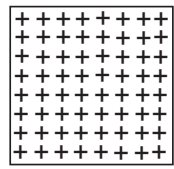

(b)

Figura 13.4: (a) Eletreto com carga resultante superficial. (b) Eletreto com carga resultante volumétrica.

Os eletretos que possuem uma carga total nula, mas com uma polarização não nula, são chamados de eletretos bipolares, dipolares ou polarizados. $\mathrm{Na}$ Figura 13.5 (a) apresentamos um eletreto polarizado em sua superfície, em (b) temos um eletreto polarizado ao longo de seu volume, enquanto que em (c) temos um eletreto no qual apenas suas moléculas estão polarizadas.

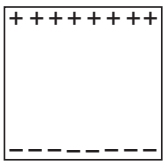

(a)

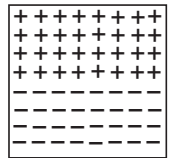

(b)

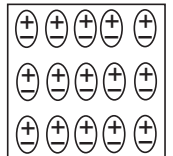

(c)

Figura 13.5: (a) Eletreto polarizado na superfície. (b) Eletreto polarizado ao longo de seu volume. (c) Eletreto com moléculas polarizadas.

No caso geral podemos ter uma mistura de um ou mais destes tipos, Figura 13.6 .

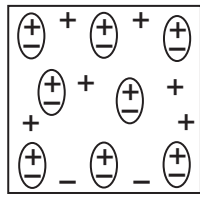

Figura 13.6: Eletreto com carga resultante não nula, cargas superficiais, cargas volumétricas e com moléculas polarizadas.

Em aplicações práticas muitos eletretos são recobertos por camadas condutoras cobrindo uma face, duas faces ou todo ele. Não entraremos nestes detalhes 
aqui.

\subsection{Fabricação de Eletretos}

\subsubsection{Materiais Utilizados}

Veremos nesta Seção como produzir eletretos que ficam eletrizados por dias, semanas ou meses. Descrevemos algumas experiências feitas por Silva Junior e Boss. $^{5}$

As pessoas devem ser cuidadosas ao realizar estas experiências, pois lidamos com fogo, gases e fumaça de diferentes substâncias. Alguns procedimentos de segurança podem ser encontrados na literatura. ${ }^{6}$

Os materiais empregados nestas experiências são parafina, cera de abelha, cera de carnaúba e goma-laca. A parafina é um derivado de petróleo, sendo utilizada na fabricação de velas. A parafina usada nestas experiências pode ser obtida de velas ou adquirida em barras. A cera de carnaúba é obtida das folhas de uma palmeira nativa da região Nordeste do Brasil, de cor marrom. É uma cera muito dura amplamente utilizada na indústria. A goma-laca é uma resina vermelha ou amarela secretada por um inseto e extraída de várias plantas orientais. É um verniz natural muito utilizado para pinturas e decorações. A cera de carnaúba pode ser encontrada em barra ou em pasta. A goma-laca pode ser encontrada em pó, em flocos, folhas ou cascas. Estas substâncias podem ser obtidas em lojas de tintas, de madeiras, de materiais de construção e em alguns supermercados.

Estas substâncias podem ser derretidas em recipientes de flandre (como as formas de empadinha), alumínio (concha de feijão), ferro ou vidro (copo). Elas apresentam ponto de fusão entre $60^{\circ} C$ e $80^{\circ} C$, podendo ser derretidas na chama de um fogão.

\section{Experiência 13.9 - Comportamento isolante antes do derretimento}

Antes de começar a fazer os eletretos, é bom verificar o seu comportamento isolante ou condutor utilizando os procedimentos da Seção 3.1. Para fazer este teste, basta eletrizar um eletroscópio, segurar a substância com a mão, encostála na cartolina do eletroscópio e verificar se a tirinha abaixa ou permanece levantada. No caso das substâncias líquidas, em pasta ou em pó, basta colocar estes materiais em um recipiente metálico e então encostar uma quina da cartolina apenas no material, Figura 3.6. Para todas as substâncias listadas aqui, encontra-se que a tirinha permanece levantada, ou seja, elas são isolantes.

\section{Experiência 13.10 - Neutralidade antes do derretimento}

Também é bom verificar se as substâncias apresentam qualquer eletrização antes de serem derretidas. Para fazer este teste, basta aproximar a substância

\footnotetext{
5 [Sil10a], [Bos11, Seção 8.2, págs. 234-248] e [BAC12, Capítulo 19].

${ }^{6}$ [Bos11, Seção 8.2] e [BAC12, Seção 19.3].
} 
de um versório metálico, do disquinho de papel de um pêndulo elétrico descarregado, da parte inferior da tirinha de um eletroscópio descarregado ou de um fino filete de água caindo de uma torneira. Caso estes corpos não sejam atraídos pela substância, podemos concluir que ela não estava eletrizada. Este é o caso mais comum. Algumas vezes a cera de carnaúba apresenta uma pequena eletrização em algumas regiões antes de ser derretida. As outras substâncias em geral não atraem estes corpos.

\subsubsection{Preparação das Peças}

Para fazer os eletretos, basta derreter as substâncias nos recipientes mencionados, deixar esfriar e solidificar, reaquecer de forma breve os recipientes para soltar os materiais, e extrair as peças. Este procedimento leva umas 4 horas desde a preparação do material, fabricação das peças e limpeza do local. O ideal é fazer um teste durante um dia para dominar todo o processo, perceber o que é preciso em cada fase, quais os materiais e procedimentos necessários, etc. Então em outro dia, depois de adquirido todo este conhecimento, preparam-se as peças que vão ser utilizadas nas experiências.

É comum as pessoas fabricarem eletretos combinando diferentes proporções destas substâncias. Mas nas experiências descritas aqui foram utilizadas substâncias de apenas um tipo em cada recipiente diferente.

As ceras e parafinas foram cortadas em pedaços antes de serem colocadas nos recipientes. Os recipientes podem ser levados ao fogo diretamente ou então colocados em banho-maria. Coloca-se um pouco de água em uma panela e sobre a água coloca-se o recipiente com a substância a ser derretida. Este processo garante um aquecimento lento e uniforme. Após o derretimento, deixa-se o recipiente de lado sobre a pia para que a substância esfrie e se solidifique. Este processo leva de 1 a 3 horas. Deve-se tomar cuidado para que não entre água nos recipientes em nenhum momento do processo. A substância vai ser retirada do recipiente depois de solidificada. Para facilitar a remoção da peça e sua posterior manipulação, é útil utilizar algum cabo isolante colocado na substância quando ainda está sendo aquecida. Pode-se utilizar, por exemplo, um tubo plástico de caneta, um prendedor de roupa de plástico, uma régua de acrílico ou outro cabo apropriado, Figura 13.7 (a).

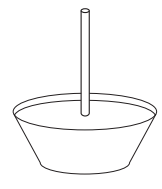

(a)

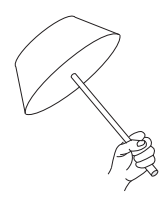

(b)

Figura 13.7: (a) Substância amolecida na forma com um cabo isolante. (b) Peça sólida depois de retirada do recipiente.

Depois que a substância resfriou e solidificou, o recipiente deve ser breve- 
mente reaquecido apenas para que a substância seja desgrudada do recipiente. A peça pode então ser retirada do recipiente pelo cabo, Figura 13.7 (b). Mesmo quando o cabo está fincado na substância, nem sempre é fácil retirar as peças dos recipientes. Algumas vezes é necessário deformar a forminha de flandre ou quebrar o copo para liberar a peça. A goma-laca, por exemplo, fica facilmente quebradiça e não é fácil retirá-la inteira do recipiente mesmo depois que este é brevemente reaquecido. A parafina diminui de volume quando passa do estado líquido para sólido. Isto faz com que seja fácil retirá-la da forma de empadinha ou da concha de alumínio, algumas vezes até sem ser necessário o reaquecimento da peça depois que solidificou.

\section{Experiência 13.11 - Comportamento condutor ou isolante}

Depois que as peças foram feitas, testamos novamente seu comportamento condutor ou isolante, assim como foi feito na Experiência 13.9. Neste caso temos de segurá-la com a mão e tocar na parte superior da cartolina de um eletroscópio eletrizado. Observa-se que estas substâncias comportam-se como isolantes mesmo depois de fundidas e solidificadas, já que não abaixam a tirinha do eletroscópio.

Veremos na Experiência 13.12 que as peças ficaram eletrizadas após serem fundidas e solidificadas. Porém, como elas ainda comportam-se como isolantes, podemos tocá-las com a mão sem ter receio de descarregá-las. Logo, caso a peça saia facilmente do recipiente depois que ele é brevemente reaquecido, o cabo isolante fincado na peça nem sempre é necessário. A peça pode ser retirada do recipiente e segurada com a mão sem problemas.

\section{Experiência 13.12 - Eletrização das peças após o derretimento}

Depois que as peças foram fundidas e solidificadas, podemos testar sua eletrização seguindo o procedimento da Experiência 13.10. Ou seja, cada peça é aproximada de uma das pernas de um versório metálico, do disco de um pêndulo elétrico descarregado, da parte inferior da tirinha de um eletroscópio descarregado ou de um fino filete de água caindo de uma torneira. Neste caso, observa-se que em geral a parafina, goma-laca, cera de carnaúba e cera de abelha encontram-se eletrizadas, já que atraem estes corpos. Esta eletrização é observada para todos os tipos de recipiente em que foram fundidas. Dependendo do tipo de cera de abelha, a eletrização pode ser bem fraca e nem sempre é perceptível.

\section{Experiência 13.13 - Sinal da carga das peças após o derretimento}

Inicialmente eletrizamos por indução dois eletroscópios, um deles negativamente e outro positivamente. ${ }^{7}$ Eles são então separados sobre a mesa com suas tirinhas levantadas. Aproximamos lentamente da tirinha de cada eletroscópio a peça obtida após o derretimento. Em geral observamos que todas as peças

\footnotetext{
${ }^{7}$ Seção 7.5 de [Ass10b], [Ass10a], [Ass11], [Ass15b] e [Ass17].
} 
repeliam as tirinhas dos eletroscópios negativos e atraíam as tirinhas dos eletroscópios positivos. Concluímos então que as peças ficaram negativamente eletrizadas.

Deve-se evitar de aproximar demais a peça da tirinha quando há uma repulsão entre ambos. Afinal de contas, pode passar a haver atração entre dois corpos eletrizados com cargas de mesmo sinal quando eles se aproximam demais. $^{8}$

Experiência 13.14 - Tempo de eletrização das peças ao ar livre

Depois que as peças ficaram prontas, as deixamos ao ar livre. De tempos em tempos testamos a eletrização de cada peça como foi feito na Experiência 13.12. As peças de parafina permaneceram eletrizadas por algumas horas ou por alguns dias. As peças de cera de carnaúba permaneceram eletrizadas por alguns dias ou por poucos meses.

Experiência 13.15 - Tempo de eletrização das peças guardadas nos recipientes em que foram solidificadas

Algumas peças foram guardadas nos recipientes em que foram fundidas logo após estarem prontas. Isto é, elas foram fundidas, esfriaram e os recipientes foram brevemente aquecidos para que elas fossem soltas deles. Elas ficaram pouco tempo ao ar livre até esfriarem, sendo então guardadas novamente nos próprios recipientes em que foram fundidas, sem nenhum material entre as peças e os recipientes. Então, de tempos em tempos, elas eram retiradas desses recipientes, suas eletrizações foram testadas como na Experiência 13.12, sendo então guardadas novamente nos mesmos recipientes. Mais tarde repetíamos este procedimento para ver por quanto tempo permaneciam eletrizadas.

As peças de parafina permaneceram eletrizadas de 5 a 20 dias. As peças de cera de carnaúba ficaram eletrizadas por alguns meses.

Experiência 13.16 - Tempo de eletrização das peças guardadas nos recipientes em que foram solidificadas quando havia um plástico entre cada peça e seu recipiente

Depois de prontas, algumas peças de parafina foram retiradas dos recipientes. Estes recipientes foram envolvidos em um saco plástico. As peças foram então colocadas novamente nestes recipientes. De tempos em tempos testávamos as eletrizações das parafinas e em seguida as colocávamos de volta nos recipientes recobertos com plásticos. Mais tarde testávamos novamente suas eletrizações e as colocávamos de volta nos recipientes recobertos. Elas ficaram eletrizadas de 7 a 8 dias.

Experiência 13.17 - Tempo de eletrização das peças embaladas em condutores e guardadas nos recipientes em que foram solidificadas

\footnotetext{
${ }^{8}$ Seção 7.10 de [Ass10b], [Ass10a], [Ass11], [Ass15b] e [Ass17].
} 
Algumas peças de parafina depois de prontas foram embaladas em condutores (flanela de algodão ou guardanapo de papel) e então colocadas de volta no recipiente metálico em que foram fundidas. De tempos em tempos testávamos suas eletrizações, as embalávamos nestes condutores e as colocávamos de volta no recipiente. Elas ficaram eletrizadas de 7 a 12 dias.

Experiência 13.18 - Tempo de eletrização das peças embaladas em flanelas condutoras

Algumas peças depois de prontas foram embaladas em flanelas ou panos de algodão. Para isto utilizaram-se peças que não tinham cabos ou então os cabos eram retirados antes de serem embaladas. O conjunto foi guardado em uma caixa para evitar perturbações. De tempos em tempos foi testada sua eletrização seguindo o procedimento da Experiência 13.12. Após cada teste elas eram novamente embaladas, permanecendo assim até o próximo teste.

As peças de cera de abelha ficaram eletrizadas por uns 5 meses. As peças de parafina ficaram eletrizadas por mais de 7 meses (testamos até 10 meses e continuaram eletrizadas). Já as peças de cera de carnaúba e de goma-laca ficaram eletrizadas por pelo menos 10 meses, quando paramos os testes.

Ao longo do tempo a eletrização das peças foi diminuindo. As atrações que elas exerciam em corpos próximos foram diminuindo de intensidade ao longo dos dias ou então ao longo dos meses. Algumas vezes era necessário chegar as peças bem próximas de condutores inicialmente neutros para então observar que atraíam estes condutores.

As Experiências 13.14 a 13.18 mostram que estas peças podem de fato ser consideradas eletretos, já que mantiveram suas eletrizações por dias ou meses após terem sido derretidas.

\subsection{Eletróforos com Bases de Eletreto}

No Capítulo 6 descrevemos um eletróforo composto de duas partes, a saber, (a) uma base isolante eletrizada e (b) um coletor de cargas composto de um disco condutor preso a um cabo isolante. Fizemos algumas experiências utilizando como base isolante uma placa de isopor ou de PVC eletrizada por atrito. Todas aquelas experiências podem ser reproduzidos utilizando um eletreto no lugar da base isolante. Podemos, por exemplo, preparar um eletreto de parafina ou de cera de carnaúba e utilizá-lo como base eletrizada.

A vantagem da base isolante ser uma placa de isopor ou de PVC é a simplicidade de encontrar estes materiais e a facilidade de eletrizá-los por atrito. A desvantagem é que perdem a eletrização depois de alguns minutos, sendo então necessário atritar novamente suas superfícies de tempos em tempos para continuar eletrizando o coletor de cargas do eletróforo. 
A vantagem de utilizar um eletreto como base é que ele permanece eletrizado por alguns dias ou meses, perdendo lentamente sua eletrização. A desvantagem é a própria preparação dos eletretos.

\subsection{Stephen Gray, os Eletretos e a Preservação Temporal da Eletrização dos Corpos}

A produção e as propriedades dos eletretos foram apresentadas pela primeira vez por Stephen Gray em 1732. ${ }^{9}$ Foi também neste mesmo artigo extremamente importante que ele apresentou seu procedimento para manter os corpos eletrizados por um longo tempo.

Du Fay resumiu as realizações de Gray neste artigo com as seguintes palavras: ${ }^{10}$

O Sr. Gray encontrou duas propriedades novas na eletricidade, uma [propriedade] é que a eletricidade é permanente, isto é, que após ter sido excitada ela pode persistir nos corpos por um tempo muito longo, e a outra [propriedade] é que ela pode ser obtida em alguns casos sem que os corpos tenham sido atritados.

Apresentamos aqui alguns trechos deste trabalho extremamente importante de Gray com nossas palavras nas notas de rodapé e entre colchetes:

Uma carta do Sr. Stephen Gray para o Dr. Cromwell Mortimer, Secretário da Royal Society contendo descrições adicionais de seus experimentos a respeito da eletricidade

Charterhouse, 7 de junho de 1732 .

Senhor,

Desde meu último [artigo] (Philosophical Transactions $\mathrm{N}^{\circ} 422$ ), ${ }^{11}$ no qual dei uma descrição de meus experimentos mostrando [que a] água será atraída por corpos elétricos [isto é, por isolantes eletrizados], e que ela pode ter uma virtude elétrica comunicada para ela, de forma a atrair corpos sólidos, tenho [me dedicado] a outra investigação, [a saber:] não poderia ser encontrado um meio para tornar mais permanente nos corpos esta propriedade de atração elétrica? O quanto tenho tido sucesso nesta tentativa [será] mostrado pelos experimentos [que] tenho feito sobre vários corpos mencionados na Tabela a seguir. ${ }^{12} \mathrm{E}$ como todos eles foram preparados da mesma maneira, exceto os de número 18 e 19, que serão descritos posteriormente, pode ser suficiente uma descrição geral do método de preparo e de preservação deles no estado de atração.

\footnotetext{
${ }^{9}[\mathrm{Grad}]$ com tradução comentada para a língua portuguesa em [Bos11, Capítulo 8] e [BAC12, Capítulo 9].

10 [DF34, pág. 341].

11 [Grab] com tradução para a língua portuguesa em [Bos11, Capítulo 7] e [BAC12, Capítulo 8].

${ }^{12}$ Esta Tabela está na página 260 deste livro.
} 
Os corpos com os quais os experimentos foram realizados: resina (rosin) (ambas, preta e branca), asfalto pétreo (stone-pitch), ${ }^{13}$ goma-laca em folhas (shell-lac) ${ }^{14}$ ou goma-laca (gum-lac), cera de abelhas (bees-wax), e enxofre. Adquiri três conchas de ferro de vários tamanhos, nas quais derreti essas substâncias, utilizando aquela que pensava [ser] mais conveniente para a quantidade que planejei derreter. Quando qualquer um desses corpos era derretido, ele era retirado do fogo e colocado de lado na concha para esfriar e endurecer. Então, voltava-o ao fogo, onde permanecia até que era derretido o fundo e as laterais [em contato com] a concha, a fim de ficar móvel. De modo que, pela inversão da concha ele poderia ser retirado, tendo quase a forma da seção de uma esfera, sendo a superfície convexa, bem como a plana, naturalmente polidas (se assim posso dizer). A exceção é o enxofre, que esfria sem manter seu polimento, exceto quando fundido em recipiente de vidro, como será mostrado posteriormente. Apresentarei agora as experiências e observações feitas com esses corpos elétricos [isto é, as experiências feitas com esses isolantes].

Quando qualquer um [dos corpos] era retirado da concha, e sua superfície convexa endurecida, a princípio ele não atraía [corpos leves colocados em suas proximidades], até que o calor (heat) fosse reduzido, ou até chegar a um certo grau de aquecimento (warmth), e então havia uma pequena atração. Estimei este aquecimento como sendo próximo àquele de um ovo de galinha quando posto há pouco. A atração ia aumentando assim até que, quando frio, [o corpo era capaz de] atrair no mínimo dez vezes mais distante do que inicialmente.

\footnotetext{
${ }^{13}$ Pitch é uma resina preta, ou piche, obtida a partir de diversas árvores coníferas, como os pinheiros.

${ }^{14}$ Goma-laca em folhas, shellac, é uma resina em camadas feita da secreção de alguns insetos como, por exemplo, a cochonilha-da-laca.
} 
Tabela 13.3: Uma Tabela com os vários corpos elétricos [isto é, isolantes] mencionados no discurso anterior.

\begin{tabular}{|c|c|c|c|c|c|}
\hline $\mathrm{N}^{0}$ & Nomes dos vários corpos & & eso & Mês & Dia \\
\hline & & onças & dracmas & & \\
\hline 1 & Resina preta fina & 2 & 0 & jan. & 31 \\
\hline 2 & $\begin{array}{l}\text { Asfalto pétreo (stone pitch) } \\
\text { e resina preta }\end{array}$ & 2 & 2 & jan. & 31 \\
\hline 3 & Resina fina e cera de abelhas & 2 & 1 & fev. & 1 \\
\hline 4 & Asfalto pétreo & 1 & 7 & fev. & 1 \\
\hline 5 & Enxofre endurecido & 3 & 6 & fev. & 4 \\
\hline 6 & Goma-laca em folhas & 10 & 0 & fev. & 10 \\
\hline 7 & Resina preta fina & 10 & 4 & fev. & 11 \\
\hline 8 & Cera de abelhas e resina & 9 & 0 & fev. & 12 \\
\hline 9 & $\begin{array}{l}\text { Resina } 4 \text { [partes] } \\
\text { e goma-laca } 1 \text { parte }\end{array}$ & 10 & 0 & fev. & 12 \\
\hline 10 & Enxofre & 18 & 0 & fev. & 15 \\
\hline 11 & Asfalto pétreo & 10 & 12 & fev. & 16 \\
\hline 12 & Resina preta & 23 & 0 & fev. & 23 \\
\hline 13 & Resina branca & 7 & 12 & fev. & 25 \\
\hline 14 & Goma-laca & 11 & 14 & fev. & 26 \\
\hline 15 & $\begin{array}{l}\text { Goma-laca e resina preta } \\
\text { em partes iguais }\end{array}$ & 9 & 12 & fev. & 26 \\
\hline 16 & Goma-laca 4 partes, resina 1 parte & 17 & 8 & fev. & 28 \\
\hline 17 & $\begin{array}{l}\text { Goma-laca em folhas e } \\
\text { resina preta fina em partes iguais }\end{array}$ & 28 & 4 & mar. & 2 \\
\hline 18 & Um cilindro de enxofre endurecido & 19 & 4 & mar. & 20 \\
\hline 19 & Um grande cone de enxofre endurecido & 30 & 0 & mar. & 29 \\
\hline 20 & Um bolo de enxofre & 11 & 4 & abr. & 29 \\
\hline
\end{tabular}

Gray não deu nenhuma dica de qual foi sua inspiração para escolher estes materiais específicos, nem do motivo pelo qual esperava que eles ficassem eletrizados com este modo de preparação. Contudo, ele era um observador atento aos detalhes. Desde 1708 fazia experiências com eletricidade. Em 1729 descobriu os condutores e isolantes quando percebeu que, ao atritar um tubo de vidro, a rolha na ponta do tubo atraía corpos leves em suas proximidades. Este fato chamou sua atenção, já que mesmo quando seguramos um pedaço de cortiça com a mão e o atritamos, a rolha atritada não vai atrair corpos leves em suas proximidades. ${ }^{15}$ Ao prosseguir com suas experiências, descobriu que podia comunicar a virtude elétrica (ou a capacidade de atrair corpos leves) a algumas substâncias que estavam em contato com o tubo de vidro eletrizado, sem que estas substâncias fossem atritadas. Estas substâncias são chamadas hoje em dia de condutores. Outras substâncias não permitiam a passagem e dissipação da

\footnotetext{
${ }^{15}$ Apêndice B de [Ass10b], [Ass10a], [Ass11], [Ass15b] e [Ass17].
} 
virtude elétrica para a Terra, sendo hoje em dia chamadas de isolantes. Entre os isolantes analisados por Gray, encontram-se um fio ou corda de seda, crina de cavalo, bolachas ou tabletes de resina endurecida, vidro previamente aquecido, cera de abelha, cera de enxofre e goma-laca. É possível que ao trabalhar com alguma destas resinas e ceras, tenha observado casualmente que algumas delas estavam eletrizadas sem que tivessem sido previamente atritadas, já que atraíam corpos leves em suas proximidades. Ele pode ter suspeitado que algumas destas substâncias podem ter ficado eletrizadas ao serem derretidas. Pode então ter feito o estudo sistemático deste fenômeno, que é o assunto deste artigo de 1732. Esses isolantes analisados por Gray que ficavam eletrizados por um longo tempo sem terem sido previamente atritados são chamados hoje em dia de eletretos. Eles podem ser eletrizados pelo procedimento que ele apresentou ou por qualquer outro método moderno. Gray parece ter sido a primeira pessoa a apresentar um procedimento para a fabricação de eletretos, assim como uma lista de materiais que poderiam se transformar em eletretos com este procedimento.

Em seguida Gray apresentou outra descoberta muito importante, a saber, uma maneira de aumentar o intervalo de tempo no qual um corpo permanece eletrizado:

A maneira de preservá-los em um estado de atração [ou seja, de mantê-los eletrizados], foi embrulhá-los em qualquer coisa que os manteria [isolados] do ar externo. Inicialmente para os corpos menores utilizei papel branco, mas para os maiores [utilizei] flanela branca. ${ }^{16}$ Mais tarde, encontrei que meias de lã preta funcionavam igualmente bem. Sendo assim revestidos, eles foram colocados dentro de uma grande caixa de abeto, ${ }^{17}[\mathrm{e}]$ ali permaneceram até que tive a oportunidade de utilizá-los.

O cilindro de enxofre, número 18 [da Tabela], foi feito pelo derretimento de enxofre e, [então] derramando-o dentro de um recipiente cilíndrico de vidro, que havia sido previamente aquecido para evitar que se quebrasse. Quando o enxofre foi endurecido, ele ficou um pouco menor do que o vidro, de forma que pela inversão do vidro, ele saiu facilmente, e tinha uma superfície polida quase tão lisa quanto o vidro no qual ele fora fundido. $\mathrm{O}$ cone grande de enxofre, número 19, foi feito da mesma maneira; a saber, sendo fundido em um grande copo de vidro.

Agora, estou para dar uma descrição das observações feitas sobre os vários corpos mencionados na Tabela, mas devo primeiro dar uma descrição da Tabela. A primeira coluna contém o número, que em um pequeno pedaço de papel é fixado em cada um dos vários corpos. O nome é dado na segunda coluna, [e indica] se eles são substâncias simples ou compostas. A terceira coluna mostra que peso eles tinham quando [eram] derretidos, em onças e dracmas ${ }^{18}$ [no sistema] de peso Averdupois. ${ }^{19}$ Na quarta coluna você tem os dias do mês em que o corpo foi derretido e recebeu a sua forma e, consequentemente, quando começou a atrair.

\footnotetext{
${ }^{16}$ White flannel, provavelmente feita de algodão.

${ }^{17}$ Madeira de um tipo de pinheiro.

${ }^{18}$ Uma onça é equivalente a $28,35 \mathrm{~g}$. Um dracma é equivalente a um oitavo de onça, ou 3,54 g.

${ }^{19}$ Averdupois, agora grafado Avoirdupois, é um sistema de medidas.
} 
Por trinta dias continuei a observar cada um desses corpos, e descobri que no final desse período eles atraíam tão vigorosamente quanto no primeiro ou no segundo dia, como eles fazem agora na escrita deste [texto]. Pelos tempos mencionados na Tabela, sendo subtraído de qualquer tempo posterior, será encontrado por quanto tempo qualquer um dos corpos tem mantido sua virtude atrativa. Por este procedimento aparecerá que alguns deles não têm perdido sua atração por mais de quatro meses. ${ }^{20}$ De modo que temos alguma razão para acreditar que agora descobrimos que existe um poder perpétuo de atração em todos os corpos elétricos, sem [a necessidade de ser] excitado por fricção, batidas, etc., ou qualquer outro [tipo de] atrito. Isso aparecerá de forma mais evidente pelas descrições que vou dar agora dos dois últimos corpos mencionados na Tabela. O cone de enxofre, número 19, que foi fundido em um grande copo de vidro, atraiu aproximadamente duas horas depois de ter sido retirado do vidro, e o vidro atraiu também, mas a uma distância pequena. No dia seguinte o enxofre foi retirado do vidro, e então ele atraiu fortemente, mas agora não existia nenhuma atração perceptível do vidro. O cone de enxofre foi então colocado com sua base sobre a tampa da caixa de abeto, dentro da qual estavam os outros corpos elétricos, e o vidro sobreposto a ele. ${ }^{21}$ Verifiquei-o todos os dias depois [disso], e ainda encontrei-o a atrair. ${ }^{22}$ Mas não achei o lugar tão conveniente, tendo de examinar dentro da caixa frequentemente. ${ }^{23}$ Transferi-o para a mesa que fica entre as duas janelas do meu quarto, onde tem continuado até o momento. E sempre que o vidro é retirado, [o enxofre que estava coberto por ele] atrai quase a aproximadamente tão grande distância quanto o enxofre que está revestido e fechado dentro da caixa [de abeto] mencionada acima. E embora na primeira [tentativa] não tenha ocorrido atração [pelo vidro] quando o vidro foi retirado [do enxofre que envolvia], encontro agora que com tempo bom o vidro também atrai. ${ }^{24}$ Mas não a tão grande distância quanto o enxofre, que nunca falha em atrair, podendo o vento ou o clima ser bem variáveis, assim como [continuam com seu poder atrativo] todos os outros corpos

\footnotetext{
${ }^{20}$ Esta carta é datada de 7 de junho de 1732. Com base neste parágrafo, temos a impressão que a Tabela da página 260 deste livro refere-se a 1732, já que Gray afirma que as substâncias mantiveram seu poder atrativo por mais de 4 meses (i.e., de 31 janeiro de 1732 , dia em que as primeiras substâncias foram derretidas de acordo com a Tabela, até 7 de junho de 1732 , dia em que a carta foi escrita). Por outro lado, Du Fay ao discutir estes experimentos [DF34, pág. 342], diz que os corpos nos experimentos que Gray aborda nesta carta, mantiveram seu poder atrativo por um ano e meio após os primeiros experimentos: "O Sr. Gray embrulhava estes diferentes corpos em papel, em flanela ou qualquer outro material similar, e assim, eles mantiveram sua eletricidade por vários meses, mesmo até a época em que escreveu [a carta], que foi cerca de um ano e meio após as suas primeiras experiências." Logo, ele interpretou que a Tabela refere-se a 1731. Provavelmente esta interpretação de Du Fay foi devida à data em que o artigo saiu publicado, a saber, no volume 37 da Philosophical Transactions, relativo aos anos de 1731-1732. Apesar disso, entendemos que o ano correto da Tabela é 1732, tendo em vista a declaração de Gray segundo a qual o poder atrativo durou mais de 4 meses.

${ }^{21}$ Isto é, Gray colocou novamente o copo de vidro sobre o cone de enxofre.

${ }^{22}$ Gray está se referindo ao enxofre.

${ }^{23}$ Provavelmente Gray continuava testando os corpos que havia deixado dentro da caixa, para ver se continuavam atraindo corpos leves. Logo, o cone de enxofre em cima da caixa atrapalhava um pouco esta atividade, motivo pelo qual resolveu retirar o cone dali.

${ }^{24}$ Isto é, ao retirar, depois de alguns dias, o vidro que estava ao redor do enxofre, Gray encontrou que o vidro conseguia atrair corpos leves ao se aproximar deles.
} 
mencionados na Tabela. Apenas em tempo úmido as atrações não são produzidas a tão grande distância como em tempo bom.

O número 20 é um bolo de enxofre que foi derretido e, como os outros corpos, tomou a forma de uma seção convexa de uma esfera. ${ }^{25}$ Este, quando frio, foi colocado com o lado plano da sua superfície para baixo, sobre a mesma mesa com o cone de enxofre. Ambos foram colocados bem perto da parede, a fim de evitar a luz do sol brilhando sobre eles. Isto ocorreu, como a Tabela mostra, no dia 18 de abril. ${ }^{26}$ E embora não estivesse coberto ou revestido de qualquer maneira, tem atraído desde então. E neste, como em outros corpos, a atração será de acordo com o tempo. $^{27}$ Mas, quando ele atrai da forma mais intensa, isto não é mais do que a décima parte do que atrai o cone de enxofre que está coberto.

A melhor maneira de observar estas atrações é segurando o corpo que atrai em uma mão, e uma fina linha branca $^{28}$ amarrada à extremidade de uma vareta na outra [mão]. Desta forma, graus muito menores de atração serão percebidos, do que utilizando lâminas de latão. Quando a linha é segurada à máxima distância, ela pode ser atraída. O movimento dela é, a princípio, muito lento, mas ainda acelerando na medida em que se aproxima mais do corpo [que está] atraindo.

Estou, agora, [trabalhando] sobre o tema da atração permanente no vidro, e depois em outros corpos, mas ainda não completei estes experimentos, [pois acabei] encontrando com mais interrupções pelo tempo. ${ }^{29}$

A partir dessa descrição, vemos que Gray conseguiu ampliar o tempo no qual os corpos ficavam eletrizados de duas maneiras. Uma foi embrulhando-os em papel, flanela ou outros materiais. A segunda maneira foi guardando-os de volta nos próprios recipientes no qual foram fundidos.

Além disso, quando o recipiente era de vidro, Gray percebeu que não apenas o corpo, mas também o vidro, atraíam corpos próximos a eles. Ou seja, no processo de fabricação dos eletretos, tanto estes corpos quanto os próprios recipientes no qual são fundidos e endurecidos também ficam eletrizados. É mais fácil perceber a eletrização dos recipientes no caso em que se comportam como isolantes, já que então podem ficar sobre a mesa ou em contato com o solo sem perder suas cargas por aterramento. Se o recipiente for condutor, é necessário isolá-lo eletricamente da Terra antes e depois da preparação dos eletretos para então poder observar se também ficou eletrizado.

Na Seção 13.2 mostramos algumas experiências nas quais conseguimos com que canudos plásticos eletrizados por atrito continuassem com seus poderes atrativos por alguns meses. Bastou embrulhá-los em guardanapos de papel ou em

\footnotetext{
${ }^{25}$ Obteve esta forma por ter sido fundido em uma das três conchas de ferro.

${ }^{26} \mathrm{Na}$ Tabela consta dia 29 de abril.

${ }^{27}$ Estado atmosférico (weather).

28 "White thread" no original. Provavelmente trata-se de uma linha de algodão ou de linho. Estes materiais comportam-se como condutores nas experiências usuais de eletrostática. Gray está utilizando aqui a sua linha pendular, ver a Seção 2.5.

${ }^{29}$ Estado atmosférico (weather).
} 
sacos plásticos, para assim mantê-los isolados do ar externo. Embora estas experiências sejam muito simples, nunca as vimos mencionadas em livros sobre eletricidade. Mas o efeito é impressionante, já que um canudo atritado e mantido ao ar livre perde sua eletrização em alguns minutos ou no máximo em algumas horas.

Só para dar uma ordem de grandeza, suponha que um canudinho permaneça eletrizado por 10 minutos quando mantido ao ar livre. Além disso, suponha que ele permaneça eletrizado por 3 meses quando guardado envolvido ou enrolado em um saco plástico. O intervalo de tempo no qual ele permanece eletrizado aumentou quase 13.000 vezes simplesmente ao protegê-lo do ar livre! É incrível como um procedimento tão simples pode ter um efeito tão grande.

Nossa inspiração para estas experiências foi exatamente este artigo fundamental de Gray de 1732 no qual utilizou este procedimento com seus eletretos.

\title{
13.8 Desenvolvimento e Aplicações dos Eletre- tos
}

Os eletretos desenvolvidos por Gray foram pesquisados por Du Fay e alguns outros pesquisadores mas permaneceram por longo tempo apenas como uma curiosidade científica. Heaviside apresentou uma receita teórica para a fabricação de eletretos no interior de um capacitor com alta voltagem em $1885 .{ }^{30}$ Mas foi apenas no início da década de 1920 que Momotaro Eguchi fabricou e estudou sistematicamente eletretos formados desta maneira a partir de uma mistura de cera de carnaúba e resina. ${ }^{31}$

Fukada descreveu as experiências de Eguchi e a duração da eletrização de seus eletretos da seguinte forma: ${ }^{32}$

\begin{abstract}
Os eletretos originais, dielétricos carregados permanentemente, foram preparados por Eguchi em 1924 utilizando uma mistura de cera de carnaúba e resina [1]. ${ }^{33}$ Um campo elétrico de aproximadamente $1.5 \mathrm{MV} / \mathrm{m}$ foi aplicado a uma mistura derretida com [uma temperatura] aproximada de $130^{\circ}$ C. Um disco de eletreto feito de cera de carnaúba e resina, com 20 $\mathrm{cm}$ de diâmetro e uma espessura de $1 \mathrm{~cm}$, está preservado no Museu de Ciências em Tóquio. Suas cargas superficiais permanecem 45 anos após terem sido preparadas e observou-se que possuem aproximadamente um sétimo das cargas originais [2] ${ }^{34}$
\end{abstract}

Desde então têm sido fabricados eletretos por diversos processos diferentes, sendo estes materiais em geral classificados pelo método de produção.

\footnotetext{
${ }^{30}[$ Hea87, Artigo 30: Electromagnetic induction and its propagation, Seção 12: Electrisation and Electrification. Natural Electrets, págs. 491-2], [JW80] e [Sil10b, págs. 20-22].

31 [Egu25], [Mas87] e [Sil10b].

32 [Fuk00].

33 [1] Eiichi FukadaEiichi Fukada and M. Eguchi, "On the permanent electret," Phil. Mag., vol. 49, págs. 178-192, 1925. [Embora esta referência [1] apareça escrita com tendo estes autores no artigo de Fukada, este trabalho foi escrito apenas por M. Eguchi, [Egu25].]

${ }^{34}[2]$ T. Takamatsu and I. Sumoto, "Life time of carnauba wax electrets," Riken Hokoku, vol. 45, págs. 141-148, 1969 (em japonês).
} 
Citamos a seguir algumas aplicações para os eletretos:

- Como base eletrizada de um eletróforo.

- Microfones.

- Fones de ouvido e alto-falantes.

- Detetores de radiação.

- Dosímetros.

- Fotocopiadoras.

- Unidades armazenadoras de memória.

- Medidores de umidade.

- Pilhas eletrostáticas.

- Filtros de ar.

- Detetores de vibrações.

- Medidores de pressão.

- Motores eletrostáticos.

- Geradores de corrente.

- Geradores de tensão.

- Figuras de Lichtenberg.

- Etc.

Os eletretos continuam sendo um tema ativo de pesquisa científica. Existem diversos livros e artigos lidando com este assunto. ${ }^{35}$

\footnotetext{
${ }^{35}$ [Net94], [Gro54], [Jef59], [Jef73, Capítulo 9: Electret motors], [JW80], [Ses87], [Fer00], [MWW07], [MW08], [Sil10b] e [GB17, Capítulo 7: Excess charge in solids: electrets].
} 


\section{Capítulo 14}

\section{As Misteriosas Forças Não Eletrostáticas}

\subsection{Força Eletrostática ou Força de Coulomb}

Charles Augustin de Coulomb obteve em 1785 a lei de força entre duas partículas eletrizadas. Apresentou seu resultado em dois artigos de 1785, publicados em 1788. ${ }^{1}$ Ele denominava as cargas de "massas elétricas," "moléculas elétricas," "moléculas eletrizadas," ou "densidades dos fluidos elétricos." 2

No caso de cargas de mesmo sinal, Coulomb expressou-se nas seguintes palavras: ${ }^{3}$

\section{Lei fundamental da eletricidade.}

A força repulsiva entre dois pequenos globos eletrizados com o mesmo tipo de eletricidade, está na razão inversa do quadrado da distância entre os centros dos dois globos.

No caso de cargas de sinais opostos, Coulomb expressou-se nas seguintes palavras: $^{4}$

Chegamos assim, por um método totalmente diferente do primeiro método, a um resultado similar; desta forma podemos concluir que a atração recíproca do fluido elétrico denominado positivo, sobre o fluido elétrico denominado comumente negativo, está na razão inversa do quadrado das distâncias; da mesma forma que havíamos obtido, em nossa primeira Memória, que a ação recíproca de um fluido elétrico de mesma natureza, está na razão inversa do quadrado das distâncias.

\footnotetext{
${ }^{1}$ [Cou85a], [Cou85b], [Pot84] e [Cou35].

2 [Gil71b] e [Gil71a, págs. 190-192].

3 [Cou85a, pág. 572], [Pot84, pág. 110] e [Cou35].

4 [Cou85b, pág. 572], [Pot84, pág. 123] e [Cou35].
} 
Até aqui Coulomb apenas mencionou como a força elétrica varia com a distância entre as cargas. Foi apenas no final de sua segunda Memória que ele mencionou que esta força também é proporcional ao produto entre as cargas: ${ }^{5}$

Recapitulação dos assuntos contidos nesta Memória.

Das pesquisas precedentes, resulta:

$1^{\circ}$. Que a ação, seja repulsiva, seja atrativa entre dois globos eletrizados e, consequentemente, entre duas moléculas elétricas, está na razão composta das densidades do fluido elétrico das duas moléculas, e na razão inversa do quadrado das distâncias.

Gillmor apontou corretamente que Coulomb não chegou a demonstrar experimentalmente que a força entre duas cargas era proporcional ao produto entre elas. ${ }^{6}$ Ele simplesmente supôs esta proporcionalidade, não considerando que fosse importante tentar demonstrá-la experimentalmente. Ainda se discute se o fato da força elétrica ser proporcional ao produto entre as cargas é uma definição da quantidade de carga ou se é um resultado experimental. ${ }^{7}$ No primeiro caso a quantidade de carga de um corpo seria definida ou medida a partir da quantidade de força que ela produz. No segundo caso seria possível definir e medir a quantidade de carga de um corpo sem utilizar a força que ele produz, podendo então vir de um resultado experimental que a força elétrica produzida por um corpo seria proporcional à sua quantidade de carga.

Esta força eletrostática é muito similar à força gravitacional que Newton apresentou em seu livro Princípios Matemáticos de Filosofia Natural. ${ }^{8}$ Ambas estão direcionadas ao longo da linha reta ligando os corpos, seguem a lei da ação e reação, e variam com o inverso do quadrado da distância entre os corpos. Além do mais, a força elétrica depende do produto de duas cargas, enquanto que na força gravitacional temos o produto de duas massas gravitacionais. Parece que Coulomb foi levado a esta expressão mais por analogia com a lei de Newton para a gravitação do que como resultado de suas poucas experiências. ${ }^{9}$

\footnotetext{
${ }^{5}$ [Cou85b, pág. 611] e [Pot84, pág. 146].

${ }^{6}$ [Gil71b] e [Gil71a, págs. 190-192].

7 [BW13].

8 [New34], [New52], [New90], [New99], [New08] e [New10].

${ }^{9}[$ Hee92].
} 


\section{Definição 14.1}

Denomina-se de força eletrostática, força coulombiana, força de Coulomb ou lei de Coulomb à interação fundamental que caracteriza os fenômenos elétricos de cargas em repouso. Partículas eletrizadas com cargas de mesmo tipo se repelem, enquanto que partículas eletrizadas com cargas opostas se atraem. Esta força é proporcional ao produto das cargas nestes dois corpos, variando com o inverso do quadrado da distância entre eles (no caso em que temos corpos com dimensões pequenas comparadas com a distância de separação entre eles). Esta força segue o princípio de ação e reação, apontando ao longo da reta que une os corpos que estão interagindo.

As chamadas forças não eletrostáticas ou forças não coulombianas são as forças entre corpos eletrizados que não seguem a lei de Coulomb.

As expressões eletrostática e eletrodinâmica foram criadas por André-Marie Ampère (1775-1836) em 1822. ${ }^{10}$

São as forças não eletrostáticas que, entre outras coisas, mantêm um sistema de partículas eletrizadas em repouso mútuo, em equilíbrio estável. Forças de origem não eletrostática também são necessárias para separar partículas eletrizadas com cargas opostas, como ocorre no efeito âmbar. Elas também são necessárias em circuitos resistivos conduzindo corrente constante, ${ }^{11}$ assim como em várias outras situações experimentais. Neste Capítulo apresentamos alguns exemplos nos quais são necessárias forças de origem não eletrostática.

\subsection{Forças Não Eletrostáticas em Situações de Equilíbrio Estável}

Samuel Earnshaw (1805-1888) provou em 1842 que é impossível haver um conjunto de corpos parados entre si, em equilíbrio estável, quando as forças que atuam entre eles é central e varia com o quadrado da distância entre eles. ${ }^{12}$ Por outro lado, encontramos na natureza diversas situações nas quais corpos eletrizados ficam parados entre si, mantidos em equilíbrio estável. Logo, em todas estas situações são necessárias forças de origem não eletrostática para contrabalançar as forças eletrostáticas entre estes corpos e para conferir um equilíbrio estável ao sistema. ${ }^{13}$

Vamos supor que temos um condutor $C$ esférico, isolado da Terra e carregado negativamente. Ele pode ter sido carregado, por exemplo, ao raspar uma

\footnotetext{
${ }^{10}$ [Amp22a, pág. 60], [Amp22c, nota na pág. 200], [Amp22b, nota na pág. 237], [Amp85b, nota na pág. 239], [Amp85a, nota na pág. 192], [Blo82, pág. 78], [Cha09, Seção 1.3], [AC11, Seção 1.4] e [AC15, Seção 1.4].

11 [AH07], [AH09] e [AH13].

12 [Ear42], [Max54a, artigo 116, págs. 174-176] e [Sco59].

${ }^{13}$ Ver [VF80], [CS02, Seção 18.7], [AH07, Seção 5.3 e Apêndice A], [AH09, Seção 5.3 e Apêndice A], [AH13, Seção 5.3 e Apêndice A], [AC11, Seção 2.4], [AC15, Seção 2.4], assim como as Seções 7.8 e 7.9 de [Ass10b], [Ass10a], [Ass11], [Ass15b] e [Ass17].
} 
régua eletrizada sobre seu corpo, ou pelo método $A C R$, ao entrar em contato com um canudo que foi atritado no cabelo. As cargas sobre o condutor se repelem mutuamente e no equilíbrio elas se distribuem uniformemente sobre sua superfície, Figura 14.1.

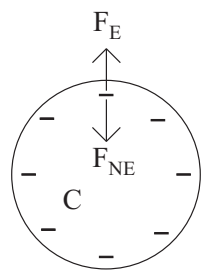

Figura 14.1: Uma esfera condutora $C$ uniformemente eletrizada. São indicadas a força repulsiva eletrostática $F_{E}$ exercida pelas outras cargas atuando sobre a carga superior, assim como a força não eletrostática $F_{N E}$ que mantém a carga superior em repouso sobre a superfície da esfera.

Vamos considerar a partícula negativamente eletrizada que se encontra no topo da esfera. Ela é repelida por todas as outras cargas negativas e, portanto, sofre uma força eletrostática vertical para fora da esfera, $F_{E}$. Para que permaneça em repouso, é necessária uma força de origem não eletrostática apontando para baixo, $F_{N E}$, de mesma intensidade que a força eletrostática apontando para cima. Nesta situação específica, esta força de origem não eletrostática é às vezes chamada de força de contato. Mas não se entende claramente sua origem, como ela é produzida, etc.

Heilbron mencionou a questão problemática de saber qual é o agente que evita a fuga dos fluidos elétricos da superfície de condutores. ${ }^{14}$

A mesma situação ocorre quando a esfera condutora está carregada positivamente, Figura 14.2 (a). A mesma situação também acontece para uma esfera isolante uniformemente eletrizada ao longo de toda sua superfície, tanto negativamente quanto positivamente, Figura 14.2 (b) e (c).

Nesta figura $F_{E}$ representa a força eletrostática exercida sobre a partícula superior eletrizada, força essa devida à repulsão eletrostática exercida por todas as outras partículas eletrizadas pertencentes à esfera na qual a partícula superior está localizada. Já $F_{N E}$ representa a força de mesma intensidade, mas de sentido oposto a $F_{E}$, atuando sobre a partícula eletrizada superior e que a mantém em repouso sobre a superfície da esfera.

Uma outra situação de equilíbrio estável é aquela na qual um condutor isolado do solo fica polarizado eletricamente devido à presença de um corpo eletrizado em suas proximidades. Vamos supor que eletrizamos um canudo de plástico negativamente ao atritá-lo contra o cabelo. Ao aproximar o canudo de um condutor isolado, este fica polarizado, Figura 14.3.

Na Figura 14.3 $F_{E}$ representa a força eletrostática resultante exercida sobre uma partícula positivamente eletrizada que está localizada na extremidade do

\footnotetext{
14 [Hei99, págs. 499-500].
} 


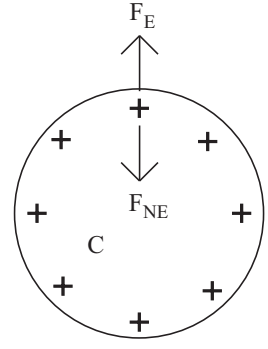

(a)

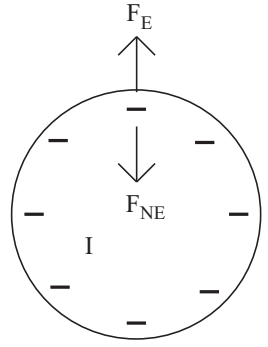

(b)

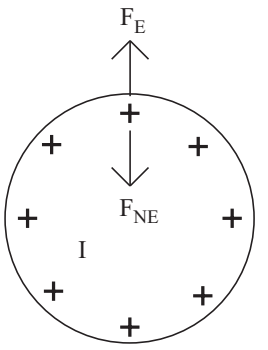

(c)

Figura 14.2: (a) Esfera condutora $C$ positivamente eletrizada. (b) Esfera isolante $I$ negativamente eletrizada. (c) Esfera isolante $I$ positivamente eletrizada.
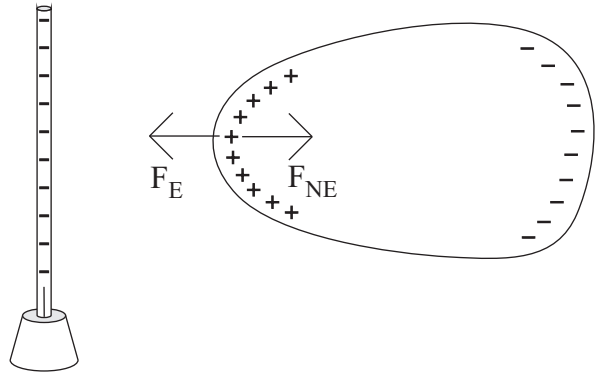

Figura 14.3: Condutor polarizado na presença de um canudo negativamente carregado.

condutor mais próxima do canudo negativamente eletrizado. Esta força é devida tanto à atração exercida pelas cargas negativas do canudo, quanto às forças exercidas pelas outras cargas distribuídas ao longo da superfície do próprio condutor. Para que esta partícula fique em equilíbrio estável, é necessária a existência de uma força de origem não eletrostática, $F_{N E}$. Esta força não eletrostática possui a mesma intensidade que $F_{E}$, mas atua em sentido oposto.

Um situação análoga vai acontecer no caso das partículas positivas e negativas que existem nas moléculas polarizadas de um isolante que está nas proximidades de um outro corpo eletrizado. Na Figura 14.4 (a) apresentamos o modelo de um isolante cujas moléculas são polarizadas devido à presença de um canudo negativamente eletrizado nas proximidades do isolante.

Na Figura 14.4 (b) separamos uma única molécula polarizada do isolante, aquela localizada mais à esquerda deste corpo e mais próxima do canudo eletrizado. As grandezas $F_{E}$ e $F_{N E}$ representam as forças eletrostática e não eletrostática que estão atuando na extremidade positiva desta molécula. A força eletrostática é exercida pelas cargas do canudo, pelas cargas positiva e negativa de todas as outras moléculas polarizadas do isolante, assim como pela carga negativa desta própria molécula. A resultante de todas estas forças aponta para 


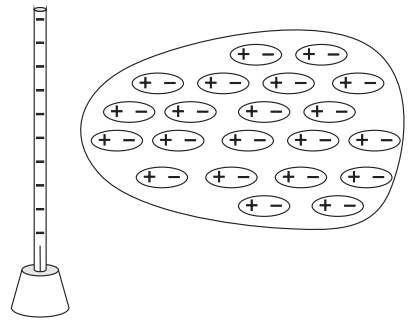

(a)

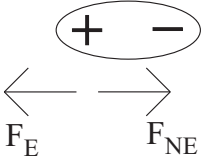

(b)

Figura 14.4: (a) Isolante polarizado na presença de um canudo negativamente carregado. (b) Forças eletrostática e não eletrostática, $F_{E}$ e $F_{N E}$, atuando na extremidade positiva de uma das moléculas polarizadas do isolante.

o canudo negativamente eletrizado. Como esta extremidade positivamente eletrizada da molécula polarizada permanece em repouso, é necessária a existência de uma força de origem não eletrostática para mantê-la em equilíbrio. Esta força não eletrostática tem a mesma intensidade que a força eletrostática, mas atua no sentido oposto a ela.

Ou seja, para impedir o movimento de partículas eletrizadas em corpos que estão eletrizados, como na Figuras 14.1 e 14.2, são necessárias forças não eletrostáticas que se oponham às forças eletrostáticas usuais. A mesma coisa ocorre no caso de condutores ou isolantes que ficam polarizados na presença de um outro corpo eletrizado, como nas Figuras 14.3 e 14.4. Sem a existência destas forças não eletrostáticas, seria impossível manter corpos eletrizados e/ou polarizados nos quais as partículas positivas e negativas permanecessem em equilíbrios estáveis.

Existem poucas situações nas quais são nulas as forças eletrostáticas resultantes atuando sobre todas partículas eletrizadas de um sistema de cargas. Um exemplo ocorre na Figura 14.5.

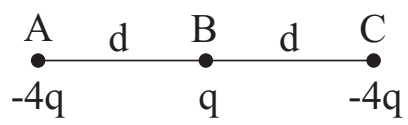

Figura 14.5: Partículas pontuais $A, B$ e $C$ igualmente espaçadas por uma distância $d$ ao longo de uma linha reta. Partículas $A$ e $C$ eletrizadas com carga $-4 q$, enquanto que a partícula $B$ está eletrizada com carga $q$.

Temos três partículas pontuais $A, B$ e $C$ igualmente espaçadas por uma distância $d$. As partículas $A$ e $C$ estão igualmente eletrizadas com carga $-4 q$, enquanto que a partícula $B$ está eletrizada com carga $q$. As forças entre elas estão representadas na Figura 14.6.

Na Figura 14.6 à esquerda temos a força repulsiva $F_{C A}$ exercida por $C$ sobre $A$ e a força atrativa $F_{B A}$ exercida por $B$ sobre $A$. De acordo com a lei de 

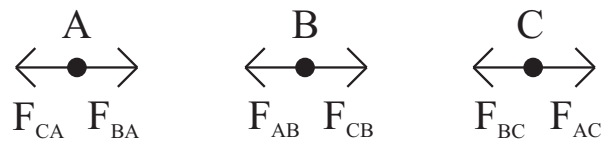

Figura 14.6: Forças eletrostáticas atuando sobre as partículas.

Coulomb, estas duas forças se equilibram. No centro da Figura 14.6 temos a força atrativa $F_{A B}$ exercida por $A$ em $B$ e a força atrativa $F_{C B}$ exercida por $C$ em $B$. De acordo com a lei de Coulomb, estas duas forças se equilibram. Na Figura 14.6 à direita temos a força atrativa $F_{B C}$ exercida por $B$ em $C$ e a força repulsiva $F_{A C}$ exercida por $A$ em $C$. Novamente, de acordo com a lei de Coulomb, estas duas forças se equilibram.

Em princípio estas três partículas poderiam permanecer em repouso em um referencial inercial, já que a força resultante sobre cada uma delas é nula, como mostra a Figura 14.6. Parece então que não são necessárias forças não eletrostáticas neste caso. Contudo, o equilíbrio deste sistema é instável. Isto pode ser visto na Figura 14.7 na qual a partícula $B$ aproximou-se um pouco da partícula $C$.
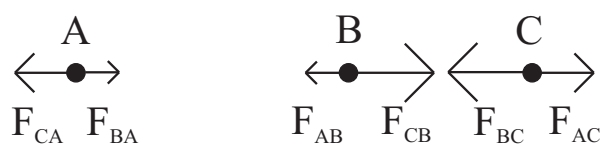

Figura 14.7: Forças eletrostáticas atuando sobre as partículas quando $B$ se aproxima de $C$.

Quando a partícula $B$ se aproxima de $C$, aumenta a força atrativa entre elas. Da mesma forma, diminui a força atrativa entre $A$ e $B$. Com isto a força resultante sobre $B$ passa a apontar para $C$. Da mesma forma, a força resultante sobre $C$ passa a apontar para $B$. Já a força resultante sobre $A$ aponta em sentido oposto à localização das partículas $B$ e $C$. Suponha que estas partículas estejam livres para se mover apenas sob a ação das forças eletrostáticas atuando sobre elas, começando na configuração da Figura 14.6. Logo, quando uma perturbação qualquer fizer com que $B$ se aproxime de $C$, elas vão continuar se aproximando cada vez mais, enquanto que $A$ vai se afastar do par $B C$. Este sistema vai então se afastar cada vez mais da configuração inicial de equilíbrio representada pela Figura 14.6.

Ou seja, embora a configuração da Figura 14.5 seja de equilíbrio, este equilíbrio é instável. Qualquer perturbação no sistema fará com que ele se desfaça. Este é um exemplo do teorema de Earnshaw. Logo, para manter este sistema em equilíbrio estável, mais uma vez temos a necessidade da existência de forças não eletrostáticas.

Um exemplo de uma estrutra composta de íons em equilíbrio estável é o cloreto de sódio ou sal de cozinha. Ele apresenta uma estrutura cristalina cúbica composta de íons de sódio e de cloro, $\mathrm{Na}^{+}$e $\mathrm{Cl}^{-}$. Novamente são necessárias 
forças não eletrostáticas para equilibrar as forças de Coulomb atuando em cada íon.

\subsection{Forças Não Eletrostáticas no Efeito Âmbar}

Forças de origem não eletrostática também são necessárias para separar partículas eletrizadas com cargas opostas, como ocorre no efeito âmbar. Antes de analisar este efeito, vamos lembrar a ação da força de Coulomb sobre corpos eletrizados com cargas opostas.

Vamos supor que temos um condutor $C 1$ eletrizado positivamente com uma carga $+Q$ e isolado eletricamente do solo, juntamente com um outro condutor $C 2$ eletrizado negativamente com uma carga $-Q$ também isolado. Ao entrarem em contato, eles se neutralizam, Figura 14.8.

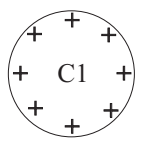

(a)

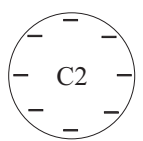

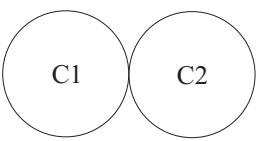

(b)

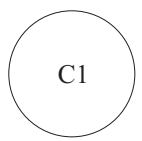

(c)

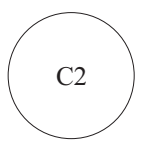

Figura 14.8: (a) Esferas condutoras $C 1$ e $C 2$ afastadas entre si e eletrizadas com cargas opostas. (b) Neutralização das esferas após o contato. (c) As esferas continuam neutras após serem separadas.

Uma experiência deste tipo foi feita no Volume 1 deste livro utilizando dois eletroscópios eletrizados com cargas opostas, ${ }^{15}$ ver a Figura 14.9.

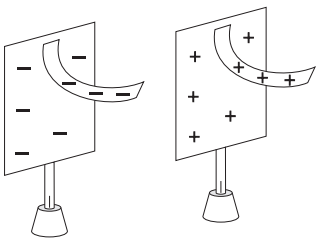

(a)

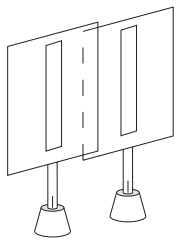

(b)
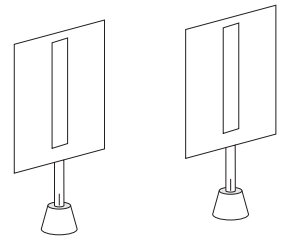

(c)

Figura 14.9: (a) Eletroscópios eletrizados com cargas opostas. (b) Após o contato eles se neutralizam, como indicado pelas tirinhas abaixadas. (c) Após a separação as tirinhas permanecem abaixadas, indicando que os eletroscópios foram descarregados.

Vamos supor agora que temos um isolante $I$ eletrizado em sua superfície, como no caso de um canudo ou régua plástica eletrizados por atrito contra um guardanapo de papel. Vimos no Volume 1 desta obra que um dos procedimentos para neutralizar este isolante é o de mergulhá-lo em uma bacia metálica aterrada contendo água de torneira. Após retirá-lo da água, observa-se que ficou

\footnotetext{
${ }^{15}$ Seção 6.9 de [Ass10b], [Ass10a], [Ass11], [Ass15b] e [Ass17].
} 
neutro, não mais atraindo papeizinhos colocados em suas proximidades. ${ }^{16}$ Este procedimento está ilustrado na Figura 14.10.

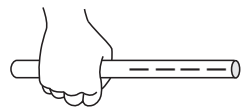

(a)

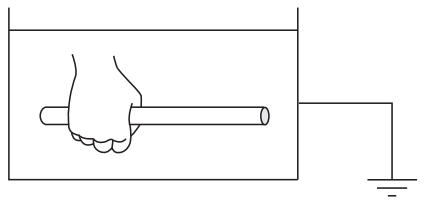

(b)

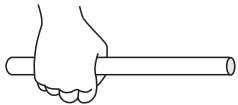

(c)

Figura 14.10: (a) Canudo plástico negativamente eletrizado. (b) Mergulhamos o canudo na água que está em uma bacia metálica aterrada água. (c) Ele está neutro ao sair da água.

A água comporta-se como um condutor nas experiências de eletrostática. Ela tem partículas eletrizadas livres (íons carregados, $\mathrm{H}_{3} \mathrm{O}^{-}, \mathrm{OH}^{-}$, além de muitas outras impurezas eletrizadas) que podem se deslocar pelo volume da água. Quando todas as partes do canudo eletrizado entram em contato com a água, ocorre a neutralização do canudo. As cargas que o canudo possuía espalhadas em sua superfície passam a ser distribuídas pela água. Como a água está aterrada neste exemplo, ocorre uma redistribuição das cargas na água por toda a Terra. Ao retirar o canudo da água, observa-se que ele está neutro, não mais atraindo pedacinhos de papel que sejam colocados em suas proximidades. Ou seja, para neutralizar um isolante eletrizado em sua superfície é necessário colocar toda sua superfície em contato com um condutor como a água, aterrando todos os pontos da superfície do isolante.

Vamos supor agora que temos dois corpos isolantes $A$ e $B$ eletrizados com cargas opostas $+Q$ e $-Q$ espalhadas por suas superfícies. As cargas não se deslocam livremente por estes corpos, já que estamos assumindo que eles são isolantes. Portanto, para que se neutralizem, é necessário que se toquem em todos os seus pontos eletrizados. O que vamos descrever a seguir é uma suposição do que poderia ocorrer neste caso ideal. Na Figura 14.11 apresentamos qualitativamente este processo hipotético de neutralização de isolantes, supondo as cargas localizadas sobre suas superfícies. Não chegamos a fazer experiências nas quais obtivemos esta neutralização de dois isolantes utilizando o processo descrito na Figura 14.11.

Na Figura 14.11 (a) temos $A$ com três cargas positivas nos pontos superficiais $A 1, A 2$ e $A 3$, enquanto que $B$ tem três cargas negativas nos pontos superficiais $B 1, B 2$ e $B 3$. Em (b) temos o toque dos pontos $A 1$ e $B 3$ com a neutralização dos isolantes nesta região. Em (c) temos o toque dos pontos $A 2$ e $B 2$ com a neutralização dos isolantes nesta região. Em (d) temos o toque dos pontos $A 3 \mathrm{e}$ $B 1$ com a neutralização dos isolantes nesta região. Em (e) terminamos com os dois isolantes neutros após a separação. Em (f) mostramos a força eletrostática, $F_{E}$, atuando para unir as cargas opostas durante o contato.

\footnotetext{
${ }^{16}$ Seção 7.14 de [Ass10b], [Ass10a], [Ass11], [Ass15b] e [Ass17].
} 


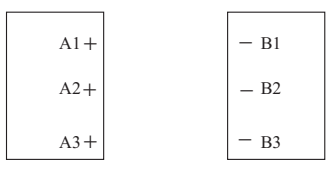

(a)

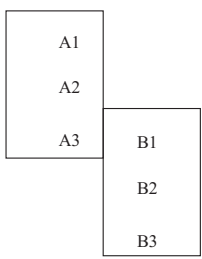

(d)

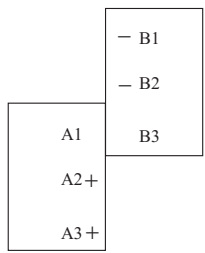

(b)

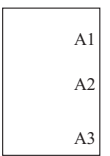

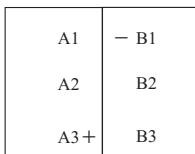

(c)

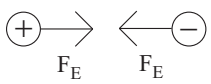

(f)

Figura 14.11: (a) Neutralização hipotética de dois isolantes $A$ e $B$ eletrizados com cargas opostas. (b) Neutralização dos pontos $A 1$ e $B 3$ após o contato entre eles. (c) Neutralização dos pontos $A 2$ e $B 2$ após o contato entre eles. (d) Neutralização dos pontos $A 3$ e $B 1$ após o contato entre eles. (e) Após a separação os isolantes permanecem neutros. (f) Forças eletrostáticas de atração, $F_{E}$, atuando entre cargas opostas.

\section{Vamos agora analisar o efeito âmbar mostrando que a separação de cargas que ocorre neste caso é totalmente contrária ao que se esperaria pela força de Coulomb.}

No efeito âmbar acontece exatamente o oposto do processo representado pela Figura 14.11. Vamos supor que começamos com dois isolantes $A$ e $B$ inicialmente neutros, feitos de materiais diferentes. Atritamos um contra o outro rapidamente com uma velocidade relativa $V$. Após separá-los, observa-se que um deles ficou positivamente eletrizado com uma carga $+Q$ e o outro ficou negativamente eletrizado com uma carga $-Q$. Este processo está ilustrado na Figura 14.12.

Logo, para que tenha ocorrido esta separação de cargas, foi necessária a atuação de uma força de origem não eletrostática, $F_{N E}$, atuando sobre as cargas enquanto estavam sendo separadas. Esta força atua no sentido contrário à força eletrostática, $F_{E}$, que tende a unir as cargas opostas. Estas forças estão representadas na Figura 14.12 (f). Enquanto as partículas opostamente eletrizadas dos dois isolantes estão sendo separadas durante o atrito, a magnitude da força não eletrostática tem de ser maior do que a magnitude da força eletrostática que tende a unir estas cargas opostas.

Ou seja, se tivéssemos apenas a existência das forças eletrostáticas, poderíamos explicar a neutralização de isolantes eletrizados com cargas opostas, como representado na Figura 14.11. Já no efeito âmbar ocorre exatamente o oposto a este processo, já que começamos com dois isolantes neutros e termina- 

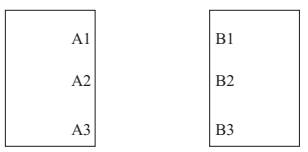

(a)

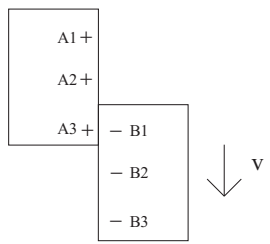

(d)

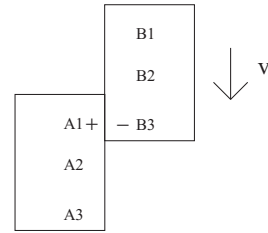

(b)

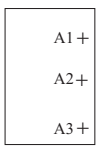

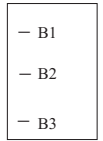

(e)

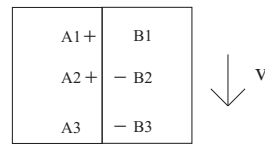

(c)

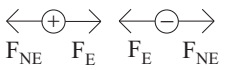

(f)

Figura 14.12: Representação qualitativa do efeito âmbar. (a) Dois isolantes $A$ e $B$ inicialmente neutros. (b) até (d): Devido ao atrito entre as superfícies, os corpos vão ficando eletrizados com cargas opostas. (e) Situação final com os dois isolantes eletrizados com cargas opostas. (f) Forças eletrostáticas de atração entre cargas opostas, $F_{E}$, juntamente com as forças não eletrostáticas, $F_{N E}$. São estas forças não eletrostáticas que causam a separação entre as cargas nas situações (b) até (d).

mos com um deles positivamente eletrizado enquanto que o outro fica negativamente eletrizado, Figura 14.12.

Concluímos então que mesmo no processo mais básico e antigo da eletricidade, é necessária a existência de forças de origem não eletrostática para que o efeito de eletrização possa ocorrer.

\subsubsection{Outros Mistérios no Efeito Âmbar}

Embora o efeito âmbar seja o fenômeno mais antigo do estudo da eletricidade, ainda existem diversos mistérios associados com ele. Não conhecemos exatamente a origem da força não eletrostática que causa a separação de cargas quando ocorre o atrito entre duas substâncias inicialmente neutras. O mesmo pode ser dito sobre a força não eletrostática que mantém as cargas em repouso sobre a superfície de corpos eletrizados ou polarizados. Mas existem outras coisas sobre as quais ainda pairam muitas dúvidas.

Na grande maioria dos livros didáticos afirma-se que a eletrização dos corpos que ocorre no efeito âmbar é devida à transferência de elétrons entre os dois corpos que estão sendo atritados, com um deles ficando com um excesso de elétrons e o outro ficando com uma diminuição de seu número usual de elétrons. Mesmo que seja isto que ocorra, não é claro o que faz com que elétrons sejam transferidos de um corpo para outro.

Mas será que realmente a eletrização de dois corpos durante o efeito âmbar é 
devida à transferência de elétrons entre eles? Nos livros didáticos esta afirmação é feita de forma genérica, sem que sejam citadas experiências que confirmem esta suposição. Contudo, quando analisamos a literatura especializada e consultamos os cientistas que fazem experiências sobre este tema, vemos que ainda há uma grande incerteza sobre o processo fundamental de eletrização de dois corpos atritados. Em seu livro de 1965, Contact and Frictional Electrification, por exemplo, W. R. Harper afirmou o seguinte: ${ }^{17}$

Uma questão crucial para a explicação da produção de carga estática é [a de saber] se a eletrização de isolantes vem de uma transferência de elétrons, de íons, ou de ambos. Montgomery diria que os portadores de carga são sempre elétrons e Loeb [diria] que eles são geralmente elétrons: Henry acredita que esta ainda é uma questão em aberto. Sou da opinião que uma resposta definitiva pode ser dada atualmente, que é a de que os portadores nunca são elétrons - quando o material que está sendo carregado é estritamente um isolante.

Não sei a resposta a esta questão. Me limito aqui a citar algumas referências discutindo este tema do ponto de vista experimental. ${ }^{18}$

\subsection{Forças Não Eletrostáticas em uma Pilha}

Em 1800 Volta publicou sua invenção da pilha elétrica. ${ }^{19}$ Colocou sequências de discos contendo os seguintes elementos, nesta ordem e debaixo para cima: prata, zinco, disco com água salgada; prata, zinco, disco com água salgada; prata, zinco, disco com água salgada; etc. Ao conectar a prata inferior com o zinco superior através de um fio metálico, observou que passava uma corrente constante pelo fio.

Na Figura 14.13 apresentamos uma representação esquemática de uma pilha ou bateria química.

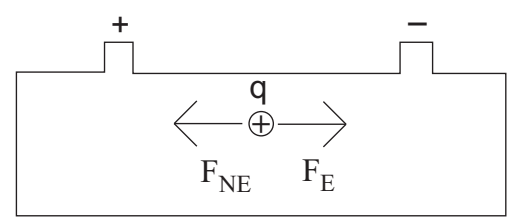

Figura 14.13: Bateria carregada, sendo $q$ uma partícula móvel positivamente eletrizada em seu interior.

A pilha tem um terminal positivo, + , e outro terminal negativo, - . Representamos ainda uma partícula eletrizada com uma carga elétrica $q$ no interior da bateria. Esta carga representa um íon que pode se deslocar pelo interior da bateria, ou seja, uma partícula eletrizada móvel. Supondo $q$ positiva, ela sofre

\footnotetext{
${ }^{17}$ Como citado em [Bai01] e [Gal14].

18 [Bai01], [Sch07], [MWW07], [MW08], [LB08], [LB09], [Wil12], [Gal14] e [GB17].

19 [Vol00a], [Vol00b], [Vol64], [Mag06] e [MA08].
} 
uma força eletrostática $F_{E}$ apontando do terminal positivo para o terminal negativo. Esta força tenderia a descarregar ou neutralizar a bateria ao fazer com que esta carga positiva se deslocasse em direção ao terminal negativo da bateria. Mas não é isto o que ocorre, já que é possível manter uma bateria carregada por vários dias quando seus terminais não estão ligados por um fio condutor. Logo, nesta situação de equilíbrio no qual a bateria permanece eletrizada apesar da existência de íons móveis em seu interior, é necessária a existência de uma força não eletrostática atuando sobre ela, $F_{N E}$. Esta força tem mesma intensidade que $F_{E}$ mas atua em sentido oposto, como indicado na Figura 14.13. Estas forças de mesma intensidade, mas com sentidos opostos, se equilibram. Desta forma o íon ou partícula positivamente eletrizado no interior da bateria permanece em repouso.

Tem uma outra maneira de perceber a existência de forças não eletrostáticas ao analisarmos o carregamento ou eletrização da pilha. Começamos com um recipiente isolante contendo ácido sulfúrico diluído, que é neutro eletricamente. Pegamos uma lâmina neutra de zinco, Zn, e outra lâmina neutra de cobre, $\mathrm{Cu}$. Colocamos uma destas lâminas parcialmente afundada no ácido em uma extremidade do recipiente, enquanto que a outra lâmina é parcialmente afundada no ácido na outra extremidade do recipiente. Observa-se que estas duas lâminas passam a ficar eletrizadas com cargas opostas ou com potenciais elétricos diferentes, o zinco negativamente eletrizado e o cobre positivamente eletrizado. Esta separação de cargas é devida à atuação de uma força de origem não eletrostática, já que as forças eletrostáticas tendem a neutralizar corpos com cargas opostas. Neste caso ocorre exatamente o oposto durante o processo de carga. Ou seja, começamos com dois corpos inicialmente neutros e terminamos com um deles positivamente eletrizado, enquanto que o outro termina negativamente eletrizado. Durante este processo de carga (ou seja, durante o intervalo de tempo desde que colocamos as duas lâminas no ácido até o instante em que elas atingem uma diferença de potencial de equilíbrio constante no tempo), a força de origem não eletrostática tem de ter intensidade maior do que a força de origem eletrostática que tende a neutralizar os corpos que estão eletrizados com cargas opostas.

Portanto, existem também forças de origem não eletrostática atuando nas reações químicas que ocorrem nos eletrodos de uma pilha ou bateria.

\subsection{Forças Não Eletrostáticas em um Circuito com Corrente Constante}

Quando ligamos um condutor metálico resistivo aos dois terminais de uma pilha ou bateria, uma corrente elétrica constante passa a fluir pelo circuito, como discutido na Seção 3.4. A lei de Ohm afirma que a voltagem ou diferença de potencial entre as extremidades do fio é proporcional à sua resistência e à corrente elétrica fluindo por ele. Esta lei pode ser expressa microscopicamente dizendo que a força elétrica atuando sobre um elétron livre do metal é contra- 
balançada por uma força resistiva proporcional à sua velocidade em relação à rede cristalina do metal.

A força elétrica atuando sobre um elétron de condução do metal é do tipo coulombiano, tendo sua origem em uma distribuição de cargas mantidas na superfície do fio. A densidade superficial destas cargas varia ao longo do comprimento do fio resistivo, mas é constante no tempo no caso de corrente constante. São estas cargas superficiais que exercem a força elétrica que impulsiona os elétrons livres, gerando a corrente elétrica.

Já a força resistiva que contrabalança a força elétrica tem origem não eletrostática. Ela é proporcional à velocidade dos elétrons livres em relação à rede cristalina do metal. Esta força resistiva vai aumentando com o crescimento da velocidade de arraste dos elétrons, até que ela tenha a mesma intensidade que a força elétrica que os impulsiona, mas atuando em sentido contrário. Esta força resistiva impede que a velocidade de migração dos elétrons aumente indefinidamente ao ligar o fio aos terminais da bateria, fazendo com que eles atinjam uma velocidade de arraste constante no tempo.

Existe também uma força não eletrostática atuando no interior da bateria e forçando as partículas negativas a deslocarem-se do polo positivo para o polo negativo, ou seja, atuando em direção contrária à força eletrostática.

Discutimos detalhadamente estes tópicos no livro A Força Elétrica de uma Corrente: Weber e as Cargas Superficiais de Condutores Resistivos com Correntes Constantes. ${ }^{20}$

\subsection{Forças Não Eletrostáticas em Outras Si- tuações}

Existem vários outros mecanismos pelos quais começamos com dois corpos $A$ e $B$ inicialmente neutros e terminamos com um deles positivamente eletrizado e com o outro negativamente eletrizado. Também existem vários outros mecanismos pelos quais começamos com um corpo neutro em todas as partes, isolado eletricamente da Terra, terminando com este corpo polarizado eletricamente, ou seja, com um lado positivo e outro lado negativo. São necessárias forças não eletrostáticas em todos estes mecanismos. Entre estes processos podemos citar:

- O simples contato de dois metais com funções trabalho diferentes gera uma diferença de potencial entre eles. Isto é, um fica positivo e o outro negativo. Este é o chamado efeito Volta, diferença de potencial de Volta, ou diferença de potencial por contato. ${ }^{21}$

- A eletrização por contato em geral. ${ }^{22}$ No Capítulo 5, por exemplo, discutimos a eletrização de fitas adesivas.

20 [AH07], [AH09] e [AH13].

21 [Whi73a, págs. 71-73] e [Whi73b, págs. 90 e 235].

$22[$ Jef59]. 
- A eletrização que ocorre por meio de reações químicas, com seus diversos mecanismos estudados na eletroquímica.

- O efeito termoelétrico, isto é, a conversão direta de diferenças de temperatura em voltagem elétrica. Um instrumento termoelétrico cria uma diferença de potencial entre dois lados quando existe uma temperatura diferente em cada lado.

- O efeito piroelétrico, que não deve ser confundido com o efeito termoelétrico. Alguns cristais e outros materiais ficam polarizados eletricamente quando são aquecidos ou esfriados.

- O efeito piezoelétrico, isto é, a geração de uma voltagem através de um material quando ele é comprimido ou deformado mecanicamente.

- A eletrização de pressão, que não deve ser confundida com o efeito piezoelétrico. $^{23}$

- O efeito fotoelétrico, isto é, a emissão de elétrons por um material quando exposto a uma radiação eletromagnética de frequência suficientemente alta, que depende do material.

- A fabricação de eletretos. Eles podem ser monopolares (com uma carga total diferente de zero) ou dipolares (com uma carga total nula, mas com uma polarização elétrica não nula). Ou seja, as forças que atuam nesta separação de cargas têm origem não eletrostática. ${ }^{24}$

- Também são necessárias forças não eletrostática para manter fixas ao longo do tempo as cargas dos eletretos.

- Etc.

Em todos estes casos uma força de origem não eletrostática é necessária para ocasionar a polarização de um corpo inicialmente neutro (com um lado deste corpo ficando positivamente eletrizado enquanto que o outro lado fica negativamente eletrizado), ou então para ocasionar a separação de cargas entre dois corpos inicialmente neutros (com um destes corpos ficando positivamente eletrizado enquanto que o outro fica negativamente eletrizado). Também são necessárias forças não eletrostáticas para fazer com que flua uma corrente em um fio resistivo formando um circuito fechado, como um anel ou uma espira.

\subsection{Origem das Forças Não Eletrostáticas}

Não nos parece que sejam bem conhecidas as forças não eletrostáticas citadas nas Seções 14.2 até 14.6. Isto é, sabemos que elas precisam atuar nestes casos.

\footnotetext{
${ }^{23}$ [Kat06, págs. 15 e 239-246], [BW10] e [WB11].

24 [Net94], [Sil10b], [Sil10a], [Bos11, Capítulo 8, págs. 226-248] e [BAC12, Capítulo 19, págs. 373-392].
} 
Porém, na nossa opinião ainda não estão esclarecidas as origens destas forças, suas expressões matemáticas, suas propriedades e as grandezas das quais dependem. Acreditamos que esta falta de conhecimento ainda se aplica até mesmo no fenômeno mais antigo da eletricidade, a saber, no efeito âmbar. Não é claro o que causa a separação de cargas no atrito entre dois corpos. Também não é claro o que causa a separação de cargas quando ocorre o simples contato íntimo entre dois corpos de naturezas diferentes, sem que haja atrito entre eles. Pode ser que o mecanismo que atue na eletrização (seja por contato ou por atrito) entre dois tipos de metais (como o cobre e o zinco), seja diferente do mecanismo que atua na eletrização entre um metal e um isolante (como o cobre e o plástico), ou então do mecanismo que atua na eletrização entre dois tipos de isolantes (como o plástico e a seda).

Contudo, nos parece que em alguns casos temos um bom conhecimento sobre a origem e as propriedades das forças não eletrostáticas. Citamos aqui alguns exemplos:

- Quando um condutor aberto, como uma barra metálica, desloca-se em relação a um ímã, o condutor pode ficar polarizado eletricamente, com um lado positivo e outro lado negativo. O mesmo efeito pode ocorrer caso a barra se desloque em relação a um fio fechado conduzindo uma corrente constante.

- Quando um condutor fechado, como um anel ou uma espira, desloca-se em relação a um ímã, uma corrente elétrica pode ser induzida ao longo do anel. O mesmo efeito pode ocorrer caso o anel se desloque em relação a um fio fechado conduzindo uma corrente constante.

- Um condutor aberto, como uma barra metálica, pode ficar polarizado eletricamente quando há uma corrente elétrica variável no tempo fluindo em um circuito próximo ao condutor. A polarização elétrica vai ser variável no tempo enquanto a corrente estiver variando.

- Se o condutor for fechado, como um anel ou uma espira, pode fluir uma corrente elétrica através dele quando há uma corrente elétrica variável no tempo fluindo em um circuito próximo ao condutor.

Nestes casos e em algumas outras situações mais gerais temos expressões matemáticas descrevendo forças não eletrostáticas e quais são os corpos que estão interagindo em cada caso:

- A força entre dois ímãs.

- A força entre dois condutores conduzindo correntes constantes.

- A força entre um ímã e um condutor conduzindo corrente constante.

- A força entre um ímã e uma partícula eletrizada quando ela está em movimento em relação ao ímã. 
- A força entre um condutor conduzindo corrente constante e uma partícula eletrizada quando ela está em movimento em relação ao condutor.

- A força entre um condutor conduzindo uma corrente variável no tempo e uma partícula eletrizada que esteja parada ou em movimento em relação ao circuito.

- A força entre duas partículas eletrizadas deslocando-se entre si.

Nestes casos específicos temos duas teorias eletromagnéticas principais que fornecem as forças atuando sobre as cargas. Estas forças podem, por exemplo, fazer com que um condutor isolado do solo fique polarizado eletricamente. $\mathrm{Ou}$ então podem fazer com que flua uma corrente ao longo de um anel metálico resistivo. Estas duas teorias descrevem as forças entre partículas eletrizadas não apenas quando elas estão em repouso mútuo, mas também quando há um movimento entre estas partículas. Este movimento pode ser uma velocidade relativa ou então uma aceleração relativa entre estas partículas.

Estas duas teorias rivais são apresentadas resumidamente nas próximas Subseções.

\subsubsection{Teoria de Faraday e Maxwell Baseada em Campos Eletromagnéticos}

A teoria eletromagnética que aparece na maioria dos livros didáticos de física foi desenvolvida por diversos autores, entre eles Michael Faraday, James Clerk Maxwell e Hendrik Antoon Lorentz (1853-1928). ${ }^{25}$ Esta teoria assume que uma carga elétrica em movimento, chamada de carga fonte, gera um campo elétrico e um campo magnético ao seu redor. Estes campos seriam propagados no espaço tipicamente com a velocidade da luz. Ao alcançarem uma outra carga elétrica em movimento, chamada de carga teste, estes campos exerceriam uma força elétrica e uma força magnética sobre ela. Um dos grandes problemas com esta teoria, que em geral não é discutido nos livros didáticos, é o de entender o que são estes campos eletromagnéticos.

Faraday, Maxwell e a maioria dos livros didáticos apresentam mais de uma definição para o conceito de campo. Algumas vezes afirmam que é uma região do espaço ao redor da carga fonte. Em outros momentos afirmam que este campo propaga-se no espaço. Outras vezes afirmam que os campos são grandezas com módulo, direção e sentido. Em outras ocasiões dizem que estes campos carregam momento linear e energia. Outras definições também são apresentadas.

O problema é que estas definições são contraditórias entre si. ${ }^{26}$ Por exemplo, como pode uma região do espaço propagar-se no espaço? Como pode uma região do espaço ter módulo, direção e sentido? O campo gravitacional, o campo elétrico e o campo magnético possuem unidades diferentes, logo estas três grandezas não deveriam ser chamadas de "campo," já que são grandezas de natureza diferente. Cada uma destas três grandezas deveria ser classificada em uma categoria diferente, recebendo um nome de acordo com a categoria em que se

\footnotetext{
25 [Far52], [Max54b] e [Lor95].

${ }^{26}$ Seção 2.9 de [Ass13], assim como Seções 3.1 e 3.2 de [Ass14].
} 
encontra. Existem muitos outros problemas com os conceitos de campo elétrico e magnético, mas não entraremos em detalhes neste livro.

A expressão matemática da força exercida pelo campo elétrico e pelo campo magnético sobre uma carga teste é devida principalmente a Maxwell e Lorentz. Esta expressão também é problemática. Na força magnética aparece a velocidade da carga teste. O problema é que o significado desta velocidade muda dependendo do cientista que está discutindo esta força. Esta velocidade tinha um significado diferente, por exemplo, para Maxwell, J. J. Thomson (1856-1940) e O. Heaviside (1850-1925), Lorentz, A. Einstein (1879-1955), etc. Ou seja, esta velocidade é a velocidade da carga teste em relação a que? Os livros didáticos em geral não discutem este significado, o que é um absurdo. Afinal só podemos entender e aplicar esta força se soubermos em relação a qual outro corpo ou em relação a qual referencial deve ser entendida esta velocidade. O problema é que, mesmo quando é mencionado o significado desta velocidade nos livros didáticos, este significado muda de um livro para outro. Algumas vezes os autores afirmam que é a velocidade em relação ao campo magnético, em outras vezes que é a velocidade em relação a um referencial inercial, em outras situações que é a velocidade em relação ao meio no qual a carga teste está se deslocando, em outras ocasiões que é a velocidade em relação ao detector de campo magnético, em outros casos que é a velocidade em relação à fonte (ímã ou espira) de campo magnético, etc. Não vamos nos aprofundar nestes problemas neste livro. ${ }^{27}$

\subsubsection{Eletrodinâmica de Weber Baseada na Interação en- tre as Partículas Eletrizadas}

Existe uma outra teoria que explica estes fenômenos sem utilizar os conceitos de campo elétrico e campo magnético. Ela é baseada na interação direta entre as partículas eletrizadas, sem haver intermediários nesta interação.

Esta teoria é um desenvolvimento das ideias de Isaac Newton, Figura 7.12. Em seu livro Princípios Matemáticos de Filosofia Natural de 1687 Newton apresentou sua lei da gravitação universal de acordo com a qual a força entre duas partículas é proporcional ao produto de suas massas, varia com o inverso do quadrado da distância entre elas, apontando ao longo da reta que as une e seguindo o princípio de ação e reação. ${ }^{28}$

Charles Augustin de Coulomb, Figura 2.16, obteve uma expressão análoga para a interação entre duas partículas eletrizadas no caso em que as cargas estão em repouso mútuo. Esta força eletrostática de Coulomb foi discutida na Seção 14.1. Coulomb chegou também a uma expressão análoga para a força entre polos magnéticos. Isto é, uma força proporcional ao produto da intensidade entre os polos magnéticos, variando com o inverso do quadrado da distância entre eles, apontando ao longo da reta que os une e seguindo o princípio de ação e reação. ${ }^{29}$

Em 1820 Oersted publicou sua famosa experiência da deflexão de uma agulha imantada ocasionada por um longo fio conduzindo corrente constante, ver

\footnotetext{
${ }^{27}$ Ver a Seção 14.5 de [Ass13] e a Seção 15.5 de [Ass14].

28 [New34], [New90], [New08] e [New10].

${ }^{29}$ Seção 2.5 de [Ass13] e [Ass14].
} 
a Seção 3.4. Esta experiência teve um impacto profundo sobre André-Marie Ampère, Figura 14.14.

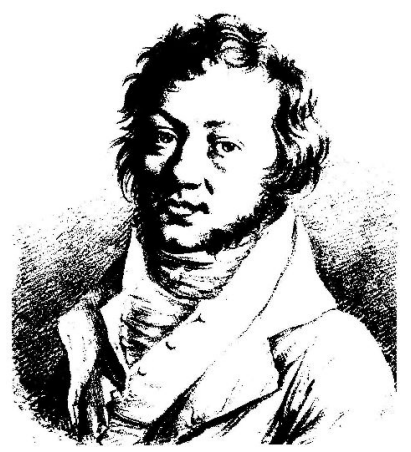

Figura 14.14: André-Marie Ampère (1775-1836).

Entre 1820 e 1827 Ampère fez uma série de descobertas experimentais e teóricas mostrando pela primeira vez as forças e torques entre condutores conduzindo correntes constantes. Além disso, para explicar a experiência de Oersted, supôs a existência de correntes elétricas microscópicas no interior dos ímãs. Obteve uma expressão teórica de grande importância que fornecia a força entre dois elementos de corrente. Esta força atua ao longo da reta que os une, é proporcional ao produto das intensidades de corrente nos dois condutores, varia com o inverso do quadrado da distância entre eles e segue o princípio de ação e reação. A força entre elementos de corrente de Ampère foi considerada por Maxwell como sendo a fórmula mais importante de toda a eletrodinâmica. ${ }^{30}$

A investigação experimental pela qual Ampère estabeleceu as leis da ação mecânica entre correntes elétricas é um dos feitos mais brilhantes na ciência. O conjunto de teoria e experiência parece como que se tivesse pulado, crescido e armado, do cérebro do "Newton da eletricidade". O conjunto é perfeito na forma, e de precisão irrefutável, e está resumido em uma fórmula a partir da qual todos os fenômenos podem ser deduzidos, e que tem de sempre permanecer como a fórmula cardeal [mais importante] da eletrodinâmica.

Infelizmente esta força de Ampère não aparece na maioria dos livros didáticos atuais que lidam com eletromagnetismo, sendo desconhecida da maior parte dos físicos. Estes livros só apresentam a força de H. G. Grassmann (18091877), baseada nos trabalhos de J.-B. Biot (1774-1862) e F. Savart (1791-1841). Maxwell conhecia a força de Grassmann entre elementos de corrente. Comparou as forças de Grassmann, de Ampère e duas outras expressões que o próprio Maxwell criou para a interação entre elementos de corrente. Maxwell fez o seguinte julgamento: ${ }^{31}$

\footnotetext{
30 [Max54b, artigo 528, pág. 175].

31 [Max54b, artigo 527, pág. 174].
} 
527.] Dentre estas quatro suposições diferentes, aquela de Ampère é sem dúvida alguma a melhor, já que é a única expressão que torna a força nos dois elementos não apenas igual e oposta, mas [atuando] ao longo da linha reta que os une.

Ao integrar sua força entre dois elementos de corrente, juntamente com a hipótese adicional das correntes microscópicas em ímãs e no interior da Terra, Ampère conseguiu explicar quantitativamente três classes de fenômenos, a saber, (I) magnetismo (forças e torques entre ímãs, assim como as forças e torques entre um ímã e a Terra); (II) eletrodinâmica (forças e torques entre condutores com corrente); e (III) eletromagnetismo (forças e torques entre um ímã e um condutor com corrente, assim como as forças e torques entre a Terra e um condutor com corrente). Sua obra fundamental foi publicada em 1826, estando disponível em francês, português e inglês. ${ }^{32}$

Os trabalhos de Newton, Coulomb e Ampère foram desenvolvidos pelo físico alemão Wilhelm Eduard Weber (1804-1891), Figura 14.15.

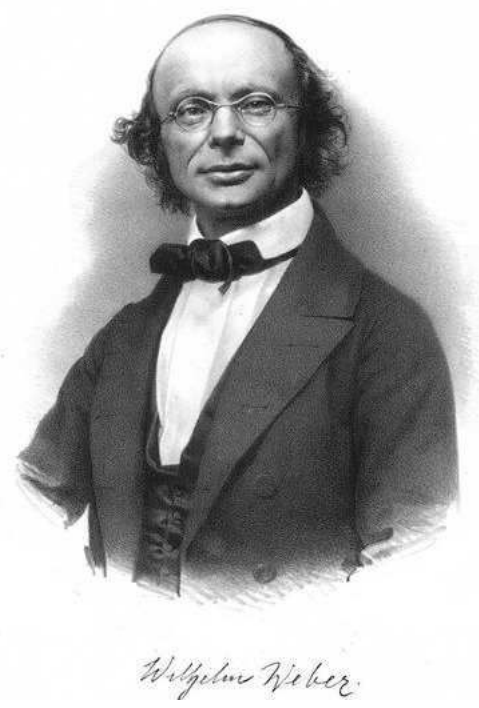

Figura 14.15: Wilhelm Eduard Weber (1804-1891).

As obras completas de Weber foram publicadas em 6 volumes entre $1892 \mathrm{e}$ 1894. ${ }^{33}$ Escreveu oito trabalhos principais entre 1846 e 1878 sob o título geral de Elektrodynamische Maassbestimmungen (Medidas Eletrodinâmicas). ${ }^{34}$ A oitava Memória só foi publicada postumamente em suas obras completas. Três

\footnotetext{
32 [Amp26], [Amp23], [Cha09], [AC11] e [AC15]. Ver também [Ass92a], [Ass94], [BA01], [BA15] e [Ass15a].

33 [Web92b], [Web92a], [Web93], [Web94b], [WW93] e [WW94].

34 [Web46], [Web52b], [Web52a], [KW57], [Web64], [Web71], [Web78] e [Web94a].
} 
destas oito Memórias principais já foram traduzidas para a língua inglesa, a saber, a primeira, Determinações de medidas eletrodinâmicas: Sobre uma lei universal da ação elétrica; ${ }^{35}$ a sexta, Medidas eletrodinâmicas-Sexta Memória, relacionada especialmente ao princípio de conservação da energia; ${ }^{36}$ e a oitava, Determinações de medidas eletrodinâmicas: Particularmente com relação à conexão das leis fundamentais da eletricidade com a lei da gravitação. ${ }^{37} \mathrm{Em} 1848$ foi publicada uma versão resumida da primeira Memória, ${ }^{38}$ que também já foi traduzida para a língua inglesa, Sobre a medida das forças eletrodinâmicas. ${ }^{39}$ Uma listagem de todas as obras de Weber já traduzidas para a língua inglesa foi publicada em 2010. ${ }^{40}$ A única obra de Weber já traduzida para a língua portuguesa é um trabalho conjunto com seu amigo Rudolf Kohlrausch (1809-1858) descrevendo a primeira medida de uma constante fundamental que aparece na força de Weber. ${ }^{41}$ O significado desta constante e a importância da medida pioneira realizada por Weber e Kohlrausch tem sido apresentado por diversos autores. $^{42}$

Weber obteve uma força entre partículas eletrizadas que depende apenas da distância entre as cargas que estão interagindo, da velocidade radial relativa entre elas, assim como da aceleração radial relativa entre elas. É uma força central que atua ao longo da linha reta que une as duas partículas e que segue o princípio de ação e reação. Ela satisfaz os três princípios de conservação da interação entre corpos, a saber, conservação de momento linear, conservação de momento angular e conservação de energia. Com a expressão de Weber podemos deduzir a força de Coulomb e a lei de C. F. Gauss (1777-1855). Com a lei de Weber também deduzimos a força de Ampère entre elementos de corrente, a lei circuital magnética e a lei de indução de Faraday.

A eletrodinâmica de Weber não é discutida na maioria dos livros didáticos atuais. Apesar disto, esta formulação tem recebido um interesse crescente nos últimos anos, tanto por motivos teóricos quanto por questões experimentais.

Acredito na eletrodinâmica de Weber e a considero como sendo a formulação mais fundamental já proposta para as interações entre as parículas eletrizadas. Tenho trabalhado com ela desde que a conheci. ${ }^{43}$

\footnotetext{
35 [Web07].

36 [Web72].

37 [Web08].

38 [Web48].

39 [Web66].

40 [Ass10c].

${ }^{41}$ [WK56], com tradução para a língua portuguesa em [WK08].

42 [Kir57], [Ros57], [Woo68], [Woo81], [Wis81], [Ros81], [Har82], [JM86, Vol. 1, págs. 144146 e 296-297] e [Hec96].

${ }^{43}$ Ver, por exemplo, [Wie60], [Wie67], [Whi73a, págs. 201-206], [Ass89], [Ass90a], [Ass90b], [Ass91b], [Ass91a], [Ass92a], [Ass92c], [Ass92b], [AC93], [Ass94], [GA94], [Ass95a], [Ass95c], [Ass95b], [AB95], [AB96], [GV99], [BA01], [ARW02], [Fuk03], [AW03], [ARW04], [AH07], [AH09], [AWW11], [AH13], [AWW14], [BA15] e [Ass15a], assim como as referências citadas nestas obras.
} 


\section{Referências Bibliográficas}

[AB95] A. K. T. Assis and M. Bueno. Longitudinal forces in Weber's electrodynamics. International Journal of Modern Physics B, 9:36893696, 1995.

[AB96] A. K. T. Assis and M. A. Bueno. Equivalence between Ampère and Grassmann's forces. IEEE Transactions on Magnetics, 32:431-436, 1996.

[AC93] A. K. T. Assis and R. A. Clemente. The influence of temperature on gravitation. Il Nuovo Cimento B, 108:713-716, 1993.

[AC11] A. K. T. Assis and J. P. M. d. C. Chaib. Eletrodinâmica de Ampère: Análise do Significado e da Evolução da Força de Ampère, Juntamente com a Tradução Comentada de Sua Principal Obra sobre Eletrodinâmica. Editora da Unicamp, Campinas, 2011. ISBN: 9788526809383 .

[AC15] A. K. T. Assis and J. P. M. C. Chaib. Ampère's Electrodynamics Analysis of the Meaning and Evolution of Ampère's Force between Current Elements, together with a Complete Translation of His Masterpiece: Theory of Electrodynamic Phenomena, Uniquely Deduced from Experience. Apeiron, Montreal, 2015. ISBN: 978-1-987980-035. Disponível em www.ifi.unicamp.br/ assis.

[Ach96] M. Achilles. Historische Versuche der Physik nachgebaut und kommentiert. Wötzel, Frankfurt, 2nd edition, 1996.

[AH07] A. K. T. Assis and J. A. Hernandes. The Electric Force of a Current: Weber and the Surface Charges of Resistive Conductors Carrying Steady Currents. Apeiron, Montreal, 2007. ISBN: 9780973291155. Disponível em www.ifi.unicamp.br/ assis.

[AH09] A. K. T. Assis and J. A. Hernandes. A Força Elétrica de uma Corrente: Weber e as Cargas Superficiais de Condutores Resistivos com Correntes Constantes. Edusp e Edufal, São Paulo e Maceió, 2009. Volume 73 da Coleção Acadêmica. ISBNs: 9788531411236 e 9788571774315 . 
[AH13] A. K. T. Assis and J. A. Hernandes. Elektrischer Strom und Oberflächenladungen: was Wilhelm Weber schon vor mehr als 150 Jahre wußte. Apeiron, Montreal, 2013. Tradução de H. Härtel. ISBN: 9780992045609. Disponível em www.ifi.unicamp.br/ assis.

[Amp22a] A.-M. Ampère. Expériences relatives à de nouveaux phénomènes électro-dynamiques. Annales de Chimie et de Physique, 20:60-74, 1822 .

[Amp22b] A.-M. Ampère. Expériences relatives aux nouveaux phénomènes électro-dynamiques que j'ai obtenus au mois de décembre 1821. In A.-M. Ampère, editor, Recueil d'Observations Électro-dynamiques, pages 237-250. Crochard, Paris, 1822. Apesar da data, este volume foi publicado apenas em 1823.

[Amp22c] A.-M. Ampère. Exposé sommaire des nouvelles Expériences électromagnétiques faites par différens Physiciens, depuis le mois de mars 1821, lu dans la séance publique de l'Académie royale des Sciences, le 8 avril 1822. In A.-M. Ampère, editor, Recueil d'Observations Électro-dynamiques, pages 199-206. Crochard, Paris, 1822. Apesar da data, este volume foi publicado apenas em 1823.

[Amp23] A.-M. Ampère. Mémoire sur la théorie mathématique des phénomènes électro-dynamiques uniquement déduite de l'expérience, dans lequel se trouvent réunis les Mémoires que $\mathrm{M}$. Ampère a communiqués à l'Académie royale des Sciences, dans les séances des 4 et 26 décembre 1820, 10 juin 1822, 22 décembre 1823, 12 septembre et 21 novembre 1825. Mémoires de l'Académie Royale des Sciences de l'Institut de France, 6:175-387, 1823. Despite this date, the work was only published in 1827 .

[Amp26] A.-M. Ampère. Théorie des Phénomènes Électro-dynamiques, Uniquement Déduite de l'Expérience. Méquignon-Marvis, Paris, 1826.

[Amp85a] A.-M. Ampère. Expériences relatives aux nouveaux phénomènes électro-dynamiques obtenus au mois de décembre 1821. In J. Joubert, editor, Collection de Mémoires relatifs a la Physique, Vol. II: Mémoires sur l'Électrodynamique, pages 192-204. Gauthier-Villars, Paris, 1885.

[Amp85b] A.-M. Ampère. Exposé sommaire des nouvelles expériences électromagnétiques faites par différens physiciens, depuis le mois de mars 1821, lu dans la séance publique de l'Académie royale des Sciences, le 8 avril 1822. In J. Joubert, editor, Collection de Mémoires relatifs a la Physique, Vol. II: Mémoires sur l'Électrodynamique, pages 238-244. Gauthier-Villars, Paris, 1885.

[APZ06] M. S. Amin, T. F. Peterson Jr., and M. Zahn. Advanced Faraday cage measurements of charge and open-circuit voltage using water dielectrics. Journal of Electrostatics, 64:424-340, 2006. 
[ARW02] A. K. T. Assis, K. Reich, and K. H. Wiederkehr. Gauss and Weber's creation of the absolute system of units in physics. 21st Century Science \& Technology, Vol. 15, No. 3:40-48, 2002.

[ARW04] A. K. T. Assis, K. Reich, and K. H. Wiederkehr. On the electromagnetic and electrostatic units of current and the meaning of the absolute system of units - For the 200th anniversary of Wilhelm Weber's birth. Sudhoffs Archiv, 88:10-31, 2004.

[Ass89] A. K. T. Assis. On Mach's principle. Foundations of Physics Letters, 2:301-318, 1989.

[Ass90a] A. K. T. Assis. Deriving Ampère's law from Weber's law. Hadronic Journal, 13:441-451, 1990.

[Ass90b] A. K. T. Assis. Modern experiments related to Weber's electrodynamics. In U. Bartocci and J. P. Wesley, editors, Proceedings of the Conference on Foundations of Mathematics and Physics, pages 8-22, Blumberg, Germany, 1990. Benjamin Wesley Publisher.

[Ass91a] A. K. T. Assis. Can a steady current generate an electric field? Physics Essays, 4:109-114, 1991.

[Ass91b] A. K. T. Assis. Wilhelm Eduard Weber (1804-1891) — Sua vida e sua obra. Revista da Sociedade Brasileira de História da Ciência, 5:53-59, 1991.

[Ass92a] A. K. T. Assis. Curso de Eletrodinâmica de Weber. Setor de Publicações do Instituto de Física da Universidade Estadual de Campinas - UNICAMP, Campinas, 1992. Notas de Física IFGW Número 5. Disponível em www.ifi.unicamp.br/ assis e www. bibliotecadigital . unicamp. br/document/?down=60362.

[Ass92b] A. K. T. Assis. On forces that depend on the acceleration of the test body. Physics Essays, 5:328-330, 1992.

[Ass92c] A. K. T. Assis. On the mechanism of railguns. Galilean Electrodynamics, 3:93-95, 1992.

[Ass94] A. K. T. Assis. Weber's Electrodynamics. Kluwer Academic Publishers, Dordrecht, 1994. ISBN: 0792331370.

[Ass95a] A. K. T. Assis. Acceleration dependent forces: reply to Smulsky. Apeiron, 2:25, 1995.

[Ass95b] A. K. T. Assis. A eletrodinâmica de Weber e seus desenvolvimentos recentes. Ciência e Natura, 17:7-16, 1995.

[Ass95c] A. K. T. Assis. Weber's force versus Lorentz's force. Physics Essays, 8:335-341, 1995. 
[Ass10a] A. K. T. Assis. The Experimental and Historical Foundations of Electricity. Apeiron, Montreal, 2010. ISBN: 9780986492631. Disponível em www.ifi.unicamp.br/ assis.

[Ass10b] A. K. T. Assis. Os Fundamentos Experimentais e Históricos da Eletricidade. Apeiron, Montreal, 2010. ISBN: 9780986492617. Disponível em www.ifi.unicamp.br/ assis.

[Ass10c] A. K. T. Assis. Wilhelm Weber's works translated into English. 21st Century Science \& Technology, Vol. 22, No. 4:67-69, 2010.

[Ass11] A. K. T. Assis. Os Fundamentos Experimentais e Históricos da Eletricidade. Editora Livraria da Física, São Paulo, 2011. ISBN: 9788578610975 .

[Ass13] A. K. T. Assis. Mecânica Relacional e Implementação do Princípio de Mach com a Força de Weber Gravitacional. Apeiron, Montreal, 2013. ISBN: 9780986492693. Disponível em www.ifi.unicamp.br/ rassis.

[Ass14] A. K. T. Assis. Relational Mechanics and Implementation of Mach's Principle with Weber's Gravitational Force. Apeiron, Montreal, 2014. ISBN: 978-0-9920456-3-0. Disponível em www.ifi.unicamp. $\mathrm{br} /$ assis.

[Ass15a] A. K. T. Assis. Eletrodinâmica de Weber: Teoria, Aplicações e Exercícios. Editora da Unicamp, Campinas, 2015. Segunda edição. e-ISBN: 978-85-268-1240-6.

[Ass15b] A. K. T. Assis. Os Fundamentos Experimentais e Históricos da Eletricidade. Apeiron, Montreal, 2015. Livro em russo traduzido da versão em inglês por A. Baraov. ISBN: 978-0-9920456-9-2. Disponível em www.ifi.unicamp.br/ assis.

[Ass17] A. K. T. Assis. I Fondamenti Sperimentali e Storici dell'Elettricità. Associazione per l'Insegnamento della Fisica, Parma, 2017. La Fisica nella Scuola, Anno L, n. 2 Supplemento, Quaderno 26. Traduzido por P. Cerreta, A. Cerreta e R. Cerreta. Editado por P. Cerreta, R. Serafini e R. Urigu. Disponível em www.ifi.unicamp.br/ assis.

[AW03] A. K. T. Assis and K. H. Wiederkehr. Weber quoting Maxwell. Mitteilungen der Gauss-Gesellschaft, 40:53-74, 2003.

[AWW11] A. K. T. Assis, K. H. Wiederkehr, and G. Wolfschmidt. Weber's Planetary Model of the Atom, volume 19 of Nuncius Hamburgensis Beiträge zur Geschichte der Naturwissenschaften. Tredition Science, Hamburg, 2011. Editado por G. Wolfschmidt. ISBN: 9783842402416. 
[AWW14] A. K. T. Assis, K. H. Wiederkehr, and G. Wolfschmidt. O Modelo Planetário de Weber para o Átomo. Apeiron, Montreal, 2014. ISBN: 9780992045654. Disponível em www.ifi.unicamp.br/ assis.

[BA01] M. d. A. Bueno and A. K. T. Assis. Inductance and Force Calculations in Electrical Circuits. Nova Science Publishers, Huntington, New York, 2001. ISBN: 1560729171.

[BA15] M. Bueno and A. K. T. Assis. Cálculo de Indutância e de Força em Circuitos Elétricos. Apeiron, Montreal, 2015. 2a edição. ISBN: 978-1-987980-01-1. Disponível em www.ifi.unicamp.br/ assis.

[BAC12] S. L. B. Boss, A. K. T. Assis, and J. J. Caluzi. Stephen Gray e a Descoberta dos Condutores e Isolantes: Tradução Comentada de Seus Artigos sobre Eletricidade e Reprodução de Seus Principais Experimentos. Editora Cultura Acadêmica da Unesp, São Paulo, 2012. Disponível em: www.culturaacademica.com.br/catalogodetalhe.asp?ctl_id=354.

[Bai01] A. G. Bailey. The charging of insulator surfaces. Journal of Electrostatics, 51-52:82-90, 2001.

[BC07] S. L. B. Boss and J. J. Caluzi. Os conceitos de eletricidade vítrea e eletricidade resinosa segundo Du Fay. Revista Brasileira de Ensino de Física, 29:635-644, 2007.

[Bea96] W. Beaty. Sticky electrostatics. Disponível em www.amasci.com/ emotor/sticky.html, 1996.

[Beu92] G. Beuermann. "Sie schwänzen aber jetzt schon, bis es blitzt und donnert" - Physik - Lichtenbergs Leidenschaft. Physikalische Blätter, 48:440-444, 1992.

[BGP16] T. A. L. Burgo, F. Galembeck, and G. H. Pollack. Where is water in the triboelectric series? Journal of Electrostatics, 80:30-33, 2016. Doi: 10.1016/j.elstat.2016.01.002.

[BJ92] P. Brix and U. Joost. Mit weningen Worten viel sagen - Georg Christoph Lichtenberg zum 250. Geburtstag. Physikalische Blätter, 48:437-439, 1992.

[Blo82] C. Blondel. A.-M. Ampère et la Création de l'Électrodynamique (1820-1827). Bibliothèque Nationale, Paris, 1982.

[Bos] T. H. S. Bossa et al. Estudo da condutividade elétrica de vidros isoladores de linhas de transmissão HVDC dopados. In: Congresso da Academia Trinacional de Ciências, II, 2007, Foz do Iguaçu, PR. Anais eletrônicos. Disponível em: www.foz.unioeste.br/ lamat/ publicvidros/condutivc3n2007.pdf. 
[Bos11] S. L. B. Boss. Tradução comentada de artigos de Stephen Gray (1666-1736) e reprodução de experimentos históricos com materiais acessiveis - subsídios para o ensino do eletricidade. Doutorado em educação para a ciência, Faculdade de Ciências, Universidade Estadual Paulista - UNESP, Bauru, 2011. Orientador: J. J. Caluzi. Co-orientador: A. K. T. Assis. Disponível em www.ifi.unicamp. $\mathrm{br} /$ assis.

[BW10] C. Blondel and B. Wolff. L'électricité de pression de Haüy et l'électricité de frottement font cause commune. Disponível em www. ampere.cnrs.fr/labo/, 2010.

[BW12a] C. Blondel and B. Wolff. La loi d'Ohm: la délicate genèse d'une loi "simple". Disponível em: www.ampere.cnrs.fr/ parcourspedagogique, 2012.

[BW12b] C. Blondel and B. Wolff. Que dit l'article ELECTRICITE de l'Encyclopédie? Disponível em www.ampere.cnrs.fr/ parcourspedagogique, 2012.

[BW12c] C. Blondel and B. Wolff. Teinturiers et tubes de verre: Gray et Dufay. Disponível em www.ampere.cnrs.fr/parcourspedagogique, 2012.

[BW12d] C. Blondel and B. Wolff. Un phénomène plus complexe qu'il n'y paraît: l'attraction des corps légers ou d'un filet d'eau. Disponível em www . ampere.cnrs.fr/labo/, 2012.

[BW13] C. Blondel and B. Wolff. La proportionnalité de la force électrique aux charges: définition ou loi expérimentale? Disponível em www. ampere.cnrs.fr/parcourspedagogique, 2013.

[CA08] J. Camillo and A. K. T. Assis. Construção de um gerador eletrostático gotejante: chuva elétrica de Kelvin. A Física na Escola, 9:29-32, 2008. Vídeo mostrando a faísca produzida nesta montagem disponível em www.ifi.unicamp.br/ assis e www.youtube.com/ watch?v=X7WPSQMtiUO.

[Cam06] J. Camillo. Geradores eletrostáticos: esfera de enxofre de Otto von Guericke e chuva elétrica de Kelvin. Trabalho realizado na disciplina de Instrumentação para Ensino, F809, do Instituto de Física da UNICAMP. Orientador: A. K. T. Assis. Disponível em www.ifi.unicamp.br/ assis e www.ifi.unicamp.br/ lunazzi/ F530_F590_F690_F809_F895/F809/F809_sem2_2006/JulianoCAssis_F809_RFcompleto.pdf, 2006.

[Cer14a] P. Cerreta, 2014. Esperimenti di elettrostatica. Disponível em: www . scienzaviva.it/Esperimenti_elettrostatica_2014.php. 
[Cer14b] P. Cerreta. Il pendolino, il versorium e l'elettroscopio, pages 5356. Associazione per l'Insegnamento della Fisica, Perugia, 2014. Supplemento al n. 3/2015 LFnS, Atti del LIII Congresso Nazionale AIF.

[Cer17] P. Cerreta, 2017. Rubbing. Electroscopes and Conductors. Video dall'edizione 2017 di Science on Stage, Debrecen, Hungary. Available at: www.scienzaviva.it/video_15.php.

[Cha09] J. P. M. d. C. Chaib, 2009. Tese de doutorado: "Análise do Significado e da Evolução do Conceito de Força de Ampère, juntamente com a Tradução Comentada de sua Principal Obra sobre Eletrodinâmica." Universidade Estadual de Campinas - UNICAMP (Campinas, SP). Orientador: A. K. T. Assis. Disponível em: webbif.ifi.unicamp.br/teses e em www.ifi.unicamp.br/ assis.

[Chi54] R. A. Chipman. An unpublished letter of Stephen Gray on electrical experiments, 1707-1708. Isis, 45:33-40, 1954.

[Coh66] I. B. Cohen. Franklin and Newton: An Inquiry into Speculative Newtonian Experimental Science and Franklin's Work in Electricity as an Example Thereof. Harvard University Press, Cambridge, 1966.

[Coh96] I. B. Cohen. Benjamin Franklin's Science. Harvard Univ. Press, Cambridge, 1996.

[Cou85a] C. A. Coulomb. Premier mémoire sur l'électricité et le magnétisme: Construction et usage d'une balance électrique, fondée sur la propriété qu'ont les fils de métal, d'avoir une force de réaction de torsion proportionelle à l'angle de torsion. Détermination expérimentale de la loi suivant laquelle les élémens des corps électrisés du même genre d'électricité, se repoussent mutuellement. Mémoires de l'Académie royale des Sciences de l'Institut de France, 88:569-577, 1785. Published in 1788 .

[Cou85b] C. A. Coulomb. Second mémoire sur l'électricité et le magnétisme, où l'on détermine, suivant quelles loix de fluide magnétique, ainsi que le fluide électrique, agissent, soit par répulsion, soit par attraction. Mémoires de l'Académie royale des Sciences de l'Institut de France, 88:578-611, 1785. Published in 1788.

[Cou35] A. Coulomb. First memoir on electricity and magnetism. In W. F. Magie, editor, A Source Book in Physics, pages 408-413, New York, 1935. McGraw-Hill. Publicação original de 1785 em francês.

[CS02] R. W. Chabay and B. A. Sherwood. Matter \& Interactions, volume 2: Electric and Magnetic Interactions. Wiley, New York, 2002. 
[Des76] A. P. Deschanel. Elementary Treatise on Natural Philosophy. D. Appleton and Co., New York, 1876. Traduzido por J. D. Everett.

[DF] C. F. d. C. Du Fay. A letter from Mons. Du Fay, F. R. S. and of the Royal Academy of Sciences at Paris, to His Grace Charles Duke of Richmond and Lenox, concerning electricity. Translated from the French by T. S. M D. Philosophical Transactions, 38:258-266, 17334 .

[DF33a] C. F. d. C. Du Fay. Premier mémoire sur l'électricité. Histoire de l'électricité. Mémoires de l'Académie Royale des Sciences, pages 23-35, 1733.

[DF33b] C. F. d. C. Du Fay. Quatriéme mémoire sur l'électricité. De l'attraction et répulsion des corps électriques. Mémoires de l'Académie Royale des Sciences, pages 457-476, 1733.

[DF33c] C. F. d. C. Du Fay. Second mémoire sur l'électricité. Quels sont les corps qui sont susceptibles d'électricité. Mémoires de l'Académie Royale des Sciences, pages 73-84, 1733.

[DF34] C. F. d. C. Du Fay. Cinquiéme mémoire sur l'électricité. Oú l'on rend compte des nouvelles découvertes sur cette matiére, faites depuis peu par M. Gray; et où l'on examine quelles sont les circonstances qui peuvent apporter quelque changement à l'électricité pour l'augmentation ou la diminution de la force, comme la tempèrature de l'air, le vuide, l'air comprimé, etc. Mémoires de l'Académie Royale des Sciences, pages 341-361, 1734.

[Ear42] S. Earnshaw. On the nature of the molecular forces which regulate the constitution of the luminiferous ether. Transactions of the Cambridge Philosophical Society, 7:97-114, 1842.

[Egu25] M. Eguchi. On the permanent electret. Philosophical Magazine, 49:178-192, 1925.

[Far38] M. Faraday. On induction. Philosophical Transactions, 128:1-40, 1838. Reimpresso em Great Books of the Western World, R. M. Hutchins (editor), (Encyclopaedia Britannica, Chicago, 1952), Vol. 45: Lavoisier, Fourier, Faraday. Págs. 440-467.

[Far43a] M. Faraday. On static electrical inductive action. Philosophical Magazine, 22:200-204, 1843. Reimpresso em Great Books of the Western World, R. M. Hutchins (editor), (Encyclopaedia Britannica, Chicago, 1952), Vol. 45: Lavoisier, Fourier, Faraday. Págs. 848-850.

[Far43b] M. Faraday. On the electricity evolved by the friction of water and steam against other bodies. Philosophical Transactions, 133:17-32, 1843. Reimpresso em Great Books of the Western World, R. M. 
Hutchins (editor), (Encyclopaedia Britannica, Chicago, 1952), Vol. 45: Lavoisier, Fourier, Faraday. Págs. 584-594.

[Far52] M. Faraday. Experimental Researches in Electricity, volume 45, pp. 253-898 of Great Books of the Western World. Encyclopaedia Britannica, Chicago, 1952.

[Fera] N. Ferreira. Mecânica. Instituto de Física, USP, São Paulo. Projeto RIPE - Rede de Instrumentação para o Ensino. Disponível em www . cienciamao.usp.br/tudo/indice.php?midia=rip.

[Ferb] N. Ferreira. Eletrostática, Vol. 1. Instituto de Física, USP, São Paulo. Projeto RIPE — Rede de Instrumentação para o Ensino. Disponível em www.cienciamao.usp.br/tudo/indice.php?midia=rip.

[Ferc] N. Ferreira. Eletrostática, Vol. 2. Instituto de Física, USP, São Paulo. Projeto RIPE - Rede de Instrumentação para o Ensino. Disponível em www.cienciamao.usp.br/tudo/indice.php?midia=rip.

[Ferd] N. C. Ferreira. Construa sua própria bússola! Disponível em: chc. cienciahoje.uol.com.br/construa-sua-propria-bussola.

[Fer78] N. C. Ferreira, 1978. Proposta de Laboratório para a Escola Brasileira - Um Ensaio sobre a Instrumentalização no Ensino Médio de Física. Dissertação de mestrado, Universidade de São Paulo, São Paulo.

[Fer00] G. F. L. Ferreira. Há 50 anos: o efeito Costa Ribeiro. Revista Brasileira de Ensino de Física, 22:434-443, 2000.

[Fer01a] N. C. Ferreira. Acende aqui, apaga ali. Ciência Hoje na Escola, 12:65-67, 2001.

[Fer01b] N. C. Ferreira. Faça como Gilbert: construa uma bússola de declinação. Ciência Hoje na Escola, 12:21-22, 2001.

[Fer01c] N. C. Ferreira. Magnetismo e eletricidade. Ciência Hoje na Escola, 12:14-17, 2001.

[Fer01d] N. C. Ferreira. O versorium. Ciência Hoje na Escola, 12:18-20, 2001.

[Fer06] N. Ferreira. Equilíbrio. Projeto RIPE - Rede de Instrumentação para o Ensino, Instituto de Física, USP, São Paulo, 2006. Disponível em: www.cienciamao.usp.br/tudo/indice.php?midia=rip.

[FLS64] R. P. Feynman, R. B. Leighton, and M. Sands. The Feynman Lectures on Physics. Addison-Wesley, Reading, 1964. Volume 2: Mainly Electromagnetism and Matter. 
[FM91] N. Ferreira and J.-P. Maury. Plus et Moins, les Charges Électriques. Qu'est-ce que c'est? Ophrys, Paris, 1991.

[FR08] N. C. Ferreira and E. M. d. F. Ramos. Cadernos de Instrumentação para o Ensino de Física: Eletrostática. Unesp, Rio Claro, 2008. Coleção Ludoteca, Volume 1.

[Fra69] B. Franklin. Experiments and Observations on Electricity, Made at Philadelphia in America. David Henry, London, 1769.

[Fra04] B. Franklin. The Works of Benjamin Franklin. G. P. Putnam's Sons, 1904. 12 Volumes.

[Fra41] B. Franklin. Benjamin Franklin's Experiments - A new edition of Franklin's Experiments and Observations on Electricity, I. B. Cohen (ed.). Harvard University Press, Cambridge, 1941.

[Fra81] O. I. Franksen. H. C. Ørsted - A Man of the Two Cultures. Strandbergs Forlag, Birkerød, 1981.

[Fre] D. Frerichs e S. Pfeiler, Historische Einführung in die Elektrostatik. Disponível em: https://www.physikalischeschulexperimente.de/physo/Historische_Einf\%C3\%BChrung_ in_die_Elektrostatik\#cite_ref-1.

[Fuk00] E. Fukada. History and recent progress in piezoelectric polymers. IEEE Transactions on Ultrasonics, Ferroelectrics, and Frequency Control, 47:1277-1290, 2000.

[Fuk03] J. Fukai. A Promenade Along Electrodynamics. Vales Lake Publishing, Pueblo West, 2003.

[GA94] P. Graneau and A. K. T. Assis. Kirchhoff on the motion of electricity in conductors. Apeiron, 19:19-25, 1994.

[Gal14] F. Galembeck et al. Friction, tribochemistry and triboelectricity: recent progress and perspectives. RSC Advances, 4:64280-64298, 2014. Doi: $10.1039 / \mathrm{c} 4 \mathrm{ra09604e.}$

[Gas91] A. Gaspar. Motor de ímã móvel. Caderno Catarinense de Ensino de Física, 8:188-193, 1991.

[Gas96] A. Gaspar. História da Eletricidade. Ática, São Paulo, 1996.

[Gas00] A. Gaspar. Eletromagnetismo - Física Moderna. Ática, São Paulo, 2000 .

[Gas03] A. Gaspar. Experiências de Ciências para o Ensino Fundamental. Ática, São Paulo, 2003. 
[Gas13] A. Gaspar. Compreendendo a Física, volume 3: Eletromagnetismo e Física Moderna. Ática, São Paulo, 2013. $2^{a}$ edição. Manual do Professor.

[GB17] F. Galembeck and A. L. Burgo. Chemical Electrostatics. Springer, Berlin, 2017.

[Gil00] W. Gilbert. On the Magnet, Magnetick Bodies also, and on the Great Magnet the Earth; a New Physiology, Demonstrated by Many Arguments $\mathcal{G}$ Experiments. Chiswick Press, London, 1900. Translated by S. P. Thompson.

[Gil71a] C. S. Gillmor. Coulomb and the Evolution of Physics and Engineering in Eighteenth-Century France. Princeton University Press, Princeton, 1971.

[Gil71b] C. S. Gillmor. Coulomb, Charles Augustin. In C. C. Gillispie, editor, Dictionary of Scientific Biography, Vol. 3, pages 439-447. Charles Scribner's Sons, New York, 1971.

[Gil78] W. Gilbert. On the Loadstone and Magnetic Bodies and on the Great Magnet the Earth, volume 28, pp. 1-121 of Great Books of the Western World. Encyclopaedia Britannica, Chicago, 1978. Translated by P. F. Mottelay.

[Graa] S. Gray. An account of some new electrical experiments. Philosophical Transactions, 31:104-107, 1720-1.

[Grab] S. Gray. The electricity of water. Philosophical Transactions, 37:227230 (addenda in page 260), 1731-2.

[Grac] S. Gray. Experiments and observations upon the light that is produced by communicating electrical attraction to animate or inanimate bodies, together with some of its most surprising effects. Philosophical Transactions, 39:16-24, 1735-6.

[Grad] S. Gray. Farther account of his experiments concerning electricity. Philosophical Transactions, 37:285-291, 1731-2.

[Grae] S. Gray. Farther accounts of his experiments concerning electricity. Philosophical Transactions, 37:397-407, 1731-2.

[Graf] S. Gray. Several experiments concerning electricity. Philosophical Transactions, 37:18-44, 1731-2.

[Grag] S. Gray. Some experiments relating to electricity. Philosophical Transactions, 39:166-170, 1735-6.

[Gre94] T. B. Greenslade Jr. The hydro-electrical machine. The Physics Teacher, 32:210-211, 1994. 
[Gro54] B. Gross. Theory of thermodielectric effect. Physical Review, 94:1545-1551, 1954.

[Gui12] J. Guisasola. Book review: Andre Koch Torres Assis (2010) The Experimental and Historical Foundations of Electricity. Science \&3 Education, 21:283-285, 2012. Doi: 10.1007/s11191-010-9318-z.

[GV99] J. Guala-Valverde. Inercia y Gravitacion. Fundacion Julio Palacios, Neuquen, Argentina, 1999. Em colaboração com J. Tramaglia e R. Rapacioli. Disponível em: www.educ.ar/sitios/educar/ recursos/ver?id=90380.

[Hae12] H. Haertel. Die Natur macht keine Sprünge - auch nicht beim Ohm'schen Gesetz. Praxis der Naturwissenschaften - Physik in der Schule, 5:31-35, 2012.

[Har67] W. S. Harris. A Treatise on Frictional Electricity, in Theory and Practice. Virtue and Co., London, 1867. Editado por C. Tomlinson.

[Har82] P. M. Harman. Energy, Force, and Matter - The Conceptual Development of Nineteenth-Century Physics. Cambridge University Press, Cambridge, 1982.

[Hau] F. Hauksbee. An account of the repetition of an experiment touching motion given bodies included in a glass, by the approach of a finger near its outside: With other experiments on the effluvia of glass. Philosophical Transactions, 26:82-86, 1708-1709.

[Hea87] O. Heaviside. Electromagnetic induction and its propagation. The Electrician, 1885-87. Reimpresso em O. Heaviside, Electrical Papers (Macmillan, London, 1892), Vol. 1, Art. 30, págs. 429-560 e O. Heaviside, Electrical Papers (Macmillan, London, 1894), Vol. 2, Art. 35, págs. 39-155.

[Hec96] L. Hecht. The significance of the 1845 Gauss-Weber correspondence. 21st Century Science 83 Technology, 9(3):22-34, 1996.

[Hee92] P. Heering. On Coulomb's inverse square law. American Journal of Physics, 60:988-994, 1992.

[Hei66] J. L. Heilbron. G. M. Bose: the prime mover in the invention of the Leyden jar? Isis, 57:264-267, 1966.

[Hei99] J. L. Heilbron. Electricity in the 17th and 18th Centuries - A Study in Early Modern Physics. Dover, New York, 1999.

[Hom81] R. W. Home. The Effluvial Theory of Electricity. Arno Press, New York, 1981.

[Jea27] J. Jeans. The Mathematical Theory of Electricity and Magnetism. Cambridge University Press, Cambridge, 1927. 
[Jec12] B. Jech. Sur l'expérience de Desaguliers de la déviation d'un filet d'eau par une tige électrisée. Bulletin de l'Union des Physiciens, 946:737-760, 2012.

[Jef59] O. Jefimenko. Lecture demonstrations on electrification by contact. American Journal of Physics, 27:604-605, 1959. DOI: 10.1119/1.1934925.

[Jef71a] O. Jefimenko. Franklin's electric motors. American Journal of Physics, 39:1139-1140, 1971.

[Jef71b] O. Jefimenko. Operation of electric motors from the atmospheric electric field. American Journal of Physics, 39:776-778, 1971.

[Jef73] O. D. Jefimenko. Electrostatic Motors: Their History, Types, and Principles of Operation. Electret Scientific, Star City, 1973.

[JG17] W. T. Jardim and A. Guerra. República das letras, academias e sociedades científicas no século XVIII: a garrafa de Leiden e a ciência no ensino. Caderno Brasileiro de Ensino de Física, 34:774-797, 2017. Doi: $10.5007 / 2175-7941.2017 v 34 n 3 p 774$.

[JM86] C. Jungnickel and R. McCormmach. Intellectual Mastery of Nature - Theoretical Physics from Ohm to Einstein, volume 1-2. University of Chicago Press, Chicago, 1986.

[JW71] O. Jefimenko and D. K. Walker. Electrostatic motors. The Physics Teacher, 9:121-129, 1971.

[JW80] O. D. Jefimenko and D. Walker. Electrets. The Physics Teacher, 18:651-659, 1980.

[Kat06] S. Katzir. The Beginnings of Piezoelectricity - A Study in Mundane Physics, volume 246 of Boston Studies in Philosophy of Science. Springer, Dordrecht, 2006.

[Kip09] N. Kipnis. A law of physics in the classroom: the case of Ohm's law. Science \& Education, 18:349-382, 2009. Doi: 10.1007/s11191-0089142-x.

[Kir49] G. Kirchhoff. Ueber eine Ableitung der Ohm'schen Gesetze, welche sich an die Theorie der Elektrostatik anschliesst. Annalen der Physik, 78:506-513, 1849. Reimpresso em G. Kirchhoff's Gesammelte Abhandlungen (Barth, Leipzig, 1882), págs. 49-55.

[Kir50] G. Kirchhoff. On a deduction of Ohm's law in connexion with the theory of electrostatics. Philosophical Magazine, 37:463-468, 1850.

[Kir57] F. Kirchner. Determination of the velocity of light from electromagnetic measurements according to W. Weber and R. Kohlrausch. American Journal of Physics, 25:623-629, 1957. 
[KW57] R. Kohlrausch and W. Weber. Elektrodynamische Maassbestimmungen insbesondere Zurückführung der StromintensitätsMessungen auf mechanisches Maass. Abhandlungen der Königl. Sächs. Gesellschaft der Wissenschaften, mathematisch-physische Klasse, 3:221-290, 1857. Reimpresso em Wilhelm Weber's Werke, Vol. 3, H. Weber (ed.), (Springer, Berlin, 1893), págs. 609-676.

[LB08] C.-Y. Liu and A. J. Bard. Electrostatic electrochemistry at insulators. Nature Materials, 7:505-509, 2008. Doi: 10.1038/nmat2160.

[LB09] C.-Y. Liu and A. J. Bard. Electrons on dielectrics and contact electrification. Chemical Physics Letters, 480:145-156, 2009. Doi: 10.1016/j.cplett.2009.08.045.

[Lic56] G. C. Lichtenberg. Über eine neue Methode, die Natur und die Bewegung der elektrischen Materie zu erforschen, volume 246 of Ostwald's Klassiker der exakten Wissenschaften. Akademische Verlagsgesellschaft, Leipzig, 1956. Herausgegeben in neuer deutscher Übersetzung von H. Pupke.

[Llo80] J. T. Lloyd. Lord Kelvin demonstrated. The Physics Teacher, 18:1624, 1980 .

[Lom17] M. V. Lomonosov, 2017. Discourse on atmospheric phenomena originating from electrical force. English translation and commentary by V. Shiltsev. arXiv:1709.08847 [physics.hist-ph].

[Lor95] H. A. Lorentz. Versuch einer Theorie der Electrischen und Optischen Erscheinungen in Bewegten Körpern. E. J. Brill, Leiden, 1895. Abschmitt I (Die Grundgleichungen für ein System in den Aether eingelagerter Ionen), $§ 12$ (Der zweite Theil der auf die ponderable Materie wirkenden Kraft), pp. 21-22.

[LSB08] C. E. Laburú, O. H. M. d. Silva, and M. A. Barros. Laboratório caseiro - pára-raios: um experimento simples e de baixo custo para a eletrostática. Caderno Brasileiro de Ensino de Física, 25:168-182, 2008.

[MA08] C. P. Magnaghi and A. K. T. Assis. Sobre a eletricidade excitada pelo simples contato entre substâncias condutoras de tipos diferentes Uma tradução comentada do artigo de Volta de 1800 descrevendo sua invenção da pilha elétrica. Caderno Brasileiro de Ensino de Física, 25:118-140, 2008.

[Mag06] C. P. Magnaghi. Origem da corrente elétrica - a invenção da pilha. Trabalho realizado na disciplina Instrumentação para Ensino, F809, do Instituto de Física da UNICAMP. Orientador: A. K. T. Assis. Disponível em www.ifi.unicamp.br/ assis e www.ifi.unicamp.br/ lunazzi/F530_F590_F690_F809_ F895/F809/F809_sem2_2006/CenoP-Assis_RF1.pdf, 2006. 
[Mas87] S. Mascarenhas. Bioelectrets: electrets in biomaterials and biopolymers. In G. M. Sessler, editor, Electrets, pages 321-346. Springer, Berlin, 2nd edition, 1987.

[Max54a] J. C. Maxwell. A Treatise on Electricity and Magnetism, volume I. Dover, New York, 1954.

[Max54b] J. C. Maxwell. A Treatise on Electricity and Magnetism. Dover, New York, 1954.

[MB17] B. A. Moura and T. Bonfim. Benjamin Franklin e a formação de temporais com raios e trovões: tradução comentada de uma carta a John Mitchel. Caderno Brasileiro de Ensino de Física, 34:460-478, 2017. Doi: $10.5007 / 2175-7941.2017 \mathrm{v} 34 \mathrm{n} 2 \mathrm{p} 460$.

[MF] G. d. C. Marques and C. Furukawa. Eletromagnetismo - Tema 2 - O potencial elétrico - Experimento 3: Máquina de indução: eletróforo de Volta. E-aulas da Universidade de São Paulo - USP. Disponível em http://eaulas.usp.br/portal/home/video.action? idItem $=5874$.

[Mil17] R. A. Millikan. The Electron: Its Isolation and Measurements and the Determination of Some of Its Properties. The University of Chicago Press, Chicago, 1917. Edited with an introduction by J. W. M. DuMond.

[Mor04a] B. Morse. Pointy tab blunt tab. Electrostatic Video Series. Wright Center for Innovative Science Education. Disponível em: https:// www . youtube . com/watch?v=6pnXOHjYj00, 2004.

[Mor04b] R. A. Morse, 2004. Benjamin Franklin and Electrostatics. Homepage criada por R. A. Morse. Disponível em: www. compadre.org/psrc/ Franklin/.

[MW08] L. S. McCarty and G. M. Whitesides. Electrostatic charging due to separation of ions at interfaces: contact electrification of ionic electrets. Angewandte Chemie (International Edition), 47:2188-2207, 2008. Doi: 10.1002/anie.200701812.

[MWW07] L. S. McCarty, A. Winkleman, and G. M. Whitesides. Ionic electrets: electrostatic charging of surfaces by transferring mobile ions upon contact. Journal of the American Chemical Society, 129:4075-4088, 2007. Doi: 10.1021/ja067301e.

[Net] L. F. Netto. Feira de ciências. Disponível em: www. feiradeciencias.com.br.

[Net94] L. F. Netto. Eletreto (o ímã da eletrostática). Disponível em: www. feiradeciencias.com.br/sala11/11_T02.asp, 1994. 
[New34] I. Newton. Mathematical Principles of Natural Philosophy. University of California Press, Berkeley, 1934. Cajori edition.

[New52] I. Newton. Mathematical Principles of Natural Philosophy, volume 34, págs. 1-372 of Great Books of the Western World. Encyclopaedia Britannica, Chicago, 1952. Traduzido por A. Motte e revisado por F. Cajori.

[New90] I. Newton. Principia - Princípios Matemáticos de Filosofia Natural. Nova Stella/Edusp, São Paulo, 1990. Livro I: O Movimento dos Corpos. Tradução de T. Ricci, L. G. Brunet, S. T. Gehring e M. H. C. Célia.

[New99] I. Newton. The Principia: Mathematical Principles of Natural Philosophy. University of California Press, Berkeley, 1999. A new translation by I. B. Cohen and A. Whitman, assisted by J. Budenz.

[New08] I. Newton. Principia - Princípios Matemáticos de Filosofia Natural. Edusp, São Paulo, 2008. Livro II: O Movimento dos Corpos (em Meios com Resistência). Livro III: O Sistema do Mundo (Tratado Matematicamente). Tradução de A. K. T. Assis. ISBN: 9788531410895 .

[New10] I. Newton. Principia - Princípios Matemáticos de Filosofia Natural. Folha de São Paulo, São Paulo, 2010. Livro III: O Sistema do Mundo (Tratado Matematicamente). Tradução de A. K. T. Assis. ISBN: 9788563270306. Coleção Folha de São Paulo: Livros que Mudaram o Mundo, Volume 9.

[Oer20a] H. C. Oersted. Expériences sur l'effet du conflict électrique sur l'aiguille aimantée. Annales de Chimie et de Physique, 14:417-425, 1820.

[Oer20b] H. C. Oersted. Experiments on the effect of a current of electricity on the magnetic needle. Annals of Philosophy, 16:273-277, 1820. Translated from a printed account drawn up in Latin by the author and transmitted by him to the Editor of the Annals of Philosophy.

[Oer65] H. C. Oersted. Experiments on the effect of a current of electricity on the magnetic needle. In R. A. R. Tricker, Early Electrodynamics - The First Law of Circulation, pages 113-117, New York, 1965. Pergamon. Reimpressão dos Annals of Philosophy editados por Thomson, outubro de 1820 .

[OF38] G. S. Ohm and G. T. Fechner. Das Grundgesetz des elektrischen Stromes, volume 244 of Ostwald's Klassiker der exakten Wissenschaften. Akad. Verlagsgesellsch., Leipzig, 1938. Drei Abhandlungen von Georg Simon Ohm (1825 und 1826) und Gustav Theodor Fechner (1829). Herausgegeben von C. Piel. 
[Ohm25] G. S. Ohm. Vorläufige Anzeige des Gesetzes, nach welchem Metalle die Kontakt-Elektrizität leiten. Journal für Chemie und Physik, 44:10-118, 1825. Reimpresso em Ostwald's Klassiker der exakten Wissenschaften, Número 244, C. Piel (ed.), (Akademische Verlagsgesellschaft, Leipzig, 1938), págs. 1-7.

[Ohm26] G. S. Ohm. Bestimmung des Gesetzes, nach welchem Metalle die Kontakt-Elektrizität leiten, nebst einem Entwurfe zu einer Theorie des Voltaschen Apparates und des Schweiggerschen Multiplikators. Journal für Chemie und Physik, 46:137-166, 1826. Reimpresso em Ostwald's Klassiker der exakten Wissenschaften, Número 244, C. Piel (ed.), (Akademische Verlagsgesellschaft, Leipzig, 1938), págs. 8-29.

[Ohm66] G. S. Ohm. The galvanic circuit investigated mathematically. In R. Taylor, editor, Scientific Memoirs, Vol. 2, pages 401-506, New York, 1966. Johnson Reprint Corporation. Tradução para o inglês por W. Francis.

[OP09] K. Ovchinnikova and G. H. Pollack. Can water store charge? Langmuir, 25:542-547, 2009. Doi: 10.1021/la802430k.

[Ørs86] H. C. Ørsted. Experiências sobre o efeito do conflito elétrico sobre a agulha magnética. Cadernos de História e Filosofia da Ciência, 10:115-122, 1986. Tradução de R. d. A. Martins.

[Per44] E. Perucca. Física General y Experimental, volume II: Optica, Electricidad y Magnetismo. Editorial Labor, Barcelona, 1944. Traduzido da quarta edição italiana por J. Melis e J. M. V. Llenas.

[Pla52] Plato. Timaeus. In Great Books of the Western World, R. M. Hutchins, Editor Chefe, Vol. 7, pages 442-477, Chicago, 1952. Encyclopaedia Britannica. Traduzido por B. Jowett.

[Pla09] Platao. Timeu e Crítias ou A Atlântida. Hemus, São Paulo, 2009. Tradução, Introdução e Notas de N. d. P. Lima.

[Pol13] G. H. Pollack. The Fourth Phase of Water: Beyond Solid, Liquid, and Vapor. Ebner \& Sons, Seattle, 2013.

[Pot84] A. Potier. Collection de Mémoires relatifs a la Physique, volume 1: Mémoires de Coulomb. Gauthiers-Villars, Paris, 1884.

[Pri75] J. Priestley. The History and Present State of Electricity, with Original Experiments, volume II. C. Bathurst and T. Lowndes, London, 3rd edition, 1775 .

[Pri66] J. Priestley. The History and Present State of Electricity, volume 2. Johnson Reprint Corporation, New York, 1966. The Sources of Science, Número 18. Reimpresso a partir da terceira edição, London, 1775 . 
[Rai15] A. C. Raicik, 2015. Experimentos exploratórios: os contextos da descoberta e da justificativa nos trabalhos de Gray e Du Fay. Dissertação de mestrado, Universidade Federal de Santa Catarina UFSC, Florianópolis.

[Ram] C. Ramsauer, Das Ohmsche Gesetz (1826), in C. Ramsauer, Grundversuche der Physik in historischer Darstellung (Springer, Berlin, 1953), Vol. 1: Von der Fallgesetzen bis zu den elektrischen Wellen.

[Roc89] J. Roche. Applying the history of electricity in the classroom: a reconstruction of the concept of 'potential'. In M. Shortland and A. Warwick, editors, Teaching the History of Science, pages 168184. Basil Blackwell, Oxford, 1989.

[Ros90] F. Rosenberger. Die Geschichte der Physik, volume 3. Friedrich Vieweg und Sohn, Braunschweig, 1887-1890.

[Ros57] L. Rosenfeld. The velocity of light and the evolution of electrodynamics. Il Nuovo Cimento, Supplement to vol. 4:1630-1669, 1957.

[Ros81] L. Rosenfeld. Kirchhoff, Gustav Robert. In C. C. Gillispie, editor, Dictionary of Scientific Biography, Vol. 7, pages 379-383, New York, 1981. Charles Scribner's Sons.

[RP13a] A. C. Raicik and L. O. Q. Peduzzi, 2013. Uma abordagem histórica e experimental à eletricidade em uma disciplina sobre a evolução dos conceitos da física. Anais do XX Simpósio Nacional de Ensino de Física - SNEF, São Paulo, SP. Págs. 1-8.

[RP13b] A. C. Raicik and L. O. Q. Peduzzi, 2013. Uma discussão sobre os contextos da descoberta e da justificativa nos estudos de Du Fay. Anais do IX Encontro Nacional de Pesquisa em Educação em Ciências IX ENPEC, Águas de Lindóia, SP, 10 a 14 de novembro. Págs. 1-8.

[RP13c] A. C. Raicik and L. O. Q. Peduzzi, 2013. Uma análise da terminologia descoberta e sua contextualização nos livros didáticos: os estudos de Gray e Du Fay. Anais do V Encontro Estadual de Ensino de Física, Porto Alegre, RS. Págs. 1-13.

[RP15a] A. C. Raicik and L. O. Q. Peduzzi. Potencialidades e limitações de um módulo de ensino: uma discussão histórico-filosófica dos estudos de Gray e Du Fay. Investigações em Ensino de Ciências, 20:138-160, 2015 .

[RP15b] A. C. Raicik and L. O. Q. Peduzzi. Um resgate histórico e filosófico dos estudos de Charles Du Fay. Revista Ensaio, 17:105-125, 2015. Doi: 10.1590/1983-211720175170105. 
[RP16] A. C. Raicik and L. O. Q. Peduzzi. A estrutura conceitual e epistemológica de uma descoberta científica: reflexões para o ensino de ciências. Alexandria - Revista de Educação em Ciência e Tecnologia, 9:149-176, 2016. Doi: 10.5007/1982-5153.2016v9n2p149.

[RR57] D. Roller and D. H. D. Roller. The Development of the Concept of Electric Charge. In J. B. Conant, editor, Harvard Case Studies in Experimental Science, chapter 8, pages 541-639. Harvard University Press, Cambridge, 1957.

[San11] L. P. Santos et al. Water with excess electric charge. The Journal of Physical Chemistry C, 115:11226-11232, 2011. Doi: $10.1021 /$ jp202652q.

[Sav] I. V. Savelyev. Physics: A General Course, volume II: Electricity and Magnetism, Waves and Optics. Mir, Moscow. Translated from Russian by G. Leib.

[Sch63] M. Schagrin. Resistance to Ohm's law. American Journal of Physics, 31:536-547, 1963.

[Sch07] L. B. Schein. Recent progress and continuing puzzles in electrostatics. Science, 316:1572-1573, 2007.

[Sco59] W. T. Scott. Who was Earnshaw? American Journal of Physics, 27:418-419, 1959.

[Ses87] G. M. Sessler (ed.). Electrets. Springer, Berlin, second edition, 1987.

[SGS31] J. B. Seth, B. Gulati, and S. Singh. On an electromotive force between two metals in relative motion. Philosophical Magazine, 12:409-429, 1931. DOI: 10.1080/14786443109461818.

[Sil10a] V. A. Silva Júnior. Fabricação e aplicação de eletretos. Trabalho realizado na disciplina Tópicos de Ensino de Física I, F609, do Instituto de Física da UNICAMP. Orientador: A. K. T. Assis. Disponível em www.ifi.unicamp.br/ assis e sites.ifi.unicamp.br/lunazzi/ files/2014/03/ValterA-Assis_RF1.pdf, 2010.

[Sil10b] V. A. Silva Júnior. História e propriedades dos eletretos. Trabalho realizado na disciplina de Monografia, F896, do Instituto de Física da UNICAMP. Orientador: A. K. T. Assis. Disponível em www.ifi. unicamp.br/ assis, 2010.

[Sil10c] F. L. d. Silveira. Resenha - Os Fundamentos Experimentais e Históricos da Eletricidade. Caderno Brasileiro de Ensino de Física, 27:411-415, 2010.

[Sil11] F. L. d. Silveira. Vídeo sobre demonstrações de eletrostática. Disponível em www.if.ufrgs.br/ lang e www.youtube.com/watch? $\mathrm{v}=\mathrm{GhYKeb990gA,} 2011$. 
[Sil16] F. L. d. Silveira. Descarga elétrica através do ar NÃO é consequente do arrancamento de elétrons dos eletrodos! Disponível em www.if. ufrgs. br/cref/?area=questions\&id=1652, 2016.

[SP06] C. C. Silva and A. C. Pimentel, 2006. Benjamin Franklin e a história da eletricidade em livros didáticos. Anais do X Encontro de Pesquisa em Ensino de Física, Londrina, PR, 15 a 19/08/2006. Disponível em: www.sbf1.sbfisica.org.br/eventos/epef/x/sys/resumos/ T0150-1.pdf.

[SP08] C. C. Silva and A. C. Pimentel. Uma análise da história da eletricidade presente em livros didáticos: o caso de Benjamin Franklin. Caderno Brasileiro de Ensino de Física, 25:141-159, 2008.

[Tho] W. Thomson. On a self-acting apparatus for multiplying and maintaining electric charges, with applications to illustrate the voltaic theory. Proceedings of the Royal Society of London, 16:67-72, 18671868.

[Tho84a] W. Thomson. Atmospheric electricity. In W. Thomson, editor, Reprint of Papers on Electrostatics and Magnetism. Macmillan, London, 1884. $2^{\text {a }}$ edição, págs. 192-239, Artigo XVI. Reimpresso de Nichol's Cyclopaedia, $2^{\text {a }}$ edição, 1860.

[Tho84b] W. Thomson. A mathematical theory of magnetism. In W. Thomson, editor, Reprint of Papers on Electrostatics and Magnetism. Macmillan, London, 1884. $2^{\text {a }}$ edição, págs. 345-430, Artigo XXIV. Reimpresso de Philosophical Transactions, Vol. 141, págs. 243-268 e 269-285 (1851).

[Tho84c] W. Thomson. Measurement of the electromotive force required to produce a spark in air between parallel metal plates at different distances. In W. Thomson, editor, Reprint of Papers on Electrostatics and Magnetism. Macmillan, London, 1884. $2^{\text {a }}$ edição, págs. 247-259, Artigo XIX. Reimpresso de Proceedings of the Royal Society, Vol. 10, págs. 326-338 (1860).

[Tho84d] W. Thomson. On the mathematical theory of electricity in equilibrium. In W. Thomson, editor, Reprint of Papers on Electrostatics and Magnetism. Macmillan, London, 1884. $2^{\text {a }}$ edição, págs. 42-68, Artigos IV (págs. 42-51) e V (págs. 52-68). Reimpresso de Cambridge and Dublin Mathematical Journal, Vol. 3, págs. 131-148 e 266-274 (1848).

[Tho21] J. J. Thomson. Elements of the Mathematical Theory of Electricity and Magnetism. Cambridge University Press, Cambridge, 5th edition, 1921. 
[TM09] P. A. Tipler and G. Mosca. Física para Cientistas e Engenheiros, volume 2: Eletricidade e Magnetismo, Óptica. LTC, Rio de Janeiro, $6^{a}$ edição, 2009. Tradução de N. M. Balzaretti.

[TP11] J. D. M. Tamayo and M. G. T. Palacio. El Papel del Experimento en la Construcción del Conocimiento Físico, el Caso de la Construcción del Potencial Eléctrico como una Magnitude Física. Elementos para Propuestas en la Formación Inicial y Continuada de Profesores de Física. Universidad de Antioquia - Facultad de Educación, Medellín, 2011. Trabajo de Investigación como requisito parcial para optar al título de Magister en Educación, línea de Educación en Ciencias Experimentales. Director: A. E. R. Chacón.

[Vas05] G. M. S. Vasconcelos. Experimentos de eletrostática de baixo custo para o ensino médio. Trabalho realizado na disciplina Instrumentação para Ensino, F809, do Instituto de Física da UNICAMP. Orientador: A. K. T. Assis. Disponível em www.ifi.unicamp.br/ rassis e www.ifi.unicamp.br/ lunazzi/F530_F590_F690_F809_ F895/F809/F809_sem2_2005/GeraldoM_Assis_RF1.pdf, 2005.

[VF80] R. N. Varney and L. H. Fisher. Electromotive force: Volta's forgotten concept. American Journal of Physics, 48:405-408, 1980.

[Vol00a] A. Volta. On the electricity excited by the mere contact of conducting substances of different kinds. Philosophical Transactions, 90:403-431, 1800. Letter in French from A. Volta to J. Banks dated March 20, 1800. It was read before the Royal Society in June 26, 1800 .

[Vol00b] A. Volta. On the electricity excited by the mere contact of conducting substances of different kinds. Philosophical Magazine, 7:289311,1800 .

[Vol64] A. Volta. On the electricity excited by the mere contact of conducting substances of different kinds. In B. Dibner, Alessandro Volta and the Electric Battery, pages 111-131. Franklin Watts, New York, 1964. Translated from the author's paper published in French in the Philosophical Transactions for 1800, Part 2.

[WB09] B. Wolff and C. Blondel. La balance électrique de Coulomb pouvaitelle constituer sa propre cage de Faraday? Disponível em: www. ampere.cnrs.fr/parcourspedagogique, 2009.

[WB11] B. Wolff and C. Blondel. Quelques questions encore posées aujourd'hui par l'histoire de l'électrostatique. Union des Professeurs de Physique et de Chimie, 105:705-717, 2011.

[Web46] W. Weber. Elektrodynamische Maassbestimmungen - Über ein allgemeines Grundgesetz der elektrischen Wirkung. Abhandlungen bei 
Begründung der Königl. Sächs. Gesellschaft der Wissenschaften am Tage der zweihundertjährigen Geburtstagfeier Leibnizen's herausgegeben von der Fürstl. Jablonowskischen Gesellschaft (Leipzig), pages 211-378, 1846. Reimpressão em Wilhelm Weber's Werke, vol. 3, H. Weber (ed.), (Springer, Berlim, 1893), págs. 25-214.

[Web48] W. Weber. Elektrodynamische Maassbestimmungen. Annalen der Physik und Chemie, 73:193-240, 1848. Reimpresso em Wilhelm Weber's Werke, Vol. 3, H. Weber (ed.), (Springer, Berlin, 1893), págs. 215-254.

[Web52a] W. Weber. Elektrodynamische Maassbestimmungen insbesondere über Diamagnetismus. Abhandlungen der Königl. Sächs. Gesellschaft der Wissenschaften, mathematisch-physische Klasse, 1:485577, 1852. Reimpresso em Wilhelm Weber's Werke, Vol. 3, H. Weber (ed.), (Springer, Berlin, 1893), págs. 473-554.

[Web52b] W. Weber. Elektrodynamische Maassbestimmungen insbesondere Widerstandsmessungen. Abhandlungen der Königl. Sächs. Gesellschaft der Wissenschaften, mathematisch-physische Klasse, 1:199381, 1852. Reimpresso em Wilhelm Weber's Werke, Vol. 3, H. Weber (ed.), (Springer, Berlin, 1893), págs. 301-471.

[Web64] W. Weber. Elektrodynamische Maassbestimmungen insbesondere über elektrische Schwingungen. Abhandlungen der Königl. Sächs. Geselschaft der Wissenschaften, mathematisch-physische Klasse, 6:571-716, 1864. Reimpresso em Wilhelm Weber's Werke, Vol. 4, H. Weber (ed.), (Springer, Berlin, 1894), págs. 105-241.

[Web71] W. Weber. Elektrodynamische Maassbestimmungen insbesondere über das Princip der Erhaltung der Energie. Abhandlungen der Königl. Sächs. Gesellschaft der Wissenschaften, mathematisch-physische Klasse (Leipzig), 10:1-61, 1871. Reimpresso em Wilhelm Weber's Werke, Vol. 4, H. Weber (ed.), (Springer, Berlin, 1894), págs. 247-299.

[Web72] W. Weber. Electrodynamic measurements - Sixth memoir, relating specially to the principle of the conservation of energy. Philosophical Magazine, 43:1-20 and 119-149, 1872.

[Web78] W. Weber. Elektrodynamische Maassbestimmungen insbesondere über die Energie der Wechselwirkung. Abhandlungen der Königl. Sächs. Gesellschaft der Wissenschaften, mathematisch-physische Klasse, (Leipzig), 11:641-696, 1878. Reimpresso em Wilhelm Weber's Werke, Vol. 4, H. Weber (ed.), (Springer, Berlin, 1894), págs. 361-412.

[Web92a] W. Weber. Wilhelm Weber's Werke, E. Riecke (ed.), volume 2, Magnetismus. Springer, Berlin, 1892. 
[Web92b] W. Weber. Wilhelm Weber's Werke, W. Voigt, (ed.), volume 1, Akustik, Mechanik, Optik und Wärmelehre. Springer, Berlin, 1892.

[Web93] W. Weber. Wilhelm Weber's Werke, H. Weber (ed.), volume 3, Galvanismus und Elektrodynamik, primeira parte. Springer, Berlin, 1893.

[Web94a] W. Weber. Elektrodynamische Maassbestimmungen insbesondere über den Zusammenhang des elektrischen Grundgesetzes mit dem Gravitationsgesetze. In H. Weber, editor, Wilhelm Weber's Werke, Vol. 4, pages 479-525, Berlin, 1894. Springer.

[Web94b] W. Weber. Wilhelm Weber's Werke, H. Weber, (ed.), volume 4, Galvanismus und Elektrodynamik, segunda parte. Springer, Berlin, 1894.

[Web66] W. Weber. On the measurement of electro-dynamic forces. In R. Taylor, editor, Scientific Memoirs, Vol. 5, pages 489-529, New York, 1966. Johnson Reprint Corporation.

[Web07] W. Weber, 2007. Determinations of electrodynamic measure: concerning a universal law of electrical action, 21st Century Science \& Technology, traduzido para a língua inglesa por S. P. Johnson, editado por L. Hecht e A. K. T. Assis. Disponível desde março de 2007 em: www.21stcenturysciencetech.com/translation.html.

[Web08] W. Weber, 2008. Determinations of electrodynamic measure: particularly in respect to the connection of the fundamental laws of electricity with the law of gravitation, 21st Century Science \& Technology, traduzido para a língua inglesa por G. Gregory, editado por L. Hecht e A. K. T. Assis. Disponível desde novembro de 2008 em: www. 21stcenturysciencetech. com/translation.html.

[Whe43] C. Wheatstone. The bakerian lecture - an account of several new instruments and processes for determining the constants of a voltaic circuit. Philosophical Transactions, 133:303-327, 1843.

[Whi73a] E. T. Whittaker. A History of the Theories of Aether and Electricity, volume 1: The Classical Theories. Humanities Press, New York, 1973.

[Whi73b] E. T. Whittaker. A History of the Theories of Aether and Electricity, volume 2: The Modern Theories. Humanities Press, New York, 1973.

[Wie60] K. H. Wiederkehr. Wilhelm Webers Stellung in der Entwicklung der Elektrizitätslehre. Dissertation, Hamburg, 1960.

[Wie67] K. H. Wiederkehr. Wilhelm Eduard Weber - Erforscher der Wellenbewegung und der Elektrizität (1804-1891), volume 32 of Grosse Naturforscher, H. Degen (ed.). Wissenschaftliche Verlagsgesellschaft, Stuttgart, 1967. 
[Wil12] M. W. Williams. What creates static electricity? American Scientist, 100:316-323, 2012. Doi: 10.1511/2012.97.316.

[Wis81] M. N. Wise. German concepts of force, energy, and the electromagnetic ether: 1845-1880. In G. N. Cantor and M. J. S. Hodge, editors, Conceptions of Ether - Studies in the History of Ether Theories 1740-1900, pages 269-307, Cambridge, 1981. Cambridge University Press.

[WK56] W. Weber and R. Kohlrausch. Über die Elektricitätsmenge, welche bei galvanischen Strömen durch den Querschnitt der Kette fliesst. Annalen der Physik und Chemie, J. C. Poggendoff (ed.), 99:10-25, 1856. Reimpresso em Wilhelm Weber's Werke, Vol. 3, H. Weber (ed.), (Springer, Berlin, 1893), págs. 597-608.

[WK08] W. Weber and R. Kohlrausch. Sobre a quantidade de eletricidade que flui através da seção reta do circuito em correntes galvânicas. Revista Brasileira de História da Ciência, 1:94-102, 2008. Traduzido por A. K. T. Assis.

[Woo68] A. E. Woodruff. The contributions of Hermann von Helmholtz to electrodynamics. Isis, 59:300-311, 1968.

[Woo81] A. E. Woodruff. Weber, Wilhelm Eduard. In C. C. Gillispie, editor, Dictionary of Scientific Biography, Vol. 14, pages 203-209, New York, 1981. Charles Scribner's Sons.

[WW93] E. H. Weber and W. Weber. Wilhelm Weber's Werke, E. Riecke (ed.), volume 5, Wellenlehre auf Experimente gegründet oder über die Wellen tropfbarer Flüssigkeiten mit Anwendung auf die Schallund Lichtwellen. Springer, Berlin, 1893. Publicado originalmente em 1825 .

[WW94] W. Weber and E. Weber. Wilhelm Weber's Werke, F. Merkel and O. Fischer (editors), volume 6, Mechanik der menschlichen Gehwerkzeuge. Eine anatomisch-physiologische Untersuchung. Springer, Berlin, 1894. Publicado originalmente em 1836. 
Errata do Volume 2 do livro de A. K. T. Assis, "Os Fundamentos Experimentais e Históricos da Eletricidade" (Apeiron, Montreal, 2018), ISBN: 978-1-987980-09-7, disponível em https://www.ifi.unicamp.br/ assis

- Páginas 16, 112 e 115. Descobri que o material que chamo de "mangueira de borracha" ou "borracha dura" nesse livro (aquelas mangueiras flexíveis brancas conectadas aos chuveiros elétricos) é feito de PVC. 
O Volume 2 de Os Fundamentos Experimentais e Históricos da Eletricidade lida com os aspectos fundamentais da fisica. Descreve as principais experiencias e descobertas da história da eletricidade. Discute-se a atração e a repulsão elétrica, as cargas positivas e negativas, condutores e isolantes, eletrização por atrito/contato/indução, a série triboelétrica, a eletrização de fitas adesivas, o equilíbrio e a distribuição de cargas em condutores, blindagem elétrica, o poder das pontas, faíscas e descargas elétricas no ar, eletretos e a preservação temporal da eletrização dos corpos. O livro explica como construir e utilizar diversos instrumentos elétricos: versório, pêndulo elétrico, eletroscópio, coletor de carga, circuito de teste, eletróforo, a garrafa de Leiden e os capacitores, etc. Todas as experiencias são descritas com clareza e realizadas com materiais simples, baratos e facilmente acessíveis. Estas experiências levam a conceitos simples, definições e leis descrevendo os fenômenos. Sempre que possível são apresentados aspectos históricos relacionados com os fenômenos que estão sendo analisados, juntamente com citações relevantes dos principais cientistas que trabalharam com estes assuntos. Uma ampla bibliografia é incluída no final da obra..

Sobre o autor: André Koch Torres Assis nasceu no Brasil em 1962. Formouse no Instituto de Física da Universidade Estadual de Campinas - UNICAMP, obtendo o bacharelado em 1983 e o doutorado em 1987. Passou o ano de 1988 na Inglaterra realizando um pósdoutorado no Culham Laboratory (United Kingdom Atomic Energy Authority). Passou um ano entre 1991-92 como Visiting Scholar no Center for Electromagnetics Research da Northeastern University (Boston, EUA). De Agosto de $200 I$ a Novembro de 2002, assim como de Fevereiro a Maio de 2009, trabalhou no Institut für Geschichte der Naturwissenschaften da Universidade de Hamburg, Alemanha, com uma bolsa de pesquisa concedida pela Fundação Alexander von Humboldt da Alemanha. De Abril a Junho de 2014 trabalhou na Universidade Técnica de Dresden, Alemanha, com uma bolsa pesquisa concedida pela Fundação Alexander von Humboldt da Alemanha. É autor de diversos livros em português, ingles, italiano, alemão e russo. Entre estas obras se destacam Eletrodinámica de Weber (1992, 1994, 1995 e 2015); Cálculo de Indutância e de Força em Circuitos Elétricos (juntamente com M. Bueno, 1998, 2001 e 2015); Mecânica Relacional (1998 e 1999); Uma Nova Física (1999); Arquimedes, o Centro de Gravidade e a Lei da Alavanca (2008 e 2010); A Força Elétrica de uma Corrente: Weber e as Cargas Superficiais de Condutores Resistivos com Correntes Constantes (juntamente com J. A. Hernandes, 2007 e 2009); Os Fundamentos Experimentais e Históricos da Eletricidade (Volume I, 2010); O Modelo Planetário de Weber para o Átomo (com K. H. Wiederkehr e G. Wolfschmidt, 20Ir e 2014); Eletrodinâmica de Ampère: Análise do significado e da evolução da força de Ampère, juntamente com a tradução comentada de sua principal obra sobre eletrodinâmica (com J. P. M. C. Chaib, $201 r$ e 2015); Stephen Gray e a Descoberta dos Condutores e Isolantes: Tradução Comentada de Seus Artigos sobre Eletricidade e Reprodução de Seus Principais Experimentos (com S. L. B. Boss e J. J. Caluzi, 2012); O Método Ilustrado de Arquimedes: Utilizando a Lei da Alavanca para Calcular Áreas, Volumes e Centros de Gravidade (com C. P. Magnaghi, 2012 e 2014); Mecânica Relacional e Implementação do Princípio de Mach com a Força de Weber Gravitacional (2013 e 2014). Traduziu para o português o livro Óptica, de Isaac Newton (1996), O Universo Vermelho, de Halton Arp (juntamente com D. Soares, 200I), assim como os livros II e III da obra Principia: Princípios Matemáticos de Filosofia Natural, de Isaac Newton (2009). É professor do Instituto de Física da UNICAMP desde Ig89 trabalhando com os fundamentos do eletromagnetismo, da gravitação e da cosmologia. 